INEEL/EXT-97-00686

Revision 5a

\title{
Screening Level Risk Assessment for the New Waste Calcining Facility
}

M. L. Abbott

K. N. Keck

R. E. Schindler

R. L. VanHorn

N. L. Hampton

M. B. Heiser

Published May 1999

\section{Idaho National Engineering and Environmental Laboratory Integrated Earth Sciences Department Lockheed Martin Idaho Technologies Company Idaho Falls, Idaho 83415}

Prepared for the

U.S. Department of Energy

Assistant Secretary for Environmental Management Under DOE Idaho Operations Office

Contract DE-AC07-94ID13223 



\section{DISCLAIMER}

This report was prepared as an account of work sponsored by an agency of the United States Government. Neither the United States Government nor any agency thereof, nor any of their employees, make any warranty, express or implied, or assumes any legal liability or responsibility for the accuracy, completeness, or usefulness of any information, apparatus, product, or process disclosed, or represents that its use would not infringe privately owned rights. Reference herein to any specific commercial product, process, or service by trade name, trademark, manufacturer, or otherwise does not necessarily constitute or imply its endorsement, recommendation, or favoring by the United States Government or any agency thereof. The views and opinions of authors expressed herein do not necessarily state or reflect those of the United States Government or any agency thereof. 


\section{DISCLAIMER}

Portions of this document may be illegible in electronic image products. Images are produced from the best available original document. 


\section{ABSTRACT}

This screening level risk assessment evaluates potential adverse human health and ecological impacts resulting from continued operations of the calciner at the New Waste Calcining Facility (NWCF) at the Idaho Nuclear Technology and Engineering Center (INTEC), Idaho National Engineering and Environmental Laboratory (INEEL). The assessment was conducted in accordance with the Environmental Protection Agency (EPA) report, Guidance for Performing Screening Level Risk Analyses at Combustion Facilities Burning Hazardous Waste. ${ }^{2}$ This screening guidance is intended to give a conservative estimate of the potential risks to determine whether a more refined assessment is warranted. The NWCF uses a fluidized-bed combustor to solidify (calcine) liquid radioactive mixed waste from the INTEC Tank Farm facility. Calciner off gas consists mostly of acid gases (primarily $\mathrm{NO}_{\mathrm{x}}$ ), low concentrations of volatilized metal species, trace organic compounds, and low-levels of radionuclides. Conservative stack emission rates were calculated based on maximum waste solution feed samples, conservative assumptions for off gas partitioning of metals and organics, stack gas sampling for mercury, and conservative measurements of contaminant removal (decontamination factors) in the off gas treatment system. Stack emissions were modeled using the ISC3 air dispersion model $\mathrm{l}^{\mathrm{b}}$ to predict maximum particulate and vapor air concentrations and ground deposition rates. The exposure assessment evaluated potential impacts to a hypothetical subsistence farmer, subsistence farmer child, adult resident, and child resident located at the maximum offsite impact location, an INEEL worker located at the maximally-exposed adjacent onsite facility (CFA), and a hypothetical herdsman located at the maximally-exposed onsite location where grazing is allowed (south of U.S. Highway 20). Direct exposures through inhalation and indirect exposures from consumption of contaminated vegetables, meat, dairy products, and incidental ingestion of soil were evaluated. Direct short-term inhalation exposure was evaluated on U.S. Highway 20 by comparing the maximum concentrations to allowable toxic air pollutant increments published by the State of Idaho. Risk to ecological receptors was quantitatively evaluated using EPA guidance and methods developed at the INEEL for EPA CERCLA clean-up activities.

Results demonstrate that NWCF emissions calculated from best-available process knowledge would result in maximum onsite and offsite health and ecological impacts that are less than EPA-established criteria for operation of a combustion facility. Additional analyses may be performed in the future if: (1) results from emissions testing scheduled for early 1999 indicate that the emissions evaluated in this SLRA are not conservative, and (2) DOE decides to continue operation of the NWCF in the Idaho High Level Waste Environmental Impact Statement (HLWEIS). A final decision on this will be made by June 1, 2000 in accordance with the Notice of Noncompliance Consent Order.

a. EPA, 1994, Guidance for Performing Screening Level Risk Analyses at Combustion Facilities Burning Hazardous Waste, Attachment C, Draft, Office of Emergency and Remedial Response, Office of Solid Waste, December 14, 1994.

b. EPA, 1995, User's Guide for the Industrial Source Complex (ISC3) Dispersion Models (Revised), EPA-450/B-95-003a, b. 


\section{EXECUTIVE SUMMARY}

This screening level risk assessment (SLRA) evaluates potential adverse human health and environmental effects resulting from continued operations of the New Waste Calcining Facility (NWCF) at the Idaho Nuclear Technology and Engineering Center (INTEC), which is part of the Idaho National Engineering and Environmental Laboratory (INEEL). The NWCF uses a fluidized-bed combustor to solidify (calcine) liquid radioactive mixed waste from the INTEC Tank Farm facility. Calcining operations were restarted in June 1997 and are currently scheduled to continue until June 1,2000. DOE will be evaluating the future disposition of the NWCF in the Idaho High Level Waste Environmental Impact Statement (HILEIS) which should be published by late 1999. A decision will be made by June 1, 2000 in accordance with the Notice of Noncompliance Consent Order.

Completion of this SLRA was specified in the Second Modification (dated July 31,1998 ) of the Consent Order to the Notice of Noncompliance signed January 29, 1990 between the U.S. Department of Energy and the Idaho Division of Environmental Quality (DEQ). Revision 3 of the SLRA was submitted to the DEQ in May 1998 along with DOE's response to Notice of Deficiency comments on Revision 2. The DEQ responded in a letter received by DOE on November 22, 1998 that DOE did not adequately address the NOD comments and another revision to the SLRA with a quantitative ecological risk assessment must be submitted no later than December 31, 1998. Revision 4a, which was submitted to DEQ on December 28, 1998, contained revised responses to the NOD comments and evaluation of additional exposure scenarios but no quantitative ecological risk assessment due to time constraints. This current revision (5a) of the SLRA: (1) provides a quantitative ecological risk assessment, (2) revised inhalation toxicity values (reference concentrations and inhalation slope factors) to be consistent with those from the ATG Risk Assessment Work Plan ${ }^{2}$ or EPA Region 9 Preliminary Remediation Goals (PRGs), (3) assessed emissions from auxiliary sources (in addition to revised estimates from the calciner), (4) provided a quantitative basis for development of contingencies for unsampled waste tanks, and (5) provided a more detailed basis and justification for the mercury emissions factor used. Toxicity values from ATG were used where appropriate because these values have been approved by EPA Region 10 and the Idaho HWPB.

This revision of the SLRA was completed in accordance with concise guidelines specified in: (1) Guidance for Performing Screening Level Risk Analyses at Combustion Facilities Burning Hazardous Waste, EPA Draft Attachment C, December 14, 1998 and, (2) Exposure Assessment Guidance for RCRA Hazardous Waste Combustion Facilities, EPA530-R-94-021, April 1994. Since submittal of Revision 3 of the SLRA in May 1998, EPA published new draft risk assessment guidelines in Human Health Protocol for Hazardous Waste Combustion Facilities (EPA530-D-98-001A, July 1998) (HHRAP). Significant

a. Allied Technology Group, Inc. (ATG) Risk Assessment Work Plan for the ATG Richland Mixed Waste Facility, October 9, 1998. 
efforts were made in this revision of the SLRA to incorporate some of these new risk assessment methods (e.g. assessment of coplaner PCBs and a subsistence farmer child scenario).

Calciner off gas consists mostly of acid gases (primarily $\mathrm{NO}_{x}$ ), low concentrations of volatilized metal species, trace organic compounds, and lowlevels of radionuclides. For this SLRA and all previous versions, Contaminants of Potential Concern (COPCs) were determined and emission rates were calculated using best available process knowledge rather than trial burn measurements, which have proven very difficult in the past due to the high acid environment of the NWCF off gas. This process knowledge consisted of:

(1) conservative feed rate concentrations, (2) the assumption that $100 \%$ of most organic compounds are released (with no destruction and removal), (3) conservative estimates of off gas partitioning and HEPA filtration for metals, and (4) conservative estimates of Products of Incomplete Combustion (PIC) formation using worst-case combinations of known PIC precursors in the feed. The emission rate for mercury was determined by an emissions factor (3.7\%) which was calculated from three long-term (2-4 month) activated carbon stack gas samples taken during 1997-1998 calcining operations. Because of uncertainties in the exact inventory partioning of mercury downstream of the calciner, an upper-bound mercury emissions factor of $13 \%$ was also evaluated.

Consistent with EPA guidance, stack emissions were modeled using the ISC3 air dispersion model ${ }^{\mathrm{b}}$ to predict maximum particulate and vapor air concentrations and ground deposition rates. Maximum annual concentrations/depositions were determined at both offsite (off-INEEL) and onsite locations. Maximum short-term (time-averaged) concentrations were calculated along U.S. Highway 20 (6 km south of the INTEC), an area in which the commuting public could be exposed for short durations.

The exposure assessment evaluated potential impacts to a hypothetical subsistence farmer, subsistence farmer child, adult resident, and child resident located at the maximum offsite impact location, an INEEL worker located at the maximally-exposed adjacent INEEL facility (CFA), and a hypothetical herdsman located at the maximally-exposed onsite location where grazing is allowed (south of U.S. highway 20). Direct exposures through inhalation and indirect exposures from consumption of contaminated vegetables, meat, dairy products, and incidental ingestion of soil were evaluated. Direct short-term inhalation exposure was evaluated on U.S. Highway 20 by comparing the maximum concentrations to allowable toxic air pollutant (TAP) increments published by the State of Idaho or EPA Region 9 Preliminary Remediation Goals (PRGs).

The total (sum of direct and indirect) chemical excess cancer risks from long-term operation of the NWCF were calculated to be $2 \times 10^{-7}$ for all exposure scenarios (see Table ES-1) which was dominated by the inhalation pathway. The direct (inhalation only) chemical cancer risk for the maximally-exposed onsite worker was estimated be $2 \times 10^{-8}$. The total (direct and indirect) chemical

b. EPA, 1995, User's Guide for the Industrial Source Complex (ICS3) Dispersion Models (Revised), EPA-450/B-95-003a,b. 
cancer risk for the hypothetical onsite herdsman was estimated to be $9 \times 10^{-8}$. Cancer risk from radionuclides was evaluated using conservative dose assessment methods and the latest EPA cancer incidence risk factors. The highest excess cancer risk from radionuclide emissions was calculated to be $1 \times 10^{-6}$ for the subsistence farmer. All of these potential excess cancer risks are less than the EPA acceptable criterion of $1 \times 10^{-5}$.

Potential noncarcinogenic health effects were evaluated as a hazard quotient (HQ), which is the ratio of the chemical-specific exposure dose and a reference dose derived by the EPA to be adequately protective of human health. HQ values for chemicals affecting the same target organ were summed to determine a hepatoxicity (liver) and neurotoxicity (nervous system) hazard index (HI). Calculated $\mathrm{HI}$ values for all of the scenarios assessed were less than the EPA criterion of 0.25 (see Table ES-2).

Potential exposure to lead from calciner emissions was evaluated by comparing the maximum modeled offsite concentrations of lead in the air to the National Ambient Air Quality Standard (NAAQS) of $1.5 \mu \mathrm{g} / \mathrm{m}^{3}$ and to the EPA soil benchmark level of $400 \mathrm{mg} / \mathrm{kg}$. Results indicate exposures to lead from calciner emissions are well below these criteria.

Maximum short-term air concentrations estimated along U.S. Highway 20 were all well below the State of Idaho acceptable ambient air concentrations for noncarcinogens (AACs) and carcinogens (AACCs) or EPA Region 9 Preliminary Remediation Goals (PRGs)

Results from the Screening Level Ecological Risk Assessment (SLERA) indicate that soil concentrations for all contaminants except 1,3-dinitrobenzene were less than Ecologically Based Screening Levels (EBSLs) at the maximum impact location (immediately adjacent to the INTEC fenceline). However, average soil concentration for this contaminant in the INEEL area of major depositional impact were less than the EBSL. Actual impacts for this contaminant (and all the PICs evaluated in this SLRA) will be significantly less because their emission rates were conservatively calculated based on 100\% of unburned fuel precursors (e.g. benzene) forming this single PIC.

New emissions testing is planned for the NWCF in an Off gas Demonstration Project (ODP) during the period of January through April, 1999. The results of the ODP, which are estimated to be available by the end of June 1999 , will be used to determine whether the COPC emission rates evaluated in this SLRA conservatively bound the impacts from NWCF operations. If the ODP results show that actual emissions are higher than those evaluated in the SLRA, or if significant additional COPCs are detected, then DOE may decide to further revise this SLRA. This decision will also be based on the results of the Idaho High Level Waste Environmental Impact Statement (HLWEIS) which will determine whether or not the NWCF will be operated in the future. If a decision is made to restart the NWCF, then the SLRA may be further revised using the COPC emission rates determined in the ODP and new risk assessment guidance published in the HHRAP. The HLWEIS decision on the future of the NWCF is scheduled to be made by June 1, 2000 . 
Table ES-1. Summary of cancer risk estimates for SLRA.

Total Excess Cancer Risk EPA screening criterion is 1E-05

\begin{tabular}{llll} 
& \multicolumn{1}{c}{ Direct } & \multicolumn{1}{c}{ Indirect $^{\mathrm{a}}$} & \multicolumn{1}{c}{ Total $^{\mathrm{b}}$} \\
\cline { 2 - 4 } All chemicals & $2 \mathrm{E}-07$ & $3 \mathrm{E}-08$ & $2 \mathrm{E}-07$ \\
Worst metal & $2 \mathrm{E}-12$ (beryllium) & $3 \mathrm{E}-14$ (beryllium) & \\
Worst non-metal & $2 \mathrm{E}-07^{\mathrm{c}}$ (pentachloronitrobenzene- & $2 \mathrm{E}-08$ (benzo(a)pyrene) \\
& $\mathrm{PIC})$ & & \\
$2,3,7,8-\mathrm{TCDD}$ & $2 \mathrm{E}-16$ & $3 \mathrm{E}-08$ & \\
Radionuclides & $7 \mathrm{E}-09$ & $1 \mathrm{E}-06$ & $1 \mathrm{E}-06$
\end{tabular}

a. Highest value from the following six exposure scenarios: subsistence farmer, subsistence farmer child, adult resident, child resident, onsite worker, and onsite herdsman.

b. Because of the differences in environmental modeling methodologies and the basis for risk factors, cancer risk from radionuclides and non-radioactive contaminants are reported separately.

c. Estimate is very conservative because it assumes that $100 \%$ of the nitroaromatic PICs from the burning of the fuel forms this one compound.

Table ES-2. Summary of noncarcinogenic hazard index estimates for SLRA.

\begin{tabular}{|c|c|c|c|}
\hline & \multicolumn{3}{|c|}{ Hazard Index EPA screening criterion is $\mathbf{0 . 2 5}$} \\
\hline & Direct & Indirect $^{\mathrm{a}}$ & Total \\
\hline All chemicals & 0.09 & 0.01 & 0.10 \\
\hline Worst metal & 0.0003 (mercury) & 0.0003 (mercury) & \\
\hline Worst non-metal & $0.09^{\mathrm{b}}(1,3$-dinitrobenzene-PIC $)$ & $0.01^{\mathrm{b}}$ (1,3-dinitrobenzene-PIC) & \\
\hline Liver & $\begin{array}{l}0.0002^{b} \\
\text { pentachloronitrobenzene-PIC }\end{array}$ & $\begin{array}{l}0.00000005^{b} \\
\text { (pentachloronitrobenzene-PIC) }\end{array}$ & \\
\hline Neurotoxin & $0.009^{\mathrm{b}}$ (2,4-dinitrotoluene-PIC) & $0.005^{\mathrm{b}}$ (2,6-dinitrotoluene-PIC) & \\
\hline \multicolumn{4}{|c|}{$\begin{array}{l}\text { a. . Highest value from the following six exposure scenarios: subsistence farmer, subsistence farmer child, adult resident, } \\
\text { child resident, onsite worker, and onsite herdsman. }\end{array}$} \\
\hline $\begin{array}{l}\text { b. Estin } \\
\text { this one }\end{array}$ & ative because it assumes that $100 \%$ & nitroaromatic PICs from the burnir & ue \\
\hline
\end{tabular}




\section{CONTENTS}

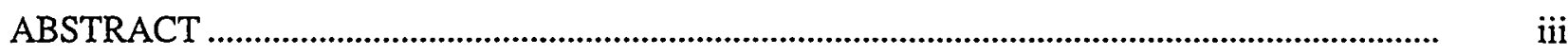

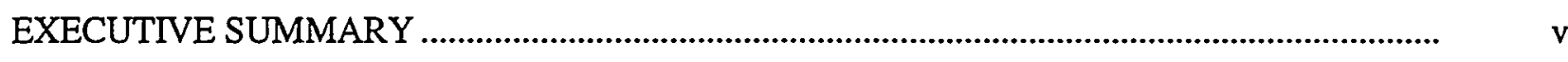

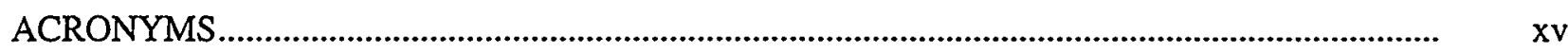

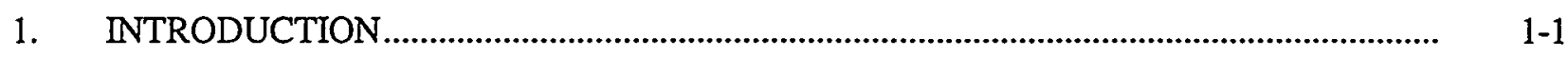

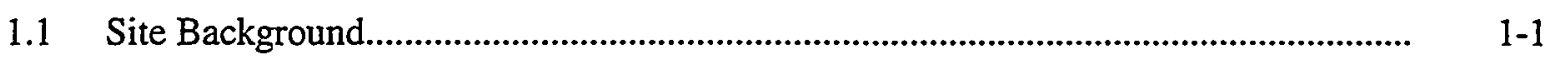

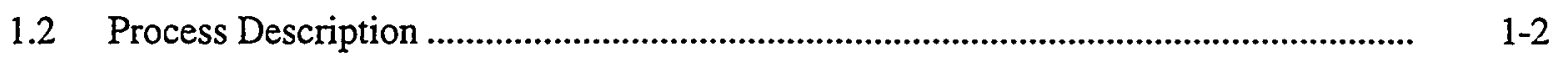

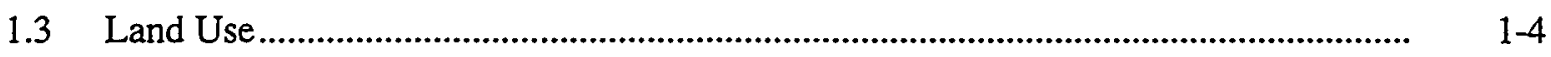

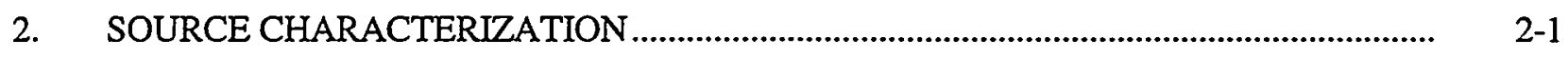

$2.1 \quad$ U.S. Environmental Protection Agency Guidance ............................................... 2-1

2.2 New Waste Calcining Facility Emissions Data ......................................................... 2-1

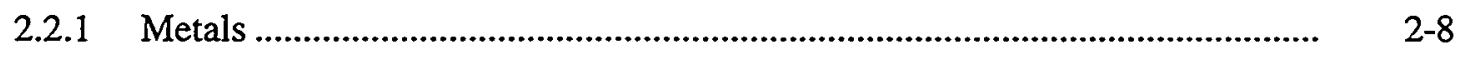

2.2.2 Acid/Combustion Gases and Vapors........................................................ 2-16

2.2.3 Emissions from Organic Compounds in the Feed ........................................ 2-20

2.2.4 Products of Incomplete Combustion ............................................................... 2-20

2.2.5 Process Upset Conditions .................................................................. 2-25

3. AIR DISPERSION AND DEPOSITION MODELING ............................................

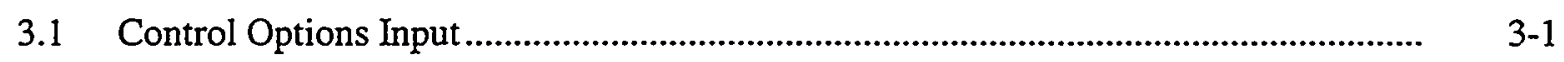

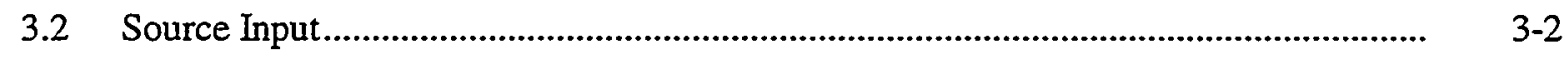

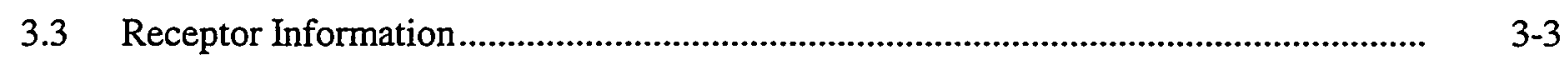

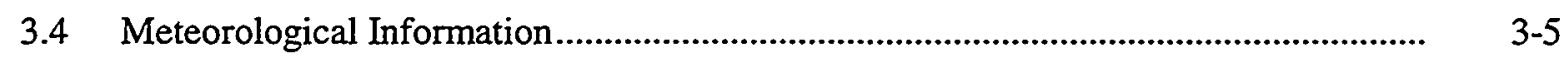

3.5 Modeling Results .........................................................................................

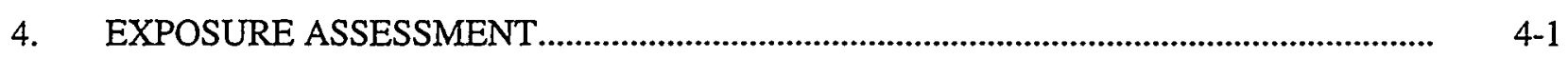

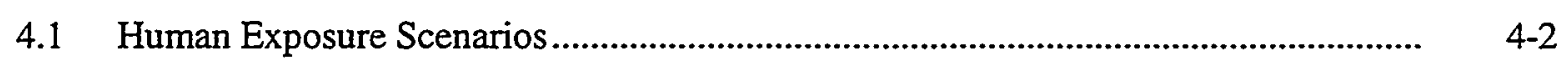

4.1.1 Subsistence Farmer and Onsite Herdsman .................................................. 4-3

4.1.2 Adult Resident .....................................................................................

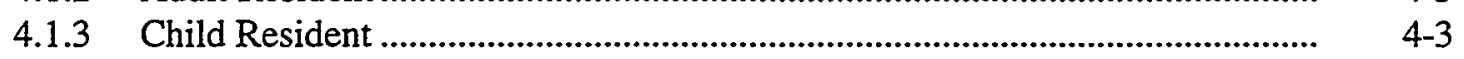

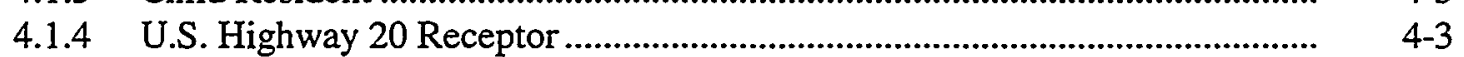

4.1.5 Onsite Worker......................................................................................... 4-3

4.1.5 Subsistence Farmer Child.......................................................................... $4-4$ 
4.2 Exposure Pathways

4.2.1 Aboveground Produce Exposure Route .

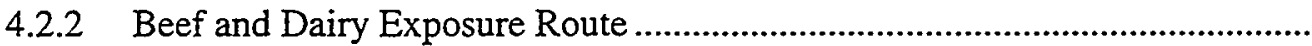

4.2.3 Soil Exposure Route

4.2.4 Air Exposure Route

5. TOXICITY ASSESSMENT

6. RISK CHARACTERIZATION

6.1 Direct Inhalation Exposures

6.2 Indirect Exposures

6.3 Lead

6.4 Radionuclides

6.4 Human Health Impacts-Conclusions

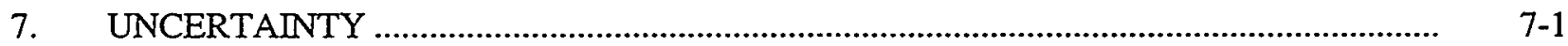

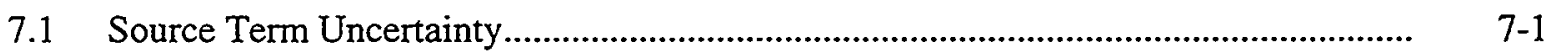

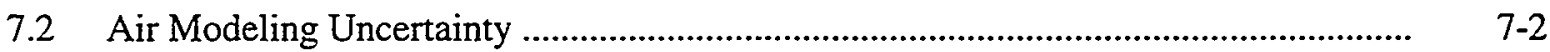

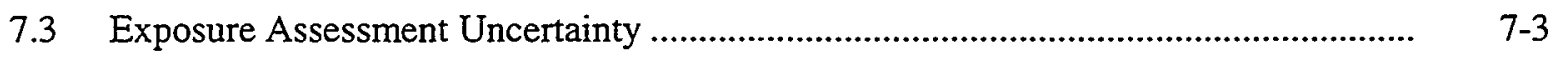

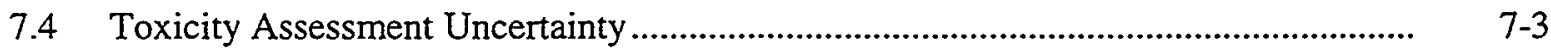

8. NWCF SCREENING LEVEL ECOLOGICAL RISK ASSESSMENT (SLERA) ................

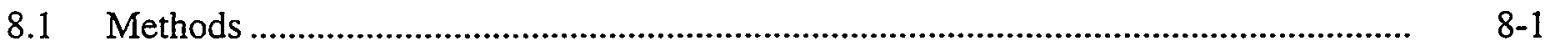

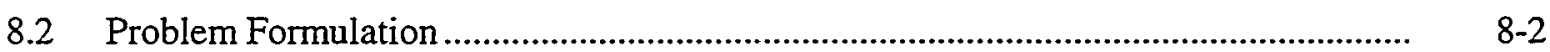

8.2.1 Contamination Extent and Concentration ................................................ 8-2

8.2.2 Ecosystem Characterization ..................................................................

8.2.3 Pathways of Contaminant Migration and Exposure ........................................ 8-13

8.2.4 Conceptual Site Model ............................................................................... 8 $\quad 8$

8.2.5 Assessment Endpoints ....................................................................... 8-13

8.2.6 Measurement Endpoint Selection.................................................................. 8-17

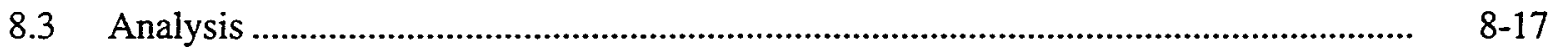

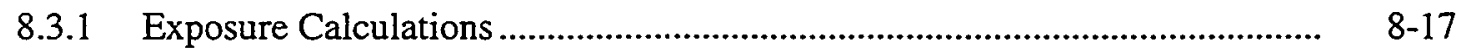

8.3.2 Ecological Effects Assessment .......................................................... 8-27

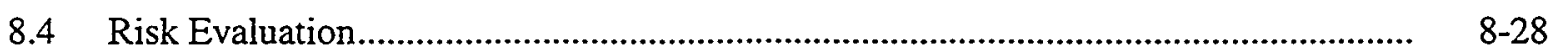


8.4.1 EBSL Screening

8.4.2 Comparison of INEEL Approach and Methods to ATG ................................. 8-28

8.4.3 Discussion of Uncertainty ....................................................................... $\quad 8-32$

8.4.4 NWCF SLERA Summary and Results ....................................................... 8-38

9. REFERENCES.

Appendix A-Chemical Emission Rates and Chemical Ambient Air Concentrations

Appendix B-Chemical Specific Inputs and Chemical Media Concentrations for Evaluation of all Receptors

Appendix C-Exposure Calculations for Subsistence Farmer

Appendix D-Exposure Calculations for Adult Resident

Appendix E-Exposure Calculations for Child Resident

Appendix F-Risk Characterization Calculations

Appendix G-WAG 5 Fauna and Functional Groups

Appendix H-Revised Responses to Technical Review Comments for the Screening Level Risk Assessment (SLRA) for the New Waste Calcining Facility

\section{FIGURES}

1. Map of the INEEL showing the location of the Idaho Nuclear Technology and Engineering Center (INTEC, formerly ICPP).

2. Partial plot plan of the Idaho Nuclear Technology and Engineering Center showing the New Waste Calcining Facility (CPP-659) and the Main Stack (CPP-708)

3. Schematic diagram of the New Waste Calcining Facility process and off-gas

treatment system.

4. Simplified flow diagram of the liquid, solid, and offgas systems at INTEC

5. The 50-km polar receptor grid (1,152 receptors) initially evaluated in the modeling. Modeling results from this grid were used to determine regional dispersion and deposition trends and to develop refined receptor grids in areas of maximum impact.

6. The two refined (100-m interval) receptor grids evaluated in offsite areas of maximum impact (South INEEL boundary and Big Southern Butte)

7. Discrete (100-m interval) receptors placed along major impact areas on U.S. Highway 20 (every other receptor is shown). 
8. The maximum vapor air concentration $\left(0.062 \mu \mathrm{g} / \mathrm{m}^{3}\right)$ occurred on the north end of the Big Southern Butte refined modeling grid. The maximum vapor wet deposition (3.7E-04 $\mathrm{g} / \mathrm{m}^{2}$-year per $\mathrm{g} /$ second) occurred in the same area.

9. The maximum particulate total deposition rate $\left(6.9 \mathrm{E}-04 \mathrm{~g} / \mathrm{m}^{2}\right.$-year) occurred on the north end of the Big Southern Butte refined modeling grid. The maximum particulate air concentration $\left(0.062 \mu \mathrm{g} / \mathrm{m}^{3}\right)$ occurred in the same area.

10. In addition to initial screening using the maximum soil concentration (located adjacent to the INTEC fence line), ecological impacts were also evaluated using an "impact area-averaged" soil concentration which was determined by integrating the areal deposition rate $\left(\mathrm{g} / \mathrm{m}^{2} / \mathrm{y}\right)$ within the $5 \%$ of maximum deposition rate isopleth and then dividing by the area encompassed by that isopleth

11. Soil types in the NWCF assessment area.

12. Vegetation cover types in the NWCF assessment area

13. Ecological pathways/exposure model for NWCF surface soil contamination

14. NWCF ecological conceptual site model

\section{TABLES}

1. Chemicals recommended for identification by EPA guidance (EPA 1994b)..

2. Estimated decontamination factors (DFs) for volatile and semi-volatile metal species in the NWCF offgas

3. Metal emission rates developed for the NWCF (calcium and auxilliary sources) (see Appendix A for detailed assumptions and calculations)

4. NWCF emissions of acid gases and organic constituents

5. Refined grid ISC3 modeling results

6. Exposure scenario consumption rates and fraction contaminated for the three major exposure scenarios specified in the EPA guidance (EPA 1994a)

7. Toxicity values for the oral route of exposure for the indirect pathway

8. Toxicity values and or health benchmarks for the inhalation route of exposure for the direct pathway

9. Cancer risk estimates for inhalation route of exposure at the INEEL boundary

10. Noncarcinogenic hazard quotient estimates for inhalation exposure at INEEL boundary .... 
11. Direct exposure (inhalation) hazard quotient and hazard index for chemicals with liver or neurotoxin effects.

12. Acute inhalation exposure to transient travelers on U.S. Highway 20

13. Indirect exposure excess cancer risk for the offsite scenarios

14. Indirect exposure hazard quotients for the offsite scenarios

15. Indirect exposure hazard quotient and hazard index for chemicals with liver or neurotoxin effects

16. Summary of cancer risk estimates for SLRA

17. Summary of noncarcinogenic hazard index estimates for SLRA

18. Surface soil concentrations ( $\mathrm{mg} / \mathrm{kg}$ ) from $\mathrm{NWCF}$ contaminant emissions. Concentrations are calculated from ISC3 modeled wet and dry deposition rates over an assumed 16 year NWCF operating period and a $1-\mathrm{cm}$ mixing depth, in accordance with combustion guidance soil equations.

19. Species composition for NWCF assessment area vegetation classes

20. Summary of vegetation in the NCWF assessment area .

21. Threatened and endangered species, species of concern, and sensitive species that may be found in the NCWF assessment area.

22. Summary of exposure media and ingestion routes for NWCF receptors

23. Summary of assessment endpoints for NWCF.

24. Summary of NWCF ERA endpoints.

25. NWCF EBSL parameter input values.

26. UFs and CFs for NWCF contaminants (unitless) used in EBSL calculations.

27. Parameter defaults and assumptions for EBSL calculations.

28. Screening of modeled concentrations ( $\mathrm{mg} / \mathrm{kg}$ ) to EBSLs for mammalian and avian receptors and other benchmarks (exceedence of benchmark is highlighted).

29. Comparison of plant, earthworm and soil microbe benchmarks to ATG values $(\mathrm{mg} / \mathrm{kg})$.......

30. Comparison of mammalian and avian toxicity values used at the INEEL to ATG values (1998).

31. Sources and effects of uncertainties in the ecological risk assessment 


\section{ACRONYMS}

AAC acceptable ambient concentrations for noncarcinogens

$\begin{array}{ll}\text { AACC } & \text { acceptable ambient concentrations for carcinogens } \\ \text { APCD } & \text { air pollution control device } \\ \text { APS } & \text { atmospheric protection system } \\ \text { CDD } & \text { chlorinated dibenzo-p-dioxin } \\ \text { CDF } & \text { chlorinated dibenzofuran } \\ \text { CSF } & \text { carcinogenic slope factor } \\ \text { DF } & \text { decontamination factors } \\ \text { DOE } & \text { U.S. Department of Energy } \\ \text { EBSL } & \text { ecologically based screening level } \\ \text { EPA } & \text { U.S. Environmental Protection Agency } \\ \text { ESRP } & \text { Eastern Snake River Plain } \\ \text { HEAST } & \text { Health Effects Assessment Summary Tables } \\ \text { HEPA } & \text { high-efficiency particulate air (filter) } \\ \text { HHRAP } & \text { Human Health Risk Assessment Protocol } \\ \text { HI } & \text { hazard index }\end{array}$

HLWEIS High Level Waste Environmental Impact Statement

HQ hazard quotient

ICPP Idaho Chemical Processing Plant

INTEC Idaho Nuclear Technology and Engineering Center (formerly ICPP)

IDHW Idaho Department of Health and Welfare

INEEL Idaho National Engineering and Environmental Laboratory

IRIS Integrated Risk Information System

MWC municipal waste combustor 


\begin{tabular}{ll} 
NAAQS & National Ambient Air Quality Standard \\
NESHAP & National Emission Standard for Hazardous Air Pollutants \\
NOAA & National Oceanic and Atmospheric Administration \\
NWCF & New Waste Calcining Facility \\
ODP & Off gas Demonstration Project \\
PAH & polycyclic aromatic hydrocarbon \\
PCB & polychlorinated biphenyl \\
PIC & product of incomplete combustion \\
PRG & Preliminary Remediation Goal (EPA Region 9) \\
RfC & reference concentration \\
RfD & reference dose \\
SLRA & screening level risk assessment \\
SLERA & screening level ecological risk assessment \\
TEQ & toxicity equivalent \\
TRV & toxicity reference value \\
UCL & upper confidence limit \\
URF & unit risk factor \\
\hline
\end{tabular}




\section{Screening Level Risk Assessment for the New Waste Calcining Facility}

\section{INTRODUCTION}

This screening level risk assessment (SLRA) evaluates potential adverse human health and environmental effects resulting from continued operations of the New Waste Calcining Facility (NWCF) at the Idaho Nuclear Technology and Engineering Center (INTEC), Idaho National Engineering and Environmental Laboratory (INEEL). Operations were restarted in June 1997 and are currently scheduled to continue through June 1, 2000. A decision on the future status of the NWCF will be made by June 1, 2000 in accordance with the Notice of Noncompliance Consent Order. This decision will be based on the Idaho High Level Waste Environmental Impact Statement (HLWEIS) which will be published in late 1999. For the purposes of this risk assessment, emissions are assumed to occur for 16 years (1997-2012). Completion of this SLRA was specified in the Second Modification (dated July 31, 1998) to the Notice of Noncompliance Consent Order signed January 29, 1990 between the Department of Energy (DOE) and the Idaho Department of Health and Welfare (IDHW).

This SLRA followed the screening procedure outlined in the U.S. Environmental Protection Agency (EPA) guidance document Guidance for Performing Screening Level Risk Analyses at Combustion Facilities Burning Hazardous Waste (EPA 1994a). Since submittal of Revision 3 of the SLRA in May 1998, the EPA published new draft risk assessment guidelines in Human Health Protocol for Hazardous Waste Combustion Facilities (EPA530-D-98-001A, July 1998) (HHRAP). Efforts were made in this revision to incorporate some of these new risk assessment methods. In addition, a quantitative screening level ecological risk assessment (SLERA) was performed (Section 8).

\subsection{Site Background}

The INEEL is located on the Eastern Snake River Plain (ESRP), a low-lying volcanic region of basalt lava beds within the rugged basin and range mountains of southern Idaho. The INEEL encompasses more than $2,305 \mathrm{~km}^{2}$, and aside from the INEEL buildings, the land is unincorporated and undeveloped desert terrain. The elevation of the ESRP is approximately $1,524 \mathrm{~m}$ above mean sea level (m.s.l.), with the surrounding mountains rising to about $3,657 \mathrm{~m}$ above mean sea level. General surface terrain on the INEEL is rolling to broken.

Average annual rainfall on the INEEL is light, $21.6 \mathrm{~cm}$, and the region is classified as arid to semiarid. The relatively dry air and infrequent low clouds permit intense solar heating of the surface during the day and rapid radiational cooling at night. These factors contribute to give a large diurnal range of temperature near the ground. The local northeast to southwest orientation of the ESRP and bordering mountain ranges tend to channel the prevailing westerly winds so that a wind coming from the southwest predominates over the INEEL. The second most frequent wind direction is from the northeast, which occurs mostly at night from mountain valley drainage.

The Big Lost River is the major surface water feature on the INEEL. Stream flows are often depleted by irrigation and infiltration losses before reaching the INEEL. Stream flow in the stretch of river near the INTEC is intermittent. During the period from 1965 to $1994,60 \%$ of the time no flow occurred. There are no recreational or consumptive uses of the water in this stretch.

The INTEC, which occupies a total of 59 hectares, is located in the south-central region of the INEEL, about $68 \mathrm{~km}$ west of Idaho Falls (Figure 1). The INTEC is $6 \mathrm{~km}$ from the nearest public 
highway, U.S. Highway 20 , and $13.6 \mathrm{~km}$ from the nearest INEEL boundary. The calciner is located in NWCF Building 659 within the INTEC fenced area (Figure 2).

\subsection{Process Description}

The main function of the calciner is to convert a liquid mixed radioactive-hazardous waste of variable composition - usually solutions of nitric acid, sodium nitrate and aluminum nitrate that are contaminated radionuclides and low concentrations of chloride, fluoride, hazardous metals-to a noncorrosive, relatively stable, dry solid material to render the waste easier to handle and store.

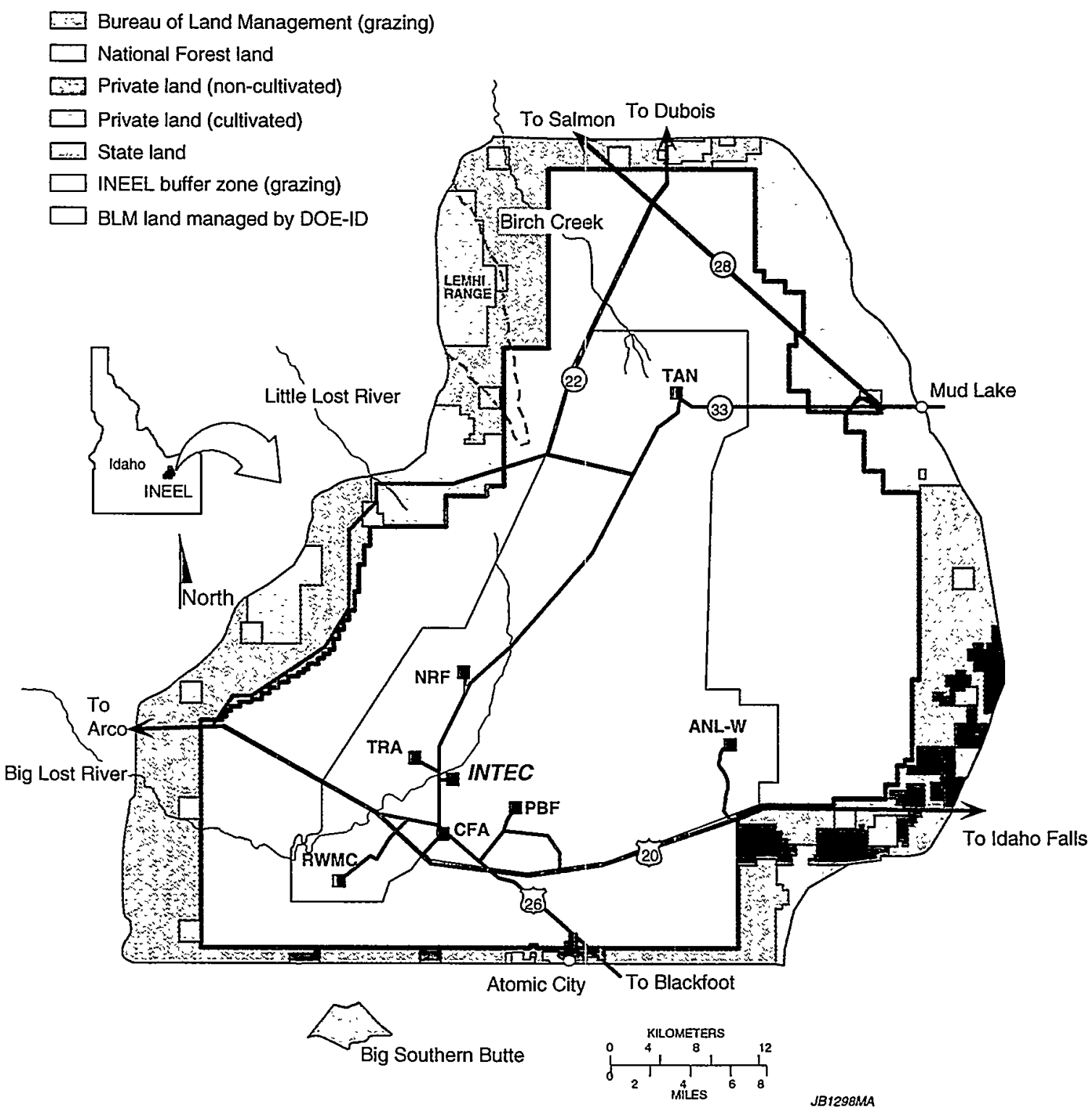

Figure 1. Map of the INEEL showing the location of the Idaho Nuclear Technology and Engineering Center (INTEC, formerly ICPP). 


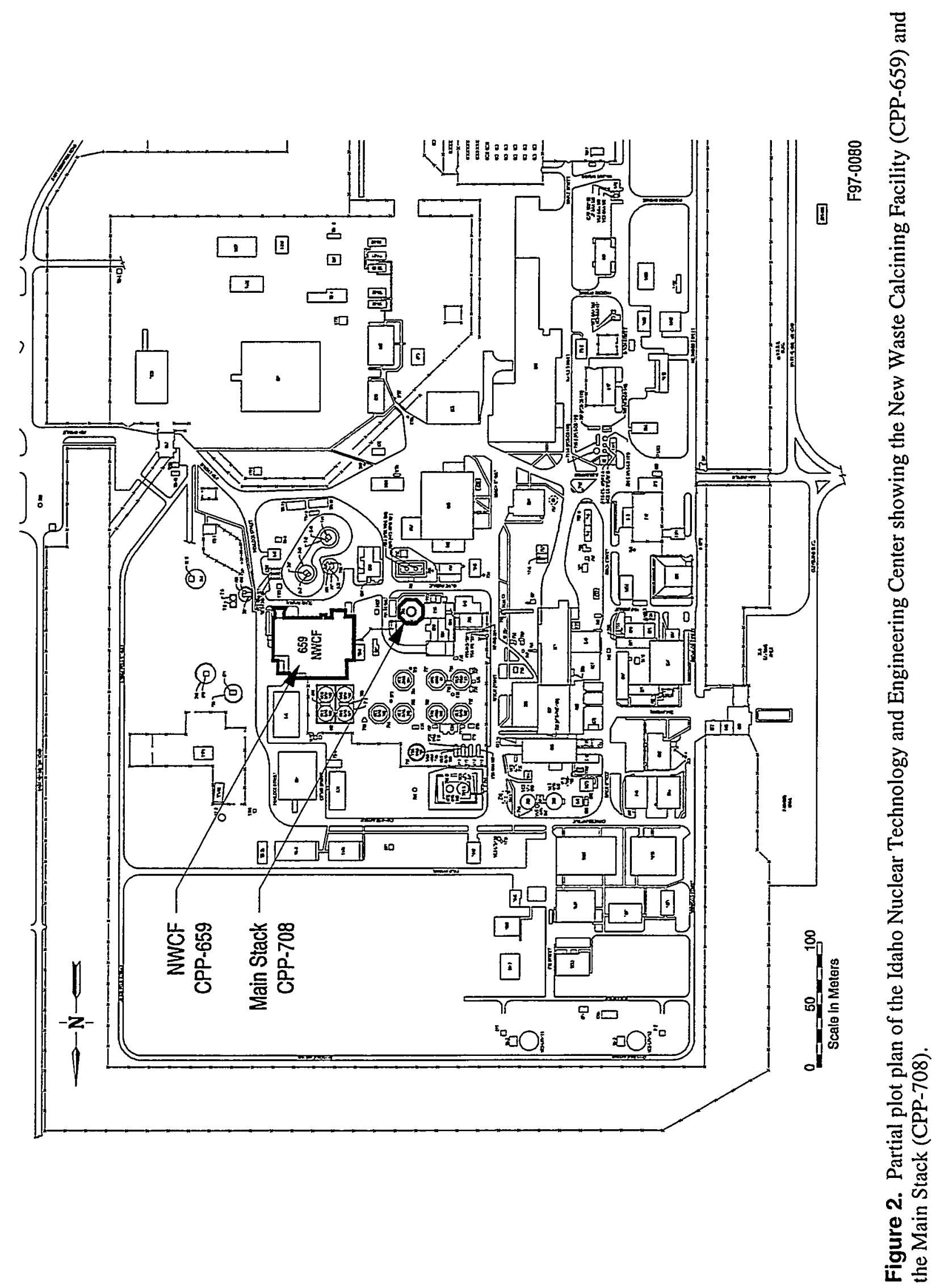


The calcination process involves spraying liquid radioactive mixed waste onto a heated fluidized bed of particles. Dissolved metals and fission products are converted to their salts and oxides through evaporation and solidification. The process removes water and decomposes acids. A detailed description of waste feed composition is given in Section 2 and Appendix A.

Waste solution feed is transferred from the Tank Farm facility to the calciner blend and hold tanks (Figure 3). Feed is then atomized by air and sprayed into a bed of heated spherical particles maintained at a temperature of approximately 500 to $600^{\circ} \mathrm{C}$. During calcination, the particle size is maintained large enough to prevent excessive carry over, yet small enough to provide good heat transfer within the bed and to minimize the quantity of air required for fluidization. The size range helps minimize the solids carryover in the off-gas yet provides sufficient fines material to furnish seed particles for maintaining a stable bed-particle growth cycle. The calciner product removed from the bed and the fines removed from the off-gas in the cyclone are pneumatically transferred to the Calcined Solids Storage Facilities (CSSFs). Process heat is provided by inbed combustion. Kerosene is atomized with oxygen and sprayed into the fluidized bed of particles. When the fuel contacts the bed, it autoignites.

A combination of dry and wet off-gas cleanup equipment is used to remove particulate as well as to cool the calciner off-gas (Figure 3). Most of the solids are removed by the high efficiency cyclone. Additional particulate removal occurs in a quench tower and in the venturi scrubber. Liquid droplets of scrub solution and dissolved solids are removed in a de-entrainment separator and a mist eliminator. Before passing through the final high efficiency particulate air (HEPA) filters, the off-gas passes through a mist collector and heater to prevent condensation of water vapor in the HEPA filter housings. The final filtration system for the process off-gas consists of one stage of HEPA prefilters and two stages of HEPA finish filters installed in series. After passing through the HEPA filters, the off-gas passes through the INTEC atmospheric protection system (APS) for an additional single-stage HEPA filtration, and then it is discharged to the atmosphere through the INTEC 250-ft-high Main Stack. The Main Stack off-gas is monitored for radionuclide particulates and $\mathrm{NO}_{\mathrm{x}}$.

\subsection{Land Use}

No resident human populations are located within the INEEL Site boundary. The nearest permanent residents reside in Atomic City (population 35) and Arco (population 1,094), located approximately $12 \mathrm{~km}$ southeast and $33 \mathrm{~km}$ west of INTEC, respectively. Other population centers in the vicinity of the INEEL include Idaho Falls (population 48,200), located $67 \mathrm{~km}$ east of the INEEL, and Blackfoot (population 9,931), located $66 \mathrm{~km}$ southeast of the INEEL. Nonresident human populations at the INEEL consist of workers and visitors at the various DOE facilities, stock herdsmen, and hunters.

Three major highways traverse the INEEL. U.S. Highway 20 crosses the southern portion of the INEEL and is the primary transportation route between Idaho Falls and Arco. U.S. Highway 26 connects Blackfoot with U.S. Highway 20. U.S. Highway $22 / 33$ bisects the northern portion of the INEEL, connecting the towns of Mud Lake and Howe. The nearest highway to the INTEC is U.S. Highway 20, approximately $6 \mathrm{~km}$ to the south.

Livestock grazing is permitted in areas along the perimeter of the INEEL. Livestock herders are likely to be present on the east and south grazing areas during the winter and to the west during the warmer months of the year. Grazing is not permitted north of U.S. Highway 20. Livestock populations are controlled, and dairy cattle are not allowed within the INEEL boundary. 


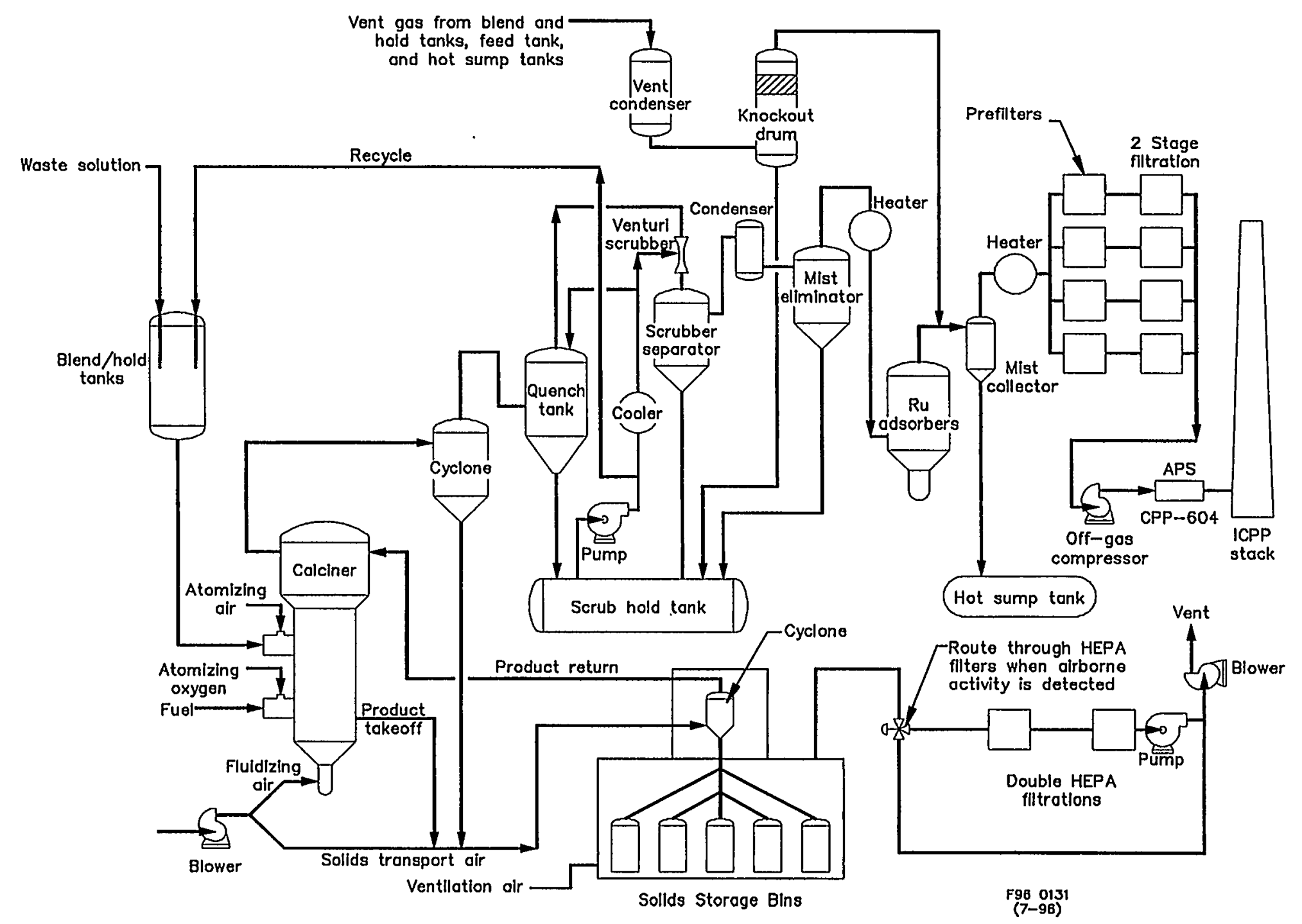

Figure 3. Schematic diagram of the New Waste Calcining Facility process and off-gas treatment system. 
In 1989, the DOE established an agreement with the Idaho Department of Fish and Game that allows controlled harvesting hunts of pronghorn antelope and elk in selected areas. The temporary hunting zone extends $0.8 \mathrm{~km}$ ( $1 / 2$ mile) inside the INEEL boundary. Most of the hunting occurs along portions of the northeast and northwest boundary lines (Figure 1). The game herds in both of these areas spend most of their time in areas that are not expected to be impacted by the NWCF plume. The area to the northeast is approximately $50 \mathrm{~km}$ from the NWCF, adjacent to farms west of Mud Lake. Hunting on the northwest boundary of the site occurs only in the southern terminus of the Lemhi Range, approximately $27 \mathrm{~km}$ north of the NWCF.

Other uses of the land are severely limited because of the climate, presence of lava flows, and general desert soil conditions on the INEEL. Because the INEEL is remotely located from most developed areas, INEEL lands and adjacent areas are not likely to experience residential and commercial development. No new development is planned near the INEEL Site (DOE-ID 1993). However, recreational and agricultural uses are expected to increase in the surrounding area in response to greater demand for recreational areas and the conversion of range land to crop land. 


\section{SOURCE CHARACTERIZATION}

Source characterization involves estimating emissions from the NWCF and identifying the chemicals to be evaluated in the SLRA. The following sections discuss the selection process for the contaminants of potential concern (COPCs) evaluated in the SLRA, and the process knowledge and analytical methods used to determine COPC emission rates.

\subsection{U.S. Environmental Protection Agency Guidance}

The EPA (1994b) has provided a table of 163 chemicals recommended for identification in the SLRA (Table 1). These chemicals and any acid gases produced in the combustion process should be evaluated for direct exposure (inhalation) impacts.

For indirect exposures, the screening guidance focuses on a subset of these constituents, 12 metals and the "critical organics" listed in Table 1, which have been judged to be of the greatest concern by routes of exposure other than direct inhalation alone (EPA 1994a). The critical organic chemicals include the following:

- Chlorinated dibenzo-p-dioxins (CDDs) and chlorinated dibenzofurans (CDFs)

- Polycyclic aromatic hydrocarbons (PAHs)

- $\quad$ Polychlorinated biphenyls (total PCBs)

- Nitroaromatics (five listed)

- $\quad$ Phthalates (two listed)

- Other chlorinated organics-hexachlorobenzene and pentachlorophenol.

The sources of these organic emissions include: (1) incinerator and combustor feed materials, (2) kerosene which is used as the fuel for the calciner, and (3) products of incomplete combustion (PICs). PICs are organic compounds not present in the feed or fuel, which are formed by thermal breakdown and recombination in the combustion chamber, or are formed downstream in air pollution control devices (APCDs).

\subsection{New Waste Calcining Facility Emissions Data}

The calciner is a significantly different operation than traditional incinerators that burn solid hazardous waste. The feed consists of a concentrated solution that is relatively high in acid $\left(\mathrm{HNO}_{3}, \mathrm{HCl}\right.$, and HF), contains dissolved metals and inorganic salts, and is relatively low in organic chemicals. The liquid feed is atomized and sprayed into a fluidized bed that is heated to a relatively low temperature of 500 to $600^{\circ} \mathrm{C}$ by combustion of kerosene fuel (at 25-30 gal/hour) and oxygen. When the liquid waste is sprayed into the calciner, the following occurs:

- Water is vaporized.

- Nitric acid and nitrates are decomposed to $\mathrm{NO}_{\mathbf{x}}$ (Schindler 1995). 
Table 1. Chemicals recommended for identification by EPA guidance (EPA 1994b).

\begin{tabular}{ll}
$\begin{array}{l}\text { Chemical Abstract } \\
\text { Service No. }\end{array}$ & \multicolumn{1}{c}{ Chemical } \\
\hline & Antimony \\
$7440-36-0$ & Arsenic \\
$7440-38-2$ & Barium \\
$7440-39-3$ & Beryllium \\
$7440-41-7$ & Cadmium \\
$7440-43-9$ & Chromium \\
$7440-47-3$ & Lead \\
$7439-2-1$ & Mercury \\
$7440-97-6$ & Nickel \\
$7440-02-0$ & Selenium \\
$7782-49-2$ & Silver \\
$7440-22-4$ & Thallium \\
$7440-28-0$ & Critical EPA organics (indirect pathway) \\
&
\end{tabular}

Dioxins and furans

TCDD, 2,3,7,8-

PeCDD, $1,2,3,7,8-$

$\mathrm{HxCDD}, 1,2,3,7,8-$

$\mathrm{HxCDD}, 1,2,3,4,7,8-$

HxCDD , 1,2,3,6,7,8-

$\mathrm{HxCDD}, 1,2,3,7,8,9-$

$\mathrm{HpCDD}, 1,2,3,4,6,7,8-$

OCDD

TCDF, 2,3,7,8-

PeCDF, 1,2,3,7,8-

PeCDF, 2,3,4,7,8-

$\mathrm{HxCDF}, 1,2,3,4,7,8-$

$\mathrm{HxCDF}, 1,2,3,6,7,8-$

$\mathrm{HxCDF}, 2,3,4,6,7,8$ -

HxCDF, 1,2,3,7,8,9-

HpCDF, 1,2,3,4,6,7,8- 
Table 1. (continued).

Chemical Abstract

Service No.

Chemical

$\mathrm{HpCDF}, 1,2,3,4,7,8,9-$

$\mathrm{OCDF}$

\section{2,3,7,8 TCDD TEQ}

Polycyclic aromatic hydrocarbons (PAHs)

$56-55-3$

Benzo (a) anthracene (BAA)

205-99-2

Benzo (b) fluoranthene (BBF)

Benzo (k) fluoranthene (BKF)

$50-32-8$

Benzo (a) pyrene (BAP)

218-01-9

Chrysene (CHY)

53-70-3

Dibenz (a,h) anthracene (DBA)

193-39-5

Indeno (1,2,3-cd)pyrene (IDP)

benzo(a)pyrene TEQ

Other critical organics

99-65-0

Dinitrobenzene, 1,3-

121-14-2

Dinitrotoluene, 2,4-

606-20-2

Dinitrotoluene, 2,6-

117-81-7

Bis(2-ethylhexyl)phthalate

117-84-0

Di(n)octyl phthlate

118-74-1

Hexachlorobenzene

98-95-3

Nitrobenzene

1336-36-3

PCBs (209 congeners)

82-68-8

Pentachloronitrobenzene

87-86-5

Pentachlorophenol

Acid gases

7647-01-0

Hydrogen chloride $(\mathrm{HCl})$

10102-44-0

Nitrogen dioxide $\left(\mathrm{NO}_{2}\right)$

7664-39-3

Hydrogen fluoride (HF)

7446-09-5

Sulfur dioxide $\left(\mathrm{SO}_{2}\right)$

\section{Others on EPA primary list}

75-07-0

Acetaldehyde

98-86-2

Acetophenone 
Table 1. (continued).

Chemical Abstract

Service No.

Chemical

107-02-8

Acrolein

107-13-1

Acrylonitrile

120-12-7

Anthracene

100-52-7

Benzaldehyde

71-43-2

Benzene

Benzo (j) fluoranthene

Benzo $(g, h)$ perylene

Benzo (e) pyrene

96-07-7

Benzotrichloride

$100-44-7$

Benzyl chloride

$92-52-4$

Biphenyl

111-91-1

Bis(2-chloroethoxy)methane

74-97-5

Bromochloromethane

75-27-4

Bromodichloromethane

590-60-2

Bromoethene

75-25-2

Bromoform

74-83-9

Bromomethane

106-99-0

Butadiene, 1,3-

85-68-7

Butylbenzyl phthalate

56-23-5

Carbon tetrachloride

57-74-9

Chlordane

532-27-4

Chloroacetophenone, 2-

106-47-8

Chloroaniline, $\mathrm{p}$ -

106-90-7

Chlorobenzene

510-15-6

Chlorobenzilate

67-66-3

Chloroform

74-87-3

Chloromethane

91-58-7

Chloronaphthalene, B-

95-57-8

Chlorophenol, 2-

75-29-6

1319-77-3

Chloropropane, 2-

Cresol, m-

1319-77-3

Cresol, o-, (Methylphenol, 2-) 
Table 1. (continued).

Chemical Abstract

Service No.

Chemical

1319-77-4

4170-30-3

94-75-7

3547-04-4

96-12-8

84-74-2

95-50-1

95-50-1

106-46-7

764-41-0

764-41-0

75-71-8

107-06-2

75-35-4

156-80-5

120-83-2

542-75-6

542-75-6

84-66-2

105-67-9

131-11-3

119-90-4

528-29-0

100-25-4

123-39-1

$100-41-4$

106-93-4

75-21-8

96-45-7

75-34-3

206-44-0

50-00-0
Cresol, p-

Crotonaldehyde

2,4-D

DDE

Dibromo-3-chloropropane, 1,2-

Dibutyl phthalate

Dichlorobenzene, 1,2-

Dichlorobenzene, 1,3-

Dichlorobenzene, 1,4

Dichloro-2-butene, (cis) 1,4-

Dichloro-2-butene, (trans) 1,4-

Dichlorodifluoromethane

Dichloroethane, 1,2-

Dichloroethylene, 1,1-

Dichloroethylene, (trans) 1,2-

Dichlorophenol, 2,4-

Dichloropropene, (cis) 1,3-

Dichloropropene, (trans) 1,3-

Diethyl phthalate

Dimethylphenol, 2,4-

Dimethyl phthalate

Dimethoxybenzidine, 3,3-

Dinitrobenzene, o-

Dinitrobenzene, $\mathrm{p}$ -

Dioxane, 1,4-

Ethylbenzene

Ethylene dibromide

Ethylene oxide

Ethylene thiourea

Ethylidene dichloride (1,1-dichloroethane)

Fluoranthene

Formaldehyde 
Table 1. (continued).

Chemical Abstract

Service No.

Chemical

$76-44-8$

Heptachlor

$87-68-3$

Hexachlorobutadine

$319-84-6$

Hexachlorocyclohexane, alpha ( $\alpha$-Lindane)

319-85-7

Hexachlorocyclohexane, beta ( $\beta$-Lindane)

58-89-9

Hexachlorocyclohexane, gamma-

$77-47-4$

Hexachlorocyclopentadiene

$67-72-1$

Hexachloroethane

70-30-4

Hexachlorophene

110-54-3

Hexane, n-

123-33-1

Maleic hydrazide

72-43-5

Methoxychlor

$71-55-6$

Methyl chloroform

106-87-2

Methylcyclohexane

78-93-3

Methyl ethyl ketone

74-95-3

Methylene bromide

75-09-2

Methylene chloride

91-20-3

Naphthalene

88-74-4

Nitroaniline, o-

100-02-7

Nitrophenol, 4-

924-16-3

Nitroso di-n-butylamine, $\mathrm{N}$ -

608-93-5

Pentachlorobenzene

108-95-2

Phenol

75-44-5

Phosgene

123-36-6

Propionaldehyde

78-87-5

Propylene dichloride

91-22-5

Quinoline

$106-51-4$

Quinone

94-59-7

Safrole (5-(2-Propenyl)-1,3-benzodioxole)

$100-42-5$

Styrene

95-94-3

Tetrachlorobenzene, 1,2,4,5-

630-20-6

Tetrachloroethane, 1,1,1,2-

79-34-5

Tetrachloroethane, 1,1,2,2- 
Table 1. (continued).

Chemical Abstract

Service No.

Chemical

127-18-4

58-90-21

106-88-3

95-53-4

106-49-0

120-82-1

79-00-5

79-01-6

$75-69-4$

95-95-4

88-06-2

96-18-4

76-13-1

108-05-4

75-01-4

75-35-4

1330-20-7

1330-20-8

1330-20-9
Tetrachloroethylene

Tetrachlorophenol, 2,3,4,6-

Toluene

Toluidine, o-

Toluidine, $\mathrm{p}$ -

Trichlorobenzene, 1,2,4-

Trichloroethane, 1,1,2-

Trichloroethylene

Trichlorofluoromethane

Trichlorophenol, 2,4,5-

Trichlorophenol, 2,4,6-

Trichloropropane, 1,2,3-

Trichloro-1,2,2-trifluoroethane, 1,1,2-

Vinyl acetate

Vinyl chloride

Vinylidine chloride

xylene, m-dimethyl benzene

xylene, o-dimethyl benzene

xylene, p-dimethyl benzene

- Dissolved metals are converted to oxides, halides, and other stable solids that coat the existing solids.

- Some of the $\mathrm{HCl}$ and $\mathrm{HF}$ vaporize.

Upper-bound emissions estimates for current and future NWCF operations were developed based on a detailed examination of worst-case calciner waste feed (Tank Farm) compositions, maximum permitted annual and hourly feed volumes, and conservative APCD removal efficiencies. Appendix A contains detailed calculations for these emission rates. Four classes of chemicals are evaluated: metals, acid gases, trace organics in the feed solution, and PICs. 


\subsubsection{Metals}

Metal emissions have been shown to be the primary risk drivers from operation of hazardous waste incinerators and incineration on a national basis. Using data from eight full-scale incinerator tests, the EPA found that the risks from metal emissions ranged from two to six orders of magnitude higher than values for organic chemical emissions (Dempsey and Oppelt 1993). This would be especially true for the NWCF because of the low concentrations of organics in its feed compared to traditional incinerators that burn solid hazardous wastes that are relatively high in organics.

The major contaminants of concern for NWCF emissions are the 12 metals listed in the EPA guidance (Table 1) and uranium, which was added based on its relatively high concentration (121 mg/L) in Tank Farm feed. Emission rates were calculated based on (1) worst-case tank feed concentrations, (2) contingencies for unanalyzed tanks and concentration increases from return of semivolatile species in the scrub solution, and (3) conservative APCD decontamination factors (DFs) (ratio of the influent concentration to the effluent concentration in a particular APCD, calculated as the reciprocal of the contaminant penetration fraction).

2.2.1.1 Non-volatile Metals. Appendix A provides a detailed description of the methods and assumptions used to calculate metal emissions rates. For calciner emissions, the methods are summarized as follows:

1. For those metals analyzed in all tanks with retrievable waste $(\mathrm{Cd}, \mathrm{Cr}, \mathrm{Hg}, \mathrm{Pb}, \mathrm{Ni}$, and $\mathrm{U})$, the maximum measured concentrations were selected (Appendix A).

2. For those metals that have been analyzed and detected in only one or two tanks (Ag, As, Ba, and Se), the concentration in the empty WM-188 tank was also considered. The maximum value was selected and one standard deviation of the mean concentration was added to account for the tanks that were not sampled.

3. For metals which have not been detected in any of the waste tanks ( $\mathrm{Be}, \mathrm{Sb}$, and $\mathrm{Tl}$ ), one-half of the minimum detection limit was assumed.

4. Upper-bound tank farm inventories (total grams) were calculated by multiplying the selected maximum upper-limit feed concentration by the total net (with scrub solution) feed volume of $1,180,000$ gallons (which includes an additional $25 \%$ to account for future waste generation).

5. Total inventories were multiplied by APCD-specific DFs which were determined by measurements of a radioactive particulate $(\mathrm{Sr}-90)$ in the feed and offgas during operations in 1991, 1993, and 1997.

6. The annual emission rate was calculated by dividing the upper-bound tank farm inventory by either 7 years (1999-2005, the fastest calcining schedule) or 14 years (1999-2012, the more probable schedule). A 7-year averaging time was used for the noncarcinogenic metals ( $\mathrm{Ag}, \mathrm{Ba}, \mathrm{Hg}, \mathrm{Pb}, \mathrm{Se}, \mathrm{Sb}, \mathrm{Tl}, \mathrm{U}$ ) because it results in the highest possible annual emission rate which is appropriate for assessing potential short-term noncarcinogenic health effects. The 14-year averaging time was used for carcinogens because it results in the most likely long-term averaged emission rate and because the soil concentration equations used in the 
exposure assessment (Appendix B) assumed 16 years of deposition (assumed for earlier SLRA versions and not changed here).

Emissions of non-volatile metals are very small because of removal by four banks of HEPA filters. The HEPA filter DFs used to calculate emission rates for this version of the SLRA ( 900 for the NWCF filters and 300 for the APS filter) are "degraded" filter DFs which include the effects of NWCF upset conditions. These assumed DFs are significantly lower than those which are demonstrated after initial filter installation ( $1 E+07$ for the three NWCF HEPA filters and $3 E+03$ for the APS HEPA filter).

In addition to the HEPA filters, other APCDs in the initial section of the calciner consist of the calciner vessel, cyclone, quench tower, venturi scrubber, mist eliminator, and silica-gel absorbers (Figure 3). The combined DF for non-volatile metals through these systems was assumed to be 2,000 based on measured data from the predecessor of the NWCF, the Waste Calcining Facility, which had an off gas system similar to that of the NWCF. This value is conservative because some of the measurements indicated a much higher DF $(5,000-10,000)$. The total DF for the filters and the initial calciner APCDs is calculated by multiplying the individual APCD DFs, as follows (Appendix A):

\begin{tabular}{ll}
\multicolumn{1}{c}{ APCD } & \multicolumn{1}{c}{$\begin{array}{c}\text { DF } \\
\text { (nonvolatile metals) }\end{array}$} \\
cyclone, scrub system & 2000 \\
Absorbers & 1 \\
NWCF HEPAs (3) & 900 \\
APS HEPA (1) & 300 \\
Overall & $\mathbf{5 . 4 E + 8}$
\end{tabular}

The APCD removal efficiency corresponding to the DFs can be calculated using the following equation:

$$
D F=\frac{1}{(1-E F)^{n}}
$$

where:

$$
\begin{aligned}
& \mathrm{EF} \quad=\text { removal efficiency fraction for a particular device (e.g. HEPA) } \\
& \mathbf{n} \quad=\quad \text { number of devices in series. }
\end{aligned}
$$

Solving for EF gives

$$
E F=1-\sqrt[n]{1 / D F}
$$

For example, the DF value of 900 assumed for the three NWCF HEPA filters corresponds to an average removal efficiency of less than $90 \%$ per filter, which is a very conservative value. These HEPA filters are tested when initially installed to greater than $99.99999 \%$ removal efficiency for the entire bank. 
HEPA filters have a minimum removal efficiency at a particle diameter, which depends on particle size and shape, between 0.1 and 0.3 microns. HEPA filters are normally rated for a test aerosol approximating the most-penetrating particle size (e.g., 0.3 micron DOP particles). Both larger and smaller particle sizes are removed at a higher efficiency than the rated efficiency (Lieberman and Scott 1970).

The size of the particles in the NWCF effluent containing the metals cannot be measured because concentrations are too small to measure. The particle size distribution expected to be discharging from a series of HEPA filters centers on the particle size for which the filters are least efficient. For air modeling purposes, particle sizes were calculated from published emissions data from medical waste incinerators and penetration through three HEPA filters (see Section 3).

Limited stack sampling was done in 1993 for some of the metals (see Table 3 and Appendix A, Table A-1). These data were not used for this SLRA because most of the analytical results were less than detection limits. The exception was mercury which showed a $0.5 \%$ feed-to-offgas emissions factor during the 1993 sampling. More recent and longer term sampling results from activated carbon filters during 1997-1998 calcining campaign indicated higher (3\%) mercury emissions which were used to develop the emission rates in the SLRA (see Mercury section below).

Other low-toxicity non-volatile metals (e.g., zinc and copper) are present in some the waste. The aluminum species in the NWCF feed all become inert solids $\left(\mathrm{Al}_{2} \mathrm{O}_{3}\right.$ or $\left.\mathrm{NaAlO}_{2}\right)$ which are emitted only in small quantities. Copper and zinc are present in the waste only in trace concentrations (from their use in chemical analyses) and are likewise emitted only as solids. The trace emissions of all these non-volatile metals are then subject to removal by the four banks of HEPA filters.

2.2.1.2 Mercury. Mercury emissions from the NWCF are a major concern because of the large inventory of mercury in the waste tanks ( $5700 \mathrm{lbs}$ ), it relatively high volatility, and because of concerns about its effects on human health and the environment. Based on sample measurements made during the 1997-1998 calcining operation, approximately $87 \%$ of the $\mathrm{Hg}$ fed to the calciner was captured in the scrub solution. Offgas samples indicated that approximately $3 \%$ of the $\mathrm{Hg}$ was released out the stack (see discussion below). The remaining $10 \%$ was either retained in the calcined solids, collected by the silica-gel absorbers, or could be due to concentration and volume measurement errors.

The calcined solids consist of the bed solids, which are larger solids that remain in the fluidized bed, and fine solids ("fines"), which are blown out of the bed and collected by the cyclone. Both the accumulated bed solids and the fines collected in the cyclone are transferred to the calcined solids storage bins. The bed solids are sampled but there is not a sampling system for the fines. Analyses of the bed solids samples indicate that the bed solids contain about $0.3 \%$ of the Hg from the feed. However, pilot-plant data indicate that the fines contain 10 to 20 times as much $\mathrm{Hg}$ as the bed solids (because of their shorter residence times in the high-temperature zone). Similar Hg distributions in the NWCF would indicate 3 to $6 \%$ of the $\mathrm{Hg}$ from the feed being in the fines transferred to the bin sets. The silica-gel absorbers contain about $25 \mathrm{~m}^{3}$ of Si-gel which is a porous solid whose high surface area gives it a high capacity for adsorbable vapors (the absorbers are not designed for sampling). However, for conservatism, maximum ecological impacts (soil concentrations) were screened using $13 \%$ (factor increase of $13 / 3=4.3$ ) as an upper-bound estimate of the $\mathrm{Hg}$ emissions factor (see section 8 ).

The emission factor for $\mathrm{Hg}$ used in this evaluation is based on offgas samples taken with an activated carbon cartridge during the 1997-1998 NWCF operation. The activated carbon cartridges used to monitor the radioiodine emissions from the stack were also analyzed for their $\mathrm{Hg}$ content which was 
used to calculate emission as a fraction of the $\mathrm{Hg}$ in the net feed. Although used to measure radioiodine, these activated carbon filters are generally very efficient $(90 \%)$ for mercury or other higher molecular weight vapors (Dunham et al. 1998). The fractional $\mathrm{Hg}$ emissions, from 3 sample cartridges with sample durations of 2 to 4 months, averaged $2.55 \%$ of the $\mathrm{Hg}$ in the net feed with a standard deviation of $0.865 \%$. An upper-limit emission factor of $3.7 \%$ (or a feed-based DF of 27) is obtained by assuming an activated carbon collection efficiency of $90 \%$ and adding one standard deviation to cover process variations.

Some concern has been expressed that the Hg emissions determined using the activated carbon cartridges could be low because of $\mathrm{Hg}$ breakthrough in the activated carbon. The following evidence provides a reasonable basis for concluding that there was no breakthrough of $\mathrm{Hg}$ during the sampling period:

1. The average $\mathrm{Hg}$ concentrations on the activated carbon samples were 11 to $22 \mathrm{ppm}$ which is much less than the typical absorption capacity of these absorbents (4000 ppm) (Dunham et al. 1998). Breakthrough does not occur until the activated carbon approaches saturation.

2. The most likely form of $\mathrm{Hg}$ is $\mathrm{HgCl}_{2}$ which is readily sorbed by activated carbon at ambient temperature because of its low ambient vapor pressure $(0.022 \mathrm{~Pa}$ ) (compounds with low vapor pressures prefer the solid or liquid phase and are therefore more readily sorbed).

3. The analysts report that the Hg on the activated carbon was very non-uniform in distribution (requiring extensive mixing for aliquote replication) which indicates loading of the $\mathrm{Hg}$ on the front of the activated carbon. A saturated activated carbon sample would have a uniform concentration at the saturation level.

4. The stack samples taken during 1993 NWCF operation using an EPA sample train (40CFR266, App. IX) showed Hg emissions averaging $0.5 \%$ of the $\mathrm{Hg}$ in the feed, which is a factor of five lower than obtained in 1997-1998 with the activated carbon sampler.

5. The sample interval for the three samples taken with the activated carbon varied. One sample spanned 2 months and the other two samples spanned 4 months. If breakthrough were occurring, the sample with the shorter span would show a higher measured offgas $\mathrm{Hg}$ concentration. Instead, the sample of shorter duration showed an offgas $\mathrm{Hg}$ concentration in between those of the longer samples.

2.2.1.3 Other Volatile/Semivolatile Metals. In addition to $\mathrm{HgCl}_{2}$, the following volatile and semivolatile metal species could be formed in the calciner: $\mathrm{PbCl}_{2}, \mathrm{Sb}_{4} \mathrm{O}_{6}, \mathrm{SbCl}_{3}, \mathrm{TlCl}, \mathrm{SeO}_{2}$, and $\mathrm{BeCl}_{2}$. Conservative emission rates for these species were calculated based on thermochemical calculations and conservative assumptions for scrubber removal (Appendix A). The conclusions of these calculations are:

1. Less than $10 \%$ of $\mathrm{Pb}, \mathrm{Be}$, and $\mathrm{Tl}$ are present in the offgas as volatile or semi-volatile chloride species. The remaining $(>90 \%)$ exist as non-volatile oxide species that are removed by the filters.

2. Most of the $\mathrm{Sb}$ and all of the Se are present as volatile or semi-volatile species $\left(\mathrm{Sb}_{4} \mathrm{O}_{6}\right.$, $\mathrm{SbCl}_{3}, \mathrm{SeO}_{2}$ ). 
3. $\mathrm{PbCl}_{2}$ and $\mathrm{Sb}_{4} \mathrm{O}_{6}$ are semi-volatile and may be partially captured by the filters. Since the filter DF for these semi-volatiles is unknown, their emission rates $(1 \mathrm{E}-4 \mathrm{~g} / \mathrm{hr}$ and $2.2 \mathrm{E}-4 \mathrm{~g} / \mathrm{hr}$, respectively) were conservatively calculated from the maximum possible mole flow rate of these vapors in the total NWCF offgas flow rate of $300 \mathrm{lb} \mathrm{mol} / \mathrm{hr}(2000 \mathrm{scfm})$.

4. Other volatile metal species were assumed to have no removal in the filters $(D F=1)$, but have the same tendency to accumulate in the scrub solution as $\mathrm{Hg}$. Therefore, a scrub system DF of 27 (the same DF as used for $\mathrm{Hg}$ ) was assumed based on their scrub solution solubility similar to $\mathrm{HgCl}_{2}$. Some of these species are likely to be more soluble than $\mathrm{HgCl}_{2}$ because of aqueous reactions. For the metals that partition between volatile and nonvolatile species $(\mathrm{Pb}, \mathrm{Be}$, and $\mathrm{Tl})$, a weighted $\mathrm{DF}(270)$ is calculated based on the percent that is nonvolatile and filterable $(90 \% \mathrm{DF}=2.7 \mathrm{E}+5)$ and the percent that is volatile (10\% DF $=27)$. Table 2 summarizes the decontamination factors used to develop the hazardous metal emission rates.

2.2.1.4 Emissions from Fugitive and Auxiliary Sources. Fugitive Emissions Sources are prevented by operating the INTEC processes, including the tank farm, under vacuum so that leakage is inward. The process equipment is located in cells whose exiting ventilation air is monitored for any increase in radioactivity to verify the absence of leakage from the process equipment.

Auxiliary Emission Sources. The calciner vessel offgas (flow rate $=1,300 \mathrm{scfm}$ ) contributes the vast majority of radionuclide, gas, chlorine, metals, and organic emissions to the main stack. Other gaseous waste streams which are intermittently vented to either the main stack or the APS include the (Figure 4):

1. Process Equipment Waste (PEW) evaporator

2. Liquid Effluent Treatment and Disposal facility (LET\&D)

3. NWCF Process Vessels (Appendix A, Figure 1)

4. WM-189 airlift pump (Appendix A, Figure 1)

5. High Level Liquid Waste Evaporator (HLLWE).

Of these only the NWCF process vessels are an integral part of the NWCF. The overall NWCF DF of 5.4E+08 for non-volatile metal emissions includes the emissions from the NWCF process vessels, the PEW evaporator, and LET\&D because the DF was developed from stack measurements made when all of these systems were operating. 
Table 2. Estimated decontamination factors (DFs) for volatile and semi-volatile metal species in the NWCF offgas.

\begin{tabular}{|c|c|c|c|c|c|}
\hline Compound & $\begin{array}{c}\text { Modeled } \\
\text { Percent }\end{array}$ & $\begin{array}{c}\text { Scrubber } \\
\text { DF }\end{array}$ & $\begin{array}{c}\text { HEPA } \\
\text { filters } D F\end{array}$ & $\begin{array}{l}\text { Overall DF or } \\
\text { emission rate }\end{array}$ & $\begin{array}{c}\text { Weighted } \\
\text { overall DF or } \\
\text { emission rate }\end{array}$ \\
\hline $\mathrm{HgCl}_{2}$ (volatile) & 100 & 27 & 1 & 27 & 27 \\
\hline $\mathrm{SeO}_{2}$ (volatile) & 100 & 27 & 1 & 27 & 27 \\
\hline $\begin{array}{l}\mathrm{Sb}_{4} \mathrm{O}_{6} \text { (volatile) } \\
\mathrm{SbCl}_{3} \text { (volatile) }\end{array}$ & $\begin{array}{l}99.9 \\
<0.01\end{array}$ & $\begin{array}{l}27 \\
27\end{array}$ & $\begin{array}{l}1 \\
1\end{array}$ & $\begin{array}{l}1 \\
27\end{array}$ & $2.2 \mathrm{E}-4 \mathrm{~g} / \mathrm{hr}^{\mathrm{a}}$ \\
\hline $\mathrm{Na}_{3} \mathrm{AsO}_{4}$ & 100 & 2000 & $2.7 \mathrm{E}+5$ & $5.4 \mathrm{E}+8$ & $5.4 \mathrm{E}+8$ \\
\hline $\begin{array}{l}\mathrm{PbO} \\
\mathrm{PbCl}_{2} \text { (volatile) }\end{array}$ & $\begin{array}{l}90 \\
10\end{array}$ & $\begin{array}{r}2000 \\
27\end{array}$ & $\begin{array}{l}2.7 \mathrm{E}+5 \\
\mathrm{NA}\end{array}$ & $\begin{array}{l}5.4 \mathrm{E}+8 \\
\mathrm{NA}\end{array}$ & $1 \mathrm{E}-4 \mathrm{~g} / \mathrm{hr}^{\mathrm{a}}$ \\
\hline $\mathrm{CdO}$ & 100 & 2000 & $2.7 E+5$ & $5.4 \mathrm{E}+8$ & $5.4 \mathrm{E}+8$ \\
\hline $\mathrm{Ag}_{2} \mathrm{O}$ & 100 & 2000 & $2.7 E+5$ & $5.4 \mathrm{E}+8$ & $5.4 E+8$ \\
\hline $\mathrm{BaO}$ & 100 & 2000 & $2.7 E+5$ & $5.4 \mathrm{E}+8$ & $5.4 \mathrm{E}+8$ \\
\hline $\begin{array}{l}\mathrm{BeO} \\
\mathrm{BeCl}_{2} \text { (volatile) }\end{array}$ & $\begin{array}{l}90 \\
10\end{array}$ & $\begin{array}{r}2000 \\
27\end{array}$ & $\begin{array}{l}2.7 E+5 \\
1\end{array}$ & $\begin{array}{l}5.4 E+8 \\
27\end{array}$ & 270 \\
\hline $\mathrm{Na}_{2} \mathrm{CrO}_{4}$ & 100 & 2000 & $2.7 \mathrm{E}+5$ & $5.4 \mathrm{E}+8$ & $5.4 \mathrm{E}+8$ \\
\hline $\mathrm{NiO}$ & 100 & 2000 & $2.7 E+5$ & $5.4 \mathrm{E}+8$ & $5.4 \mathrm{E}+8$ \\
\hline $\begin{array}{l}\mathrm{Th}_{2} \mathrm{O} \\
\mathrm{ThCl} \text { (volatile) }\end{array}$ & $\begin{array}{l}90 \\
10\end{array}$ & $\begin{array}{r}2000 \\
27\end{array}$ & $\begin{array}{l}2.7 \mathrm{E}+5 \\
1\end{array}$ & $\begin{array}{l}5.4 \mathrm{E}+8 \\
27\end{array}$ & 270 \\
\hline
\end{tabular}




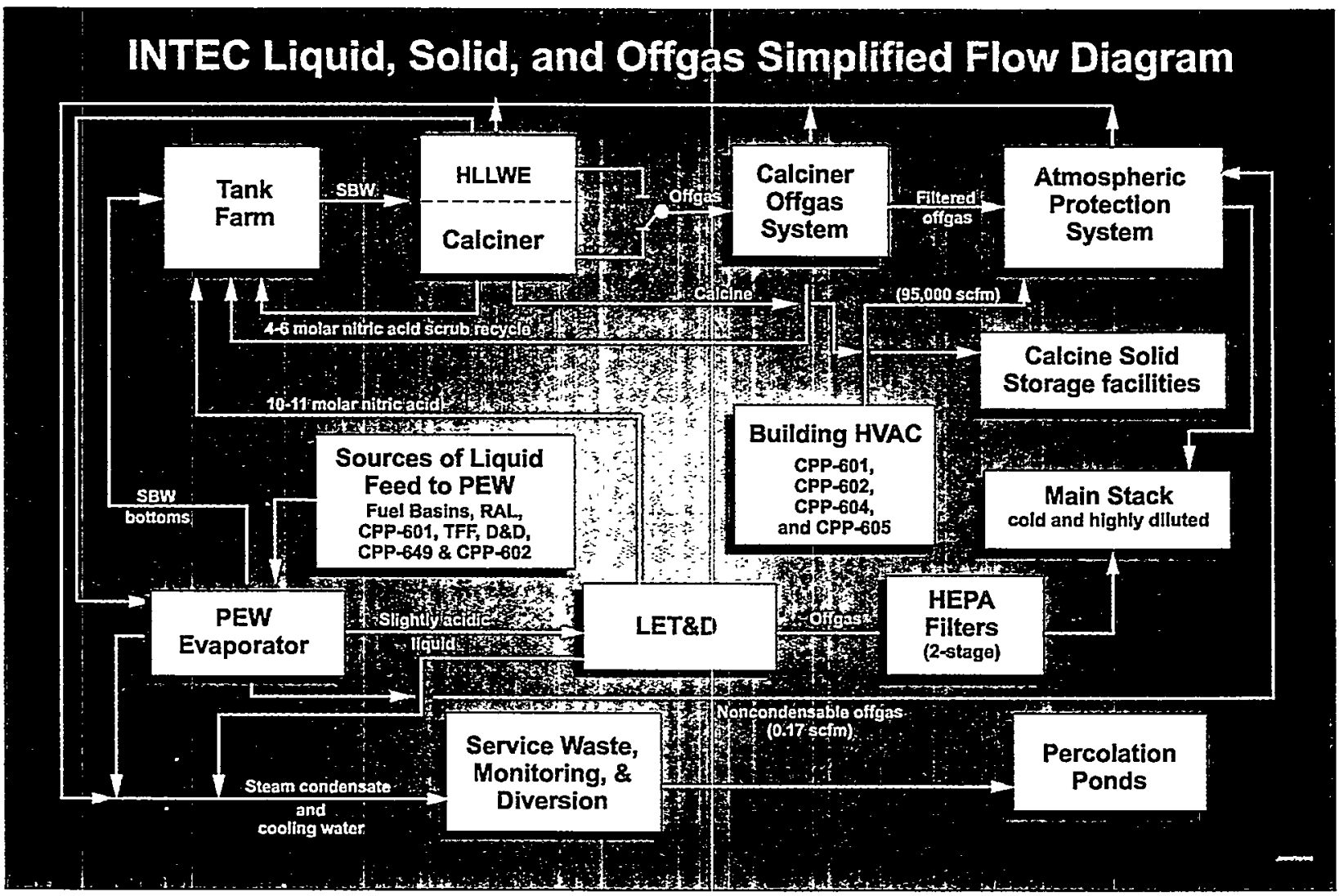

Figure 4. Simplified flow diagram of the liquid, solid, and offgas systems at INTEC. The yellow lines show waste streams that vent to the APS or main stack.

\subsection{PEW Evaporator and LET\& [1-The PEW evaporator and LET\&D are} independent of the NWCF, but they often operate at the same time as the NWCF and always operate in sequence. The PEW evaporator condensate is vaporized by the LET\&D, filtered ( 2 stages of HEPA filters) and then discharged to the main stack. The emission route for the two systems is the LET\&D vapor.

Non-volatile metal emissions from the LET\&D vapor are very low (at least a factor of a 1000 lower than from the NWCF) because the PEW is evaporated in series by the PEW evaporator and LET \&D (each of which have a DF for non-volatile solutes of 1000 to 10,000; Appendix A), and the vapor is then filtered through two HEPA filters in series. In addition, the concentrations of solutes in the PEW are about a factor of 100 lower than in the NWCF feed (Appendix A).

The only direct emission source from the PEW evaporator is a vent from the condenser to the APS (Figure 4). The vent discharges purge air from the instrument probes and air displaced by filling the Vessel Off Gas (VOG) system. Potential emissions from this vent are extremely small compared to those evaluated from the calciner because of the small flow rate (maximum of $0.17 \mathrm{scfm}$ or $0.009 \%$ of the calciner offgas), the low temperature, and because vapors are washed at the condenser outlet vent location. Therefore, no quantitative assessment of additional emissions from this vent were made. 
2.2.1.4.2 NWCF Process Vessels-The NWCF facility contains sparged feed-storage vessels, sump vessels, and air-lifts whose offgas bypasses the calciner and scrub system, and joins the calciner off gas before the filters. The emissions from these process vessels are included in the overall NWCF DF because the DF was developed from stack measurements made when all of these systems were operating. These systems are a minor fraction of the overall NWCF emissions because their gas flow rates and velocities are lower than in the NWCF scrub system.

The primary mechanism of particulate emission from the NWCF process vessels and airlifts is entrainment of liquid droplets by the sparge and airlift air. An entrainment study on evaporators (Appendix A) indicates that an entrainment factor of $1 \mathrm{E}-4 \mathrm{~kg}$ liquid $/ \mathrm{kg}$ gas is conservative for gas flows well in excess of the NWCF sparge rates of about $1 \mathrm{ft}^{3} / \mathrm{s}-\mathrm{ft}^{2}$. The total air input to the NWCF sparges and airlifts is $<100 \mathrm{scfm}$ which is $<214 \mathrm{~kg}$ air $/ \mathrm{hr}$. The maximum entrainment from the vessels and airlifts for this air input is $0.0214 \mathrm{~kg} / \mathrm{hr}$ (which is reduced greatly by the NWCF and APS filters before reaching the stack). The NWCF (maximum) feed rate of $778 \mathrm{~L} / \mathrm{hr}$ (with a density of $1.27 \mathrm{~kg} / \mathrm{L}$ ) is $988 \mathrm{~kg} / \mathrm{hr}$. The entrainment relative to the feed is 2.15E-05 which corresponds to a DF of 46,000 (before filtration).

2.2.1.4.3 WM-189 Air-lift-One active waste storage tank (WM-189) uses a 3-stage air-lift pump for liquid transfers. The air input, which is not metered, is estimated at a maximum of $300 \mathrm{scf} / \mathrm{min}$ which has a potential for substantial entrainment of particulate metals. Most of the air-lift motive air discharges to the VOG system which filters it through the (single-stage) VOG filter and the APS filter before discharging to the stack. A minor potion of the air goes with the liquid waste to the calcium vessel, where it is subject to treatment by the NWCF offgas system. The WM-189 airlift has an atmospheric emission only when being used to transfer liquid out of WM-189. The other (active) waste storage tanks use steam jets which have no effluent gases. The airlift pump was not operating during the time of the stack measurements which were the basis for the overall NWCF non-volatile metal DF $(5.4 E+8)$. Therefore, additional calculations were made to account for the potential increase in emissions from this source as follows:

The maximum relative entrainment from the airlift comes with the maximum air input of $300 \mathrm{scfm}$ $(640 \mathrm{~kg} / \mathrm{hr})$ and the minimum liquid flow of about $30 \mathrm{gpm}(130 \mathrm{~kg} / \mathrm{min})$. An entrainment factor of $5 \mathrm{E}-5 \mathrm{~kg}$ liquid $/ \mathrm{kg}$ air is used because of the long settling time and low air velocity in the tank. With this entrainment factor, the entrainment from the tank is $0.032 \mathrm{~kg} / \mathrm{hr}$ from the tank, and the relative entrainment is one part in 240,000 of the liquid transferred. The filter DF's for this analysis are 30 for the VOG filter (the same as for a single NWCF filter) and 300 for the APS filter. The overall particulate $\mathrm{DF}$ for the airlift filtered effluent is $2.2 \mathrm{E}+09$ as compared to $5.4 \mathrm{E}+08$ for the overall NWCF. For annual average emissions calculations, the airlift DF was adjusted to account for $33 \%$ maximum lifetime usage because WM-189 is the only active tank with an airlift. This airlift results in an annual average airlift pump DF of 6.7E+9:

$\frac{1}{\frac{1}{2.2 E+9}(0.33)}=6.7 E+9$

2.2.1.4.4 High Level Liquid Waste Evaporator-The High Level Liquid Waste Evaporator (HLLWE) uses the same feed and sump vessels as the NWCF, but is not a part of the NWCF. It does not operate at the same time as the NWCF because of conflicting needs for the same feed and sump vessels. Therefore, it does not contribute emissions to the main stack while the calciner is operating. The HLLWE emits entrained liquid drops from the sparged NWCF vessels it uses for the feed and product. As during NWCF operation, the vessel off gas discharges through the NWCF and APS 
filters. The emissions are about the same as estimated above for sparging the same vessels with NWCF operation-about $4 \%$ of the particulate emissions estimated for NWCF operation.

The HLLWE condensate is transferred to the PEW evaporator for reevaporation, and then vaporization and discharge from the LET\&D. The emissions via this route are very small because liquid discharged by this route goes through three stages of evaporation (each with particulate DF's of 1000 to 10,000 ) and two sets of HEPA filters (with a combined DF of about 1000) before discharge.

Another minor HLLWE emission route is the vent on the condenser which vents the HLLWE purge air and the air displaced by filling (Figure 4). The emissions from this vent are negligible compared to that calculated for the calciner and airlift pump because of the small purge air input (less than $10 \mathrm{scf} / \mathrm{hr}$ or $0.17 \mathrm{scfm}$ ), the lower temperature, and because the discharge route is via the NWCF and APS filters. Therefore, no quantitative assessment of additional emissions from this vent were made.

2.2.1.4.5 Combined Non-Volatile Metal Emissions for the NWCF and Auxiliary Systems - The overall NWCF DF of 5.4E+08 for non-volatile metals includes the emissions from the NWCF process vessels, the PEW evaporator, and the LET\&D because the DF was developed from stack measurements made when all of these systems were operating. The non-volatile metal emissions from the HLLWE and the PEW evaporator condenser vent were determined to be negligible. To account for potential increases in emissions from the WM-189 airlift pump (DF $=6.7 \mathrm{E}+9)$, the overall NWCF DF of $5.4 \mathrm{E}+8$ was reduced to $5 \mathrm{E}+8$ as follows:

$\frac{1}{\frac{1}{5.4 E+8}+\frac{1}{6.7 E+9}}=5 E+8$

2.2.1.4.6 Mercury Emissions from Auxiliary Systems-The NWCF Hg DF of 27 includes $\mathrm{Hg}$ emissions from the PEW evaporator, the LET\&D, and the NWCF process vessels because all of these systems were operating when the activated carbon filter samples were taken. Additional Hg emissions from the other auxiliary systems, WM-189 airlift pump, and the HLLWE) were calculated to be less than $0.1 \%$ that of the calciner (Appendix A). Therefore, no reduction in the overall $\mathrm{Hg} \mathrm{DF}$ (27) was made.

2.2.1.5 Estimation of Total Metal Emission Rates. A summary of metal emissions from the calciner and auxiliary systems associated with the NWCF is given in Table 3 . These calculated emission rates are compared to those determined during NWCF stack sampling in 1993 (Appendix A, Table A-1).

\subsubsection{Acid/Combustion Gases and Vapors}

Most of the materials emitted from calciner operations are acid and combustion gases-primarily $\mathrm{NO}_{x}$ and $\mathrm{CO}$ with smaller amounts of $\mathrm{HNO}_{3}, \mathrm{SO}_{2}, \mathrm{HCl}$, and $\mathrm{HF}$ (Table 4). These gases are evaluated in this SLRA for their direct (inhalation) impacts. A major constraint on the annual NWCF feed volume (and, therefore, other contaminant emission rates) is the Permit to Construct (PTC) annual $\mathrm{NO}_{\mathrm{x}}$ emission limit of 1,700 tons/year and short-term emission limit of $472 \mathrm{lb} /$ hour (NEL 1995). The NOx emissions from the main stack are monitored during NWCF operations, and the waste feed rate to the NWCF is controlled at a rate such that the measured NOx emission remains below the PTC permit limit. Most of this $\mathrm{NO}_{\mathrm{x}}$ is in the form of $\mathrm{NO}_{2}$ in the offgas. To be conservative, $100 \%$ of the $\mathrm{NO}_{\mathrm{x}}$ is assumed to be $\mathrm{NO}_{2}$. The basis for the emission rates in Table 4 is discussed in Appendix A. In this revision, $\mathrm{HCl}$ emissions were reduced based on: (1) upper-limit estimates of the maximum one-year chlorine feed, and (2) 
ASPEN model calculations which showed a maximum of $30 \%$ of the chlorine in the feed is discharged to the off gas (Appendix A). Emissions of acid or combustion gases from the auxiliary system, if any, would be negligible compared to those calculated for operation of the calciner.

Table 3. Metal emission rates developed for the NWCF (calciner and auxiliary sources) (see Appendix A for detailed assumptions and calculations).

\begin{tabular}{lccccc}
\hline & $\begin{array}{c}\text { Upper-Limit } \\
\text { Metal }\end{array}$ & $\begin{array}{c}\text { Combentory } \\
(\mathrm{g})\end{array}$ & $\begin{array}{c}\text { DF } \\
\text { for all }\end{array}$ & APCDs & \multicolumn{2}{c}{$\begin{array}{c}\text { Worst-case calculated } \\
\text { stack emission rate } \\
(\mathrm{g} / \mathrm{yr})\end{array}$} & $\begin{array}{c}\text { Stack Emission } \\
(\mathrm{g} / \mathrm{s})^{\mathrm{b}}\end{array}$ & $\begin{array}{c}\text { Rate from } \\
\text { Stack Sampling } \\
(\mathrm{g} / \mathrm{s})\end{array}$ \\
\hline Mercury (Hg) & $2.60 \mathrm{E}+06$ & 27 & $4.9 \mathrm{E}+04$ & $1.6 \mathrm{E}-03$ & $5.27 \mathrm{E}-04$ \\
Thallium (Tl) & $1.50 \mathrm{E}+04$ & 270 & 8 & $2.5 \mathrm{E}-07$ & $<1.97 \mathrm{E}-03$ \\
Selenium (Se) & $4.48 \mathrm{E}+03$ & 27 & 24 & $7.6 \mathrm{E}-07$ & $<1.97 \mathrm{E}-03$ \\
Antimony (Sb) & $5.50 \mathrm{E}+03$ & $2.2 \mathrm{E}-04^{\mathrm{d}}$ & 0.94 & $3.0 \mathrm{E}-08$ & $<1.97 \mathrm{E}-03$ \\
Lead $(\mathrm{Pb})$ & $1.30 \mathrm{E}+03$ & $1.0 \mathrm{E}-04^{\mathrm{d}}$ & 0.43 & $1.4 \mathrm{E}-08$ & $<1.69 \mathrm{E}-03$ \\
Berylium $(\mathrm{Be})$ & $1.80 \mathrm{E}+03$ & 270 & 0.5 & $1.6 \mathrm{E}-08$ & $<3.62 \mathrm{E}-06$ \\
Cadmium $(\mathrm{Cd})$ & $5.56 \mathrm{E}+03$ & $5 \mathrm{E}+08$ & $7.9 \mathrm{E}-04$ & $2.5 \mathrm{E}-11$ & $<1.23 \mathrm{E}-04$ \\
Chromium $(\mathrm{Cr})$ & $1.95 \mathrm{E}+06$ & $5 \mathrm{E}+08$ & $2.8 \mathrm{E}-04$ & $8.9 \mathrm{E}-12$ & $<1.69 \mathrm{E}-04$ \\
Nickel $(\mathrm{Ni})$ & $1.88 \mathrm{E}+06$ & $5 \mathrm{E}+08$ & $2.7 \mathrm{E}-04$ & $8.5 \mathrm{E}-12$ & $<3.62 \mathrm{E}-04$ \\
Uranium $(\mathrm{U})$ & $8.69 \mathrm{E}+05$ & $5 \mathrm{E}+08$ & $2.5 \mathrm{E}-04$ & $7.9 \mathrm{E}-12$ & Not sampled \\
Arsenic $(\mathrm{As})$ & $2.60 \mathrm{E}+05$ & $5 \mathrm{E}+08$ & $3.7 \mathrm{E}-05$ & $1.2 \mathrm{E}-12$ & $<3.16 \mathrm{E}-03$ \\
Barium $(\mathrm{Ba})$ & $7.62 \mathrm{E}+04$ & $5 \mathrm{E}+08$ & $2.2 \mathrm{E}-05$ & $7.0 \mathrm{E}-13$ & $<1.06 \mathrm{E}-04$ \\
Silver $(\mathrm{Ag})$ & $6.27 \mathrm{E}+04$ & $5 \mathrm{E}+08$ & $1.8 \mathrm{E}-05$ & $5.7 \mathrm{E}-13$ & $<9.28 \mathrm{E}-05$
\end{tabular}

a. Maximum concentration in any of the tanks times the total net waste volume $(1,180,000$ gal) without accounting for dilution by aluminum nitrate (required for proper calcining chemistry). $\mathrm{Be}, \mathrm{Sb}$, and $\mathrm{T}$ have not been detected; concentrations were assumed to be $1 / 2$ of the minimum detection limit. The $\mathrm{Hg}$ inventory is the total currently in the tank farm.

b. Upper-limit inventory divided by a minimum 7-year calcining schedule for non-carcinogens ( $\mathrm{Ag}, \mathrm{Ba}, \mathrm{Hg}, \mathrm{Pb}, \mathrm{Se}, \mathrm{Sb}, \mathrm{Tl}$, $\mathrm{U}$ ) or a 14-year schedule (more probable) for carcinogens ( $\mathrm{As}, \mathrm{Be}, \mathrm{Cd}, \mathrm{Ni}, \mathrm{Cr}$ ). The annual rate (g/yr) is then converted to g/s assuming continuous $(3.15 \mathrm{E}+7 \mathrm{~s} / \mathrm{yr})$ operation to be consistent with the annual average air modeling results.

c. These rates are provided for comparison only and where not used in the exposure assessment. See Appendix A, Table A-1.

d. Values given are the $\mathrm{Sb}$ and $\mathrm{Pb}$ emission rates in grams/hour. $\mathrm{Sb}$ and $\mathrm{Pb}$ emission rates are calculated based on their maximum vapor pressures and mole fractions in the offgas (Appendix A). Annual emissions assume a 50\% on-line factor. 
Table 4. NWCF emissions of acid gases and organic constituents. ${ }^{2}$

\begin{tabular}{|c|c|c|c|c|}
\hline Constituent & $\begin{array}{c}\text { Maximum Feed } \\
\text { Concentration } \\
(\mu \mathrm{g} / \mathrm{L})\end{array}$ & $\begin{array}{c}\text { NWCF Input } \\
\text { (g/year) }\end{array}$ & DF & $\begin{array}{c}\text { Assumed Stack } \\
\text { Emission Rate } \\
\text { (g/second) }\end{array}$ \\
\hline \multicolumn{5}{|l|}{ Gases } \\
\hline $\mathrm{NO}_{x}$ as $\mathrm{NO}_{2}$ & $\mathrm{NA}$ & $\mathrm{NA}$ & NA & $4.88 \mathrm{E}+01$ \\
\hline $\mathrm{CO}$ & NA & NA & NA & $3.06 \mathrm{E}+01$ \\
\hline $\mathrm{HNO}_{3}$ & NA & $\mathrm{NA}$ & $\mathrm{NA}$ & $1.39 E+01$ \\
\hline $\mathrm{SO}_{2}$ & $\mathrm{NA}$ & $\mathrm{NA}$ & NA & $2.29 \mathrm{E}-01$ \\
\hline $\mathrm{HCl}$ & $\mathrm{NA}$ & NA & $\mathrm{NA}$ & $9.03 \mathrm{E}-02$ \\
\hline $\mathrm{HF}$ & NA & $\mathrm{NA}$ & NA & $5.14 \mathrm{E}-02$ \\
\hline \multicolumn{5}{|l|}{ Organics in feed } \\
\hline Pyridine & $1.45 E+04$ & $7.67 \mathrm{E}+04$ & 1 & $2.43 \mathrm{E}-03$ \\
\hline Thiourea & $2.11 E+03$ & $1.12 \mathrm{E}+04$ & $100^{d}$ & $3.54 \mathrm{E}-06$ \\
\hline Aniline & $8.08 \mathrm{E}+02$ & 4.27E+03 & 1 & $1.36 \mathrm{E}-04$ \\
\hline Carbon disulfide & $3.97 E+02$ & $2.10 E+03$ & 1 & $6.66 \mathrm{E}-05$ \\
\hline 1,4 dioxane & $3.75 E+02$ & $1.98 \mathrm{E}+04$ & 1 & $6.29 E-04$ \\
\hline Formic acid & $2.42 \mathrm{E}+02$ & $1.28 \mathrm{E}+03$ & 1 & $4.06 \mathrm{E}-05$ \\
\hline Hydrazine & $1.70 E+02$ & $8.99 \mathrm{E}+02$ & 1 & $2.85 E-05$ \\
\hline Methyl ethyl ketone & $1.70 \mathrm{E}+02$ & $8.99 E+02$ & 1 & $2.85 \mathrm{E}-05$ \\
\hline Phenol & $1.70 \mathrm{E}+02$ & $8.99 E+02$ & 1 & $2.85 \mathrm{E}-05$ \\
\hline Diethylphthalate & $1.28 \mathrm{E}+02$ & $6.77] \Xi+02$ & $100^{d}$ & $2.15 \mathrm{E}-07$ \\
\hline 2,4-Dinitrotoluene & $9.50 \mathrm{E}+01$ & $5.03 E+02$ & 1 & $1.59 \mathrm{E}-05$ \\
\hline 2,4-Dinitrophenol & $8.10 \mathrm{E}+01$ & $4.28 \mathrm{E}+02$ & 1 & $1.36 \mathrm{E}-05$ \\
\hline Acetonitrile & $4.80 E+01$ & $2.54 E+02$ & 1 & $8.05 E-06$ \\
\hline Benzo(a)pyrene & 10 & 53 & 1 & $1.68 \mathrm{E}-06$ \\
\hline Butylbenzylphthalate & 10 & 53 & $100^{d}$ & $1.68 \mathrm{E}-08$ \\
\hline Di-n-butylphthalate & 10 & 53 & $100^{d}$ & $1.68 \mathrm{E}-08$ \\
\hline Di-n-octylphthalate & 10 & 53 & $100^{d}$ & $1.68 \mathrm{E}-08$ \\
\hline Naphthalene & 10 & 53 & 1 & $1.68 \mathrm{E}-06$ \\
\hline Pentachlorophenol & 10 & 53 & 1 & $1.68 \mathrm{E}-06$ \\
\hline 1,2,4-trichlorobenzene & 10 & 53 & 1 & $1.68 \mathrm{E}-06$ \\
\hline Formaldehyde & 4.3 & 23 & 1 & $7.29 \mathrm{E}-07$ \\
\hline Benzene & $<10$ & 26 & 1 & 8.39E-07 \\
\hline
\end{tabular}


Table 4. (continued).

\begin{tabular}{|c|c|c|c|c|}
\hline Constituent & $\begin{array}{c}\text { Maximum Feed } \\
\text { Concentration } \\
(\mu \mathrm{g} / \mathrm{L})\end{array}$ & $\begin{array}{c}\text { NWCF Input } \\
\text { (g/year) }\end{array}$ & $\mathrm{DF}$ & $\begin{array}{c}\text { Assumed Stack } \\
\text { Emission Rate }^{c} \\
\text { (g/second) } \\
\end{array}$ \\
\hline Bromoform & $<10$ & 26 & 1 & 8.39E-07 \\
\hline Carbon tetrachloride & $<10$ & 26 & 1 & 8.39E-07 \\
\hline Chlorobenzene & $<10$ & 26 & 1 & 8.39E-07 \\
\hline Chloroform & $<10$ & 26 & 1 & $8.39 \mathrm{E}-07$ \\
\hline 1,2-Dichloroethane & $<10$ & 26 & 1 & 8.39E-07 \\
\hline Methylene chloride & $<10$ & 26 & 1 & 8.39E-07 \\
\hline Tetrachloroethylene & $<10$ & 26 & 1 & 8.39E-07 \\
\hline Toluene & $<10$ & 26 & 1 & 8.39E-07 \\
\hline 1,1,1-Trichloroethane & $<10$ & 26 & 1 & 8.39E-07 \\
\hline 1,1,2-Trichloroethane & $<10$ & 26 & 1 & 8.39E-07 \\
\hline Trichloroethylene & $<10$ & 26 & 1 & 8.39E-07 \\
\hline \multicolumn{5}{|c|}{ Products of Incomplete Combustion (PICs) } \\
\hline 2,3,7,8-TCDD TEQ & NA & NA & 1 & $1.1 \mathrm{E}-10$ \\
\hline Coplaner PCB TEQ & NA & NA & 1 & $1.6 \mathrm{E}-11$ \\
\hline 1,3-Dinitrobenzene ${ }^{e}$ & NA & NA & 1 & $4.8 \mathrm{E}-01$ \\
\hline Nitrobenzene $^{e}$ & NA & NA & 1 & $3.5 \mathrm{E}-01$ \\
\hline 2,4-Dinitrotoluene $e^{e}$ & NA & NA & 1 & $5.2 \mathrm{E}-01$ \\
\hline 2,6-Dinitrotoluene ${ }^{e}$ & NA & NA & 1 & $5.2 \mathrm{E}-01$ \\
\hline Pentachloronitrobenzene $e^{e}$ & NA & $\mathrm{NA}$ & 1 & $4.0 \mathrm{E}-02$ \\
\hline
\end{tabular}

Unquantified organics in feed ${ }^{\mathrm{f}}$

$\begin{array}{lll}\text { Acetone } & \text { Cyanogen } & \text { Hexachoroethane } \\ \text { Methyl isobutyl ketone } & \text { p-Nitrophenol } & \text { Phthalic anhydride } \\ \text { Cresols } & \text { Dimethyl sulfate } & \text { Furfural } \\ \text { Methyl tert-butyl ether } & \text { 2-Nitropropane } & \text { o-Toluidine } \\ \text { Cumene } & \text { Hexachorobenzene } & \text { Iodomethane } \\ \text { Nitrobenzene } & \text { PCBs } & \text { Xylene }\end{array}$

a. See Appendix A for detailed assumptions and calculations.

b. Maximum feed concentration times maximum gross NWCF waste feed of $5.3 \mathrm{E}+6 \mathrm{Ly}$ (1.4E+6 gal/year).

c. Calculated from (NWCF Input, g/year)(1 year/3.154E+7 second)(1/DF). $\mathrm{CO}, \mathrm{HNO}_{3}, \mathrm{SO}_{2}, \mathrm{HCl}$, and $\mathrm{HF}$ use maximum hourly emission rates from Appendix $A$ because they are evaluated against short-term (averaging time) air concentration toxicity criteria.

d. Thermal destruction is $>99 \%$ at temperatures less than $500^{\circ} \mathrm{C}$ (Appendix A). Emissions are increased by $45 \%$ to account for startup, shutdown, and process upset conditions.

e. These are maximum upper-bound values that assume $100 \%$ of the limiting fuel precursor (benzene, toluene, and chlorine) is converted to each constituent (see section 2.2.4).

f. These organics are possible contaminants in the feed that cannot be quantified. 


\subsubsection{Emissions from Organic Compounds in the Feed}

The primary organic emissions from the calciner are from the burning of the kerosene fuel and consist of $\mathrm{CO}, \mathrm{CO}_{2}$, and some unburned fuel consisting mostly of nontoxic light hydrocarbons (methane and ethane) (Schindler 1995). Trace emissions of other organic compounds (Table 5) that are potentially in the calciner or PEW feeds were calculated based on: (1) purchase records of all chemicals thought to have possibly entered the INTEC aqueous waste systems, including PEW and tank farm, and (2) sampling data from 3 tanks which showed concentrations were less than a minimum quantification level of $10 \mathrm{ng} / \mathrm{mL}$ (Appendix A). For these undetected chemicals, concentrations were assumed to be $1 / 2$ of the minimum quantification level $(10 \mathrm{ng} / \mathrm{L} \times 0.5=5 \mathrm{ng} / \mathrm{L})$. Concentrations were then converted to total inventory using an upper-bound estimate of total (gross) feed volume of 1,400,000 gal and assumed to be released in one year. To be conservative, most of the organics were assumed to have no destruction or removal in the calciner or offgas treatment system (assumed DF $=1$ ). For five chemicals, data were obtained that indicated the calciner conditions would result in $>99 \%$ thermal decomposition (Appendix A). For these chemicals, a DF of 100 was used (Table 4).

Although organic feed emissions were calculated based on identification of organics that could have been historically discharged to all the INTEC liquid waste systems, future emissions of organics from the PEW/LET\&D systems will likely be negligible because discharges of organic chemicals to these systems are currently prohibited.

\subsubsection{Products of Incomplete Combustion}

Products of incomplete combustion (PICs) may be formed in the calciner due to the incomplete combustion and recombination of organics in the kerosene fuel with other constituents in the feed (e.g. nitrogen and chlorine). Extensive laboratory studies performed by Radian Corporation have indicated that it is not possible to reliably measure NWCF organic emissions because of the high concentrations of $\mathrm{NO}_{2}$ in the offgas ${ }^{2}$. The analytical results showed poor recoveries of dynamically spiked analytes, very poor reproducibility, deterioration of the sample sorbent, and extensive corrosion of the analytical system. Also, no published emission factors have been identified that are suitable for application at the NWCF because of the nature of the feed materials, acidic operating conditions, and relatively low operating temperature.

An offgas demonstration project (ODP) which is attempting to measure contaminant concentrations in the NWCF offgas will be initially completed in late April, 1999, but the results will not be available until after submittal of this SLRA. Therefore, upper-bound estimates of PIC emission rates were calculated based on known compositions of the kerosene fuel, process knowledge, and conservative assumptions. These upper-bound estimates should conservatively bound any contribution of PIC emissions from auxiliary systems (PEW, LET\&D, HLLWE) because the calciner contributes most of the chlorine emissions and all of the unburned fuel precursors (benzene and toluene).

a. Michael Fuchs, Radian Corporation, letter to C. A. Richert, Lockheed Martin Idaho Technologies Company, April 28, 1995. 
The PICs of concern listed in EPA (1994a) include: (1) dioxins and dioxin-like compounds, (2) polycyclic aromatic hydrocarbons (PAHs), (3) PCBs, (4) nitroaromatics, (5) phthalates, and (6) other chlorinated organics (hexachlorobenzene and pentachlorophenol). In addition to the trace organics detected in the waste feed (section 2.2.3), the only PICs that could be created in any significant quantity from unburned fuel include dioxins/furans and nitroaromatics.

2.2.4.1 Dioxin and Furan Emissions. Polychlorinated dibenzo-p-dioxins (CDDs) and polychlorinated dibenzofurans (CDFs) emissions are identified by EPA guidance to be critical PIC contaminants for assessment of indirect pathway risks. However, no CDD/CDF sampling data are available for the calciner offgas, and no emission factor data have been identified that are appropriate for the conditions in the calciner (concentrated aqueous waste feed material, kerosene fuel, relatively low combustion temperature). An EPA dioxin report (EPA 1994c) lists three principal theories on sources of $\mathrm{CDD} / \mathrm{CDF}$ in combustion sources: (1) feed material containing CDDs or CDFs that survive combustion, (2) feed material containing CDD/CDF precursors-chlorinated aromatic compounds such as $\mathrm{PCBs,}$ chlorinated phenols, and chlorinated benzenes-that thermally break down, molecularly rearrange in the offgas at a temperature range of 250 to $450^{\circ} \mathrm{C}$, and condense onto the surface of fly-ash particles, and (3) de novo formation by nonprecursors in feed material such as petroleum products, chlorinated plastics, nonchlorinated plastics, cellulose, lignin, coke, coal, particulate carbon, and hydrogen chloride gas (which requires a chlorine donor). Based on these theories and the following conditions at the INTEC, anticipated calciner emissions of CDDs and CDFs are judged to be very small:

- No CDD/CDF have been detected in waste feed material (Schindler 1995; Appendix A).

- The calciner waste feed has very low or nonexistent concentrations of CDD and CDF precursors. The organic feed rates are composed almost entirely of the kerosene fuel, which is fed at $283 \mathrm{lb} /$ hour (Schindler 1995). Maximum feed rates of nonfuel organic compound are very small, consisting mostly of pyridine (67 kg/year), isobutyl alcohol ( $25.8 \mathrm{~kg} /$ year), and 1,4 dioxane $(17 \mathrm{~kg} /$ year) (Appendix $\mathrm{A}$ ).

- Calciner effluent gases are rapidly quenched from 500 to $600^{\circ} \mathrm{C}\left(930\right.$ to $\left.1100^{\circ} \mathrm{F}\right)$ in the combustion chamber to 65 to $75^{\circ} \mathrm{C}\left(150\right.$ to $160^{\circ} \mathrm{F}$ ) and then heated to 90 to $120^{\circ} \mathrm{C} \mathrm{(190} \mathrm{to}$ $250^{\circ} \mathrm{F}$ ) before passage through the HEPA filters (to keep them dry). Rapid quenching to temperatures below 180 to $250^{\circ} \mathrm{C}$ in APCDs has been shown to inhibit the processes involved in CDD/CDF formation (EPA 1994c; 1994d).

Although it is likely that emissions of CDDs/CDFs from the calciner are low, a conservative upper-bound estimate of emissions is made in this SLRA because of the importance of these contaminants in combustion facility risk assessments. An upper-bound emission rate for the calciner can be derived from data in EPA guidance document Combustion Emissions Technical Resource Document (CETRED) (EPA 1994d). This same methodology was used to estimate CDD/CDF emissions for the INEEL Pit 9 Arc Melter operational risk assessment. ${ }^{a}$ The CETRED contains CDD/CDF emissions data for various types of hazardous waste incinerators that, because of their relatively high chlorinated organic waste feed and high APCD temperature (compared to the calciner), would likely provide an upper-bound estimate of CDD /CDF emissions from the calciner. Data from 12 municipal waste combustors (MWC) with spray dryers and fabric filters (Table 4.7-4 in CETRED) are the most appropriate for developing a conservative emission rate for the calciner. The average emission factor for these MWC units is $0.20 \mathrm{ng} / \mathrm{dscm}$ (nanograms/dry standard cubic meter in offgas) at $7 \% \mathrm{O}_{2}(2,3,7,8-\mathrm{TCDD} \mathrm{TEQ})$. 
The MWC emission value is slightly greater than the values proposed in CETRED (0.12-0.17 ng $\mathrm{TEQ} / \mathrm{dscm}$ ) as being achievable by the "best controlled sources." It also is slightly greater than the Pit 9 Arc Melter 95\% upper confidence limit (UCL) value calculated from the same data less "outliers" (0.17 ng TEQ/dscm).

The EPA dioxin report (EPA 1994c) lists an MWC emission factor range of 0.05 to $3 \mathrm{ng} T E Q / \mathrm{kg}$ waste combusted. For comparison, the upper range value ( $3 \mathrm{ng} \mathrm{TEQ} / \mathrm{kg}$ ) can be converted to $\mathrm{ng} / \mathrm{dscm}$ in the calciner offgas based on kerosene fuel input ( $283 \mathrm{lb} /$ hour) and calculated dry standard offgas flow rate by the following:

NWCF cyclone offgas (CYCL-OG) dry flow rate (Schnidler 1995) =

302.33 lbmol/hour (total) - $101.3 \mathrm{lbmol} /$ hour $\left(\mathrm{H}_{2} \mathrm{O}\right)=\underline{201 \mathrm{lbmol} / \text { hour }}$

$$
\begin{aligned}
\begin{aligned}
\mathrm{dscm} / \text { second } & =\left(\frac{201 \mathrm{lbmol}}{\text { hour }}\right)\left(\frac{359 \mathrm{ft}^{3}\left[0^{\circ} \mathrm{C}, 1 \mathrm{~atm}\right]}{\mathrm{lbmol}}\right)\left(\frac{0.0283 \mathrm{~m}^{3}}{\mathrm{ft}^{3}}\right)\left(\frac{1 \text { hour }}{3,600 \text { second }}\right) \\
& =\underline{0.57 \mathrm{~m}^{3} / \text { second }} \\
\text { emission factor } & =\left(\frac{3 \mathrm{ng}}{\mathrm{kg}}\right)\left(\frac{1 \mathrm{~kg}}{2.2 \mathrm{lb}}\right)\left(\frac{283 \mathrm{lb}}{\text { hour }}\right)\left(\frac{1 \text { hour }}{3,600 \text { second }}\right)\left(\frac{\text { second }}{0.57 \mathrm{dscm}}\right) \\
& =0.19 \mathrm{ng} / \mathrm{dscm}
\end{aligned}
\end{aligned}
$$

This value is nearly identical to the CETRED value $(0.20 \mathrm{ng} T E Q / \mathrm{dscm})$. No conversion was made to adjust the calciner offgas to the $7 \% \mathrm{O}_{2}$ emission factor basis because: (1) this method $\left(7 \% \mathrm{O}_{2}\right.$ adjustment) applies to traditional air-oxidized incinerators, (2) the calciner is fed excess $\mathrm{O}_{2}$ to facilitate combustion of the kerosene and has excess $\mathrm{O}_{2}(15$ mole \%) in the offgas, and (3) it is conservative not to adjust the calciner flow rate down to $7 \% \mathrm{O}_{2}$ because the adjustment results in a higher flow rate and, therefore, a mass emission rate using the emission factor.

Using the 0.20 -ng TEQ/dscm emission factor and dry standard calciner offgas flow rate, the calciner TCDD emission rate is calculated as

$2,3,7,8-\mathrm{TCDD} T E Q$ emission rate $=\left(\frac{0.2 \mathrm{E}-9 \mathrm{~g}}{\mathrm{~m}^{3}}\right)\left(\frac{0.57 \mathrm{~m}^{3}}{\text { second }}\right)=\underline{1.1 \mathrm{E}-10 \mathrm{~g} / \mathrm{s}}$

2.2.4.2 Polynuclear Aromatic Hydrocarbons and Phthalates. Polynuclear aromatic hydrocarbons (PAHs) and phthalates are two other PICs of concern that may be formed in combustion units. Phthalates are very unlikely to be emitted from combustion units unless the units burn plastics or materials with phthalate plasticizers (EPA 1998). As such, U.S. EPA OSW does not recommend automatic inclusion of phthalates in risk assessments. However, these compounds were evaluated in the SLRA as previously described in section 2.2.3 -- any of these chemicals identified in INTEC purchase 
records that could have possibly entered either the tank farm or the PEW were conservatively assumed to be released on an annual basis (the entire potential feed inventory was assumed to be released each year over the assumed 16 year operating time). Four constituents were evaluated in the SLRA in this manner:

benzo(a)pyrene (PAH with the highest relative potency factor [RPF])
butylbenzylphthalate
di-n-butylphthalate
di-n-octylphthalate

2.2.4.3 Polychlorinated Biphenyls. Polychlorinated biphenyls (PCBs) have not been identified as present or being input into the tank farm or PEW evaporator. However, some limited data suggest that they might be formed as PICs in boilers or incinerators (EPA 1998) that burn at higher temperatures (700 $-1000^{\circ} \mathrm{C}$ ) than the calciner $\left(500-600^{\circ} \mathrm{C}\right)$. Other studies suggest that PCBs might only be formed to a very limited amount $(0.3 \%$ of the chlorine input) and only in incinerators burning hazardous waste with a high chlorine content (60\% or greater) (EPA 1998). Since the maximum chlorine content of the tank farm waste is less than $0.1 \%(0.03 \mathrm{M})$ and the calciner operates at a relatively low temperature, it is unlikely that any PCBs are formed as PICs in the calciner.

For conservatism, however, potential health impacts from dioxin-like coplaner PCBs were evaluated in this SLRA using a coplaner emissions factor of $0.55 \mathrm{ng} / \mathrm{dscm}$, which is a low temperature boiler emissions factor provided by EPA (1998). Using the stack gas flow rate calculated in the previous section $(0.57 \mathrm{dscm} / \mathrm{s})$, the coplaner PCB emission rate was calculated to be $3.14 \mathrm{E}-10 \mathrm{~g} / \mathrm{s}$. Multiplying by the most conservative toxicity equivalency factor (TEF) for any coplaner PCB (0.1) (EPA 1998), the PCB coplaner toxicity equivalent quotient (TEQ) emission rate is 3.14E-11. Since an annual average emission rate is required to calculate appropriate carcinogenic impacts, this short-term rate is further multiplied by an annual operating time fraction ("on-stream factor") of 0.5 , giving an annual average coplaner TEQ emission rate of $1.6 \mathrm{E}-11 \mathrm{~g} / \mathrm{s}$. This emission rate was then modeled using the fate and transport parameters of Arochlor 1254 (EPA 1998), and both direct and indirect risks were calculated using dioxin slope factors (section 5) as specified in EPA (1998).

2.2.4.4 Nitroaromatics. Five nitroaromatic compounds are listed in EPA (1994a) for analyzing indirect exposures: (1) 1,3-Dinitrobenzene, (2) Nitrobenzene, (3) 2,4-Dinitrotoluene, (4) 2,6Dinitrotoluene, and (5) Pentachloronitrobenzene (PCNB). These compounds may be formed in the calciner by reaction of the unburned aromatics in the kerosene fuel (benzene and toluene rings) with the high concentration of nitrogen (nitric acid) in the feed. PCNB is less likely to be formed because of the limited availability of chlorine in the feed and the difficulty of synthesizing a penta-chlorinated organic molecule (the benzene and toluene in the unburned fuel is more likely to form nitrobenzene and nitrotoluene).

Since it is not known which specific chlorinated organic PICs might be formed in the offgas, it was conservatively assumed that all of the chlorine in the offgas reacted to form the highly toxic PCNB. Assessment of the maximum potential formation of PCNB provides a reasonably conservative bound for impacts from any combination of potential chlorinated PICs that are of concern in the NWCF offgas because of its relatively high toxicity. For example, PCNB has an EPA Region 9 Preliminary Remediation Goal (PRG) in air of $0.026 \mathrm{ug} / \mathrm{m}^{3}$ compared to $1.1 \mathrm{ug} / \mathrm{m}^{3}$ for trichloroethylene and $4.1 \mathrm{ug} / \mathrm{m}^{3}$ for methylene chloride. The lower PRG for PCNB indicates that this compound is from 42-160 times as 
toxic and therefore provides a conservative bound to the health impact assessment. If the available chlorine were apportioned to the actual (unknown) PICs being formed in the off gas, it is highly likely that the calculated health impacts would be significantly less than those calculated by assuming all of the available chlorine forms PCNB.

Upper-bound estimates of nitroaromatic emission rates were calculated as follows:

\section{Assumptions:}

1. Average kerosene feed rate $=30 \mathrm{gal} / \mathrm{hour}$.

2. Kerosene aromatic volume fraction $(\max )=0.18$ (average from two NWCF kerosene supplier test reports).

3. Conservative estimate of unburned fuel fraction $(\max )=0.05$

4. Density of kerosene $=0.78 \mathrm{~g} / \mathrm{cm}^{3}$

5. Unlimited nitrogen availability.

\section{Methods:}

1. Maximum rate of unburned aromatic PIC precursors (benzene and toluene rings) $\left(Q_{a}\right)$ :

$$
Q_{a}=\left(\frac{30 \mathrm{gal}}{\mathrm{hr}}\right)\left(\frac{3785 \mathrm{~cm}^{3}}{\mathrm{gal}}\right)\left(\frac{\mathrm{hr}}{3600 \mathrm{~s}}\right)\left(\frac{0.78 \mathrm{~g}}{\mathrm{~cm}^{3}}\right)(0.18)(0.05)=\underline{0.22 \mathrm{~g} / \mathrm{s}}
$$

The fraction of the $\mathrm{Q}_{\mathrm{a}}$ that is either benzene or toluene is unknown. Therefore, it is conservatively assumed that $100 \%$ of $\mathrm{Q}_{\mathrm{a}}$ is available for formation of both the benzene precursor PICs (e.g. 1,3-Dinitrobenzene) and the toluene precursor PICs (e.g. 2,4Dinitrotoluene).

2. Upper-bound emission rate of any single nitroaromatic PIC, assuming unlimited $\mathrm{N}$ and $\mathrm{Cl}$ availability $\left(\mathrm{Q}_{\mathrm{ap}}\right)$ :

$$
Q_{a p}=Q_{a}\left(\frac{M W_{a p}}{M W_{a}}\right)
$$

where

$$
\begin{array}{ll}
\mathrm{MW}_{\mathrm{ap}} & =\text { molecular weight of the nitroaromatic PIC (g) } \\
\mathrm{MW}_{\mathrm{a}} & =\text { molecular weight of the aromatic precursor (benzene or toluene) }
\end{array}
$$




$\begin{array}{lll}\mathrm{PIC} & \mathrm{MW}_{\mathrm{ap}} / \mathrm{MW}_{\mathrm{a}} & \mathrm{Q}_{\mathrm{ap}}(\mathrm{g} / \mathrm{s}) \\ \text { 1,3-Dinitrobenzene } & 2.15 & 0.48 \\ \text { Nitrobenzene } & 1.58 & 0.35 \\ \text { 2,4-Dinitrotoluene } & 2.33 & 0.52 \\ \text { 2,6-Dinitrotoluene } & 2.33 & 0.52 \\ \text { Pentachloronitrobenzene } & 3.78 & 0.84 \quad \text { (see step 3) }\end{array}$

3. Chlorine was determined to be the limiting precursor for PCNB. Therefore, a Cl-limiting emission rate was calculated and used for this PIC instead of the benzene-limiting rate calculated above $(0.84 \mathrm{~g} / \mathrm{s})$ :

Maximum $\mathrm{Cl}$ in the offgas $=680 \mathrm{~kg} / \mathrm{y}$ as $\mathrm{HCl}(0.022 \mathrm{~g} / \mathrm{s}$ or $6.2 \mathrm{E}-04 \mathrm{~mol} / \mathrm{s})($ from Appendix A).

One mole of $\mathrm{PCNB}\left(\mathrm{C}_{6} \mathrm{Cl}_{5} \mathrm{NO}_{2}\right)$ requires 5 moles of $\mathrm{HCl}$.

The Cl-limiting emission rate for PCNB is therefore:

$$
\begin{aligned}
& \mathrm{Q}_{\mathrm{a}}(\mathrm{PCNB})=\left(\frac{6.2 \mathrm{E}-04 \mathrm{~mol} \mathrm{Cl}}{\mathrm{s}}\right)\left(\frac{1 \mathrm{~mol} \mathrm{PCNB}}{5 \mathrm{~mol} \mathrm{Cl}}\right)\left(\frac{295 \mathrm{~g}}{\mathrm{~mol} \mathrm{PCNB}}\right) \\
& \mathrm{Q}_{\mathrm{a}}(\mathrm{PCNB})=0.04 \mathrm{~g} / \mathrm{s} \text { (less than that calculated in step 2) }
\end{aligned}
$$

4. The emission rates calculated in steps 3 and 4 assume that $100 \%$ of the aromatic precursors are converted to a single PIC. Because the actual distribution of the mass between the nitroaromatics is unknown, all of the PICs are evaluated with their respective $Q_{a p}$ in the exposure and risk assessment sections of this document. However, when impacts are summed across all contaminants (hazard index and total cancer risk), only the nitroaromatic with the highest hazard quotient (HQ) or cancer risk is included. This will conservatively bound the impacts from any combination of nitroaromatic PICs.

It should be noted that the calculation of maximum nitroaromatic PIC production using the above methods conservatively accounts for any potential contribution of these PICs from auxiliary systems because they are based on unburned fuel which can only be present in the calciner offgas.

2.2.4.5 Other Potential PICs. Fluorinated (and chloro-fluoro) compounds were not evaluated in the SLRA for the following reasons: (1) reasonably conservative estimates of fluorine in the offgas are low $(0.043 \mathrm{~g} / \mathrm{s})$ and (2) the only fluorinated (and chloro-fluoro) compounds listed on the EPA PIC list are freon species that have very low toxicity values compared to the PICs.

\subsubsection{Process Upset Conditions}

The most significant air pollution control by-pass event is filter deterioration that is a partial bypass. Filter deterioration is considered in Appendix A and factored into the average filter efficiency used 
for the calculations (see discussion on upset factors below). The silica-gel adsorbers can be by-passed. The emission rate calculations took no credit for the adsorbers $(D F=1)$ to conservatively account for this. The scrub system cannot be bypassed. Its loss of scrub solution leads to rapid calciner shutdown.

Most operating upsets result in reduced feed rates or shutdown, thus reducing emissions. Maximum emissions of the most significant species (e.g., $\mathrm{Hg}$ ) occur with smooth operation at the maximum feed rate. Temperature excursions have not been observed. The controller is programmed to shut off feed if a temperature excursion occurs. Inadequate fluidization leads to reduced feed rates and often to shutdown. Plugging of the solids discharge from the product removal cyclone leads to increased solids flow into the scrub system. The incremental solids from the cyclone are relatively large and readily removed by the scrubber. The increased solids to the scrubber usually leads to increased scrub solution purging which reduces the $\mathrm{Hg}$ emission. Excessive fines generation from improper feed composition results in increased fines to the scrub system and possibly to increased solids emissions. Improper feed formulations usually lead to reduced feed rates and they are normally corrected when the problem is recognized.

The EPA (1994a) recommends that organic emissions be increased by an "upset factor" to account for startup, shutdown, and process upset conditions. If no site-specific data are available, the EPA recommends a factor of 1.45. This factor was applied to the five organics with an assumed DF of 100 . For those organics with an assumed DF of 1 , no increase is needed because $100 \%$ of the feed was assumed to be emitted to the atmosphere. No upset factors were used or needed for PICs because PIC emissions assumed $100 \%$ of the necessary precursors (all available unburned fuel and chlorine) were converted to a worst-case PIC release rate.

An upset factor was indirectly incorporated for non-volatile metal emissions by using "degraded" HEPA filter DFs (see section 2.2.1.1) which were determined by examining 3 years of on-line filter performance measurements. The DFs assumed for this SLRA ( 900 for the 3 NWCF filters and 300 for the APS filter; total DF of 2.7E+5) include the effects of process upset conditions over the 3 years of operations over which the measurements were made. The NWCF filters always meet minimum HEPA filter test criteria of $\mathrm{DF}>1 \mathrm{E}+7$ (penetration $<9 \mathrm{E}-8$ ) at installation. The APS filter always meets the test criteria of DF $>3000$ (penetration < 3E-04, 99.97\% efficiency). The use of the degraded DF (2.7E+5 total for all filters) in the risk assessment is equivalent to a "filtration upset factor" greater than $100,000[(1 \mathrm{E}+7)(3000) / 2.7 \mathrm{E}+5]$, which conservatively bounds the EPA default upset factor of 1.45 . 


\section{AIR DISPERSION AND DEPOSITION MODELING}

Air modeling was performed to evaluate the atmospheric dispersion, transport, and ground deposition of contaminants from the NWCF release point to downwind locations at which members of the public could potentially be located. In accordance with EPA guidance (EPA 1994b), the modeling was conducted using a $1 \mathrm{~g} / \mathrm{second}$ release of a generic particulate contaminant and a generic vapor contaminant. Model output for maximum air concentrations $\left(\mu \mathrm{g} / \mathrm{m}^{3}\right.$ per g/second released) and maximum ground depositions ( $\mathrm{g} / \mathrm{m}^{2}$-year per $\mathrm{g} / \mathrm{second}$ ) were then multiplied by contaminant-specific release rates ( $\mathrm{g} / \mathrm{second}$ ) and vapor and particulate partitioning factors to obtain contaminant-specific results (Section 4).

The ISCST3 model (EPA 1995a, code version 96113, BEE-LINE Software, Version 3.3) was used for the analysis. This model has been approved by the EPA and the State of Idaho and is specified for use in EPA SLRA guidance (EPA 1994a). The following sections detail model input parameter values, many of which are specified in the guidance.

\subsection{Control Options Input}

The following control pathway modeling options $(\mathrm{CO})$ were selected:

- Regulatory default job control and dispersion options (EPA 1995a):

- $\quad$ Final plume rise, stack-tip downwash.

- Buoyancy-induced dispersion.

- Calms processing routine.

- $\quad$ No use of missing data processing routine.

- $\quad$ Default wind profile exponents.

- Default vertical potential temperature gradients.

- Upper bound values for supersquat buildings.

- No exponential decay for RURAL mode.

- RURAL dispersion coefficients (sigmas).

- Concentration; dry, wet, and total deposition and depletion for particulate runs.

- Concentration; wet deposition and depletion for vapor runs.

- Annual averaging time for offsite receptor runs.

- Annual, 24-hour, and 1-hour averaging times for U.S. Highway 20 receptor runs. 
- Terrain heights evaluated [taken from the INEEL Graphical Information System (GIS) database]. These elevations were developed from U.S. Geological Survey 1:24,000 scale maps and have a vertical accuracy to within $7 \mathrm{~m}$ for $90 \%$ of the data.

\subsection{Source Input}

The following parameter values were used for the source (SO) pathway for the INTEC Main Stack (INEL 1995):

- $\quad$ Release rate $(\mathrm{QS})=1 \mathrm{~g} / \mathrm{second}$

- $\quad$ Location $=($ UTM) 343923 E., 4825948 N.

- $\quad$ Elevation $=1498.3 \mathrm{~m}$

- $\quad$ Height $(\mathrm{HS})=76.2 \mathrm{~m}$

- Exit diameter (DS) $=1.98 \mathrm{~m}$

- Effluent temperature (TS) $=29.44^{\circ} \mathrm{C}$

- Effluent exit velocity $(\mathrm{VS})=18.83 \mathrm{~m} / \mathrm{s}$, calculated from diameter and flow rate $\left(\mathrm{V}_{\mathrm{A}}\right)$

- Effluent flow rate $\left(\mathrm{V}_{\mathrm{A}}\right)=123,000 \mathrm{acfm}$, calculated by

$V_{A}=V_{S}\left(\frac{P_{S}}{P_{A}}\right)\left(\frac{T_{A}}{T_{S}}\right)$

where

$$
\begin{aligned}
& \mathrm{V}_{\mathrm{S}} \quad=\quad \begin{array}{l}
\text { standard conditions flow rate as measured by stack flow meter }(100,000 \text { to } \\
110,000 \text { scfm nominal). (The } 100,000 \mathrm{scfm} \text { value is used to be conservative } \\
\text { because it results in a lower plume height.) }
\end{array} \\
& \mathrm{P}_{\mathrm{S}} \quad=\quad \text { standard pressure }(29.92 \mathrm{in.} \mathrm{Hg}) \\
& \mathrm{P}_{\mathrm{A}} \quad=\quad \text { ambient pressure at the INEEL (25.06 in. Hg) (Clawson, et al. 1989) } \\
& \mathrm{T}_{\mathrm{S}} \quad=\quad \begin{array}{l}
\text { standard temperature [ } 294 \mathrm{~K} \text {, as specified by the flow meter manufacturer } \\
\text { (Kurtz)] }
\end{array} \\
& \mathrm{T}_{\mathrm{A}} \quad=\quad \text { stack gas temperature }(302.5 \mathrm{~K} \text {.). }
\end{aligned}
$$

Other parameters include the following:

- Particulate diameter (PARTDIAM): $0.25,0.75,1.25,1.75,2.5,3.5$, and $4.5 \mu \mathrm{m}$ (from California Air Resources Board test report C-87-122, January 31, 1990 on medical waste incinerators). 
- $\quad$ Mass fraction (MASSFRAX): $0.033,0.152,0.3160 .259,0.187,0.047$, and 0.005

(calculated penetration of the given particle sizes through 3 banks of HEPA filters). This method produces a size distribution that is smaller than the generic default values given in the EPA (1994a) guidance. Smaller particulate sizes have been shown to be more conservative for INEEL assessments because the particulate are transported the longer distances required to reach the relatively distant INEEL receptor locations (less particulate falls out near the facility).

- $\quad$ Particulate density (PARTDENS): $1 \mathrm{~g} / \mathrm{cm}^{3}$

- $\quad$ Particle scavaging coefficients (PARTSLIQ, PARTSICE): $1.0,0.4,0.6,0.69,1.8,2.6$, and 3.7 ( $\times 10^{-4}$ second-mm/hour-1), from data in ISC3 manual (EPA 1995a) (liquid and ice are assumed to be the same)

- Vapor scavaging coefficients (GAS-SCAV) are assumed to be $1.7 \times 10^{-4}$ (both liquid and ice) based on scavaging coefficient data given in the ISC3 manual for the smallest available particulate size and the EPA guidance (EPA 1994a).

Building downwash was not evaluated because the Main Stack height is greater than $2.5 \times$ adjacent building heights (EPA 1995b).

\subsection{Receptor Information}

Three different receptor (RE) grids were evaluated for each particulate and vapor modeling run:

1. POL50: A large 50-km radius polar grid (Figure 5) was evaluated for the initial annual average modeling runs to determine regional dispersion and deposition trends for contour plotting and for locating refined discrete grids in areas of maximum impact. Receptors were placed at 10-degree radials at the following distances (in meters): $100,150,200,300,400$, $500,700,1,000,1,500$ to 5,000 (at 500-m intervals), 6,000 to 10,000 (at 1,000 -m intervals), 12,000 to 20,000 (at 2,000-m intervals), and 25,000 to 50,000 (at 5,000-m intervals). This placement required 1,152 receptors ( 36 radials $\times 32$ distances).

This coarse grid was also used to assess maximum air concentrations and depositon rates at additional onsite scenarios evaluated in this revision (worker and herdsman). By examining isopleths in Figures 8 and 9, conservative estimates of maximum impacts at the Central Facilities Area (CFA) and grazing locations south of U.S. 20 were made. . The assessment of maximum short-term impacts did not require a coarse receptor grid because, for the NWCF, maximum short-term impacts occur along U.S. Highway 20 , which is adequately evaluated using a discrete line of receptors (see $\underline{\text { US20, }}$, below).

2. $\quad$ RG3: Two refined (100-m interval) receptor grids were placed in two major offsite impact areas identified from the POL50 coarse grid modeling (Figure 6). The first major impact area was located along the southern INEEL boundary and used seven rows of receptors over a distance of $3,500 \mathrm{~m}$ (252 receptors). The second major impact area was located on Big Southern Butte and used 224 receptors. Big Southern Butte is a major impact area because the higher terrain elevations intersect the elevated plume centerline height. 


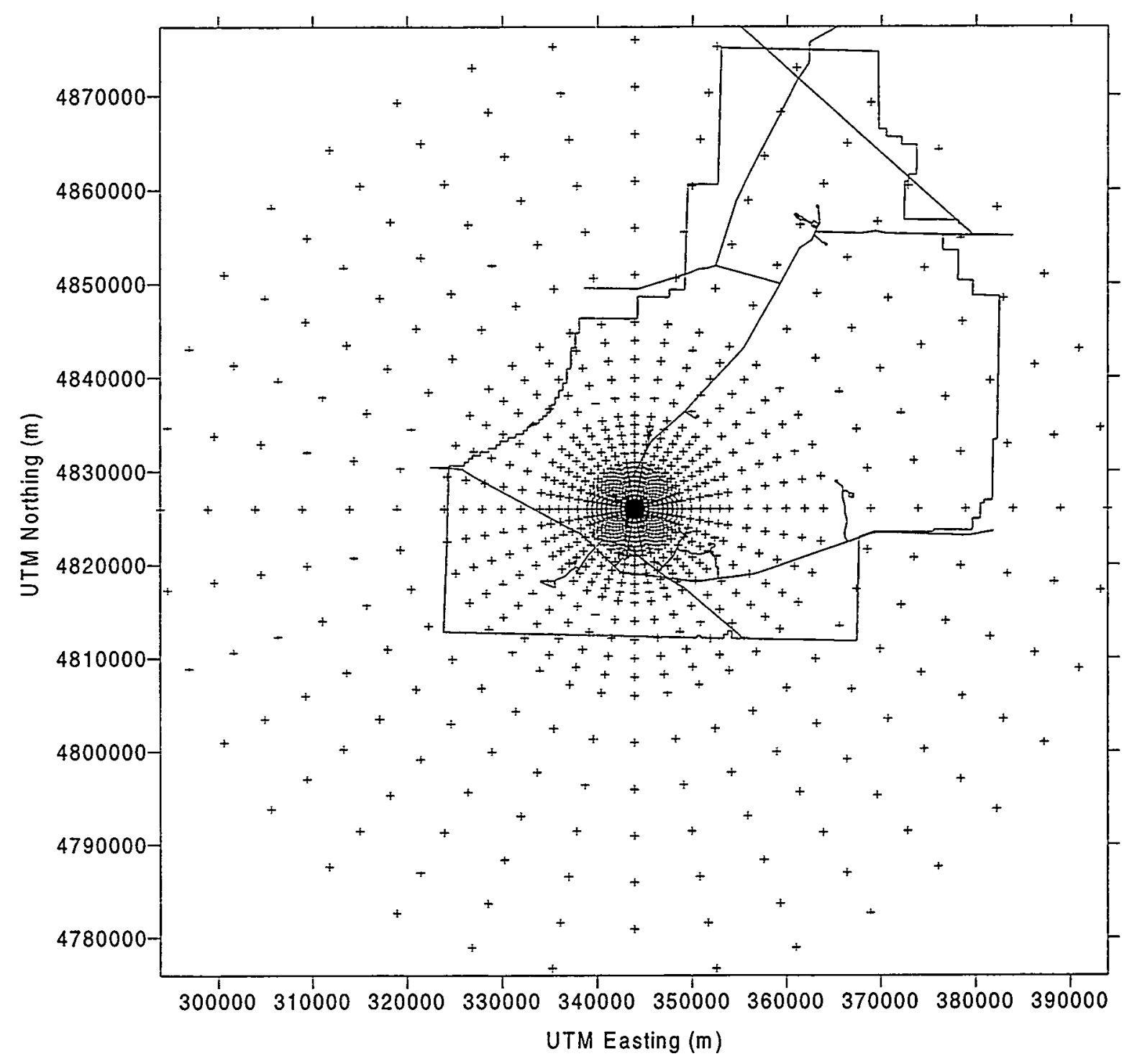

Figure 5. The 50-km polar receptor grid (1,152 receptors) initially evaluated in the modeling. Modeling results from this grid were used to determine regional dispersion and deposition trends and to develop refined receptor grids in areas of maximum impact.

3. US20: Discrete receptors were placed at 100-m intervals along major impact areas of U.S. Highway 20/26 (160 total receptors), which lies on the INEEL (Figure 7). These receptors were only evaluated for direct inhalation impacts because the only potential receptors are transient motorists. Chronic exposure scenarios or indirect exposures are not possible because no residences, farming, grazing, or off-road public access is allowed in the area. 


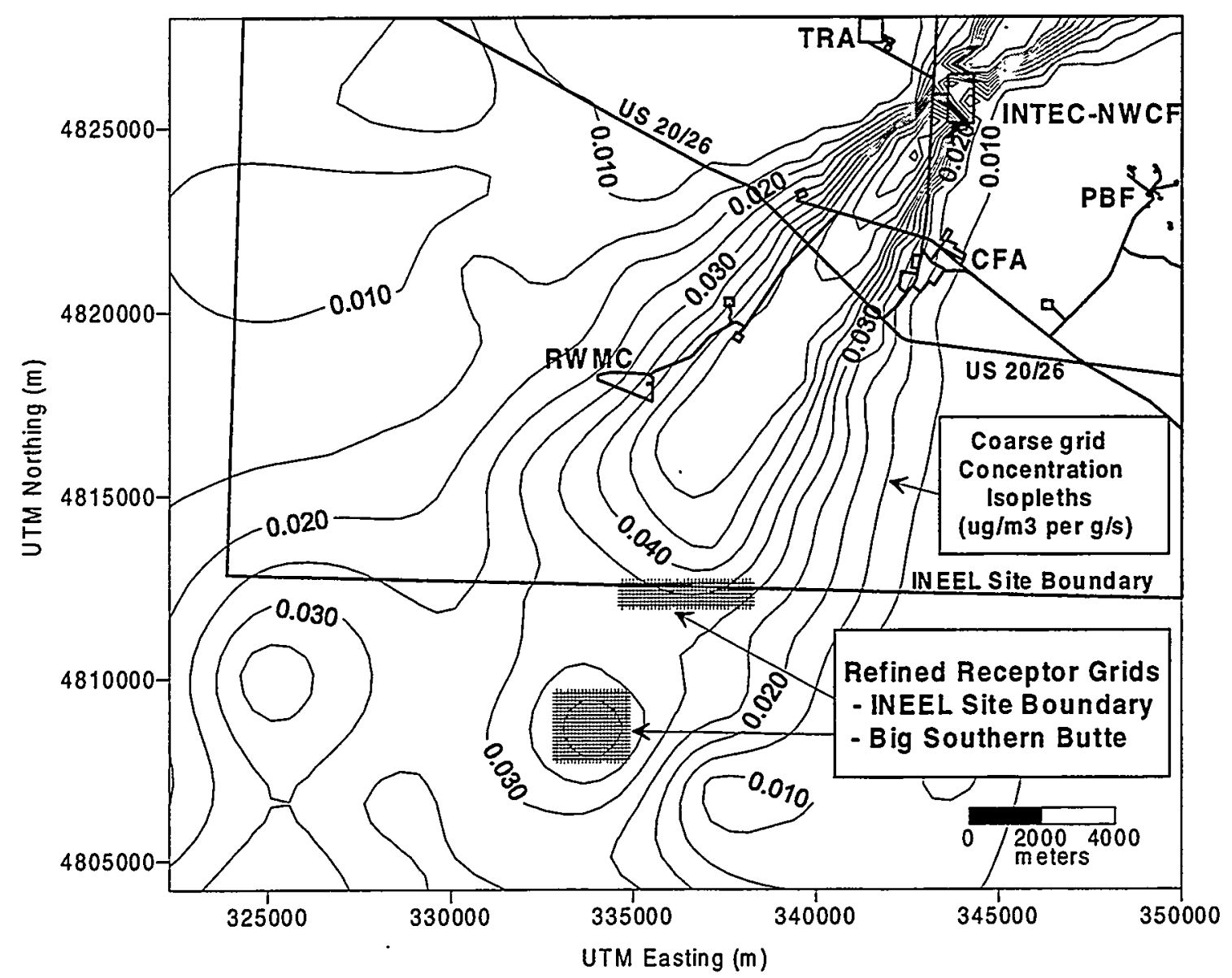

Figure 6. The two refined (100-m interval) receptor grids evaluated in offsite areas of maximum impact (South INEEL boundary and Big Southern Butte).

\subsection{Meteorological Information}

Three years (1993 to 1995) of onsite meteorological (ME) data were available from the Grid 3 (GRD3) $250-\mathrm{ft}(61-\mathrm{m})$ tower, which is located approximately $1.5 \mathrm{~km}$ north of the INTEC. The GRD3 data were processed into sequential hourly ISC3 data input format by the National Oceanic and Atmospheric Administration (NOAA) Air Resources Laboratory in Idaho Falls, Idaho. One to three years of site-specific meteorological data have typically been used at the INEEL and approved by the State of Idaho DEQ for air permitting, toxics assessments, PSD, and NEPA analyses. The EPA's Guideline on Air Quality Models, which is the basis for the EPA guidance on this subject, specifies that "5 years of NWS data or at least 1 year's site-specific data is required" (EPA 1995b). The five-year data recommendation applies to National Weather Service (NWS) data from airports, which are generally a significant distance away from the site being assessed and may have significant data gaps. The INEEL NOAA data has few data gaps, is considered to be of high quality, and provides very representative data for the source-to-receptor transport distances evaluated in this assessment. In addition, previous modeling analyses have shown that the maximum annual concentration observed over 5 years at the INEEL is not significantly different than that observed over a 2 to 3 -year period. 
TRA

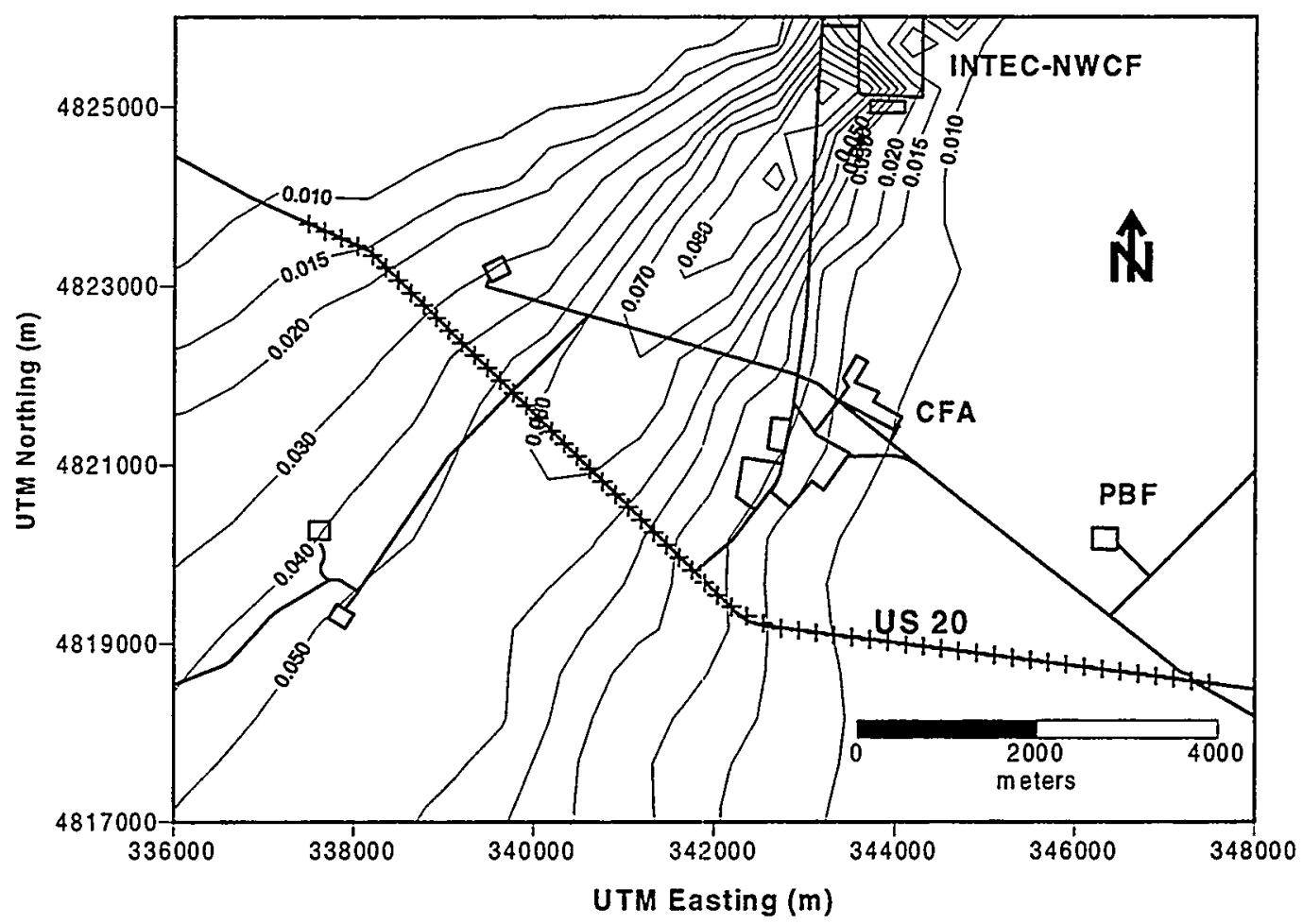

Figure 7. Discrete (100-m interval) receptors placed along major impact areas on U.S. Highway 20 (every other receptor is shown).

The NOAA determined stability classes using the lateral turbulence $\left(\sigma_{\mathrm{A}}\right)$ and wind speed method as outlined in the EPA report Onsite Meteorological Program Guidance for Regulatory Modeling Applications (EPA 1987). The percent of recoverable data was $99.5 \%$ for $1993,99.1 \%$ for 1994 , and $99.98 \%$ for 1995 . The small amount of missing data in the NOAA files was filled using hourly data (for the same month, day, and hour) from other INEEL towers (e.g., the CFA) or, for single hour gaps, linear interpolation. Wind speeds less than the anemometer starting threshold $(0.26 \mathrm{~m} / \mathrm{second})$ were set to 0.0 for calms processing in ISC 3 . Wind speeds between the anemometer starting threshold and $1.0 \mathrm{~m} / \mathrm{second}$ were set to $1.0 \mathrm{~m} / \mathrm{second}$ to ensure that unrealistic concentration estimates are not calculated by the model (EPA 1995a; EPA 1996). Mixing heights from Salt Lake City (the location of the closest available upper air station) were used because no site-specific database currently exists for the INEEL. follows:

Additional processing to determine ISC3-required deposition parameters was accomplished as

1. Surface roughness length $\left(z_{0}\right)$ was taken from the ISC3 manual (EPA 1995a) for desert shrub land terrain $(0.26 \mathrm{~m})$.

2. The Monin-Obukhov length (L) was calculated using a published relationship between surface roughness length and stability class (Golder 1972). The calculation of this parameter by the Meteorological Preprocessor for Regulatory Models (MPRM) (EPA 1996) was not possible because the model requires cloud cover input, which is not recorded at the INEEL. 
3. Friction velocity ( $\mathrm{u}^{*}$ ) was calculated using an equation for atmospheric boundary layer similarity theory described by Ramsdell et al. (1994).

4. Required hourly precipitation codes (MPRM, Table F-9) are not reported at the INEEL. Test modeling runs were made with several precipitation codes. This parameter was found not to affect wet deposition results (probably because the ISC3 input values for liquid and frozen scavaging coefficients were set to the same value in accordance with EPA guidance). Therefore, all code input was set to "19" (light snow).

\subsection{Modeling Results}

Maximum modeled concentrations and ground deposition rates are summarized in Table 5. The offsite results are as follows:

Cyv- maximum offsite vapor air concentration $\left(\mu \mathrm{g}-\mathrm{second} / \mathrm{g}-\mathrm{m}^{3}\right)$

Cyp - maximum offsite particulate air concentration $\left(\mu \mathrm{g}-\mathrm{second} / \mathrm{g}-\mathrm{m}^{3}\right)$

Dywv- maximum offsite vapor wet deposition rate (second $/ \mathrm{m}^{2}$-year)

Dydp - maximum offsite particulate dry deposition rate (second $/ \mathrm{m}^{2}$-year)

Dywp - maximum offsite particulate wet deposition rate (second $/ \mathrm{m}^{2}$-year).

In addition to these maximum offsite values, maximum onsite values were determined for: (1) the maximum annual and short-term (time-averaged) concentrations on U.S. Highway 20 for evaluation of an acute direct inhalation scenario, (2) the maximum onsite vapor concentration at an adjacent INEEL facility (CFA) for evaluation of a worker scenario, and (3) the maximum onsite vapor concentration and particulate deposition rate south of U.S. 20 for evaluation of a herdsman scenario. All of the maximum offsite values occurred in the same area of the north end of Big Southern Butte, which is where the elevated plume centerline began to impact the rising terrain (Figures 8 and 9). The maximums in that area were approximately $50 \%$ higher than those obtained at the south INEEL Site boundary. Although it is extremely unlikely that any individual would reside in this maximum impact area, these values are used in the exposure assessment (Section 4 ) to be conservative. 
Table 5. Refined grid ISC3 modeling results.

\begin{tabular}{|c|c|c|c|c|}
\hline $\begin{array}{c}\text { Output } \\
\text { Parameter }\end{array}$ & $\begin{array}{l}\text { Receptor } \\
\text { Location }\end{array}$ & $\begin{array}{c}\text { Averaging } \\
\text { Time } \\
\end{array}$ & $\begin{array}{c}\text { Maximum } \\
\text { Value }^{\mathrm{a}}\end{array}$ & $\begin{array}{l}\text { UTM Location } \\
(\mathrm{m})\end{array}$ \\
\hline $\begin{array}{l}\text { Cyv } \\
\left(\mu g-s e c o n d / g-m^{3}\right)\end{array}$ & Offsite & Annual & 0.06213 & $\begin{array}{l}334200 \mathrm{E} \\
4809700 \mathrm{~N}\end{array}$ \\
\hline $\begin{array}{l}\text { Cyp } \\
\left(\mu g-\text { second } / g-m^{3}\right)\end{array}$ & Offsite & Annual & 0.06156 & $\begin{array}{l}334200 \mathrm{E} \\
4809700 \mathrm{~N}\end{array}$ \\
\hline $\begin{array}{l}\text { Dywv } \\
\text { (second/m²-year) }\end{array}$ & Offsite & Annual & 3.7E-04 & $\begin{array}{l}334200 \mathrm{E} \\
4809800 \mathrm{~N}\end{array}$ \\
\hline $\begin{array}{l}\text { Dydp } \\
\text { (second } / \mathrm{m}^{2} \text {-year) }\end{array}$ & Offsite & Annual & $4.5 E-04$ & $\begin{array}{l}334200 \mathrm{E} \\
4809700 \mathrm{~N}\end{array}$ \\
\hline $\begin{array}{l}\text { Dywp } \\
\text { (second } / \mathrm{m}^{2} \text {-year) }\end{array}$ & Offsite & Annual & $2.4 \mathrm{E}-04$ & $\begin{array}{l}334200 \mathrm{E} \\
4809800 \mathrm{~N}\end{array}$ \\
\hline $\begin{array}{l}\text { Particulate } \\
\text { total deposition }\end{array}$ & Offsite & Annual & $6.9 \mathrm{E}-04$ & $\begin{array}{l}334200 \mathrm{E} \\
4809800 \mathrm{~N}\end{array}$ \\
\hline $\begin{array}{l}\text { Particulate } \\
\text { concentration }^{b}\end{array}$ & U.S. 20 & Annual & 0.06387 & $\begin{array}{l}340264 \mathrm{E} \\
4821311 \mathrm{~N}\end{array}$ \\
\hline $\begin{array}{l}\text { Particulate } \\
\text { concentration }^{\mathrm{b}}\end{array}$ & U.S. 20 & 24-hour & 0.46083 & $\begin{array}{l}340122 \mathrm{E} \\
4821452 \mathrm{~N}\end{array}$ \\
\hline $\begin{array}{l}\text { Particulate } \\
\text { concentration }^{\mathrm{b}}\end{array}$ & U.S. 20 & 1-hour & 2.92910 & $\begin{array}{l}341609 \mathrm{E} \\
4819969 \mathrm{~N}\end{array}$ \\
\hline $\begin{array}{l}\text { Vapor } \\
\text { concentration }^{\mathrm{b}}\end{array}$ & U.S. 20 & Annual & 0.06390 & $\begin{array}{l}\text { Same as annual } \\
\text { particulate }\end{array}$ \\
\hline $\begin{array}{l}\text { Vapor } \\
\text { concentration }^{\mathrm{b}}\end{array}$ & U.S. 20 & 24-hour & 0.46153 & $\begin{array}{l}\text { Same as } 24 \text {-hour } \\
\text { particulate }\end{array}$ \\
\hline $\begin{array}{l}\text { Vapor } \\
\text { concentration }^{b}\end{array}$ & U.S. 20 & 1-hour & 2.94854 & $\begin{array}{l}\text { Same as 1-hour } \\
\text { particulate }\end{array}$ \\
\hline $\begin{array}{l}\text { Vapor } \\
\text { concentration }^{b}\end{array}$ & $\mathrm{CFA}^{\mathrm{c}}$ & Annual & 0.025 & $342630 \mathrm{E} 4821520 \mathrm{~N}$ \\
\hline $\begin{array}{l}\text { Vapor } \\
\text { concentration }\end{array}$ & $\begin{array}{l}\text { Onsite, S of } \\
\text { US } 20^{d}\end{array}$ & Annual & 0.065 & 340320 E $4821200 \mathrm{~N}$ \\
\hline $\begin{array}{l}\text { Particulate } \\
\text { deposition }\end{array}$ & $\begin{array}{l}\text { Onsite, } S \text { of } \\
\text { US } 20^{d}\end{array}$ & Annual & $1.3 \mathrm{E}-03$ & 340240 E $4821330 \mathrm{~N}$ \\
\hline \multicolumn{5}{|c|}{$\begin{array}{l}\text { a. The ISC3 model output is provided to five decimal places to minimize rounding error in the exposure assessment } \\
\text { calculations. }\end{array}$} \\
\hline \multicolumn{5}{|c|}{$\begin{array}{l}\text { b. Direct inhalation is the only potential exposure pathway for receptors at this location (transient motorists only). } \\
\text { Adjacent onsite facility with the highest air concentration. }\end{array}$} \\
\hline
\end{tabular}




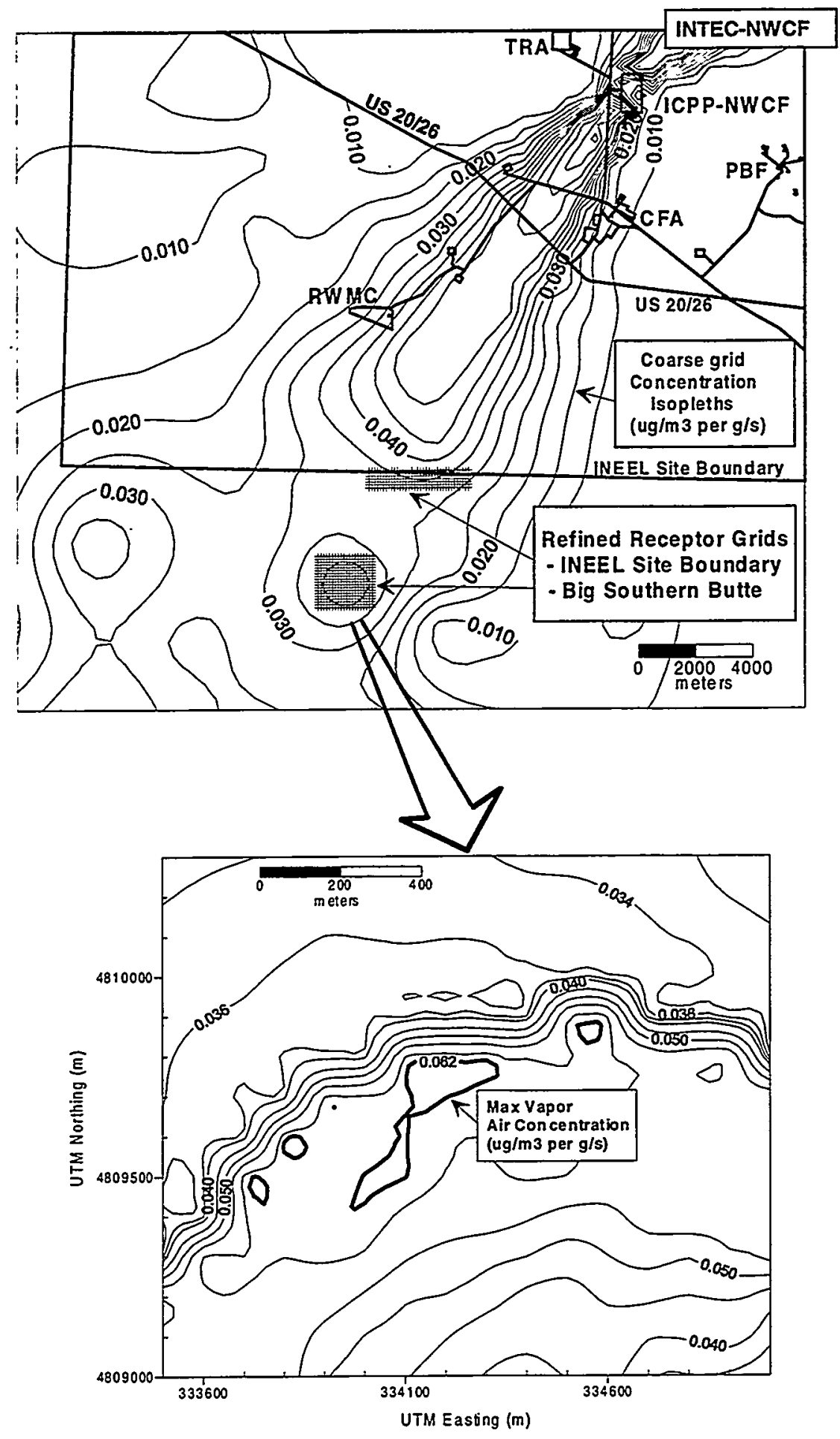

Figure 8. The maximum vapor air concentration $\left(0.062 \mu \mathrm{g} / \mathrm{m}^{3}\right)$ occurred on the north end of the Big Southern Butte refined modeling grid. The maximum vapor wet deposition $\left(3.7 \mathrm{E}-04 \mathrm{~g} / \mathrm{m}^{2}\right.$-year per $\mathrm{g} / \mathrm{second}$ ) occurred in the same area. 


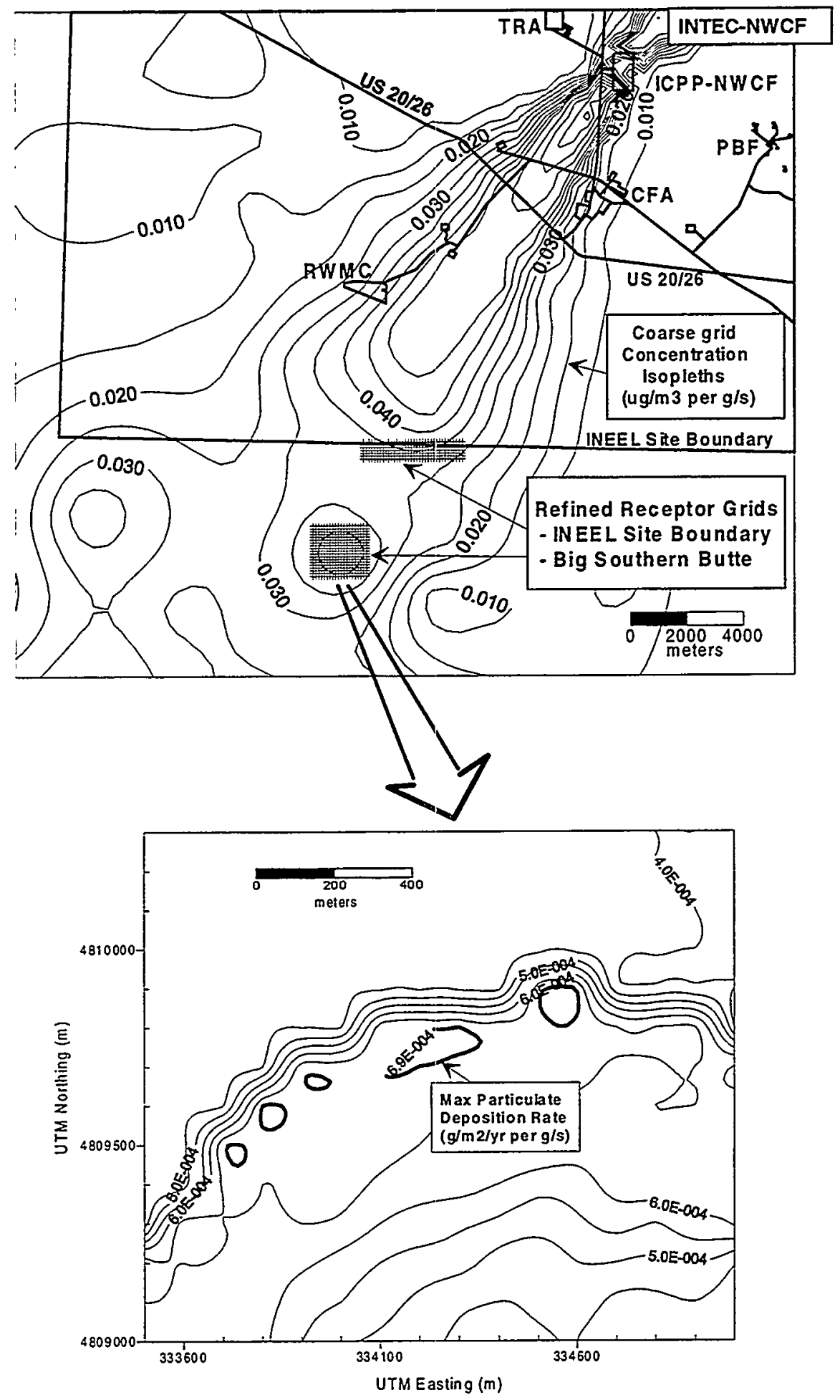

Figure 9. The maximum particulate total deposition rate $\left(6.9 \mathrm{E}-04 \mathrm{~g} / \mathrm{m}^{2}\right.$-year) occurred on the north end of the Big Southern Butte refined modeling grid. The maximum particulate air concentration $(0.062$ $\mu \mathrm{g} / \mathrm{m}^{3}$ ) occurred in the same area. 


\section{EXPOSURE ASSESSMENT}

The objective of the exposure assessment is to estimate the type and magnitude of exposures to constituents released in stack emissions from the NWCF. The exposure assessment guidance (EPA 1994a) specifies four exposure scenarios that should be considered: (1) subsistence farming, (2) subsistence fishing, (3) adult residential, and (4) child residential. Additional exposure scenarios evaluated at the request of EPA Region 10 and the Idaho DEQ include a subsistence farmer child, an onsite worker, and an onsite herdsman.

Onsite hunting was investigated and determined to not be a significant exposure scenario for impacts from the NWCF because:

1. Controlled hunting access is allowed only within one-half mile of the INEEL boundary on infrequent occasions. Most of the hunting occurs on the northeast site boundary, adjacent to the farms west of Mud Lake (approximately $50 \mathrm{~km}$ northeast of NWCF), and on the northwest site boundary on the southern terminus of the Lemhi Range (Figure 1).

2. The Environmental Science and Research Foundation (Warren and Mitchell, in press) recently completed a major big game dose study on the INEEL that examined measured radionuclide concentrations in deer and pronghorn antelope on the INEEL over the period 1972 through 1996 . In the vast majority of animals examined, tissue concentrations were similar to background levels and were attributed to global fallout from nuclear weapons testing. Although this study did not examine organic or metal contaminant concentrations, it indicates that this exposure pathway is not likely to be significant at the INEEL.

3. Calculated impacts for a hypothetical hunter are bounded by the subsistence farmer scenario because of the relative ingestion rates of contaminated meat assumed in the exposure equations (the hunter eats limited amounts of potentially contaminated game while the farmer continuously consumes contaminated beef, milk, and vegetables). Since the calculated subsistence farmer risk and hazard index were significantly less than the SLRA criteria (1E-05 risk and 0.25 hazard index), the calculated hypothetical hunter impacts would also be less than these criteria.

Ingestion of fish was investigated and determined to not be a significant exposure pathway for impacts from the NWCF because:

1. There are no watershed areas that support subsistence or significant recreational fishing within $50 \mathrm{~km}$ of the NWCF.

2. All streams near the INEEL are intermittent streams that terminate inside the INEEL. Therefore, there is no potential for contaminant transport in surface waters to offsite locations.

Both direct and indirect exposures were evaluated for the subsistence farmer, subsistence farmer child, adult, child, and onsite herdsman scenarios. The direct exposure consists of inhalation of the maximum air concentration at the receptor location. Only direct inhalation exposure is assessed for the onsite worker because there are no food products grown or produced at the site. The maximum air concentration is assumed to be collocated with the point of maximum combined wet and dry deposition. U.S. Highway 20 bisects the southern portion of the INEEL; therefore, a short-term direct inhalation 
exposure also is evaluated by estimating the maximum short-term air concentration at this location and comparing it to the State of Idaho acceptable ambient air concentrations for noncarcinogens and carcinogens (AAC/AACC). The indirect exposures include the ingestion of aboveground produce, beef and milk, and soil. The ingestion of contaminated drinking water was not evaluated in this SLRA because: (1) surface water is not a source of drinking water in the area, and (2) the groundwater, which is a source of drinking water, is at a depth of approximately $140 \mathrm{~m}$ below land surface and, moreover, the low annual precipitation of $21.6 \mathrm{~cm}$, combined with the degradative and sorptive properties of chemicals in the soil, eliminates groundwater as a potential exposure pathway to offsite individuals.

\subsection{Human Exposure Scenarios}

Table 6 presents the rates of consumption of contaminated food, ingestion of contaminated soil, and inhalation rates for each of the three major exposure scenarios specified in the EPA (1994a) guidance. Additional scenarios evaluated in this revison at the request of EPA Region 10 and the Idaho DEQ were a subsistence farmer child and an onsite herdsman. The onsite herdsman scenario assumed the same values as the subsistence farmer. The inhalation impacts evaluated for all scenarios, including the onsite worker, were calculated using a Unit Risk Factor (URF) and Reference Concentration (RfC), both of which assume an inhalation rate of $20 \mathrm{~m}^{3} /$ day (EPA 1997).

A discussion of indirect and direct exposures for each of the three major exposure scenarios evaluated is described below.

Table 6. Exposure scenario consumption rates and fraction contaminated for the three major exposure scenarios specified in the EPA (1994a) guidance (EPA 1994a).

\begin{tabular}{|c|c|c|c|c|c|c|}
\hline \multirow{3}{*}{$\begin{array}{l}\text { Contaminated Food } \\
\text { or Medium }\end{array}$} & \multicolumn{6}{|c|}{ Exposure Scenario } \\
\hline & \multicolumn{2}{|c|}{ Subsistence Farmer ${ }^{\mathrm{a}}$} & \multicolumn{2}{|c|}{ Adult Resident } & \multicolumn{2}{|c|}{ Child Resident } \\
\hline & Rate & Fraction & Rate & Fraction & Rate & Fraction \\
\hline Beef (g/day) & 57 & 1 & $N A^{b}$ & $\mathrm{NA}$ & $\mathrm{NA}$ & $\mathrm{NA}$ \\
\hline Milk (g/day) & 181 & 1 & NA & NA & NA & $\mathrm{NA}$ \\
\hline $\begin{array}{l}\text { Aboveground } \\
\text { produce } \\
\text { (g dry weight/day) }\end{array}$ & 28 & 1 & 28 & 0.25 & 5 & 0.25 \\
\hline Soil (mg/day) & 100 & 1 & 100 & 1 & 200 & 1 \\
\hline $\operatorname{Air}\left(\mathrm{m}^{3} / \mathrm{day}\right)^{\mathrm{c}}$ & 20 & 1 & 20 & 1 & 4.3 & 1 \\
\hline \multicolumn{7}{|c|}{ a. Same values were assumed for the onsite herdsman. } \\
\hline
\end{tabular}




\subsubsection{Subsistence Farmer and Onsite Herdsman}

In the subsistence-farmer scenario, an adult farmer is exposed via consumption of home-grown beef and milk, consumption of home-grown produce (aboveground), incidental soil ingestion, and direct inhalation of vapors and particles. The subsistence farmer is assumed to raise cattle for both beef and milk consumption and grow crops for home consumption. The subsistence farmer is assumed to continuously reside at the location of maximum air concentration and wet and dry deposition.

The onsite herdsman added for this revision is assumed to reside $1 / 3$ of a year at the location of maximum air concentration and deposition rate south of U.S. Highway 20 (no grazing is allowed north of the highway). The herdsman scenario assumes the same intake rates as the subsistence farmer; therefore impacts were calculated by scaling the subsistence farmer risk/hazard index based on the ratio of air concentrations (for direct impacts) and deposition rates (for indirect impacts) at the two assumed locations. Carcinogenic risk, which is based on total intake, was further scaled by the ratio of annual residence times assumed for the two scenarios (the onsite herdsman resides for $1 / 3$ of a year; therefore, the subsistence farmer risk was further multiplied by $1 / 3$ ).

\subsubsection{Adult Resident}

In the adult-resident scenario, an adult is exposed via consumption of home-grown produce (aboveground), incidental soil ingestion, and direct inhalation of vapors and particles. The adult resident is assumed to reside at the location of maximum air concentration and wet and dry deposition.

\subsubsection{Child Resident}

In the child-resident scenario, a child is exposed via consumption of home-grown produce (aboveground), incidental soil ingestion, and direct inhalation of vapors and particles. Typically the incidental soil ingestion rate is higher for children than for adults. The child resident is assumed to reside at the location of maximum air concentration and wet and dry deposition.

\subsubsection{U.S. Highway 20 Receptor}

U.S. Highway 20 bisects the southern portion of the INEEL; therefore, a short-term direct inhalation exposure was evaluated by estimating the maximum short-term air concentration at this location and comparing it to the State of Idaho acceptable ambient concentrations for noncarcinogens and carcinogens (AAC/AACC).

\subsubsection{Onsite Worker}

Maximum inhalation impacts for an INEEL worker at any adjacent onsite INEEL facility (excluding INTEC) were added for this revision. Indirect (ingestion) impacts to workers were not assessed because there is no food grown or produced at the INEEL. Since inhalation impacts were evaluated for all scenarios using a URF or RfC, worker impacts were calculated by scaling the susbsistence farmer inhalation impacts based on the ratio of the air concentrations determined for the two locations. Carcinogenic risk, which is based on total inhalation intake, was further scaled by the ratio of annual residence times assumed for the two scenarios (the worker spends 2000 hours per year onsite; therefore, the subsistence farmer risk was multiplied by 2000/8760). 


\subsubsection{Subsistence Farmer Child}

For this revision, impacts were also calculated for a "subsistence farmer child," as requested by EPA Region 10. This scenario is basically the same as the child resident scenario except that it also assumes consumption of contaminated beef and milk, and the fractions of contaminated soil and food products are assumed to be 1.0 . Only those chemicals that accounted for greater than $99 \%$ of the total risk (benzo[a]pyrene and 2,3,6,7 TCDD) and total hazard quotient (1,3-dinitrobenzene, 2,4dinitrotoluene, and 2,6-dinitrotoluene) from the previous scenario results (see section 6) were assessed since these chemicals would also account for the vast majority of impacts in this scenario. Also, reassessment of these chemicals for this scenario was done using the most current the fate and transport parameters from EPA (1998).

\subsection{Exposure Pathways}

The indirect and direct exposure pathways selected for screening analyses are described in the following paragraphs.

\subsubsection{Aboveground Produce Exposure Route}

Aboveground produce is ingested by humans and cattle. For human ingestion of aboveground produce, the following two pathways of contaminant transport are included: (1) deposition of particle phase contaminants directly onto the plant surfaces, and (2) direct transfer of vapor phase contaminants into plant material. Cattle ingestion of aboveground plants is discussed below in the section for beef and dairy.

\subsubsection{Beef and Dairy Exposure Route}

For concentration of a contaminant in beef, three pathways are included. The first pathway is deposition directly onto forage plant surfaces and direct transfer of vapor-phase contaminants into forage plant material, followed by cattle consuming contaminated forage which results in bioaccumulation in muscle tissue. The second pathway is grain and silage root uptake of contaminants in soil, followed by cattle consuming contaminated grain and silage which results in bioaccumulation in muscle tissue. The third pathway is incidental ingestion of soil by cattle resulting in bioaccumulation in muscle tissue. For concentration of contaminants in cow's milk, the same three pathways also are included, except that the bioaccumulation of contaminants is in the cow's milk not muscle tissue.

\subsubsection{Soil Exposure Route}

For incidental ingestion of soil by adults and children, the soil is assumed to be contaminated by deposition of emissions onto soils. The concentration of chemicals in soil was developed from the maximum modeled deposition (combined wet and dry) at the hypothetical receptor location.

\subsubsection{Air Exposure Route}

Direct inhalation exposure for the subsistence farmer, adult, and child scenarios were evaluated at the offsite location of maximum air concentration. Maximum short-term concentrations were calculated along U.S. Highway 20 , along which the commuting public could be exposed for short durations. The onsite herdsman was evaluated at the location of maximum air concentration south of U.S. Highway 20 
where grazing is allowed. Maximum onsite worker impacts were determined to occur at the Central Facilities Area (CFA), approximately $4 \mathrm{~km}$ south of NWCF.

Equations that are used in the screening analysis to calculate concentrations of contaminants in media and food for the indirect exposure pathway are presented in table format in Appendix B. The tables show the equations, identify the exposure scenario and list all input parameters (air modeling results, calculated values, and site-specific or chemical-specific values). Chemical-specific parameter values are presented in Table B-1 of Appendix B. Default values were used in the exposure algorithms when site-specific values were not available or when guidance specified their use for conservatism. The default values are typically conservative and tend to overestimate the actual risk associated with exposure to emissions (EPA 1994a). Equations that are used in the screening analysis to calculate both indirect and direct exposures to the subsistence farmer, adult resident, and child resident are presented in table format in appendices $C, D$, and $E$, respectively. 


\section{TOXICITY ASSESSMENT}

A toxicity assessment was conducted to identify toxicity values or health benchmarks for the contaminants of concern. A toxicity value is the numerical expression of a substance dose-response relationship that is used in the risk evaluation. The toxicity values or health benchmarks used in this toxicity assessment include the reference dose (RfD), reference concentration (RfC), cancer slope factor (CSF), and unit risk factor (URF), as well as the State of Idaho acceptable ambient concentrations for noncarcinogens (AACs) and carcinogens (AACCs) for the short-term exposure scenario on U.S. Highway 20/26. The RfD and RfC are used to evaluate noncarcinogenic effects. They are an estimate of the daily exposure to the human population (including sensitive subgroups) that is likely to be without an appreciable risk of deleterious effects. The CSF and URF are used to evaluate carcinogenic effects and represent a plausible upper-bound estimate of the probability of a response per unit intake of a chemical over an individual's lifetime.

Toxicity values and health benchmarks were obtained from the following references, in order of hierarchy: (1) the EPA Integrated Risk Information System (IRIS) database (on-line), (2) the EPA Health Effects Assessment Summary Tables (HEAST) (EPA 1997), (3) the Allied Technical Group (ATG) Risk Assessment Work Plan (RAWP)', (4) EPA Region 9 (on-line), and (5) State of Idaho AACs/AACCs, as published in the Rules for the Control of Air Pollution in Idaho (IDAPA 16.01.01, Sections 585 and 586) (on-line). The ATG toxicity data were used because they have been approved by EPA Region 10 and the State of Idaho DEQ. In addition, for some criteria pollutants (carbon monoxide, sulfur dioxide, and lead), National Ambient Air Quality Standards (NAAQS) were used when toxicity values were not available in the other sources. Tables 7 and 8 summarize the toxicity values for the oral and inhalation routes of exposure, respectively.

a. Allied Technical Group, Inc. (ATG) Risk Assessment Work Plan for the ATG Richland Mixed Waste Facility, October 9, 1998. 
Table 7. Toxicity values for the oral route of exposure for the indirect pathway.

\begin{tabular}{|c|c|c|c|c|}
\hline \multirow[b]{2}{*}{ Chemical } & \multicolumn{2}{|c|}{$\begin{array}{c}\mathrm{CSF}^{\text {oral }} \\
(\mathrm{mg} / \mathrm{kg} / \mathrm{day})^{-1}\end{array}$} & \multicolumn{2}{|c|}{$\begin{array}{c}\mathrm{RfD}^{\text {oral }} \\
\text { (mg/kg/day) }\end{array}$} \\
\hline & Value & Reference & Value & Reference \\
\hline Antimony & $\mathrm{ND}$ & & $4.00 \mathrm{E}-04$ & IRIS \\
\hline Arsenic & $1.51 \mathrm{E}+00$ & IRIS & $3.00 \mathrm{E}-04$ & IRIS \\
\hline Barium & ND & & $7.00 \mathrm{E}-02$ & IRIS \\
\hline Benzo(a)pyrene & $7.30 \mathrm{E}+00$ & IRIS & ND & \\
\hline Beryllium & $4.30 \mathrm{E}+00$ & IRIS & $5.00 \mathrm{E}-03$ & IRIS \\
\hline Cadmium & $\mathrm{ND}$ & & $1.00 \mathrm{E}-03$ & IRIS \\
\hline Chromium VI & $\mathrm{ND}$ & & $5.00 \mathrm{E}-03$ & IRIS \\
\hline 1,3-Dinitrobenzene & $\mathrm{ND}$ & & $1.00 \mathrm{E}-04$ & IRIS \\
\hline 2,4-Dinitrotoluene & $\mathrm{ND}$ & & $2.00 \mathrm{E}-03$ & IRIS \\
\hline 2,6-Dinitrotoluene & $\mathrm{ND}$ & & $1.00 \mathrm{E}-03$ & HEAST \\
\hline Di(n)octylphthalate & $\mathrm{ND}$ & & $2.00 \mathrm{E}-02$ & HEAST \\
\hline 2,3,7,8-TCDD (TEQ) & $1.50 \mathrm{E}+05$ & HEAST & $\mathrm{ND}$ & \\
\hline Lead & $\mathrm{ND}$ & & $\mathrm{ND}$ & \\
\hline Mercury & $\mathrm{ND}$ & & $3.00 \mathrm{E}-04$ & IRIS \\
\hline Nickel & $\mathrm{ND}$ & & $2.00 \mathrm{E}-02$ & IRIS \\
\hline Nitrobenzene & $\mathrm{ND}$ & & $5.00 \mathrm{E}-04$ & IRIS \\
\hline Pentachloronitrobenzene & 2.60E-01 & HEAST & $3.00 \mathrm{E}-03$ & IRIS \\
\hline Penatachlorophenol & $1.20 \mathrm{E}-01$ & IRIS & $3.00 \mathrm{E}-02$ & IRIS \\
\hline Selenium & ND & & $5.00 \mathrm{E}-03$ & IRIS \\
\hline Silver & ND & & $5.00 \mathrm{E}-03$ & IRIS \\
\hline Thallium & $\mathrm{ND}$ & & $8.00 \mathrm{E}-04$ & IRIS \\
\hline
\end{tabular}


Table 8. Toxicity values and or health benchmarks for the inhalation route of exposure for the direct pathway.

\begin{tabular}{|c|c|c|c|c|}
\hline \multirow[b]{2}{*}{ Chemical } & \multicolumn{2}{|c|}{$\begin{array}{c}\mathrm{URF} \\
\left(\mu \mathrm{g} / \mathrm{m}^{3}\right)^{-1}\end{array}$} & \multicolumn{2}{|c|}{$\begin{array}{c}\mathrm{RfC} \\
\left(\mathrm{mg} / \mathrm{m}^{3}\right) \\
\end{array}$} \\
\hline & Value & Reference & Value & Reference \\
\hline Acetonitrile & $\mathrm{ND}$ & & $5.00 \mathrm{E}-02$ & HEAST \\
\hline Aniline & ND & & $1.00 \mathrm{E}-03$ & IRIS \\
\hline Antimony & $\mathrm{ND}$ & & $2.50 \mathrm{E}-02$ & IDHW \\
\hline Arsenic & $4.30 \mathrm{E}-03$ & IRIS & ND & \\
\hline Barium & ND & & $5.00 \mathrm{E}-04$ & HEAST \\
\hline Benzene & $7.80 \mathrm{E}-06$ & IRIS & $9.00 \mathrm{E}-03$ & NCEA \\
\hline Benzo(a)pyrene & $8.86 \mathrm{E}-04$ & ATG & ND & \\
\hline Beryllium & $2.40 \mathrm{E}-03$ & IRIS & $2.00 \mathrm{E}-05$ & IRIS \\
\hline Bromoform & $1.10 \mathrm{E}-06$ & IRIS & $7.00 \mathrm{E}-02$ & ATG \\
\hline Butylbenzylphthalate & $\mathrm{ND}$ & & $7.00 \mathrm{E}-01$ & ATG \\
\hline Cadmium & $1.80 \mathrm{E}-03$ & IRIS & $2.00 \mathrm{E}-04$ & EPA9 \\
\hline Carbon disulfide & ND & & $7.30 \mathrm{E}-01$ & IRIS \\
\hline Carbon monoxide & ND & & $1.00 \mathrm{E}+01$ & NAAQS \\
\hline Carbon tetrachloride & $2.00 \mathrm{E}-03$ & ATG & $2.00 \mathrm{E}-03$ & ATG \\
\hline Chlorobenzene & $\mathrm{ND}$ & & $2.00 \mathrm{E}-02$ & HEAST \\
\hline Chloroform & $2.30 \mathrm{E}-05$ & IRIS & $3.01 \mathrm{E}-03$ & ATG \\
\hline Chromium VI & $1.20 \mathrm{E}-02$ & IRIS & ND & \\
\hline Dibutylphthalate & $\mathrm{ND}$ & & $3.50 \mathrm{E}-01$ & ATG \\
\hline 1,2-Dichloroethane & $2.60 \mathrm{E}-05$ & IRIS & $1.00 \mathrm{E}-02$ & EPA9 \\
\hline Diethylphthalate & ND & & $2.80 \mathrm{E}+00$ & ATG \\
\hline 1,3-Dinitrobenzene & $\mathrm{ND}$ & & $3.50 \mathrm{E}-04$ & ATG \\
\hline 2,4-Dinitrophenol & ND & & $7.00 \mathrm{E}-03$ & ATG \\
\hline 2,4-Dinitrotoluene & $\mathrm{ND}$ & & $7.00 \mathrm{E}-03$ & ATG \\
\hline 2,6-Dinitrotoluene & $\mathrm{ND}$ & & $3.50 \mathrm{E}-03$ & ATG \\
\hline Di(n)octylphthalate & ND & & 7.00E-02 & ATG \\
\hline 1,4-Dioxane & $3.14 \mathrm{E}-06$ & ATG & ND & \\
\hline Ethylene glycol & ND & & $7.00 \mathrm{E}+00$ & ATG \\
\hline Formaldehyde & $1.30 \mathrm{E}-05$ & IRIS & ND & \\
\hline Formic acid & $\mathrm{ND}$ & & $7.00 \mathrm{E}+00$ & EPA9 \\
\hline
\end{tabular}


Table 8. (continued).

\begin{tabular}{|c|c|c|c|c|}
\hline \multirow[b]{2}{*}{ Chemical } & \multicolumn{2}{|c|}{$\begin{array}{c}\text { URF } \\
\left(\mu \mathrm{g} / \mathrm{m}^{3}\right)^{-1}\end{array}$} & \multicolumn{2}{|c|}{$\begin{array}{c}\mathrm{RfC} \\
\left(\mathrm{mg} / \mathrm{m}^{3}\right) \\
\end{array}$} \\
\hline & Value & Reference & Value & Reference \\
\hline 2,3,7,8-TCDD (TEQ) & $3.43 E+01$ & ATG & $\mathrm{ND}$ & \\
\hline Hydrazine & $4.90 \mathrm{E}-03$ & IRIS & $\mathrm{ND}$ & \\
\hline Hydrogen chloride & $\mathrm{ND}$ & & $2.00 \mathrm{E}-02$ & IRIS \\
\hline Hydrogen fluoride & $\mathrm{ND}$ & & $2.60 \mathrm{E}-02$ & Calculated \\
\hline (Iso)thiourea & $5.56 \mathrm{E}-04$ & $\mathrm{DHW}$ & ND & \\
\hline Lead & $\mathrm{ND}$ & & $1.50 \mathrm{E}-03$ & NAAQS \\
\hline Mercury & $\mathrm{ND}$ & & $3.00 E-04$ & IRIS \\
\hline Methyl ethyl ketone & ND & & $1.00 E+00$ & IRIS \\
\hline Methylene chloride & 4.70E-07 & IRIS & $3.00 E+00$ & HEAST \\
\hline Napthalene & ND & & $3.00 \mathrm{E}-03$ & EPA9 \\
\hline Nickel & $2.40 \mathrm{E}-04$ & EPA9 & ND & \\
\hline Nitric acid & ND & & $2.50 \mathrm{E}-01$ & $\mathrm{DHHW}$ \\
\hline Nitrobenzene & ND & & $2.00 \mathrm{E}-03$ & HEAST \\
\hline Nitrogen dioxide & ND & & $3.50 \mathrm{E}+00$ & EPA9 \\
\hline Pentachloronitrobenzene & $7.43 E-05$ & ATG & $1.05 \mathrm{E}-02$ & ATG \\
\hline Pentachlorophenol & $3.40 \mathrm{E}-05$ & ATG & $1.05 \mathrm{E}-01$ & ATG \\
\hline Phenol & ND & & $2.10 \mathrm{E}+00$ & ATG \\
\hline Pyridine & ND & & $3.50 \mathrm{E}-03$ & ATG \\
\hline Selenium & ND & & $1.00 \mathrm{E}-02$ & IDHW \\
\hline Silver & ND & & $5.00 \mathrm{E}-03$ & IDHW \\
\hline Sulfur dioxide & ND & & $8.00 \mathrm{E}-02$ & NAAQS \\
\hline Tetrachloroethylene & $3.14 \mathrm{E}-05$ & EPA9 & $2.70 \mathrm{E}-01$ & ATG \\
\hline Thallium & $\mathrm{ND}$ & & $2.80 \mathrm{E}-04$ & ATG \\
\hline Uranium & ND & & $1.00 \mathrm{E}-02$ & IDHW \\
\hline Toluene & $\mathrm{ND}$ & & $4.00 \mathrm{E}-01$ & IRIS \\
\hline 1,2,4-Trichlorobenzene & $\mathrm{ND}$ & & $2.00 \mathrm{E}-01$ & ATG \\
\hline 1,1,1-Trichloroethane & ND & & $1.00 \mathrm{E}-01$ & ATG \\
\hline 1,1,2-Trichloroethane & $1.60 \mathrm{E}-05$ & IRIS & $1.40 \mathrm{E}-02$ & ATG \\
\hline Trichloroethylene & ND & & $2.10 \mathrm{E}-02$ & ATG \\
\hline
\end{tabular}


Table 8. (continued).

\begin{tabular}{|c|c|c|c|c|}
\hline \multirow[b]{2}{*}{ Chemical } & \multicolumn{2}{|c|}{$\begin{array}{c}\mathrm{URF} \\
\left(\mu \mathrm{g} / \mathrm{m}^{3}\right)^{-1}\end{array}$} & \multicolumn{2}{|r|}{$\begin{array}{c}\mathrm{RfC} \\
\left(\mathrm{mg} / \mathrm{m}^{3}\right) \\
\end{array}$} \\
\hline & Value & Reference $^{\mathrm{a}}$ & Value & Reference $^{\mathrm{a}}$ \\
\hline Hydrogen chloride & ND & & $2.00 \mathrm{E}-02$ & IRIS \\
\hline Hydrogen fluoride & ND & & 2.60E-02 & Calculated \\
\hline (Iso)thiourea & $5.56 \mathrm{E}-04$ & IDHW & ND & \\
\hline Lead & $\mathrm{ND}$ & & $1.50 \mathrm{E}-03$ & NAAQS \\
\hline Mercury & ND & & $3.00 \mathrm{E}-04$ & IRIS \\
\hline Methyl ethyl ketone & ND & & $1.00 E+00$ & IRIS \\
\hline Methylene chloride & 4.70E-07 & IRIS & $3.00 \mathrm{E}+00$ & HEAST \\
\hline Napthalene & $\mathrm{ND}$ & & 3.00E-03 & EPA9 \\
\hline Nickel & $2.40 E-04$ & EPA9 & ND & \\
\hline Nitric acid & ND & & $2.50 E-01$ & IDHW \\
\hline Nitrobenzene & ND & & $2.00 \mathrm{E}-03$ & HEAST \\
\hline Nitrogen dioxide & ND & & $3.50 \mathrm{E}+00$ & EPA9 \\
\hline Pentachloronitrobenzene & $7.43 E-05$ & ATG & $1.05 \mathrm{E}-02$ & ATG \\
\hline Pentachlorophenol & $3.40 \mathrm{E}-05$ & ATG & 1.05E-01 & ATG \\
\hline Phenol & $\mathrm{ND}$ & & $2.10 \mathrm{E}+00$ & ATG \\
\hline Pyridine & $\mathrm{ND}$ & & $3.50 \mathrm{E}-03$ & ATG \\
\hline Selenium & $\mathrm{ND}$ & & $1.00 E-02$ & IDHW \\
\hline Silver & $\mathrm{ND}$ & & $5.00 \mathrm{E}-03$ & IDHW \\
\hline Sulfur dioxide & ND & & $8.00 \mathrm{E}-02$ & NAAQS \\
\hline Tetrachloroethylene & $3.14 \mathrm{E}-05$ & EPA9 & $2.70 \mathrm{E}-01$ & ATG \\
\hline Thallium & ND & & $2.80 \mathrm{E}-04$ & ATG \\
\hline Uranium & ND & & $1.00 \mathrm{E}-02$ & IDHW \\
\hline Toluene & ND & & $4.00 \mathrm{E}-01$ & IRIS \\
\hline 1,2,4-Trichlorobenzene & ND & & $2.00 \mathrm{E}-01$ & ATG \\
\hline 1,1,1-Trichloroethane & ND & & $1.00 \mathrm{E}-01$ & ATG \\
\hline 1,1,2-Trichloroethane & $1.60 \mathrm{E}-05$ & IRIS & $1.40 \mathrm{E}-02$ & ATG \\
\hline Trichloroethylene & ND & & $2.10 \mathrm{E}-02$ & ATG \\
\hline $\begin{array}{l}\text { a. Sources: } \\
\text { ND }=\text { no toxicity data a } \\
\text { IDHW }=\text { Idaho Divisio } \\
\text { NCEA }=\text { National Cent } \\
\text { ATG }=\text { Allied Technica } \\
\text { EPA9 }=\text { Derived from } \\
\text { NAAQS }=\text { National Am } \\
\text { Calculated }=1 \% \text { of AC }\end{array}$ & $\begin{array}{l}\text { available. } \\
\text { f Health and We } \\
\text { or Environment } \\
\text { roup Risk Asse } \\
\text { Region } 9 \text { on-li } \\
\text { ent Air Quality } \\
\text { H-TLV. }\end{array}$ & $\begin{array}{l}\text { Toxic Air Pollutan } \\
\text { sessment (EPA) } \\
\text { at Work Plan } \\
\text { xicity values } \\
\text { ard }\end{array}$ & $\mathrm{ACC}$ & \\
\hline
\end{tabular}




\section{RISK CHARACTERIZATION}

The objective of the risk characterization, the final step in the overall risk assessment process, is to integrate the results of the exposure assessment and the toxicity assessment to estimate risk to humans from the exposure of onsite contaminants. The toxicity and exposure assessments are summarized and integrated into quantitative expressions of risk. These quantitative expressions of risk include: (1) the increased probability of cancer in an individual over a lifetime, referred to as the excess lifetime individual cancer risk arising from both oral and inhalation routes of exposure; (2) for oral exposures, a measure of an individual's exposure to chemicals with noncancer health effects relative to the RfD, referred to as the hazard quotient; (3) for inhalation exposures, a hazard quotient relative to the $\mathrm{RfC}$ in air; and (4) where appropriate, a hazard index, which represents the combined hazard quotients for chemicals with the same noncarcinogenic health effects.

The carcinogenic effects or probability that an individual will develop cancer over a lifetime of exposure are estimated from projected intakes and chemical-specific dose-response relationships or URFs. The calculation of health risks from the potential exposure to carcinogenic contaminants involves multiplying the CSF for each carcinogen by the estimated average daily intake value. When a CSF is not established for a contaminant but a URF has been established for the contaminant, then the health risk is calculated by multiplying the URF for the carcinogen to the estimated air concentration. The risk is expressed probabilistically and is compared to EPA's acceptable risk critieria of $1 \times 10^{-5}$ for combustion units (EPA 1998a). The risks are summed across all chemicals and pathways to determine the total excess cancer risk from NWCF emissions (including auxiliary systems).

Noncarcinogenic effects are characterized by comparing projected intakes of substances to toxicity values or health benchmarks. The chronic $\mathrm{RfD}$ for ingestion and the $\mathrm{RfC}$ for inhalation are used to compare toxic effects of noncarcinogenic contaminants. The hazard potential from toxic effects is computed as the ratio of estimated average daily intake to the RfD, or the ratio of the estimated air concentration to the RfC, and is referred to as the hazard quotient. The sum of the hazard quotients is equal to the hazard index. Hazard quotients for noncarcinogens may be added if health effects caused by exposure to the contaminant are similar, affecting the same target organs (i.e., liver or neurotoxic effects) to calculate an overall hazard index for, liver or neurotoxic effects. The hazard quotient (HQ) or hazard index (HI) should be interpreted as an index of relative health and does not provide a probabilistic expression of risk. A value less than one indicates that it is unlikely for even sensitive subpopulations to experience adverse health effects. However, for this SLRA EPA recommends that stack emissions may only contribute $25 \%$ of the total noncarcinogenic health standard (EPA 1998a). Therefore, if the estimated $\mathrm{HI}$ and $\mathrm{HQ}$ values are less than 0.25 , no further risk analysis is necessary and emissions are considered protective of the public health. Exposures to noncarcinogens from the direct exposure pathway should not be added to those from the indirect pathways (EPA 1994a).

\subsection{Direct Inhalation Exposures}

The excess lifetime individual cancer risk from direct inhalation of a chemical carcinogen is calculated from the URF for each exposure scenario as follows:

Cancer $_{\text {Risk }}^{(i n h) i j}=C_{(a i r) i j} * U R F_{(i n h) i}$ 
where

$$
\begin{array}{ll}
\text { Cancer Risk }_{(i n h) i j} & =\begin{array}{l}
\text { Excess lifetime cancer risk via inhalation (unitless), for chemical } \mathrm{i} \\
\text { and exposure receptor } \mathrm{j}
\end{array} \\
C_{(a i r) i j} & =\text { Concentration in air }\left(\mu \mathrm{g} / \mathrm{m}^{3}\right), \text { for chemical } \mathrm{i} \text {, exposure } \mathrm{j} \\
U R F_{(i n h) i} & =\text { Inhalation unit risk factor }\left(\text { per } \mu \mathrm{g} / \mathrm{m}^{3}\right), \text { for chemical } \mathrm{i} .
\end{array}
$$

The total cancer risk to the individual via inhalation is estimated by summing the lifetime individual cancer risk for all carcinogenic chemicals via the inhalation route of exposure. Results for the offsite scenarios are presented in Table 9 and indicate inhalation exposures are well below the EPA acceptable criterion of $1 \times 10^{-5}$ (EPA 1998a).

The hazard quotient for inhalation exposures to noncarcinogenic chemicals is calculated for each exposure scenario as follows:

$$
H Q_{(i n h) i j}=\left(C_{(a i r) i j} / R f C_{i}\right) * 10^{-3}
$$

where

$$
\begin{aligned}
& H Q_{(i n h) i j}=\text { hazard quotient via inhalation (unitless), chemical } \mathrm{i} \text {, exposure } \mathrm{j} \\
& C_{(a i r) i j}=\text { concentration in air }\left(\mu \mathrm{g} / \mathrm{m}^{3}\right), \text { chemical } \mathrm{i} \text {, exposure scenario } \mathrm{j} \\
& R f C_{i}=\text { reference concentration }\left(\mathrm{mg} / \mathrm{m}^{3}\right), \text { chemical } \mathrm{i} \\
& 10^{-3}=\text { unit conversion factor }(\mathrm{mg} / \mu \mathrm{g}) .
\end{aligned}
$$

Table 10 presents the hazard quotients for inhalation exposure to noncarcinogenic chemicals for the offsite scenarios. The results indicate that all hazard quotients are well below the EPA acceptable level of 0.25 . Table 11 lists chemicals with neurotoxin and liver effects. Chemicals with neurotoxin effects include 2,4-dinitrotoluene, 2,6-dinitrotoluene, and mercury. The HI for neurotoxin effects is 0.009. The PIC 2,6-dinitrotoluene is the biggest contributor to this HI. Chemicals with liver effects include di-n-octylphthalate, pentatchloronitrobenzene, and pentachlorophenol. The $\mathrm{HI}$ for liver effects is 0.0002 . The total hazard index (irrespective of specific toxic effects) for inhalation of noncarcinogenic chemicals is 0.09 .

For the acute inhalation exposure to transient travelers on U.S. Highway 20, estimated ambient air concentrations for chemical emissions are compared to the State of Idaho acceptable ambient concentrations for noncarcinogens and carcinogens (AAC/AACC) or EPA Region 9 Preliminary Remediation Goals (PRGs) for ambient air. The AACs are 24-hour averages and the AACCs are annual averages. These criteria are chronic exposure criteria that will conservatively bound any short-term acute exposure criteria. It should be noted that the State of Idaho does not require evaluation of carcinogenic impacts at public highways because the short-term receptor exposure time (perhaps 10 minutes per day) is not appropriate for evaluating the long-term, chronic intake required for carcinogenic exposure assessment. However, to demonstrate the low potential hazards from these chemicals, carcinogenic risks at U.S. Highway 20 are presented in this SLRA, indicating the potential risks that a receptor might be exposed to if the receptor were to remain on the highway location of maximum air concentration for a lifetime. Table 12 presents the results and indicates all chemical emissions are well below the State of Idaho AAC/AACC or the EPA Region 9 PRG. 
Table 9. Cancer risk estimates for inhalation route of exposure at the INEEL boundary.

\begin{tabular}{|c|c|c|c|}
\hline Chemical & $\begin{array}{c}\text { Air Concentration }{ }^{2} \\
\left(\mathrm{ug} / \mathrm{m}^{3}\right)\end{array}$ & $\begin{array}{r}U_{R F}^{b} \\
\left(\mathrm{ug} / \mathrm{m}^{3}\right)\end{array}$ & Cancer risk \\
\hline Aniline & $8.45 \mathrm{E}-06$ & $1.63 \mathrm{E}-06$ & $1 E-11$ \\
\hline Arsenic & 7.33E-14 & $4.30 E-03$ & $3 E-16$ \\
\hline Benzene & $5.21 \mathrm{E}-08$ & $7.80 \mathrm{E}-06$ & $4 \mathrm{E}-13$ \\
\hline Benzo(a)pyrene & $1.04 \mathrm{E}-07$ & $8.86 \mathrm{E}-04$ & $9 E-11$ \\
\hline Beryllium & $9.94 \mathrm{E}-10$ & $2.40 \mathrm{E}-03$ & $2 \mathrm{E}-12$ \\
\hline Bromoform & $5.21 \mathrm{E}-08$ & $1.10 \mathrm{E}-06$ & $6 \mathrm{E}-14$ \\
\hline Cadmium & $1.55 \mathrm{E}-12$ & $1.80 \mathrm{E}-03$ & $3 E-15$ \\
\hline Carbon tetrachloride & $5.21 \mathrm{E}-08$ & $1.50 \mathrm{E}-05$ & $8 \mathrm{E}-13$ \\
\hline Chloroform & $5.21 \mathrm{E}-08$ & $2.30 \mathrm{E}-05$ & $1 E-12$ \\
\hline Chromium & $5.53 \mathrm{E}-13$ & $1.20 \mathrm{E}-02$ & $7 \mathrm{E}-15$ \\
\hline Coplaner PCBs & $9.94 \mathrm{E}-13$ & $3.43 E+1$ & $3 E-11$ \\
\hline 1,2-Dichloroethane & $5.21 \mathrm{E}-08$ & $2.60 \mathrm{E}-05$ & $1 E-12$ \\
\hline 1,4-Dioxane & 3.91E-05 & $3.14 \mathrm{E}-06$ & $1 \mathrm{E}-10$ \\
\hline Formaldehyde & $4.53 \mathrm{E}-08$ & $1.30 \mathrm{E}-05$ & $6 \mathrm{E}-13$ \\
\hline $2,3,7,8-\mathrm{TCDD}$ & $6.83 \mathrm{E}-12$ & $3.43 E+01$ & $2 E-10$ \\
\hline Hydrazine & 1.77E-06 & 4.90E-03 & $9 E-09$ \\
\hline (Iso)thiourea & $2.20 \mathrm{E}-07$ & $5.56 \mathrm{E}-04$ & $1 E-10$ \\
\hline Methylene chloride & $5.21 \mathrm{E}-08$ & $4.70 \mathrm{E}-07$ & $2 E-14$ \\
\hline Nickel & $5.30 \mathrm{E}-13$ & $2.40 \mathrm{E}-04$ & $2 E-16$ \\
\hline Pentachloronitrobenzene(PIC) & $2.49 \mathrm{E}-03$ & 7.43E-05 & $2 \mathrm{E}-07$ \\
\hline Pentachlorophenol & $1.04 \mathrm{E}-07$ & $3.43 \mathrm{E}-05$ & $4 \mathrm{E}-12$ \\
\hline Tetrachloroethylene & $5.21 E-08$ & $3.14 \mathrm{E}-05$ & $2 \mathrm{E}-12$ \\
\hline 1,1,2-Trichloroethane & $5.21 \mathrm{E}-08$ & $1.60 \mathrm{E}-05$ & $8 \mathrm{E}-13$ \\
\hline \multicolumn{3}{|l|}{ Total Cancer Risk } & 2E-07 \\
\hline \multicolumn{4}{|c|}{$\begin{array}{l}\text { a. The air concentration value is the product of the emission rate (see Section } 2 \text { ) and Cyv value of } 6.21 \mathrm{E}-02 \text {. Because vapor } \\
\text { and particulate concentrations are similar, the higher of the two is assumed for all chemicals. }\end{array}$} \\
\hline
\end{tabular}


Table 10. Noncarcinogenic hazard quotient estimates for inhalation exposure at INEEL boundary.

\begin{tabular}{|c|c|c|c|}
\hline Chemical & $\begin{array}{c}\text { Air Concentration } \\
\left(\mathrm{ug} / \mathrm{m}^{3}\right)\end{array}$ & $\begin{array}{c}\mathrm{RfC}^{\mathrm{b}} \\
\left(\mathrm{mg} / \mathrm{m}^{3}\right)\end{array}$ & $\mathrm{HQ}$ \\
\hline Acetonitrile & 5.00E-07 & $5.00 \mathrm{E}-02$ & $1 \mathrm{E}-08$ \\
\hline Aniline & $8.45 \mathrm{E}-06$ & $1.00 \mathrm{E}-03$ & $8 \mathrm{E}-06$ \\
\hline Antimony & $1.86 \mathrm{E}-09$ & $2.50 \mathrm{E}-02$ & $7 \mathrm{E}-11$ \\
\hline Barium & $4.35 \mathrm{E}-14$ & $5.00 \mathrm{E}-04$ & $9 \mathrm{E}-14$ \\
\hline Benzene & $5.21 \mathrm{E}-08$ & $9.00 \mathrm{E}-03$ & $6 \mathrm{E}-09$ \\
\hline Beryllium & $9.94 \mathrm{E}-10$ & $2.00 \mathrm{E}-05$ & $5 \mathrm{E}-08$ \\
\hline Bromoform & $5.21 E-08$ & $7.00 \mathrm{E}-02$ & $7 \mathrm{E}-10$ \\
\hline Butylbenzylphthalate & $1.04 \mathrm{E}-09$ & $7.00 \mathrm{E}-01$ & $1 \mathrm{E}-12$ \\
\hline Cadmium & $1.55 \mathrm{E}-12$ & $2.00 \mathrm{E}-04$ & $8 \mathrm{E}-12$ \\
\hline Carbon disulfide & $4.14 \mathrm{E}-06$ & $7.30 \mathrm{E}-01$ & $6 \mathrm{E}-09$ \\
\hline Carbon monoxide & $1.90 E+00$ & $1.00 \mathrm{E}+01$ & $2 \mathrm{E}-04$ \\
\hline Carbon tetrachloride & $5.21 \mathrm{E}-08$ & $2.00 \mathrm{E}-03$ & $3 \mathrm{E}-08$ \\
\hline Chlorobenzene & $5.21 \mathrm{E}-08$ & $2.00 \mathrm{E}-02$ & $3 E-09$ \\
\hline Chloroform & $5.21 \mathrm{E}-08$ & $3.01 \mathrm{E}-03$ & $2 \mathrm{E}-08$ \\
\hline Chromium & $5.53 \mathrm{E}-13$ & $1.02 \mathrm{E}-04$ & $5 E-12$ \\
\hline Dibutylphthalate & $1.04 \mathrm{E}-09$ & $3.50 \mathrm{E}-01$ & $3 E-12$ \\
\hline 1,2-Dichloroethane & $5.21 \mathrm{E}-08$ & $1.02 \mathrm{E}-02$ & $5 \mathrm{E}-09$ \\
\hline Diethylphthalate & $1.34 \mathrm{E}-08$ & $2.80 \mathrm{E}+00$ & $5 E-12$ \\
\hline 1,3-Dinitrobenzene(PIC) & $2.98 \mathrm{E}-02$ & $3.50 \mathrm{E}-04$ & $9 \mathrm{E}-02$ \\
\hline 2,4-Dinitrophenol & $8.45 \mathrm{E}-07$ & $7.00 \mathrm{E}-03$ & $1 E-07$ \\
\hline 2,4-Dinitrotoluene & $9.88 \mathrm{E}-07$ & $7.00 \mathrm{E}-03$ & $1 E-07$ \\
\hline 2,4-Dinitrotoluene(PIC) & $3.23 \mathrm{E}-02$ & $7.00 \mathrm{E}-03$ & $5 E-03$ \\
\hline 2,6-Dinitrotoluene(PIC) & $3.23 \mathrm{E}-02$ & $3.50 \mathrm{E}-03$ & $9 E-03$ \\
\hline Di(n)octyl phthalate & $1.04 \mathrm{E}-09$ & $7.00 \mathrm{E}-02$ & $1 E-11$ \\
\hline Ethylene glycol & $6.52 \mathrm{E}-06$ & $7.00 \mathrm{E}+00$ & $9 \mathrm{E}-10$ \\
\hline Formic acid & $2.52 \mathrm{E}-06$ & $7.00 E+00$ & $4 \mathrm{E}-10$ \\
\hline Hydrogen chloride & $5.61 E-03$ & $1.99 \mathrm{E}-02$ & $3 \mathrm{E}-04$ \\
\hline Hydrogen fluoride & $3.19 \mathrm{E}-03$ & $2.60 \mathrm{E}-02$ & $1 \mathrm{E}-04$ \\
\hline Lead & $8.70 \mathrm{E}-10$ & $1.50 \mathrm{E}-03$ & $6 \mathrm{E}-10$ \\
\hline Mercury & $9.94 \mathrm{E}-05$ & $3.00 \mathrm{E}-04$ & $3 \mathrm{E}-04$ \\
\hline Methyl ethyl ketone & $1.77 \mathrm{E}-06$ & $1.00 \mathrm{E}+00$ & $2 \mathrm{E}-09$ \\
\hline \multirow[t]{2}{*}{ Methylene chloride } & $5.21 \mathrm{E}-08$ & $3.00 \mathrm{E}+00$ & $2 \mathrm{E}-11$ \\
\hline & $6-4$ & & \\
\hline
\end{tabular}


Table 10. (continued).

\begin{tabular}{lccc}
\hline \multicolumn{1}{c}{ Chemical } & $\begin{array}{c}\text { Air Concentration } \\
\left(\mathrm{ug}^{\mathrm{a}} \mathrm{m}^{3}\right)\end{array}$ & $\begin{array}{c}\text { RfC } \\
\left(\mathrm{mg} / \mathrm{m}^{3}\right)\end{array}$ & HQ \\
\hline Naphthalene & $1.04 \mathrm{E}-07$ & $3.01 \mathrm{E}-03$ & $3 \mathrm{E}-08$ \\
Nitric acid & $8.64 \mathrm{E}-01$ & $2.50 \mathrm{E}-01$ & $3 \mathrm{E}-03$ \\
Nitrobenzene(PIC) & $2.17 \mathrm{E}-02$ & $2.00 \mathrm{E}-03$ & $1 \mathrm{E}-02$ \\
Nitrogen dioxide & $3.03 \mathrm{E}+00$ & $3.50 \mathrm{E}+00$ & $9 \mathrm{E}-04$ \\
Pentachloronitrobenzene(PIC) & $2.49 \mathrm{E}-03$ & $1.05 \mathrm{E}-02$ & $2 \mathrm{E}-04$ \\
Pentachlorophenol & $1.04 \mathrm{E}-07$ & $1.05 \mathrm{E}-01$ & $1 \mathrm{E}-09$ \\
Phenol & $1.77 \mathrm{E}-06$ & $2.10 \mathrm{E}+00$ & $8 \mathrm{E}-10$ \\
Pyridine & $1.51 \mathrm{E}-04$ & $3.50 \mathrm{E}-03$ & $4 \mathrm{E}-05$ \\
Selenium & $4.72 \mathrm{E}-08$ & $1.00 \mathrm{E}-02$ & $5 \mathrm{E}-09$ \\
Silver & $3.54 \mathrm{E}-14$ & $5.00 \mathrm{E}-03$ & $7 \mathrm{E}-15$ \\
Sulfur dioxide & $1.42 \mathrm{E}-02$ & $8.00 \mathrm{E}-02$ & $2 \mathrm{E}-04$ \\
Tetrachloroethylene & $5.21 \mathrm{E}-08$ & $2.70 \mathrm{E}-01$ & $2 \mathrm{E}-10$ \\
Thallium & $1.55 \mathrm{E}-08$ & $2.80 \mathrm{E}-04$ & $6 \mathrm{E}-08$ \\
Toluene & $5.21 \mathrm{E}-08$ & $4.00 \mathrm{E}-01$ & $1 \mathrm{E}-10$ \\
1,2,4-Trichlorobenzene & $1.04 \mathrm{E}-07$ & $2.00 \mathrm{E}-01$ & $5 \mathrm{E}-10$ \\
1,1,1-Trichloroethane & $5.21 \mathrm{E}-08$ & $1.02 \mathrm{E}-01$ & $5 \mathrm{E}-10$ \\
$1,1,2-$ Trichloroethane & $5.21 \mathrm{E}-08$ & $1.40 \mathrm{E}-02$ & $4 \mathrm{E}-09$ \\
Trichloroethylene & $5.21 \mathrm{E}-08$ & $2.10 \mathrm{E}-02$ & $2 \mathrm{E}-09$ \\
Uranium & $4.91 \mathrm{E}-13$ & $1.00 \mathrm{E}-02$ & $5 \mathrm{E}-14$ \\
Total Hazard Index & & & 0.09 \\
& & &
\end{tabular}

a. The air concentration value is the product of the emission rate (see Section 2) and Cyv value of 6.21E-02. Because vapor and particulate concentrations are similar, the higher of the two is assumed for all chemicals.

b. See Section 5 for the source of the RfC values.

c. The total hazard index irrespective of specific toxic effects (i.e., liver or neurotoxin). Also, the total hazard index only includes the nitroaromatic PIC with the highest hazard quotient (1,3-dinitrobenzene). 
Table 11. Direct exposure (inhalation) hazard quotient and hazard index for chemicals with liver or neurotoxin effects.

\begin{tabular}{|c|c|c|c|c|c|c|}
\hline \multirow[b]{2}{*}{ Chemical } & \multicolumn{2}{|c|}{ Subsistence-Farmer HQ } & \multicolumn{2}{|c|}{ Adult-Resident HQ } & \multicolumn{2}{|c|}{ Child-Resident HQ } \\
\hline & Liver & Neurotoxim & Liver & Neurotoxin & Liver & Neurotoxin \\
\hline $\begin{array}{l}\text { 2,4-Dinitrotoluene } \\
\text { (PIC) }\end{array}$ & & $5 E-03$ & & $5 \mathrm{E}-03$ & & $5 \mathrm{E}-03$ \\
\hline $\begin{array}{l}\text { 2,6-Dinitrotoluene } \\
(\mathrm{PIC})\end{array}$ & & 9E-03 & & 9E-03 & & 9E-03 \\
\hline Di(n)octylphthalate & $1 E-11$ & & $1 E-11$ & & $1 E-11$ & \\
\hline Mercury & & $3 E-04$ & & $3 E-04$ & & $3 E-04$ \\
\hline $\begin{array}{l}\text { Pentachloronitro- } \\
\text { benzene(PIC) }\end{array}$ & $2 E-04$ & & $2 \mathrm{E}-04$ & & $2 \mathrm{E}-04$ & \\
\hline Pentachlorophenol & $1 E-09$ & & $1 E-9$ & & $1 \mathrm{E}-09$ & \\
\hline $\begin{array}{l}\text { Total Hazard } \\
\text { Index }{ }^{2}\end{array}$ & 2E-04 & 9E-03 & 2E-04 & $9 \mathrm{E}-03$ & $2 E-04$ & $9 E-03$ \\
\hline
\end{tabular}


Table 12. Acute inhalation exposure to transient travelers on U.S. Highway 20.

\begin{tabular}{|c|c|c|c|c|}
\hline Chemical & $\begin{array}{c}\text { Air Concentration } \\
\left(\mathrm{ug} / \mathrm{m}^{3}\right)\end{array}$ & $\begin{array}{c}\text { Screening } \\
\text { Concentration } \\
\text { Criteria } \\
\left(\mathrm{ug} / \mathrm{m}^{3}\right) \\
\end{array}$ & Source $^{b}$ & $\begin{array}{l}\text { Ratio of Air } \\
\text { Concentration to } \\
\text { Screening } \\
\text { Concentration }\end{array}$ \\
\hline Acetonitrile & $3.72 \mathrm{E}-06$ & $3.35 \mathrm{E}+03$ & $\mathrm{AAC}$ & $1.11 \mathrm{E}-09$ \\
\hline Aniline & $8.69 \mathrm{E}-06$ & $1.40 \mathrm{E}-01$ & AACC & $6.21 E-05$ \\
\hline Antimony & $1.38 \mathrm{E}-08$ & $2.50 \mathrm{E}+01$ & $\mathrm{AAC}$ & $5.54 \mathrm{E}-10$ \\
\hline Arsenic & $7.54 \mathrm{E}-14$ & $2.30 \mathrm{E}-04$ & AACC & $3.28 \mathrm{E}-10$ \\
\hline Barium & 3.23E-13 & $2.50 \mathrm{E}+01$ & $\mathrm{AAC}$ & $1.29 \mathrm{E}-14$ \\
\hline Benzene & $5.36 \mathrm{E}-08$ & $1.20 \mathrm{E}-01$ & $\mathrm{AACC}$ & 4.47E-07 \\
\hline Benzo(a)pyrene & $1.07 \mathrm{E}-07$ & $3.00 \mathrm{E}-04$ & $\mathrm{AACC}$ & $3.58 \mathrm{E}-04$ \\
\hline Beryllium & $1.02 \mathrm{E}-09$ & $4.20 \mathrm{E}-03$ & $\mathrm{AACC}$ & $2.43 \mathrm{E}-07$ \\
\hline Bromoform & $3.87 \mathrm{E}-07$ & $2.50 \mathrm{E}+02$ & $\mathrm{AAC}$ & $1.55 \mathrm{E}-09$ \\
\hline Butylbenzylphthalate & $7.75 \mathrm{E}-09$ & $7.30 \mathrm{E}+02$ & PRG & $1.06 \mathrm{E}-11$ \\
\hline Cadmium & $1.60 \mathrm{E}-12$ & $5.60 \mathrm{E}-04$ & $\mathrm{AACC}$ & $2.85 \mathrm{E}-09$ \\
\hline Carbon disulfide & $3.07 \mathrm{E}-05$ & $1.50 \mathrm{E}+03$ & $\mathrm{AAC}$ & $2.05 \mathrm{E}-08$ \\
\hline Carbon monoxide & $1.41 \mathrm{E}+01$ & $1.00 \mathrm{E}+04$ & NAAQS & $1.41 \mathrm{E}-03$ \\
\hline Carbon tetrachloride & $5.36 \mathrm{E}-08$ & $6.70 \mathrm{E}-02$ & AACC & $8.00 \mathrm{E}-07$ \\
\hline Chlorobenzene & $3.87 \mathrm{E}-07$ & $1.75 \mathrm{E}+04$ & $\mathrm{AAC}$ & $2.21 \mathrm{E}-11$ \\
\hline Chloroform & $5.36 \mathrm{E}-08$ & $4.30 \mathrm{E}-02$ & AACC & $1.25 \mathrm{E}-06$ \\
\hline Chromium & $5.69 \mathrm{E}-13$ & $8.30 \mathrm{E}-05$ & AACC & $6.85 \mathrm{E}-09$ \\
\hline Dibutylphthalate & 7.75E-09 & $2.50 \mathrm{E}+02$ & AAC & $3.10 \mathrm{E}-11$ \\
\hline 1,2-Dichloroethane & $5.36 \mathrm{E}-08$ & $2.00 \mathrm{E}+03$ & $\mathrm{AACC}$ & $2.68 \mathrm{E}-11$ \\
\hline Diethylphthalate & $9.92 \mathrm{E}-08$ & $2.50 \mathrm{E}+02$ & $\mathrm{AAC}$ & $3.97 \mathrm{E}-10$ \\
\hline 1,3-Dinitrobenzene(PIC) & $2.22 \mathrm{E}-01$ & $5.00 \mathrm{E}+01$ & AAC & $4.43 \mathrm{E}-03$ \\
\hline 2,4-Dinitrophenol & $6.28 \mathrm{E}-06$ & $7.30 \mathrm{E}+00$ & PRG & $8.60 \mathrm{E}-07$ \\
\hline 2,4-Dinitrotoluene & 7.34E-06 & $7.30 \mathrm{E}+00$ & PRG & $1.01 \mathrm{E}-06$ \\
\hline 2,4-Dinitrotoluene(PIC) & $2.40 \mathrm{E}-01$ & $7.30 \mathrm{E}+00$ & PRG & $3.29 \mathrm{E}-02$ \\
\hline 2,6-Dinitrotoluene(PIC) & $3.32 \mathrm{E}-02$ & $3.70 \mathrm{E}+00$ & PRG & $8.98 \mathrm{E}-03$ \\
\hline Di(n)octyl phthalate & $7.75 \mathrm{E}-09$ & $7.30 \mathrm{E}+01$ & PRG & $1.06 \mathrm{E}-10$ \\
\hline 1,4-Dioxane & $4.02 \mathrm{E}-05$ & $7.10 \mathrm{E}-01$ & $\mathrm{AACC}$ & $5.66 \mathrm{E}-05$ \\
\hline Ethylene glycol & $4.85 \mathrm{E}-05$ & $6.35 \mathrm{E}+03$ & $\mathrm{AAC}$ & 7.63E-09 \\
\hline Formaldehyde & $4.66 \mathrm{E}-08$ & 7.70E-02 & $\mathrm{AACC}$ & $6.05 \mathrm{E}-07$ \\
\hline Formic acid & $1.87 \mathrm{E}-05$ & $4.70 \mathrm{E}+02$ & AAC & $3.99 \mathrm{E}-08$ \\
\hline $2,3,7,8-\mathrm{TCDD}$ & $7.03 \mathrm{E}-12$ & $2.20 \mathrm{E}-08$ & $\mathrm{AACC}$ & $3.20 \mathrm{E}-04$ \\
\hline Hydrazine & $1.82 \mathrm{E}-06$ & $3.40 \mathrm{E}-04$ & $\mathrm{AACC}$ & $5.36 \mathrm{E}-03$ \\
\hline
\end{tabular}


Table 12. (continued).

\begin{tabular}{|c|c|c|c|c|}
\hline Chemical & $\begin{array}{c}\text { Air Concentration }{ }^{\mathrm{a}} \\
\left(\mathrm{ug} / \mathrm{m}^{3}\right)\end{array}$ & $\begin{array}{c}\text { Screening } \\
\text { Concentration } \\
\text { Criteriab } \\
\left(\mathrm{ug} / \mathrm{m}^{3}\right) \\
\end{array}$ & Source ${ }^{b}$ & $\begin{array}{l}\text { Ratio of Air } \\
\text { Concentration to } \\
\text { Screening } \\
\text { Concentration } \\
\end{array}$ \\
\hline Hydrogen chloride & 4.17E-02 & $3.75 E+02$ & $\mathrm{AAC}$ & $1.11 \mathrm{E}-04$ \\
\hline Hydrogen fluoride & $2.37 \mathrm{E}-02$ & $2.60 \mathrm{E}+01$ & $\mathrm{AAC}$ & $9.12 \mathrm{E}-04$ \\
\hline (Iso)thiourea & $1.63 \mathrm{E}-06$ & $1.80 \mathrm{E}-03$ & AACC & $9.08 \mathrm{E}-04$ \\
\hline Lead & $6.46 \mathrm{E}-09$ & $1.50 \mathrm{E}+00$ & NAAQS & $4.31 E-09$ \\
\hline Mercury & $7.38 \mathrm{E}-04$ & $2.50 E+00$ & $\mathrm{AAC}$ & 2.95E-04 \\
\hline Methyl ethyl ketone & $1.32 \mathrm{E}-05$ & $2.95 E+04$ & $\mathrm{AAC}$ & $4.46 \mathrm{E}-10$ \\
\hline Methylene chloride & 5.36E-08 & $2.40 \mathrm{E}-01$ & AACC & 2.23E-07 \\
\hline Naphthalene & 7.75E-07 & $2.50 E+04$ & $\mathrm{AAC}$ & $3.10 \mathrm{E}-11$ \\
\hline Nickel & $5.50 \mathrm{E}-13$ & 4.20E-03 & AACC & $1.30 \mathrm{E}-10$ \\
\hline Nitric acid & $6.42 E+00$ & $2.50 \mathrm{E}+02$ & $\mathrm{AAC}$ & $2.57 \mathrm{E}-02$ \\
\hline Nitrobenzene(PIC) & $1.62 \mathrm{E}-01$ & $2.50 \mathrm{E}+02$ & AAC & $6.46 \mathrm{E}-04$ \\
\hline Nitrogen dioxide & $2.25 E+01$ & $1.00 \mathrm{E}+02$ & NAAQS & $2.25 \mathrm{E}-01$ \\
\hline Pentachloronitrobenzene(PIC) & $1.85 \mathrm{E}-02$ & $1.40 \mathrm{E}-02$ & PRG & $7.10 \mathrm{E}-01$ \\
\hline Pentachlorophenol & 7.75E-07 & $2.50 \mathrm{E}+01$ & AAC & $3.10 \mathrm{E}-08$ \\
\hline Phenol & $1.32 \mathrm{E}-05$ & $9.50 \mathrm{E}+02$ & $\mathrm{AAC}$ & $1.38 \mathrm{E}-08$ \\
\hline Pyridine & $1.12 \mathrm{E}-03$ & $7.50 \mathrm{E}+02$ & $\mathrm{AAC}$ & $1.50 \mathrm{E}-06$ \\
\hline Selenium & $3.51 \mathrm{E}-07$ & $1.00 \mathrm{E}+01$ & $\mathrm{AAC}$ & $3.51 \mathrm{E}-08$ \\
\hline Silver & $2.63 \mathrm{E}-13$ & $5.00 E+00$ & $A A C$ & $5.26 \mathrm{E}-14$ \\
\hline Sulfur dioxide & $1.06 \mathrm{E}-01$ & $8.00 \mathrm{E}+01$ & NAAQS & $1.32 \mathrm{E}-03$ \\
\hline Tetrachloroethylene & $5.36 \mathrm{E}-08$ & $2.10 \mathrm{E}+00$ & AACC & $2.55 \mathrm{E}-08$ \\
\hline Thallium & $1.15 \mathrm{E}-07$ & $5.00 \mathrm{E}+00$ & AAC & $2.31 \mathrm{E}-08$ \\
\hline Toluene & 3.87E-07 & $1.88 \mathrm{E}+04$ & $\mathrm{AAC}$ & $2.07 \mathrm{E}-11$ \\
\hline 1,2,4-Trichlorobenzene & $7.75 \mathrm{E}-07$ & $1.85 \mathrm{E}+03$ & $\mathrm{AAC}$ & 4.19E-10 \\
\hline 1,1,1-Trichloroethane & 3.87E-07 & $9.55 E+04$ & $\mathrm{AAC}$ & $4.05 \mathrm{E}-12$ \\
\hline 1,1,2-Trichloroethane & $5.36 \mathrm{E}-08$ & $6.20 \mathrm{E}-02$ & AACC & 8.65E-07 \\
\hline Trichloroethylene & 3.87E-07 & $1.35 \mathrm{E}+04$ & AACC & $2.88 \mathrm{E}-11$ \\
\hline Uranium & $3.65 E-12$ & $1.00 \mathrm{E}+01$ & $A A C$ & $3.65 \mathrm{E}-13$ \\
\hline
\end{tabular}

a. The air concentration value is the product of the emission rate (see Section 2) and Cyv value of 6.21E-02. Because vapor and particulate concentrations are similar, the higher of the two is assumed for all chemicals.

b. State of Idaho Acceptable Ambient Air Concentration (AAC) for noncarcinogens or carcinogens (AACC), EPA Region 9 Preliminary Remediation Goal (PRG) value for ambient air, or National Ambient Air Quality Standard. 
Onsite Scenarios. For the two added onsite scenarios (herdsman and worker) evaluated in this revision, inhalation impacts were calculated by scaling the maximum offsite risk and hazard index based on the ratio of air concentrations at the two onsite scenario locations relative to the air concentration at the maximum offsite location. This can be done because intake, and therefore risk, are directly proportional to air concentration. Carcinogenic risk, which is based on total intake, was further scaled by the ratio of annual residence times assumed for the two scenarios relative to the continuously-exposed offsite scenarios. Hazard index was not scaled based on residence time because subchronic or acute affects can occur over short exposure durations.

Using Figure 8, the maximum air concentration at any location south of U.S. Highway 20 (maximum herdsman impact location) is $0.065 \mathrm{ug} / \mathrm{m}^{3}$ per $\mathrm{g} / \mathrm{s}$ which is almost the same as the maximum offsite location $\left(0.062 \mathrm{ug} / \mathrm{m}^{3}\right.$ per $\mathrm{g} / \mathrm{s}$ ) (the offsite value is relatively high because the elevated terrain is closer to the elevated plume centerline). The risk at the herdsman location was therefore calculated by multiplying the maximum offsite risk (2E-07) by the ratio of the air concentrations $(0.065 / 0.062)$ and the ratio of the assumed annual residence times at the two locations (1/3), giving a maximum inhalation risk of 7E-08. The maximum total hazard index would be approximately the same as that at the maximum offsite location in Table 10,0.09.

Using Figure 8, the maximum air concentration at any onsite facility is $0.025 \mathrm{ug} / \mathrm{m}^{3} \mathrm{per} \mathrm{g} / \mathrm{s}$ at the northwest corner of the Central Facilities Area (CFA) (UTM location 342630 East and 4821520 North), which is $40 \%$ of the maximum offsite concentration $\left(0.062 \mathrm{ug} / \mathrm{m}^{3}\right.$ per $\left.\mathrm{g} / \mathrm{s}\right)$. The concentration at CFA is lower because of the relative heights between the elevated plume centerline and the receptor location. The risk at the CFA location was therefore calculated by multiplying the maximum offsite risk (2E-07) by the ratio of the air concentrations (0.025/0.062) and assumed annual residence times $(2000 / 8760)$ at the two locations, giving a maximum inhalation risk of $2 \mathrm{E}-8$. The maximum total hazard index was calculated by multiplying the maximum offsite hazard index by the ratio of the air concentrations $(0.09$ $\times 0.025 / 0.062$ ) at the two locations, giving a maximum inhalation hazard index of 0.04 .

\subsection{Indirect Exposures}

The excess lifetime individual cancer risk from indirect exposure of a chemical carcinogen via ingestion is calculated as follows:

Cancer risk $=\frac{I * E D * E F * C S F}{B W * A T * 365}$

where

$$
\begin{aligned}
& I \quad=\text { total daily intake of contaminant (mg/day) } \\
& E D \quad=\text { exposure duration (year) } \\
& E F \quad=\text { exposure frequency (day/year) } \\
& C S F \quad=\text { oral cancer slope factor }(\mathrm{mg} / \mathrm{kg} / \mathrm{day})^{-1} \\
& B W \quad=\text { body weight }(\mathrm{kg})
\end{aligned}
$$




$$
\begin{aligned}
& A T=\text { averaging time (year) } \\
& 365 \quad=\text { units conversion factor (days/year). }
\end{aligned}
$$

The total cancer risk via ingestion is estimated by summing the lifetime individual cancer risk for all carcinogenic chemicals via the ingestion route of exposure. Table 13 presents the results for the offsite scenarios. Summed across all chemicals, the total risk estimates for the subsistence farmer, adult resident, child resident, and subsistence farmer child are $3 \mathrm{E}-08,1 \mathrm{E}-10,5 \mathrm{E}-10$, and $3 \mathrm{E}-8$, respectively, which are well below the EPA acceptable criterion of $1 \times 10^{-5}$ (EPA 1998a).

The hazard quotient for indirect exposures to noncarcinogenic chemicals via ingestion is calculated for each exposure scenario as follows:

$H Q=I /(B W * R f D)$

where

$$
\begin{array}{lll}
I & = & \text { total daily intake of contaminant (mg/day) } \\
B W & = & \text { body weight }(\mathrm{kg}) \\
R f D & = & \text { reference dose }(\mathrm{mg} / \mathrm{kg} / \text { day }) .
\end{array}
$$

Hazard quotients for indirect exposures to chemicals that affect the same target organ are added together to obtain a hazard index for the target organ. Tables 14 and 15 present the hazard quotient and hazard index results for the three offsite scenarios. In all cases, the values are less than the EPA acceptable criterion of 0.25 (EPA 1998a). In addition, the noncancer effects of dioxin (2,3,7,8-TCDD) were evaluated by comparing the general background level of exposure of adults to dioxins $(1-3 \mathrm{pg} / \mathrm{kg} / \mathrm{d})$ to the estimated daily intake of dioxin for subsistence farmer and adult (maximum of $0.0003 \mathrm{pg} / \mathrm{kg} / \mathrm{d}$ ) from the calciner emissions. The noncancer effects from this incremental exposure are negligible.

Tables used for estimating individual cancer risk and hazard quotients for the various chemicals and exposure scenarios are presented in Appendix F. The tables provide the equations used, identify the parameters in the equation, and provide the parameter values (or if calculated, the tables from which the values are obtained). 
Table 13. Indirect exposure excess cancer risks for the offsite scenarios.

\begin{tabular}{|c|c|c|c|c|}
\hline Chemical & $\begin{array}{l}\text { Subsistence } \\
\text { Farmer }\end{array}$ & Adult Resident & Child Resident & $\begin{array}{l}\text { Subsistence } \\
\text { Farmer Child }^{\mathrm{a}}\end{array}$ \\
\hline Arsenic & $1 \mathrm{E}-17$ & $8 \mathrm{E}-20$ & $7 \mathrm{E}-20$ & a \\
\hline Benzo(a)pyrene ${ }^{b}$ & $1 E-08$ & $3 E-11$ & $7 \mathrm{E}-11$ & $1 \mathrm{E}-08$ \\
\hline Coplaner PCBs ${ }^{b}$ & $9 \mathrm{E}-12$ & $3 E-13$ & $1 \mathrm{E}-12$ & a \\
\hline Beryllium & $3 E-14$ & $3 E-15$ & $5 E-15$ & a \\
\hline $2,3,7,8-\mathrm{TCDD}^{\mathrm{b}}$ & $2 \mathrm{E}-08$ & $8 \mathrm{E}-11$ & $4 \mathrm{E}-10$ & $2 \mathrm{E}-08$ \\
\hline Pentachloronitrobenzene & $1 E-11$ & $3 E-12$ & $3 E-12$ & a \\
\hline Pentachlorophenol & $3 \mathrm{E}-12$ & $2 E-13$ & $4 \mathrm{E}-13$ & a \\
\hline Total Risk & $3 \mathrm{E}-08$ & 1E-10 & 5E-10 & 3E-08 \\
\hline \multicolumn{5}{|c|}{$\begin{array}{l}\text { a. Only those chemicals which accounted for greater than } 99 \% \text { of the total risk were evaluated for this scenario. Because } \\
\text { the relative contribution of individual chemical risk to total risk is approximately the same for all scenarios; evaluation of } \\
\text { the remaining chemicals would not change the total risk. }\end{array}$} \\
\hline b. For this revision, these cher & ere re-evaluated & $\mathrm{g}$ the fate and trar & it parameter values & en in EPA (1998). \\
\hline
\end{tabular}

Onsite Herdsman Scenario. Indirect impacts for the onsite herdsman scenario were calculated by multiplying the indirect risk and hazard index for the subsistence farmer (from Tables 13 and 14) by the ratio of the ground deposition rate at the maximum herdsman location relative to the ground deposition rate at the subsistence farmer (maximum offsite) location. This can be done because media concentrations, intake, and risk are directly proportional to ground deposition rate. Carcinogenic risk, which is based on total intake, was further scaled by the ratio of annual residence time assumed for the herdsman relative to the continuously-exposed subsistence farmer scenario (1/3). Hazard index was not scaled based on residence time because subchronic or acute effects can occur over short exposure durations. This method (scaling subsistence farmer indirect impacts to determine the herdsman impacts) will overestimate any potential herdsman impacts because the herdsman scenario does not include consumption of contaminated milk or produce (as assumed for the farmer).

Using Figure 9, the maximum ground deposition rate at any location south of U.S. Highway 20 (maximum herdsman impact location) is $1.3 \mathrm{E}-03 \mathrm{~g} / \mathrm{m}^{2}$-year per $\mathrm{g} / \mathrm{s}$. The maximum ground deposition rate at the maximum offsite impact location is $6.9 \mathrm{E}-04 \mathrm{~g} / \mathrm{m}^{2}$-year per $\mathrm{g} / \mathrm{s}$. The indirect risk at the herdsman location was therefore calculated by multiplying the subsistence farmer indirect risk ( $3 \mathrm{E}-08$, Table 13$)$ by the ratio of the ground deposition rates $(1.3 \mathrm{E}-03 / 6.9 \mathrm{E}-04)$ and the ratio of the assumed annual residence times for the two scenarios $(1 / 3)$, giving a maximum indirect risk of $1.9 \mathrm{E}-08$. The maximum total hazard index was calculated by multiplying the subsistence farmer hazard index $(0.002$, Table 14) by the ratio of the ground deposition rates, giving a maximum indirect hazard index of 0.0038 . This is less than the maximum offsite hazard index ( 0.01 for the subsistence farmer child scenario). 
Table 14. Indirect exposure hazard quotients for the offsite scenarios.

\begin{tabular}{|c|c|c|c|c|}
\hline Chemical & $\begin{array}{c}\text { Subsistence } \\
\text { Farmer }\end{array}$ & $\begin{array}{c}\text { Adult } \\
\text { Resident }\end{array}$ & $\begin{array}{c}\text { Child } \\
\text { Resident }\end{array}$ & $\begin{array}{c}\text { Subsistence } \\
\text { Farmer Child }^{\mathrm{a}}\end{array}$ \\
\hline Antimony & $6 \mathrm{E}-11$ & $6 \mathrm{E}-12$ & $9 E-12$ & a \\
\hline Arsenic & $4 \mathrm{E}-14$ & $4 \mathrm{E}-16$ & $2 E-15$ & a \\
\hline Barium & $8 \mathrm{E}-17$ & $2 \mathrm{E}-17$ & $8 \mathrm{E}-17$ & a \\
\hline Beryllium & $2 \mathrm{E}-12$ & $3 E-13$ & $3 \mathrm{E}-12$ & a \\
\hline Cadmium & $2 \mathrm{E}-12$ & $2 \mathrm{E}-14$ & $1 \mathrm{E}-13$ & a \\
\hline Chromium VI & $1 \mathrm{E}-14$ & $1 \mathrm{E}-15$ & $3 E-15$ & a \\
\hline 1,3-Dinitrobenzene $(\mathrm{PIC})^{\mathrm{b}}$ & $2 \mathrm{E}-03$ & $7 \mathrm{E}-04$ & $3 E-03$ & $1 \mathrm{E}-02$ \\
\hline 2,4-Dinitrotoluene(PIC) ${ }^{b}$ & $1 \mathrm{E}-04$ & $4 \mathrm{E}-05$ & $2 \mathrm{E}-04$ & $8 \mathrm{E}-04$ \\
\hline 2,6-Dinitrotoluene $(\mathrm{PIC})^{b}$ & $2 \mathrm{E}-04$ & $7 \mathrm{E}-05$ & $3 E-04$ & $2 \mathrm{E}-03$ \\
\hline Di(n)octyl phthalate & $1 E-09$ & $4 \mathrm{E}-10$ & $8 E-10$ & a \\
\hline Mercury & $3 E-04$ & $3 E-07$ & 4E-06 & a \\
\hline Nickel & $2 E-15$ & $5 \mathrm{E}-17$ & $5 E-16$ & a \\
\hline Nitrobenzene(PIC) & $9 E-05$ & $3 \mathrm{E}-05$ & $9 \mathrm{E}-05$ & a \\
\hline Pentachloronitrobenzene(PIC) & $3 \mathrm{E}-08$ & $8 \mathrm{E}-09$ & $5 E-08$ & a \\
\hline Pentachlorophenol & $1 \mathrm{E}-09$ & $2 \mathrm{E}-10$ & 1E-09 & a \\
\hline Selenium & $2 \mathrm{E}-09$ & $1 \mathrm{E}-11$ & $2 E-11$ & a \\
\hline Silver & $5 E-15$ & $9 \mathrm{E}-18$ & $1 \mathrm{E}-17$ & a \\
\hline Thallium & $8 \mathrm{E}-08$ & $1 E-09$ & 7E-09 & a \\
\hline Total Hazard Index ${ }^{c}$ & 0.002 & 0.0007 & 0.003 & 0.01 \\
\hline
\end{tabular}

a. Only those chemicals which accounted for greater than $99 \%$ of the total hazard quotient were evaluated for this scenario. Because the relative contribution of individual chemical risk to total risk is approximately the same for all scenarios; evaluation of the remaining chemicals would not change the total risk.

b. For this revision, these chemicals were re-evaluated using the fate and transport parameter values given in EPA (1998).

c. The total hazard index is irrespective of specific toxic effects (i.e. liver and neurotoxin). Also, the total hazard index includes only the nitroaromatic PIC with the highest hazard quotient (see PIC calculations in Section 2).

\subsection{Lead}

No health-effects benchmark for inhalation (or ambient air) is available for lead. Therefore, a hazard quotient was calculated by comparing the maximum estimated air concentration of $9 \mathrm{E}-10 \mu \mathrm{g} / \mathrm{m}^{3}$ (Table 10) to the National Ambient Air Quality Standard for lead, $1.5 \mu \mathrm{g} / \mathrm{m}^{3}$. In addition the maximum offsite soil lead concentration of $1 \mathrm{E}-08 \mathrm{mg} / \mathrm{kg}$ (Appendix B) was compared to the EPA soil health-based level of $400 \mathrm{mg} / \mathrm{kg}$ (EPA Region 9). Both the estimated soil and air lead levels are well below these screening criteria. 
Table 15. Indirect exposure hazard quotient and hazard index for chemicals with liver or neurotoxin effects.

\begin{tabular}{|c|c|c|c|c|c|c|c|c|}
\hline \multirow[b]{2}{*}{ Chemical } & \multicolumn{2}{|c|}{ Subsistence Farmer } & \multicolumn{2}{|c|}{ Adult Resident } & \multicolumn{2}{|c|}{ Child Resident } & \multicolumn{2}{|c|}{$\begin{array}{c}\text { Subsistence Farmer } \\
\text { Child }\end{array}$} \\
\hline & Liver & Neuro & Liver & Neuro & Liver & Neuro & Liver & Neuro \\
\hline 2,4-Dinitrotoluene & & $1 \mathrm{E}-04$ & & $4 \mathrm{E}-05$ & & $2 \mathrm{E}-04$ & & $8 \mathrm{E}-04$ \\
\hline 2,6-Dinitrotoluene & & 2E-04 & & $7 \mathrm{E}-05$ & & $3 E-04$ & & 2E-03 \\
\hline Mercury & & $3 E-04$ & & $3 E-07$ & & $4 \mathrm{E}-06$ & & a \\
\hline Di(n)octyl phthalate & $1 \mathrm{E}-09$ & & $4 \mathrm{E}-10$ & & $8 \mathrm{E}-10$ & & a & \\
\hline $\begin{array}{l}\text { Pentachloronitro- } \\
\text { benzene }\end{array}$ & $3 E-08$ & & $8 \mathrm{E}-09$ & & $5 \mathrm{E}-08$ & & a & \\
\hline Pentachlorophenol & $1 E-09$ & & $2 E-10$ & & $1 \mathrm{E}-09$ & & a & \\
\hline $\begin{array}{l}\text { Total Hazard } \\
\text { Index }\end{array}$ & $3 E-08$ & 5E-04 & 9E-09 & 7E-05 & $5 E-08$ & 3E-04 & a & $2 \mathrm{E}-03$ \\
\hline $\begin{array}{l}\text { a. Only those chemical } \\
\text { Table 14). }\end{array}$ & hich acco & ted for gre: & th than 99 & $f$ the total $h$ & card quotier & were evalua & for this se & ario (see \\
\hline
\end{tabular}

\subsection{Radionuclides}

Radionuclide emissions were evaluated for lifetime excess cancer risk using: (1) the maximum annual dose from ICPP main stack emissions calculated in the 1997 INEEL National Emission Standards for Hazardous Air Pollutants (NESHAPS) dose assessment, (2) current EPA risk factors for morbidity (cancer incidence) (EPA 1994e), and (3) conservative exposure durations of 40 years for the subsistence farmer, 30 years for the adult resident, and 6 years for the child resident and subsistence farmer child scenarios.

The INEEL annual NESHAPS dose assessment evaluates the maximum annual effective dose equivalent (EDE) to any potential offsite residence, office, or school from all INEEL radionuclide emissions. Effective dose equivalent is a risk-weighted sum of the organ doses in the body (EPA 1989).

In 1997, the combined emissions from the ICPP main stack (including those from NWCF) resulted in a maximum calculated annual EDE of 0.0316 mrem to any potential offsite receptor. ${ }^{a}$ For 1997 and

a. LMITCO letter from S.K. Zohner to J.P. Law, ${ }^{129}$ I CORRECTION TO THE 1996 RADIOACTIVE NESHAP REPORT FOR THE INEEL - SKZ-05-98, July 28, 1998. 
which is near the maximum impact location determined in the SLRA air modeling (see Section 3.3 Receptor Information).

The NESHAPS dose assessment provides a conservative assessment of the maximum potential EDE that could occur through direct inhalation, ingestion of contaminated food products, external exposure from ground surface deposits, and air immersion (submersion). These pathways have been demonstrated to account for the vast majority of doses to individuals who may be exposed to airborne releases of radionuclides (EPA 1989). The exposure pathway models used in the NESHAPS dose assessment have been compared to those in the combustion guidance and were determined to produce more conservative (higher predictions of) media concentrations and human intakes (Abbott 1997).

The emissions used in the annual NESHAPS dose assessment are obtained from a combination of EPA-approved stack monitoring as reported in the INEEL Radioactive Waste Management System (RWMIS) database and conservative calculations for volatile radionuclides that are likely to be released but are at less than instrument detection limits. In 1997, emissions of ${ }^{129} \mathrm{I}(0.106 \mathrm{Ci})$ accounted for $99 \%$ of the calculated effective dose equivalent (EDE) $(0.0316 \mathrm{mrem})$ from the ICPP main stack, which is a cancer risk-weighted sum of the organ doses. The vast majority of this EDE (98.6\%) was through the ingestion pathway. Tritium $\left({ }^{3} \mathrm{H}\right)$ emissions (144 Ci) accounted for most of the remaining EDE (3.2E-04 mrem). A summary of the 1997 NESHAPS results for the INEEL is given below:

\begin{tabular}{lccc} 
Nuclide & $\begin{array}{c}\text { Emission } \\
\text { Rate } \\
\text { (Ci/yr) }\end{array}$ & $\begin{array}{c}\text { Annual } \\
\text { Dose } \\
\text { (mrem/yr) }\end{array}$ & $\begin{array}{c}\text { Percent of } \\
\text { Total Dose } \\
\text { and Risk }\end{array}$ \\
\hline I-129 & $1.06 E-01^{d}$ & $3.16 E-02$ & $98.8 \%$ \\
H-3 & $1.32 E+02$ & $3.21 E-04$ & $1.0 \%$ \\
Ba-137m & $2.44 E-03$ & $3.14 E-05$ & $0.1 \%$ \\
Cs-137 & $2.44 E-03$ & $1.73 E-05$ & $0.1 \%$ \\
C-14 & $2.94 E-02$ & $7.72 E-06$ & $0.0 \%$ \\
Pu-238 & $4.98 E-06$ & $7.56 E-06$ & $0.0 \%$ \\
Sr-90 & $3.13 E-04$ & $7.01 E-06$ & $0.0 \%$ \\
Pu-239 & $5.65 E-07$ & $9.28 E-07$ & $0.0 \%$ \\
Y-90 & $3.13 E-04$ & $2.24 E-07$ & $0.0 \%$ \\
Ru-106 & $6.34 E-05$ & $2.21 E-07$ & $0.0 \%$ \\
Cs-134 & $6.18 E-06$ & $1.08 E-07$ & $0.0 \%$ \\
Rh-106 & $6.34 E-05$ & $3.59 E-08$ & $0.0 \%$ \\
Sb-125 & $1.03 E-05$ & $3.39 E-08$ & $0.0 \%$ \\
Co-60 & $1.10 E-06$ & $3.23 E-08$ & $0.0 \%$ \\
Eu-154 & $9.52 E-07$ & $1.39 E-08$ & $0.0 \%$ \\
Te-125m & $2.58 E-06$ & $1.29 E-09$ & $0.0 \%$ \\
\multicolumn{1}{c}{ Total } & $1.32 E+02$ & $3.20 E-02$ & $100.0 \%$ \\
\hline
\end{tabular}


The vast majority (99.4\%) of the organ dose (dose equivalent) from ${ }^{129} \mathrm{I}$ occurs in the thyroid organ. Lifetime excess cancer incidence risk for the total body can therefore be calculated by:

1. Dividing the thyroid organ dose equivalent ( $1.0 \mathrm{mrem}$ ) by a quality factor of 1 (for beta, gamma radiation) and a conversion factor ( $1 \mathrm{mrad} / 1000 \mathrm{rad})$ to obtain absorbed dose (1.0E-03 rad),

2. Multiplying the absorbed dose by the EPA (1994e) cancer incidence risk factor for the thyroid (3.21E-05 risk/rad) to obtain annual risk (3.24E-08),

3. Multiplying the annual risk by the exposure durations for the subsistence farmer, adult, and child scenarios $\left(40,30\right.$, and 6 years respectively) to obtain lifetime risks $\left(1.3 \times 10^{-6}\right.$ for the subsistence farmer, $9.7 \times 10^{-7}$ for the adult and $2.0 \times 10^{-7}$ for the child). 


\subsection{Human Health Impacts-Conclusions}

Tables 16 and 17 summarize the SLRA cancer risk estimates and noncarcinogenic hazard index estimates. The total cancer risk estimate for the inhalation route of exposure for any offsite scenario is 2 $\times 10^{-7}$ (see Table 9). The total inhalation cancer risk estimates for both onsite scenarios $\left(7 \times 10^{-8}\right.$ for the herdsman; $2 \times 10^{-8}$ for the worker) are less than this value because these receptors have shorter residency times times at their work locations and because of the effects of the elevated plume height at receptor locations that are closer to the stack. The total cancer risk estimate for the indirect exposure is $3 \times 10^{-8}$, $1 \times 10^{-10}, 5 \times 10^{-10}$, and $3 \times 10^{-8}$ for the subsistence farmer, adult resident, child resident, and subsistence farmer child respectively (see Table 13). The total indirect cancer risk for the onsite herdsman scenario $\left(1.9 \times 10^{-8}\right)$ is less than the subsistence farmer and subsistence farmer child risks for the same reasons cited above. The highest total (direct plus indirect) excess cancer risk estimate for any scenario is $2 \times 10^{-}$ 7. The maximum lifetime excess cancer risk estimate for releases of radionuclides is $1 \times 10^{-6}$, which almost enitirely due to ingestion of $\mathrm{I}^{129}$. The risk estimates for all scenarios are less than the EPA screening criterion of $1 \times 10^{-5}$.

The noncarcinogenic hazard index (irrespective of specific toxic effects) for the inhalation route of exposure for all offsite scenarios is 0.09 (see Table 10). The inhalation hazard index for the onsite herdsman scenario (0.09) is the same as the offsite scenarios. The inhalation hazard index for the onsite worker is less $(0.04)$ because of the effects of the elevaied plume height at receptor locations that are closer to the stack. The indirect exposure hazard indices for the offsite scenarios (irrespective of specific toxic effects) are $0.002,0.0007,0.003$, and 0.01 for the subsistence farmer, adult resident, child resident, and subsistence farmer child, respectively (see Table 14). The indirect hazard index for the onsite herdsman scenario (0.0038) is less than the maximum indirect hazard index for the offsite scenarios. The biggest contributor to both the direct and indirect hazard indices is 1,3-dinitrobenzene (PIC). However, the hazard index estimates for all of the nitroaromatic PICs are very conservative because the emission rate calculations assumed $100 \%$ of the unburned fuel PIC precursors formed each single compound (see Section 2). All noncarcinogenic hazard indices are well below the EPA screening criterion of 0.25 .

The results of this SLRA demonstrate that NWCF emissions calculated from best-available process knowledge (including stack gas measurements of mercury) and conservative assumptions would result in maximum onsite and offsite health impacts that are less than EPA-established criteria for operation of a combustion facility. Additional analyses may be performed in the future if: (1) results from emissions testing scheduled for early 1999 indicate that the emissions evaluated in this SLRA are not conservative, and (2) DOE decides to continue operation of the NWCF in the Idaho High Level Waste Environmental Impact Statement, scheduled to be decided by June 1, 2000. 
Table 16. Summary of cancer risk estimates for SLRA.

Total Excess Cancer Risk EPA screening criterion is 1E-05

\begin{tabular}{llll} 
& \multicolumn{1}{c}{ Direct } & \multicolumn{1}{c}{ Indirect $^{\mathrm{a}}$} & \multicolumn{1}{c}{ Total $^{\mathrm{b}}$} \\
\cline { 2 - 4 } All chemicals & $2 \mathrm{E}-07$ & $3 \mathrm{E}-08$ & $2 \mathrm{E}-07$ \\
Worst metal & $2 \mathrm{E}-12$ (beryllium) & $3 \mathrm{E}-14$ (beryllium) & \\
Worst non-metal & $2 \mathrm{E}-07^{\mathrm{c}}$ (pentachloronitrobenzene- & $2 \mathrm{E}-08(2,3,7,8-\mathrm{TCDD})$ & \\
& PIC) & & \\
Radionuclides & $7 \mathrm{E}-09$ & $1 \mathrm{E}-06$ & $1 \mathrm{E}-06$
\end{tabular}

a. Highest value from the following scenarios: subsistence farmer, subsistence farmer child, adult resident, child resident, onsite worker, and onsite herdsman.

b. Because of the differences in environmental modeling methodologies and the basis for risk factors, cancer risk from radionuclides and non-radioactive contaminants were reported separately and not summed together.

c. Estimate is very conservative because it assumes $100 \%$ of the nitroaromatic PICs from the burning of the fuel forms this one compound.

Table 17. Summary of noncarcinogenic hazard index estimates for SLRA.

\begin{tabular}{|c|c|c|c|}
\hline \multirow[b]{3}{*}{ All chemicals } & \multicolumn{3}{|c|}{ Hazard Index EPA screening criterion is $\mathbf{0 . 2 5}$} \\
\hline & Direct & \multirow[t]{2}{*}{ Indirect $^{a}$} & \multirow{2}{*}{$\frac{\text { Total }}{0.10}$} \\
\hline & 0.09 & & \\
\hline Worst metal & 0.0003 (mercury) & 0.0003 (mercury) & \\
\hline Worst non-metal & $0.09^{b}$ (1,3-dinitrobenzene-PIC) & $0.01^{b}(1,3$-dinitrobenzene-PIC) & \\
\hline Liver & $\begin{array}{l}0.0002 \\
\text { (pentachloronitrobenzene-PIC) }\end{array}$ & $\begin{array}{l}0.00000005 \\
\text { (pentachloronitrobenzene-PIC) }\end{array}$ & \\
\hline Neurotoxin & $0.009^{\mathrm{b}}$ (2,6-dinitrotoluene-PIC) & $0.002^{\mathrm{b}}$ (2,6-dinitrotoluene-PIC) & \\
\hline $\begin{array}{l}\text { a. Highest value fro } \\
\text { onsite worker, and o }\end{array}$ & $\begin{array}{l}\text { following scenarios: subsistence farme } \\
\text { herdsman.. }\end{array}$ & istence farmer child, adult resident, ch & resident, \\
\hline
\end{tabular}




\section{UNCERTAINTY}

In this risk assessment, methodologies are employed to evaluate the risks to human health and the environment from NWCF emissions. It should be recognized that such risk assessment methodologies represent an inexact science, and uncertainties are associated with their application. Uncertainties arise because of the need to make assumptions and inferences to compensate for the unknowns or lack of data. In this SLRA, conservative assumptions and methods were employed to adequately bound any potential health impacts that might actually occur as a result of these uncertainties. Uncertainties associated with evaluating the impacts on ecological receptors are addressed in Section 8 . The following text summarizes the major uncertainties in the human health portion of this SLRA.

\subsection{Source Term Uncertainty}

Two major sources of uncertainty in the source term development are selection of the chemical species emitted to the stack and the development of accurate emission rates. Because calculation of the risks and hazards quotients are directly proportional to the emission rates used in the exposure assessment, best or conservative estimates of actual emission rates must be used.

The emission rate estimates for metals used in this SLRA are considered to be conservative (higher than what would be likely observed) because they are based on the following assumptions:

1. For each metal, the maximum concentration measured in any of the seven tanks with retrievable waste was used. To account for tanks that do not have sample analyses for all thirteen metal constituents (see Table 2, Appendix A), the higher of the concentrations in the analyzed tank(s) or the empty WM-188 tank (generally highest in concentration from all the sampled tanks) plus one standard deviation was assumed.

2. No credit was taken for dilution of the feed concentrations with aluminum nitrate (added for proper calcining chemistry), which would reduce the metal feed rates by at least a factor of two.

3. Conservative assumptions were made for off gas partitioning of semivolatiles (e.g., $\mathrm{PbO} / \mathrm{PbCl}_{2}$ )

4. For non-carcinogenic metals, the total inventory was assumed to be fed over an accelerated 7-year calcining schedule (1999-2005) which is not considered likely at this time. This results in a factor of two higher maximum annual emission rate than that which would occur if the existing inventories of waste are calcined over the more likely 14-year schedule (to 2012).

5. Mercury emission rate estimates are based on long-term activated carbon filter analysis from previous calcining campaigns and are likely to be the most accurate metal emission rate used in this assessment. However, based on requests from EPA Region 10, an upper-bound emission rate was also evaluated in the ecological risk assessment (Section 8) which assumed that $10 \%$ of the feed mercury unaccounted for in either the scrub solution or the stack offgas also went up the stack. This likely overestimates the actual stack emission rate of mercury by a factor of four. 
There is a significant amount of uncertainty associated with the PICs that may be formed in the NWCF off gas. PICs are formed by incomplete combustion of organic compounds in the feed or fuel and reactions with other compounds or compound fragments that are present (Dempsey and Oppelt 1993). Actual PIC emission rates in the NWCF have not been quantified in this SLRA because previous attempts to accurately measure their low levels in the highly acidic NWCF off gas have not been successful and because they are difficult or impossible to actually predict (Dempsey and Oppelt 1993). Of particular concern in the NWCF are the benzene and toluene PIC precursors in the kerosene fuel and the chlorine in the off gas $(680 \mathrm{~kg} / \mathrm{year}, 0.02 \mathrm{~g} / \mathrm{s}$ as HCl) which can result in toxic chlorinated organic species. Although there is significant uncertainty regarding which PIC species are actually emitted, the dioxins/furan, nitroaromatic, and PCB emissions calculated in Section 2 provide a reasonably conservative estimate of the maximum potential impact (risk or hazard index) from any combination of PICs that could possibly be formed.

The emission rates estimated for organic chemicals are believed to be conservative for several reasons. First, most of the trace organic constituents detected in the feed are assumed to be released to the atmosphere with no destruction and removal efficiency. For 2,3,7,8-TCDD, a conservative emission rate was calculated using emission factors developed from municipal waste combustors with much higher dioxin precursor feed rates. Also, coplaner PCBs that might be formed in the offgas were calculated using a published EPA emissions factor from a combustion unit with much higher PIC precursor (chlorine and organic material) feed rates. Nitroaromatic PIC production was calculated assuming $100 \%$ reaction of all the aromatic precursors in a conservative estimate $(5 \%)$ of the unburned kerosene fuel with all of the chlorine in the off gas. Finally, no credit was taken for removal of these PICs in the off-gas treatment system, which operates below the boiling point of the semi-volatiles of concern. These factors are judged to result in significant overestimates of all organic emission rates.

\subsection{Air Modeling Uncertainty}

In general, models are imperfect mathematical tools that attempt to simulate highly complex environmental phenomena. Therefore, significant uncertainty usually exists in modeling output for both air concentration and ground deposition rate. These uncertainties result from imperfect model structures and inaccuracies or natural variability in the model input parameter values. Although ISC3 is the preferred EPA air dispersion model for this SLRA and for other regulatory compliance issues, ISC3 is subject to the same uncertainties.

A major source of model structural uncertainty results when the "straight-line" Gaussian plume model algorithm is applied in ISC3 for large offsite receptor distances at the INEEL. The Gaussian plume model assumes that atmospheric dispersion conditions (wind direction, wind speed, and turbulence) do not change between the release point and any receptor location over the time interval of the meteorological data (1-hour). Offsite distances from the ICPP are large (e.g., 15 to $20 \mathrm{~km}$ ), and dispersion conditions will likely change over the time required to transport the contaminants to receptors (2-hour average). However, published validation studies have indicated that the Gaussian plume model is reasonably reliable for estimating the longer time-averaged (e.g., annual) concentrations and relatively flat terrain conditions evaluated in this SLRA. Errors in the highest estimated concentrations of +10 to $40 \%$ are found to be typical (EPA 1995b). The longer plume transport times required at the INEEL increase this uncertainty somewhat.

A related major source of uncertainty exists in the prediction of model output at specific receptor locations. Because of shifting winds, contaminants may follow trajectories that are not straight, which may cause model predictions at specific downwind locations, especially over the large RNEEL distances, 
to be highly uncertain. Adding to this spatial prediction problem, is the uncertainty that exists in the meteorological data file wind vectors. Measurement or processing (time-averaging) errors of 5 to 10 degrees can result in concentration errors of 20 to $70 \%$ (EPA 1995b). Such uncertainties indicate that the precise time and location are in doubt, not necessarily that an estimated concentration does not occur.

Potential underprediction of impacts due to this spatial prediction uncertainty is avoided in this SLRA by selecting the maximum offsite air concentrations and ground deposition rate at any offsite location for use in the exposure assessment. This assumption ensures that the exposure assessment conservatively bounds any potential offsite receptor regardless of the uncertainty in wind direction. This maximum impact location occurred on the lower north slopes of Big Southern Butte (Figure 5) in uninhabited, desert shrub land about a half mile east-southeast of "Frenchman's Cabin." The particulate air concentration at Frenchman's Cabin (transient residents) and Atomic City (nearest continually inhabited location) was calculated to be less than half of the maximum impact location value. Therefore, the air modeling results used in the exposure assessment are likely to significantly over predict the actual impacts that might occur to any real resident.

\subsection{Exposure Assessment Uncertainty}

Exposure scenario assumptions also may contribute to the uncertainties of the study. All of these assumptions would likely produce upper-bound estimates of the potential risks to actual receptors that might be exposed in the area. Some of these conservatisms include continuous 30 to 40 -year exposure for the adult scenarios, the assumption that food products are produced at the point of maximum air concentration and ground deposition rate, and, for the subsistence farmer and child, the assumption that $100 \%$ of their food products are grown at the point of maximum ground deposition rate.

The onsite herdsman scenario, which was added to this revision, assumes the same continuous contaminated food (meat, milk, and produce) ingestion rates as the high-end scenario, the subsistence farmer. This produces estimates of impact from indirect pathways that are likely to be biased significantly high since the herdsman would not have food processing facilities onsite and would not consume food products that have been grown on the grazing location (especially milk and produce).

In the radionuclide exposure assessment (Section 6.4), the annual risk determined from the 1997 NESHAPS dose was multiplied by exposure durations of 40 years for the subsistence farmer and 30 years for the adult resident to obtain lifetime dose and risk. Unless the NWCF actually operates for this length of time, the lifetime risk calculated in this manner will significantly overpredict actual potential lifetime risk. This is because the vast majority of the maximum annual NESHAPS dose was due to surficial contamination of crops which can only occur while the facility is operating. Annual doses from residual activity in the soil and from root uptake after operations have ceased will be significantly less. Therefore, the assumed exposure duration assumptions ( 40 and 30 years) will likely overpredict lifetime risk by a factor of at least two (30 years assumed exposure/16 years maximum operations).

\subsection{Toxicity Assessment Uncertainty}

Many uncertainties and unknowns are associated with the toxic effects of the contaminants of concern for this study. The EPA has outlined some of these sources of uncertainty in its Guidelines for Carcinogenic Risk Assessment (EPA 1986). They include extrapolation from high to low doses and from animals to humans; species differences in uptake, metabolism, and organ distribution; species differences 
in target site susceptibility; and human population variability in diet, environment, activity patterns, and for cultural factors. Safety factors are built into the toxicity and exposure values to compensate for these sources of uncertainty, and result in a bias toward overestimating risk.

Although the risk assessment methodology contains considerable sources of uncertainty, the consistent adoption of conservative assumptions and parameter values, and adherence to EPA guideline recommendations, are considered to provide reasonably conservative estimates of the risk posed by NWCF operations. 


\section{NWCF SCREENING LEVEL ECOLOGICAL RISK ASSESSMENT (SLERA)}

The objective of this assessment is to determine the potential for adverse effects on ecological receptor populations, including protected wildlife species, as a result of exposure to NWCF emissions.

\subsection{Methods}

The assessment was performed using the same basic methodology developed in the Guidance Manual for Conducting Screening Level Ecological Risk Assessments at the INEL (VanHorn et al., 1995), subsequently referred to as the Guidance Manual. The methodology has been applied in INEEL ERAs for various Waste Area Groups (WAGs) including the WAG 3 Comprehensive RI/BRA and RI/FS (DOE-ID, 1997, DOE-ID, 1998). The methodology was specifically designed to follow the direction provided by the Framework for Ecological Risk Assessment (EPA, 1992a) Ecological Risk Assessment Guidance for Superfund, Process for Designing and Conducting Ecological Risk Assessments (EPA 1997b), EPA Region 10 Supplemental Risk Assessment Guidance for Superfund (1997), and other EPA guidelines (1998b, 1991, 1992b, 1993a, 1994f). This framework divides the ERA process into three steps: problem formulation, analysis, and risk characterization.

The interactions between the stressor characteristics, the ecosystem potentially at risk, and the ecological effects are defined in the problem formulation step of the ERA (EPA, 1992a). The problem formulation phase includes in characterization of stressors (i.e., identification of the contaminants, extent and concentrations), definition of assessment and measurement endpoints, and construction of the conceptual site model (CSM) (Section 8.2).

In the analysis step (Section 8.3), the likelihood and significance of an adverse reaction from exposure to the stressor(s) were evaluated. The behavior and fate of the contaminants of potential concern (COPCs) in the terrestrial environment was presented in a general manner since no formal fate and transport modeling (other than deposition) was conducted for this assessment. The ecological effects assessment includes a hazard evaluation and dose-response assessment, including a comprehensive review of toxicity data for contaminants to identify the nature and severity of toxic properties. Dose receptors from surface deposition of NWCF emissions were developed and used to assess potential risk to receptors. Because no dose-based toxicological criteria exist for ecological receptors, it was necessary to apply appropriate toxicity reference values (TRVs) for the contaminants and functional groups at INEEL.

The risk characterization step includes two primary elements (EPA, 1992a). The first element is the development of an indication of the likelihood of adverse effects to ecological receptors. The second element is the presentation of the assessment results in a form that serves as input to the risk management process. To determine whether there is any indication of risk due to the contaminant concentrations a screening against INEEL specific ecologically-based screening levels (EBSLs) was performed. Exceedence of the EBSL concentration was used as an indicator of potential effects. The risk characterization section of this assessment is presented in Section 8.4.

A comparison of the screening level ecological risk assessment (SLERA) approach used in the Risk Assessment Work Plan for the Mixed Waste Facility RCRA/TSCA permit application (ATG, 1998) to the INEEL methods and parameters was performed. The exposure calculations are similar with the exception to the use of the functional groups at the INEEL. 


\subsection{Problem Formulation}

Primary elements of the problem formulation step for the NWCF ERA are described in the following sections. The problem formulation includes the definition of contaminant extent and concentrations (Section 8.2.1), ecosystem characterization (Section 8.2.2), identification of pathways and routes of exposure (Section 8.2.3), presentation of the conceptual site model (CSM) (Section 8.2.4), and definition of assessment endpoints (Section 8.2.5).

\subsubsection{Contamination Extent and Concentration}

Contaminant-specific soil concentrations $(\mathrm{mg} / \mathrm{kg}$ ) for the SLERA were calculated using ISC3modeled deposition rates (wet + dry) and the soil concentration $\left(\mathrm{Sc}_{\mathrm{tc}}\right)$ equation given in EPA 1994a (Appendix B, Table B-3). This equation calculates the maximum 1-year average soil concentration over the entire deposition period (assumed to be 16 years for NWCF) and provides a conservative measure to assess both maximum short-term and long-term (chronic) impacts. The use of the maximum 1-year soil concentration will likely overestimate ecosystem impacts that require longer chronic exposure. For the SLERA, all of the NWCF contaminants with calculated emission rates (Section 2) and soil transport parameters published in EPA (1998a) were assessed.

Soil concentrations vary spatially, ranging from a maximum close in to the stack (depending on stack parameters and particle settling properties) to increasingly lower levels at greater distances from the stack. For initial screening purposes, the maximum contaminant-specific soil concentration was used in the SLERA which was determined by ISC 3 modeling to be immediately adjacent to the INTEC facility fenceline (southwest and northeast). This maximum soil concentration will overestimate impacts to biota over the vast majority of the plume impact area, especially if population-level impacts are considered. Therefore, an "impact-area-averaged" soil concentration was also assessed which provides a more appropriate estimate of soil concentrations at locations beyond the INTEC fence. This area of impact was determined by integrating the ISC3-modeled deposition rate (wet and dry) within the 5\%-of-maximum deposition rate isopleth and then dividing by the area encompassed by that isopleth (Figure 10). This gives an average soil concentration in the area where most of contaminants have been deposited. The average integrated concentration within the 5\%-of-maximum isopleth was calculated using Surfer ${ }^{\circledR}$ for Windows 3D surface mapping software. ${ }^{2}$ For vapor deposition (mercury and organics), the average deposition rate was calculated to be $7 \%$ of the maximum point value near the INTEC fence line and 3.4 times the maximum off-site deposition rate. For particulate deposition, the average deposition rate was calculated to be $10 \%$ of the maximum point value near the INTEC fence line and 1.6 times the maximum off-site soil concentration. Contaminant-specific soil concentrations are listed in Table 18.

Soil concentrations for mercury were calculated by assuming $48.2 \%$ of the total mercury emissions (1.5E-03 g/s, from Section 2) are deposited locally, in accordance with EPA (1998a) guidance. Soil concentrations for radionuclides were not assessed for ecological receptors because it is assumed that, for low levels of radioactivity, the human population (residential scenario) is for the most sensitive receptor (ATG 1998).

\subsubsection{Ecosystem Characterization}

The INEEL is located in a cool desert ecosystem characterized by shrub-steppe vegetative communities typical of the northern Great Basin and Columbia Plateau region. The surface of the INEEL is relatively flat with several prominent volcanic buttes and numerous basalt flows that provide important habitat for small and large mammals, reptiles, and some raptors. The shrub-steppe communities are dominated by sagebrush (Artemisia spp.) and provide habitat for sagebrush community species such as

a. Golden Software, Inc., $80914^{\text {th }}$ Street, Golden, CO $80401-1866$ (303-279-1021). 


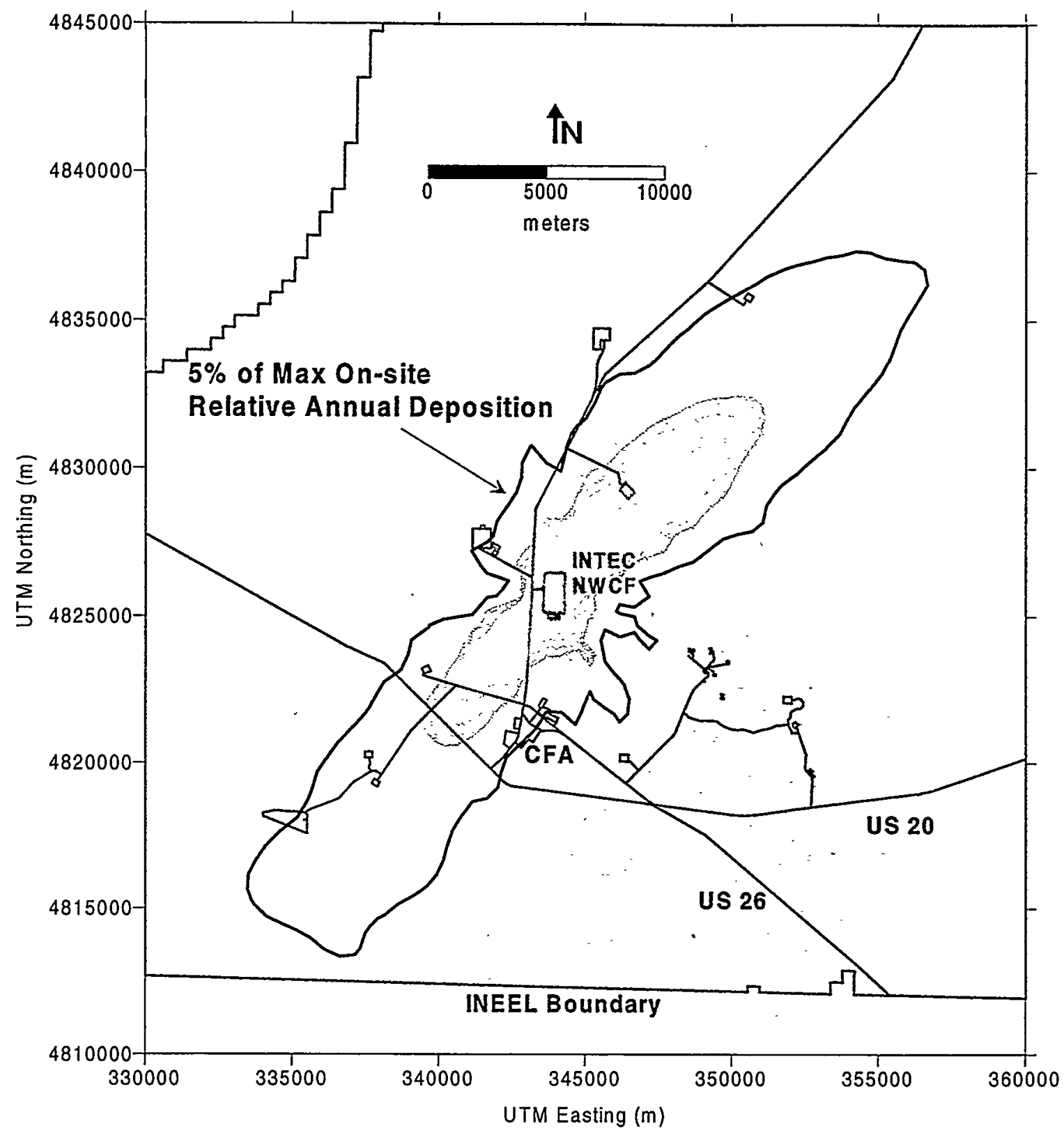

Figure 10. In addition to initial screening using the maximum soil concentration (located adjacent to the INTEC fence line), ecological impacts were also evaluated using an "impact area-averaged" soil concentration which was determined by integrating the areal deposition rate $\left(\mathrm{g} / \mathrm{m}^{2} / \mathrm{y}\right)$ within the $5 \%$ of maximum deposition rate isopleth and then dividing by the area encompassed by that isopleth. 
Table 18. Surface soil concentrations ( $\mathrm{mg} / \mathrm{kg}$ ) from NWCF contaminant emissions. Concentrations are calculated from ISC3 modeled wet and dry deposition rates over an assumed 16 year NWCF operating period and a 1-cm mixing depth, in accordance with combustion guidance soil equations.

Maximum Soil Concentration $(\mathrm{mg} / \mathrm{kg})$

\begin{tabular}{|c|c|c|c|}
\hline \multirow[b]{2}{*}{ Metals } & \multirow{2}{*}{\multicolumn{2}{|c|}{ Max On-site }} & \multirow[b]{2}{*}{ Average $^{c}$} \\
\hline & & & \\
\hline Antimony (Sb) & $3.41 \mathrm{E}-11$ & $5.45 \mathrm{E}-10$ & $5.45 \mathrm{E}-11$ \\
\hline Arsenic (As) & $1.86 \mathrm{E}-14$ & $2.98 \mathrm{E}-13$ & $2.98 \mathrm{E}-14$ \\
\hline Barium (Ba) & $1.83 \mathrm{E}-13$ & $2.93 \mathrm{E}-12$ & $2.93 \mathrm{E}-13$ \\
\hline Beryllium (Be) & $5.60 \mathrm{E}-10$ & $8.96 \mathrm{E}-09$ & $8.96 \mathrm{E}-10$ \\
\hline Cadmium (Cd) & $2.13 E-12$ & $3.41 E-11$ & $3.41 E-12$ \\
\hline Chromium $(\mathrm{Cr})$ & $8.59 \mathrm{E}-14$ & $1.37 \mathrm{E}-12$ & $1.37 \mathrm{E}-13$ \\
\hline Lead $(\mathrm{Pb})$ & $1.02 \mathrm{E}-08$ & $1.64 \mathrm{E}-07$ & $1.64 \mathrm{E}-08$ \\
\hline Mercury $\left(\mathrm{Hg}^{+2}\right)^{d}$ & $5.78 \mathrm{E}-05$ & $2.83 \mathrm{E}-03$ & $1.96 \mathrm{E}-04$ \\
\hline Mercury (methyl) & $1.16 \mathrm{E}-06$ & $5.66 \mathrm{E}-05$ & $3.92 \mathrm{E}-06$ \\
\hline Nickel (Ni) & $3.72 \mathrm{E}-13$ & $5.95 \mathrm{E}-10$ & $5.95 \mathrm{E}-11$ \\
\hline Selenium (Se) & $1.79 \mathrm{E}-09$ & $2.87 \mathrm{E}-08$ & $2.87 \mathrm{E}-09$ \\
\hline Silver $(\mathrm{Ag})$ & $1.62 E-16$ & $2.59 \mathrm{E}-15$ & $2.59 \mathrm{E}-16$ \\
\hline Thallium (Tl) & $9.87 \mathrm{E}-09$ & $1.58 \mathrm{E}-07$ & $1.58 \mathrm{E}-08$ \\
\hline Aluminum $(\mathrm{Al})^{\mathrm{f}}$ & $1.12 E-05$ & $1.79 E-04$ & $1.79 \mathrm{E}-05$ \\
\hline Manganese $(\mathrm{Mn})^{\mathrm{f}}$ & $5.62 E-06$ & $8.99 \mathrm{E}-05$ & $8.99 E-06$ \\
\hline $\operatorname{Zinc}(\mathrm{Zn})^{\mathrm{f}}$ & $3.31 \mathrm{E}-06$ & $5.30 \mathrm{E}-05$ & $5.30 \mathrm{E}-06$ \\
\hline Organics (feed) & & . & \\
\hline 1,1,1-Trichloroethane & $2.18 \mathrm{E}-15$ & $1.07 \mathrm{E}-13$ & $7.43 E-15$ \\
\hline 1,1,2-Trichloroethane & $7.54 \mathrm{E}-12$ & $3.70 \mathrm{E}-10$ & $2.56 \mathrm{E}-11$ \\
\hline 1,2,4-trichlorobenzene & $1.68 \mathrm{E}-10$ & $8.25 E-09$ & $5.72 \mathrm{E}-10$ \\
\hline 1,2-Dichloroethane & $1.14 \mathrm{E}-12$ & $5.57 \mathrm{E}-11$ & $3.86 \mathrm{E}-12$ \\
\hline 1,4 dioxane & $8.36 \mathrm{E}-09$ & $4.10 \mathrm{E}-07$ & $2.84 \mathrm{E}-08$ \\
\hline 2,4-Dinitrophenol & $4.48 \mathrm{E}-09$ & $2.19 \mathrm{E}-07$ & $1.52 \mathrm{E}-08$ \\
\hline Acetonitrile & $5.34 \mathrm{E}-18$ & $2.61 \mathrm{E}-16$ & $1.81 \mathrm{E}-17$ \\
\hline Aniline & $8.14 \mathrm{E}-09$ & $3.99 \mathrm{E}-07$ & $2.77 \mathrm{E}-08$ \\
\hline Benzene & $6.00 \mathrm{E}-13$ & $2.94 \mathrm{E}-11$ & $2.04 \mathrm{E}-12$ \\
\hline Benzo(a)pyrene & $3.44 \mathrm{E}-05$ & $1.69 \mathrm{E}-03$ & $1.17 E-04$ \\
\hline Bromoform & $4.48 \mathrm{E}-11$ & $2.20 \mathrm{E}-09$ & $1.52 \mathrm{E}-10$ \\
\hline Butylbenzylphthalate & $1.63 E-09$ & $8.01 E-08$ & $5.56 \mathrm{E}-09$ \\
\hline Carbon disulfide & $1.85 \mathrm{E}-11$ & $9.05 \mathrm{E}-10$ & $6.28 \mathrm{E}-11$ \\
\hline
\end{tabular}


Table 18. (continued).

\begin{tabular}{|c|c|c|c|}
\hline \multirow[b]{2}{*}{ Metals } & \multicolumn{3}{|c|}{$\begin{array}{c}\text { Maximum Soil Concentration } \\
(\mathrm{mg} / \mathrm{kg})\end{array}$} \\
\hline & Max Off-site ${ }^{\mathbf{a}}$ & Max On-site ${ }^{b}$ & Average $^{c}$ \\
\hline Carbon tetrachloride & $6.24 \mathrm{E}-13$ & $3.06 \mathrm{E}-11$ & $2.12 \mathrm{E}-12$ \\
\hline Chlorobenzene & $4.09 \mathrm{E}-12$ & $2.00 \mathrm{E}-10$ & $1.39 \mathrm{E}-11$ \\
\hline Chloroform & $1.21 \mathrm{E}-12$ & $5.92 \mathrm{E}-11$ & $4.10 \mathrm{E}-12$ \\
\hline Diethylphthalate & $3.45 E-09$ & $1.69 \mathrm{E}-07$ & $1.17 \mathrm{E}-08$ \\
\hline Di-n-butylphthalate & $1.43 \mathrm{E}-09$ & $6.99 \mathrm{E}-08$ & $4.85 \mathrm{E}-09$ \\
\hline Di-n-octylphthalate & 8.39E-07 & 4.11E-05 & $2.85 \mathrm{E}-06$ \\
\hline Formaldehyde & $1.64 \mathrm{E}-13$ & $8.05 E-12$ & $5.59 \mathrm{E}-13$ \\
\hline Formic acid & $3.58 \mathrm{E}-09$ & $1.76 \mathrm{E}-07$ & $1.22 \mathrm{E}-08$ \\
\hline Methyl ethyl ketone & $1.06 \mathrm{E}-10$ & $5.20 \mathrm{E}-09$ & $3.61 \mathrm{E}-10$ \\
\hline Methylene chloride & $2.72 \mathrm{E}-13$ & $1.33 \mathrm{E}-11$ & $9.26 \mathrm{E}-13$ \\
\hline Naphthalene & $4.48 \mathrm{E}-10$ & $2.20 \mathrm{E}-08$ & $1.52 \mathrm{E}-09$ \\
\hline Pentachlorophenol & $1.35 \mathrm{E}-06$ & $6.60 \mathrm{E}-05$ & $4.58 \mathrm{E}-06$ \\
\hline Phenol & $7.00 \mathrm{E}-08$ & $3.43 \mathrm{E}-06$ & $2.38 \mathrm{E}-07$ \\
\hline Pyridine & $1.10 E-10$ & $5.41 \mathrm{E}-09$ & $3.75 \mathrm{E}-10$ \\
\hline Tetrachloroethylene & $1.13 \mathrm{E}-12$ & $5.52 \mathrm{E}-11$ & $3.83 \mathrm{E}-12$ \\
\hline Toluene & $1.37 \mathrm{E}-12$ & $6.73 E-11$ & $4.67 \mathrm{E}-12$ \\
\hline Trichloroethylene & $8.74 \mathrm{E}-13$ & $4.28 \mathrm{E}-11$ & $2.97 \mathrm{E}-12$ \\
\hline \multicolumn{4}{|l|}{ Organics (PICs) } \\
\hline 2,3,7,8-TCDD TEQ & 1.62E-09 & $7.95 \mathrm{E}-08$ & $5.52 \mathrm{E}-09$ \\
\hline 1,3-Dinitrobenzene & $2.75 E-03$ & $1.35 \mathrm{E}-01$ & $9.35 \mathrm{E}-03$ \\
\hline Nitrobenzene & $8.39 \mathrm{E}-05$ & 4.11E-03 & $2.85 \mathrm{E}-04$ \\
\hline 2,4-Dinitrotoluene & $8.55 \mathrm{E}-03$ & 4.19E-01 & $2.91 \mathrm{E}-02$ \\
\hline 2,6-Dinitrotoluene & $1.02 \mathrm{E}-02$ & $4.99 \mathrm{E}-01$ & $3.46 \mathrm{E}-02$ \\
\hline Pentachloronitrobenzene & $4.28 \mathrm{E}-06$ & 2.10E-04 & $1.46 \mathrm{E}-05$ \\
\hline
\end{tabular}

a. South of the INEEL near Big Southern Butte. This is the location where maximum human health impacts were evaluated (section 3).

b. Immediately adjacent to the SW and NE INTEC fence line.

c. An integrated average within the $5 \%$ of maximum deposition rate isopleth.

d. Based on a conservative best-estimate of the $\mathrm{Hg}$ emission rate (3.7\% of feed). Upper-bound soil concentrations are a factor of 4.3 higher based on the ratio of the upper-bound emissions factor (13\%) to the best-estimate emissions factor (3\%).

e. Assumed to be $2 \%$ of the total $\mathrm{Hg}$ (EPA 1998). Upper-bound soil concentrations are a factor of 4.3 higher.

f. Metal emissions that may be present based on preliminary (4/99) offgas sampling data. Soil concentrations were calculated using emission rates from the highest of 3 sample results and fate and transport parameters for zinc (EPA 1998). 
sage grouse (Centrocercus urophasianus), pronghom antelope (Antilocapra americana), and sage sparrows (Amphispiza belli). Other communities include rabbitbrush (Chrysothamnus spp.), grasses and forbs, salt desert shrubs (Atriplex spp.), and exotic or weed species. Juniper woodlands are located near the buttes and in the northwest portion of the INEEL. The juniper woodlands provide important habitat for raptors and large mammals. Limited riparian communities exist on the INEEL along intermittently flowing waters of the Big Lost River and Birch Creek drainages. Stream flow that reaches the INEEL flows to the Big Lost River playa or the Birch Creek playa, in which water is lost to evaporation and infiltration.

8.2.2.1 Abiotic Components. The INTEC facility is located on the alluvial plain of the Big Lost River. The main channel of the Big Lost River passes within $100 \mathrm{~m}$ of the northwest corner of INTEC facility fences along its route to the Sinks (approximately $18 \mathrm{~km}[11 \mathrm{mi}]$ to the north).

The topography surrounding the facility is relatively flat. The soils surrounding the facilities are comprised primarily of Typic-Camborthids-Typic Calciorthids (TCC), Typic Torrifluvents (TTF) and Malm-Bondfarm-Matheson complex soils (Figure 11).

Both TCC and TTF soils are alluvium, which are deposited by the Big Lost River. TTF soils are somewhat newer than TCC soils and are found in closer proximity to the river. The TCC soils are loams or silty loams over gravelly or sandy loams, and the surface is frequently hardened due to alkaline conditions. The TTF soils are also loams or sandy loams over gravelly subsoils. However, the gravels associated with TTF soils are finer and more frequently found on the surface than those of TCC soils. Both soil types are often dry and generally alkaline and saline, impermeable, erodible and have little organic accumulation in the upper layer (Olson et al. 1995). Spring thaws and intense rainstorms may lead to significant soil erosion in these soil types.

The Malm-Bondfarm-Matheson complex consists of moderately deep, well drained, sandy-loam soils on basalt plains. A calcic horizon is present at approximately $30 \mathrm{~cm}$ (12 in.). Permeability of these soils is moderately rapid, and the erosion hazards for these soils are slight to moderate (Olson et al. 1995).

8.2.2.2 Biotic Components. Sagebrush-steppe habitat on the INEEL supports a number of species including sage grouse, pronghorn elk (Cervus elaphus), and waterfowl (all important game species). Grasslands provide habitat for species such as the western meadowlark (Sturnella neglecta) and mule deer (also a game species). Rock outcroppings support species such as bats, woodrats (Neotoma cinerea), and cottontail (Sylvilagus nuttalli). No areas of critical habitat as defined in 40 CFR 300 are known to exist within the assessment area.

The flora and fauna that exist in the assessment are representative of those found across the INEEL and are described in the following subsections. Flora was determined using a vegetation map constructed for the INEEL using Landsat imagery and field measurements from vegetation plots (EG\&G Idaho, 1993). Fauna was characterized using a 1986 vertebrate survey performed on the INEEL (Reynolds et al., 1986) and data collected subsequent to that survey. The flora and fauna present in the assessment area have not been verified with a comprehensive field survey. However, information presented here is supported by previous field surveys and observations described in the WAG 3 ERA conducted as part of the OU 3-13 Comprehensive RI/FS (DOE 1997).

8.2.2.2.1 Flora-The 15 INEEL vegetation cover classes defined using Landsat imagery data (Kramber et al., 1992) have been combined into eight cover classes applied for INEEL ERAs (VanHorn et al., 1995). The vegetation mapped in the NWCF assessment area is shown in Figure 12. Six of the eight vegetation cover classes are represented, including sagebrush-steppe on lava, sagebrush/rabbitbrush, grassland, salt desert shrub, playa-bareground/disturbed, and juniper. The species composition for each 


\section{Soil Types}

$\ldots$ Fine-loamy over sandy or sand-cobble mix in recent to ancient floodplains.

$\square$ Moderately deep to very deep silty and loamy windblown deposits over lava.

Exposed lava or very shallow loamy windblown sediments over lava.

Well drained loamy soils over limestone rubble.

Deep, fine-silty and clayey deposits from ancient Lake Terreton. Some "slick spots" high in sodium.

Very deep, coarse-textured soils on alluvial fans and terraces.

Moderately coarse textured eolian or alluvial deposits on rolling basalt plains. Depth highly variable.

Coarse textured eolian deposits over basalt.

Coarse-textured soils over limestone gravel, alluvium, or glacial outwash.

$\square$ Rock Outcrop.

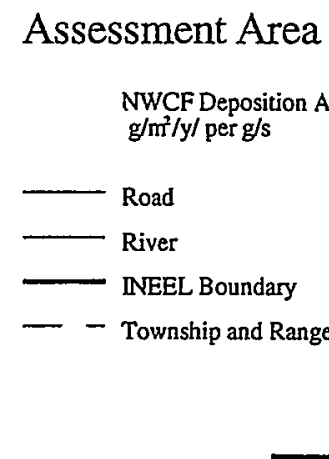

$30 E$

R $9 \mathrm{E}$

R 325

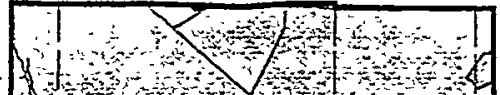

A

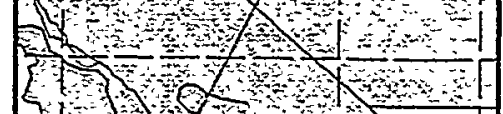

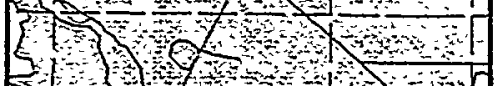
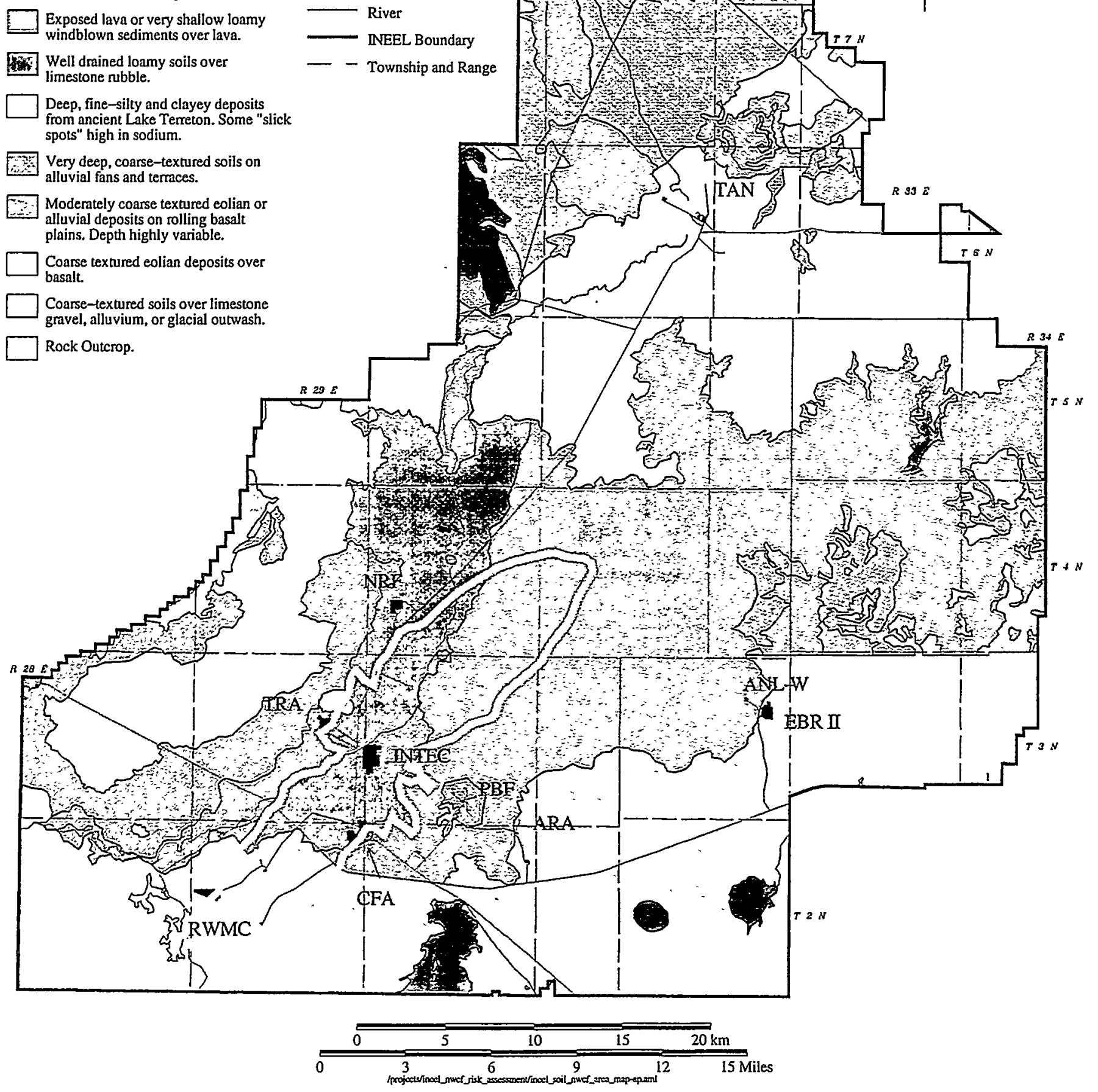

Figure 11. Soil types in the NWCF assessment area. 


\section{Vegetation Classification}
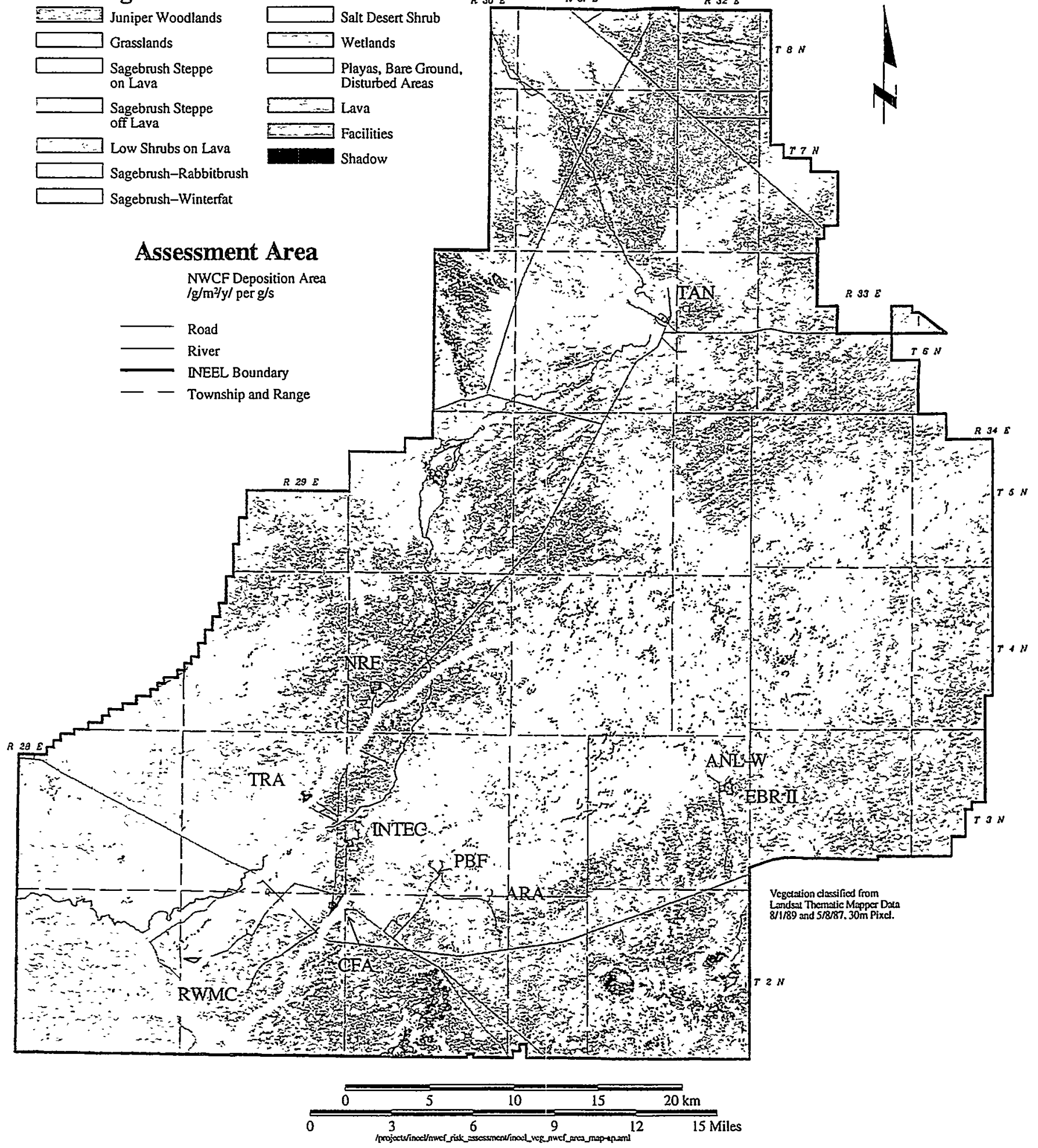

Figure 12. Vegetation cover types in the NWCF assessment area 
of these classes is summarized on Table 19. Sagebrush-steppe on lava and sagebrush/rabbitbrush are the two predominant vegetation types found in the assessment area. The dominant vegetation species within these two communities is Wyoming big sagebrush (Artemisia tridentata spp. wyomingensis). Grasslands present in the area are comprised primarily of wheat grasses (Agropyron spp., Elymus spp). Table 20 summarizes the vegetative composition within the assessment area.

8.2.2.2.2 Fauna-A comprehensive list of fauna potentially present within the assessment area is presented in Appendix G. The list incorporates the concept of functional grouping as described in the Guidance Manual (VanHorn et al., 1995). The functional grouping approach is designed to group similar species to aid in analyzing the effects of stressors on INEEL ecosystem components. The primary purpose for functional grouping is to apply existing data from one or more species within the group to assess the risk to the group as a whole. Functional groups are used to perform a limited evaluation of exposures for all potential receptors and provide a mechanism for focusing subsequent analyses on receptors that best characterize potential contaminant effects. Species characteristics including trophic level, breeding, and feeding locations were used to construct functional groups for INEEL species. Individual groups were assigned a unique identifier consisting of a one- or two-letter code to indicate taxon $(\mathrm{A}=$ amphibians, $\mathrm{AV}=$ birds, $\mathrm{M}=$ mammals, $\mathrm{R}=$ reptiles, $\mathrm{I}=$ insects), and a three-digit code derived from the combination of trophic category and feeding habitats. For example, AV122 represents

Table 19. Species composition for NWCF assessment area vegetation classes.

\begin{tabular}{lll}
\hline Vegetation Cover Class & INEEL Vegetation Cover Class & \multicolumn{1}{c}{ Dominant Species } \\
\hline Grasslands & Steppe & Leymus cinereus \\
& Basin Wildrye & Descurainia sophia \\
& Grassland & Sisymbrium altissimum \\
& & Elymus lanceolatus \\
& & Artemisia tridentata ssp. wyomingensis \\
& & Elymus elymoides \\
& Chrysothamnus viscidiflorus \\
Sagebrush/Rabbitbrush & Sagebrush-steppe off lava & Artemisia tridentata ssp. wyomingensis \\
& Sagebrush-winterfat & Chrysothamnus viscidiflorus \\
& Sagebrush-rabbitbrush & Bromus tectorum \\
& & Sisymbrium altissimum \\
Salt desert shrubs & Achnatherum hymenoides \\
& Salt desert shrub & Atriplex nuttallii \\
& & Atriplex canescens \\
& & Atriplex confertifolia \\
Sagebrush-steppe on & Srascheninnikovia lanata \\
lava & & Artemisia tridentata ssp. wyomingensis \\
& & Achnatherum hymenoides \\
Playa-bare & & Chrysothamnus viscidiflorus \\
ground/disturbed areas & borrow pits old fields, & Sochia scoparia \\
& disturbed areas, seedings & Artemisia tridentata ssp. wyomingensis \\
& & Chrysothamnus viscidiflorus \\
\hline
\end{tabular}


Table 20. Summary of vegetation in the NCWF assessment area

\begin{tabular}{lccc} 
Vegetation cover class & $\begin{array}{c}\text { Area } \\
\text { (hectares) }\end{array}$ & $\begin{array}{c}\text { Area } \\
\text { (acres) }\end{array}$ & $\begin{array}{c}\text { Percent cover } \\
(\%)\end{array}$ \\
\hline Juniper & $<1$ & 3 & $<1$ \\
Grassland & 805 & 1,990 & 9.4 \\
Sagebrush/Rabbitbrush & 6,400 & 15,900 & 37.1 \\
Salt Desert Shrub & 43 & 106 & $<1$ \\
Sagebrush-Steppe on lava & 8,400 & 20,800 & 48.2 \\
Playa-bareground/ & 100 & 250 & 1.5 \\
disturbed areas & & & 3.8 \\
Facilities & 300 & 730 & 100.00 \\
Totals & 16,050 & 39,800 & \\
\hline
\end{tabular}

the group of seed-eating (herbivorous) bird species whose feeding habitat is the terrestrial surface and/or understory. The trophic categories (first digit in three-digit code) are as follows: $1=$ herbivore, 2 $=$ insectivore, $3=$ carnivore, $4=$ omnivore, and $5=$ detrivore. The feeding habitat codes (second and third digits in three-digit code) are derived as follows:

\subsection{Air}

\subsection{Terrestrial}

$2.1 \quad$ Vegetation canopy

2.2 Surface/understory

2.3 Subsurface

2.4 Vertical habitat (man-made structures, cliffs, etc.)

3.0 Terrestrial/Aquatic Interface

$3.1 \quad$ Vegetation canopy

3.2 Surface/understory

3.3 Subsurface

3.4 Vertical habitat

\subsection{Aquatic}

\subsection{Surface water}

4.2 Water column

\subsection{Bottom}


The functional grouping methodology is described in detail in the Guidance Manual (VanHorn et al., 1995).

The list of species potentially present in the assessment area was developed by updating 1986 data on the relative abundance, habitat use, and seasonal presence of fish, amphibians, reptiles, birds, and mammals recorded on the INEEL (Reynolds et al., 1986) and communicating with INEEL researchers and personnel conducting ecological studies since 1986. Fauna that are not supported by the existing habitat or that are rare or uncommon or otherwise unlikely to be found in the assessment area were not included in the literature search for species-specific exposure and/or toxicity data. Those species are represented by the functional group with which they are associated. A complete list of species within individual functional groups, as well as those not included in the literature search can be found in Appendix G.

Species potentially present in the NWCF assessment area represent all 23 INEEL avian functional groups and 9 of 10 mammalian functional groups. Both reptilian functional groups are represented by species inhabiting the assessment area. No surface hydrology exists to support fish.

Although some population studies have been conducted for cyclic rabbit and rodent populations, several game species (e.g., pronghorn, sagegrouse), and raptors, no recent comprehensive studies have been conducted to assess either WAG-specific or INEEL-wide wildlife population status and/or trends with respect to contaminant effects.

Wildlife species present in the assessment area include birds, mammals, and reptiles that are associated with facilities, sagebrush-steppe, rock outcroppings, shrubs, and grasslands. The varying behaviors of these species include but are not limited to grazing and browsing on vegetation, burrowing and flying, and preying on insects and small mammals. If prey, such as a small mammal, becomes contaminated by ingesting contaminated soil or vegetation, and is then captured by a predator, such as a ferruginous hawk, the contamination can be taken offsite when the hawk returns to its nest to feed nestlings. Scenarios for potential exposure of fauna to NWCF contaminants are discussed in Section 8.2.3.

The flora and fauna present within the assessment area are combined into a simplified food web model. Variability in environmental conditions, such as population sizes or seasons, is not considered in this model, and a constant environment is assumed. Because aquatic (i.e., percolation and sewage treatment ponds) and terrestrial habitats are present in the area, the model includes only terrestrial species. Present at the site are decomposers, producers (vegetation), primary consumers or herbivores (e.g., rodents), secondary consumers or carnivores (e.g., snakes), and tertiary or top carnivores (e.g., raptors). These relationships were incorporated to identify direct and indirect exposure to contaminants for the CSM as discussed in Section 8.2.3. This model depicts the possible transport of NWCF contaminants through the food web.

8.2.2.2.3 Threatened, Endangered and Sensitive Species-A list of threatened and endangered (T/E) and sensitive species was compiled from the U.S. Fish and Wildlife Service (Martin 1997); the Idaho Department of Fish and Game Conservation Data Center threatened, endangered, and sensitive species for the State of Idaho (CDC 1994); and Radiological and Environmental Sciences Laboratory (RESL) documentation for the INEEL (Reynolds et al. 1986). Threatened, endangered (T/E) or sensitive species that could exist in the NWCF assessment area are listed in Table 21.

Avian species include six terrestrial species: the ferruginous hawk (Buteo regalis), the peregrine falcon (Falco peregrinus), the northern goshawk (Accipiter gentilis), the loggerhead shrike (Lanius ludovicianus), the burrowing owl (Athene cunicularia), and the bald eagle (Haliaeetus leucocephalus). 
Table 21. Threatened and endangered species, species of concern, and sensitive species that may be found in the NCWF assessment area.

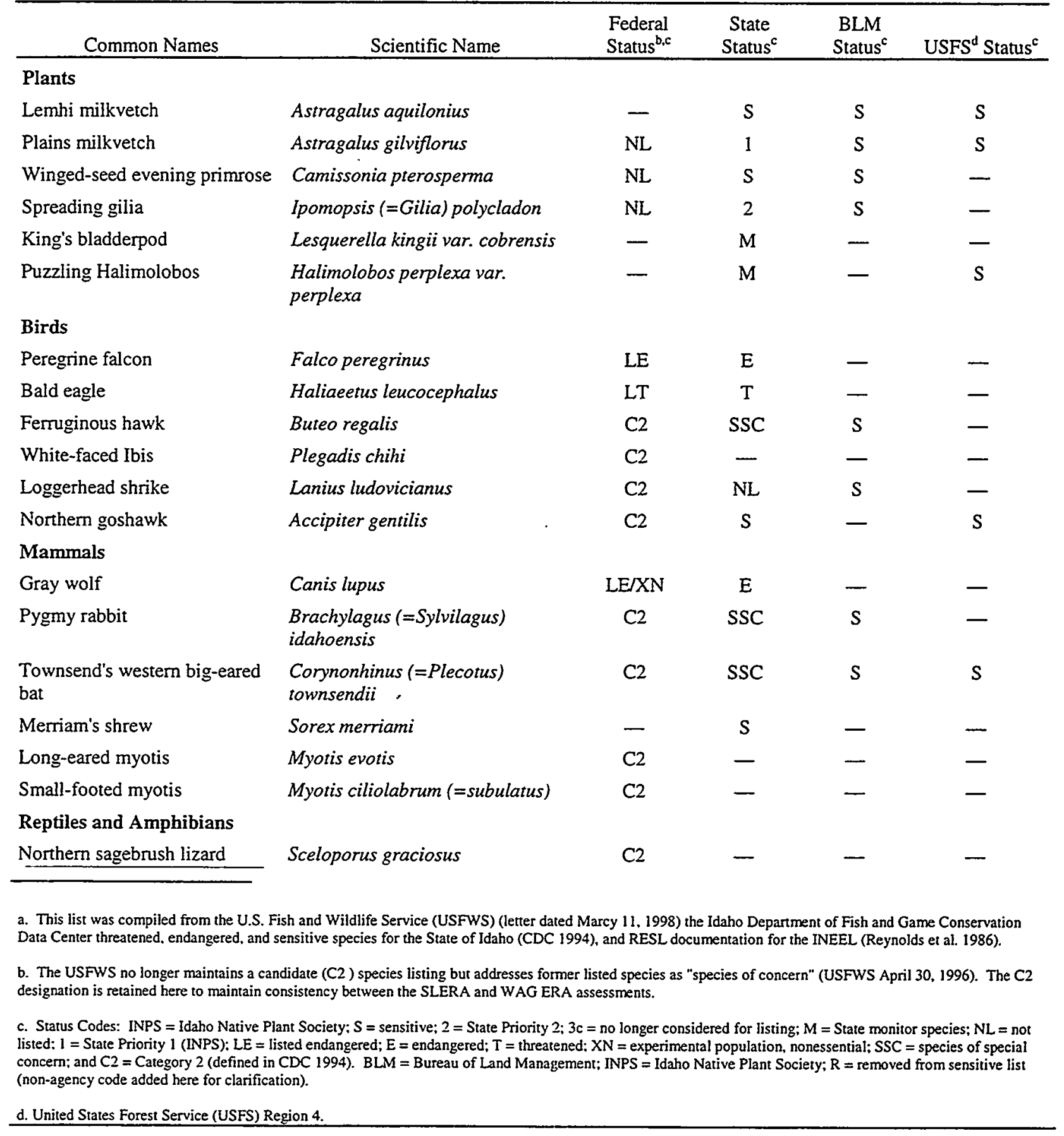


Three aquatic species: the white-faced ibis (Plegadis chihi), the black tern (Childonias niger), and the trumpeter swan (Cygnus buccinator) are not likely to occur in the assessment area because of the absence of permanent surface water. Therefore, these species are not evaluated as potential receptors in this assessment. The bald eagle and peregrine falcon are federally listed species. The remaining avian species are species of concern (formerly $\mathrm{C} 2$ ).

Five mammalian species species of concern potentially occur in the assessment including: the pygmy rabbit (Brachylagus idahoensis), Townsend's western big-eared bat [Corynorhinus(=Plecotus) townsendii], long-eared myotis (Myotis evotis), small-footed myotis [Myotis ciliolabrum (=subulatus)] and gray wolf (Canis lupus). The occurrence of the gray wolf on the INEEL is unverified. However, because of anecdotal evidence (Morris 1998) and the fact that the wolf is federally listed, the species is evaluated in the assessment.

The sagebrush lizard (Sceloporous graciosus) is the only reptile species of concern with a potential presence in the assessment area.

\subsubsection{Pathways of Contaminant Migration and Exposure}

Contaminated surface soil represents the major source of possible contaminant exposure for ecological components within the NCWF assessment area. Subsurface soil and surface water pathways were not analyzed as part of this assessment. Surface soil, as defined in the combustion guidance (see Section 8.2.1) includes the uppermost $1 \mathrm{~cm}$.

The ecological pathways/exposure model for NWCF contaminated surface soil is shown in Figure 13. This model depicts surface soil contamination transport through plant uptake and direct exposure to vegetation and primary consumers. Ecological receptors in upper trophic levels may then be exposed indirectly by ingesting prey that have bioaccumulated contaminants in their tissue. Receptors having potential for direct exposure to surface soils are presented in Table 22.

\subsubsection{Conceptual Site Model}

The pathways/exposure model for surface soil and food web analysis were integrated to produce the NWCF CSM shown in Figure 14. This model reflects both direct and indirect (i.e., predation) receptor exposure pathways for NWCF COPCs.

\subsubsection{Assessment Endpoints}

Assessment endpoints are "formal expressions of the actual environmental values that are to be protected" (Suter, 1989). Assessment endpoints developed for this ERA are presented on Table 23. The endpoints were developed around the protection of NEEL biota represented by functional groups and individual T/E and sensitive species known to exist in the assessment and identified as having potential for exposure to COPCs. Each T/E and sensitive species with the potential for exposure is addressed individually in the risk analysis, whereas potential effects to other receptors of concern are dealt with at the functional group level. Assessment endpoints defined for the ERA reflect INEEL-wide hazard/policy goals discussed in the Guidance Manual (VanHorn et al., 1995) and incorporate the suggested criteria for developing assessment endpoints, including ecological relevance and policy goals (EPA, 1992a; Suter, 1993).

These assessment endpoints are the focus for ERA risk characterization and link the measurement endpoints to the ERA goals. The primary objective of this ERA is to identify COPCs and levels of those contaminants that represent potential risk to ecological components in the assessment area. 


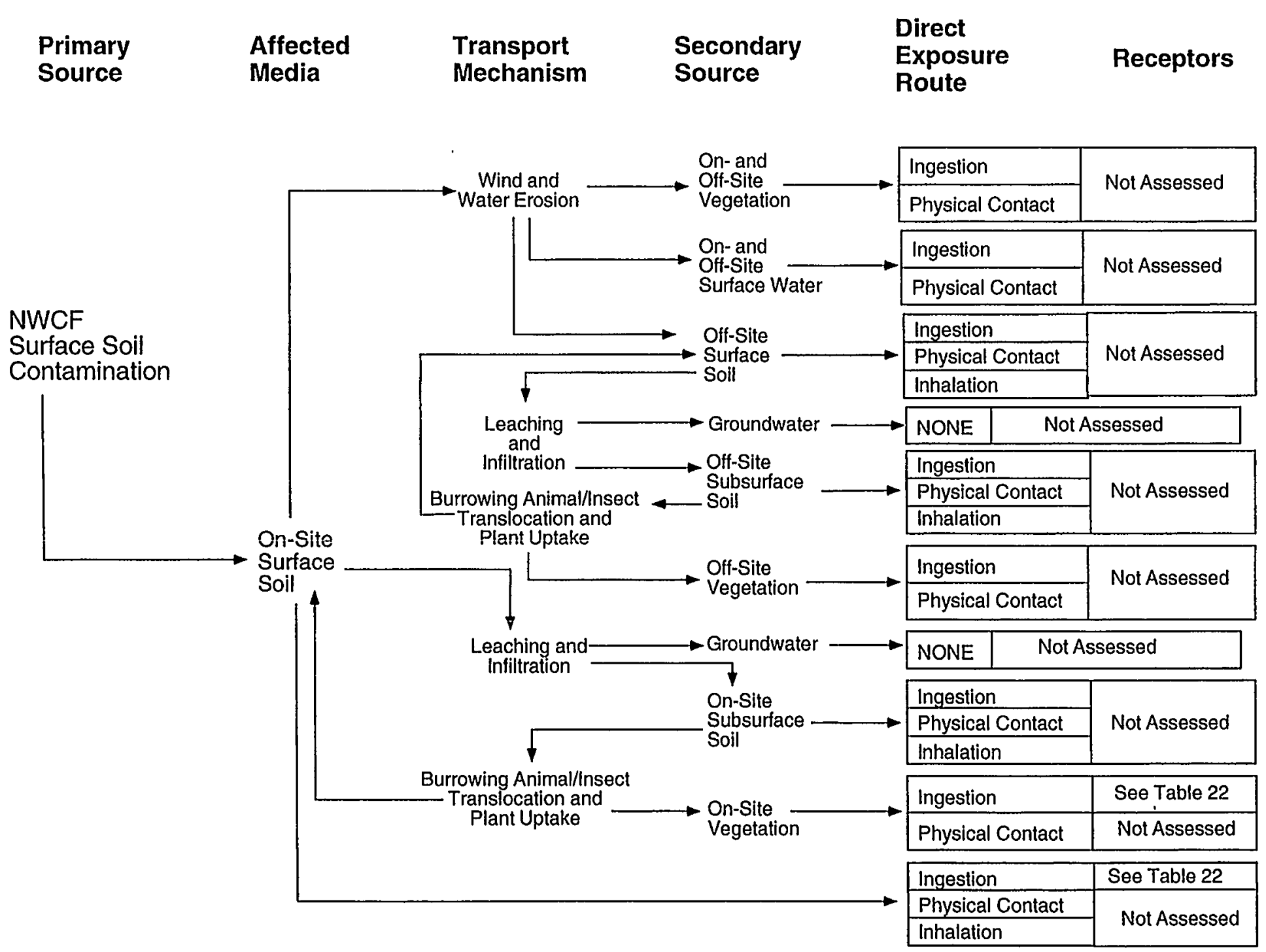

Figure 13. Ecological pathways/exposure model for NWCF surface soil contamination. 
Table 22. Summary of exposure media and ingestion routes for NWCF receptors.

\begin{tabular}{|c|c|c|c|c|c|}
\hline \multirow{2}{*}{ Receptor } & \multirow{2}{*}{$\begin{array}{l}\text { Surface } \\
\text { Soils }\end{array}$} & \multirow[b]{2}{*}{ Vegetation } & \multicolumn{3}{|c|}{ Prey Ingestion ${ }^{a}$} \\
\hline & & & Invertebrates & Mammals & Birds \\
\hline Avian herbivores (AV122) & $X$ & $\mathrm{X}$ & & & \\
\hline Avian insectivores (AV210A) & $X$ & & $X$ & & \\
\hline Avian insectivores (AV222) & $\mathrm{X}$ & & $\mathrm{X}$ & & \\
\hline Avian insectivores (AV232) & $X$ & & $\mathrm{X}$ & & \\
\hline Avian carnivores (AV310) & $X$ & & & $X$ & $\mathrm{X}$ \\
\hline Northern goshawk & $\mathrm{X}$ & & & $\mathrm{X}$ & $X$ \\
\hline Peregrine falcon & $X$ & & & $\mathrm{X}$ & \\
\hline Avian carnivores (AV322) & $\mathrm{X}$ & & & $\mathrm{X}$ & \\
\hline Bald eagle & $X$ & & & $\mathrm{X}$ & \\
\hline Ferruginous hawk & $X$ & & & $\mathrm{X}$ & \\
\hline Loggerhead shrike & $X$ & & & $\mathrm{X}$ & $\mathrm{X}$ \\
\hline $\begin{array}{l}\text { Avian carnivores (AV322A) } \\
\text { Burrowing owl }\end{array}$ & $X$ & & $X$ & $\mathrm{X}$ & \\
\hline Avian omnivores (AV422) & $X$ & $\mathrm{X}$ & $X$ & $\mathrm{X}$ & $X$ \\
\hline Mammalian herbivores (M122) & $\mathrm{X}$ & $\mathrm{X}$ & & & \\
\hline $\begin{array}{l}\text { Mammalian herbivores } \\
\text { (M122A) }\end{array}$ & $X$ & $X$ & & & \\
\hline Pygmy rabbit & $X$ & $X$ & & & \\
\hline $\begin{array}{l}\text { Mammalian insectivores } \\
\text { (M210A) }\end{array}$ & $\mathrm{X}$ & & $X$ & & \\
\hline $\begin{array}{l}\text { Townsend's western } \\
\text { big-eared bat }\end{array}$ & $X$ & & $\mathrm{X}$ & & \\
\hline Small-footed myotis & $\mathrm{X}$ & & $\mathrm{X}$ & & \\
\hline Long-eared myotis & $\mathrm{X}$ & & $\mathrm{X}$ & & \\
\hline $\begin{array}{l}\text { Mammalian insectivores } \\
\text { (M222) } \\
\text { Merriam's shrew }\end{array}$ & $\mathrm{X}$ & & $\mathrm{X}$ & & \\
\hline Mammalian carnivore (M322) & $X$ & & & $\mathrm{X}$ & \\
\hline Mammalian omnivores (M422) & $X$ & $X$ & $\mathrm{X}$ & & \\
\hline Reptilian carnivores (R322) & $X$ & & & $\mathrm{X}$ & \\
\hline Plants & $\mathrm{X}$ & & & & \\
\hline
\end{tabular}




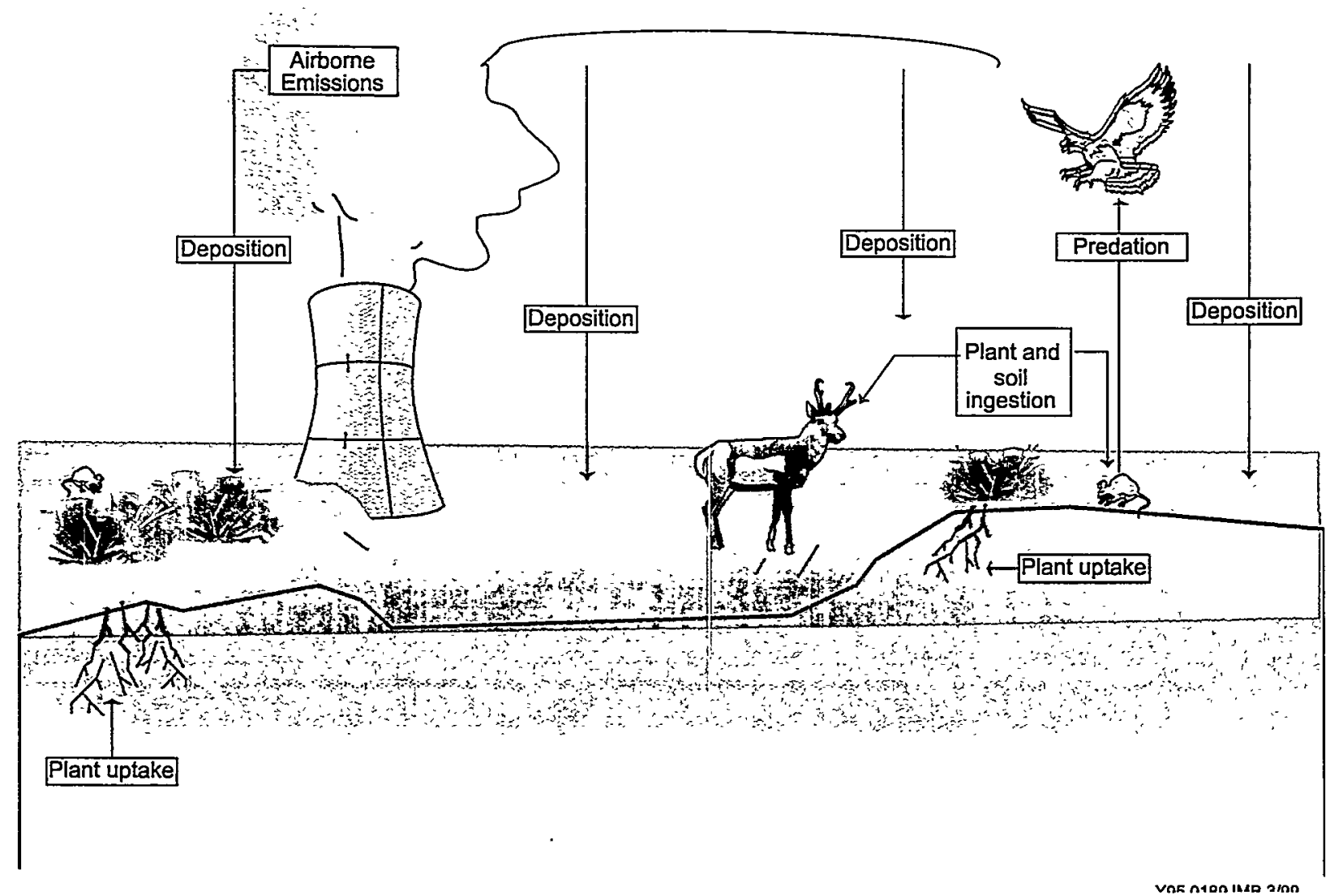

Figure 14. NWCF ecological conceptual site model.

Table 23. Summary of assessment endpoints for NWCF.

\begin{tabular}{|c|c|c|}
\hline Management Goal & NWCF ERA Assessment Endpoint & $\begin{array}{c}\text { Indicator of } \\
\text { Risk }\end{array}$ \\
\hline $\begin{array}{l}\text { Maintain INEEL T/E } \\
\text { individuals and populations by } \\
\text { limiting exposure to organic and } \\
\text { inorganic contamination. }\end{array}$ & $\begin{array}{l}\text { Survival of T/E individuals and reproductive } \\
\text { success of T/E populations: bald eagle, peregrine } \\
\text { falcon, northern goshawk, burrowing owl, } \\
\text { ferruginous hawk, pygmy rabbit, Townsend's } \\
\text { western big-eared bat, long-eared myotis, small- } \\
\text { footed myotis, gray wolf, and sagebrush lizard. }\end{array}$ & $\begin{array}{l}\text { Avg. soil } \\
\text { concentration } \\
>\text { EBSL }\end{array}$ \\
\hline \multirow{2}{*}{$\begin{array}{l}\text { Maintain abundance and } \\
\text { diversity of INEEL native biota } \\
\text { by limiting exposure to organic } \\
\text { and inorganic contamination. }\end{array}$} & Survival and growth of native vegetation & $\begin{array}{l}\text { Avg. soil } \\
\text { concentration } \\
>\text { EBSL }\end{array}$ \\
\hline & $\begin{array}{l}\text { Survival and reproduction of wildlife populations } \\
\text { (identified in the site conceptual model: small } \\
\text { mammals, large mammals, song birds, raptors, } \\
\text { top predators; represented by functional groups). }\end{array}$ & $\begin{array}{l}\text { Avg. soil } \\
\text { concentration } \\
>\text { EBSL }\end{array}$ \\
\hline
\end{tabular}


Consequently, toxic effects to ecological components as a result of exposure to COPCs were considered a primary concern for biota. Although adverse effects due to physical and/or behavioral stressors are also of concern in evaluating potential risks to INEEL ecological components, these effects are not addressed by this ERA.

\subsubsection{Measurement Endpoint Selection}

This section describes the selection of measurement endpoints for the WAG ERA. Measurement endpoints are measurable responses of ecological receptors to contaminants that can be related to ERA assessment endpoints. For this ERA, ecological components (flora and fauna) inside the assessment area were not measured or surveyed directly. Rather, published references were used as the primary sources of ecological and toxicological data from which measurement endpoints were derived. Values extracted from these references were used to calculate dose for all ecological receptors and to develop TRVs for contaminants.

Table 24 summarizes the measurement endpoints developed to address NWCF ERA assessment endpoints. Quantified critical exposure levels (QCELs) and adjustment factors (AFs) were constructed from the literature to develop appropriate TRVs for receptors associated with NWCF contaminant pathways. Criteria for development of these TRVs are discussed in Appendix G. In general, the criteria incorporate the requirements for appropriate measurement endpoints, including relevance to an assessment endpoint, applicability to the route of exposure, use of existing data, and consideration of scale (VanHorn et al., 1995).

Values for species dietary habits, home ranges, site use, exposure duration, soil ingestion, food digestion, and body weights for the representative species are documented in Appendix D3 of the OU 10-04 Comprehensive RI/FS (DOE, 1999). The exposure-point concentrations of contaminants in surface soil were used to calculate dose for each affected receptor.

\subsection{Analysis}

The risk analysis step involves assessing exposure to contaminants (characterization of exposure) and potential effects of exposure (characterization of effects). These activities are conducted interactively to ensure that the methods used to assess exposure and effects are compatible. Assessing exposure and effects is based on the ecological endpoints and conceptual models derived during the problem formulation presentation.

\subsubsection{Exposure Calculations}

Potential exposures for functional groups, including T/E, and sensitive species were determined based on site-specific life history and feeding habits when possible. Quantification of group and individual exposures incorporated species-specific numerical exposure factors including body weight, ingestion rate, and fraction of diet composed of vegetation or prey, and soil consumed from the affected area. Parameters used to model contaminant intakes by the functional groups and species (assessment endpoints) are presented in Table 25. These values were derived from a combination of parameters that produced the most conservative overall exposure for the group. The functional group parameters in Table 25 represent the most conservative combination of percent prey, percent vegetation, percent soil, $E D$, ingestion rate, body weight, and home ranges from species within the functional group. The input parameters and exposure equations are documented in detail in the OU 10-04 RI/FS Workplan (DOE, 1999). 
Table 24. Summary of NWCF ERA endpoints.

\begin{tabular}{|c|c|c|c|}
\hline $\begin{array}{c}\text { NWCF } \\
\text { Assessment Endpoint }\end{array}$ & Ecological Component & $\begin{array}{c}\text { Functional Group } \\
\text { (Other Groups Represented) }\end{array}$ & $\begin{array}{c}\text { Measurement Species } \\
\text { (Toxicity Reference Value Test } \\
\text { Species) } \\
\end{array}$ \\
\hline \multirow{6}{*}{$\begin{array}{l}\text { No indication of possible } \\
\text { effects on } T / E \text { and } C 2 \\
\text { individuals and populations } \\
\text { as a result of contaminant } \\
\text { exposure. }\end{array}$} & Pygmy rabbit & M122A (M123) & $\begin{array}{l}\text { Rat, mouse/meadow vole } \\
\text { (M122A), and deer mouse } \\
\text { (M422) }\end{array}$ \\
\hline & Gray wolf & M322 & Dog, mouse (M422) \\
\hline & $\begin{array}{l}\text { Peregrine falcon, and northern } \\
\text { goshawk }\end{array}$ & AV310 & $\begin{array}{l}\text { Chicken, goshawk, and American } \\
\text { kestrel/red-tailed hawk (AV322) }\end{array}$ \\
\hline & $\begin{array}{l}\text { Ferruginous hawk, loggerhead } \\
\text { shrike, bald eagle, and burrowing } \\
\text { owl }\end{array}$ & AV322, AV322A & $\begin{array}{l}\text { Chicken, goshawk, and American } \\
\text { kestrel/red-tailed hawk (AV322) }\end{array}$ \\
\hline & Sagebrush lizard & $\mathrm{R} 222$ & None located \\
\hline & Bats & $\mathrm{M} 210, \mathrm{M} 210 \mathrm{~A}$ & $\begin{array}{l}\text { Rat, mouse/meadow vole } \\
\text { (M122A), and deer mouse } \\
\text { (M422) }\end{array}$ \\
\hline $\begin{array}{l}\text { No indication of possible } \\
\text { effects on native vegetation } \\
\text { communities as a result of } \\
\text { contaminant exposure. }\end{array}$ & Vegetation & Sagebrush and bunchgrass & Bush beans and crop plants \\
\hline \multirow{10}{*}{$\begin{array}{l}\text { No indication of possible } \\
\text { effects on wildlife } \\
\text { populations as a result of } \\
\text { contaminant exposure } \\
\text { (represented by functional } \\
\text { groups identified in the site } \\
\text { conceptual model: small } \\
\text { mammals, large mammals, } \\
\text { song birds, raptors, and top } \\
\text { predators, invertebrates). }\end{array}$} & Small mammals & M422, M122A (M222, M123) & $\begin{array}{l}\text { Rat, mouse/meadow vole } \\
\text { (M122A), and deer mouse } \\
\text { (M422) }\end{array}$ \\
\hline & $\begin{array}{l}\text { Mammalian carnivores and } \\
\text { omnivores }\end{array}$ & M422A, M322 & $\begin{array}{l}\text { Rat, mouse, dog, cat, and } \\
\text { mink/fox }\end{array}$ \\
\hline & Mammalian herbivores & $\mathrm{M} 121, \mathrm{M} 122, \mathrm{M} 122 \mathrm{~A}$ & $\begin{array}{l}\text { Rat, mouse, and mule } \\
\text { deer/pronghorn }\end{array}$ \\
\hline & Avian camivores & AV322, AV322A, M122A & $\begin{array}{l}\text { Goshawk (AV310) and American } \\
\text { kestrel/red-tailed hawk (AV322) }\end{array}$ \\
\hline & Avian herbivores & AV121, AV122 & $\begin{array}{l}\text { Chicken, pheasant, quail, and } \\
\text { passerines/sharp-tailed and ruffed } \\
\text { grouse }\end{array}$ \\
\hline & Avian insectivore & $\begin{array}{l}\text { AV210, AV222 (AV210A, } \\
\text { AV221, AV22A) }\end{array}$ & $\begin{array}{l}\text { Chicken, pheasant, quail, } \\
\text { passerines/American robin } \\
\text { (AV222), and cliff swallow } \\
\text { (AV210A) }\end{array}$ \\
\hline & Avian omnivores & AV422 & $\begin{array}{l}\text { Chicken, pheasant, turkey, black, } \\
\text { mallard }\end{array}$ \\
\hline & Mammalian insectivore & M210A (M210) & $\begin{array}{l}\text { Rat, mouse/meadow vole } \\
\text { (M122A), and deer mouse } \\
\text { (M422) }\end{array}$ \\
\hline & Reptiles & $\mathrm{R} 222, \mathrm{R} 322$ & Western racer (none located) \\
\hline & Invertebrates & $\begin{array}{l}\text { Phytophagous, saprophagous, } \\
\text { and entomophagous }\end{array}$ & Unidentified \\
\hline
\end{tabular}


8.3.1.1 Exposure Modeling. Exposure models are used to calculate dose to functional groups and $\mathrm{T} / \mathrm{E}$ species. For exposure to surface soil contamination, dose (intake) in $\mathrm{mg} / \mathrm{kg}$ body weight-day can be estimated using the following equation, as adapted from EPA's Wildlife Exposure Factors Handbook (EPA, 1993b):

$E E_{\text {soil }}=\frac{[(P P \times C P)+(P V \times C V)+(P S \times C S)] \times I R \times E D \times S U F}{B W}$

where

$$
\begin{aligned}
& E E_{\text {soil }}=\quad \text { estimated exposure from all soil exposure pathways (mg/kg body weight-day) } \\
& P P=\text { percentage of diet represented by prey ingested (unitless) } \\
& C P=\text { concentration of contaminant in prey item ingested (mg/kg) } \\
& P V=\text { percentage of diet represented by vegetation ingested (unitless) } \\
& C V=\text { concentration of contaminant in vegetation ingested (mg/kg) } \\
& P S=\text { percentage of diet represented by soil ingested (unitless) } \\
& C S=\text { concentration of contaminant in soil ingested (mg/kg) } \\
& I R=\text { ingestion rate (kg/day), food intake rate (g/day) divided by } 1,000 \mathrm{~g} / \mathrm{kg} \\
& E D=\quad \text { exposure duration (fraction of year spent in the affected area) (unitless) } \\
& B W=\quad \text { receptor-specific body weight (kg) } \\
& S U F=\quad \text { site usage factor (site area divided by home range; cannot exceed 1) (unitless). }
\end{aligned}
$$

The concentration of contaminant in prey can be estimated using the equation (VanHorn et al, 1995):

$$
C P=C S \times C F
$$

where

$$
\begin{aligned}
& C P=\text { concentration in prey item ingested }(\mathrm{mg} / \mathrm{kg}) \\
& C S=\text { concentration of contaminant in soil (mg/kg) } \\
& C F=\text { contaminant-specific bioaccumulation factor (unitless). }
\end{aligned}
$$


Table 25. NWCF EBSL parameter input values.

\begin{tabular}{|c|c|c|c|c|c|c|c|}
\hline $\begin{array}{c}\text { Functional } \\
\text { Groups }\end{array}$ & PP & PV & PS & SUF & $\mathrm{ED}$ & $\begin{array}{c}\text { IR } \\
\text { (kg/day) }\end{array}$ & $\begin{array}{l}\mathrm{BW} \\
(\mathrm{kg}) \\
\end{array}$ \\
\hline Amphibians (A232) & $9.41 \mathrm{E}-01$ & $0.00 \mathrm{E}+00$ & $5.90 \mathrm{E}-02$ & $1.00 \mathrm{E}-00$ & $1.00 \mathrm{E}-00$ & $6.49 \mathrm{E}-0.5$ & $8.00 \mathrm{E}-03$ \\
\hline Avian herbivores (AV!21) & $0.00 \mathrm{E}+00$ & $9.90 \mathrm{E}-01$ & $1.00 \mathrm{E}-02$ & $1.00 \mathrm{E}-00$ & $1.00 \mathrm{E}-00$ & $3.50 \mathrm{E}-03$ & $1.29 \mathrm{E}-02$ \\
\hline Avian herbivores (AV122) & $0.00 \mathrm{E}+00$ & $9.07 \mathrm{E}-01$ & $9.30 \mathrm{E}-02$ & $1.00 \mathrm{E}-00$ & $1.00 \mathrm{E}-00$ & $1.46 \mathrm{E}-03$ & $3.50 \mathrm{E}-03$ \\
\hline Avian herbivores (AV132) & $0.00 \mathrm{E}+00$ & $8.20 \mathrm{E} \cdot 0 \mathrm{l}$ & $1.80 \mathrm{E}-01$ & $1.00 \mathrm{E}-00$ & $1.00 \mathrm{E}-00$ & $1.07 \mathrm{E}-02$ & $7.46 \mathrm{E}-02$ \\
\hline Avian herbivores (AV142) & $0.00 \mathrm{E}+00$ & $9.18 \mathrm{E}-01$ & $8.20 \mathrm{E}-02$ & $1.00 \mathrm{E}-00$ & $1.00 \mathrm{E}-00$ & $2.75 \mathrm{E}-02$ & $3.16 \mathrm{E}-01$ \\
\hline Trumpeter swan & $0.00 \mathrm{E}+00$ & $9.18 \mathrm{E}-01$ & $8.20 \mathrm{E} \cdot 02$ & $1.00 \mathrm{E}-00$ & $1.00 \mathrm{E}-00$ & $2.75 \mathrm{E}-01$ & $1.09 \mathrm{E}+01$ \\
\hline Avian herbivores (AV!43) & $0.00 \mathrm{E}+00$ & $9.18 \mathrm{E}-01$ & $8.20 \mathrm{E}-02$ & $1.00 \mathrm{E}-00$ & $1.00 \mathrm{E}-00$ & $2.92 \mathrm{E}-02$ & $3.47 \mathrm{E}-01$ \\
\hline Avian insectivores (AV210) & $9.80 \mathrm{E}-01$ & $0.00 \mathrm{E}+00$ & $2.00 \mathrm{E}-02$ & $1.00 \mathrm{E}-00$ & $1.00 \mathrm{E}-00$ & $2.90 \mathrm{E}-03$ & $1.00 \mathrm{E}-02$ \\
\hline Black tern & $9.80 \mathrm{E}-01$ & $0.00 \mathrm{E}+00$ & $2.00 \mathrm{E}-02$ & $1.00 \mathrm{E}-00$ & $1.00 \mathrm{E}-00$ & $9.84 \mathrm{E}-03$ & $6.53 \mathrm{E}-02$ \\
\hline Avian insectivores (AV2I0A) & $9.70 \mathrm{E}-01$ & $0.00 \mathrm{E}+00$ & $3.00 \mathrm{E}-02$ & $1.00 \mathrm{E}-00$ & $1.00 \mathrm{E}-00$ & $3.89 \mathrm{E}-03$ & $1.46 \mathrm{E}-02$ \\
\hline Avian insectivores (AV221) & $9.70 \mathrm{E}-01$ & $0.00 \mathrm{E}+00$ & $3.00 \mathrm{E}-02$ & $1.00 \mathrm{E}-00$ & $1.00 \mathrm{E}-00$ & $1.99 \mathrm{E}-03$ & $6.65 \mathrm{E}-03$ \\
\hline Avian insectivores (AV222) & $9.07 \mathrm{E}-01$ & $0.00 \mathrm{E}+00$ & $9.30 \mathrm{E}-02$ & $1.00 \mathrm{E}-00$ & $1.00 \mathrm{E}-00$ & $3.07 \mathrm{E}-03$ & $1.09 \mathrm{E}-02$ \\
\hline Avian insectivores (AV222A) & $9.07 \mathrm{E}-01$ & $0.00 \mathrm{E}+00$ & $9.30 \mathrm{E}-02$ & $1.00 \mathrm{E}-00$ & $1.00 \mathrm{E}-00$ & $2.82 \mathrm{E}-03$ & $1.00 \mathrm{E}-02$ \\
\hline Avian insectivores (AV232) & $8.20 \mathrm{E}-01$ & $0.00 \mathrm{E}+00$ & $1.80 \mathrm{E}-01$ & $1.00 \mathrm{E}-00$ & $1.00 \mathrm{E}-00$ & $1.12 \mathrm{E}-03$ & $2.32 \mathrm{E}-02$ \\
\hline Avian insectivores (AV233) & $8.20 \mathrm{E}-01$ & $0.00 \mathrm{E}+00$ & $1.80 \mathrm{E}-0 \mathrm{I}$ & $1.00 \mathrm{E}-00$ & $1.00 \mathrm{E}-00$ & $4.78 \mathrm{E}-03$ & 2.15E-02 \\
\hline White-faced ibis & $8.90 \mathrm{E}-01$ & $0.00 \mathrm{E}+00$ & $1.10 \mathrm{E}-01$ & $1.00 \mathrm{E}-00$ & $1.00 \mathrm{E}-00$ & $4.27 \mathrm{E}-02$ & $6.22 \mathrm{E}-0 \mathrm{I}$ \\
\hline Avian insectivores (AV241) & $8.20 \mathrm{E}-0 !$ & $0.00 \mathrm{E}+00$ & $1.80 \mathrm{E}-01$ & $1.00 \mathrm{E}-00$ & $1.00 \mathrm{E}-00$ & $6.41 \mathrm{E}-03$ & $3.38 \mathrm{E}-02$ \\
\hline Avian insectivores (AV242) & $8.20 \mathrm{E}-01$ & $0.00 E+00$ & $1.80 \mathrm{E}-01$ & $1.00 \mathrm{E}-00$ & $1.00 \mathrm{E}-00$ & $1.13 \mathrm{E}-02$ & 8. $10 \mathrm{E}-02$ \\
\hline Avian carnivores (AV310) & $9.80 \mathrm{E}-01$ & $0.00 \mathrm{E}+00$ & $2.00 \mathrm{E}-02$ & $1.00 \mathrm{E}-00$ & $1.00 \mathrm{E}-00$ & $1.61 \mathrm{E}-02$ & $1.39 \mathrm{E}-01$ \\
\hline Northern goshawk & $9.80 \mathrm{E}-01$ & $0.00 E+00$ & $2.00 \mathrm{E}-02$ & $1.00 \mathrm{E}-00$ & $1.00 \mathrm{E}-00$ & $6.00 \mathrm{E}-02$ & $1.05 \mathrm{E}-00$ \\
\hline Peregrine falcon & $9.80 \mathrm{E}-01$ & $0.00 \mathrm{E}+00$ & $2.00 \mathrm{E}-02$ & $1.00 \mathrm{E}-00$ & $1.00 \mathrm{E}-00$ & $4.96 \mathrm{E}-02$ & $7.82 \mathrm{E}-01$ \\
\hline Avian camivores (AV322) & $9.80 \mathrm{E}-01$ & $0.00 \mathrm{E}+00$ & $2.00 \mathrm{E}-02$ & $1.00 \mathrm{E}-00$ & $1.00 \mathrm{E}-00$ & 7.44E-03 & $4.25 \mathrm{E}-02$ \\
\hline Bald cagle & $9.80 \mathrm{E}-0 !$ & $0.00 \mathrm{E}+00$ & $2.00 \mathrm{E}-02$ & $1.00 \mathrm{E}-00$ & $1.00 \mathrm{E}-00$ & $1.60 \mathrm{E}-01$ & $4.74 \mathrm{E}-00$ \\
\hline Ferruginous hawk & $9.80 \mathrm{E}-01$ & $0.00 \mathrm{E}+00$ & $2.00 \mathrm{E}-02$ & $1.00 \mathrm{E}-00$ & $1.00 \mathrm{E}-00$ & $6.19 \mathrm{E}-02$ & $1.10 \mathrm{E}-00$ \\
\hline Loggerhead shrike & $9.80 \mathrm{E}-01$ & $0.00 \mathrm{E}+00$ & $2.00 \mathrm{E} \cdot 02$ & $1.00 \mathrm{E}-00$ & $1.00 \mathrm{E}-00$ & $7.44 \mathrm{E}-03$ & $4.25 \mathrm{E}-02$ \\
\hline Avian carnivores (AV322A) & $9.70 \mathrm{E}-01$ & $0.00 \mathrm{E}+00$ & $3.00 \mathrm{E}-02$ & $1.00 \mathrm{E}-00$ & $1.00 \mathrm{E}-00$ & $1.73 \mathrm{E}-02$ & $1.55 \mathrm{E}-01$ \\
\hline Burrowing owl & $9.70 \mathrm{E}-01$ & $0.00 \mathrm{E}+00$ & $3.00 \mathrm{E}-02$ & $1.00 \mathrm{E}-00$ & $1.00 \mathrm{E}-00$ & $1.73 \mathrm{E}-02$ & $1.55 \mathrm{E}-01$ \\
\hline Avian carnivores ( $\mathrm{AV} 333$ ) & $8.20 \mathrm{E}-01$ & $0.00 \mathrm{E}+00$ & $1.80 \mathrm{E}-01$ & $1.00 \mathrm{E}-00$ & $1.00 \mathrm{E}-00$ & $1.84 \mathrm{E}-02$ & $1.71 \mathrm{E}-01$ \\
\hline Avian camivores ( $A \vee 342$ ) & $9.80 \mathrm{E}-01$ & $0.00 \mathrm{E}+00$ & $2.00 \mathrm{E}-02$ & $1.00 \mathrm{E}-00$ & $1.00 \mathrm{E}-00$ & $4.64 \mathrm{E}-02$ & $7.06 \mathrm{E}-01$ \\
\hline Avian omnivores (AV422) & $6.27 \mathrm{E}-01$ & $2.80 \mathrm{E}-01$ & $9.30 \mathrm{E}-02$ & $1.00 \mathrm{E}-00$ & $1.00 \mathrm{E}-00$ & $1.13 \mathrm{E}-02$ & 8.02E-02 \\
\hline Avian omnivores (AV432) & $5.70 \mathrm{E}-01$ & $2.50 \mathrm{E}-01$ & $1.80 \mathrm{E}-01$ & $1.00 \mathrm{E}-00$ & $1.00 \mathrm{E}-00$ & $2.75 \mathrm{E}-02$ & $3.16 \mathrm{E}-01$ \\
\hline Avian omnivores (AV433) & $5.70 \mathrm{E}-0 !$ & $2.50 \mathrm{E}-01$ & $1.80 \mathrm{E}-01$ & $1.00 \mathrm{E}-00$ & $1.00 \mathrm{E}-00$ & 5.33E-02 & $8.74 \mathrm{E}-01$ \\
\hline
\end{tabular}


Table 25. (continued).

\begin{tabular}{|c|c|c|c|c|c|c|c|}
\hline $\begin{array}{l}\text { Functional } \\
\text { Groups }\end{array}$ & PP & PV & PS & SUF & ED & $\begin{array}{c}\text { IR } \\
\text { (kg/day) }\end{array}$ & $\begin{array}{l}\text { BW } \\
(\mathrm{kg})\end{array}$ \\
\hline Avian oinnivores (AV442) & $6.20 \mathrm{E}-01$ & $2.70 \mathrm{E}-01$ & $1.10 \mathrm{E}-01$ & $1.00 \mathrm{E}-00$ & $1.00 \mathrm{E}-00$ & $4.41 \mathrm{E}-02$ & $6.54 \mathrm{E}-01$ \\
\hline Mammalian herbivores (M 121 ) & $0.00 \mathrm{E}+00$ & $9.80 \mathrm{E}-01$ & $2.00 \mathrm{E}-02$ & $1.00 \mathrm{E}-00$ & $1.00 \mathrm{E}-00$ & $3.14 \mathrm{E}-01$ & $5.80 \mathrm{E}-00$ \\
\hline Mammalian herbivores (M122) & $0.00 \mathrm{E}+00$ & 9.37E-01 & $6.30 \mathrm{E}-02$ & $1.00 \mathrm{E}-00$ & $1.00 \mathrm{E}-00$ & $3.30 \mathrm{E}-03$ & $1.10 \mathrm{E}-02$ \\
\hline $\begin{array}{l}\text { Mammalian herbivores } \\
\text { (MI22A) }\end{array}$ & $0.00 \mathrm{E}+00$ & $9.23 \mathrm{E}-01$ & $7.70 \mathrm{E}-02$ & $1.00 \mathrm{E}-00$ & $1.00 \mathrm{E}-00$ & 4.27E-03 & $1.57 \mathrm{E}-02$ \\
\hline Pygıny rabbit & $0.00 \mathrm{E}+00$ & $9.80 \mathrm{E}-01$ & $2.00 \mathrm{E}-02$ & $1.00 \mathrm{E}-00$ & $1.00 \mathrm{E}-00$ & $4.53 \mathrm{E}-02$ & $4.04 \mathrm{E}-01$ \\
\hline Mammalian herbivores (M123) & $0.00 \mathrm{E}+00$ & $9.23 \mathrm{E}-01$ & $7.70 \mathrm{E}-02$ & $1.00 \mathrm{E}-00$ & $1.00 \mathrm{E}-00$ & $1.51 \mathrm{E}-02$ & $8.89 \mathrm{E}-02$ \\
\hline $\begin{array}{l}\text { Matnmalian insectivores } \\
\text { (M210) }\end{array}$ & $9.80 \mathrm{E}-01$ & $0.00 \mathrm{E}+00$ & $2.00 \mathrm{E}-02$ & $1.00 \mathrm{E}-00$ & $1.00 \mathrm{E}-00$ & $1.43 \mathrm{E}-03$ & $9.03 \mathrm{E}-03$ \\
\hline $\begin{array}{l}\text { Mammalian insectivores } \\
\text { (M210A) }\end{array}$ & $9.80 \mathrm{E}-01$ & $0.00 \mathrm{E}+00$ & $2.00 \mathrm{E}-02$ & $1.00 \mathrm{E}-00$ & $1.00 \mathrm{E}-00$ & $1.43 \mathrm{E}-03$ & $4.65 \mathrm{E}-03$ \\
\hline $\begin{array}{l}\text { Townsend's western big-eared } \\
\text { bat }\end{array}$ & $9.90 \mathrm{E}-0 \mathrm{I}$ & $0.00 \mathrm{E}+00$ & $1.00 \mathrm{E}-02$ & $1.00 \mathrm{E}-00$ & $1.00 \mathrm{E}-00$ & $2.37 \mathrm{E}-03$ & $1.10 \mathrm{E}-02$ \\
\hline Small-footed myotis & $9.90 \mathrm{E}-01$ & $0.00 E+00$ & $1.00 \mathrm{E}-02$ & $1.00 \mathrm{E}-00$ & $1.00 \mathrm{E}-00$ & $1.44 \mathrm{E}-03$ & $4.69 \mathrm{E}-03$ \\
\hline Long-cared myotis & $9.90 \mathrm{E}-01$ & $0.00 \mathrm{E}+00$ & $1.00 \mathrm{E}-02$ & $1.00 \mathrm{E}-00$ & $1.00 \mathrm{E}-00$ & $1.77 \mathrm{E}-0.3$ & $6.65 \mathrm{E}-03$ \\
\hline $\begin{array}{l}\text { Mammalian insectivores } \\
\text { (M222) }\end{array}$ & $9.76 \mathrm{E}-01$ & $0.00 \mathrm{E}+00$ & $2.40 \mathrm{E}-02$ & $1.00 \mathrm{E}-00$ & $1.00 \mathrm{E}-00$ & $1.66 \mathrm{E}-03$ & $6.00 \mathrm{E}-03$ \\
\hline Mammalian carnivores (M322) & $9.23 \mathrm{E}-01$ & $0.00 \mathrm{E}+00$ & $7.70 \mathrm{E}-02$ & $1.00 \mathrm{E}-00$ & $1.00 \mathrm{E}-00$ & 1.66E-02 & $1.78 \mathrm{E}-01$ \\
\hline Maımmalian omnivores (M422) & $8.06 \mathrm{E}-01$ & $1.00 \mathrm{E}-01$ & $9.40 \mathrm{E}-02$ & $1.00 \mathrm{E}-00$ & $1.00 \mathrm{E}-00$ & $3.06 \mathrm{E}-03$ & $1.70 \mathrm{E}-02$ \\
\hline $\begin{array}{l}\text { Mammalian omnivores } \\
\text { (M422A) }\end{array}$ & $8.06 \mathrm{E}-01$ & $1.00 \mathrm{E}-01$ & $9.40 \mathrm{E}-02$ & $1.00 \mathrm{E}-00$ & $1.00 \mathrm{E}-00$ & $2.60 \mathrm{E}-01$ & $5.05 \mathrm{E}-00$ \\
\hline Reptilian insectivores (R222) & $9.76 \mathrm{E}-01$ & $0.00 \mathrm{E}+00$ & $2.40 \mathrm{E}-02$ & $1.00 \mathrm{E}-00$ & $1.00 \mathrm{E}-00$ & $5.60 \mathrm{E}-05$ & $6.61 \mathrm{E}-03$ \\
\hline Sagebrush lizard & $9.76 \mathrm{E}-01$ & $0.00 \mathrm{E}+00$ & $2.40 \mathrm{E}-02$ & $1.00 \mathrm{E}-00$ & $1.00 \mathrm{E}-00$ & $5.60 \mathrm{E}-05$ & $6.61 \mathrm{E}-03$ \\
\hline Reptilian carnivores (R322) & $9.52 \mathrm{E}-01$ & $0.00 \mathrm{E}+00$ & $4.80 \mathrm{E}-02$ & $1.00 \mathrm{E}-00$ & $1.00 \mathrm{E}-00$ & $6.80 \mathrm{E}-03$ & $1.50 \mathrm{E}-02$ \\
\hline Plants & $0.00 \mathrm{E}+00$ & $0.00 \mathrm{E}+00$ & $1.00 \mathrm{E}-00$ & $1.00 \mathrm{E}-00$ & $1.00 \mathrm{E}-00$ & & \\
\hline
\end{tabular}


The concentration of contaminant in vegetation (CV) can be estimated using the equation (VanHorn et al. 1995):

$C V=C S \times P U F$

where

$$
\begin{aligned}
& C V=\text { concentration of contaminant in vegetation }(\mathrm{mg} / \mathrm{kg}) \\
& C S=\text { concentration of contaminant in soil }(\mathrm{mg} / \mathrm{kg}) \\
& P U F=\text { contaminant-specific plant uptake factor (unitless). }
\end{aligned}
$$

Contaminant-specific PUFs (from Baes et al. 1984 and other literature sources) and concentration factors (CFs) for calculating EBSLs for metals are presented in Table 26. Concentration factors for metals were developed as discussed in the OU 10-04 Workplan (DOE, 1999). The log of PUF and CFs for organics is estimated using 1.588-0.578 $\log \mathrm{K}_{\text {ow }}$, and $-7.735+1.033 \log \mathrm{K}_{\mathrm{ow}}$, respectively (Travis and Arms 1988). Log partitioning coefficients $\left(\mathrm{K}_{\text {ow }}\right)$ were taken from the Groundwater Chemicals Desk Reference (Montgomery and Welkom 1990).

8.3.1.2 EBSL Calculations. As discussed in detail in Appendix D of the OU 10-04 Workplan (DOE 1999), the EBSLs for contaminates of concern are useful for quickly screening sites for ecological receptors at the INEEL. The similarity in receptors across the facility makes it possible to develop these INEEL-wide screening levels. EBSLs are defined as concentrations of COPCs in soil (or other media) that are not expected to produce an adverse effect to selected ecological receptors under chronic exposure conditions. EBSLs are calculated by inverting the exposure equation presented previously. The exposure model estimates the potential intake. In the risk assessment process these intake values are compared to toxicity reference values (TRVs) to evaluate potential effects to receptors. These equations can be manipulated to allows the calculation of a contaminant concentration in a medium that would not be potentially harmful to the receptors with chronic exposure.

To calculate EBSLs for screening against nonradiological soil contamination concentrations, the target hazard quotient (TQ) will be determine. This is defined as a quantitative method for evaluating potential adverse impacts to exposed populations, and is calculated using the equation.

$$
T H Q=\frac{E E_{\text {soil }}}{T R V}
$$

where

$$
\begin{aligned}
& T H Q=\quad \begin{array}{l}
\text { target hazard quotient (unitless), established at } 1.0 \text { for nonradionuclide contaminate } \\
\text { exposure }
\end{array} \\
& E E_{\text {soil }}=\quad \text { estimated exposure from soil }(\mathrm{mg} / \mathrm{kg} \text { body weight-day) } \\
& T R V=\quad \text { contaminant-specific toxicity reference value }(\mathrm{mg} / \mathrm{kg} \text {-day). }
\end{aligned}
$$

Thus, solving for the concentration of the nonradionuclide contaminant in the soil (CS) and assuming that when THQ equals 1 that $\mathrm{EE}_{\text {soil }}=\mathrm{TRV}$. The EBSL for contaminant in the soil is calculated using the equation: 
Table 26. PUFs and CFs for NWCF contaminants (unitless) used in EBSL calculations.

\begin{tabular}{|c|c|c|c|}
\hline & $\mathrm{PUF}^{\mathrm{a}}$ & PUFs for EBSLs ${ }^{b}$ & CF for EBSLs ${ }^{c}$ \\
\hline \multicolumn{4}{|l|}{ Metals $^{d}$} \\
\hline Antimony & $2.0 \mathrm{E}-02$ & $1.0 \mathrm{E}+00$ & $1.0 \mathrm{E}+00$ \\
\hline Arsenic & $4.0 \mathrm{E}-02$ & $1.0 \mathrm{E}+00$ & $1.0 \mathrm{E}+00$ \\
\hline Barium & $1.5 \mathrm{E}-02$ & $1.0 \mathrm{E}+00$ & $1.0 \mathrm{E}+00$ \\
\hline Beryllium & $1.0 \mathrm{E}-02$ & $1.0 \mathrm{E}+00$ & $1.0 \mathrm{E}+00$ \\
\hline Cadmium & $5.5 \mathrm{E}-01$ & $1.0 \mathrm{E}+00$ & $1.0 \mathrm{E}+00$ \\
\hline Chromium III & 1.9E-01 & $1.0 \mathrm{E}+00$ & $1.0 \mathrm{E}+00$ \\
\hline Chromium VI & $7.5 \mathrm{E}-03$ & $1.0 \mathrm{E}+00$ & $1.0 \mathrm{E}+00$ \\
\hline Lead & $2.0 \mathrm{E}-02$ & $1.0 \mathrm{E}+00$ & $1.0 \mathrm{E}+00$ \\
\hline Mercury & $9.0 \mathrm{E}-01$ & $1.0 \mathrm{E}+00$ & $1.0 \mathrm{E}+00$ \\
\hline Nickel & $6.0 \mathrm{E}-02$ & $1.0 \mathrm{E}+00$ & $1.0 \mathrm{E}+00$ \\
\hline Selenium & $2.5 \mathrm{E}-02$ & $1.0 \mathrm{E}+00$ & $1.0 \mathrm{E}+00$ \\
\hline Silver & $4.0 \mathrm{E}-01$ & $1.0 \mathrm{E}+00$ & $1.0 \mathrm{E}+00$ \\
\hline Thallium & 4.0E-03 & $1.0 \mathrm{E}+00$ & $1.0 \mathrm{E}+00$ \\
\hline \multicolumn{4}{|l|}{ Organics (feed) ${ }^{e}$} \\
\hline 1,1,1-Trichloroethane & $1.4 \mathrm{E}+00$ & $1.4 \mathrm{E}+00$ & $1.0 \mathrm{E}+00$ \\
\hline 1,1,2-Trichloroethane & NA & $\mathrm{NA}$ & NA \\
\hline 1,2,4-trichlorobenzene & $1.3 \mathrm{E}-01$ & $1.0 \mathrm{E}+00$ & $1.0 \mathrm{E}+00$ \\
\hline 1,2-Dichloroethane & $5.4 \mathrm{E}+00$ & $5.4 \mathrm{E}+00$ & $1.0 \mathrm{E}+00$ \\
\hline 1,4 dioxane & $3.8 \mathrm{E}+01$ & $3.8 \mathrm{E}+01$ & $1.0 \mathrm{E}+00$ \\
\hline 2,4-Dinitrophenol & $\mathrm{NA}$ & NA & $\mathrm{NA}$ \\
\hline Acetonitrile & $6.1 \mathrm{E}+01$ & $6.1 \mathrm{E}+01$ & $1.0 \mathrm{E}+00$ \\
\hline Aniline & NA & $\mathrm{NA}$ & NA \\
\hline Benzene & $2.3 E+00$ & $2.3 \mathrm{E}+00$ & $1.0 \mathrm{E}+00$ \\
\hline Benzo(a)pyrene & $1.2 \mathrm{E}-02$ & $1.0 \mathrm{E}+00$ & $1.0 \mathrm{E}+00$ \\
\hline Bromoform & NA & NA & $\mathrm{NA}$ \\
\hline Butylbenzylphthalate & $6.5 \mathrm{E}-02$ & $1.0 E+00$ & $1.0 \mathrm{E}+00$ \\
\hline Carbon disulfide & $2.7 E+00$ & $2.7 \mathrm{E}+00$ & $1.0 \mathrm{E}+00$ \\
\hline Carbon tetrachloride & $1.2 \mathrm{E}+00$ & $1.2 \mathrm{E}+00$ & $1.0 \mathrm{E}+00$ \\
\hline Chlorobenzene & NA & NA & $\mathrm{NA}$ \\
\hline Chloroform & $2.8 \mathrm{E}+00$ & $2.8 \mathrm{E}+00$ & $1.0 \mathrm{E}+00$ \\
\hline Diethylphthalate & $1.4 E+00$ & $1.4 \mathrm{E}+00$ & $1.0 \mathrm{E}+00$ \\
\hline
\end{tabular}


Table 26. (continued).

\begin{tabular}{|c|c|c|c|}
\hline & $\mathrm{PUF}^{a}$ & PUFs for EBSLs ${ }^{b}$ & CF for EBSLs ${ }^{c}$ \\
\hline Di-n-butylphthalate & 2.3E-02 & $1.0 \mathrm{E}+00$ & $1.0 \mathrm{E}+00$ \\
\hline Di-n-octylphthalate & $1.9 \mathrm{E}-04$ & $1.0 \mathrm{E}+00$ & $1.0 \mathrm{E}+00$ \\
\hline Formaldehyde & $3.9 \mathrm{E}+01$ & $3.9 \mathrm{E}+01$ & $1.0 \mathrm{E}+00$ \\
\hline Formic acid & $\mathrm{NA}$ & $N A$ & NA \\
\hline Methyl ethyl ketone & $2.7 \mathrm{E}+01$ & $2.7 \mathrm{E}+01$ & $1.0 E+00$ \\
\hline Methylene chloride & $6.9 \mathrm{E}+00$ & $6.9 \mathrm{E}+00$ & $1.0 \mathrm{E}+00$ \\
\hline Naphthalene & $4.0 \mathrm{E}-01$ & $1.0 \mathrm{E}+00$ & $1.0 \mathrm{E}+00$ \\
\hline Pentachlorophenol & $1.0 \mathrm{E}+00$ & $1.0 \mathrm{E}+00$ & $1.0 \mathrm{E}+00$ \\
\hline Phenol & $5.6 E+00$ & $5.6 \mathrm{E}+00$ & $1.0 \mathrm{E}+00$ \\
\hline Pyridine & NA & $N A$ & NA \\
\hline Tetrachloroethylene & $1.2 \mathrm{E}+00$ & $1.2 E+00$ & $1.0 \mathrm{E}+00$ \\
\hline Toluene & $1.0 \mathrm{E}+00$ & $1.0 \mathrm{E}+00$ & $1.0 E+00$ \\
\hline Trichloroethylene & $1.6 \mathrm{E}+00$ & $1.6 E+00$ & $1.0 \mathrm{E}+00$ \\
\hline \multicolumn{4}{|l|}{ Organics (PICs) } \\
\hline 2,3,7,8-TCDD TEQ & $5.1 \mathrm{E}-03$ & $1.0 \mathrm{E}+00$ & $1.0 \mathrm{E}+00$ \\
\hline 1,3-Dinitrobenzene & $4.5 \mathrm{E}+00$ & $4.5 \mathrm{E}+00$ & $1.0 \mathrm{E}+00$ \\
\hline Nitrobenzene & $3.3 E+00$ & $3.3 E+00$ & $1.0 \mathrm{E}+00$ \\
\hline 2,4-Dinitrotoluene & $2.7 E+00$ & $2.7 E+00$ & $1.0 \mathrm{E}+00$ \\
\hline 2,6-Dinitrotoluene & $2.7 \mathrm{E}+00$ & $2.7 \mathrm{E}+00$ & $1.0 \mathrm{E}+00$ \\
\hline Pentachloronitrobenzene & 2.7E-02 & $1.0 \mathrm{E}+00$ & $1.0 \mathrm{E}+00$ \\
\hline \multicolumn{4}{|c|}{$\begin{array}{l}\text { a. PUF = plant uptake factor. } \\
\text { b. Plant uptake factor used in EBSL calculations. }\end{array}$} \\
\hline \multicolumn{4}{|c|}{$\begin{array}{l}\text { c. Bioconcentration factor used in EBSL calculations. } \\
\text { d. Values for metals come from Baes et al. (1984) or literature values as discussed in the OU 10-04 Workplan (DOE 1999). } \\
\text { e. Values for organics come from allometric equations presented in Travis and Arms (1988). }\end{array}$} \\
\hline
\end{tabular}




$$
E B S L_{\text {soil }}=\frac{T R V \times B W}{[(P P \times C F)+(P V \times P U F)+(P S)] \times I R \times E D \times S U F}
$$

where

$$
\begin{array}{ll}
E B S L_{\text {soil }}= & \text { INEEL-specific ecological based screening level for non-radionuclide } \\
\text { contaminants in soil }(\mathrm{mg} / \mathrm{kg}) .
\end{array}
$$

Exposure parameters including dietary composition (percent soil [PS], percent prey [PP], and percent vegetation [PV]), home range, temporal and spatial habitat use data (site use factor [SUF] and exposure duration [ED]), soil ingestion rate, food ingestion rate (IR), body weight (BW), and uptake factors (bioaccumulation factors [CF or BAFs] and plant uptake factors [PUFs]) are input to calculate the EBSL. The input values for calculating EBSLs for each functional group/contaminant combination, assume that members of the functional groups are exposed to stressors to the maximum extent, perhaps beyond what is actually expected. For example, it is assumed that a raptor captures $100 \%$ of its prey from a contaminated site, and that all the prey are exposed to maximum contaminant concentrations at the site. This is similar to the human risk assessment concept of the "maximally exposed individual," a hypothetical individual who is assumed to live and grow his own food at a location of maximum exposure to a stressor. Each parameter is discussed in Appendix D in more detail of the OU 10-04 Workplan (DOE 1999). The defaults used in the calculation of EBSLs are presented in Table 27.

\subsubsection{Uncertainty Associated with Functional Groups. The selection of receptor} parameters used is designed to ensure that each of the members of the functional groups is conservatively represented. Since all members of a functional group are considered similar, it is reasonable to assume that all members of a group will be equally exposed to site-related contaminants. Quantification of dose for each functional group is expected to provide sufficient data to assess the general condition of the ecosystem and to be adequately protective of the majority of species potentially inhabiting the assessment area. In addition, sensitive species are included on the list of receptors for which dose is calculated. Hence, uncertainty associated with the selection of receptor parameters is expected to minimally influence dose estimates.

\subsubsection{Uncertainty Associated with the Ingestion Rate. Estimation for terrestrial receptors} intake (ingestion) estimates used for the terrestrial receptors are based upon data in the scientific literature, when available. Food ingestion rates are calculated by use of allometric equations reported in Nagy (1987). Uncertainties associated with the use of allometric equations could result in either an overor underestimation of the true dose rate, since actual ingestion rates are known for few species.

\subsubsection{Uncertainty Associated with the Receptor Site Usage. The calculation of dose} incorporated the probability that the receptors may use or inhabit each site. The SUF is defined as the affected area (ha) divided by the home range (ha) of the receptor. If a given receptor's home range is larger than the affected area, then it is reasonable to assume that the receptor may not spend $100 \%$ of its life within the site area. Incorporation of the SUF adjusts the dose to account for the estimated time the receptor spends on the site. The less time spent on the site, the lower the dose. However, most home ranges are estimated from available literature values and allometric equations. Home range and usage of areas also vary from season to season as well as year to year (depending on the species of interest), and are difficult to measure. This uncertainty could result in either an over-or underestimation of the true dose rates. For EBSL calculations this SUF is defaulted to 1 or $100 \%$. 
Table 27. Parameter defaults and assumptions for EBSL calculations.

\begin{tabular}{|c|c|}
\hline Parameter & EBSL Soil/Sediment Calculations \\
\hline PV & $\begin{array}{l}\text { Herbivores }-100 \text { minus PS } \\
\text { Insectivores-0 } \\
\text { Carnivores-0 } \\
\text { Omnivores-PV from literature minus PS/2. }\end{array}$ \\
\hline $\mathrm{PP}$ & $\begin{array}{l}\text { Herbivores-0 } \\
\text { Insectivores-100 minus PS } \\
\text { Carnivores-100 minus PS } \\
\text { Omnivores-PP from literature minus PS/2. }\end{array}$ \\
\hline PS & $\begin{array}{l}\text { The highest value (i.e., greatest exposure) was selected from species within a functional } \\
\text { group. Individual species evaluated using values as presented. }\end{array}$ \\
\hline BAFs & $\begin{array}{l}\text { A BAFs for all metals was taken from Baes et al. (1984) and other available literature. } \\
\text { The log of the BAF for organics will be estimated using the Travis and Arms (1988) } \\
\text { equation }-7.735+1.033 \log \mathrm{K}_{\text {ow }} \text {. Log partitioning coefficients }\left(\mathrm{K}_{\text {ow }} \mathrm{s}\right) \text { are available from } \\
\text { Montgomery and Welkom }(1990) \text {. BAFs for EBSL calculation are assumed to be } 1.0 \text { if } \\
\text { not greater. }\end{array}$ \\
\hline PUFs & $\begin{array}{l}\text { PUFs for all metals examined from Baes et al. (1984) and other available literature. The } \\
\text { log of PUF for organics will be estimated using the Travis and Arms (1988) equation of } \\
1.588-0.578 \log \mathrm{K}_{\text {ow. }} \text { Log partitioning coefficients }\left(\mathrm{K}_{\mathrm{ow}} \mathrm{s}\right) \text { are available from } \\
\text { Montgomery and Welkom (1990). Assumed to be } 1.0 \text { if not larger by calculation using } \\
\text { allometric equations. PUFs for EBSL calculation are assumed to be } 1.0 \text { if not greater. }\end{array}$ \\
\hline ED & Defaulted to 1 . \\
\hline SUF & Defaulted to 1. \\
\hline BW & The smallest BW/IR ratio was selected from species within each functional group. \\
\hline $\operatorname{IR}$ & $\begin{array}{l}\text { Calculated using allometric equations from Nagy (1987). The largest IR/BW ratio was } \\
\text { used from the species within each functional group. }\end{array}$ \\
\hline
\end{tabular}

8.3.1.6 Uncertainty Associated with the PUFs and CFs. Using PUFs to estimate plant concentrations has the advantages that it is easy to use and requires minimum data inputs (i.e., the measured or estimated concentration of metal in soil and a PUF taken from the literature). A PUF of 0.01 indicates that the plant concentration should be $1 / 100$ th of the total concentration in soil. PUFs for metals are taken from Baes et al. (1984) and other studies. Although preference is given to studies that reported the steady-state concentration of metals in plants at edible maturity, various soil properties are not considered and data for numerous plant species (both animal feeds and those consumed by humans) are combined. However, since root uptake of metals is a complex process that depends on various soil properties (e.g., pH, CEC, and organic matter content) as well as the metal and type of plant involved, the use of generic or crop-specific PUFs taken from the literature may not accurately estimate the concentration of metals in plants for all environmental conditions and species that may occur. The PUF for organics is estimated using the geometric mean regression equation developed by Travis and Arms (1988) and using $\log \mathrm{K}_{\text {ow }}$ values. The reliability of estimated PUFs is directly related to the reliability of the $\mathrm{K}_{\text {ow }}$ values used for the organics. Since $\mathrm{K}_{\text {ow }}$ values can vary greatly, use of the Travis and Arms (1988) equation to estimate a PUF for organics may over- or underestimate the true dose for organics. There is a great deal of uncertainty associated with the bioaccumulation factors (BAFs) or concentration factors (CFs) used to calculate dose. Very few CFs are available in the scientific literature, since they must be both contaminant- and receptor-specific. In the absence of specific CFs, a value of 1 was 
assumed. This assumption could over- or underestimate the true dose from the contaminant, and the magnitude of error cannot be quantified. Travis and Arms (1988) and Baes et al. (1984) report CFs for contaminants to beef and milk; all of these are less than 1 for the contaminants in the assessment area. If the terrestrial receptors of concern accumulate metals and PCBs in a similar way and to a comparable degree as beef and dairy cattle, the use of a CF of 1 for all contaminants and receptors would overestimate the dose. On the other hand, if the terrestrial receptors of concern accumulate metals and PCBs to a much larger degree than beef and dairy cattle, the assumption of CFs equal to 1 could underestimate the true dose.

8.3.1.7 Uncertainty Associated with Soil Ingestion. The exposure assessment incorporates percentage of soil ingested by each representative of the functional groups. Although food ingestion rates have the greatest effect on intake estimates, soil ingestion rates could also influence intake rates and, therefore, dose estimates. The EPA Wildlife Exposure Factors Handbook (EPA 1993b) and Beyer et al. (1994) was used to assign soil ingestion parameters to four of the 12 functional groups, and Arthur and Gates (1988) was used to assign percent soil ingested by two common species. Estimating the percent soil ingested may over- or underestimate the dose since the effect of the estimated values on the overall dose outcome is dependent on the concentration of contaminant in the media of concern.

\subsubsection{Ecological Effects Assessment}

Ecological effects assessment consists of three elements:

- $\quad$ Selecting quantified critical exposure (QCE) levels

- $\quad$ Developing adjustment factors (AFs)

- $\quad$ Developing TRVs.

Appendix $\mathrm{G}$ contains a general description of the procedures of ecological effects assessment and discussions of the each of the three elements as they apply to the development of TRVs for individual COPCs evaluated in this assessment.

Information on the toxicological effects on mammalian receptors of the following contaminants was not located. Therefore, these contaminations could not be evaluated for potential risk.
1,1,2-Trichloroethane
2,4-Dinitrophenol
Bromoform
Chlorobenzene
Formic Acid
Pyridine

Pentachloronitrobenzene

Information on the toxicological effects on avian receptors of the following contaminants was not located. Therefore these contaminations could not be evaluated for potential risk. 


$\begin{array}{lll}\text { Antimony } & \text { Barium } & \text { Beryllium } \\ \text { Chromium VI } & \text { 1,1,1-Trichloroethane } & \text { 1,1,2-Trichloroethane } \\ \text { 1,2,4-trichlorobenzene } & 1,4 \text { dioxane } & \text { 2,4-Dinitrophenol } \\ \text { Acetonitrile } & \text { Aniline } & \text { Benzene } \\ \text { Benzo(a)pyrene } & \text { Bromoform } & \text { Butylbenzylphthalate } \\ \text { Carbon disulfide } & \text { Carbon tetrachloride } & \text { Chlorobenzene } \\ \text { Chloroform } & \text { Diethylphthalate } & \text { Di-n-butylphthalate } \\ \text { Di-n-octylphthalate } & \text { Formaldehyde } & \text { Formic acid } \\ \text { Hydrazine } & \text { Methyl ethyl ketone } & \text { Methylene chloride } \\ \text { Naphthalene } & \text { Pentachlorophenol } & \text { Phenol } \\ \text { Pyridine } & \text { Tetrachloroethylene } & \text { Toluene } \\ \text { Trichloroethylene } & \text { 1,3-Dinitrobenzene } & \text { Nitrobenzene } \\ \text { 2,4-Dinitrotoluene } & \text { 2,6-Dinitrotoluene } & \end{array}$

\subsection{Risk Evaluation}

Risk evaluation is the final step of the process. The risk evaluation determines whether there is any indication of risk due to the contaminant concentrations to INEEL functional groups, and subsequently $\mathrm{T} / \mathrm{E}$, and sensitive species and discusses the uncertainty inherent in the assessment.

\subsubsection{EBSL'Screening}

Table 28 compares modeled concentrations to the EBSLs for the COPCs identified at the NWCF. Concentrations were developed as discussed in Section 8.2.1. An additional screen of EBSL/4 is provided to be consistent with the ATG approach of evaluating .25 of the HQ for their screening level risk assessment (ATG, 1998). Plant, earthworm, and soil microbes benchmark values taken from Oak Ridge (Efroymson et al, 1997a, 1977b) were screened against modeled contaminant concentrations. Based on this screening, only 1,3 dinitrobenzene exceeds an EBSL. As shown in Table 28, the highlighted concentration for 1,3 dinitrobenzene indicates that this contaminant may pose a potential risk to ecological receptors from maximum modeled concentrations. However, the average on-site concentration is below the EBSL or any benchmark values.

\subsubsection{Comparison of INEEL Approach and Methods to ATG}

A comparison of the SLERA approach used in the Risk Assessment Work Plan for the Mixed Waste Facility RCRAVTSCA permit application (ATG, 1998) to the INEEL methods and parameters was performed. The exposure calculations are similar with the exception to the use of the functional groups at the INEEL. The use of functional groups may provide an additional level of conservatism compared to the evaluation of individual species. 
Table 28. Screening of modeled concentrations to EBSLs for mammalian and avian receptors and other benchmarks (exceedence of benchmark is highlighted). All values are in $\mathrm{mg} / \mathrm{kg}$.

\begin{tabular}{|c|c|c|c|c|c|c|c|c|c|c|}
\hline & Max Off-site & Max On-sitc & Average & $\begin{array}{c}\text { Mammalian } \\
\text { EBSL }\end{array}$ & $\begin{array}{c}\text { Mammalian } \\
\text { EBSL/4 }\end{array}$ & Avian EBSL & Avian EBSU/4 & $\begin{array}{c}\text { Plant " } \\
\text { Benchmarks }\end{array}$ & $\begin{array}{c}\text { Earthworm } \\
\text { Screening } \\
\text { Values } \\
\end{array}$ & $\begin{array}{c}\text { Soil Microbes } \\
\text { Screening } \\
\text { Values } \\
\end{array}$ \\
\hline \multicolumn{11}{|l|}{ Metals } \\
\hline Antimony (Sb) & $3.41 \mathrm{E}-11$ & $5.45 \mathrm{E}-10$ & $5.45 \mathrm{E}-11$ & $1.35 \mathrm{E}+00$ & $3.38 \mathrm{E}-01$ & NA & NA & $5.00 \mathrm{E}+00$ & NA & NA \\
\hline Arsenic (As) & $1.86 \mathrm{E}-14$ & $2.98 \mathrm{E}-13$ & $2.98 \mathrm{E}-14$ & $8.44 \mathrm{E}-01$ & $2.11 \mathrm{E}-01$ & $1.28 \mathrm{E}+00$ & $3.20 \mathrm{E}-01$ & $1.00 \mathrm{E}+01$ & $6.00 \mathrm{E}+01$ & $1.00 \mathrm{E}+02$ \\
\hline Barium (Ba) & $1.83 \mathrm{E}-13$ & $2.93 \mathrm{E}-12$ & $2.93 \mathrm{E}-13$ & $1.10 \mathrm{E}+01$ & $2.75 \mathrm{E}+00$ & NA & NA & $5.00 \mathrm{E}+02$ & $\mathrm{~N}$ & $3.00 \mathrm{E}+03$ \\
\hline Beryllium (Be) & $5.60 \mathrm{E}-10$ & 8.96E-09 & $8.96 \mathrm{E}-10$ & $7.14 \mathrm{E}-01$ & $1.79 \mathrm{E}-01$ & NA & NA & $1.00 \mathrm{E}+01$ & $\mathrm{~N}$ & $\mathbf{n}$ \\
\hline Cadmium (Cd) & $2.13 \mathrm{E}-12$ & $3.41 \mathrm{E}-11$ & $3.41 \mathrm{E}-12$ & 3.8.3E-02 & $9.58 \mathrm{E}-03$ & $2.36 \mathrm{E}-03$ & $5.90 \mathrm{E}-04$ & $4.00 \mathrm{E}+00$ & $2.00 \mathrm{E}+01$ & $2.00 \mathrm{E}+01$ \\
\hline Chromium (Cr) as $\mathrm{Cr}$ III & $8.59 \mathrm{E}-14$ & $1.37 \mathrm{E}-12$ & $1.37 \mathrm{E}-13$ & $8.11 \mathrm{E}+02$ & $2.03 \mathrm{E}+02$ & $2.82 \mathrm{E}+00$ & $7.05 \mathrm{E}-01$ & $1.00 \mathrm{E}+00$ & $4.00 \mathrm{E}-01$ & $1.00 \mathrm{E}+01$ \\
\hline Chromium (Cr) as $\mathrm{Cr}$ VI & $8.59 \mathrm{E}-14$ & $1.37 \mathrm{E}-12$ & $1.37 \mathrm{E}-13$ & $1.62 \mathrm{E}-01$ & $4.05 \mathrm{E}-02$ & NA & NA & NA & NA & NA \\
\hline Lead $(\mathrm{Pb})$ & $1.02 \mathrm{E}-08$ & $1.64 \mathrm{E}-07$ & $1.64 \mathrm{E}-08$ & $8.76 \mathrm{E}+00$ & $2.19 \mathrm{E}+00$ & $9.94 \mathrm{E}-01$ & $2.49 \mathrm{E}-01$ & $5.00 \mathrm{E}+0 \mathrm{I}$ & $5.00 \mathrm{E}+02$ & $9.00 \mathrm{E}+02$ \\
\hline Mercury $\left(\mathrm{Hg}^{+2}\right)$ as inorganic ${ }^{\mathrm{c}}$ & $5.78 \mathrm{E}-0.5$ & $2.83 \mathrm{E}-03$ & $1.96 \mathrm{E}-04$ & $3.57 \mathrm{E}-01$ & $8.93 \mathrm{E}-02$ & $4.18 \mathrm{E}+00$ & $1.05 E+00$ & $3.00 \mathrm{E}-01$ & $1.00 \mathrm{E}-01$ & $3.00 \mathrm{E}+01$ \\
\hline Mercury $(\mathrm{Hg})$ as organic" & $1.16 \mathrm{E}-06$ & $5.66 \mathrm{E}-0.5$ & $3.92 \mathrm{E}-06$ & $6.21 \mathrm{E}-03$ & $1.55 \mathrm{E}-03$ & $6.49 \mathrm{E}-02$ & $1.62 \mathrm{E}-02$ & NA & $1.00 \mathrm{E}-01$ & $3.00 \mathrm{E}+01$ \\
\hline Nickel (Ni) & $3.72 \mathrm{E}-13$ & $5.95 \mathrm{E}-10$ & $5.95 \mathrm{E}-11$ & $6.17 \mathrm{E}+01$ & $1.54 \mathrm{E}+0 \mathrm{I}$ & $6.83 \mathrm{E}+01$ & $1.71 \mathrm{E}+01$ & $3.00 \mathrm{E}+01$ & $2.00 \mathrm{E}+02$ & $9.00 \mathrm{E}+01$ \\
\hline Selenium (Sc) & $1.79 \mathrm{E}-09$ & $2.87 \mathrm{E} \cdot 08$ & $2.87 \mathrm{E}-09$ & $4.22 \mathrm{E}-01$ & $1.06 \mathrm{E}-01$ & $1.72 \mathrm{E}-01$ & 4.30E-02 & $1.00 \mathrm{E}+00$ & $7.00 \mathrm{E}+01$ & $1.00 \mathrm{E}+02$ \\
\hline Silver (Ag) & $1.62 \mathrm{E}-16$ & $2.59 \mathrm{E}-1.5$ & $2.59 \mathrm{E}-16$ & $3.67 \mathrm{E}+01$ & $9.18 \mathrm{E}+00$ & $3.02 \mathrm{E}+01$ & $7.55 \mathrm{E}+00$ & $2.00 \mathrm{E}+00$ & NA & $5.00 \mathrm{E}+01$ \\
\hline Thallium (TI) & $9.87 \mathrm{E}-09$ & $1.58 \mathrm{E}-07$ & $1.58 \mathrm{E}-08$ & $1.30 \mathrm{E}-01$ & $3.25 \mathrm{E}-02$ & $1.01 \mathrm{E}-01$ & $2.53 \mathrm{E}-02$ & $1.00 \mathrm{E}+00$ & $\mathrm{NA}$ & NA \\
\hline Aluminum $(\mathrm{Al})^{\mathrm{C}}$ & $1.12 \mathrm{E}-05$ & $1.79 \mathrm{E}-04$ & $1.79 \mathrm{E}-05$ & $8.50 \mathrm{E}+00$ & $2.13 \mathrm{E}+00$ & NA & NA & NA & NA & NA \\
\hline Managanese $(M n)^{c}$ & $5.62 \mathrm{E}-06$ & $8.99 \mathrm{E}-05$ & $8.99 \mathrm{E}-06$ & $1.05 E+01$ & $2.63 E+00$ & NA & NA & NA & NA & NA \\
\hline $\operatorname{Zinc}(\mathrm{Zn})^{\mathbf{c}}$ & $3.31 \mathrm{E}-06$ & $5.30 \mathrm{E}-05$ & $5.30 \mathrm{E}-06$ & NA & NA & $3.29 c+00$ & $8.23 \mathrm{c}-01$ & NA & NA & NA \\
\hline \multicolumn{11}{|l|}{ Organics (feed) } \\
\hline 1,1,1-Trichlorocthane & $2.18 \mathrm{E}-15$ & $1.07 \mathrm{E}-13$ & $7.43 \mathrm{E}-1.5$ & $8.13 E+01$ & $2.03 \mathrm{E}+0 \mathrm{I}$ & NA & NA & NA & NA & NA \\
\hline 1,1,2-Trichlorocthane & $7.54 \mathrm{E} \cdot 12$ & $3.70 \mathrm{E}-10$ & $2.56 \mathrm{E}-1 !$ & NA & NA & NA & $\mathrm{NA}$ & NA & NA & NA \\
\hline 1,2,4-trichlorobenzene & $1.68 \mathrm{E}-10$ & 8.25E-09 & $5.72 \mathrm{E}-10$ & $1.82 \mathrm{E}+00$ & $4.55 \mathrm{E}-01$ & NA & NA & NA & $2.00 \mathrm{E}+01$ & NA \\
\hline 1,2-Dichloroethane & $1.14 \mathrm{E}-12$ & $5.57 \mathrm{E}-11$ & $3.86 \mathrm{E}-12$ & $1.11 \mathrm{E}+01$ & $2.77 \mathrm{E}+00$ & $1.39 \mathrm{E}+00$ & $3.47 \mathrm{E}-01$ & NA & NA & NA \\
\hline 1,4 dioxane & $8.36 \mathrm{E}-09$ & $4.10 \mathrm{E}-07$ & $2.84 \mathrm{E}-08$ & $1.58 \mathrm{E}-02$ & 3.95E-03 & NA & $\mathrm{NA}$ & $\mathrm{NA}$ & NA & NA \\
\hline 2,4-Dinitrophenol & $4.48 \mathrm{E}-09$ & $2.19 \mathrm{E}-07$ & $1.52 \mathrm{E}-08$ & NA & $\mathrm{NA}^{\circ}$ & NA & $\mathrm{NA}$ & NA & NA & NA \\
\hline
\end{tabular}


Table 28. (continued).

\begin{tabular}{|c|c|c|c|c|c|c|c|c|c|c|}
\hline & Max Off-sitc & Max On-site & Avernge & $\begin{array}{c}\text { Mammalian } \\
\text { EBSL }\end{array}$ & $\begin{array}{c}\text { Mammalian } \\
\text { EBSL } 44\end{array}$ & Avian EBSL & Avian EBSL44 & $\begin{array}{c}\text { Plant } \\
\text { Benchmarks } \\
\end{array}$ & $\begin{array}{c}\text { Earthworm" } \\
\text { Screening } \\
\text { Values } \\
\end{array}$ & $\begin{array}{c}\text { Soil Microbes } \\
\text { Screening } \\
\text { Values } \\
\end{array}$ \\
\hline Acetonitrile & $5.34 \mathrm{E}-18$ & $2.61 \mathrm{E}-16$ & $1.81 \mathrm{E}-17$ & $3.08 \mathrm{E}-01$ & $7.70 \mathrm{E}-02$ & NA & NA & NA & NA & NA \\
\hline Aniline & $8.14 \mathrm{E}-09$ & $3.99 \mathrm{E}-07$ & $2.77 \mathrm{E}-08$ & NA & NA & NA & NA & NA & NA & NA \\
\hline Benzene & $6.00 \mathrm{E}-13$ & $2.94 \mathrm{E}-11$ & $2.04 \mathrm{E}-12$ & $5.50 \mathrm{E}+00$ & $1.38 \mathrm{E}+00$ & NA & NA & NA & NA & NA \\
\hline Benzo(a)pyrene & $3.44 \mathrm{E}-0.5$ & $1.69 \mathrm{E}-03$ & $1.17 \mathrm{E}-04$ & $2.69 \mathrm{E}+00$ & $6.73 \mathrm{E}-01$ & NA & NA & NA & NA & $\mathrm{N} \wedge$ \\
\hline $\begin{array}{l}\text { Bromoform } \\
\text { (tribromomethane) }\end{array}$ & $4.48 \mathrm{E}-11$ & $2.20 \mathrm{E}-09$ & $1.52 \mathrm{E}-10$ & $N A$ & NA & NA & NA & NA & NA & NA \\
\hline Butylbenzylphthalate & $1.63 \mathrm{E}-09$ & $8.01 \mathrm{E}-08$ & $5.56 \mathrm{E}-09$ & $1.43 \mathrm{E}+01$ & $3.58 \mathrm{E}+00$ & NA & NA & NA & NA & NA \\
\hline Carbon disulfide & $1.85 \mathrm{E}-11$ & $9.05 \mathrm{E}-10$ & $6.28 \mathrm{E}-11$ & $5.91 \mathrm{E}-01$ & $1.48 \mathrm{E}-01$ & NA & NA & NA & NA & NA \\
\hline Carbon tetrachloride & $6.24 \mathrm{E}-1.3$ & $3.06 \mathrm{E}-11$ & $2.12 \mathrm{E}-12$ & $9.71 \mathrm{E}+01$ & $2.43 \mathrm{E}+00$ & NA & NA & NA & NA & NA \\
\hline Chlorobenzene & $4.09 \mathrm{E}-12$ & $2.00 \mathrm{E}-10$ & $1.39 \mathrm{E}-11$ & $\mathrm{NA}$ & $\mathrm{NA}$ & NA & NA & NA & $4.00 \mathrm{E}+01$ & NA \\
\hline Chloroform & $1.21 \mathrm{E}-12$ & $5.92 \mathrm{E}-1 \mathrm{I}$ & $4.10 \mathrm{E}-12$ & $1.54 \mathrm{E}+01$ & $3.85 E+00$ & NA & NA & NA & NA & NA \\
\hline Diethylphthalate & $3.45 \mathrm{E}-09$ & $1.69 \mathrm{E}-07$ & $1.17 \mathrm{E}-08$ & $1.53 \mathrm{E}+02$ & $3.83 \mathrm{E}+01$ & NA & $N A$ & NA & NA & NA \\
\hline Di-n-butylphthalate & $1.43 \mathrm{E}-09$ & $6.99 \mathrm{E}-08$ & 4.85E-09 & $1.50 \mathrm{E}+01$ & $3.75 \mathrm{E}+00$ & NA & NA & $2.00 \mathrm{E}+02$ & NA & NA \\
\hline Di-n-octylphthalate & $8.39 \mathrm{E}-07$ & $4.11 \mathrm{E}-05$ & $2.85 \mathrm{E}-06$ & $4.71 E+01$ & $1.18 \mathrm{E}+01$ & NA & NA & NA & NA & NA \\
\hline Formaldchyde & $1.64 \mathrm{E}-13$ & $8.05 E-12$ & $5.59 \mathrm{E}-13$ & $4.59 \mathrm{E}-01$ & $1.15 \mathrm{E}-01$ & NA & NA & NA & NA & NA \\
\hline Formic acid & $3.58 \mathrm{E}-09$ & $1.76 \mathrm{E}-07$ & $1.22 \mathrm{E}-08$ & NA & NA & NA & NA & NA & NA & NA \\
\hline Hydrazine & none & none & none & $1.43 \mathrm{E}-03$ & $3.58 \mathrm{E}-04$ & NA & NA & NA & NA & NA \\
\hline $\begin{array}{l}\text { Methyl ethyl ketone } \\
\text { (2-butanone) }\end{array}$ & $1.06 \mathrm{E}-10$ & $5.20 \mathrm{E}-09$ & $3.61 \mathrm{E}-10$ & $3.83 \mathrm{E}+01$ & $9.58 \mathrm{E}+00$ & NA & NA & NA & $N A$ & NA \\
\hline Methylene chloride & $2.72 \mathrm{E}-13$ & $1.33 \mathrm{E}-11$ & $9.26 \mathrm{E}-13$ & $1.00 \mathrm{E}+00$ & $2.50 \mathrm{E}-01$ & NA & $\mathrm{NA}$ & NA & NA & NA \\
\hline Naphthalene & $4.48 \mathrm{E}-10$ & $2.20 \mathrm{E}-08$ & $1.52 \mathrm{E}-09$ & $1.43 E+00$ & $3.58 \mathrm{E}-01$ & NA & NA & NA & NA & NA \\
\hline Pentachlorophenol & 1.35E-06 & $6.60 \mathrm{E}-0.5$ & $4.58 \mathrm{E}-06$ & $1.30 \mathrm{E}-01$ & $3.25 \mathrm{E}-02$ & NA & NA & $3.00 \mathrm{E}+00$ & $6.00 \mathrm{E}+00$ & $4.00 \mathrm{E}+02$ \\
\hline Phenol & $7.00 \mathrm{E}-08$ & $3.43 \mathrm{E}-06$ & $2.38 \mathrm{E}-07$ & $8.23 \mathrm{E}+00$ & $2.06 E+00$ & NA & NA & NA & $3.00 \mathrm{E}+01$ & $1.00 \mathrm{E}+02$ \\
\hline Pyridine & $1.10 \mathrm{E}-10$ & $5.41 \mathrm{E}-09$ & $3.75 \mathrm{E}-10$ & NA & NA & NA & NA & NA & NA & NA \\
\hline Tetrachloroethylene & $1.13 \mathrm{E}-12$ & $5.52 \mathrm{E}-11$ & $3.83 \mathrm{E}-12$ & $3.33 \mathrm{E}+00$ & $8.33 \mathrm{E}-01$ & $\mathrm{NA}$ & $\mathrm{NA}$ & NA & NA & $\mathrm{NA}$ \\
\hline Toluene & $1.37 \mathrm{E}-12$ & $6.73 \mathrm{E}-11$ & $4.67 \mathrm{E}-12$ & $6.04 \mathrm{E}+01$ & $1.51 E+01$ & NA & $N A$ & $2.00 \mathrm{E}+02$ & NA & NA \\
\hline Trichloroethylene & $8.74 \mathrm{E}-13$ & $4.28 \mathrm{E}-11$ & $2.97 \mathrm{E}-12$ & $1.74 \mathrm{E}+0 \mathrm{I}$ & $4.35 \mathrm{E}+00$ & NA & $\mathrm{NA}$ & NA & NA & NA \\
\hline
\end{tabular}


Table 28. (continued).

\begin{tabular}{|c|c|c|c|c|c|c|c|c|c|c|}
\hline & Max Orf-site & Max On-sile & Avernge & $\begin{array}{c}\text { Mamınalian } \\
\text { EBSL }\end{array}$ & $\begin{array}{c}\text { Mammalian } \\
\text { EBSU4 }\end{array}$ & Avian EBSL & Avian EBSL4 & $\begin{array}{c}\text { Plant }{ }^{*} \\
\text { Benchmarks }\end{array}$ & $\begin{array}{l}\text { Earthworm" } \\
\text { Screening } \\
\text { Values }\end{array}$ & $\begin{array}{l}\text { Soil Microbes } \\
\text { Screening } \\
\text { Values }\end{array}$ \\
\hline \multicolumn{11}{|l|}{ Organics (PICs) } \\
\hline 2,3,7,8-TCDD TEQ & $1.62 \mathrm{E}-09$ & 7.95E-08 & $5.52 \mathrm{E}-09$ & $1.07 \mathrm{E}-06$ & $2.68 \mathrm{E}-07$ & $4.76 \mathrm{E}-06$ & $1.19 \mathrm{E}-06$ & NA & NA & NA \\
\hline 1,3-Dinitrobenzene & $2.75 E-03$ & $1.35 \mathrm{E}-01$ & $9.35 \mathrm{E}-03$ & $7.82 \mathrm{E}-02$ & $1.96 \mathrm{E}-02$ & NA & NA & NA & NA & NA \\
\hline Nitrobenzene & $8.39 \mathrm{E}-05$ & $4.11 \mathrm{E}-03$ & 2.85E-04 & $1.96 \mathrm{E}+00$ & $4.90 \mathrm{E}-01$ & NA & NA & NA & NA & NA \\
\hline 2,4-Dinitrotoluenc & $8.55 \mathrm{E}-03$ & $4.19 \mathrm{E}-01$ & $2.91 \mathrm{E}-02$ & $1.54 \mathrm{E}+00$ & $3.85 \mathrm{E}-01$ & NA & NA & NA & NA & NA \\
\hline 2,6-Dinitrotoluenc & 1.02E-02 & $4.99 \mathrm{E}-01$ & $3.46 \mathrm{E}-02$ & $2.18 \mathrm{E}+00$ & $5.46 \mathrm{E}-01$ & NA & NA & NA & NA & NA \\
\hline Pentachloronitrobenzene & $4.28 \mathrm{E}-06$ & $2.10 \mathrm{E}-04$ & $1.46 \mathrm{E}-0.5$ & NA & NA & $2.44 \mathrm{E}+00$ & $6.10 \mathrm{E}-01$ & NA & NA & NA \\
\hline
\end{tabular}

a. Values from Efroymson, R. A., M. E. Will, G. W. Suter II, and A. C. Wooten, 1997, Toxicological Benchmarks for Screening Contaminamts of Potential Comcern for Effects on Terrestrial Plans, 1997 Revision, Oak Ridge National Laboratory, Oak Ridge, TN, 128 pp., ES/ER/TM-85/R3.

b. Values from Efroymson, R. A., M. E. Will, and G. W. Suter II, 1997, Toxicological Benchmarks for Comfaminants of Potential Concem for Effects on Soil and Litter Invertebrates and Heterotropic Processes, 1997 Revision, Oak Ridge National Laboratory, Oak Ridge, TN, 128 pp., ES/ER/TM-126/R2.

c. Based on a conservative best-estimate of the $\mathrm{Hg}$ emission rate (3.7\% of feed). Upper-bound soil concentrations are a factor of 4.3 higher based on the ratio of the upper-bound cmissions factor (13\%) to the best-estimate cmissions factor (3\%).

$\stackrel{\omega}{\omega} \quad$ d. Assumed to be methyl $\mathrm{Hg}$ which is calculated as $2 \%$ of the total $\mathrm{Hg}$ (EPA 1998). Upper-bound soil concentrations are a factor of 4.3 higler.

c. Metal emissions that may be present based on preliminary offgas sampling data. Soil concentrations calculated using emission rates from the highest of 3 sample results and fate and transport parameters for zinc (EPA 1998). 
The PUF and CF input parameters were compared and both use the Travis and Arms (1988) allometric equations to calculate PUFs and CFs for organics. Baes et al. (1984) were used solely by ATG while the INEEL did an extensive search to identify additional PUFs for metals. However, in all cases the metal values are similar. The default of 1.0 or higher (whichever was greater) was used in the calculation of the EBSL (as shown in Table 27). This should add an additional level of conservatism.

A major uncertainty in any assessment is the selection of benchmarks for screening. For plants, earthworms, and soil microbes this assessment used those values developed by the Oak Ridge National Laboratory (Efroymson et al. 1997a, Efroymson et al. 1997b, and others). The values used by ATG (ATG, 1998) are summarized in Table 29 and are compared to the values used in this assessment. Although there are significant differences in some of the organic values, investigation of the modeled contaminant concentrations indicates that none of them are exceeded.

As shown in Table 30, the toxicity reference development for avian and mammalian receptors was also evaluated. The studies selected for development of toxicity values and the adjustment factors used to extrapolate to other species may vary considerably. The ATG document (ATG, 1998) did not reference or discuss the studies adequately to make a complete comparison, however, INEEL values appear to be both less than or greater than ATG values depending on the contaminant. Investigation of the modeled contaminant concentrations for both the metals and the organic feed indicates that neither the ATG or INEEL values would be exceeded. However, this is not the cases for the organic pics. As noted several of the studies used by ATG could not be located. In these cases either different studies were selected or the contaminant was not assessed. Specifically, this includes 1,3 dinitrobenzene, the ATG (ATG 1998) avian study cited evaluating this contaminant could not be located. The mammalian study used is $10^{4}$ higher than the avian study. If the avian study was located and found to be applicable then this contaminant would potentially be at unacceptable levels given the concentration modeled. Pentachloronitrobenzene was also assessed in this SLERA using a different study than selected by ATG (ATG, 1998). However, the lower toxicity values would not be exceeded by the modeled contaminant concentrations.

\subsubsection{Discussion of Uncertainty}

The NWCF SLERA, by definition, is a conservative approach to assess potential risk to ecological receptors from emission contaminants. The assessment incorporates levels of uncertainty that could either overestimate or underestimate the actual risk to these receptors. To compensate for potential uncertainties, the assessment incorporates various factors that are designed to be conservative rather than result in a conclusion of no indication of risk when actual risk may exist. Regardless, uncertainties exist that could affect the estimation of true risk associated with the assessment area. These are summarized in Table 31 .

Principal sources of uncertainty lie within the development of an exposure assessment and toxicity assessment. Uncertainties inherent in the exposure assessment are associated with estimation of receptor ingestion rates, estimation of site usage, and estimation of PUFs and CFs. Additional uncertainties are associated with the depiction of site characteristics, the determination of the nature and extent of contamination, and the derivation of TRVs. All of these uncertainties are likely to influence risk estimates. 
Table 29. Comparison of plant, earthworm and soil microbe benchmarks to ATG values (mg/kg).

ATG Soil

Oak Ridge Plant Benchmarks
Oak Ridge

ATG Plant
Earthworm

Benchmarks
Oak Ridge Soil $^{\mathrm{b}}$ Invertebrate And Microbes Benchmarks Microorganisms

\section{Metals}

Antimony (Sb)

$5.00 \mathrm{E}+00$

5.00E-01

NA

Arsenic (As)

$1.00 \mathrm{E}+01$

$1.00 \mathrm{E}+00$

$6.00 \mathrm{E}+01$

NA

Barium (Ba)

$5.00 \mathrm{E}+02$

$5.00 \mathrm{E}+00$

NA

Beryllium (Be)

$1.00 \mathrm{E}+01$

1.00E-01

NA

Cadmium (Cd)

$4.00 \mathrm{E}+00$

$2.00 \mathrm{E}-01$

$2.00 \mathrm{E}+01$

Chromium (Cr) as $\mathrm{Cr}$ III $1.00 \mathrm{E}+00$

Chromium ( $\mathrm{Cr}$ ) as $\mathrm{Cr}$ VI NA

Lead $(\mathrm{Pb})$

$5.00 \mathrm{E}+01$

Mercury $(\mathrm{Hg})$ as

3.00E-01

inorganic

Mercury ( $\mathrm{Hg})$ as organic NA

Nickel (Ni)

$3.00 E+01$

Selenium (Se)

$1.00 \mathrm{E}+00$

NA

4.00E-01

$1.80 \mathrm{E}-02$

$4.60 \mathrm{E}+00$

$5.00 \mathrm{E}+02$

3.00E-03

$1.00 \mathrm{E}-01$

Silver (Ag)

$2.00 \mathrm{E}+00$

Thallium (Tl)

$1.00 \mathrm{E}+00$

3.00E-03 1.00E-01

$2.50 \mathrm{E}+01$

$2.00 \mathrm{E}+02$

5.00E-02

$7.00 \mathrm{E}+01$

2.00E-02

NA

$1.00 \mathrm{E}-02 \quad \mathrm{NA}$

NA

Organics (feed)

$\begin{array}{lll}\text { 1,1,1-Trichloroethane } & \text { NA } & \text { NA } \\ \text { 1,1,2-Trichloroethane } & \text { NA } & \text { NA } \\ \text { 1,2,4-trichlorobenzene } & \text { NA } & \text { NA } \\ \text { 1,2-Dichloroethane } & \text { NA } & \text { NA } \\ \text { 1,4 dioxane } & \text { NA } & \text { NA } \\ \text { 2,4-Dinitrophenol } & \text { NA } & \text { NA } \\ \text { Acetonitrile } & \text { NA } & \text { NA } \\ \text { Aniline } & \text { NA } & \text { NA } \\ \text { Benzene } & \text { NA } & \text { NA } \\ \text { Benzo(a)pyrene } & \text { NA } & 1.20 \mathrm{E}+00 \\ \text { Bromoform } & \text { NA } & \text { NA } \\ \text { (tribromomethane) } & & \text { NA } \\ \text { Butylbenzylphthalate } & \text { NA } & \text { NA } \\ \text { Carbon disulfide } & \text { NA } & \text { NA } \\ \text { Carbon tetrachloride } & \text { NA } & \text { NA } \\ \text { Chlorobenzene } & \text { NA } & \end{array}$

NA

NA

NA

NA

NA

NA

$2.00 \mathrm{E}+01$

NA

NA

$\mathrm{NA}$

NA

NA

NA

NA

NA

NA

NA

NA

NA

NA

NA

NA

NA

NA

NA

NA

NA

NA

NA

$2.50 \mathrm{E}+01$

NA

NA

NA

NA

NA

NA

NA

NA

NA

NA

NA

$1.00 \mathrm{E}+03$

$4.00 \mathrm{E}+01$

NA

$4.00 \mathrm{E}+01$ 
Table 29. (continued).

\begin{tabular}{|c|c|c|c|c|c|}
\hline & $\begin{array}{c}\text { Oak Ridge Plant } \\
\text { Benchmarks }\end{array}$ & $\begin{array}{l}\text { ATG } \\
\text { Plant }\end{array}$ & $\begin{array}{l}\text { Oak Ridge }^{a} \\
\text { Earthworm } \\
\text { Benchmarks }\end{array}$ & $\begin{array}{c}\text { Oak Ridge Soil }{ }^{\mathrm{b}} \\
\text { Microbes } \\
\text { Benchmarks }\end{array}$ & $\begin{array}{c}\text { ATG Soil } \\
\text { Invertebrate And } \\
\text { Soil } \\
\text { Microorganisms } \\
\end{array}$ \\
\hline Chloroform & NA & NA & NA & NA & NA \\
\hline Diethylphthalate & NA & $\mathrm{NA}$ & NA & NA & NA \\
\hline Di-n-butylphthalate & $2.00 E+02$ & NA & NA & NA & NA \\
\hline Di-n-octylphthalate & NA & NA & NA & NA & NA \\
\hline Formaldehyde & NA & NA & NA & NA & NA \\
\hline Formic acid & $\mathrm{NA}$ & NA & NA & NA & $\mathrm{NA}$ \\
\hline $\begin{array}{l}\text { Methyl ethyl ketone } \\
\text { (2-butanone) }\end{array}$ & NA & $\mathrm{NA}$ & NA & NA & NA \\
\hline Methylene chloride & NA & NA & NA & NA & NA \\
\hline Naphthalene & NA & $\mathrm{NA}$ & NA & NA & NA \\
\hline Pentachlorophenol & $3.00 E+00$ & $\mathrm{NA}$ & $6.00 \mathrm{E}+00$ & $4.00 \mathrm{E}+02$ & NA \\
\hline Phenol & NA & $\mathrm{NA}$ & $3.00 E+01$ & $1.00 \mathrm{E}+02$ & NA \\
\hline Pyridine & NA & NA & NA & NA & NA \\
\hline Tetrachloroethylene & NA & $\mathrm{NA}$ & NA & NA & NA \\
\hline Toluene & $2.00 E+02$ & $2.00 \mathrm{E}+02$ & NA & NA & NA \\
\hline Trichloroethylene & NA & $\mathrm{NA}$ & NA & NA & NA \\
\hline \multicolumn{6}{|l|}{ Organics (PICs) } \\
\hline $2,3,7,8-\mathrm{TCDD}$ TEQ & NA & NA & NA & NA & NA \\
\hline 1,3-Dinitrobenzene & NA & $\mathrm{NA}$ & NA & $\mathrm{NA}$ & $2.26 \mathrm{E}+00$ \\
\hline Nitrobenzene & NA & $\mathrm{NA}$ & NA & NA & $2.26 \mathrm{E}+00$ \\
\hline 2,4-Dinitrotoluene & NA & NA & NA & NA & NA \\
\hline 2,6-Dinitrotoluene & NA & NA & NA & NA & NA \\
\hline Pentachloronitrobenzene & NA & NA & NA & NA & NA \\
\hline
\end{tabular}

a. Values from Efroymson, R. A., M. E. Will, G. W. Suter II, and A. C. Wooten, 1997, Toxicological Benchmarks for Screening Contaminants of Potential Concern for Effects on Terrestrial Plans, 1997 Revision, Oak Ridge National Laboratory, Oak Ridge, TN, 128 pp., ES/ERTM-85/R3.

b. Values from Efroymson, R. A., M. E. Will, and G. W. Suter II, 1997, Toxicological Benchmarks for Contaminants of Potential Concern for Effects on Soil and Litter Invertebrates and Heterotropic Processes, 1997 Revision, Oak Ridge National Laboratory, Oak Ridge, TN, 128 pp., ES/ER/TM-126/R2. 
Table 30. Comparison of mammalian and avian toxicity values used at the INEEL to ATG values (all values in $\mathrm{mg} / \mathrm{kg}$-day).

\begin{tabular}{|c|c|c|c|c|c|c|}
\hline & \multicolumn{3}{|c|}{ Mammalian Toxicity Values } & \multicolumn{3}{|c|}{ Avian Toxicity Values } \\
\hline & $\begin{array}{c}\text { INEEL TRV } \\
(\mathrm{R} 1)\end{array}$ & $\begin{array}{c}\text { INEEL } \\
\text { QCE }\end{array}$ & $\begin{array}{l}\text { ATG } \\
\text { TRVs }\end{array}$ & $\begin{array}{c}\text { INEEL TRV } \\
(\mathrm{R} 1)\end{array}$ & $\begin{array}{l}\text { INEEL } \\
\text { QCE }\end{array}$ & $\begin{array}{l}\text { ATG } \\
\text { TRVs }\end{array}$ \\
\hline \multicolumn{7}{|l|}{ Metals } \\
\hline Antimony (Sb) & $1.25 E+00$ & $1.25 \mathrm{E}+00$ & $6.60 \mathrm{E}-02$ & NA & NA & NA \\
\hline Arsenic (As) & $7.80 \mathrm{E}-01$ & $3.10 \mathrm{E}+00$ & $1.25 \mathrm{E}+00$ & $1.29 \mathrm{E}+00$ & $5.14 \mathrm{E}+00$ & $2.46 \mathrm{E}+00$ \\
\hline Barium $(\mathrm{Ba})$ & $1.02 \mathrm{E}+01$ & $5.10 \mathrm{E}+00$ & $5.10 \mathrm{E}-01$ & NA & NA & $2.08 \mathrm{E}+01$ \\
\hline Beryllium (Be) & $6.60 \mathrm{E}-01$ & $6.60 \mathrm{E}-01$ & $6.60 \mathrm{E}-01$ & NA & NA & NA \\
\hline Cadmium (Cd) & $3.00 \mathrm{E}-03$ & $5.50 \mathrm{E}-03$ & $1.90 \mathrm{E}-01$ & $7.00 \mathrm{E}-02$ & $1.40 \mathrm{E}-01$ & $1.13 \mathrm{E}+01$ \\
\hline Chromium $(\mathrm{Cr})$ as $\mathrm{Cr}$ III & $7.50 \mathrm{E}+02$ & $1.50 \mathrm{E}+03$ & $2.74 \mathrm{E}+03$ & $4.10 \mathrm{E}+00$ & $4.90 \mathrm{E}+01$ & $1.00 \mathrm{E}+00$ \\
\hline Chromium ( $\mathrm{Cr}$ ) as $\mathrm{Cr}$ VI & $1.50 \mathrm{E}-01$ & $3.00 \mathrm{E}-01$ & $2.40 \mathrm{E}+\infty 0$ & NA & NA & $1.00 \mathrm{E}+00$ \\
\hline Lead $(\mathrm{Pb})$ & $8.00 \mathrm{E}+\infty 0$ & $8.00 E+00$ & 4.80E-01 & $1.40 \mathrm{E}+00$ & $2.60 \mathrm{E}+01$ & $2.50 \mathrm{E}-01$ \\
\hline Mercury $(\mathrm{Hg})$ as inorganic & $3.40 \mathrm{E}-01$ & $6.80 \mathrm{E}-01$ & $1.01 \mathrm{E}+00$ & $6.05 E+00$ & $1.21 \mathrm{E}+01$ & $3.25 E+00$ \\
\hline Mercury $(\mathrm{Hg})$ as organic & 7.00E-02 & $1.40 \mathrm{E}-01$ & $3.20 \mathrm{E}-02$ & $8.00 \mathrm{E}-03$ & $6.40 \mathrm{E}-02$ & $3.25 \mathrm{E}+00$ \\
\hline Nickel (Ni) & $5.70 \mathrm{E}+01$ & $1.14 E+02$ & $8.00 \mathrm{E}+00$ & $3.87 \mathrm{E}+01$ & $7.74 \mathrm{E}+01$ & $6.50 \mathrm{E}+01$ \\
\hline Selenium (Se) & $4.00 \mathrm{E}-01$ & $2.00 \mathrm{E}-01$ & $5.80 \mathrm{E}-02$ & $2.50 \mathrm{E}-01$ & $5.00 \mathrm{E}-01$ & $5.00 \mathrm{E}-01$ \\
\hline Silver (Ag) & $3.40 \mathrm{E}+01$ & $6.80 \mathrm{E}+01$ & $3.75 \mathrm{E}-01$ & 4.37E+01 & $8.73 E+01$ & $1.78 \mathrm{E}+02$ \\
\hline Thallium (TI) & $1.10 \mathrm{E}-01$ & $1.80 \mathrm{E}+00$ & $2.70 \mathrm{E}-03$ & $1.50 \mathrm{E}-01$ & $1.20 \mathrm{E}+01$ & $3.50 \mathrm{E}-01$ \\
\hline \multicolumn{7}{|l|}{ Organics (feed) } \\
\hline 1,1,1-Trichloroethane & $1.00 \mathrm{E}+03$ & $1.00 \mathrm{E}+03$ & $1.00 E+03$ & $\mathrm{NA}$ & NA & NA \\
\hline 1,1,2-Trichloroethane & NA & NA & NA & NA & $\mathrm{NA}$ & NA \\
\hline 1,2,4-trichlorobenzene & $1.70 \mathrm{E}+\infty 0$ & $2.00 \mathrm{E}+01$ & $\mathrm{NA}$ & $\mathrm{NA}$ & NA & NA \\
\hline 1,2-Dichloroethane & $5.00 \mathrm{E}+01$ & $5.00 \mathrm{E}+01$ & $5.00 \mathrm{E}+01$ & $8.60 E+\infty$ & $1.72 \mathrm{E}+01$ & $1.72 E+01$ \\
\hline 1,4 dioxane & $5.00 \mathrm{E}-01$ & $5.00 \mathrm{E}-01$ & $1.07 \mathrm{E}-01$ & NA & NA & NA \\
\hline 2,4-Dinitrophenol & NA & NA & $\mathrm{NA}$ & $\mathrm{NA}$ & NA & NA \\
\hline Acetonitrile & $1.60 \mathrm{E}+01$ & $1.90 \mathrm{E} \div 02$ & NA & NA & NA & NA \\
\hline Aniline & NA & $\mathrm{NA}$ & NA & $\mathrm{NA}$ & $\mathrm{NA}$ & $\mathrm{NA}$ \\
\hline Benzene & $1.10 \mathrm{E}+01$ & $2.64 E+02$ & $2.64 E+01$ & NA & NA & NA \\
\hline Benzo(a)pyrene & $2.78 \mathrm{E}+01$ & $5.00 \mathrm{E}+02$ & $1.00 \mathrm{E}-01$ & NA & NA & $3.00 \mathrm{E}-03$ \\
\hline $\begin{array}{l}\text { Bromoform } \\
\text { (tribromomethane) }\end{array}$ & NA & NA & NA & NA & NA & $\mathrm{NA}$ \\
\hline Butylbenzylphthalate & $1.33 \mathrm{E}+01$ & $1.59 \mathrm{E}+02$ & NA & NA & NA & NA \\
\hline Carbon disulfide & $9.20 \mathrm{E}-01$ & $1.10 \mathrm{E}+01$ & NA & NA & NA & $\mathrm{NA}$ \\
\hline Carbon tetrachloride & $1.00 \mathrm{E}+01$ & $1.00 \mathrm{E}+01$ & $1.60 \mathrm{E}+01$ & $\mathrm{NA}$ & NA & NA \\
\hline Chlorobenzene & NA & NA & NA & NA & NA & NA \\
\hline Chloroform & $3.75 E+01$ & $1.50 \mathrm{E}+02$ & $5.14 \mathrm{E}+01$ & NA & NA & NA \\
\hline Diethylphthalate & $1.88 \mathrm{E}+02$ & $7.50 \mathrm{E}+02$ & NA & $\mathrm{NA}$ & NA & NA \\
\hline Di-n-butylphthalate & $1.39 \mathrm{E}+01$ & $1.25 E+02$ & NA & $\mathrm{NA}$ & NA & NA \\
\hline
\end{tabular}


Table 30. (continued).

\begin{tabular}{|c|c|c|c|c|c|c|}
\hline & \multicolumn{3}{|c|}{ Mammalian Toxicity Values } & \multicolumn{3}{|c|}{ Avian Toxicity Values } \\
\hline & $\begin{array}{c}\text { INEEL TRV } \\
(\mathrm{R} 1)\end{array}$ & $\begin{array}{l}\text { INEEL } \\
\text { QCE }\end{array}$ & $\begin{array}{l}\text { ATG } \\
\text { TRVs }\end{array}$ & $\begin{array}{c}\text { INEEL TRV } \\
\text { (R1) }\end{array}$ & $\begin{array}{c}\text { INEEL } \\
\text { QCE }\end{array}$ & $\begin{array}{l}\text { ATG } \\
\text { TRVs }\end{array}$ \\
\hline Di-n-octylphthalate & $4.35 \mathrm{E} \div 01$ & $1.74 \mathrm{E}+02$ & $\mathrm{NA}$ & NA & NA & NA \\
\hline Formaldehyde & $1.50 \mathrm{E}+01$ & $1.50 \mathrm{E}+01$ & $2.30 \mathrm{E}+00$ & NA & NA & NA \\
\hline Formic acid & NA & NA & $\mathrm{NA}$ & $\mathrm{NA}$ & NA & NA \\
\hline $\begin{array}{l}\text { Methyl ethyl ketone } \\
\text { (2-butanone) }\end{array}$ & $8.86 \mathrm{E}+02$ & $1.77 \mathrm{E}+03$ & NA & NA & NA & $\mathrm{NA}$ \\
\hline Methylene chloride & $5.85 \mathrm{E}+00$ & $5.85 \mathrm{E}+00$ & $5.85 \mathrm{E}+00$ & $\mathrm{NA}$ & NA & $\mathrm{NA}$ \\
\hline Naphthalene & $1.30 \mathrm{E}+00$ & $5.30 \mathrm{E}+00$ & NA & NA & NA & NA \\
\hline Pentachlorophenol & $1.20 \mathrm{E}-01$ & $2.40 \mathrm{E}-01$ & $3.00 \mathrm{E}-01$ & NA & NA & NA \\
\hline Phenol & $4.00 \mathrm{E}+01$ & $6.00 \mathrm{E}+01$ & NA & NA & NA & NA \\
\hline Pyridine & NA & NA & NA & NA & NA & NA \\
\hline Tetrachloroethylene & $3.50 \mathrm{E}+00$ & $1.40 E+01$ & $1.40 \mathrm{E}+00$ & NA & NA & NA \\
\hline Toluene & $5.58 \mathrm{E}+01$ & $2.23 E+02$ & $2.60 \mathrm{E}+01$ & NA & NA & NA \\
\hline Trichloroethylene & $2.50 \mathrm{E}+01$ & $1.00 \mathrm{E}+02$ & $7.00 \mathrm{E}-01$ & NA & NA & NA \\
\hline \multicolumn{7}{|l|}{ Organics (PICs) } \\
\hline 2,3,7,8-TCDD TEQ & $1.00 \mathrm{E}-06$ & $1.00 \mathrm{E}-06$ & NA & $7.00 \mathrm{E}-05$ & $1.40 \mathrm{E}-05$ & NA \\
\hline 1,3-Dinitrobenzene & $4.00 \mathrm{E}-01$ & $4.00 \mathrm{E}-01$ & $1.25 \mathrm{E}+00$ & NA & $\mathrm{NA}$ & $3.76 \mathrm{E}-04$ \\
\hline Nitrobenzene & $5.56 \mathrm{E}+00$ & $3.00 \mathrm{E}+02$ & $\mathrm{NA}$ & NA & $\mathrm{NA}$ & NA \\
\hline 2,4-Dinitrotoluene & $3.50 \mathrm{E}+00$ & $1.40 \mathrm{E}+01$ & $\mathrm{NA}$ & NA & NA & $\mathrm{NA}$ \\
\hline 2,6-Dinitrotoluene & $5.00 \mathrm{E}+00$ & $2.00 \mathrm{E}+01$ & $4.00 \mathrm{E}-01$ & NA & $\mathrm{NA}$ & NA \\
\hline Pentachloronitrobenzene & $\mathrm{NA}$ & $\mathrm{NA}$ & 4.75E-04 & $3.54 \mathrm{E}+00$ & $7.07 \mathrm{E}+00$ & $7.07 \mathrm{E}+00$ \\
\hline
\end{tabular}


Table 31. Sources and effects of uncertainties in the ecological risk assessment.

\begin{tabular}{|c|c|c|}
\hline Uncertainty Factor & $\begin{array}{l}\text { Effect of Uncertainty } \\
\text { (Level of Magnitude) }\end{array}$ & Comment \\
\hline $\begin{array}{l}\text { Estimation of ingestion rates } \\
\text { (soil and food) }\end{array}$ & $\begin{array}{l}\text { May overestimate or } \\
\text { underestimate risk } \\
\text { (moderate) }\end{array}$ & $\begin{array}{l}\text { Few intake ingestion estimates used for } \\
\text { terrestrial receptors are based on data in } \\
\text { the scientific literature (preferably site- } \\
\text { specific) when available. Food ingestion } \\
\text { rates are calculated by using allometric } \\
\text { equations available in the literature } \\
\text { (Nagy 1987). Soil ingestion values are } \\
\text { generally taken from Beyer et al. (1987). }\end{array}$ \\
\hline $\begin{array}{l}\text { Estimation of bioaccumulation } \\
\text { and plant uptake factors and } \\
\text { use of default values in } \\
\text { calculating PUFs }\end{array}$ & $\begin{array}{l}\text { May overestimate risk and } \\
\text { the magnitude of error } \\
\text { cannot be quantified (high). }\end{array}$ & $\begin{array}{l}\text { Few bioaccumulation factors (CFs) or } \\
\text { plant uptake factors (PUFs) are available } \\
\text { in the literature that are both } \\
\text { contaminant- and receptor-specific. In } \\
\text { the absence of more specific information, } \\
\text { PUFs and CFs for metals were obtained } \\
\text { from Baes et al. (1984) and other } \\
\text { literature sources and for organics from } \\
\text { Travis and Arms (1988). }\end{array}$ \\
\hline $\begin{array}{l}\text { Use of modeled screening } \\
\text { concentrations. }\end{array}$ & $\begin{array}{l}\text { May overestimate (high) } \\
\text { risk. }\end{array}$ & $\begin{array}{l}\text { The calculated screening impacts from } \\
\text { organic PICs are based on very } \\
\text { conservative emissions estimates which } \\
\text { assume all of the unburned fuel is } \\
\text { converted to this single PIC (see } \\
\text { Section } 2 \text { ). Actual emissions and the } \\
\text { resulting soil concentrations, although } \\
\text { unknown, would likely be significantly } \\
\text { less than the values evaluated. }\end{array}$ \\
\hline $\begin{array}{l}\text { Estimation of toxicity } \\
\text { reference values }\end{array}$ & $\begin{array}{l}\text { May overestimate (high) or } \\
\text { underestimate (moderate) } \\
\text { risk }\end{array}$ & $\begin{array}{l}\text { To compensate for potential uncertainties } \\
\text { in the exposure assessment, various } \\
\text { adjustment factors are incorporated to } \\
\text { extrapolate toxicity from the test } \\
\text { organism to other species. }\end{array}$ \\
\hline Use of functional grouping & May overestimate (high) & $\begin{array}{l}\text { Functional groups were designed as an } \\
\text { assessment tool that would ensure that all } \\
\text { species potentially present at the facility } \\
\text { would be addressed. A hypothetical } \\
\text { species is developed using input values } \\
\text { to the exposure assessment that } \\
\text { represents the greatest exposure of the } \\
\text { combined functional group members. }\end{array}$ \\
\hline
\end{tabular}


Ecotoxicological data is recognized as one of the major uncertainties in ERA. As with the human health risk assessments, the TRVs are updated as new information is available. This is an ongoing effort that will continue throughout the ERA process at the INEEL.

In relation to extrapolations between individuals and populations, it is difficult to accurately predict ecological effects of toxic substances because of the complexity of the ecosystem. Most toxicity information comes from laboratory studies of single contaminant impacts on single species. Hence, there is a great deal of uncertainty in extrapolating controlled laboratory results to complex field situations and from one species to another. Single contaminant studies cannot predict the interactions of multiple contaminants with each other and with the ecosystem. Additionally, interactions of organisms with the ecosystem are complex and not easily predicted.

Few data are available for the invertebrate populations at the INEEL. Invertebrates are important links in dietary exposure for wildlife. There is sufficient ecological and toxicological data to adequately characterize the contaminant effects in the invertebrate component of the ecosystem. Such uncertainty will propagate into some of the other endpoint compartments, in particular those representing mammalian, avian, and reptilian insectivores.

There are a number of T/E or sensitive species that could occur in the NWCF assessment area. In some cases, they are known to exist in close proximity to INTEC facilities. The lack of information concerning the presence or absence of $T / E$ and/or sensitive species in the vicinity of INEEL facilities and at the INEEL in general has been previously identified as an acceptable data gap.

\subsubsection{NWCF SLERA Summary and Results}

A screening of modeled concentrations of contaminant deposited to soil from activities planned at the NWCF to 0.25 of the EBSLs was performed. The maximum modeled concentration of 1,3dinitrobenzene was the only contaminant to exceed any EBSL. However, the average concentration was below EBSL values. The calculated screening impacts from 1,3-dinitrobenzene are based on very conservative emissions estimates which assume all of the unburned fuel is converted to this single PIC (see section 2). Actual emissions and the resulting soil concentrations, although unknown, would likely be significantly less than the values evaluated.

Based on these results adverse effects to ecological receptors from the continued use of the NWCF appear to be unlikely. However, limited or no toxicity data is available for many of these contaminants and this limitation (as well as other uncertainties) needs to be recognized. 


\section{REFERENCES}

40 CFR 61, Subpart H, Code of Federal Regulations, Title 40, "Protection of the Environment," Subchapter C, "Air Programs," Part 61, "National Emission Standards for Hazardous Air Pollutants," Subpart H, "National Emission Standards for Emissions of Radionuclides Other than Radon for Department of Engineering Facilities.

Abbott, M. L., 1997, DOE Approach to Radioactive Risk Assessment and EPA Slope Factor Methodology, National Technical Workgroup on Mixed Waste Treatment, annual meeting November 5-7, 1997, Newport Beach, CA.

Allied Technology Group, Inc. (ATG), 1998, Risk Assessment Work Plan for the ATG Richland Mixed Waste Facility.

Anderson, J. E., 1991, Final Report: Vegetation Studies to Support the NPR Environmental Impact Statement, Subcontract No. C34-110421, Task Order No. 72, EG\&G Idaho, Inc.

Arthur, W. J. et al., 1984, Vertebrates of the Idaho National Engineering Laboratory, DOE/ID-12099, U.S. Department of Energy Idaho Operations Office, Radiological and Environmental Sciences Laboratory.

Arthur, W. J., and R. J. Gates, 1988, "Trace Element Intake via Soil Ingestion in Pronghorns and in Black-tailed Jack Rabbits," Journal of Range Management, 41:162-166.

Arthur, W. J., J. W. Connelly, D. K. Halford, and T. D. Reynolds, 1984, Vertebrates of the Idaho National Engineering Laboratory, DOE/D-12099, U.S. Department of Energy, Idaho Operations Office, Idaho Falls, Idaho.

Baes, C. F., II, et al., 1984, A Review and Analysis of Parameters for Assessing Transport of Environmentally Released Radionuclides Through Agriculture, ORNL-5786, U.S. Department of Energy, Oak Ridge National Laboratory, Oak Ridge, TN.

Barnthouse, L. W., Suter, G. W., II, Bartell, S. M., Beauchamp, J. J., Gardner, R. H., Linder, E., O’Neill, R. v., and Rosen, A. E. (1986) User's Manual for Ecological Risk Assessment. Environmental Sciences Division Publication No. 2679. Oak Ridge National Laboratory, Oak Ridge, Tennessee.

Beyer, W. N., E. E. Conner, and S. Geroud, 1994, "Estimates of Soil Ingestion by Wildlife," Journal of Wildlife Management, 58, pp. 375-382.

Burt, W. H., and R. P. Gossenheider, 1976, A Field Guide to the Mammals of America North of Mexico, Houghton Mifflin, Boston.

CDC, 1994, Rare, Threatened, and Endangered Plants and Animals of Idaho, Third edition, Idaho Department of Fish and Game, Boise, Idaho, 39p.

Cholewa, A. F. and LD. M. Henderson, 1984, A Survey and Assessment of Rare Vascular Plants of the Idaho National Engineering Laboratory Site, DOE/ID-12100, Radiological and Environmental Sciences Laboratory, Idaho Falls, ID, pp. 45. 
Chowlewa, A. F., and D. M. Henderson, 1984, A Survey and Assessment of the Rare Vascular Plants of the INEL, DOE/ID-12100, U.S. Department of Energy, Idaho Operations Office, Radiological and Environmental Sciences Laboratory, Idaho Falls, Idaho.

Clawson, K. L., G. E. Start, N. R. Ricks, 1989, Climatography of the Idaho National Engineering Laboratory, 2nd ed., DOE/ID-12118, U.S. Department of Energy, Idaho Operations Office, Idaho Falls, Idaho.

Dempsey, C. R., and E. T. Oppelt, 1993, "Incineration of Hazardous Waste: A Critical Review Update," Journal of the Air \& Waste Management Association, Vol. 43: pp. 25-73, January.

DOE, 1991, Idaho National Engineering Laboratory, Idaho Chemical Processing Plant, New Waste Calcining Facility Subpart X Application of Part B Permit Application.

DOE, 1993, The Idaho National Engineering Laboratory Site Environmental Report for Calendar Year 1992, DOE/ID-12082(92), U.S. Department of Energy, Idaho Operations Office, Idaho Falls, Idaho.

DOE, 1997, Comprehensive RI/FS for the Idaho Chemical Processing Plant OU 3-13 at the INEELPart A, RI/BRA Report (Draft), DOE/ID-10534, U.S. Department of Energy, Idaho Operations Office, Idaho Falls, Idaho.

DOE, 1998, Comprehensive Remedial Investigation/Feasibility Study for the Idaho Chemical Processing Plant Operable Unit 3-13 at the Idaho National Engineering and Environmental Laboratory, (DOE/ID-10534), U.S.Department of Energy, Idaho Operations Office, Idaho Falls, ID.

DOE, 1999, Work Plan for Waste Area Groups 6 and 10 Operable Unit 10-04 Comprehensive Remedial Investigation/Feasibility Study (DRAFT), DOE-ID-10554(99), U.S. Department of Energy, Idaho Operations Office, Idaho Falls, ID, March 1999.

Efroymson, R. A., M. E. Will, G. W. Suter II, and A. C. Wooten, 1997, Toxicological Benchmarks for Screening Contaminants of Potential Concern for Effects on Terrestrial Plans, 1997 Revision, Oak Ridge National Laboratory, Oak Ridge, TN, 128 pp., ES/ER/TM-85/R3.

Efroymson, R. A., M. E. Will, and G. W. Suter II, 1997, Toxicological Benchmarks for Contaminants of Potential Concern for Effects on Soil and Litter Invertebrates and Heterotropic Processes, 1997 Revision, Oak Ridge National Laboratory, Oak Ridge, TN, 128 pp., ES/ER/TM-126/R2.

EPA, 1986, “Guidelines for Carcinogenic Risk Assessment," Federal Register, Vol. 51, pp. 3399234003.

EPA, 1987, On-Site Meteorological Program Guidance for Regulatory Modeling Applications, EPA-450/4-87-013.

EPA, 1988, Review of Ecological Risk Assessment Methods, EPA/230/10-88-041, Office of Planning and Evaluation, Washington, D.C.

EPA, 1989, Risk Assessment Methodology Environmenial Impact Statement, NESHAPS for Radionuclides, Background Information Document-Volume 1, EPA/520-1-89-005. 
EPA, 1990, The Clean Air Act Assessment Package - 1988 (CAP-88), A Dose and Risk Assessment Methodology for Radionuclide Emissions to Air, Volumes 1-3, prepared by D. A. Beres, SC\&A, Inc., for the U.S. Environmental Protection Agency.

EPA, 1991, Ecological Assessment of Superfund Sites: An Overview, Vol. 1, No. 2, PN 9345.0-05I, Office of Solid Waste and Emergency Response, U.S. Environmental Protection Agency, December.

EPA, 1992a, Framework for Ecological Risk Assessment, EPA/630/R-92/001, PB93-102192, U.S. Environmental Protection Agency, ORD/Risk Assessment Forum, February, 55 pp.

EPA, 1992b, Developing A Work Scope for Ecological Assessments, Vol. 1, No. 4, PN 9345.0-05I, Office of Solid Waste and Emergency Response, U.S. Environmental Protection Agency, May.

EPA, 1993a, A Review of Ecological Risk Assessment Case Studies from a Risk Assessment Perspective, U.S. Environmental Protection Agency, Office of Research and Development, Washington, D.C., EPA/630/R-92/005, May.

EPA, 1993b, Wildlife Exposure Factors Handbook, U.S. Environmental Protection Agency, Office of Research and Development, Washington, D.C., EPA/600/R-93/187B, December.

EPA, 1994a, Guidance for Performing Screening Level Risk Analyses at Combustion Facilities Burning Hazardous Waste, Attachment C, Draft, Office of Emergency and Remedial Response, Office of Solid Waste, December 14.

EPA, 1994b, Exposure Assessment Guidance for RCRA Hazardous Waste Combustion Facilities, EPA 530-R-021, April.

EPA, 1994c, Estimating Exposure to Dioxin-Like Compounds, Vol. 1: Executive Summary, EPA/600/6-88/005Ca, June.

EPA, 1994d, Combustion Emissions Technical Resource Document (CETRED), EPA 530-R-94-014, May.

EPA, 1994e, Estimating Radiogenic Cancer Risk, EPA 402-R-93-076.

EPA, 1994f, A Review of Ecological Risk Assessment Case Studies from a Risk Assessment Perspective, Vol. II, U.S. Environmental Protection Agency, Office of Research and Development, Washington, D.C., EPA/630/R-94/003, May.

EPA, 1995a, User's Guide for the Industrial Source Complex (ISC3) Dispersion Models (Revised), EPA-450/B-95-003a, b.

EPA, 1995b, Guidelines on Air Quality Models, Revised ed., EPA-450/2-78-027R.

EPA, 1996, Meteorological Processor for Regulatory Models (MPRM) User's Guide, EPA-454/B-96-002.

EPA, 1997a, Health Effects Assessment Summary Tables Annual Updates, Fiscal Year 1997, EPA/540/R-97/036, Office of Solid Waste and Emergency Response, Washington, D.C. 
EPA, 1997b, Ecological Risk Assessment Guidance For Superfund: Process for Designing and Conducting Ecological Risk Assessments, Interim Final, Environmental Response Team, EPA/540/1-89-002

EPA, Region 10, 1997, Supplemental Risk Assessment Guidance for Superfund, Office of Environmental Assessment, Risk Evaluation Unit, EPA/910/R-97/005, June.

EPA, 1998a, Human Health Risk Assessment Protocol for Hazardous Waste Combustion Facilities, Peer Review Draft, EPA530-D-98-001A, July.

EPA, 1998b, Guidelines for Ecological Assessment, Office of Research and Development, EPA/630/R-95/002FA (also published in the Federal Register, Volume 63, No., 93, May 14, 1998). Previously referred to as the Proposed Guidelines for Ecological Risk Assessment, 1996.

Golder, D., 1972, "Relations Among Stability Parameters in the Surface Layer," Boundary-Layer Meteorology, Vol. 3, No. 1, pp. 47-58.

Hampton, N. L. et al., 1995, A Preliminary Survey of the National Wetlands Inventory as Mapped for the Idaho National Engineering Laboratory, INEL-95/0101, February.

IDAPA, 1996, Rules for the Control of Air Pollution in Idaho, Idaho Administrative Procedures Act 16.01.01.000-999.

INEL, 1993, 1992 INEL National Emission Standard for Hazardous Air Pollutants Annual Report, June 1993, DOE/ID-10342(92), U.S. Department of Energy, Idaho Operations Office, Idaho Falls, Idaho.

INEL, 1995, Application for a Title V Operating Permit for the Idaho National Engineering Laboratory, Vol. IV, Idaho Chemical Processing Plant, INEL-95/0155-IV, July.

Kramber, W. J. et al., 1992, "Producing a Vegetation Map of the Idaho National Engineering Laboratory Using Landsat Thematic Mapper Data," Proceedings of ASPRS 1992 Annual Meeting, Albuquerque, NM, March.

Lieberman, A. and R. D. Scott, "Atmospheric Particle Penetration through High Efficiency Filters", Proceedings of the 11th AEC Air Cleaning Conference, (1970), Conf 700816, p. 751-764.

Ludwig, D. F., Frantzen, K., Friello, P., Kester, J., and Banton, M. I., 1993, An approach to toxicity reference values for ecological risk assessment. Presented at the 14th Annual Meeting, Society of Environmental Toxicology and Chemistry, 14-18 November 1993, Houston, TX.

Martin, S. B., 1996, U. S. Fish and Wildlife Service letter to T. Reynolds, Environmental Science and Research Foundation, "INEEL-DOE Species List Update," SP No. 1-4-97-SP-31, December 6.

Montgomery, J. H. and L. M. Welkom, 1990, Groundwater Chemicals Desk Reference, Lewis Publishers, Chelsea, MI.

Nagy, K. A., 1987, "Field Metabolic Rate and Food Requirement Scaling in Mammals and Birds," Ecological Mono., 57:111-128. 
Olson, G. L., D. J. Jeppesen, and R. D. Lee, 1995, The Status of Soil Mapping for the Idaho National Engineering Laboratory, INEL-95/0051, Idaho Falls, ID, January.

Opresko, D. M., B. E. Sample, and G. W. Suter, II, 1995, Toxicological Benchmarks for Wildlife: 1995 Revision, ES/ER/TM-86/R2, Oak Ridge National Laboratory, Oak Ridge, TN.

Ramsdell, J.V. Jr., C.A. Simonen, and K. W. Burk, 1994, Regional Atmospheric Transport Code for Hanford Emission Tracking (RATCHET), PNWD-2224 HEDR, Battelle Pacific Northwest Laboratories, Richland Washington, February.

Reynolds, T. D. et al., 1986, "Vertebrate Fauna of the Idaho National Engineering Laboratory," Great Basin Naturalist, 46:513-527.

Reynolds, T. D., J. W. Connelly, D. K. Halford, and W. J. Arthur, 1986, "Vertebrate Fauna of the Idaho National Environmental Research Park," Great Basin Naturalist, Vol. 46, No. 3, pp. 513-527.

Rood, S. M., G. A. Harris, and G. J. White, 1995, Background Dose Equivalent Rates and Surficial Soil Metal and Radionuclide Concentrations for Idaho National Engineering Laboratory, INEL94/0250, Rev. 0, February

Rope, R. C., N. L. Hampton, and K. A. Finley, 1993, "Ecological Resources," Environmental Resource Document for the Idaho National Engineering Laboratory, Vol. 1 and 2, EGG-WMO-10279, EG\&G Idaho Inc.

Schindler, R. E., 1995, Emissions Model of ICPP Waste Treatment Operations for the Permit to Operate Application, INEL-95/098, Lockheed Martin Idaho Technologies Company, February.

Suter, G. W. II, 1993, Ecological Risk Assessment, Lewis Publishers, Chelsea, Michigan, 538 pp.

Suter, G. W., II, 1989, Chapter 2, "Ecological Endpoints," Ecological Assessments of Hazardous Waste Sites: A Field and Laboratory Reference document, W. Warren-Hicks, B. R. Parkhurst, and S. S. Baker (eds.), U.S. Environmental Protection Agency, March, EPA 1600/3-89/013.

Suter, G. W., II, M. E. Will, and C. Evans, 1993, Toxicological Benchmarks for Screening Potential Contaminants of Concern for Effects on Terrestrial Plants, Environmental Restoration Division, ORNL Environmental Restoration Program, Oak Ridge National Laboratory, September, ES/ER/TM-85.

Travis, C. C. and A. D. Arms, 1988, "Bioconcentration of Organics in Beef, Milk, and Vegetation," Environmental Science and Technology, 22:271-274.

VanHorn, R., N. L. Hampton, and R. C. Morris, 1995, Guidance Manual for Conducting Screening Level Ecological Risk Assessment at the INEL, Idaho National Engineering Laboratory, EG\&G Idaho, Inc., Idaho Falls, D, INEL-95/0190, April.

Warren, R.W. and R.G. Mitchell, in press, Radionuclide Concentrations in Big Game from a Nuclear Power Research Site in Idaho, 1972-1996. 
Appendix A

Chemical Emission Rates 


\section{UPPER-ENVELOPE NWCF EMISSIONS FOR SCREENING-LEVEL RISK ANALYSIS}

Estimates of maximum atmospheric emissions of hazardous chemicals from NWCF operations are needed for a screening-level risk analysis of the NWCF emissions. The following section develops an upper-envelope NWCF feed composition and calculates maximum annual, maximum hourly, and long-term emissions of the hazardous metals, acid vapors, and organic compounds from the feed for current and future NWCF operation at temperatures of 500 to $600^{\circ} \mathrm{C}$. The estimated emissions are upper-envelope values based on an upper-envelope feed composition except for $\mathrm{Hg}$ whose lifetime emission is based on the total inventory $\mathrm{Hg}$ of the tank farm. The calculated emissions are for most species much higher than actual emissions.

\section{NWCF Feed Term}

Most of the upper-envelope emissions estimates are based on upper-envelope feed compositions which are estimates of the maximum concentrations that might be expected in any current or future NWCF feed based on current analyses of the tank farm. Separate upper-envelope (worst single year) annual and hourly feed rates are developed based on the NWCF $\mathrm{NO}_{x}$ emissions limits.

\subsection{Feed composition}

The derivation of the upper-envelope NWCF feed composition begins with Table 1 which gives the tank farm composition data available at the end of 1998. Two of the tanks are empty (to their operating heels of 5000 to $15,000 \mathrm{gal}$ ), two contain small quantities of dilute wastes, and seven contain significant volumes of waste. Some of the wastes from WM-189 and -185 are being calcined during 1999 NWCF operation. Current plans are to evaporate blends of wastes from WM-181, -184 , and -186 in the High Level Liquid Waste (HLLWE), and store the concentrated bottoms in two tanks. Table 2 shows the expected compositions and volumes in the tank farm after the evaporation in the HLLWE (ignoring waste calcination in 1999 and future waste generation). Table 3 identifies the highest concentration in Table 2 for each of the RCRA

metals. The upper-envelope concentrations are selected depending on the number of tanks for which analyses are available:

1. The highest concentration from Table 2 is used when analyses are available for every tank.

2. For those species for which not all the tanks are analyzed, one standard deviation of the concentrations was added to the highest concentration. For those species for which only one or two tanks have been analyzed, the concentrations in empty WM-188 were also considered 
3. For species which were not detected in the analyses $(\mathrm{Be}, \mathrm{Sb}, \mathrm{Tl})$, one half of the minimum detection limit was used.

4. The upper-limit concentration for $\mathrm{Hg}$ in Table 3 is derived in Section 3 based on the total tank farm $\mathrm{Hg}$ inventory from Table 1 accumulating in a postulated last tank.

Table 1. Chemical compositions of wastes in tank farm, December, 1998.

\begin{tabular}{|c|c|c|c|c|c|c|c|c|c|c|c|}
\hline $\begin{array}{l}\text { Waste } \\
\text { tank }\end{array}$ & WM-180 & WM-181 & WM-182 & WM-183 & WM-184 & WM-185 & WM-186 & WM-187 & WM-188 & WM-189 & WM-19 \\
\hline Vol. gal & 278600 & 275900 & 10300 & 23300 & 262600 & 74800 & 281500 & 29100 & 13500 & 146100 & 500 \\
\hline Sp. G. & 1.262 & 1.156 & 1.2 & 1.216 & 1.219 & 1.25 & 1.158 & 1.134 & 1.306 & 1.307 & \\
\hline Acid, $N$ & 1.14 & 1.8 & 1.07 & 1.69 & 1.67 & 1.58 & 1.36 & 1.78 & 2.65 & 2.57 & 0.022 \\
\hline $\mathrm{NO} 3, \mathrm{M}$ & 4.56 & 3.68 & 3.77 & 4.34 & 3.99 & 4.93 & 2.945 & 3.04 & 5.85 & 6.23 & $0.01 \varepsilon$ \\
\hline $\mathrm{F}, \mathrm{M}$ & 0.042 & 0.089 & 0.042 & 0.046 & 0.0232 & 0.16 & 0.040 & 0.119 & 0.302 & 0.222 & 0.007 \\
\hline $\mathrm{Cl}, \mathrm{M}$ & 0.031 & 0.012 & 0.019 & 0.0109 & 0.0275 & 0.028 & 0.0180 & 0.0035 & 0.0148 & 0.024 & $3.4 \mathrm{E}--$ \\
\hline $\mathrm{SO} 4, \mathrm{M}$ & 0.032 & 0.024 & 0.025 & 0.025 & 0.0274 & 0.036 & 0.029 & 0.010 & 0.0348 & 0.0067 & \\
\hline $\mathrm{P}, \mathrm{M}$ & & 0.0061 & $3 E-5$ & IE-4 & 0.0105 & 0.0026 & 0.0005 & & $3.5 \mathrm{E}-4$ & $2.9 \mathrm{E}-4$ & \\
\hline $\mathrm{Al}, \mathrm{M}$ & 0.63 & 0.22 & 0.604 & 0.59 & 0.507 & 0.74 & 0.264 & 0.323 & 0.828 & 0.915 & \\
\hline $\mathrm{Na}, \mathrm{M}$ & 2.0 & 0.9 & 1.113 & 0.695 & 1.284 & 1.313 & 0.841 & 0.118 & 0.738 & 0.901 & \\
\hline $\mathrm{K}, \mathrm{M}$ & 0.18 & 0.14 & 0.108 & 0.093 & 0.085 & 0.184 & 0.139 & 0.0137 & 0.142 & 0.114 & \\
\hline $\mathrm{Ca}, \mathrm{M}$ & 0.034 & 0.044 & 0.025 & 0.0366 & 0.016 & 0.070 & 0.050 & 0.046 & 0.148 & 0.084 & \\
\hline $\mathrm{B}, \mathrm{M}$ & 0.01 & 0.015 & 0.009 & 0.013 & $<0.014$ & 0.0195 & $<0.014$ & 0.014 & 0.037 & 0.025 & \\
\hline $\mathrm{Fe}, \mathrm{M}$ & 0.018 & 0.012 & 0.024 & 0.052 & 0.0146 & 0.0248 & 0.0156 & 0.0126 & 0.0535 & 0.025 & \\
\hline $\mathrm{Zr}, \mathrm{M}$ & $<0.001$ & 0.0046 & 0.006 & $<0.016$ & $<0.012$ & 0.011 & $<0.012$ & 0.015 & 0.0255 & 0.0357 & \\
\hline $\mathrm{Ag}, \mathrm{mg} / \mathrm{l}$ & 0.48 & 3.66 & & & & $\begin{array}{c}<0.8 \text { to } \\
10\end{array}$ & & & 5.1 & & \\
\hline As, $\mathrm{mg} / 1$ & 3.5 & $<3$ & & & & $\begin{array}{c}0.11 \text { to } \\
23\end{array}$ & & & 46 & & \\
\hline $\mathrm{Ba}, \mathrm{mg} / \mathrm{l}$ & 7.1 & 5.1 & & & & 9 & & & 13.5 & & \\
\hline $\mathrm{Be}, \mathrm{mg} / \mathrm{l}$ & & & & & & $<0.79^{\mathrm{u}}$ & & & $<0.79^{\mathrm{U}}$ & & \\
\hline $\mathrm{Cd}, \mathrm{mg} / \mathrm{l}$ & 90 & 584 & 105 & 135 & $<530$ & 172 & $<530$ & $<530$ & 1210 & 540 & \\
\hline $\mathrm{Cr}, \mathrm{mg} / \mathrm{l}$ & 198 & 151 & 260 & 675 & $<210$ & 255 & 215 & $<210$ & 750 & 225 & \\
\hline $\mathrm{Hg}, \mathrm{mg} /$ & 195 & 90 & 200 & 580 & 138 & 782 & 181 & 540 & 1500 & $\begin{array}{l}1024 / \\
2800^{\mathrm{a}}\end{array}$ & \\
\hline $\mathrm{Pb}, \mathrm{mg} /$ & 290 & 207 & & & 59 & 190 & 87 & & 200 & 216 & \\
\hline $\mathrm{Ni}, \mathrm{mg} / \mathrm{l}$ & 94 & 70 & & & $<243$ & 88 & $<243$ & & 270 & $<117$ & \\
\hline $\mathrm{Se}, \mathrm{mg} / \mathrm{l}$ & 0.82 & $<1$ & & & & $<1$ & & & & & \\
\hline $\mathrm{Sb}, \mathrm{mg} / \mathrm{l}$ & & & & & & $<2.45^{\mathrm{u}}$ & & & $<2.45^{\mathrm{U}}$ & & \\
\hline $\mathrm{Tl}, \mathrm{mg} / \mathrm{l}$ & & & & & & $<6.8^{\mathrm{u}}$ & & & $<6.8^{\mathrm{U}}$ & & \\
\hline $\mathrm{U}, \mathrm{mg} / \mathrm{l}$ & 78 & 76 & 63 & 89 & 43 & 76 & 91 & 11 & 120 & 54 & \\
\hline
\end{tabular}


Table 2. Expected calcineable wastes in tank farm after evaporation in the HLLWE.

\begin{tabular}{|c|c|c|c|c|c|c|}
\hline $\begin{array}{l}\text { Waste } \\
\text { tank }\end{array}$ & WM-180 & $\begin{array}{c}\text { WM- } \\
181 / 184\end{array}$ & $\begin{array}{c}\text { WM- } \\
181 / 186\end{array}$ & WM-185 & WM-187 & WM-189 \\
\hline Vol.gal & 278,600 & 233,000 & 185,000 & $74,800^{6}$ & 29,100 & $146,100^{5}$ \\
\hline Acid, $N$ & 1.14 & 2.9 & 3.35 & 1.58 & 1.78 & 2.57 \\
\hline NO3, M & 4.56 & 7.7 & 7.8 & 4.93 & 3.04 & 6.23 \\
\hline $\mathrm{F}, \mathrm{M}$ & 0.042 & 0.079 & 0.127 & 0.16 & 0.119 & 0.222 \\
\hline $\mathrm{Cl}, \mathrm{M}$ & 0.031 & 0.038 & 0.036 & 0.028 & 0.0035 & 0.024 \\
\hline $\mathrm{SO} 4, \mathrm{M}$ & 0.032 & 0.045 & 0.062 & 0.036 & 0.010 & 0.0067 \\
\hline $\mathrm{Al}, \mathrm{M}$ & 0.63 & 0.70 & 0.565 & 0.74 & 0.323 & 0.915 \\
\hline $\mathrm{Na}, \mathrm{M}$ & 2.0 & 2.00 & 1.95 & 1.313 & 0.118 & 0.901 \\
\hline $\mathrm{K}, \mathrm{M}$ & 0.18 & 0.18 & 0.32 & 0.184 & 0.0137 & 0.114 \\
\hline $\mathrm{Ca}, \mathrm{M}$ & 0.034 & 0.044 & 0.11 & 0.070 & 0.046 & 0.084 \\
\hline $\mathrm{B}, \mathrm{M}$ & 0.01 & $<0.025$ & $<0.033$ & 0.0195 & 0.014 & 0.025 \\
\hline $\mathrm{Fe}, \mathrm{M}$ & 0.018 & 0.024 & 0.033 & 0.0248 & 0.0126 & 0.025 \\
\hline $\mathrm{Zr}, \mathrm{M}$ & $<0.001$ & $<0.016$ & $<0.022$ & 0.011 & 0.015 & 0.0357 \\
\hline $\mathrm{Ag}, \mathrm{mg} / \mathrm{l}$ & 0.48 & & & $<0.8$ to 10 & & \\
\hline $\mathrm{As}, \mathrm{mg} / \mathrm{l}$ & 3.5 & & & 0.11 to 23 & & \\
\hline $\mathrm{Ba}, \mathrm{mg} / \mathrm{l}$ & 7.1 & & & 9 & & \\
\hline $\mathrm{Be}, \mathrm{mg} / \mathrm{l}$ & & & & $<0.79^{\mathrm{u}}$ & & \\
\hline $\mathrm{Cd}, \mathrm{mg} / \mathrm{l}$ & 90 & $<945$ & $<1240$ & 172 & $<530$ & 540 \\
\hline $\mathrm{Cr}, \mathrm{mg} / \mathrm{l}$ & 198 & $<325$ & 440 & 255 & $<210$ & 225 \\
\hline $\mathrm{Hg}, \mathrm{mg} / \mathrm{l}$ & 195 & 210 & 343 & 782 & 540 & $\begin{array}{l}1024 / \\
2800^{\mathrm{a}}\end{array}$ \\
\hline $\mathrm{Pb}, \mathrm{mg} / \mathrm{l}$ & 290 & 190 & 285 & 190 & & 216 \\
\hline $\mathrm{Ni}, \mathrm{mg} / \mathrm{l}$ & 94 & $<315$ & $<420$ & 88 & & $<117$ \\
\hline $\mathrm{Se}, \mathrm{mg} / \mathrm{l}$ & 0.82 & & & $<1$ & & \\
\hline $\mathrm{Sb}, \mathrm{mg} / \mathrm{l}$ & & & & $<2.45^{\mathrm{u}}$ & & \\
\hline $\mathrm{Tl}, \mathrm{mg} / \mathrm{l}$ & & & & $<6.8^{\mathrm{u}}$ & & \\
\hline $\mathrm{U}, \mathrm{mg} / \mathrm{l}$ & 78 & 93 & 194 & 76 & 11 & 54 \\
\hline
\end{tabular}

$\mathrm{u}, \quad$ not detected; given value is the minimum detection limit.

a, There is a discrepancy between the measured concentration of 1024 and the concentration of 2800 calculated from known inputs.

b, Much of this volume will be solidified by 1999 NWCF operation.

Aluminum nitrate must be added to the wastes in the tank farm to achieve $\mathrm{Al}$ concentrations significantly greater than the combined concentrations of $\mathrm{Na}$ and $\mathrm{K}$ before the waste can be calcined in the NWCF. The upper-envelope flowsheet ignores the need for addition of aluminum nitrate and other chemicals and assumes that the NWCF can calcine straight tank farm waste. This assumption provides a margin of conservatism of at least a factor of two for every actual flowsheet. 
Table 3. Composition of upper-limit NWCF feed.

\begin{tabular}{|c|c|c|c|c|}
\hline & $\begin{array}{c}\text { Highest } \\
\text { concentration in } \\
\text { Table } 2 \\
\end{array}$ & $\begin{array}{l}\text { Concentration in } \\
\text { WM-188 }\end{array}$ & $\begin{array}{l}\text { Number of non- } \\
\text { empty tanks with } \\
\text { analyses }\end{array}$ & $\begin{array}{l}\text { Upper-limit } \\
\text { concentration }\end{array}$ \\
\hline Acid, $\mathrm{N}$ & 3.35 & & 7 & 3.35 \\
\hline $\mathrm{Cl}, \mathrm{M}$ & 0.038 & & 7 & 0.043 \\
\hline $\mathrm{Ag}, \mathrm{mg} / \mathrm{l}$ & 10 & 5 & 2 & 14 \\
\hline As, mg/l & 23 & 46 & 2 & 58 \\
\hline $\mathrm{Ba}, \mathrm{mg} / \mathrm{l}$ & 9 & 13.5 & 2 & 17 \\
\hline $\mathrm{Be}, \mathrm{mg} / 1$ & $<0.79^{u}$ & $<0.79^{u}$ & 1 & 0.4 \\
\hline $\mathrm{Cd}, \mathrm{mg} / \mathrm{l}$ & $<1240$ & & 7 & 1240 \\
\hline $\mathrm{Cr}, \mathrm{mg} / \mathrm{l}$ & 440 & & 7 & 440 \\
\hline $\mathrm{Hg}, \mathrm{mg} / \mathrm{l}$ & 2800 & & 7 & 3000 \\
\hline $\mathrm{Pb}, \mathrm{mg} / \mathrm{l}$ & 290 & & 7 & 290 \\
\hline $\mathrm{Ni}, \mathrm{mg} / \mathrm{l}$ & $<420$ & & 7 & 420 \\
\hline $\mathrm{Se}, \mathrm{mg} / \mathrm{l}$ & $<1$ & & 1 & 1 \\
\hline $\mathrm{Sb}, \mathrm{mg} / \mathrm{l}$ & $<2.45^{\mathrm{u}}$ & $<2.45^{\mathrm{u}}$ & 1 & 1.225 \\
\hline $\mathrm{Tl}, \mathrm{mg} / \mathrm{l}$ & $<6.8^{\mathrm{u}}$ & $<6.8^{\mathrm{u}}$ & 1 & 3.4 \\
\hline $\mathrm{U}, \mathrm{mg} / \mathrm{l}$ & 194 & & 7 & 194 \\
\hline
\end{tabular}

\subsection{NWCF feed volumes and maximum rate}

The total volume of the wastes in Table 2 is 947,000 gal. An additional allowance of $25 \%$ for future wastes (returned scrub solutions, decontamination solutions, PEW evaporator bottoms) brings the volume to be calcined to $1,180,000 \mathrm{gal}(4,480,0001)$.

Major constraints on the NWCF feed rate are an hourly $\mathrm{NO}_{x}$ emission limit of $472 \mathrm{lb} / \mathrm{hr}$ and an annual $\mathrm{NO}_{\mathrm{x}}$ emission limit of 1700 tons/yr. The feed that allows the largest feed volume with a fixed $\mathrm{NO}_{\mathrm{x}}$ limit is the one with the lowest nitrate concentration, which is a WM-185 blend (not the upper-envelope feed of Table 3 ) containing about $6 \mathrm{M}$ nitrate. This feed allows a gross hourly feed rate of $205 \mathrm{gph}(778 \mathrm{l} / \mathrm{hr})$. (This calculation ignores the nitrate content of the calcined solids and assumes that every mole of nitrate in the feed results in an atmospheric emission of one mole of $\mathrm{NO}_{\mathrm{x}}$.) The NWCF feed contains 7.5 to $25 \%$ recycled scrub solution. With the maximum $92.5 \%$ waste (and the scrub solution having the same nitrate concentration as the waste), the upper-envelope net feed rate becomes $190 \mathrm{gph}(718 \mathrm{l} / \mathrm{hr})$.

\section{Removal of Non-Volatile Calcine Species}

The non-volatile calcine species can be emitted both directly in the calciner off-gas and indirectly from auxiliary systems as shown in Figure 3 of the SLRA. The auxiliary systems are: 1) NWCF sparged feed and sump vessels which are an integral part of the NWCF, 2) PEW evaporator and LET\&D which are independent systems that operate at the same time as the 


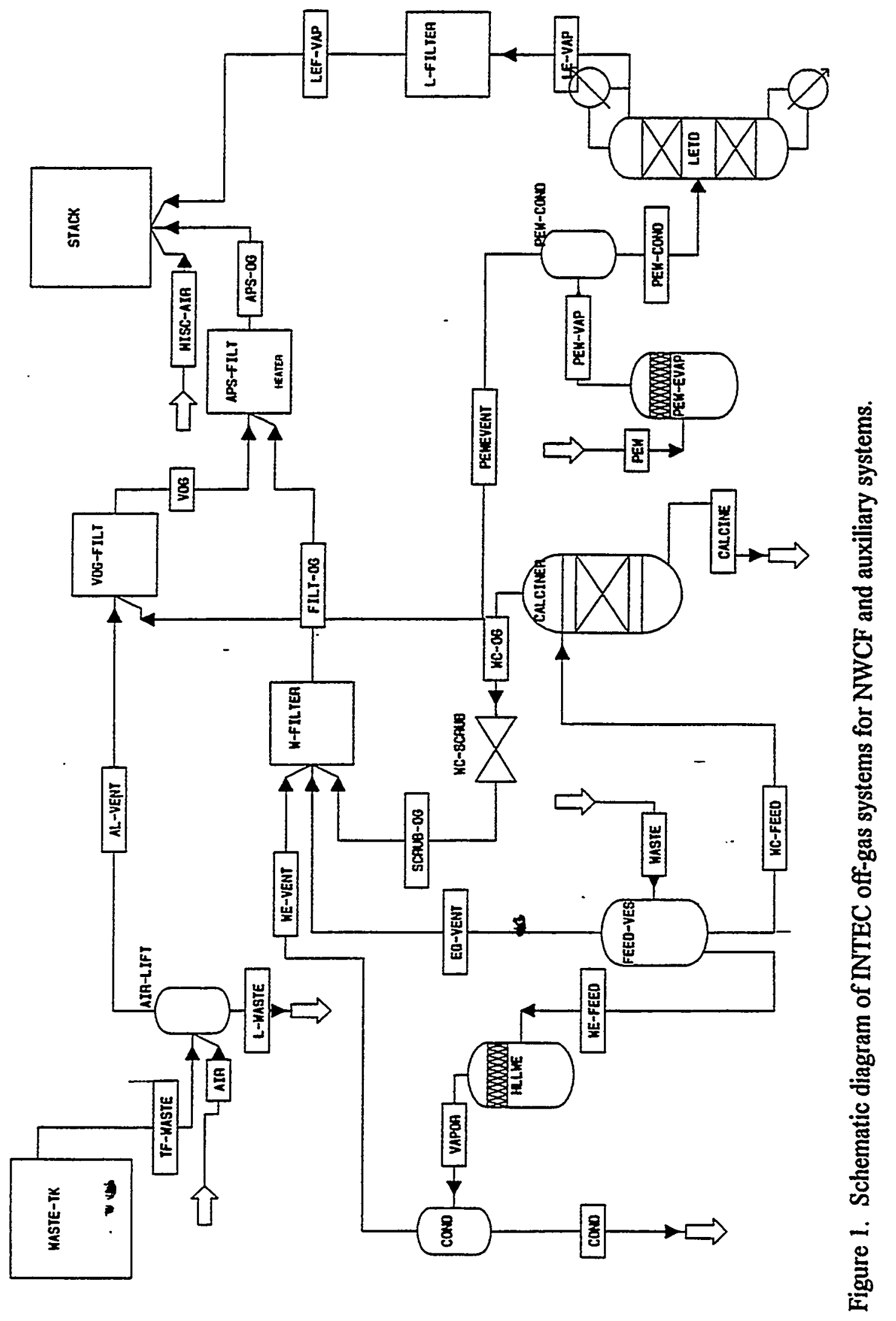


NWCF, 3) the air-lift pump in waste tank WM-189 which is used transfer waste from WM-189 (and no other tank) to the NWCF, and 4) the HLLWE which is an independent system that does not operate at the same time as the NWCF.

\subsection{NWCF calciner emissons}

When calcined, most of the metals of Tables 1,2 , and 3 form non-volatile oxides which are readily scrubbed and filtered from the off gas in the off-gas system, shown in Figure 1 and in Figure 3 of the the SLRA, which contains a scrub system, a set of Si-gel absorbers, and a set of HEPA filters. It is followed by the APS filters which are an independent system. The decontamination efficiency (DF) of the off-gas system (input/effluent) is assumed to be be the same for all of the non-volatile metal oxides.

The solids retention in the initial section of the calciner, consisting of the calciner vessel, cyclone, quench tower, Venturi scrubber, and mist eliminator, is lumped together for estimating the emissions of non-volatile solids, because the most extensive measured data ${ }^{1}$ on this section of a calciner are overall DF's for this section from the WCF (the predecessor of the NWCF) which had an off-gas system similar to that of the NWCF. The measured ${ }^{1} D F ' s$, in this section of the WCF, for non-volatile solids represented by ${ }^{90} \mathrm{Sr}$, exceeded 2000 for the runs using in-bed combustion. Some measurements ${ }^{2,3}$ during NWCF cold operation indicate that the overall DF (feed-to-effluent) through the scrub system for the NWCF is 5000 to 10,000 .

The silica-gel absorbers that follow the scrub system can also remove solids. For conservatism, no credit is taken for the absorbers in this model because they are occasionally left off line. (When operating, they achieve a DF for solids of about 10.)

The NWCF filter system consists of four parallel banks of filters which each filter the off gas through three HEPA filters in series. The filters are tested individually, when purchased, for the HEPA filter standard of $99.97 \%$ removal of a 0.3 micron test aerosol. Although each filter bank contains three stages of filters, these banks are leak tested after installation to verify an overall efficiency for the set of three filters equivalent to two HEPA filters in series (i. e., two stages of filters with a test aerosol removal efficiency of $99.97 \%$ each). Thus, the filter banks always meet the test criteria (penetration of $<9 \mathrm{E}-8$ ) when put on line. Filter deterioration in service is detected by changes in pressure drops or by radiation buildup on the APS filters that follow. Filters are taken out of service and replaced whenever signs of filter degradation are observed.

The NWCF off-gas next goes to the APS system which provides another stage of filtration with HEPA filters. The APS filters are well heated and essentially always meet their test criteria of $99.97 \%$ efficiency as determined by the guidelines of ASME N 510, Section 10.

The overall (long-term average) NWCF DF for non-volatile species was determined by comparison ${ }^{4}$ of the stack emissions ${ }^{5,6,7}$ of ${ }^{90} \mathrm{Sr}$ with the ${ }^{90} \mathrm{Sr}$ in the NWCF feeds during months of NWCF operation in 1991, 1993, and 1997. The ratio of the total ${ }^{90} \mathrm{Sr}$ in the NWCF feed during 
these years to the total stack ${ }^{90} \mathrm{Sr}$ emission for the months of NWCF operation is $5.4 \mathrm{E}+08$ which is used as an overall DF for all non-volatile species in the NWCF. This overall DF based on stack emissions includes emissions from all auxiliary operations and coincident INTEC operations (e. g., the PEW evaporator and LET\&D). This DF based on long-term emissions data includes the effects of operating upsets. The DF of $5.4 \mathrm{E}+08$ is lower than for "normal" operation because it is effected strongly by periods of upset operation.

The decontamination factors (reciprocal of penetration) of non-volatile species for the NWCF and APS filters in Table 4 were selected to obtain an overall DF of 5.4E+08. The APS filter, which is less vulnerable to wetting and has a good retest record, is assigned a DF of 300 , and the NWCF filter set is assigned a DF of 900 (about $97 \%$ efficiency for each of two filters in series). The "normal' filter efficiencies are much higher, but short periods of degraded operation weigh heavily on the long-term average efficiency.

Table 4. Decontamination factors of the NWCF and APS off-gas systems used in emissions calculations for non-volatile solids.

\begin{tabular}{lc}
\hline \multicolumn{1}{c}{ Section } & Decontamination Factor \\
\hline Calciner, cyclone, and scrub system & 2000 \\
Absorbers & 1 \\
NWCF filters & 900 \\
APS filter & 300 \\
Overall & $5.4 \mathrm{E}+8$ \\
\hline
\end{tabular}

\subsection{Auxiliary emissions sources}

Auxiliary systems with emissions are 1) the NWCF process vessels, 2) the PEW evaporator and Liquid Effluent Treatment and Disposal (LET\&D) systems, 3) the WM-189 airlift, and 4) the High Level Liquid Waste Evaporator (HLLWE). Only the NWCF process vessels are an integral part of the NWCF. The overall NWCF DF of 5.4E+08 includes emissions from the NWCF process vessels, and coincident operation of the PEW evaporator, and LET\&D (starting in 1993).

\section{NWCF process vessels}

The NWCF facility contains sparged feed-storage vessels, sump vessels, and air-lifts whose offgas bypasses the calciner and scrub system and joins the calciner off gas before the NWCF filters. The emissions from these vessels and air-lifts are a minor fraction of the NWCF emissions because their gas flows and velocities are lower than in the NWCF scrub system. The emissions from the process vessels are included in the overall NWCF DF of 5.4E+08 because these emissions were included in the stack effluent samples on which the overall NWCF DF is based.

The primary mechanism of particulate emission from the NWCF process vessels and airlifts is entrainment of liquid droplets by the sparge and airlift air. An entrainment study ${ }^{10}$ on evaporators indicates that an entrainment factor of $1 \mathrm{E}-4 \mathrm{~kg}$ liquid/ $\mathrm{kg}$ gas is conservative for gas flows well in excess of the NWCF sparge rates of about $1 \mathrm{ft}^{3} / \mathrm{s}-\mathrm{ft}^{2}$. The total air input to the NWCF sparges and airlifts is $<100 \mathrm{scfm}$ which is $<214 \mathrm{~kg}$ air $/ \mathrm{hr}$. The maximum particulate entrainment from the vessels and airlifts for this air input is $0.0214 \mathrm{~kg} / \mathrm{hr}$ (which is reduced 
greatly by the NWCF and APS filters before reaching the stack). The NWCF (maximum) feed rate of $778 \mathrm{l} / \mathrm{hr}$ (with a density of $1.27 \mathrm{~kg} / \mathrm{l}$ ) is $988 \mathrm{~kg} / \mathrm{hr}$. The entrainment relative to the feed is $2.15 \mathrm{E}-05$ which corresponds to a DF of 46,000 (before filtration). This entrainment is $4.3 \%$ of the particulate emission from the calciner and scrub system, obtained using the DF of Table 4, for the point before the NWCF filters where the vessel off-gas flow joins the calciner off gas.

\section{PEW evaporator and LET\&D}

The PEW evaporator and LET\&D are independent of the NWCF, but they often operate at the same time as the NWCF. The PEW evaporator and LET\&D operate in sequence and usually operate together. The PEW evaporator condensate is vaporized by the LET\&D, filtered (double HEPA filters) and discharged to the stack as a vapor. The emission route for the two systems is the LET\&D vapor. Emissions for coincident operation of the PEW evaporator and LET\&D are included in the overall DF for the NWCF because emissions for PEW evaporator and LET\&D operation at normal rates were included in the stack effluent samples on which the overall NWCF DF is based.

The non-volatile particulate emissions in the LET\&LD vapor are very low (at least a factor of a 1000 lower than from the NWCF) because the PEW is evaporated in series by the PEW evaporator and LET\&D systems (each of which have a DF for non-volatile solutes ${ }^{8,9}$ of 1000 to $10,000)$, and the vapor is then filtered through two HEPA filters in series. In addition, the solute concentrations of solutes in the PEW are about a factor of 100 lower than in the NWCF feed.

The only other emission source from the PEW evaporator is a vent from the condenser. The vent discharges the purge air from the instrument probes and air displaced by vessel filling to the Vessel Off Gas (VOG) system which filters effluents with a VOG filter and the APS filter (Figure 1). The emission from the vent is very small because of the small gas flow (5 to 10 $\mathrm{scf} / \mathrm{hr}$ ), and the vent location at the condenser outlet cools the off gas and washes the off gas with condensing vapor before it vents.

\section{WM-189 air-lift}

One active waste storage tank (WM-189, and also spare tank WM-190) uses a 3-stage air-lift pump for liquid transfers. Emissions from use of the WM-189 air-lift pump are not included in the NWCF overall DF because this air-lift pump was not operated during the NWCF operating period on which the overall DF is based. The motive air input, which is not metered, is estimated at a maximum of $300 \mathrm{scf} / \mathrm{min}$ which has a potential for substantial entrainment. (Normally the motive air input is much less than the maximum capacity.) Most of the air-lift motive air discharges into the tank, which serves as a huge (50-ft diameter) settling chamber, and then goes to the VOG system which filters it through the (single-stage) VOG filter and the APS filter before discharging to the stack. (A small portion of the air goes with the liquid to the NWCF and discharges through the NWCF off-gas system which has one more filter than the VOG system.) The WM-189 airlift has an atmospheric emission only when being used to transfer liquid out of WM-189. The other (active) waste storage tanks use steam jets which have no effluent gases. 
The maximum relative entrainment from the airlift comes with the maximum air input of 300 $\operatorname{scfm}(640 \mathrm{~kg} / \mathrm{hr})$ and the minimum liquid flow of about $30 \mathrm{gpm}(130 \mathrm{~kg} / \mathrm{min})$. An entrainment factor of $5 \mathrm{E}-5 \mathrm{~kg}$ liquid $/ \mathrm{kg}$ air is used because of the long settling time and low air velocity $(<1$ $\%$ of the air velocities in the sparged tanks) in the tank. (The entrainment factor of $5 \mathrm{E}-5 \mathrm{~kg}$ liquid $/ \mathrm{kg}$ air is conservative compared to the data ${ }^{10}$ for low gas velocities.) With this entrainment factor, the particulate entrainment from the tank is $0.032 \mathrm{~kg} / \mathrm{hr}$ from the tank; and the relative entrainment is one part in 240,000 of the liquid transferred. The filter DF's assumed for this analysis are 30 for the VOG filter (the same as for a single NWCF filter in Table 4) and 300 for the APS filter (from Table 4). The overall particulate DF for the filtered effluent is 2.2E+09 as compared to $5.4 \mathrm{E}+08$ for the NWCF (i. e., addition of the calculated airlift emission to the NWCF emission would increase the calculated overall emission by about $50 \%$ ).

\section{High level liquid waste evaporator}

The high level liquid waste evaporator (HLLWE) uses the same feed and sump vessels as the NWCF, but is not a part of the NWCF. It does not operate at the same time as the NWCF because of conflicting needs for the same feed and sump vessels.

HLLWE operation emits entrained liquid drops from the sparged NWCF vessels it uses for the feed and product. As during NWCF operation, the vessel off gases discharge through the NWCF and APS filters. The emissions are about the same as estimated above for sparging the same vessels with NWCF operation -- about $4 \%$ of the particulate emissions estimated for NWCF operation.

The HLLWE condensate is evaporated by the PEW evaporator, whose condensate is vaporized and discharged from the LET\&D. The emissions via this route are very small the liquid goes through three stages of evaporation (each with particulate DF's of 1000 to 10,000) and two sets of HEPA filters (with a combined DF of about 900 ) before discharge.

Another minor HLLWE emission route is the vent on the condenser which vents the HLLWE purge air and the air displaced by filling. The emission is very small because of the small purge air input (about $10 \mathrm{scf} / \mathrm{hr}$ ). The discharge route is via the NWCF and APS filters. 


\subsection{Combined particulate emissions}

The WM-189 air-lift pump is only one of the above sources that is not included in the overall NWCF DF of 5.4E+08. The overall particulate emission DF (reciprocal of emission fraction), obtained by adding the WM-189 air-lift pump emission to the emission for the NWCF and coincident operations is $4 \mathrm{E}+08$. This DF would apply to the maximum annual and hourly emissions. The DF for the lifetime emissions can consider that an airlift is found only in one (WM-189) of the five tanks of Table 2. Weighting of the airlift usage for long-term emissions at $33 \%$ of the wastes (which is a conservative weighting allowing for some reuse of WM-189) gives a combined $\mathrm{DF}$ of $5 \mathrm{E}+08$.

\section{Volatile Mercury Compounds}

Mercury volatilization during calcination is a major concern because the mercury in the NWCF feed is essentially all volatilized from the calciner, mostly as $\mathrm{HgCl}_{2}$. (The $\mathrm{Hg}$ is $\mathrm{HgCl}_{2}$ in the calciner off gas and scrub system because of the presence of $\mathrm{HNO}_{3}$ and $\mathrm{HCl}$ in the off gas.) The mercury volatilized from the calciner is collected in the scrub solution in which the mercury accumulates throughout the campaign. Scrub solution is recycled back into every feed batch, but the recycled mercury is revolatilized and returns to the scrub solution.

\subsection{Emission factor for mercury}

$\mathrm{Hg}$ compounds are emitted from the NWCF scrub system because of: 1) the volatility of $\mathrm{HgCl}_{2}$ (and other molecular $\mathrm{Hg}$ compounds) in the scrub solution, and 2) incomplete absorption of the $\mathrm{Hg}$ compounds in the scrub system. There is essentially no removal of molecular $\mathrm{Hg}$ compounds by the filters. Thus, the NWCF Hg emission depends on the concentration and chemical species distribution in the scrub solution as well as the $\mathrm{Hg}$ concentration in the feed.

The emission factor for $\mathrm{Hg}$ used in this evaluation is based on off-gas samples taken with a activated carbon cartridge during 1997-1998 NWCF operation. The charcoal cartridges used to monitor the radioiodine emissions from the stack were also analyzed for their $\mathrm{Hg}$ content which was used to calculate emission as a fraction of the $\mathrm{Hg}$ in the net feed. [Although used to measure radioiodine, activated carbon filters are generally very efficient (90\%) for mercury ${ }^{11}$ or other higher molecular weight vapors]. The fractional $\mathrm{Hg}$ emissions, from 3 sample cartridges with sample durations of 2 to 4 months, averaged $2.55 \%$ of the $\mathrm{Hg}$ in the net feed with a standard deviation of $0.865 \%$. An upper-limit emission of $3.7 \%$ (or a feed-based DF of 27) is obtained by assuming a charcoal collection efficiency of $90 \%$ and adding one standard deviation to cover process variations. (The $3.7 \%$ could also be considered to represent $70 \%$ collection efficiency without an allowance for process variation.)

Some concern has been expressed that the $\mathrm{Hg}$ emissions determined using the charcoal cartridges could be low because of charcoal saturation and $\mathrm{Hg}$ breakthrough. We do have some evidences that there was no significant breakthrough of $\mathrm{Hg}$ during the sampling period:

1. The average $\mathrm{Hg}$ concentrations on the charcoal samples were 11 to $22 \mathrm{ppm}$ which is much less than the typical absorption capacity of these absorbents $\left(25,000 \mathrm{ppm}^{12}\right)$. 
2. The most likely form of $\mathrm{Hg}$ is $\mathrm{HgCl}_{2}$ which is readily sorbed by charcoal at ambient temperature because of its low ambient vapor pressure $(0.022 \mathrm{~Pa}$ by the equation of Bernard $^{13}$ ).

3. The analysts report that the $\mathrm{Hg}$ on the charcoal was very non-uniform in distribution (requiring extensive mixing for aliquot replication) which indicates loading of the $\mathrm{Hg}$ on the front of the charcoal. A saturated charcoal sample would have a uniform concentration at the saturation level.

4. The stack samples ${ }^{14,15,16}$ taken during 1993 NWCF operation using an EPA sample train (40CFR266, App. IX) showed $\mathrm{Hg}$ emissions averaging $0.5 \%$ of the $\mathrm{Hg}$ in the feed which is a factor of five lower than obtained in 1997-1998 with the charcoal sampler.

5. The sample interval for the three samples taken with the charcoal varied. One sample spanned 2 months and the other two samples spanned 4 months. If significant breakthrough were occurring, the sample with the shorter span would show a higher measured off-gas $\mathrm{Hg}$ concentration because it operated for the smaller fraction of the sample period after breakthrough. Instead, the sample of shorter duration showed an offgas $\mathrm{Hg}$ concentration in between those of the longer samples.

\subsection{Lifetime emission}

The waste in the INTEC tank farm contains about $2.6 \mathrm{Mg}$ (nearly 3 tons) of $\mathrm{Hg}$ which could be recycled to the tank farm and fed to the NWCF more than once during the calcination of the waste in the tank farm. Most of the Hg in NWCF feed is collected in the scrub solution and returned to the tank farm at the end of the operating campaign or when the scrub solution is purged because of operating upsets. In the 1997-1998 NWCF operation, about $87 \%$ of the $\mathrm{Hg}$ fed to the NWCF was returned tank farm in the scrub solution and vessel flushes at the end of the campaign. (The $13 \%$ of the $\mathrm{Hg}$ not returned to the tank farm includes the 2.5 to $3.7 \%$ emitted from the stack, the $\mathrm{Hg}$ in the calcined solids, $\mathrm{Hg}$ absorbed in the $\mathrm{Si}$-gel absorbers, and $\mathrm{Hg}$ plated out in process piping.) For a conservative analysis, this return fraction is increased to $90 \%$.

The lifetime Hg emission depends on the management of the high-Hg scrub solutions which, after the 1997-1998 NWCF operation, contained over half of the Hg in the tank farm. The usual practice is to evaporate the scrub solutions (and decontamination wastes) from the previous run in the HLLWE and blend them into the feed for the next run. (The Hg emissions from HLLWE operation are discussed in section 3.3.) This practice minimizes the number of tanks in use, but also produces the worst case lifetime emission because the $\mathrm{Hg}$ in the scrub solutions is refed to the NWCF several times. The worst-case lifetime Hg emission is calculated assuming calcination of all of the waste in the tank farm with the returned scrub solution:

1. The waste is calcined in 5 runs: 1) (the current run) the wastes from WM-185 and -189 , 2) an evaporated blend (0.5:1) of wastes from WM-181 and -184,3) an evaporated blend $0.5: 1)$ of wastes from WM-181 and $-186,4)$ the waste from WM-180, and 5) the newlygenerated and miscellaneous wastes. 
2. $90 \%$ of the $\mathrm{Hg}$ in the feed to each run is returned to the tank farm in the scrub solution and flushes and then blended into the feed for the next run (worst-case sequence).

3. The emission for each run is $3.7 \%$ of the $\mathrm{Hg}$ in the feed.

The lifetime $\mathrm{Hg}$ emission for the above scenario is $340 \mathrm{~kg}$.

\subsection{Auxiliary sources}

Most of the $\mathrm{Hg}$ emissions from the auxiliary systems (Figure 1) are included in the $3.7 \%$ emission factor because the $3.7 \%$ factor is based on stack measurements with the auxiliary systems running. The Hg emissions from the NWCF scrub system are much higher than the auxiliary system emissions because the NWCF scrub system has a higher liquid temperature $\left(74^{\circ} \mathrm{C}\right.$ ), a higher gas flow (about $1300 \mathrm{scf} / \mathrm{min}$ ), and a higher $\mathrm{Hg}$ concentration in the liquid (10 to $50 \mathrm{~g} / \mathrm{l})$.

\section{PEW evaporator and LET\&D}

The PEW evaporator and LET\&D operate in sequence and usually operate together. The PEW evaporator condensate is vaporized by the LET\&D, filtered (double HEPA filters) and discharged to the stack. The emission route is the LET\&D vapor. The PEW evaporator and LET\&D were processing a normal volume of feed (about 30,000 gal/mo.) during 1997-1998 period of NWCF operation during which the NWCF Hg emission was measured. Hence the NWCF emission factor of $3.7 \%$ includes concurrent operation of the PEW evaporator and LET\&D.

Planning is beginning on the characterization of the PEW evaporator and LET\&D. There is a set $^{8}$ of data on $\mathrm{Hg}$ behavior in the LET\&D during a period in 1993 which included some NWCF operation. The Hg concentrations in the condensate fed to the LET\&D ranged from 0.1 to 10 $\mathrm{mg} / \mathrm{l}$. The $\mathrm{Hg}$ behavior was evaluated by comparing the $\mathrm{Hg}$ concentrations in the feed and bottoms. The test results ${ }^{8}$ indicate that essentially all of the $\mathrm{Hg}$ is retained in the LET\&D bottoms; the material balances were 93.6 to $158 \%$ retention in the bottoms. A worst-case LET\&D Hg emission, based on $30,000 \mathrm{gal} / \mathrm{mo}$. of PEW containing $10 \mathrm{mg} \mathrm{Hg} / 1$ and on a LET\&D $\mathrm{Hg}$ retention of $93.6 \%$, is $0.9 \mathrm{~kg} / \mathrm{yr}$ which is minor compared to the $\mathrm{Hg}$ emissions attributed (above) to the NWCF. The more likely LET\&D Hg emissions are a few $\mathrm{g} / \mathrm{yr}$.

The only direct emission source from the PEW evaporator is a vent from the condenser. The vent discharges the purge air from the instrument probes and air displaced by filling. The $\mathrm{Hg}$ emission from the vent is very small because of the small gas flow (5 to $10 \mathrm{scf} / \mathrm{hr}$ ), the low temperature at the condenser $\left(<35^{\circ} \mathrm{C}\right)$, and the low $\mathrm{Hg}$ concentrations in the condensate $(<10$ $\mathrm{mg} / \mathrm{l}$ ). The vent emissions are included in the stack effluent sampled by the charcoal filter sampler used to develop the $3.7 \% \mathrm{Hg}$ emissions fraction.

2. NWCF process vessels 
The NWCF facility, shown in Figure 1, contains sparged feed-storage vessels, sump vessels, and air-lifts whose off-gas bypasses the calciner and scrub system and joins the calciner off gas before the filters. The $\mathrm{Hg}$ emissions from these vessels and air-lifts are a minor fraction (estimated by ratioing off-gas flows and $\mathrm{HgCl}_{2}$ vapor pressures at about $0.1 \%$ ) of the NWCF $\mathrm{Hg}$ emissions because their temperatures $\left(<35^{\circ} \mathrm{C}\right.$ ) and gas flows (totaling $<100 \mathrm{scf} / \mathrm{min}$ ) are much lower than in the NWCF scrub system. The Hg concentrations are also much lower than in the scrub system except for the one tank which receives some scrub solution. Emissions in the off gas from these vessels are also included in the stack effluent sampled by the charcoal filter sampler used to develop the $3.7 \% \mathrm{Hg}$ emissions fraction.

\section{WM-189 air-lift}

One active waste storage tank (WM-189 and also spare tank WM-190) uses an air-lift pump for liquid transfers. The air input, which is not metered, is estimated at maximum of $300 \mathrm{scf} / \mathrm{min}$ which is substantial but still less than the $1300 \mathrm{scf} / \mathrm{min}$ in the NWCF scrub system. (Normally the motive air input is much less than the maximum capacity.) The $\mathrm{Hg}$ emission, which was not included in the 1997 stack charcoal samples because the air-lift was not used at that time, is a small fraction (estimated by ratioing off-gas flows and $\mathrm{HgCl}_{2}$ vapor pressures at less than $0.1 \%$ ) of the emission from the NWCF scrub system because of the lower liquid temperature $\left(<20^{\circ} \mathrm{C}\right)$, air throughput, and aqueous $\mathrm{Hg}$ concentration. The WM-189 airlift has an atmospheric emission only when being used to transfer liquid out of WM-189. The other (active) waste storage tanks use steam jets which do not have a non-condensable off gas.

\section{High level liquid waste evaporator}

The high level liquid waste evaporator (HLLWE) is not a part of the NWCF and does not operate at the same time because of conflicting needs for the same vessels. The primary HLLWE emission route is via the PEW evaporator and LET\&D. The HLLWE condensate is transferred to the PEW evaporator whose condensate is vaporized and discharged from the LET\&D. The $\mathrm{Hg}$ concentrations in the HLLWE condensate average between 20 and $30 \mathrm{mg} / \mathrm{l}$ which represent a $\mathrm{DF}$ of about 30 from the feed. The PEW evaporator, which has not been characterized, is expected to reduce the $\mathrm{Hg}$ in its condensate to less than $10 \mathrm{mg} / \mathrm{l}$; and the LET\&D to remove another $93.6 \%$ of the Hg. For maximum HLLWE operation, which cannot occur in the same year as NWCF operation, the HLLWE would produce about 400,000 gal of condensate for which the $\mathrm{Hg}$ emission from LET\&D would be less than $1 \mathrm{~kg} / \mathrm{yr}$.

HLLWE operation also emits some Hg from the sparged NWCF vessels it uses for the feed and product. The emissions are estimated based on the similarity of sparge gas flows, temperature, and liquid compositions as about the same as from the same vessels during NWCF operation -about $0.1 \%$ of the Hg emissions estimated (above) for NWCF operation.

The other HLLWE emission route is the vent on the condenser which vents the HLLWE purge air and the air displaced by filling. The emission is very small because of the small purge air input (about $10 \mathrm{scf} / \mathrm{hr}$ ), low condenser temperature (near ambient), and the low Hg concentration in the condensate. 


\section{Other Volatile and Semi-Volatile Calcine Species}

In order to check the possibility of other volatile compounds of the hazardous metals, the vapor pressures ${ }^{17}$ of the oxides and chlorides of the hazardous metals having measurable vapor pressures at temperatures between 50 and $750^{\circ} \mathrm{C}$ are plotted in Figure 2. (Most of the metal oxides have measurable vapor pressures only at temperatures above $750^{\circ} \mathrm{C}$.) At the calciner temperature of 500 to $600^{\circ} \mathrm{C}, \mathrm{Sb}_{2} \mathrm{O}_{3}, \mathrm{CdCl}_{2}, \mathrm{PbCl}_{2}$, and all the compounds on Figure 2 with higher vapor pressures would probably vaporize from the calcine. The emissions of these species vaporized from the calciner depend on whether they remain vapors or condense as filterable solids when the off gas is cooled to 65 to $75^{\circ} \mathrm{C}$ in the scrub system, and then reheated to the (about 85 to $95^{\circ} \mathrm{C}$ ) temperature of the filters. The more volatile compounds with vapor pressures greater than that of $\mathrm{HgCl}_{2}$ will behave like $\mathrm{HgCl}_{2}$ with vapor not absorbed in the scrub system being sufficiently volatile to pass through the filters.

The metal chlorides are much more volatile than the oxides. The question of which of the hazardous metals species are thermochemically favorable in the calciner was addressed by a series of Gibbs free energy minimization calculations using an ASPEN Gibbs reactor block (RGIBBS) for the calculation. The calculations were done at 500 and $600^{\circ} \mathrm{C}$ using the bulk calciner off-gas composition from the the ASPEN waste systems model ${ }^{18}$. (The program used the "solids" OPSET and the "solids" and "inorganic" data bases, which are the NBS ${ }^{19}$ and Barin ${ }^{20}$ data bases, respectively.) The calculations were run in three steps:

1. The first set of calculations introduced the hazardous metals (as oxides) with the off gas and $\mathrm{HCl}$, but no $\mathrm{Na}, \mathrm{K}$, or $\mathrm{Ca}$ compounds, in order to determine whether $\mathrm{HCl}$ could react with the oxides. These calculations showed that the chlorides of $\mathrm{Pb}, \mathrm{Tl}, \mathrm{Cr}$, and $\mathrm{Be}$ are thermochemically favored over the oxides in NWCF off-gas containing $\mathrm{HCl}$. 


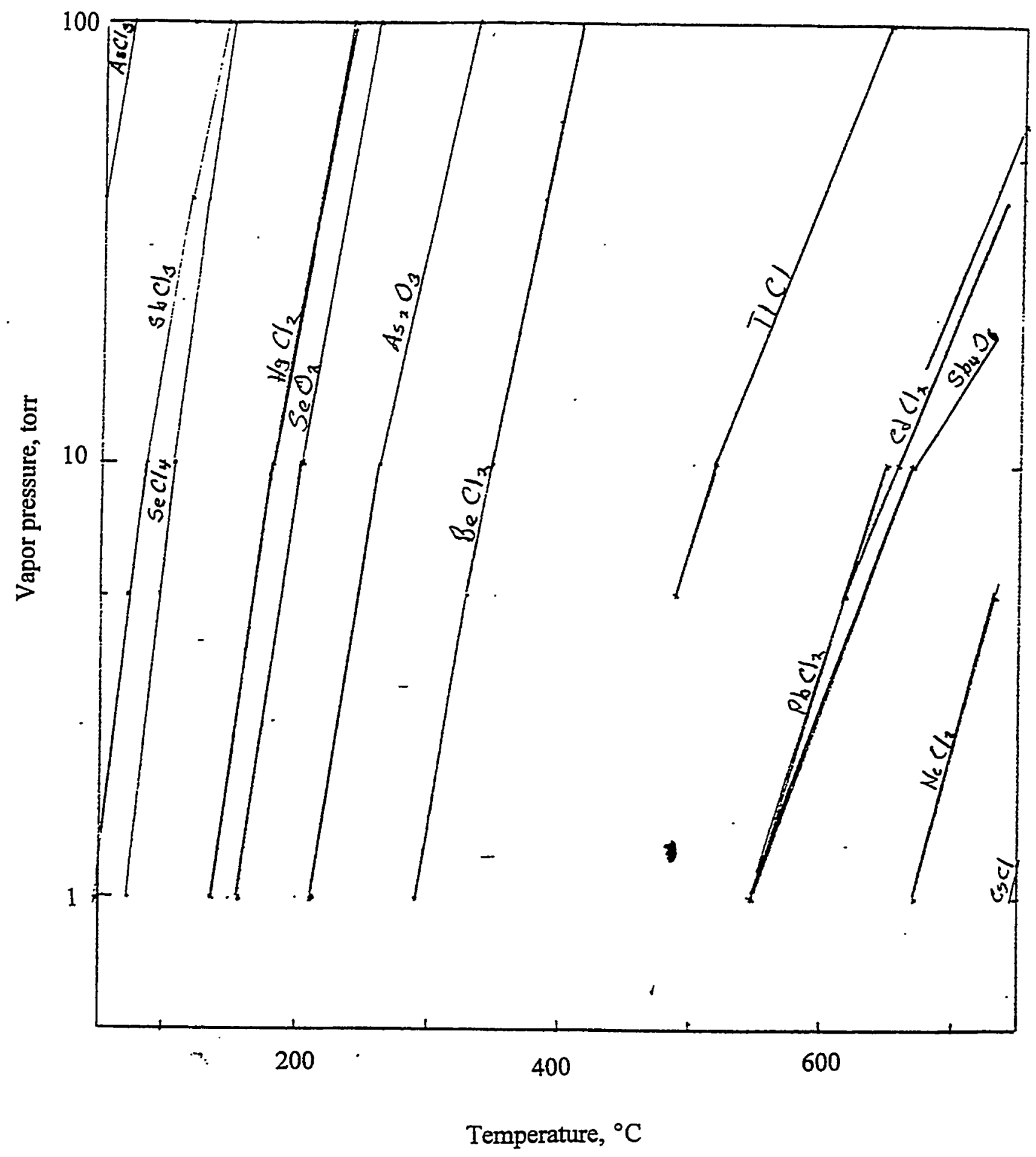

Figure 2. Vapor pressures ${ }^{17}$ of hazardous metal compounds. 
2. The second set of calculations added $\mathrm{Na}, \mathrm{K}$, and $\mathrm{Ca}$ (nitrates or oxides) to test their calculated ability to tie up $\mathrm{Cl}$. These calculations indicate that $\mathrm{Na}, \mathrm{K}$, and $\mathrm{Ca}$ could each react quantitatively with the $\mathrm{HCl}$ and force the equilibria for $\mathrm{Pb}, \mathrm{Tl}, \mathrm{Cr}$, and $\mathrm{Be}$ to the oxides. (There may be kinetic constraints on this conclusion.)

3. The third set of calculations repeated set 2 with the formation of $\mathrm{NaCl}, \mathrm{KCl}$, and $\mathrm{CaCl}_{2}$ suppressed to test the favorability of $\mathrm{Na}_{2} \mathrm{CrO}_{4}$ and $\mathrm{Na}_{3} \mathrm{AsO}_{4}$ in the presence of $\mathrm{HCl}$. These calculations indicate that $\mathrm{Na}_{2} \mathrm{CrO}_{4}$ and $\mathrm{Na}_{3} \mathrm{AsO}_{4}$ form quantitatively even in the presence of $\mathrm{HCl}$.

The calculated speciation is compiled in Table 5. The first two columns show the calculated speciation without the reactions with $\mathrm{Na}, \mathrm{K}$, and $\mathrm{Ca}$; the last two columns show the calculated speciation with the reactions with $\mathrm{Na}, \mathrm{K}$, and $\mathrm{Ca}$. The presence of $\mathrm{Na}$ compounds shifts the calculated equilibria of $\mathrm{Pb}, \mathrm{Tl}, \mathrm{Be}, \mathrm{Cr}$, and As from volatile chlorides to non-volatile oxides, chromates, and arsenates. (Some support for the calculated speciation of $\mathrm{Cr}$ as non-volatile is provided by a material balance on $\mathrm{Cr}$ for a pilot plant test which accounted for all of the $\mathrm{Cr}$ in the solids streams.)

There is some uncertainty about the thermodynamic calculations because 1) lack of experimental verification, 2) questions on whether the solid species can mix sufficiently to react, 3) potential kinetic constraints, and 4) an uncertainty about the accuracy of the ASPEN data bases used to extrapolate free energies to calcination temperatures. To allow for these uncertainties and possible kinetic constraints, the upper-envelope emissions calculations assume that the $\mathrm{Pb}, \mathrm{Tl}$, and $\mathrm{Be}$ are $10 \%$ as the chloride and $90 \%$ as an oxide rather than the very low fractions of chlorides shown in columns 3 and 4 of Table 5. The $\mathrm{Cr}$ and As are considered to be the sodium chromates and arsenates, as predicted, because all NWCF feeds contain large concentrations of sodium.

The volatile and semi-volatile species identified in Table 5 as possibly being formed in the NWCF are $\mathrm{PbCl}_{2}, \mathrm{Sb}_{4} \mathrm{O}_{6}, \mathrm{TlCl}, \mathrm{SeO}_{2}$, and $\mathrm{BeCl}_{2}$. The question of their filterability after cooling to the NWCF filter temperature $\left(85\right.$ to $95^{\circ} \mathrm{C}$ ) was addressed as follows (and illustrated with the calculations for $\mathrm{PbCl}_{2}$ and $\mathrm{Sb}_{4} \mathrm{O}_{6}$ ):

1. The vapor pressures of Figure 2 were replotted as $\log$ pressure vs $1 / \mathrm{T}$ and extrapolated to $100^{\circ} \mathrm{C}$ to estimate the vapor pressure at $100^{\circ} \mathrm{C}$. (1E-11 torr for $\mathrm{PbCl}_{2}$ and $\mathrm{Sb}_{4} \mathrm{O}_{6}$ )

2. For conservatism, the extrapolated vapor pressure at $100^{\circ} \mathrm{C}$ was increased by a factor of 2 to 100 depending on the distance extrapolated. (to $1 \mathrm{E}-9$ torr for $\mathrm{PbCl}_{2}$ and $\mathrm{Sb}_{4} \mathrm{O}_{6}$ )

3. The mole flow of each vapor carried by a total off-gas flow ${ }^{18}$ of $300 \mathrm{lbmol} / \mathrm{hr}(2000$ $\mathrm{scfm}$ ) at a pressure of 300 torr ${ }^{18}$ was calculated (1E-8 lbmol/hr for $\mathrm{PbCl}_{2}$ and $\left.\mathrm{Sb}_{4} \mathrm{O}_{6}\right)$ and then converted to mass flow (1E-4 g/hr of $\mathrm{PbCl}_{2}$ and $2.2 \mathrm{E}-4 \mathrm{~g} / \mathrm{hr}$ of $\mathrm{Sb}_{4} \mathrm{O}_{6}$ ).

5. The feed rate of each vapor was calculated from the feed concentrations of Table 3 , then reduced by a factor of 27 for removal in the scrub system $\left(2 \mathrm{~g} / \mathrm{hr}\right.$ of $\mathrm{PbCl}_{2}$ and $0.02 \mathrm{~g} / \mathrm{hr}$ of $\mathrm{Sb}_{4} \mathrm{O}_{6}$ ) and compared with the mass flows from step 4. 
Table 5. Fractions of hazardous metal species formed during calcination as calculated by Gibbs free energy minimization without and with sodium.

\begin{tabular}{||l|c|c|c|c||}
\hline \hline Species evaluated & $\begin{array}{c}\mathrm{No} \mathrm{Na} \\
\text { at } 500^{\circ} \mathrm{C}\end{array}$ & $\begin{array}{c}\text { No Na } \\
\text { at } 600^{\circ} \mathrm{C}\end{array}$ & $\begin{array}{c}\text { With Na } \\
\text { at } 500^{\circ} \mathrm{C}\end{array}$ & $\begin{array}{c}\text { With Na } \\
\text { at } 600^{\circ} \mathrm{C}\end{array}$ \\
\hline $\mathrm{PbCl}_{2}$ & $\begin{array}{c}1.0 \\
\mathrm{PbO}\end{array}$ & $\begin{array}{c}1.0 \\
2 \mathrm{E}-7\end{array}$ & $\begin{array}{c}2 \mathrm{E}-18 \\
1.0\end{array}$ & $\begin{array}{c}3 \mathrm{E}-16 \\
1.0\end{array}$ \\
\hline $\mathrm{SbCl}_{3}$ & $1 \mathrm{E}-4$ & $2 \mathrm{E}-5$ & & \\
$\mathrm{Sb}_{4} \mathrm{O}_{6}$ & 1.0 & 1.0 & & \\
\hline $\mathrm{CdCl}_{2}$ & $6 \mathrm{E}-22$ & $7 \mathrm{E}-22$ & & \\
$\mathrm{CdO}$ & 1.0 & 1.0 & & \\
\hline $\mathrm{NiCl}_{2}$ & $8 \mathrm{E}-8$ & $3 \mathrm{E}-8$ & & \\
$\mathrm{NiO}$ & 1.0 & 1.0 & & 1.0 \\
\hline $\mathrm{TlCl}_{\mathrm{Tl}_{2} \mathrm{O}}$ & 1.0 & 1.0 & $2 \mathrm{E}-7$ & $6 \mathrm{E}-6$ \\
\hline $\mathrm{AsCl}_{3}$ & $9 \mathrm{E}-12$ & $3 \mathrm{E}-10$ & 1.0 & 1.0 \\
$\mathrm{Na}_{3} \mathrm{AsO}_{4}$ & 0 & 0 & 0 & 0 \\
$\mathrm{As}_{2} \mathrm{O}_{3}$ & 1.0 & 1.0 & 1.0 & 1.0 \\
\hline $\mathrm{SeCl}_{4}$ & 0 & 0 & & 0 \\
$\mathrm{SeO}_{2}$ & 1.0 & 1.0 & & \\
\hline $\mathrm{CrO}_{2} \mathrm{Cl}_{2}$ & 1.0 & 1.0 & 0 & $2 \mathrm{E}-16$ \\
$\mathrm{Na}_{2} \mathrm{CrO}_{4}$ & 0 & 0 & 1.0 & 1.0 \\
$\mathrm{CrO}_{3}$ & $7 \mathrm{E}-7$ & $1.4 \mathrm{E}-4$ & 0 & 0 \\
\hline $\mathrm{BeCl}_{2}$ & 1.0 & 1.0 & $2 \mathrm{E}-9$ & $2 \mathrm{E}-7$ \\
$\mathrm{BeO}$ & 0 & 0 & 1.0 & 1.0 \\
\hline
\end{tabular}

The conclusions of the above set of calculations are:

1. The low concentrations of $\mathrm{TlCl}, \mathrm{BeCl}_{2}$, and $\mathrm{SeO}_{2}$ are completely volatile at filter temperatures because of their relatively high vapor pressures and hence will not be removed by the filters.

2. The vapor pressures of $\mathrm{PbCl}_{2}$ and $\mathrm{Sb}_{4} \mathrm{O}_{6}$ are in a range where filter $\mathrm{DF}$ 's for $\mathrm{PbCl}_{2}$ and $\mathrm{Sb}_{4} \mathrm{O}_{6}$ will be limited by volatility. Their emissions can be characterized conservatively by the mass flows of $1 \mathrm{E}-4 \mathrm{~g} / \mathrm{hr}$ for $\mathrm{PbCl}_{2}$ and $2.2 \mathrm{E}-4 \mathrm{~g} / \mathrm{hr}$ for $\mathrm{Sb}_{4} \mathrm{O}_{6}$.

3. The species with vapor pressures less than $\mathrm{Sb}_{4} \mathrm{O}_{6}$ are non-volatile at $100^{\circ} \mathrm{C}$. 
The scrub system DF of 27 (the same DF as for $3.7 \% \mathrm{Hg}$ emission) is used for the vaporized hazardous metal species assuming they have the same scrub inefficiencies and solubilities as $\mathrm{HgCl}_{2}$. Some of them are probably more soluble than $\mathrm{HgCl}_{2}$ because of aqueous reactions. These volatile species would have the same tendency to accumulate in the scrub solution as $\mathrm{Hg}$.

\section{Emissions Calculations for Hazardous Metals}

The decontamination factors for the hazardous metals with volatile compounds are estimated in Table 6 from the percents of each compound from Table 5 by a weighted averaging of the DF's for the compounds using:

1) a DF for the calciner through scrub system of 2000 if non volatile or 27 (based on $\mathrm{Hg}$ ) if volatile (and absorbed in the scrub system);

2) a DF for the filters of $2.7 \mathrm{E}+05$ if filterable or 1 if volatile;

3) the previously calculated vapor flows of $\mathrm{PbCl}_{2}$ and $\mathrm{Sb}_{4} \mathrm{O}_{6}$.

Conservative lifetime and annual average emissions are estimated in Table 7 based mostly on the upper-limit feed concentrations of Table 3. The calculated emissions are conservative because the upper-limit feed concentrations are much higher than the average concentrations. The calculations proceed from left to right:

1. The feed concentrations are from Table 3.

2. The upper-limit inventories (except for $\mathrm{Hg}$ ) are obtained by multiplying the concentration by a total net feed volume of $1,180,000$ gal (which allows $25 \%$ for future waste generation). The Hg inventory is the total in the tank farm (from the concentrations and volumes in Table 1).

3. The emissions DF's are from Table 6 except that the overall DF's for the non-volatiles are decreased to $5 E+08$ (as described in section 2) to include some operation of the WM189 air lift.

4. The lifetime emissions are obtained (except for $\mathrm{Hg}$ ) by dividing inventory by DF. The $\mathrm{Hg}$ emission is derived in section 3 based on the potential operating scenario providing the highest $\mathrm{Hg}$ emissions. The $\mathrm{Pb}$ and $\mathrm{Sb}$ emissions are calculated using the $\mathrm{g} / \mathrm{hr}$ emissions values derived in section 4 and the assumption of a long-term on-stream factor of $50 \%$.

5. NWCF operation will operate from 7 to 14 years (to 2005 or 2012) depending on operability and flowsheet efficiency (i. e., net:gross feed ratio). The annual average emissions average the life-time emissions over either a 7-or 14-year period chosen for conservatism. Carcinogens $\mathrm{As}, \mathrm{Be}, \mathrm{Cd}$, and $\mathrm{Cr}$ are averaged over 14 years; the noncarginogens, which may produce short-term health effects, are averaged over 7 years, which gives the higher annual emission rate. 
Table 6. Estimation of weighted overall decontamination factors or mass emissions for the hazardous metals.

\begin{tabular}{|c|c|c|c|c|c|}
\hline Compound & Percent & $\begin{array}{l}\text { DF for calc. } \\
\text {... scrubber }\end{array}$ & DF for filters & $\begin{array}{l}\text { Overall DF } \\
\text { or emission } \\
\text { for specie }\end{array}$ & $\begin{array}{l}\text { Weighted } \\
\text { overall DF or } \\
\text { emission }^{\text {a }}\end{array}$ \\
\hline $\mathrm{HgCl}_{2}$ & 27 & 27 & 1 & 27 & 27 \\
\hline $\mathrm{SeO}_{2}$ & 27 & 27 & 1 & 27 & 27 \\
\hline $\begin{array}{l}\mathrm{Sb}_{4} \mathrm{O}_{6} \\
\mathrm{SbCl}_{3} \\
\end{array}$ & $\begin{array}{l}99.9 \\
<0.01 \\
\end{array}$ & $\begin{array}{l}27 \\
27 \\
\end{array}$ & $\begin{array}{l}\text { n. a. } \\
1\end{array}$ & $\begin{array}{l}2.2 \mathrm{E}-4 \mathrm{~g} / \mathrm{hr} \\
27\end{array}$ & $2.2 \mathrm{E}-4 \mathrm{~g} / \mathrm{hr}$ \\
\hline $\mathrm{Na}_{3} \mathrm{AsO}_{4}$ & 100 & 2000 & $2.7 \mathrm{E}+5$ & $5.4 \mathrm{E}+8$ & $5.4 \mathrm{E}+8$ \\
\hline $\begin{array}{l}\mathrm{PbO} \\
\mathrm{PbCl}_{2} \\
\end{array}$ & $\begin{array}{l}90 \\
10 \\
\end{array}$ & $\begin{array}{l}2000 \\
27 \\
\end{array}$ & $\begin{array}{l}2.7 \mathrm{E}+5 \\
\text { n. a. }\end{array}$ & $\begin{array}{l}5.4 \mathrm{E}+8 \\
1 \mathrm{E}-4 \mathrm{~g} / \mathrm{hr}\end{array}$ & $1 \mathrm{E}-4 \mathrm{~g} / \mathrm{hr}$ \\
\hline $\mathrm{CdO}$ & 100 & 2000 & $2.7 E+5$ & $5.4 \mathrm{E}+8$ & $5.4 \mathrm{E}+8$ \\
\hline $\mathrm{Ag}_{2} \mathrm{O}$ & 100 & 2000 & $2.7 \mathrm{E}+5$ & $5.4 \mathrm{E}+8$ & $5.4 \mathrm{E}+8$ \\
\hline $\mathrm{BaO}$ & 100 & 2000 & $2.7 \mathrm{E}+5$ & $5.4 \mathrm{E}+8$ & $5.4 \mathrm{E}+8$ \\
\hline $\begin{array}{l}\mathrm{BeO} \\
\mathrm{BeCl}_{2}\end{array}$ & $\begin{array}{l}90 \\
10\end{array}$ & $\begin{array}{l}2000 \\
27\end{array}$ & $\begin{array}{l}2.7 \mathrm{E}+5 \\
1\end{array}$ & $\begin{array}{l}5.4 \mathrm{E}+8 \\
27\end{array}$ & 270 \\
\hline $\mathrm{Na}_{2} \mathrm{CrO}_{4}$ & 100 & 2000 & $2.7 \mathrm{E}+5$ & $5.4 \mathrm{E}+8$ & $5.4 \mathrm{E}+8$ \\
\hline $\mathrm{NiO}$ & 100 & 2000 & $2.7 \mathrm{E}+5$ & $5.4 \mathrm{E}+8$ & $5.4 \mathrm{E}+8$ \\
\hline $\begin{array}{l}\mathrm{Tl}_{2} \mathrm{O} \\
\mathrm{TlCl}\end{array}$ & $\begin{array}{l}90 \\
10\end{array}$ & $\begin{array}{l}2000 \\
27 \\
\end{array}$ & $\begin{array}{l}2.7 \mathrm{E}+5 \\
1 \\
\end{array}$ & $\begin{array}{l}5.4 \mathrm{E}+8 \\
27\end{array}$ & 270 \\
\hline$\overline{\mathrm{U}_{3} \mathrm{O}_{8}}$ & 100 & 2000 & $2.7 \mathrm{E}+5$ & $5.4 \mathrm{E}+8$ & $5.4 \mathrm{E}+8$ \\
\hline
\end{tabular}

a) DF for NWCF only; use of WM-189 air lift would reduce DF for non-volatile species. 
Table 7. Estimation of conservative lifetime and annual-average emission.

\begin{tabular}{|c|c|c|c|c|c|c|}
\hline$\overline{\text { Specie }}$ & $\begin{array}{c}\text { Upper-limit } \\
\text { concentration, } \\
\mathrm{mg} / \mathrm{l}\end{array}$ & $\begin{array}{l}\text { Upper-limit } \\
\text { inventory, } \\
\mathrm{g}\end{array}$ & Emission DF & $\begin{array}{l}\text { Lifetime } \\
\text { emission, } \\
\mathrm{g}\end{array}$ & $\begin{array}{l}\text { Annual } \\
\text { Ave }^{c} \text {. } \\
\text { emission, } \\
\mathrm{g} / \mathrm{yr}\end{array}$ & $\begin{array}{c}\text { Annual } \\
\text { Ave. } \\
\text { emission, } \\
\mathrm{g} / \mathrm{s}\end{array}$ \\
\hline$\overline{\mathrm{Ag}}$ & 14 & $6.27 \mathrm{E}+04$ & $5 \mathrm{E}+08$ & $1.25 \mathrm{E}-04$ & $1.8 \mathrm{E}-05$ & $5.7 \mathrm{E}-13$ \\
\hline As & 58 & $2.60 E+05$ & $5 E+08$ & $5.20 \mathrm{E}-04$ & 3.7E-05 & $1.15 \mathrm{E}-12$ \\
\hline $\mathrm{Ba}$ & 17 & $7.62 \mathrm{E}+04$ & $5 E+08$ & $1.52 \mathrm{E}-04$ & $2.2 \mathrm{E}-05$ & 7.0E-13 \\
\hline $\mathrm{Be}^{\mathrm{b}}$ & 0.4 & $1.8 \mathrm{E}+03$ & 270 & 7 & 0.5 & $1.6 \mathrm{E}-08$ \\
\hline $\mathrm{Cd}$ & 1240 & $5.56 \mathrm{E}+06$ & $5 E+08$ & $1.11 \mathrm{E}-02$ & $7.9 \mathrm{E}-04$ & $2.5 \mathrm{E}-11$ \\
\hline $\mathrm{Cr}$ & 440 & $1.95 \mathrm{E}+06$ & $5 E+08$ & $3.90 \mathrm{E}-03$ & $2.8 \mathrm{E}-04$ & $8.9 \mathrm{E}-12$ \\
\hline $\mathrm{Hg}^{\mathrm{a}}$ & 3000 & $2.60 E+06$ & & $3.43 E+05$ & 49000 & $1.6 \mathrm{E}-03$ \\
\hline $\mathrm{Pb}^{\mathrm{d}}$ & 290 & $1.30 E+06$ & $\begin{array}{r}1.0 \mathrm{E}-04 \\
\mathrm{~g} / \mathrm{hr}\end{array}$ & 3 & 0.43 & $1.4 \mathrm{E}-08$ \\
\hline $\mathrm{Ni}$ & 420 & 1.88 & $5 \mathrm{E}+08$ & $3.76 \mathrm{E}-03$ & 2.7E-04 & $8.5 \mathrm{E}-12$ \\
\hline $\mathrm{Se}$ & 1 & $4.48 \mathrm{E}+03$ & 27 & 166 & 24 & $7.6 \mathrm{E}-07$ \\
\hline $\mathrm{Sb}^{\mathrm{b}, \mathrm{d}}$ & 1.225 & $5.5 \mathrm{E}+03$ & $\begin{array}{r}2.2 \mathrm{E}-4 \\
\mathrm{~g} / \mathrm{hr}\end{array}$ & 6.6 & 0.94 & $3.0 \mathrm{E}-08$ \\
\hline $\mathrm{Tl}^{\mathrm{b}}$ & 3.4 & $1.5 \mathrm{E}+04$ & 270 & 56 & 8 & $2.5 \mathrm{E}-07$ \\
\hline U & 194 & $8.69 \mathrm{E}+05$ & $5 E+08$ & $1.74 \mathrm{E}-03$ & $2.5 \mathrm{E}-04$ & 7.9E-12 \\
\hline
\end{tabular}

a) $\mathrm{Hg}$ emission is based on $343 \mathrm{~kg}$ lifetime emission.

b) $\mathrm{Be}, \mathrm{Sb}, \mathrm{Tl}$ have not been detected, concentrations are $1 / 2$ of $\mathrm{MDL}$ values

c) based for As, Be, Cd, Cr \& Ni on 14 yr of operation (1999-2012), and for others on $7 \mathrm{yr}$ of operation (1999-2005).

d) $\mathrm{Pb} \& \mathrm{Sb}$ are based on $\mathrm{g} / \mathrm{hr}$ emissions and $50 \%$ on line factor.

The upper-limit hourly emissions of Table 8 are calculated in a similar way using the upper-limit feed concentrations and the maximum net feed rate of $718 \mathrm{l} / \mathrm{hr}$ from section 2 . The calculations are conservative primarily because the net feed rate is conservative. The emissions DF's for non-volatile species are 4E+08 as derived in section 2 for including operation of the WM-189 air lift, the PEW evaporator and LET\&D. The $\mathrm{Pb}$ and $\mathrm{Sb}$ emissions again are based on the $\mathrm{g} / \mathrm{hr}$ values. 
Table 8. Estimation of upper-limit hourly emissions.

\begin{tabular}{lccccc}
\hline Specie & $\begin{array}{c}\text { Upper-limit } \\
\text { concentration, } \\
\mathrm{mg} / 1\end{array}$ & $\begin{array}{c}\text { Upper-limit } \\
\text { feed rate, } \mathrm{g} / \mathrm{hr}\end{array}$ & Emissions DF & $\begin{array}{c}\text { Emissions, } \\
\mathrm{g} / \mathrm{hr}\end{array}$ & $\begin{array}{c}\text { Emissions, } \\
\mathrm{g} / \mathrm{s}\end{array}$ \\
\hline $\mathrm{Ag}$ & 14 & 10 & $4 \mathrm{E}+08$ & $2.5 \mathrm{E}-08$ & $6.9 \mathrm{E}-12$ \\
$\mathrm{As}$ & 58 & 42 & $4 \mathrm{E}+08$ & $1.0 \mathrm{E}-07$ & $2.8 \mathrm{E}-11$ \\
$\mathrm{Ba}$ & 17 & 12 & $4 \mathrm{E}+08$ & $3.1 \mathrm{E}-08$ & $8.6 \mathrm{E}-12$ \\
$\mathrm{Be}^{\mathrm{b}}$ & 0.4 & 0.28 & 27 & 0.011 & $3.1 \mathrm{E}-06$ \\
$\mathrm{Cd}$ & 1240 & 890 & $4 \mathrm{E}+08$ & $2.2 \mathrm{E}-06$ & $6.1 \mathrm{E}-10$ \\
$\mathrm{Cr}$ & 435 & 312 & $4 \mathrm{E}+08$ & $7.8 \mathrm{E}-07$ & $2.2 \mathrm{E}-10$ \\
$\mathrm{Hg}$ & 3000 & 2154 & 27 & 80 & $2.2 \mathrm{E}-02$ \\
$\mathrm{~Pb}$ & 290 & 208 & $1.0 \mathrm{E}-04 \mathrm{~g} / \mathrm{hr}$ & $1.0 \mathrm{E}-04$ & $2.8 \mathrm{E}-08$ \\
$\mathrm{Ni}$ & 420 & 302 & $4 \mathrm{E}+08$ & $7.5 \mathrm{E}-07$ & $2.1 \mathrm{E}-10$ \\
$\mathrm{Se}$ & 1 & 0.72 & 27 & 0.027 & $7.5 \mathrm{E}-06$ \\
$\mathrm{Sb}$ & 1.225 & 0.9 & $2.2 \mathrm{E}-04 \mathrm{~g} / \mathrm{hr}$ & $2.2 \mathrm{E}-04$ & $6.1 \mathrm{E}-08$ \\
$\mathrm{Tl}$ & 3.4 & 2.4 & 270 & $9.0 \mathrm{E}-03$ & $2.5 \mathrm{E}-06$ \\
$\mathrm{U}$ & 194 & 139 & $4 \mathrm{E}+08$ & $3.5 \mathrm{E}-07$ & $9.7 \mathrm{E}-11$
\end{tabular}

a) $\mathrm{Pb}$ and $\mathrm{Sb}$ emissions are based on $\mathrm{g} / \mathrm{hr}$ rates.

b) $\mathrm{Be}, \mathrm{Sb}, \mathrm{Tl}$ have not been detected, concentrations are $1 / 2$ of $\mathrm{MDL}$ values

\section{Emissions of Hazardous Organic Chemicals from Feed}

The upper-envelope emissions from calcination of hazardous organic chemicals possibly in the tank farm are developed below in Table 9. The chemicals listed in Table 9 are those determined ${ }^{21,22}$ to have possibly entered the PEW and then gone to the tank farm (with or without a waste $\operatorname{code}^{23}$ ). The concentrations are upper-limit based on all INTEC chemical receipts, not otherwised accounted for, going (via PEW) to the tank farm. The feed volume is a maximum volume of $1,400,000 \mathrm{gal} / \mathrm{yr}$ (before evaporation from Table 1). The feed concentrations are 1) set at $1 / 2$ of the minimum quantification level if waste tank analyses ${ }^{24}$ show their concentrations as less than the minimum detection level, or 2) a "process knowledge" estimate ${ }^{21}$. The analyses of the wastes in the tank farm done to date indicate that the process knowledge estimates of Table 9 are very conservative. For the species for which both process knowledge estimates ${ }^{21}$ and analyses ${ }^{24}$ are available, the analyses are much lower. No information is available for many of the compounds.

The NWCF input is the feed concentration multiplied by the total waste volume $(1,400,000$ gal). The NWCF DF in Table 9 is based on an thermal stability-based incinerability index ${ }^{25}$, derived at the University of Dayton, which gives the temperature for $99 \%$ thermal decomposition in 2 seconds. A DF of 100 is used when the incinerability index is $\angle 500^{\circ} \mathrm{C}$; and a DF of 1 is used when the incinerability index is $>500^{\circ} \mathrm{C}$. The NWCF provides a temperature of 500 to $600^{\circ} \mathrm{C}$ for 6 seconds, so it should provide decompositions much greater than $99 \%$ (at least for species whose decomposition is first order) for species with incinerability indices is $<500^{\circ} \mathrm{C}$. The analysis assumes, except for the incinerable species, that the organic species in the tank farm are emitted totally to the atmosphere. Some may be emitted from the HLLWE or other indirect routes; however, the route does not effect the total emission. The compounds that are incinerable are low volatility species not readily volatilized by indirect routes. 
Most of the estimate upper-envelope emissions are less than $1 \mathrm{~kg} / \mathrm{yr}$. The highest calculated emission from Table 9 is for pyridine $(77 \mathrm{~kg} / \mathrm{yr})$.

The evaporation of current PEW in the PEW evaporator and LET\&D adds minor quantities of organic chemicals to the quantities calculated in Table 9. Current chemical handling procedures follow RCRA requirements and limit organic chemicals to soluble chemicals (e. g., acetone) dissolved in waste solutions. Recent analyses of PEW for organic chemicals (VOA's) report nearly all as undetected. A few soluble solvents (e. g., acetone) are are sometimes reported at concentrations of $<1 \mathrm{ppm}$. The largest potential emission via the PEW evaporator and LET\&D would be $<1 \mathrm{~kg} / \mathrm{yr}$ of acetone.

Table 9. Upper-envelope emissions of hazardous organic chemicals in the NWCF feed.

\begin{tabular}{|c|c|c|c|c|c|}
\hline Chemical & $\begin{array}{l}\text { Max Conc. } \\
\mathrm{ng} / \mathrm{ml}\end{array}$ & $\begin{array}{l}\text { Feed conc. } \\
\mathrm{ng} / \mathrm{ml}\end{array}$ & $\begin{array}{l}\text { NWCF input } \\
\mathrm{g}\end{array}$ & $\begin{array}{c}\text { NWCF } \\
\text { DF }\end{array}$ & $\begin{array}{l}\text { Emission } \\
\mathrm{g}\end{array}$ \\
\hline$\overline{\text { Acetone }}$ & (c) & & & & \\
\hline Acetonitrile & $48(b)$ & 48 & 250 & 1 & 250 \\
\hline Aniline & $808(b)$ & 808 & 4200 & 1 & 4200 \\
\hline Benzene & $<10(a)$ & 5 & 26 & 1 & 26 \\
\hline Benzo(a)pyrene & $10(\mathrm{~b})$ & 10 & 53 & 1 & 53 \\
\hline Bromoform & $<10(a)$ & 5 & 26 & 1 & 26 \\
\hline Butylbenzylphthalate(c & (d) 10 (b) & 10 & 53 & 100 & $<1$ \\
\hline Carbon disulphide & 397 (b) & 397 & 2100 & 1 & 2100 \\
\hline Carbon tetrachloride & $<10$ (a) & 5 & 26 & 1 & 26 \\
\hline Chlorobenzene & $<10(a)$ & 5 & 26 & 1 & 26 \\
\hline Chloroform & $<10$ (a) & 5 & 26 & 1 & 26 \\
\hline Cresols & \multicolumn{2}{|l|}{ (c) } & & & \\
\hline Cumene & (c) & & & & \\
\hline Cyanogen & (c) & & & & \\
\hline 1,2-dichloroethane & $<10$ (a) & 5 & 26 & 1 & 26 \\
\hline Diethylphthalate (d) & $128(b)$ & 128 & 660 & 100 & 7 \\
\hline Dimethyl sulfate & (c) & & & & \\
\hline Di-n-buthyphthalate(d) & $10(b)$ & 10 & 53 & 100 & $<1$ \\
\hline 2,4-dinitrophenol & $81(\mathrm{~b})$ & 81 & 420 & 1 & 420 \\
\hline 2,4-dinitrotoluene & 95 (b) & 95 & 500 & 1 & 500 \\
\hline Di-n-octhyphthalate & 10 (b) & 10 & 53 & 100 & $<1$ \\
\hline 1,4-dioxane & 3750 (b) & 3750 & 20,000 & 1 & 20,000 \\
\hline Ethylene glycol (e) & & & 3300 & 1 & 3300 \\
\hline Hexachlorobenzene & (c) & & & & \\
\hline Hexachloroethane & (c) & & & & \\
\hline Formaldehyde & $4.3(\mathrm{~b})$ & 4.3 & 23 & 1 & 23 \\
\hline Formic acid & 242 (b) & 242 & 1300 & 1 & 1300 \\
\hline Furfural & (c) & & & & \\
\hline Hydrazine & $170(b)$ & 170 & 880 & 1 & 880 \\
\hline Iodomethane & (c) & & & & \\
\hline Methylene chloride & $<10$ (a) & 5 & 26 & 1 & 26 \\
\hline
\end{tabular}




\begin{tabular}{|c|c|c|c|c|c|}
\hline Methyl ethyl ketone & $170(\mathrm{~b})$ & 170 & 880 & 1 & 880 \\
\hline Methyl isobutyl keton & (c) & & & & \\
\hline Methyl tert-butyl ethe & (c) & & & & \\
\hline Naphthalene & $10(\mathrm{~b})$ & 10 & 53 & 1 & 53 \\
\hline Nitrobenzene & (c) & & & & \\
\hline p-nitrophenol & (c) & & & & \\
\hline 2-nitropropane & (c) & & & & \\
\hline PCB's & (c) & & & & \\
\hline Pentachlorophenol & 10 (b) & 10 & 53 & 1 & 53 \\
\hline Phenol & $170(\mathrm{~b})$ & 170 & 900 & 1 & 900 \\
\hline Phthalic anhydride & (c) & & & & \\
\hline Pyridine & $14,500(b)$ & 14,500 & 75,000 & 1 & 75,000 \\
\hline Tetrachloroethylene & $<10$ (a) & 5 & 26 & 1 & 26 \\
\hline Thiourea (d) & $2110(b)$ & 2110 & 11,000 & 100 & 110 \\
\hline 1,2,4-trichlorobenzene & 10 (b) & 10 & 53 & 1 & 53 \\
\hline 1,1,1-Trichloroethane & $<10$ (a) & 5 & 26 & 1 & 26 \\
\hline 1,1,2-Trichloroethane & $<10$ (a) & 5 & 26 & 1 & 26 \\
\hline Trichloroethylene & $<10$ (a) & 5 & 26 & 1 & 26 \\
\hline Toluene & $<10$ (a) & 5 & 26 & 1 & 26 \\
\hline o-toluidine & (c) & & & & \\
\hline xylene & (c) & & & & \\
\hline
\end{tabular}

(a) less than a minimum quantification level of $10 \mathrm{ng} / \mathrm{ml}$ and also less than a minimum detection level estimated at $1 \mathrm{ng} / \mathrm{ml}$; analyzed ${ }^{24}$ in 3 tanks

(b) Process knowledge estimate ${ }^{21}$ based on the assumption that all of the chemical purchased went to the tank farm via the Process Equipment Waste system.

(c) Possible contamination that cannot be quantified.

(d) Thermally decomposes ${ }^{26}>99 \%$ at temperatures less than $500^{\circ} \mathrm{C}$.

(e) Process knowledge for one-time transfer to one tank.

\section{Emissions of Acid Vapors and Gases}

Calculated upper-envelope emissions of acid vapors and gaseous pollutants for NWCF operation are tabulated in Table 10. The bases of the emissions estimates are discussed below. 
Table 10. Calculated upper-envelope emissions of acid vapors and gases for NWCF operation.

\begin{tabular}{|c|c|c|c|c|}
\hline Specie & $\begin{array}{l}\text { Maximum } \\
\text { Hourly } \\
\text { Emission, } \mathrm{kg} / \mathrm{hr}\end{array}$ & $\begin{array}{l}\text { Maximum } \\
\text { Hourly } \\
\text { Emission, g/s }\end{array}$ & $\begin{array}{c}\text { Maximum } \\
\text { Annual } \\
\text { Emission, } \\
\mathrm{Mg}_{\mathrm{yr}}{ }^{2}\end{array}$ & $\begin{array}{l}\text { Maximum } \\
\text { Annual } \\
\text { Emission, g/s }\end{array}$ \\
\hline $\mathrm{NO}_{x}$ & 214 & 59.4 & 1540 & 48.8 \\
\hline $\mathrm{CO}$ & 110 & 30.6 & 790 & 25.0 \\
\hline $\mathrm{SO}_{2}$ & 0.825 & 0.229 & 6.0 & 0.19 \\
\hline $\mathrm{HNO}_{3}$ & 50 & 13.9 & 360 & 11.4 \\
\hline $\mathrm{HCl}$ & 0.325 & 0.0903 & 0.68 & 0.022 \\
\hline $\mathrm{HF}$ & 0.185 & 0.0514 & 1.35 & 0.043 \\
\hline
\end{tabular}

a) A year is 300 days of operation.

The $\mathrm{NO}_{\mathrm{x}}$ emissions in Table 10 are permit limits. The $\mathrm{NO}_{\mathrm{x}}$ emissions from the ICPP stack are monitored during NWCF operation; and the the waste feed rate to the NWCF is controlled at a rate such that the measured $\mathrm{NO}_{\mathrm{x}}$ emission remains below the permit limit.

The $\mathrm{CO}$ emission is based on 1) 40 percent of the carbon in the fuel becoming $\mathrm{CO}$, and 2) the maximum NWCF fuel capacity of $45.6 \mathrm{gph}(138 \mathrm{~kg} / \mathrm{hr})$ rather than the normal fuel rate of about $30 \mathrm{gph}$. The 40 percent of the carbon becoming $\mathrm{CO}$ is based on a measured ${ }^{27}$ value of 30 percent in the original WCF with a contingency added for the potential for operation with damaged fuel nozzles. (Limited sampling ${ }^{28}$ during NWCF cold operation indicates that the CO in the NWCF off gas is less than in the WCF.)

The $\mathrm{SO}_{2}$ emission is based on the NWCF fuel capacity $(138 \mathrm{~kg} / \mathrm{hr})$ and a low-grade fuel containing 0.3 percent $\mathrm{S}$. (The NWCF currently uses kerosene specified for $<0.04$ percent $\mathrm{S}$.)

The emissions of $\mathrm{HNO}_{3}, \mathrm{HCl}$, and $\mathrm{HF}$ depend on vapor-liquid equilibria in the NWCF scrub system. Nitric acid is added to the scrub solution to dissolve the calcine solids collected in the scrub solution. The nitric acid not consumed by the dissolution reaction can volatilize from the scrub solution into the off gas. The nitric acid also reacts with the chlorides and fluorides collected in the scrub solution to form $\mathrm{HCl}$ and $\mathrm{HF}$ which can also volatilize into the off gas. Thus, the volatilization of the three acids depends on the chemical equilibria in the solution and the vapor-liquid equilibria between the scrub solution and the off gas.

The scrub solution chemical and vapor-liquid equilibria calculations were done using two ASPEN models. The models are steady-state models which are assumed to envelope the unsteady-state operation of the scrub system. An earlier model ${ }^{18}$ for ICPP was modified, by removing non-NWCF processes, and using the NWCF feed composition and flow, and scrub solution flow of this document. The resulting model is a steady-state model which includes scrub recycle to feed and a (steady state) scrub discharge to the tank farm. The second model 
replaced the property parameter set of the first model with a more-recent ${ }^{29}$ property parameter set.

The models are set for upper-envelope emissions by: 1) using a relatively high ratio of nitric acid addition to scrub recycle ( 0.85 gal. of $\mathrm{HNO}_{3}$ per gal. of scrub solution recycled), 2) using a relatively low scrub solution return to the tank farm $(0.033$ gal. per gal. of scrub solution recycled), and 3) using the upper-envelope feed concentration of Table 1 . The models were run using both a low scrub recycle rate $(16 \mathrm{gph})$ and a high scrub recycle rate $(30 \mathrm{gph})$. The highest calculated emissions from any of the calculations is used in Table 11.

The $\mathrm{HNO}_{3}$ emissions of Table 11 were verified with material balances for nitrate in the NWCF scrub system during NWCF Run $\mathrm{H}-4$. The $\mathrm{HNO}_{3}$ emission of Table 11 is a little higher than the median value from the material balances.

The models calculate that $30 \%$ of the $\mathrm{Cl}$ in the net feed is discharged in the off-gas from the scrub system. The maximum hourly $\mathrm{HCl}$ emission is $30 \%$ of the maximum $\mathrm{Cl}$ feed rate based on the $\mathrm{Cl}$ concentration in Table 3 . The maximum annual $\mathrm{HCl}$ emission is based on $\mathrm{Cl}$ availability in the tank farm. It assumes that the two tanks with the highest $\mathrm{Cl}$ content (WM-180 and the postulated last tank) are calcined in one year with $30 \%$ of their $\mathrm{Cl}$ emitted as $\mathrm{HCl}$.

\section{References}

1. R. E. Schindler, Removal of Particulate Solids from the Off-Gas of the WCF and NWCF, ICP-1157, June, 1978, p. 20.

2. M. C. Swenson, MCS-12-84 to R. I. Donavan/B. H. O'Brien, "Comments Relative to the NWCF Filter Leaching Study", dated November 7, 1984.

3. M. C. Swenson, MCS-6-82 to A. P. Hoskins/L. P. Mickelsen, "Particulate removal Efficiency of NWCF Ruthenium Absorbers", dated July 9, 1982.

4. T. S. Yoder, TCY-01-99 to R. E. Schindler, "Calculated DF Values for Sr-90 in the NWCF Off-gas System", March 10, 1999.

5. J. K. Neff, "ICPP Environmental Monitoring Report for CY-1991", WINCO-1102.

6. Environmental Characterization, "ICPP Environmental Monitoring Report for CY-1993", WINCO-1207.

7. J. K. Neff, "ICPP Environmental Monitoring Report for CY-1997", INEEL/EXT-99-tbd, draft, 1999.

8. R. L. Hastings, "Idaho Chemical Processing Plant Liquid Effluent Treatment and Disposal Facility Hot Test Report”, WINCO-1146, 1993. 
9. H. W. Godbee, "The Use of Evaporation for the Treatment of Liquids in the Nuclear Industry”, ORNL-4790, 1973.

10. F. H. Garner, et. al., "The Size Distribution and Entrainment of Droplets", Trans. Instn Chem. Engrs, 32, 1954, p. 222-235.

11. G. E. Dunham, et. al., "Mercury Capture by an Activated Carbon in a Fixed-Bed BenchScale System", Environmental Progress, 17, (No. 3), p. 203-208.

12. T. Duckwall, Barnebey \& Sutcliffe, personal communication, March, 1999.

13. L. Bernard, et. al., "Determination de la pression de $\mathrm{HgCl} 2$ par la methode d'effusion de Knudsen", J. Phys. III France, 7, (1997), p. 311-319.

14. F. A. Hohorst, FAH-08-95 to B. G. Motes, "RESULTS OF MAIN STACK AIR METALS SAMPLING RESULTS OF APRIL 1, 1993", dated April 27, 1995.

15. F. A. Hohorst, FAH-20-93 to B. G. Motes, "CHANGES IN MAIN STACK SAMPLING ON JULY 28, 1993", dated April 27, 1995.

16. F. A. Hohorst, FAH-09-95 to B. G. Motes, "RESULTS OF MAIN STACK AIR METALS", dated April 27, 1995.

17. Chemical Engineer's Handbook, 6th Ed., p. 3-47.

18. R. E. Schindler, Emissions Model of ICPP Waste Treatment Operations for the Permit to Operate Application, INEL-95/098, February, 1995.

19. Wagman, D. D., et. al., "The NBS tables of chemical thermodynamic properties", J. Phys. Chem. Ref. Data, Vol. 11, Suppl. 2, 1982.

20. Barin, I., Thermochemical Data of Pure Substances, VCH Verlagsgesellschaft mbH, FRG, 1989.

21. Wichmann, T., et. al., Regulatory Analysis and Proposed Path Forward for the Idaho National Engineering Laboratory High-Level Waste Program, Rev. 1, DOE/ID-10544, October, 1996, Tables 8-1 and 8-2.

22. Listed Waste Determination Report, WINCO-1132, June, 1993.

23. K. L. Gilbert \& T. E. Venneman, "A Regulatory Analysis and Reassessment of U. S. Environmental Protection Agency Listed Hazardous Waste Numbers for Applicability to the INTEC Liquid Waste System", INEEL/EXT-98-01213, Rev. 1, February 1999.

24. R. E. Schindler, Schi-26-97 to J. H. Valentine, "Tank Farm Characterization Baseline with Waste Codes", November 21, 1997. 
25. Guidance on Setting Permit Conditions and Reporting Trial Burn Results, EPA/625/689/019, January, 1989.

26. "Exposure Assessment Guidance for RCRA Hazardous Waste Combustion Facilities, EPA530-R-94-021, April, 1994.

27. J. A. Weilang, et. al., The Fourth Processing Campaign in the Waste Calcining Facility, FY-1971, ICP-1004, 1972.

28. M. C. Swenson, MCS-23-92 to S. F. Henderson, "NWCF Off-gas CO/CO2 Sample Results", Dated November 18, 1992.

29. R. E. Schindler, Physical Property Parameter Set for Modeling ICPP Aqueous Wastes with ASPEN Electrolyte NRTL Model, INEL-96/0234, September, 1996. 

Table A-1. Calculation of stack emission rates from stack sampling during NWCF "hot feed" in 1993a.

\begin{tabular}{|c|c|c|c|c|c|c|}
\hline \multirow[b]{2}{*}{ Metal } & \multirow[b]{2}{*}{$\begin{array}{c}\text { Sampling } \\
\text { Date }\end{array}$} & \multirow[b]{2}{*}{$\begin{array}{c}\text { Conc. } \\
\text { (ug/m3@STP) }\end{array}$} & \multicolumn{2}{|c|}{ Stack Flowrate@STP } & \multirow{2}{*}{$\begin{array}{c}\text { Emission } \\
\text { Rate }^{\mathrm{c}} \\
(\mathrm{g} / \mathrm{s}) \\
\end{array}$} & \multirow{2}{*}{$\begin{array}{c}\text { Average } \\
\text { Rate } \\
(\mathrm{g} / \mathrm{s}) \\
\end{array}$} \\
\hline & & & scfm & $\mathrm{M}^{3} / \mathrm{s}$ & & \\
\hline \multirow[t]{3}{*}{$\mathrm{Sb}$} & $4 / 1 / 93$ & $<81$ & 118470 & 55.92 & $<4.53 \mathrm{E}-03$ & \\
\hline & $7 / 28 / 93$ & $<14$ & 100390 & 47.38 & $<6.63 \mathrm{E}-04$ & $<1.97 \mathrm{E}-03$ \\
\hline & $8 / 11 / 93$ & $<15$ & 102120 & 48.20 & $<7.23 \mathrm{E}-0.4$ & \\
\hline \multirow[t]{3}{*}{$\mathrm{Hg}$} & $4 / 1 / 93$ & 16 & 118470 & 55.92 & $8.95 \mathrm{E}-04$ & \\
\hline & $7 / 28 / 93$ & 10 & 100390 & 47.38 & $4.74 \mathrm{E}-04$ & $5.27 \mathrm{E}-04$ \\
\hline & $8 / 11 / 93$ & 4.4 & 102120 & 48.20 & 2.12E-04 & \\
\hline \multirow[t]{3}{*}{$\mathrm{Cr}$} & $4 / 1 / 93$ & $<4.1$ & 118470 & 55.92 & $<.29 \mathrm{E}-04$ & \\
\hline & $7 / 28 / 93$ & $<2.8$ & 100390 & 47.38 & $<1.33 \mathrm{E}-04$ & $<1.69 \mathrm{E}-04$ \\
\hline & $8 / 11 / 93$ & $<3$ & 102120 & 48.20 & $<1.45 \mathrm{E}-04$ & \\
\hline \multirow[t]{3}{*}{ As } & $4 / 1 / 93$ & $<120$ & 118470 & 55.92 & $<6.71 \mathrm{E}-03$ & \\
\hline & $7 / 28 / 93$ & $<28$ & 100390 & 47.38 & $<1.33 \mathrm{E}-03$ & $<3.16 \mathrm{E}-03$ \\
\hline & $8 / 11 / 93$ & $<30$ & 102120 & 48.20 & $<1.45 \mathrm{E}-03$ & \\
\hline \multirow[t]{3}{*}{$\mathrm{Se}$} & $4 / 1 / 93$ & $<81$ & 118470 & 55.92 & $<4.53 \mathrm{E}-03$ & \\
\hline & $7 / 28 / 93$ & $<14$ & 100390 & 47.38 & $<6.63 E-04$ & $<1.97 \mathrm{E}-03$ \\
\hline & $8 / 11 / 93$ & $<15$ & 102120 & 48.20 & $<7.23 E-04$ & \\
\hline \multirow[t]{3}{*}{$\mathrm{Pb}$} & $4 / 1 / 93$ & $<41$ & 118470 & 55.92 & $<2.29 \mathrm{E}-03$ & \\
\hline & $7 / 28 / 93$ & $<28$ & 100390 & 47.38 & $<1.33 \mathrm{E}-03$ & $<1.69 \mathrm{E}-03$ \\
\hline & $8 / 11 / 93$ & $<30$ & 102120 & 48.20 & $<1.45 \mathrm{E}-03$ & \\
\hline \multirow[t]{3}{*}{$\mathrm{Cd}$} & $4 / 1 / 93$ & $<4.1$ & 118470 & 55.92 & $<2.29 \mathrm{E}-04$ & \\
\hline & $7 / 28 / 93$ & $<1.4$ & 100390 & 47.38 & $<6.63 \mathrm{E}-05$ & $<1.23 \mathrm{E}-04$ \\
\hline & $8 / 11 / 93$ & $<1.5$ & 102120 & 48.20 & $<7.23 \mathrm{E}-05$ & \\
\hline \multirow[t]{3}{*}{$\mathrm{Ba}$} & $4 / 1 / 93$ & $<3.2$ & 118470 & 55.92 & $<1.79 \mathrm{E}-04$ & \\
\hline & $7 / 28 / 93$ & 1.4 & 100390 & 47.38 & $6.63 E-05$ & $<1.06 \mathrm{E}-04$ \\
\hline & $8 / 11 / 93$ & $<1.5$ & 102120 & 48.20 & $<7.23 \mathrm{E}-05$ & \\
\hline \multirow[t]{3}{*}{$\mathrm{Be}$} & $4 / 1 / 93$ & $<0.12$ & 118470 & 55.92 & $<6.71 E-06$ & \\
\hline & $7 / 28 / 93$ & $<0.042$ & 100390 & 47.38 & $<1.99 \mathrm{E}-06$ & $<.62 \mathrm{E}-06$ \\
\hline & $8 / 11 / 93$ & $<0.045$ & 102120 & 48.20 & $<2.17 \mathrm{E}-06$ & \\
\hline \multirow[t]{3}{*}{$\mathrm{Ni}$} & $4 / 1 / 93$ & $<12$ & 118470 & 55.92 & $<6.71 \mathrm{E}-04$ & \\
\hline & $7 / 28 / 93$ & $<4.2$ & 100390 & 47.38 & $<1.99 \mathrm{E}-04$ & $<3.62 \mathrm{E}-04$ \\
\hline & $8 / 11 / 93$ & $<4.5$ & 102120 & 48.20 & $<.17 E-04$ & \\
\hline \multirow[t]{3}{*}{$\mathrm{Ag}$} & $4 / 1 / 93$ & $<.5$ & 118470 & 55.92 & $<1.40 \mathrm{E}-04$ & \\
\hline & $7 / 28 / 93$ & $<1.4$ & 100390 & 47.38 & $<6.63 \mathrm{E}-05$ & $<9.28 \mathrm{E}-05$ \\
\hline & $8 / 11 / 93$ & $<1.5$ & 102120 & 48.20 & $<7.23 \mathrm{E}-05$ & \\
\hline \multirow[t]{3}{*}{ Th } & $4 / 1 / 93$ & $<81$ & 118470 & 55.92 & $<4.53 \mathrm{E}-03$ & \\
\hline & $7 / 28 / 93$ & $<14$ & 100390 & 47.38 & $<6.63 \mathrm{E}-04$ & $<1.97 \mathrm{E}-03$ \\
\hline & $8 / 11 / 93$ & $<15$ & 102120 & 48.20 & $<7.23 \mathrm{E}-04$ & \\
\hline
\end{tabular}




\section{Appendix B}

\section{Chemical Specific Inputs and}

Chemical Media Concentrations for Evaluation of all Receptors 
Table B-1. Chemical-specific inputs for indirect and direct exposure assessment.

\begin{tabular}{|c|c|c|c|c|c|c|c|c|c|c|c|c|c|c|c|c|}
\hline Chemical & Fv & ksg & $K_{d s}$ & $K_{d s w}$ & $K_{\mathrm{uhs}}$ & $\mathrm{H}$ & $\mathrm{Da}$ & Dw & Bv & $\mathrm{Br}$ & $\mathrm{Ba}_{\mathrm{hecr}}$ & $\mathrm{Ba}_{\text {mill }}$ & $\mathrm{BCF}$ & BAF & BSAF & $\mathrm{Fw}$ \\
\hline Antimony & $0.00 \mathrm{E}+00$ & NA & $2.00 \mathrm{E}+00$ & $2.00 \mathrm{E}+00$ & $2.00 \mathrm{E}+00$ & NA & NA & $8.00 \mathrm{E}-06$ & NA & $2.00 \mathrm{E}-01$ & $1.00 \mathrm{E}-03$ & $1.00 \mathrm{E}-04$ & $1.00 \mathrm{E}+00$ & NA & NA & $2.00 \mathrm{E}-01$ \\
\hline Arsenic & $0.00 \mathrm{E}+00$ & NA & $2.90 \mathrm{E}+01$ & $2.90 \mathrm{E}+0 \mathrm{I}$ & $2.90 \mathrm{E}+01$ & NA & NA & $8.00 \mathrm{E}-06$ & NA & $3.60 \mathrm{E}-02$ & $2.00 \mathrm{E}-03$ & $6.00 \mathrm{E}-03$ & $4.40 \mathrm{E}+01$ & NA & NA & $2.00 \mathrm{E}-01$ \\
\hline Barium & $0.00 \mathrm{E}+00$ & NA & $5.30 \mathrm{E}+02$ & $5.30 \mathrm{E}+02$ & $5.30 \mathrm{E}+02$ & NA & NA & $8.00 \mathrm{E}-06$ & NA & $1.50 \mathrm{E}-01$ & $1.50 \mathrm{E}-04$ & $3.50 \mathrm{E}-04$ & NA & $4.00 \mathrm{E}+00$ & NA & $6.00 \mathrm{E}-01$ \\
\hline Benzo(a)pyrene & $4.00 \mathrm{E}-01$ & NA & $1.20 \mathrm{E}+04$ & $9.00 \mathrm{E}+04$ & $4.80 \mathrm{E}+04$ & $8.40 \mathrm{E}-07$ & $4.30 \mathrm{E}-02$ & $9.00 \mathrm{E}-06$ & $1.30 \mathrm{E}+06$ & $1.10 \mathrm{E}-02$ & $3.40 \mathrm{E}-02$ & $1.10 \mathrm{E}-02$ & NA & $1.00 \mathrm{E}+06$ & $\mathrm{NA}$ & $6.00 \mathrm{E}-01$ \\
\hline Beryllium & $0.00 \mathrm{E}+00$ & NA & $7.00 \mathrm{E}+01$ & $7.00 \mathrm{E}+0 \mathrm{I}$ & $7.00 \mathrm{E}+01$ & NA & NA & $8.00 \mathrm{E}-06$ & $\mathrm{NA}$ & $1.00 \mathrm{E}-02$ & $1.00 \mathrm{E}-03$ & $9.00 \mathrm{E}-07$ & $2.00 \mathrm{E}+01$ & NA & NA & $6.00 \mathrm{E}-01$ \\
\hline Cadmium & $0.00 \mathrm{E}+00$ & NA & $1.60 \mathrm{E}+02$ & $1.60 \mathrm{E}+02$ & $1.60 \mathrm{E}+02$ & NA & NA & $8.00 \mathrm{E}-06$ & $\mathrm{NA}$ & $1.80 \mathrm{E}-01$ & $1.20 \mathrm{E}-01$ & $7.60 \mathrm{E}-03$ & $6.40 \mathrm{E}+01$ & NA & NA & $6.00 \mathrm{E}-01$ \\
\hline Chromium VI & $0.00 \mathrm{E}+00$ & NA & $1.80 \mathrm{E}+01$ & $1.80 \mathrm{E}+01$ & $1.80 \mathrm{E}+01$ & NA & NA & $8.00 \mathrm{E}-06$ & NA & $1.10 \mathrm{E}+00$ & $5.50 \mathrm{E}-03$ & $1.50 \mathrm{E}-03$ & $1.60 \mathrm{E}+01$ & NA & NA & $6.00 \mathrm{E}-01$ \\
\hline 1,3-dinitrobenzene & $1.00 \mathrm{E}+00$ & NA & $2.80 \mathrm{E}-01$ & $2.00 \mathrm{E}+00$ & $1.10 \mathrm{E}+00$ & $1.20 \mathrm{E}-07$ & $2.80 \mathrm{E}-01$ & $7.60 \mathrm{E}-06$ & $6.80 \mathrm{E}-03$ & $5.30 \mathrm{E}+00$ & $7.90 \mathrm{E}-07$ & $2.50 \mathrm{E}-07$ & $1.40 \mathrm{E}+00$ & NA & NA & $6.00 \mathrm{E}-01$ \\
\hline 2,4-dinitrotoluene & $1.00 \mathrm{E}+00$ & NA & $8.70 \mathrm{E}-01$ & $6.50 \mathrm{E}+00$ & $3.50 \mathrm{E}+00$ & $1.50 \mathrm{E}-07$ & $2.00 \mathrm{E}-01$ & $7.10 \mathrm{E}-06$ & $1.50 \mathrm{E}+02$ & $2.70 \mathrm{E}+00$ & $2.50 \mathrm{E}-06$ & $7.90 \mathrm{E}-07$ & $3.20 \mathrm{E}+00$ & NA & NA & $6.00 \mathrm{E}-01$ \\
\hline 2,6-dinitrotoluenc & $1.00 \mathrm{E}+00$ & NA & $6.70 \mathrm{E}-01$ & $5.00 \mathrm{E}+00$ & $2.70 \mathrm{E}+00$ & 1.30E-07 & $8.00 \mathrm{E}-02$ & $8.00 \mathrm{E}-06$ & $1.30 \mathrm{E}+02$ & $3.20 \mathrm{E}+00$ & $1.90 \mathrm{E}-06$ & $6.10 \mathrm{E}-07$ & $2.60 \mathrm{E}+00$ & NA & $\mathrm{NA}$ & $6.00 \mathrm{E}-01$ \\
\hline Di(n)octylphthalate & $8.00 \mathrm{E}-01$ & NA & $2.80 \mathrm{E}+05$ & $2.10 \mathrm{E}+06$ & $1.10 \mathrm{E}+06$ & $7.70 \mathrm{E}-07$ & $8.00 \mathrm{E}-02$ & $8.00 \mathrm{E}-06$ & $9.50 \mathrm{E}+06$ & $1.80 \mathrm{E}-03$ & NA & NA & NA & $6.60 \mathrm{E}+04$ & NA & $6.00 \mathrm{E}-01$ \\
\hline 2,3,7,8-TCDD & $2.70 \mathrm{E}-01$ & NA & $1.40 \mathrm{E}+05$ & $1.00 \mathrm{E}+06$ & $5.70 \mathrm{E}+05$ & $9.10 \mathrm{E}-06$ & $4.70 \mathrm{E}-02$ & $8.00 \mathrm{E}-06$ & $4.55 \mathrm{E}+0.5$ & $3.30 \mathrm{E}-03$ & $4.00 \mathrm{E}-02$ & $7.00 \mathrm{E}-03$ & NA & NA & $6.70 \mathrm{E}-02$ & $6.00 \mathrm{E}-01$ \\
\hline Lead & $0.00 \mathrm{E}+00$ & NA & $8.80 \mathrm{E}+04$ & $8.80 \mathrm{E}+04$ & $8.80 \mathrm{E}+04$ & NA & NA & $8.00 \mathrm{E}-06$ & $\mathrm{NA}$ & $1.80 \mathrm{E}-02$ & $3.00 \mathrm{E}-04$ & $2.50 \mathrm{E}-04$ & NA & $8.00 \mathrm{E}+00$ & NA & $6.00 \mathrm{E}-01$ \\
\hline Mercury & $0.00 E+00$ & NA & $1.50 \mathrm{E}+02$ & $1.50 \mathrm{E}+02$ & $1.50 \mathrm{E}+02$ & $9.00 \mathrm{E}-03$ & NA & $8.00 \mathrm{E}-06$ & NA & $2.00 \mathrm{E}-03$ & $2.50 \mathrm{E}-01$ & $4.50 \mathrm{E}-04$ & NA & $1.30 \mathrm{E}+05$ & NA & $6.00 \mathrm{E}-01$ \\
\hline Nickel & $0.00 \mathrm{E}+00$ & NA & $8.20 \mathrm{E}+01$ & $8.20 \mathrm{E}+01$ & $8.20 \mathrm{E}+01$ & NA & NA & $8.00 \mathrm{E}-06$ & NA & $1.60 \mathrm{E}-02$ & $6.00 \mathrm{E}-03$ & $1.00 \mathrm{E}-03$ & $4.70 \mathrm{E}+01$ & NA & NA & $6.00 \mathrm{E}-01$ \\
\hline Nitrobenzene & $1.00 \mathrm{E}+00$ & NA & $6.00 \mathrm{E}-01$ & $4.50 \mathrm{E}+00$ & $2.40 \mathrm{E}+00$ & $2.10 \mathrm{E}-05$ & $7.60 \mathrm{E}-02$ & $8.60 \mathrm{E}-06$ & $7.00 \mathrm{E}-01$ & $3.40 \mathrm{E}+00$ & 1.70E-06 & $5.40 \mathrm{E}-07$ & $2.40 \mathrm{E}+00$ & NA & NA & $6.00 \mathrm{E}-01$ \\
\hline $\begin{array}{l}\text { Pentachloro- } \\
\text { nitrobenzene }\end{array}$ & $1.00 \mathrm{E}+00$ & NA & $3.80 \mathrm{E}+02$ & $2.90 \mathrm{E}+03$ & $1.50 \mathrm{E}+03$ & $2.90 \mathrm{E}-02$ & $8.00 \mathrm{E}-02$ & $8.00 \mathrm{E}-06$ & $7.90 \mathrm{E}-01$ & $8.10 \mathrm{E}-02$ & $1.10 \mathrm{E}-03$ & $3.50 \mathrm{E}-04$ & $1.40 \mathrm{E}+02$ & NA & NA & $6.00 \mathrm{E}-01$ \\
\hline Pentachlorophenol & $1.00 \mathrm{E}+00$ & NA & $1.10 \mathrm{E}+03$ & $8.30 \mathrm{E}+03$ & $4.40 \mathrm{E}+03$ & $1.40 \mathrm{E}-05$ & $5.60 \mathrm{E}-02$ & $5.10 \mathrm{E}-06$ & $5.10 \mathrm{E}+03$ & $4.50 \mathrm{E}-02$ & $3.00 \mathrm{E}-03$ & $9.60 \mathrm{E}-04$ & NA & NA & $\mathrm{NA}$ & $6.00 \mathrm{E}-01$ \\
\hline Selenitum & $0.00 \mathrm{E}+00$ & $N A$ & $4.30 \mathrm{E}+00$ & $4.30 \mathrm{E}+00$ & $4.30 \mathrm{E}+00$ & NA & NA & $8.00 \mathrm{E}-06$ & NA & $1.60 \mathrm{E}-02$ & $1.50 \mathrm{E}-02$ & $4.00 \mathrm{E}-03$ & $6.00 \mathrm{E}+00$ & NA & NA & $2.00 \mathrm{E}-01$ \\
\hline Silver & $0.00 \mathrm{E}+00$ & $\mathrm{NA}$ & $4.00 \mathrm{E}-01$ & $4.00 \mathrm{E}-01$ & $4.00 \mathrm{E}-01$ & NA & NA & $8.00 \mathrm{E}-06$ & NA & $4.00 \mathrm{E}-01$ & $3.00 \mathrm{E}-03$ & $2.00 \mathrm{E}-02$ & $5.00 \mathrm{E}-01$ & NA & NA & $6.00 \mathrm{E}-01$ \\
\hline Thallium & $0.00 \mathrm{E}+00$ & $N A$ & $7.40 \mathrm{E}+01$ & $7.40 \mathrm{E}+01$ & $7.40 \mathrm{E}+01$ & NA & NA & $8.00 \mathrm{E}-06$ & NA & $2.10 \mathrm{E}-01$ & $4.00 \mathrm{E}-02$ & $2.00 \mathrm{E}-03$ & $1.20 \mathrm{E}+02$ & NA & NA & $6.00 \mathrm{E}-01$ \\
\hline
\end{tabular}


Table B-2. Toxicity values and or health benchmarks for the inhalation and oral routes of exposure.

\begin{tabular}{|c|c|c|c|c|c|c|c|c|}
\hline \multirow[b]{2}{*}{ Chemical } & \multicolumn{2}{|c|}{$\begin{array}{c}\mathrm{CSF}_{\text {oral }} \\
(\mathrm{mg} / \mathrm{kg} / \text { day })^{-1}\end{array}$} & \multicolumn{2}{|c|}{$\begin{array}{c}\mathrm{RfD}_{\text {oral }} \\
(\mathrm{mg} / \mathrm{kg} / \mathrm{day})^{-1}\end{array}$} & \multicolumn{2}{|c|}{$\begin{array}{c}\text { URF } \\
\left(\mu \mathrm{g} / \mathrm{m}^{3}\right)^{-1}\end{array}$} & \multicolumn{2}{|c|}{$\begin{array}{c}\mathrm{RfC} \\
\left(\mathrm{mg} / \mathrm{m}^{3}\right) \\
\end{array}$} \\
\hline & Value & Reference & Value & Reference & Value & Reference & Value & Reference \\
\hline Acetonitrile & $\mathrm{NA}$ & & $\mathrm{NA}$ & & ND & & $5.00 \mathrm{E}-02$ & HEAST \\
\hline Aniline & $\mathrm{NA}$ & & NA & & ND & & $1.00 \mathrm{E}-03$ & IRIS \\
\hline Antimony & $\mathrm{ND}$ & & $4.00 \mathrm{E}-04$ & IRIS & ND & & $2.50 \mathrm{E}-02$ & IDHW \\
\hline Arsenic & $1.50 \mathrm{E}+01$ & IRIS & $3.00 \mathrm{E}-04$ & IRIS & 4.3E-03 & IRIS & ND & \\
\hline Barium & ND & & $7.00 \mathrm{E}-02$ & IRIS & ND & & $5.00 \mathrm{E}-04$ & HEAST \\
\hline Benzene & NA & & NA & & $7.8 \mathrm{E}-06$ & IRIS & $9.00 \mathrm{E}-03$ & NCEA \\
\hline Benzo(a)pyrene & $7.30 \mathrm{E}+00$ & IRIS & ND & & 8.86E-04 & ATG & ND & \\
\hline Beryllium & $4.30 \mathrm{E}+00$ & IRIS & $5.00 \mathrm{E}-03$ & IRIS & $2.40 \mathrm{E}-03$ & IRIS & $2.00 \mathrm{E}-05$ & IRIS \\
\hline Bromoform & NA & & NA & & $1.10 \mathrm{E}-06$ & IRIS & $7.00 \mathrm{E}-02$ & ATG \\
\hline Butylbenzylphthalate & $\mathrm{NA}$ & & NA & & ND & & $7.00 \mathrm{E}-01$ & ATG \\
\hline Cadmium & ND & & $1.00 \mathrm{E}-03$ & IRIS & $1.80 \mathrm{E}-03$ & IRIS & $2.00 \mathrm{E}-04$ & EPA9 \\
\hline Carbon disulfide & NA & & NA & & ND & & $7.30 \mathrm{E}-01$ & IRIS \\
\hline Carbon monoxide & NA & & $\mathrm{NA}$ & & ND & & $1.00 \mathrm{E}+01$ & NAAQS \\
\hline Carbon tetrachloride & NA & & NA & & $2.00 \mathrm{E}-03$ & ATG & $2.00 \mathrm{E}-03$ & EPA9 \\
\hline Chlorobenzene & $\mathrm{NA}$ & & NA & & ND & & $2.00 \mathrm{E}-02$ & HEAST \\
\hline Chloroform & NA & & NA & & $2.30 \mathrm{E}-05$ & IRIS & $3.01 \mathrm{E}-03$ & ATG \\
\hline Chromium VI & $\mathrm{ND}$ & & $5.00 \mathrm{E}-03$ & IRIS & $1.20 \mathrm{E}-02$ & IRIS & ND & \\
\hline Dibutylphthalate & NA & & NA & & ND & & $3.50 \mathrm{E}-01$ & ATG \\
\hline 1,2-dichloroethane & NA & & NA & & $2.60 \mathrm{E}-05$ & IRIS & $1.00 \mathrm{E}-02$ & $\mathrm{EPA}^{\mathrm{b}}$ \\
\hline Diethylphthalate & NA & & NA & & ND & & $2.80 \mathrm{E}+00$ & ATG \\
\hline 1,3-dinitrobenzene & ND & & $1.00 \mathrm{E}-04$ & IRIS & ND & & $3.50 \mathrm{E}-04$ & ATG \\
\hline
\end{tabular}


Table B-2. (continued).

\begin{tabular}{|c|c|c|c|c|c|c|c|c|}
\hline \multirow[b]{2}{*}{ Chemical } & \multicolumn{2}{|c|}{$\begin{array}{c}\mathrm{CSF}_{\text {oral }} \\
(\mathrm{mg} / \mathrm{kg} / \text { day })^{-1}\end{array}$} & \multicolumn{2}{|c|}{$\begin{array}{c}\mathrm{RfD}_{\text {oral }} \\
(\mathrm{mg} / \mathrm{kg} / \text { day })^{-1} \\
\end{array}$} & \multicolumn{2}{|c|}{$\begin{array}{c}\text { URF } \\
\left(\mu \mathrm{g} / \mathrm{m}^{3}\right)^{-1}\end{array}$} & \multicolumn{2}{|c|}{$\begin{array}{c}\mathrm{RfC} \\
\left(\mathrm{mg} / \mathrm{m}^{3}\right) \\
\end{array}$} \\
\hline & Value & Reference & Value & Reference & Value & Reference & Value & Reference \\
\hline 2,4-dinitrophenol & NA & & NA & & ND & & $7.00 \mathrm{E}-03$ & ATG \\
\hline 2,4-dinitrotoluene & ND & & $2.00 \mathrm{E}-03$ & IRIS & ND & & $7.00 \mathrm{E}-03$ & ATG \\
\hline 2,6-dinitrotoluene & ND & & $1.00 \mathrm{E}-03$ & HEAST & ND & & $3.50 \mathrm{E}-03$ & ATG \\
\hline Di(n)octylphthalate & ND & & $2.00 \mathrm{E}-02$ & HEAST & ND & & $7.00 \mathrm{E}-02$ & ATG \\
\hline 1,4-dioxane & NA & & NA & & 3.14E-06 & ATG & ND & \\
\hline Ethylene glycol & NA & & NA & & ND & & $7.00 \mathrm{E}+00$ & ATG \\
\hline Formaldehyde & NA & & NA & & $1.30 \mathrm{E}-05$ & IRIS & ND & \\
\hline Formic acid & NA & & NA & & ND & & $7.00 \mathrm{E}+00$ & EPA9 \\
\hline 2,3,7,8-TCDD & $1.50 \mathrm{E}+5$ & HEAST & ND & & $3.43 \mathrm{E}+01$ & ATG & ND & \\
\hline Hydrazine & NA & & NA & & 4.90E-03 & IRIS & ND & \\
\hline Hydrogen chloride & NA & & NA & & ND & & $2.00 \mathrm{E}-02$ & IRIS \\
\hline Hydrogen fluoride & NA & & NA & & ND & & $2.60 \mathrm{E}-02$ & Calculated \\
\hline (Iso)thiourea & NA & & NA & & $5.56 \mathrm{E}-04$ & IDHW & ND & \\
\hline Lead & ND & & ND & & ND & & $1.53 \mathrm{E}-03$ & NAAQS \\
\hline Mercury & ND & & $3.00 \mathrm{E}-04$ & IRIS & ND & & $3.00 \mathrm{E}-04$ & IRIS \\
\hline Methyl ethyl ketone & NA & & NA & & ND & & $1.00 E+00$ & IRIS \\
\hline Methylene chloride & NA & & NA & & 4.70E-07 & IRIS & $3.00 E+00$ & HEAST \\
\hline Napthalene & NA & & NA & & ND & & $3.00 \mathrm{E}-03$ & EPA9 \\
\hline Nickel & ND & & $2.00 \mathrm{E}-02$ & IRIS & $2.40 \mathrm{E}-04$ & EPA9 & ND & \\
\hline Nitrobenzene & ND & & $5.00 \mathrm{E}-04$ & IRIS & ND & & $2.00 \mathrm{E}-03$ & HEAST \\
\hline Nitric acid & NA & & NA & & ND & & $2.50 \mathrm{E}-01$ & IDHW \\
\hline Nitrogen dioxide & NA & & NA & & ND & & $3.50 \mathrm{E}+00$ & EPA9 \\
\hline
\end{tabular}


Table B-2. (continued).

\begin{tabular}{|c|c|c|c|c|c|c|c|c|}
\hline \multirow[b]{2}{*}{ Chemical } & \multicolumn{2}{|c|}{ 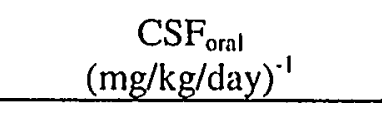 } & \multicolumn{2}{|c|}{$\begin{array}{c}\mathrm{RfD}_{\text {oral }} \\
\text { (mg/kg/day) }^{-1}\end{array}$} & \multicolumn{2}{|c|}{$\begin{array}{c}\text { URF } \\
\left(\mu \mathrm{g} / \mathrm{m}^{3}\right)^{-1}\end{array}$} & \multicolumn{2}{|c|}{$\begin{array}{c}\mathrm{RfC} \\
\left(\mathrm{mg} / \mathrm{m}^{3}\right)\end{array}$} \\
\hline & Value & Reference & Value & Reference & Value & Reference & Value & Reference \\
\hline Pentachloronitrobenzene & $2.60 \mathrm{E}-01$ & HEAST & 3.00E-03 & IRIS & $7.43 \mathrm{E}-05$ & ATG & $1.05 \mathrm{E}-02$ & ATG \\
\hline Pentachlorophenol & $1.20 \mathrm{E}-01$ & IRIS & 3.00E-02 & IRIS & $3.40 \mathrm{E}-05$ & ATG & $1.05 \mathrm{E}-01$ & ATG \\
\hline Phenol & $\mathrm{NA}$ & & NA & & ND & & $2.10 \mathrm{E}+00$ & ATG \\
\hline Pyridine & $\mathrm{NA}$ & & NA & & ND & & $3.50 \mathrm{E}-03$ & ATG \\
\hline Selenium & ND & & $5.00 \mathrm{E}-03$ & IRIS & ND & & $1.00 \mathrm{E}-02$ & IDHW \\
\hline Silver & ND & & $5.00 \mathrm{E}-03$ & IRIS & ND & & $5.00 \mathrm{E}-03$ & IDHW \\
\hline Sulfur dioxide & $\mathrm{NA}$ & & $\mathrm{NA}$ & & ND & & $8.00 \mathrm{E}-02$ & NAAQS \\
\hline Tetrachloroethylene & $\mathrm{NA}$ & & NA & & $3.14 \mathrm{E}-05$ & EPA9 & $2.70 \mathrm{E}-01$ & ATG \\
\hline Thallium & ND & & $8.00 \mathrm{E}-04$ & IRIS & ND & & $2.80 \mathrm{E}-04$ & ATG \\
\hline Uranium & NA & & $\mathrm{NA}$ & & ND & & $1.00 \mathrm{E}-02$ & IDHW \\
\hline Toluene & $\mathrm{NA}$ & & $\mathrm{NA}$ & & ND & & $4.00 \mathrm{E}-01$ & IRIS \\
\hline 1,2,4-Trichorobenzene & NA & & $\mathrm{NA}$ & & ND & & $2.00 \mathrm{E}-01$ & ATG \\
\hline 1,1,1-Trichloroethane & $\mathrm{NA}$ & & $\mathrm{NA}$ & & ND & & $1.00 \mathrm{E}-01$ & ATG \\
\hline 1,1,2-Trichloroethane & NA & & $\mathrm{NA}$ & & $1.60 \mathrm{E}-05$ & IRIS & $1.40 \mathrm{E}-02$ & ATG \\
\hline Trichloroethylene & NA & & NA & & $\mathrm{ND}$ & & $2.10 \mathrm{E}-02$ & ATG \\
\hline \multicolumn{9}{|c|}{$\begin{array}{l}\text { ND = No toxicity data are available. } \\
\text { NA = Not applicable. The oral route of exposure was not evaluated for this chemical. } \\
\text { IDHW = Idaho Division of Health and Welfare, Toxic Air Pollutant AAC/AACC } \\
\text { NCEA = National Center for Environmental Assessment (EPA) } \\
\text { ATG = Allied Technical Group Risk Assessment Work Plan } \\
\text { EPA9 = Derived from EPA Region } 9 \text { on-line toxicity values } \\
\text { NAAQS = National Ambient Air Quality Standard. } \\
\text { Calculated = } 1 \% \text { of ACGIH-TLV. }\end{array}$} \\
\hline
\end{tabular}


Table B-3. Soil concentration from deposition.

\begin{tabular}{|c|c|c|}
\hline \multicolumn{3}{|c|}{ Exposure Scenarios } \\
\hline \multicolumn{3}{|c|}{ All } \\
\hline \multicolumn{3}{|c|}{ Equation } \\
\hline$D s=\frac{100 *}{z * B}$ & $\begin{array}{l}=\frac{\left(\frac{D s * T c-S c_{T c}}{k s}\right)+\left(\frac{S c_{T c}}{k s} *\left[1-\exp \left(-k s *\left(T_{2}-\right.\right.\right.\right.}{\left(T_{2}-T_{1}\right)} \\
S c_{T c}=\frac{D s *(1-\exp (-k s * T c))}{k s} \\
*\left[F_{v}(0.31536 * V d v * C y v+D y w v)+(D y d p+I\right.\end{array}$ & $\left.v p)^{*}\left(1-F_{v}\right)\right]$ \\
\hline Parameter & Definition & Value \\
\hline Sc & Average soil concentration over exposure duration $(\mathrm{mg} / \mathrm{kg})$ & \\
\hline Ds & Deposition term (mg $/ \mathrm{kg}$-year) & Calculated (Tables B-11 and B-13) \\
\hline $\mathrm{Tc}$ & Time period over which deposition occurs (years) & 16 \\
\hline $\mathrm{Sc}_{\mathrm{Tc}_{\mathrm{c}}}$ & Soil concentration at time $\mathrm{Tc}(\mathrm{mg} / \mathrm{kg})$ & Calculated (Tables B-11 and B-13) \\
\hline ks & Soil loss constant (year ${ }^{-1}$ ) & (Tables B-11 and B-13) \\
\hline $\mathrm{T}_{2}$ & Exposure duration (year) & Scenario-specific $(40,30$, and 9$)$ \\
\hline$z$ & Soil mixing depth (cm) & $\begin{array}{l}1 \text { ( } 20 \text { used for soluble COPCs with root } \\
\text { uptake as the critical exposure pathway) }\end{array}$ \\
\hline $\mathrm{BD}$ & Soil bulk density $\left(\mathrm{g} / \mathrm{cm}^{3}\right)$ & 1.5 \\
\hline 0.31536 & Units conversion factor (m-g-s/cm- $\mu \mathrm{g}$-year) & \\
\hline $\mathrm{Vdv}$ & Dry deposition velocity (cm/second) & 3 \\
\hline Cyv & Normalized vapor-phase air concentration ( $\mu \mathrm{g}$-second $/ \mathrm{g}-\mathrm{m}^{3}$ ) & 0.06213 \\
\hline Q & Stack emissions ( $\mathrm{g} /$ second) & Site-specific (Table A-2) \\
\hline$F_{v}$ & Fraction of air concentration in vapor phase (dimensionless) & Chemical-specific (Table B-1) \\
\hline Dywv & $\begin{array}{l}\text { Normalized yearly wet deposition from vapor phase } \\
\text { (second } / \mathrm{m}^{2} \text { year) }\end{array}$ & 0.00037 \\
\hline Dydp & $\begin{array}{l}\text { Normalized yearly dry deposition from particle phase } \\
\text { (second } / \mathrm{m}^{2} \text {-year) }\end{array}$ & 0.00045 \\
\hline Dywp & $\begin{array}{l}\text { Normalized yearly wet deposition from particle phase } \\
\text { (second } / \mathrm{m}^{2} \text {-year) }\end{array}$ & 0.00024 \\
\hline 100 & Units conversion factor $\left(\left[\mathrm{mg}-\mathrm{m}^{2}\right] /\left[\mathrm{kg}-\mathrm{cm}^{2}\right]\right)$ & \\
\hline \multicolumn{3}{|c|}{ Description } \\
\hline \multicolumn{3}{|c|}{$\begin{array}{l}\text { These equations calculate an average soil concentration over the exposure duration caused by wet and dry deposition onto soil, } \\
\text { deposition of wet vapors to soil, and diffusion of dry vapors to soil. Contaminants are assumed to be incorporated only to a } \\
\text { finite depth (the mixing depth, Z). }\end{array}$} \\
\hline \multicolumn{3}{|c|}{$\begin{array}{l}\text { Source: EPA, 1994, Guidance for Performing Screening Level Risk Analyses as Combustion Facilities Burning Hazardous Wastes. Draft. U.S. Environmental } \\
\text { Protection Agency. Office of Emergency and Remedial Response. Office of Solid Waste, December } 14 .\end{array}$} \\
\hline
\end{tabular}


Table B-4. Loss constant from leaching.

\begin{tabular}{|c|c|c|}
\hline \multicolumn{3}{|c|}{ Exposure Scenarios } \\
\hline \multicolumn{3}{|c|}{ All } \\
\hline \multicolumn{3}{|c|}{ Equation } \\
\hline \multicolumn{3}{|c|}{$k s l=\frac{P+I-R-E V}{\Theta_{s} * Z *\left[1.0+\left(B D^{*} K d_{s} / \Theta_{s}\right)\right]}$} \\
\hline Parameter & Definition & Value \\
\hline $\mathrm{ksl}$ & Loss constant from leaching (year ${ }^{-1}$ ) & \\
\hline $\mathrm{P}$ & Average annual precipitation ( $\mathrm{cm} /$ year) & 22.1 \\
\hline I & Average annual irrigation (cm/year) & 138 \\
\hline $\mathrm{R}$ & Average surface runoff $(\mathrm{cm} /$ year $)$ & 1.27 \\
\hline Ev & Average annual evapotranspiration (cm/year) & 30.48 \\
\hline$\Theta_{\mathrm{s}}$ & Soil volumetric water content $\left(\mathrm{mL} / \mathrm{cm}^{3}\right)$ & 0.2 \\
\hline $\mathrm{Z}$ & Soil depth from which leaching removal occurs $(\mathrm{cm})$ & 1 \\
\hline $\mathrm{Kd}_{\mathrm{s}}$ & Soil-water partition coefficient $\left(\mathrm{cm}^{3} / \mathrm{g}\right)$ & $\begin{array}{l}\text { Chemical-specific (Table B- } \\
\text { 1) }\end{array}$ \\
\hline $\mathrm{BD}$ & Soil bulk density $\left(\mathrm{g} / \mathrm{cm}^{3}\right)$ & 1.5 \\
\hline \multicolumn{3}{|c|}{ Description } \\
\hline \multicolumn{3}{|c|}{ This equation calculates the contaminant loss constant caused by leaching from soil. } \\
\hline \multicolumn{3}{|c|}{$\begin{array}{l}\text { Source: EPA, 1994, Guidance for Performing Screening Level Risk Analyses at Combustion Facilities Burning Hazardous } \\
\text { Wastes, Draft, U.S. Environmental Protection Agency, Office of Emergency and Remedial Response, Office of Solid Waste, } \\
\text { December 14. }\end{array}$} \\
\hline
\end{tabular}


Table B-5. Loss constant from surface runoff.

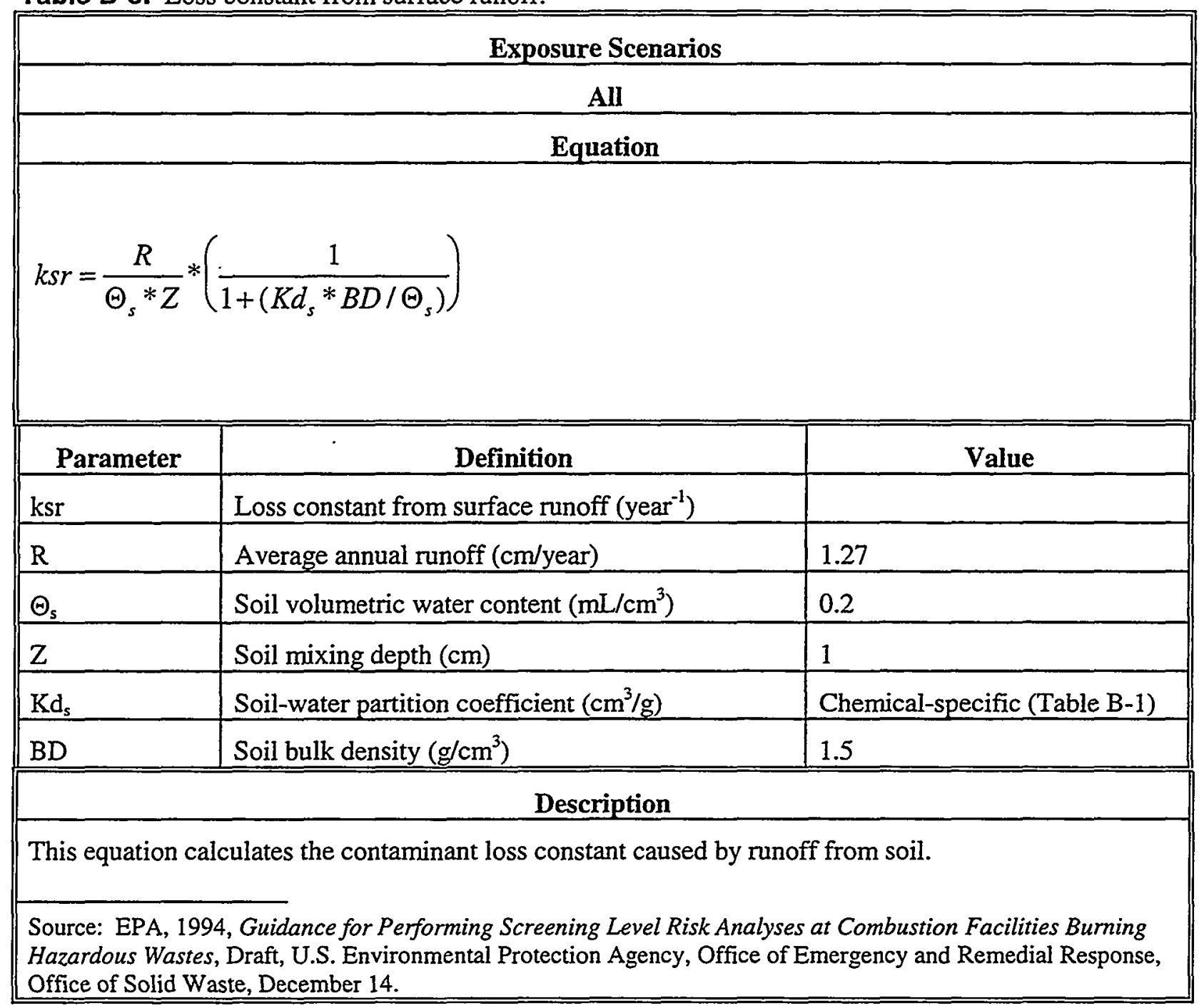


Table B-6. Loss constant from all processes.

\begin{tabular}{|c|c|c|}
\hline \multicolumn{3}{|c|}{ Exposure Scenarios } \\
\hline \multicolumn{3}{|c|}{ All } \\
\hline \multicolumn{3}{|c|}{ Equation } \\
\hline \multicolumn{3}{|c|}{$k s=k s l+k s e+k s r+k s g+k s v$} \\
\hline Parameter & Definition & Value \\
\hline ks & Soil loss constant from all processes (year ${ }^{-1}$ ) & \\
\hline $\mathrm{ksl}$ & Loss constant from leaching (year $\left.{ }^{-1}\right)$ & Calculated (Tables B-11 to B-13) \\
\hline kse & Loss constant from soil erosion (year ${ }^{-1}$ ) & 0 \\
\hline ksr & Loss constant from surface runoff $\left(\right.$ year $\left.^{-1}\right)$ & Calculated (Tables B-11 to B-13) \\
\hline $\mathrm{ksg}$ & Loss constant from degradation (year ${ }^{-1}$ ) & Calculated (Tables B-11 to B-13) \\
\hline ksv & Loss constant from volatilization $\left(\right.$ year $\left.^{-1}\right)$ & Calculated (Tables B-11 to B-13) \\
\hline \multicolumn{3}{|c|}{ Description } \\
\hline \multicolumn{3}{|c|}{$\begin{array}{l}\text { This equation is used to calculate the soil loss constant, which accounts for the loss of contaminant from } \\
\text { soil by several mechanisms. }\end{array}$} \\
\hline \multicolumn{3}{|c|}{$\begin{array}{l}\text { Source: EPA, 1994, Guidance for Performing Screening Level Risk Analyses at Combustion Facilities Buming Hazardous } \\
\text { Wastes, Draft, U.S. Environmental Protection Agency, Office of Emergency and Remedial Response, Office of Solid Waste, } \\
\text { December 14. }\end{array}$} \\
\hline
\end{tabular}


Table B-7. Loss constant from volatilization

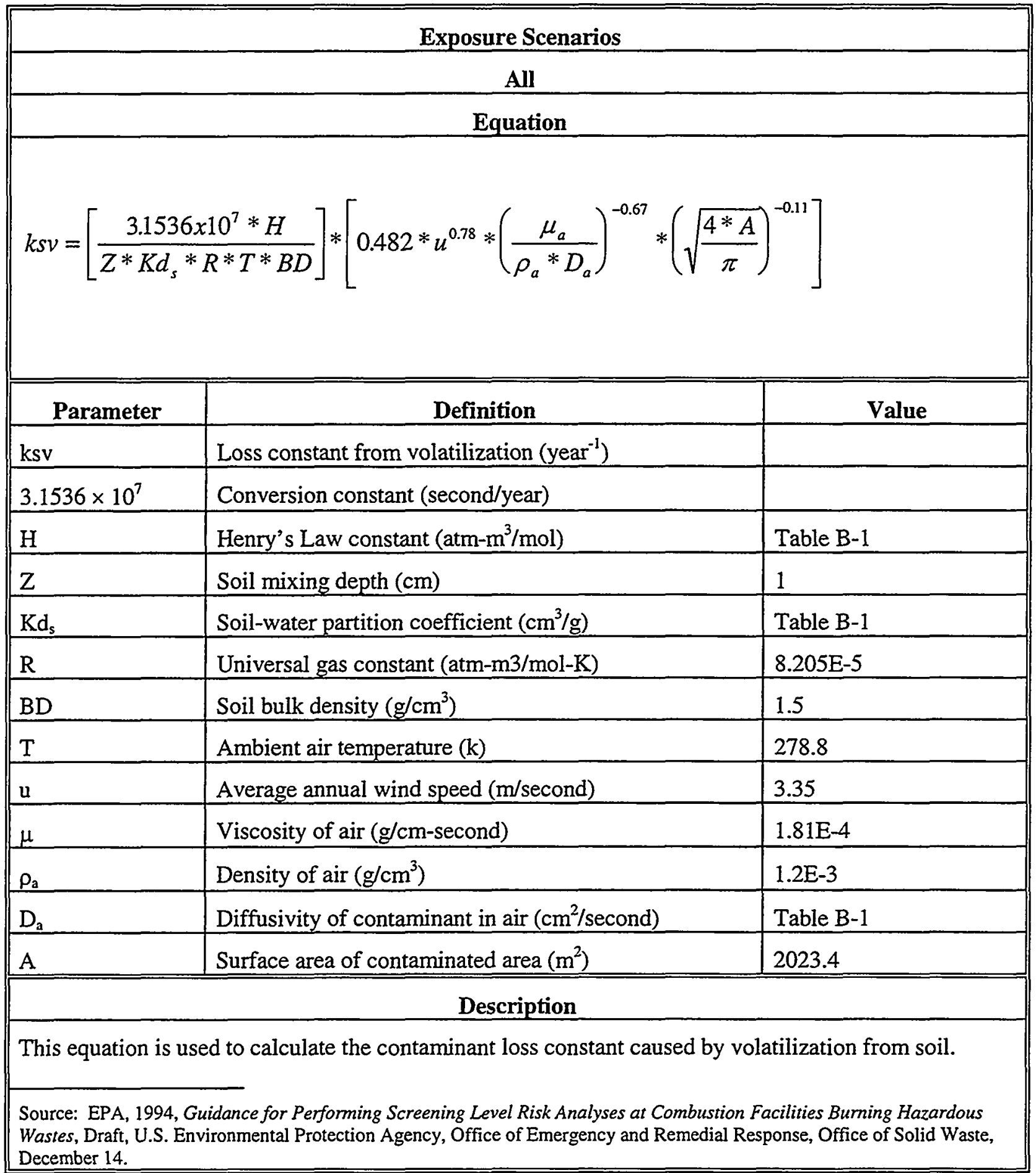


Table B-8. Aboveground plant concentration from direct deposition.

\begin{tabular}{|c|c|c|}
\hline \multicolumn{3}{|c|}{ Exposure Scenarios } \\
\hline \multicolumn{3}{|c|}{ All } \\
\hline \multicolumn{3}{|c|}{ Equation } \\
\hline \multicolumn{3}{|c|}{$P d=\frac{1000 * Q *(1-F v) *[D y d p+(F w * D y w p)] * R p *[1.0-\exp (-k p * T p)]}{Y p * k p}$} \\
\hline Parameter & Definition & Value \\
\hline $\mathrm{Pd}$ & Concentration in plant from direct deposition $(\mathrm{mg} / \mathrm{kg})$ & \\
\hline 1000 & Units conversion factor $(\mathrm{mg} / \mathrm{g})$ & \\
\hline$Q$ & Stack emissions ( $\mathrm{g} /$ second) & Site-specific (Section 2) \\
\hline Fv & $\begin{array}{l}\text { Fraction of air concentration present in vapor phase } \\
\text { (dimensionless) }\end{array}$ & $\begin{array}{l}\text { Chemical-specific } \\
\text { (Table B-1) }\end{array}$ \\
\hline Dydp & Yearly dry deposition rate ( $\mathrm{s} / \mathrm{m}^{2}$-year) & 0.00045 \\
\hline Fw & $\begin{array}{l}\text { Fraction of wet deposition that adheres to plant surfaces } \\
\text { (dimensionless) }\end{array}$ & $\begin{array}{l}\text { Chemical-specific } \\
\text { (Table B-1) }\end{array}$ \\
\hline Dywp & Yearly particle phase wet deposition rate $\left(\mathrm{g} / \mathrm{m}^{2} /\right.$ year) & 0.00024 \\
\hline $\mathrm{Rp}$ & $\begin{array}{l}\text { Interception fraction of edible portion of plant tissue } \\
\text { (dimensionless) }\end{array}$ & 0.04 \\
\hline $\mathrm{kp}$ & Plant surface loss coefficient (year ${ }^{-1}$ ) & 18 \\
\hline $\mathrm{Tp}$ & $\begin{array}{l}\text { Length of plant exposure to deposition of edible portion } \\
\text { of plant, per harvest (year) }\end{array}$ & 0.16 \\
\hline Yp & $\begin{array}{l}\text { Yield or standing crop biomass of the edible portion of } \\
\text { the plant }\left(\mathrm{kg} \mathrm{DW} / \mathrm{m}^{2}\right)\end{array}$ & 1.7 \\
\hline \multicolumn{3}{|c|}{$\begin{array}{r}\text { Description } \\
\end{array}$} \\
\hline \multicolumn{3}{|c|}{$\begin{array}{l}\text { This equation calculates the contaminant concentration in aboveground vegetation caused by wet and } \\
\text { dry deposition of contaminant on the plant surface. }\end{array}$} \\
\hline \multicolumn{3}{|c|}{$\begin{array}{l}\text { Source: EPA, 1994, Guidance for Performing Screening Level Risk Analyses at Combustion Facilities Burning Hazardous } \\
\text { Wastes, Draft, U.S. Environmental Protection Agency, Office of Emergency and Remedial Response, Office of Solid Waste, } \\
\text { December 14. }\end{array}$} \\
\hline
\end{tabular}


Table B-9. Aboveground vegetable concentration from air-to-plant transfer.

\begin{tabular}{|c|c|c|}
\hline \multicolumn{3}{|c|}{ Exposure Scenarios } \\
\hline \multicolumn{3}{|c|}{ All } \\
\hline \multicolumn{3}{|c|}{ Equation } \\
\hline \multicolumn{3}{|c|}{$P v=Q * F_{v} * \frac{C y v^{*} B v^{*} V G_{a g}}{\rho_{a}}$} \\
\hline Parameter & Definition & Value \\
\hline $\mathrm{Pv}$ & $\begin{array}{l}\text { Concentration of pollutant in the plant from air-to-plant } \\
\text { transfer }(\mathrm{mg} / \mathrm{kg})\end{array}$ & . \\
\hline Q & Stack emissions (g/second) & Section 2 \\
\hline Tv & $\begin{array}{l}\text { Fraction of air concentration in vapor phase } \\
\text { (dimensionless) }\end{array}$ & $\begin{array}{l}\text { Chemical-specific } \\
\text { (Table B-1) }\end{array}$ \\
\hline Cyv & $\begin{array}{l}\text { Normalized vapor-phase air concentration } \\
\left(\mu \mathrm{g}-\mathrm{second} / \mathrm{g}-\mathrm{m}^{3}\right)\end{array}$ & 0.06213 \\
\hline $\mathrm{Bv}$ & $\begin{array}{l}\text { Air-to-plant biotransfer factor } \\
([\mathrm{mg} \text { pollutant } / \mathrm{kg} \text { plant tissue } \mathrm{DW}] /[\mu \mathrm{g} \text { pollutant } / \mathrm{g} \text { air }])\end{array}$ & $\begin{array}{l}\text { Chemical-specific } \\
\text { (Table B-1) }\end{array}$ \\
\hline $\mathrm{Vg}_{\mathrm{ag}}$ & $\begin{array}{l}\text { Empirical correction factor for aboveground produce } \\
\text { (dimensionless) }\end{array}$ & 0.01 \\
\hline$\underline{\underline{\rho_{a}}}$ & Density of air $\left(\mathrm{g} / \mathrm{m}^{3}\right)$ & $1.2 \times 10^{3}$ \\
\hline \multicolumn{3}{|c|}{ Description } \\
\hline \multicolumn{3}{|c|}{$\begin{array}{l}\text { This equation calculates the contaminant concentration in aboveground vegetation caused by direct } \\
\text { uptake of vapor-phase contaminants into the plant leaves. }\end{array}$} \\
\hline \multicolumn{3}{|c|}{$\begin{array}{l}\text { Source: EPA, 1994, Guidance for Performing Screening Level Risk Analyses at Combustion Facilities Burning Hazardous } \\
\text { Wastes, Draft, U.S. Environmental Protection Agency, Office of Emergency and Remedial Response, Office of Solid Waste, } \\
\text { December 14. }\end{array}$} \\
\hline
\end{tabular}


Table B-10. Aboveground produce concentration from root uptake.

\begin{tabular}{|c|c|c|}
\hline \multicolumn{3}{|c|}{ Exposure Scenarios } \\
\hline \multicolumn{3}{|c|}{ All } \\
\hline \multicolumn{3}{|c|}{ Equation } \\
\hline \multicolumn{3}{|l|}{$P r=S c^{*} B r$} \\
\hline Parameter & Definition & Value \\
\hline $\operatorname{Pr}$ & $\begin{array}{l}\text { Concentration of pollutant in the plant from direct uptake } \\
\text { from soil }(\mathrm{mg} / \mathrm{kg})\end{array}$ & \\
\hline Sc & $\begin{array}{l}\text { Average soil concentration of pollutant over exposure } \\
\text { duration }(\mathrm{mg} / \mathrm{kg})\end{array}$ & $\begin{array}{l}\text { Calculated } \\
\text { (Tables B-11 to B-13) }\end{array}$ \\
\hline $\mathrm{Br}$ & $\begin{array}{l}\text { Plant-soil bioconcentration factor for aboveground } \\
\text { produce }[\mu \mathrm{g} / \mathrm{g} \text { DW }] /[\mu \mathrm{g} / \mathrm{g} \text { soil] }\end{array}$ & $\begin{array}{l}\text { Chemical-specific } \\
\text { (Table B-1) }\end{array}$ \\
\hline \multicolumn{3}{|c|}{ Description } \\
\hline \multicolumn{3}{|c|}{$\begin{array}{l}\text { This equation calculates the contaminant concentration in aboveground vegetation caused by direct } \\
\text { uptake of contaminants from soil. }\end{array}$} \\
\hline \multicolumn{3}{|c|}{$\begin{array}{l}\text { Source: EPA, 1994, Guidance for Performing Screening Level Risk Analyses at Combustion Facilities Burning Hazardous } \\
\text { Wastes, Draft, U.S. Environmental Protection Agency, Office of Emergency and Remedial Response, Office of Solid Waste, } \\
\text { December 14. }\end{array}$} \\
\hline
\end{tabular}


Table B-11. Subsistence farmer produce calculations.

\begin{tabular}{|c|c|c|c|c|c|c|c|c|c|c|c|c|}
\hline Chemical & $\begin{array}{c}\mathrm{Sc} \\
(\mathrm{mg} / \mathrm{kg})\end{array}$ & $\begin{array}{c}\mathrm{ScTc} \\
(\mathrm{mg} / \mathrm{kg})\end{array}$ & $\begin{array}{c}\text { Ds } \\
(\mathrm{mg} / \mathrm{kg} / \mathrm{y})\end{array}$ & $\begin{array}{c}k s \\
\left(Y_{e a r}^{-1}\right) \\
\end{array}$ & $\begin{array}{c}\text { ksl } \\
\left(\text { Year }^{-1}\right) \\
\end{array}$ & $\begin{array}{c}\text { kse } \\
\left(\text { Year }^{-1}\right) \\
\end{array}$ & $\begin{array}{c}\text { ksr } \\
\left(Y_{\text {car }}^{-1}\right)\end{array}$ & $\begin{array}{c}\text { ksg } \\
\left(\text { Year }^{-1}\right)\end{array}$ & $\begin{array}{c}\text { ksv } \\
\left(\text { Year }^{-1}\right) \\
\end{array}$ & $\begin{array}{c}\mathrm{Pd} \\
(\mathrm{mg} / \mathrm{kg})\end{array}$ & $\begin{array}{c}\mathrm{Pv} \\
(\mathrm{mg} / \mathrm{kg})\end{array}$ & $\begin{array}{c}\mathrm{Pr} \\
(\mathrm{mg} / \mathrm{kg}) \\
\end{array}$ \\
\hline Antimony & $1.36 \mathrm{E}-11$ & $3.41 \mathrm{E}-11$ & $1.38 \mathrm{E}-09$ & $4.05 \mathrm{E}+01$ & $4.01 E+01$ & $0.00 \mathrm{E}+00$ & $3.97 \mathrm{E}-01$ & $0.00 \mathrm{E}+00$ & $0.00 \mathrm{E}+00$ & $1.84 \mathrm{E}-11$ & $0.00 \mathrm{E}+00$ & $2.73 E-12$ \\
\hline Arsenic & $7.44 \mathrm{E}-15$ & $1.86 \mathrm{E}-14$ & $5.52 \mathrm{E}-14$ & $2.97 \mathrm{E}+00$ & $2.94 \mathrm{E}+00$ & $0.00 \mathrm{E}+00$ & $2.91 \mathrm{E}-02$ & $0.00 \mathrm{E}+00$ & $0.00 \mathrm{E}+00$ & $7.37 \mathrm{E}-16$ & $0.00 \mathrm{E}+00$ & $2.68 \mathrm{E}-16$ \\
\hline Barium & $7.85 \mathrm{E}-14$ & $1.83 \mathrm{E}-13$ & $3.22 \mathrm{E}-14$ & $1.63 \mathrm{E}-0 \mathrm{I}$ & $1.61 \mathrm{E}-01$ & $0.00 \mathrm{E}+00$ & $1.60 \mathrm{E}-03$ & $0.00 \mathrm{E}+00$ & $0.00 \mathrm{E}+00$ & $5.13 \mathrm{E}-16$ & $0.00 \mathrm{E}+00$ & $1.18 \mathrm{E}-14$ \\
\hline Benzo(a)pyrene & $2.22 \mathrm{E}-05$ & $3.44 \mathrm{E}-05$ & $2.70 \mathrm{E}-06$ & 2.95E-02 & $7.13 \mathrm{E}-03$ & $0.00 \mathrm{E}+00$ & $7.06 \mathrm{E}-05$ & $0.00 \mathrm{E}+00$ & $2.23 \mathrm{E}-02$ & $7.39 \mathrm{E}-10$ & $4.52 \mathrm{E}-07$ & $2.44 \mathrm{E}-07$ \\
\hline Beryllium & $2.24 \mathrm{E}-10$ & $5.60 \mathrm{E}-10$ & $6.90 \mathrm{E}-10$ & $1.23 \mathrm{E}+00$ & $1.22 \mathrm{E}+00$ & $0.00 \mathrm{E}+00$ & $1.21 \mathrm{E}-02$ & $0.00 \mathrm{E}+00$ & $0.00 \mathrm{E}+00$ & $1.10 \mathrm{E}-11$ & $0.00 \mathrm{E}+00$ & $2.24 \mathrm{E}-12$ \\
\hline Cadmium & $8.52 \mathrm{E}-13$ & $2.13 \mathrm{E}-12$ & $1.15 \mathrm{E}-12$ & $5.40 \mathrm{E}-01$ & $5.34 \mathrm{E}-01$ & $0.00 \mathrm{E}+00$ & $5.29 \mathrm{E}-03$ & $0.00 \mathrm{E}+00$ & $0.00 \mathrm{E}+00$ & $1.83 \mathrm{E}-14$ & $0.00 \mathrm{E}+00$ & $1.53 \mathrm{E}-13$ \\
\hline Chromium VI & $3.44 \mathrm{E}-14$ & $8.59 \mathrm{E}-14$ & $4.09 \mathrm{E}-13$ & $4.77 \mathrm{E}+00$ & $4.72 E+00$ & $0.00 \mathrm{E}+00$ & $4.67 \mathrm{E}-02$ & $0.00 \mathrm{E}+00$ & $0.00 \mathrm{E}+00$ & $6.52 \mathrm{E}-1.5$ & $0.00 \mathrm{E}+00$ & $3.78 \mathrm{E}-14$ \\
\hline 1,3-dinitrobenzene(PIC) & $1.10 \mathrm{E}-03$ & $2.75 \mathrm{E}-03$ & $1.89 \mathrm{E}+00$ & $6.88 \mathrm{E}+02$ & $2.07 \mathrm{E}+02$ & $0.00 \mathrm{E}+00$ & $2.05 E+00$ & $0.00 \mathrm{E}+00$ & $4.79 \mathrm{E}+02$ & $0.00 \mathrm{E}+00$ & $0.00 \mathrm{E}+00$ & $5.83 \mathrm{E}-03$ \\
\hline 2,4-dinitrotoluene & $1.05 \mathrm{E}-07$ & 2.61E-07 & $6.27 \mathrm{E}-05$ & $2.40 \mathrm{E}+02$ & $8.53 \mathrm{E}+01$ & $0.00 \mathrm{E}+00$ & $8.44 \mathrm{E}-01$ & $0.00 \mathrm{E}+00$ & $1.54 \mathrm{E}+02$ & $0.00 \mathrm{E}+00$ & $1.23 \mathrm{E}-09$ & $2.82 \mathrm{E}-07$ \\
\hline 2,4-dinitrotoluene(PIC) & $3.42 \mathrm{E}-03$ & $8.55 \mathrm{E}-03$ & $2.05 \mathrm{E}+00$ & $2.40 \mathrm{E}+02$ & $8.53 E+01$ & $0.00 \mathrm{E}+00$ & $8.44 \mathrm{E}-01$ & $0.00 \mathrm{E}+00$ & $1.54 \mathrm{E}+02$ & $0.00 \mathrm{E}+00$ & $4.04 \mathrm{E}-05$ & $9.23 \mathrm{E}-03$ \\
\hline 2,6-dinitrotoluene(PIC) & $4.08 \mathrm{E}-0.3$ & $1.02 \mathrm{E}-02$ & $2.05 \mathrm{E}+00$ & $2.01 \mathrm{E}+02$ & $1.07 \mathrm{E}+02$ & $0.00 \mathrm{E}+00$ & $1.05 \mathrm{E}+00$ & $0.00 \mathrm{E}+00$ & $9.37 \mathrm{E}+01$ & $0.00 \mathrm{E}+00$ & 3.50E-05 & $1.30 \mathrm{E}-02$ \\
\hline Di(n)octyl phthalate & $6.62 \mathrm{E}-07$ & 8.39E-07 & $5.32 \mathrm{E}-08$ & $1.64 \mathrm{E}-03$ & $3.06 \mathrm{E}-04$ & $0.00 \mathrm{E}+00$ & $3.02 \mathrm{E}-06$ & $0.00 \mathrm{E}+00$ & $1.33 \mathrm{E}-03$ & $2.46 \mathrm{E}-12$ & $6.61 E-08$ & $1.19 \mathrm{E}-09$ \\
\hline 2,3,78-TCDD & $1.10 \mathrm{E}-09$ & $1.62 \mathrm{E}-09$ & $1.21 \mathrm{E}-10$ & $2.26 \mathrm{E}-02$ & $6.11 \mathrm{E}-04$ & $0.00 \mathrm{E}+00$ & $6.05 \mathrm{E}-06$ & $0.00 \mathrm{E}+00$ & $2.20 \mathrm{E}-02$ & $5.89 \mathrm{E}-14$ & $7.00 \mathrm{E}-12$ & $3.61 \mathrm{E}-12$ \\
\hline Lead & $8.11 \mathrm{E}-09$ & $1.02 \mathrm{E}-08$ & $6.44 \mathrm{E}-10$ & $9.82 \mathrm{E}-04$ & $9.72 \mathrm{E}-04$ & $0.00 \mathrm{E}+00$ & $9.62 \mathrm{E}-06$ & $0.00 \mathrm{E}+00$ & $0.00 \mathrm{E}+00$ & $1.03 \mathrm{E}-11$ & $0.00 \mathrm{E}+00$ & $1.46 \mathrm{E}-10$ \\
\hline Mercury & $2.31 \mathrm{E}-05$ & $5.78 \mathrm{E}-05$ & $3.33 \mathrm{E}-05$ & $5.76 \mathrm{E}-01$ & $5.70 \mathrm{E}-01$ & $0.00 \mathrm{E}+00$ & $5.64 \mathrm{E}-03$ & $0.00 \mathrm{E}+00$ & $0.00 \mathrm{E}+00$ & $5.30 \mathrm{E}-07$ & $0.00 \mathrm{E}+00$ & $4.62 \mathrm{E}-08$ \\
\hline Nickel & $2.97 \mathrm{E}-13$ & $7.43 \mathrm{E}-13$ & $7.82 \mathrm{E}-1.3$ & $1.05 E+00$ & $1.04 \mathrm{E}+00$ & $0.00 \mathrm{E}+00$ & $1.03 \mathrm{E}-02$ & $0.00 \mathrm{E}+00$ & $0.00 \mathrm{E}+00$ & $1.25 \mathrm{E}-14$ & $0.00 \mathrm{E}+00$ & $4.76 \mathrm{E}-15$ \\
\hline Nitrobenzene(PIC) & $3.36 \mathrm{E}-0.5$ & $8.39 \mathrm{E}-05$ & $1.38 \mathrm{E}+00$ & $1.64 \mathrm{E}+04$ & $1.17 \mathrm{E}+02$ & $0.00 \mathrm{E}+00$ & $1.15 \mathrm{E}+00$ & $0.00 \mathrm{E}+00$ & $1.63 \mathrm{E}+04$ & $0.00 \mathrm{E}+00$ & $1.27 \mathrm{E}-07$ & $1.14 \mathrm{E}-04$ \\
\hline Pentachloronitrobenzene(PIC) & $1.71 \mathrm{E}-06$ & $4.28 \mathrm{E}-06$ & $1.58 \mathrm{E}-01$ & $3.68 \mathrm{E}+04$ & $2.25 \mathrm{E}-01$ & $0.00 \mathrm{E}+00$ & 2.23E-03 & $0.00 \mathrm{E}+00$ & $3.68 \mathrm{E}+04$ & $0.00 \mathrm{E}+00$ & $1.64 \mathrm{E}-08$ & $1.39 \mathrm{E}-07$ \\
\hline Pentachlorophenol & $5.39 \mathrm{E}-07$ & $1.35 \mathrm{E}-06$ & $6.62 \mathrm{E}-06$ & $4.92 \mathrm{E}+00$ & $7.78 \mathrm{E}-02$ & $0.00 \mathrm{E}+00$ & $7.70 \mathrm{E}-04$ & $0.00 \mathrm{E}+00$ & $4.84 \mathrm{E}+00$ & $0.00 \mathrm{E}+00$ & 4.44E-09 & $2.42 \mathrm{E}-08$ \\
\hline Selenium & $7.17 \mathrm{E}-10$ & $1.79 \mathrm{E}-09$ & $3.50 \mathrm{E}-08$ & $1.95 \mathrm{E}+01$ & $1.93 \mathrm{E}+01$ & $0.00 \mathrm{E}+00$ & $1.91 \mathrm{E}-01$ & $0.00 \mathrm{E}+00$ & $0.00 \mathrm{E}+00$ & $4.67 \mathrm{E}-10$ & $0.00 \mathrm{E}+00$ & $1.15 \mathrm{E}-11$ \\
\hline Silver & $6.47 \mathrm{E}-17$ & $1.62 \mathrm{E}-16$ & $2.62 \mathrm{E}-14$ & $1.62 \mathrm{E}+02$ & $1.60 \mathrm{E}+02$ & $0.00 \mathrm{E}+00$ & $1.59 \mathrm{E}+00$ & $0.00 \mathrm{E}+00$ & $0.00 \mathrm{E}+00$ & $4.18 \mathrm{E}-16$ & $0.00 \mathrm{E}+00$ & $2.59 \mathrm{E}-17$ \\
\hline Thallium & $3.95 \mathrm{E}-09$ & $9.87 \mathrm{E}-09$ & $1.15 \mathrm{E}-08$ & $1.17 \mathrm{E}+00$ & $1.15 \mathrm{E}+00$ & $0.00 \mathrm{E}+00$ & $1.14 \mathrm{E}-02$ & $0.00 \mathrm{E}+00$ & $0.00 \mathrm{E}+00$ & $1.83 \mathrm{E}-10$ & $0.00 \mathrm{E}+00$ & $8.29 \mathrm{E}-10$ \\
\hline
\end{tabular}


Table B-12. Adult resident produce calculations.

\begin{tabular}{|c|c|c|c|c|c|c|c|c|c|c|c|c|}
\hline Chernical & $\begin{array}{c}\mathrm{Sc} \\
(\mathrm{mg} / \mathrm{kg})\end{array}$ & $\begin{array}{c}\mathrm{ScTc} \\
(\mathrm{mg} / \mathrm{kg})\end{array}$ & $\begin{array}{c}\text { Ds } \\
(\mathrm{mg} / \mathrm{kg} / \mathrm{y})\end{array}$ & $\begin{array}{c}\text { ks } \\
\left(Y_{\mathrm{car}}^{-1}\right)\end{array}$ & $\begin{array}{c}\text { ksl } \\
\left(\text { Year }^{-1}\right) \\
\end{array}$ & $\begin{array}{c}\text { kse } \\
\left(\text { Year }^{-\mathrm{l}}\right)\end{array}$ & $\begin{array}{c}\text { ksr } \\
\left(Y_{\text {ear }}^{-1}\right)\end{array}$ & $\begin{array}{c}\text { ksg } \\
\left(Y_{\text {car }}^{-1}\right)\end{array}$ & $\begin{array}{c}\text { ksv } \\
\left(\text { Year }^{-1}\right)\end{array}$ & $\begin{array}{c}\mathrm{Pd} \\
(\mathrm{mg} / \mathrm{kg})\end{array}$ & $\begin{array}{c}\text { Pv } \\
(m g / k g)\end{array}$ & $\begin{array}{c}\mathrm{Pr} \\
(\mathrm{mg} / \mathrm{kg}) \\
\end{array}$ \\
\hline Antimony & $1.82 \mathrm{E}-11$ & $3.41 \mathrm{E}-11$ & $1.38 \mathrm{E}-09$ & $4.05 E+01$ & $4.01 E+01$ & $0.00 \mathrm{E}+00$ & $3.97 \mathrm{E}-01$ & $0.00 \mathrm{E}+00$ & $0.00 \mathrm{E}+00$ & $1.84 \mathrm{E}-11$ & $0.00 \mathrm{E}+00$ & $3.63 \mathrm{E}-12$ \\
\hline Arsenic & $9.93 E-15$ & $1.86 \mathrm{E}-14$ & $5.52 \mathrm{E}-14$ & $2.97 \mathrm{E}+00$ & $2.94 \mathrm{E}+00$ & $0.00 \mathrm{E}+00$ & $2.91 \mathrm{E}-02$ & $0.00 E+00$ & $0.00 \mathrm{E}+00$ & $7.37 \mathrm{E}-16$ & $0.00 \mathrm{E}+00$ & $3.57 \mathrm{E}-16$ \\
\hline Barium & $1.02 \mathrm{E}-1.3$ & $1.83 \mathrm{E}-1.3$ & $3.22 \mathrm{E}-14$ & $1.63 \mathrm{E}-01$ & $1.61 \mathrm{E}-01$ & $0.00 \mathrm{E}+00$ & $1.60 \mathrm{E}-03$ & $0.00 \mathrm{E}+00$ & $0.00 E+00$ & $5.13 \mathrm{E}-16$ & $0.00 \mathrm{E}+00$ & $1.52 \mathrm{E}-14$ \\
\hline Benzo(a)pyrene & $2.30 \mathrm{E}-0.5$ & $3.44 \mathrm{E}-0.5$ & $2.70 \mathrm{E}-06$ & $2.95 \mathrm{E}-02$ & 7. $13 \mathrm{E}-03$ & $0.00 \mathrm{E}+00$ & $7.06 \mathrm{E}-05$ & $0.00 \mathrm{E}+00$ & $2.23 \mathrm{E}-02$ & $7.39 \mathrm{E}-10$ & $4.52 \mathrm{E}-07$ & $2.53 \mathrm{E}-07$ \\
\hline Beryllium & $2.99 \mathrm{E}-10$ & $5.60 \mathrm{E}-10$ & $6.90 \mathrm{E}-10$ & $1.23 \mathrm{E}+00$ & $1.22 \mathrm{E}+00$ & $0.00 \mathrm{E}+00$ & $1.21 \mathrm{E}-02$ & $0.00 \mathrm{E}+00$ & $0.00 \mathrm{E}+00$ & $1.10 \mathrm{E}-11$ & $0.00 \mathrm{E}+00$ & $2.99 \mathrm{E}-12$ \\
\hline Cadmium & $1.14 \mathrm{E}-12$ & $2.13 \mathrm{E}-12$ & $1.15 \mathrm{E}-12$ & $5.40 \mathrm{E}-0 \mathrm{I}$ & $5.34 \mathrm{E}-01$ & $0.00 \mathrm{E}+00$ & $5.29 \mathrm{E}-03$ & $0.00 \mathrm{E}+00$ & $0.00 \mathrm{E}+00$ & $1.83 \mathrm{E}-14$ & $0.00 \mathrm{E}+00$ & $2.05 \mathrm{E}-13$ \\
\hline Chromium VI & $4.58 \mathrm{E}-14$ & $8.59 \mathrm{E}-14$ & $4.09 \mathrm{E}-13$ & $4.77 \mathrm{E}+00$ & $4.72 \mathrm{E}+00$ & $0.00 \mathrm{E}+00$ & 4.67E-02 & $0.00 \mathrm{E}+00$ & $0.00 \mathrm{E}+00$ & $6.52 \mathrm{E}-15$ & $0.00 \mathrm{E}+00$ & $5.04 \mathrm{E}-14$ \\
\hline 1,3-dinitrobenzene(PIC) & $1.47 \mathrm{E}-03$ & $2.75 \mathrm{E}-0.3$ & $1.89 \mathrm{E}+00$ & $6.88 \mathrm{E}+02$ & $2.07 \mathrm{E}+02$ & $0.00 \mathrm{E}+00$ & $2.05 \mathrm{E}+00$ & $0.00 \mathrm{E}+00$ & $4.79 \mathrm{E}+02$ & $0.00 \mathrm{E}+00$ & $0.00 \mathrm{E}+00$ & $7.78 \mathrm{E}-03$ \\
\hline 2,4-dinitrotoluene & $1.39 \mathrm{E}-07$ & $2.61 \mathrm{E}-07$ & $6.27 \mathrm{E}-0.5$ & $2.40 \mathrm{E}+02$ & $8.53 \mathrm{E}+01$ & $0.00 \mathrm{E}+00$ & $8.44 \mathrm{E}-01$ & $0.00 \mathrm{E}+00$ & $1.54 \mathrm{E}+02$ & $0.00 \mathrm{E}+00$ & $1.23 \mathrm{E}-09$ & $3.76 \mathrm{E}-07$ \\
\hline 2,4-dinitrotoluene(PIC) & $4.56 \mathrm{E}-03$ & $8.55 \mathrm{E}-0.3$ & $2.05 \mathrm{E}+00$ & $2.40 \mathrm{E}+02$ & $8.53 \mathrm{E}+01$ & $0.00 \mathrm{E}+00$ & $8.44 \mathrm{E}-01$ & $0.00 \mathrm{E}+00$ & $1.54 \mathrm{E}+02$ & $0.00 \mathrm{E}+00$ & $4.04 \mathrm{E}-05$ & $1.23 \mathrm{E}-02$ \\
\hline 2,6-dinitrotoluene(PIC) & $5.43 \mathrm{E}-03$ & $1.02 \mathrm{E}-02$ & $2.05 E+00$ & $2.01 E+02$ & $1.07 \mathrm{E}+02$ & $0.00 \mathrm{E}+00$ & $1.05 \mathrm{E}+00$ & $0.00 \mathrm{E}+00$ & $9.37 E+01$ & $0.00 \mathrm{E}+00$ & $3.50 \mathrm{E}-0.5$ & $1.74 \mathrm{E}-02$ \\
\hline Di(n)octyl phthalate & $6.12 \mathrm{E}-07$ & $8.39 \mathrm{E}-07$ & $5.32 \mathrm{E}-08$ & $1.64 \mathrm{E}-03$ & $3.06 \mathrm{E}-04$ & $0.00 \mathrm{E}+00$ & $3.02 \mathrm{E}-06$ & $0.00 \mathrm{E}+00$ & $1.33 \mathrm{E}-03$ & $2.46 \mathrm{E}-12$ & $6.61 \mathrm{E}-08$ & $1.10 \mathrm{E}-09$ \\
\hline 2,3,78-TCDD & $1.11 \mathrm{E}-09$ & $1.62 \mathrm{E}-09$ & $1.21 \mathrm{E}-10$ & $2.26 \mathrm{E}-02$ & $6.11 \mathrm{E}-04$ & $0.00 \mathrm{E}+00$ & $6.05 \mathrm{E}-06$ & $0.00 \mathrm{E}+00$ & $2.20 \mathrm{E}-02$ & $5.89 \mathrm{E}-14$ & $7.00 \mathrm{E}-12$ & $3.65 \mathrm{E}-12$ \\
\hline Lend & 7.47E-09 & $1.02 \mathrm{E}-08$ & $6.44 \mathrm{E}-10$ & $9.82 \mathrm{E}-04$ & $9.72 E-04$ & $0.00 \mathrm{E}+00$ & $9.62 \mathrm{E}-06$ & $0.00 \mathrm{E}+00$ & $0.00 \mathrm{E}+00$ & $1.03 \mathrm{E}-11$ & $0.00 \mathrm{E}+00$ & $1.34 \mathrm{E}-10$ \\
\hline Mercury & $3.08 \mathrm{E}-05$ & $5.78 \mathrm{E}-0.5$ & 3.33E-05 & $5.76 \mathrm{E}-01$ & $5.70 \mathrm{E}-01$ & $0.00 \mathrm{E}+00$ & $5.64 \mathrm{E}-0.3$ & $0.00 \mathrm{E}+00$ & $0.00 \mathrm{E}+00$ & $5.30 \mathrm{E}-07$ & $0.00 E+00$ & $0.16 \mathrm{E}-08$ \\
\hline Nickel & $3.96 \mathrm{E}-13$ & $7.43 \mathrm{E}-1.3$ & $7.82 \mathrm{E}-13$ & $1.05 \mathrm{E}+00$ & $1.04 \mathrm{E}+00$ & $0.00 \mathrm{E}+00$ & $1.03 \mathrm{E}-02$ & $0.00 \mathrm{E}+00$ & $0.00 \mathrm{E}+00$ & $1.25 \mathrm{E}-14$ & $0.00 \mathrm{E}+00$ & $6.34 \mathrm{E}-15$ \\
\hline Nitrobenzene(PIC) & $4.48 \mathrm{E}-05$ & $8.39 \mathrm{E}-0.5$ & $1.38 \mathrm{E}+00$ & $1.64 \mathrm{E}+04$ & $1.17 \mathrm{E}+02$ & $0.00 \mathrm{E}+00$ & $1.15 \mathrm{E}+00$ & $0.00 \mathrm{E}+00$ & $1.63 \mathrm{E}+04$ & $0.00 \mathrm{E}+00$ & $1.27 \mathrm{E}-07$ & $1.52 \mathrm{E}-04$ \\
\hline Pentachloronitrobenzene(PIC) & $2.28 \mathrm{E}-06$ & $4.28 \mathrm{E}-06$ & $1.58 \mathrm{E}-01$ & $3.68 \mathrm{E}+04$ & $2.25 \mathrm{E}-01$ & $0.00 \mathrm{E}+00$ & $2.23 \mathrm{E}-0.3$ & $0.00 \mathrm{E}+00$ & $3.68 \mathrm{E}+04$ & $0.00 \mathrm{E}+00$ & $1.64 \mathrm{E}-08$ & $1.85 \mathrm{E}-07$ \\
\hline Pentachlorophenol & $7.19 \mathrm{E}-07$ & $1.35 \mathrm{E}-06$ & $6.62 \mathrm{E}-06$ & $4.92 E+00$ & $7.78 \mathrm{E}-02$ & $0.00 \mathrm{E}+00$ & $7.70 \mathrm{E}-04$ & $0.00 \mathrm{E}+00$ & $4.84 \mathrm{E}+00$ & $0.00 \mathrm{E}+00$ & 4.44E-09 & $3.23 \mathrm{E}-08$ \\
\hline Selcnium & $9.57 \mathrm{E}-10$ & $1.79 \mathrm{E}-09$ & $3.50 \mathrm{E}-08$ & $1.95 \mathrm{E}+01$ & $1.93 \mathrm{E}+01$ & $0.00 \mathrm{E}+00$ & $1.91 \mathrm{E}-01$ & $0.00 \mathrm{E}+00$ & $0.00 \mathrm{E}+00$ & $4.67 \mathrm{E}-10$ & $0.00 \mathrm{E}+00$ & $1.53 \mathrm{E}-11$ \\
\hline Silver & $8.63 \mathrm{E}-17$ & $1.62 \mathrm{E}-16$ & $2.62 \mathrm{E}-14$ & $1.62 E+02$ & $1.60 \mathrm{E}+02$ & $0.00 \mathrm{E}+00$ & $1.59 \mathrm{E}+00$ & $0.00 \mathrm{E}+00$ & $0.00 E+00$ & $4.18 \mathrm{E}-16$ & $0.00 \mathrm{E}+00$ & $3.45 \mathrm{E}-17$ \\
\hline Thallium & $5.26 \mathrm{E}-09$ & $9.87 \mathrm{E}-09$ & $1.15 \mathrm{E}-08$ & $1.17 \mathrm{E}+00$ & $1.15 E+00$ & $0.00 \mathrm{E}+00$ & $1.14 \mathrm{E}-02$ & $0.00 \mathrm{E}+00$ & $0.00 \mathrm{E}+00$ & $1.83 \mathrm{E}-10$ & $0.00 \mathrm{E}+00$ & $1.10 \mathrm{E}-09$ \\
\hline
\end{tabular}




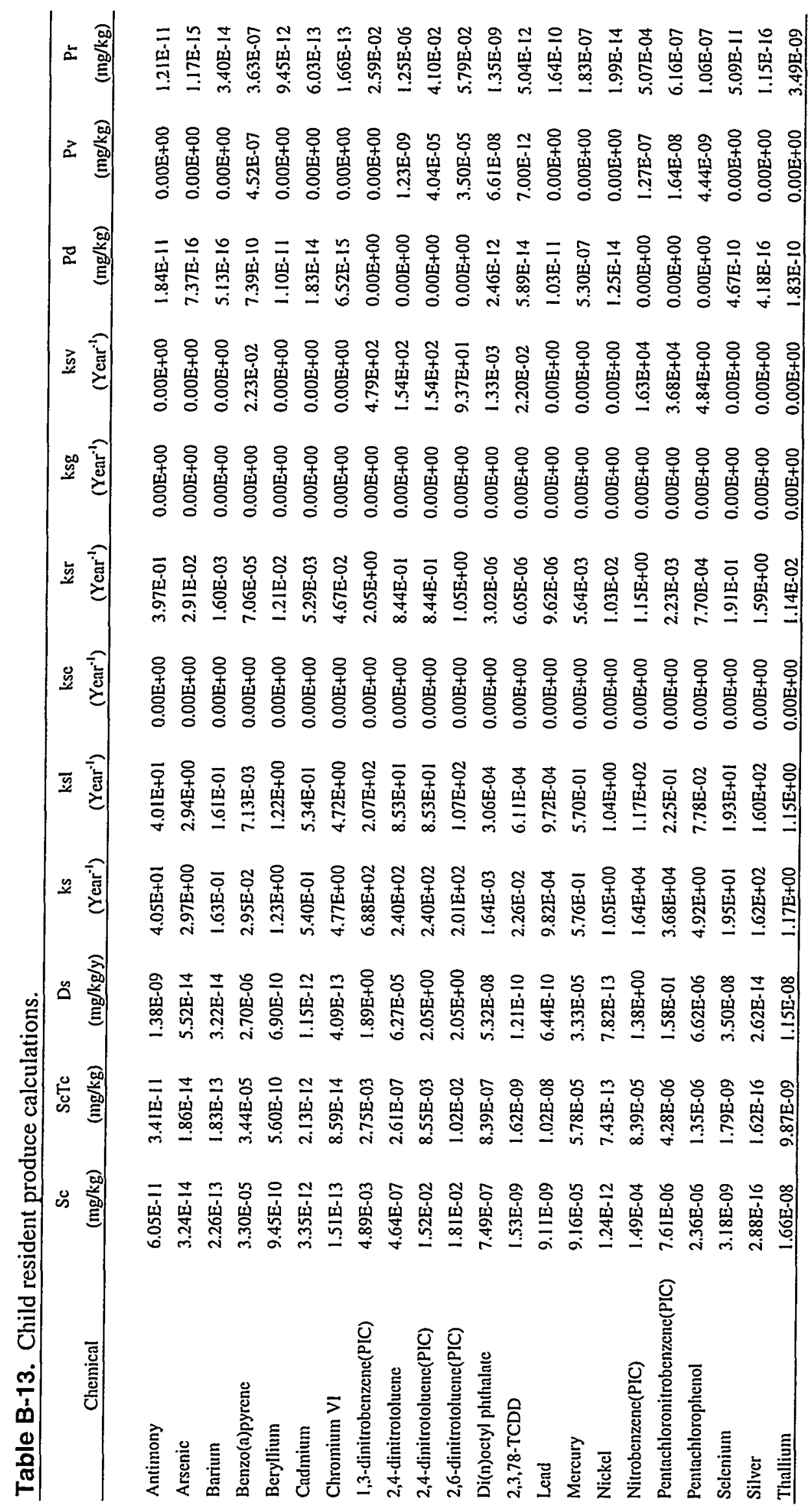


Table B-14. Air concentration.

\begin{tabular}{|c|c|c|}
\hline \multicolumn{3}{|c|}{ Exposure Scenarios } \\
\hline \multicolumn{3}{|c|}{ All } \\
\hline \multicolumn{3}{|c|}{ Equation } \\
\hline \multicolumn{3}{|c|}{$C_{a}=Q *[F v * C y v+(1.0-F v) * C y p]$} \\
\hline Parameter & Definition & Value \\
\hline $\mathrm{C}_{\mathrm{a}}$ & Total air concentration $\left(\mu \mathrm{g} / \mathrm{m}^{3}\right)$ & \\
\hline Q & Stack emissions ( $\mathrm{g} /$ second) & $\begin{array}{l}\text { Site-specific } \\
\text { (see Tables } 9 \text { and } 10 \text { ) }\end{array}$ \\
\hline Fv & $\begin{array}{l}\text { Fraction of air concentration in vapor phase } \\
\text { (dimensionless) }\end{array}$ & $\begin{array}{l}\text { Chemical-specific } \\
\text { (Table B-1) }\end{array}$ \\
\hline Cyv & $\begin{array}{l}\text { Normalized vapor-phase air concentration } \\
\left(\mu g-s e c o n d / g-m^{3}\right)\end{array}$ & 0.06213 \\
\hline Cyp & $\begin{array}{l}\text { Normalized particle phase air concentration } \\
\left(\mu \mathrm{g}-\mathrm{second} / \mathrm{g}-\mathrm{m}^{3}\right)\end{array}$ & 0.06156 \\
\hline \multicolumn{3}{|c|}{ Description } \\
\hline \multicolumn{3}{|c|}{$\begin{array}{l}\text { This equation calculates the total air concentration of a constituent based on the fraction in the vapor } \\
\text { phase and the fraction in the particle phase. }\end{array}$} \\
\hline \multicolumn{3}{|c|}{$\begin{array}{l}\text { Source: EPA, 1994, Guidance for Performing Screening Level Risk Analyses at Combustion Facilities Buming Hazardous } \\
\text { Wastes, Draft, U.S. Environmental Protection Agency, Office of Emergency and Remedial Response, Office of Solid Waste, } \\
\text { December 14. }\end{array}$} \\
\hline
\end{tabular}




\section{Appendix C}

\section{Exposure Calculations for Subsistence Farmer}


Table C-1. Forage (pasture grass or hay) concentration from direct deposition.

\begin{tabular}{|c|c|c|}
\hline \multicolumn{3}{|c|}{ Equation } \\
\hline$P d$ & \multicolumn{2}{|c|}{$1,000 * Q *(1-F v)\left[D y d p+\left(F w^{*} D y w p\right)\right] * R p *[1.0-\exp (-k p * T p)]$} \\
\hline Parameter & Definition & Value \\
\hline $\mathrm{Pd}$ & Concentration in plant from direct deposition $(\mathrm{mg} / \mathrm{kg})$ & \\
\hline 1,000 & Units conversion factor $(\mathrm{mg} / \mathrm{g})$ & \\
\hline Q & Stack emissions (g/second) & Site-specific (Section 2) \\
\hline Dydp & Yearly dry deposition rate of pollutant $\left(\mathrm{s} / \mathrm{m}^{2}\right.$-year) & 0.00045 \\
\hline Fw & $\begin{array}{l}\text { Fraction of wet deposition that adheres to plant surfaces } \\
\text { (dimensionless) }\end{array}$ & $\begin{array}{l}\text { Chemical-specific } \\
\text { (Table B-1) }\end{array}$ \\
\hline Fv & $\begin{array}{l}\text { Fraction of pollutant air concentration present in the } \\
\text { vapor phase (dimensionless) }\end{array}$ & $\begin{array}{l}\text { Chemical-specific } \\
\text { (Table B-1) }\end{array}$ \\
\hline Dywp & Yearly particle phase wet deposition rate $\left(\mathrm{g} / \mathrm{m}^{2} /\right.$ year) & 0.00024 \\
\hline $\mathrm{Rp}$ & $\begin{array}{l}\text { Interception fraction of edible portion of the plant tissue } \\
\text { (dimensionless) }\end{array}$ & 0.5 \\
\hline $\mathrm{kp}$ & Plant surface loss coefficient $\left(\right.$ year $^{-1}$ ) & 18 \\
\hline $\mathrm{Tp}$ & $\begin{array}{l}\text { Length of plant's exposure to deposition per harvest of } \\
\text { edible portion of plant (year) }\end{array}$ & 0.12 \\
\hline Yp & $\begin{array}{l}\text { Yield or standing crop biomass of the edible portion of } \\
\text { the plant }\left(\mathrm{kg} \mathrm{DW} / \mathrm{m}^{2}\right)\end{array}$ & 0.24 \\
\hline \multicolumn{3}{|c|}{ Description } \\
\hline $\begin{array}{l}\text { This equation } \\
\text { dry depositio }\end{array}$ & $\begin{array}{l}\text { ates the contaminant concentration in aboveground ve } \\
\text { ntaminant on the plant surface. }\end{array}$ & ion caused by wet and \\
\hline
\end{tabular}

Source: EPA, 1994, Guidance for Performing Screening Level Risk Analyses at Combustion Facilities Burning Hazardous Wastes, Draft, U.S. Environmental Protection Agency, Office of Emergency and Remedial Response, December 14. 
Table C-2. Forage (pasture grass or hay) concentration from air-to-plant transfer.

\begin{tabular}{|c|c|c|}
\hline \multicolumn{3}{|c|}{ Equation } \\
\hline \multicolumn{3}{|c|}{$P v=\underline{\left(C y v * B v * V G_{a g}\right)}$} \\
\hline Parameter & Definition & Value \\
\hline Pv & $\begin{array}{l}\text { Concentration of pollutant in the plant from air-to-plant } \\
\text { transfer }(\mathrm{mg} / \mathrm{kg})\end{array}$ & \\
\hline Fv & $\begin{array}{l}\text { Fraction of pollutant air concentration in the vapor phase } \\
\text { (dimensionless) }\end{array}$ & $\begin{array}{l}\text { Chemical-specific } \\
\text { (Table B-1) }\end{array}$ \\
\hline Cyv & $\begin{array}{l}\text { Vapor-phase air concentration of pollutant in air caused } \\
\text { by direct emissions ( } \mu \mathrm{g} \text { pollutant } / \mathrm{m}^{3} \text { ) }\end{array}$ & 0.06213 \\
\hline $\mathrm{Bv}$ & $\begin{array}{l}\text { Air-to-plant biotransfer factor } \\
\text { [(mg pollutant } / \mathrm{kg} \text { plant tissue } \mathrm{DW}) /(\mu \mathrm{g} \text { pollutant } / \mathrm{g} \text { air })]\end{array}$ & $\begin{array}{l}\text { Chemical-specific } \\
\text { (Table B-1) }\end{array}$ \\
\hline $\mathrm{Vg}_{\mathrm{ag}}$ & $\begin{array}{l}\text { Empirical correction factor that reduces produce } \\
\text { concentration because } \mathrm{Bv} \text { was developed for azalea } \\
\text { leaves }\end{array}$ & 1.0 \\
\hline$\rho_{a}$ & Density of air $\left(\mathrm{g} / \mathrm{m}^{3}\right)$ & $1.2 \times 10^{3}$ \\
\hline \multicolumn{3}{|c|}{ Description } \\
\hline $\begin{array}{l}\text { This equatio } \\
\text { uptake of va }\end{array}$ & $\begin{array}{l}\text { lates the contaminant concentration in aboveground veg } \\
\text { ase contaminants into the plant leaves. }\end{array}$ & ion caused by direc \\
\hline
\end{tabular}

Source: EPA, 1994, Guidance for Performing Screening Level Risk Analyses at Combustion Facilities Burning Hazardous Wastes, Draft, U.S. Environmental Protection Agency, Office of Emergency and Remedial Response, December 14. 
Table C-3. Forage, silage, and grain concentration from root uptake.

\begin{tabular}{|c|c|c|}
\hline \multicolumn{3}{|c|}{ Exposure Scenarios } \\
\hline \multicolumn{3}{|c|}{ All } \\
\hline \multicolumn{3}{|c|}{ Equation } \\
\hline \multicolumn{3}{|c|}{$\operatorname{Pr}=\sum_{i} S c^{*} B r_{i}$} \\
\hline Parameter & Definition & Value \\
\hline $\operatorname{Pr}$ & $\begin{array}{l}\text { Concentration of pollutant in the plant from direct uptake } \\
\text { from soil }(\mathrm{mg} / \mathrm{kg})\end{array}$ & \\
\hline $\mathrm{Sc}$ & $\begin{array}{l}\text { Average soil concentration of pollutant over exposure } \\
\text { duration }(\mathrm{mg} / \mathrm{kg})\end{array}$ & Calculated (Table B-11) \\
\hline $\mathrm{Br}_{\mathrm{j}}$ & 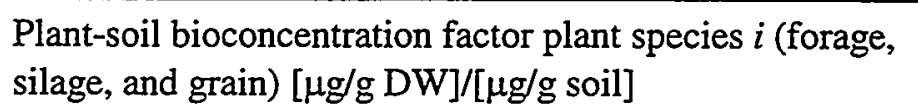 & $\begin{array}{l}\text { Chemical-specific } \\
\text { (Table B-1) }\end{array}$ \\
\hline
\end{tabular}

Description

This equation calculates the contaminant concentration in aboveground vegetation caused by direct uptake of contaminants from soil.

Source: EPA, 1994, Guidance for Performing Screening Level Risk Analyses at Combustion Facilities Burning Hazardous Wastes, Draft, U.S. Environmental Protection Agency, Office of Emergency and Remedial Response, December 14. 
Table C-4. Beef concentration from plant and soil ingestion.

\begin{tabular}{|c|c|c|}
\hline \multicolumn{3}{|c|}{ Exposure Scenarios } \\
\hline \multicolumn{3}{|c|}{ Subsistence Farmer } \\
\hline \multicolumn{3}{|c|}{ Equation } \\
\hline \multicolumn{3}{|c|}{$A_{b e e f}=(F * Q p * P+Q s * S c) * B a_{b e f f}$} \\
\hline Parameter & Definition & Value \\
\hline$A_{\text {beef }}$ & Concentration of pollutant in beef $(\mathrm{mg} / \mathrm{kg})$ & \\
\hline $\mathrm{F}$ & $\begin{array}{l}\text { Fraction of plant grown on contaminated soil and eaten } \\
\text { by bovine animal (dimensionless) }\end{array}$ & 1 \\
\hline Qp & $\begin{array}{l}\text { Quantity of plant eaten by bovine each day } \\
\text { (kg plant tissue DW/day) }\end{array}$ & 8.8 \\
\hline $\mathrm{P}$ & $\begin{array}{l}\text { Total concentration of pollutant in the plant eaten by } \\
\text { bovine animal }(\mathrm{mg} / \mathrm{kg})=\mathrm{Pd}+\mathrm{Pv}+\mathrm{Pr}\end{array}$ & $\begin{array}{l}\text { Calculated } \\
\text { (Table B-11) }\end{array}$ \\
\hline Qs & Quantity of soil eaten by bovine animal ( $\mathrm{kg}$ soil/day) & 0.5 \\
\hline Sc & Soil concentration $(\mathrm{mg} / \mathrm{kg})$ & Calculated (Table B-11) \\
\hline$B a_{\text {beef }}$ & Biotransfer factor for beef (day $/ \mathrm{kg}$ ) & $\begin{array}{l}\text { Chemical-specific } \\
\text { (Table B-1) }\end{array}$ \\
\hline \multicolumn{3}{|c|}{ Description } \\
\hline
\end{tabular}

Source: EPA, 1994, Guidance for Performing Screening Level Risk Analyses at Combustion Facilities Burning Hazardous Wastes, Draft, U.S. Environmental Protection Agency, Office of Emergency and Remedial Response, December 14. 
Table C-5. Milk concentration from plant and soil ingestion.

\begin{tabular}{|c|c|c|}
\hline \multicolumn{3}{|c|}{ Exposure Scenarios } \\
\hline \multicolumn{3}{|c|}{ Subsistence Farmer } \\
\hline \multicolumn{3}{|c|}{ Equation } \\
\hline \multicolumn{3}{|c|}{$A_{\text {milk }}=(F * Q p * P+Q s * S c) * B a_{\text {milk }}$} \\
\hline Parameter & Definition & Value \\
\hline$A_{\text {milk }}$ & Concentration of pollutant in milk (mg/kg) & \\
\hline $\mathrm{F}$ & $\begin{array}{l}\text { Fraction of plant grown on contaminated soil and eaten } \\
\text { by animal (dimensionless) }\end{array}$ & 1 \\
\hline Qp & $\begin{array}{l}\text { Quantity of plant eaten by animal each day } \\
\text { (kg plant tissue DW/day) }\end{array}$ & 13.2 \\
\hline $\mathrm{P}$ & $\begin{array}{l}\text { Total concentration of pollutant in the plant eaten by } \\
\text { animal }(\mathrm{mg} / \mathrm{kg})=\mathrm{Pd}+\mathrm{Pv}+\mathrm{Pr}\end{array}$ & Calculated (Table B-11) \\
\hline Qs & Quantity of soil eaten by animal ( $\mathrm{kg}$ soil/day) & 0.4 \\
\hline Sc & Soil concentration (mg/kg) & $\begin{array}{l}\text { Calculated (see } \\
\text { Table B-11) }\end{array}$ \\
\hline $\mathrm{Ba}_{\text {milk }}$ & Biotransfer factor for milk (day $/ \mathrm{kg}$ ) & $\begin{array}{l}\text { Chemical-specific } \\
\text { (Table B-1) }\end{array}$ \\
\hline \multicolumn{3}{|c|}{ Description } \\
\hline
\end{tabular}

Source: EPA, 1994, Guidance for Performing Screening Level Risk Analyses at Combustion Facilities Burning Hazardous Wastes, Draft, U.S. Environmental Protection Agency, Office of Emergency and Remedial Response, December 14. 
Table C-6. Soil intake for subsistence-farmer scenario.

\begin{tabular}{|c|c|c|c|}
\hline \multicolumn{4}{|c|}{ Equation } \\
\hline \multicolumn{4}{|c|}{$I_{\text {soil }}=S C * C R_{\text {soil }} * F_{\text {soil }}$} \\
\hline Parameter & \multicolumn{2}{|c|}{ Definition } & Value \\
\hline$I_{\text {soil }}$ & \multicolumn{2}{|c|}{ Daily intake of contaminant from ingested soil (mg/day) } & \\
\hline Sc & \multicolumn{2}{|c|}{ Soil concentration $(\mathrm{mg} / \mathrm{kg})$} & Calculated (Table B-11) \\
\hline $\mathrm{CR}_{\text {soil }}$ & \multicolumn{2}{|c|}{ Consumption rate of soil ( $\mathrm{kg} /$ day) } & 0.0001 \\
\hline$F_{\text {soil }}$ & \multicolumn{2}{|c|}{ Fraction of consumed soil contaminated (unitless) } & 1 \\
\hline \multicolumn{4}{|c|}{ Chemicals } \\
\hline \multicolumn{2}{|c|}{$\begin{array}{l}\text { 2,3,7,8-TCDD-TEQ } \\
\text { 1,3-dinitrobenzene } \\
\text { 2,4-dinitrotoluene } \\
\text { 2,6-dinitrotoluene } \\
\text { Antimony } \\
\text { Arsenic } \\
\text { Barium } \\
\text { Benzo(a)pyrene toxicity equivalents } \\
\text { Beryllium } \\
\text { Bis (2-ethylhexyl) phthalate } \\
\text { Cadmium } \\
\text { Chromium }\end{array}$} & \multicolumn{2}{|c|}{$\begin{array}{l}\text { Di(n)octyl phthalate } \\
\text { Hexachlorobenzene } \\
\text { Mercury } \\
\text { Nickel } \\
\text { Nitrobenzene } \\
\text { Pentachloronitrobenzene } \\
\text { Pentachlorophenol } \\
\text { Selenium } \\
\text { Silver } \\
\text { Thallium } \\
\text { Total polychlorinated biphenyls (PCBs) }\end{array}$} \\
\hline
\end{tabular}

Source: EPA, 1994, Guidance for Performing Screening Level Risk Analyses at Combustion Facilities Burning Hazardous Wastes, Draft, U.S. Environmental Protection Agency, Office of Emergency and Remedial Response, December 14. 
Table C-7. Aboveground produce intake for subsistence-farmer scenario.

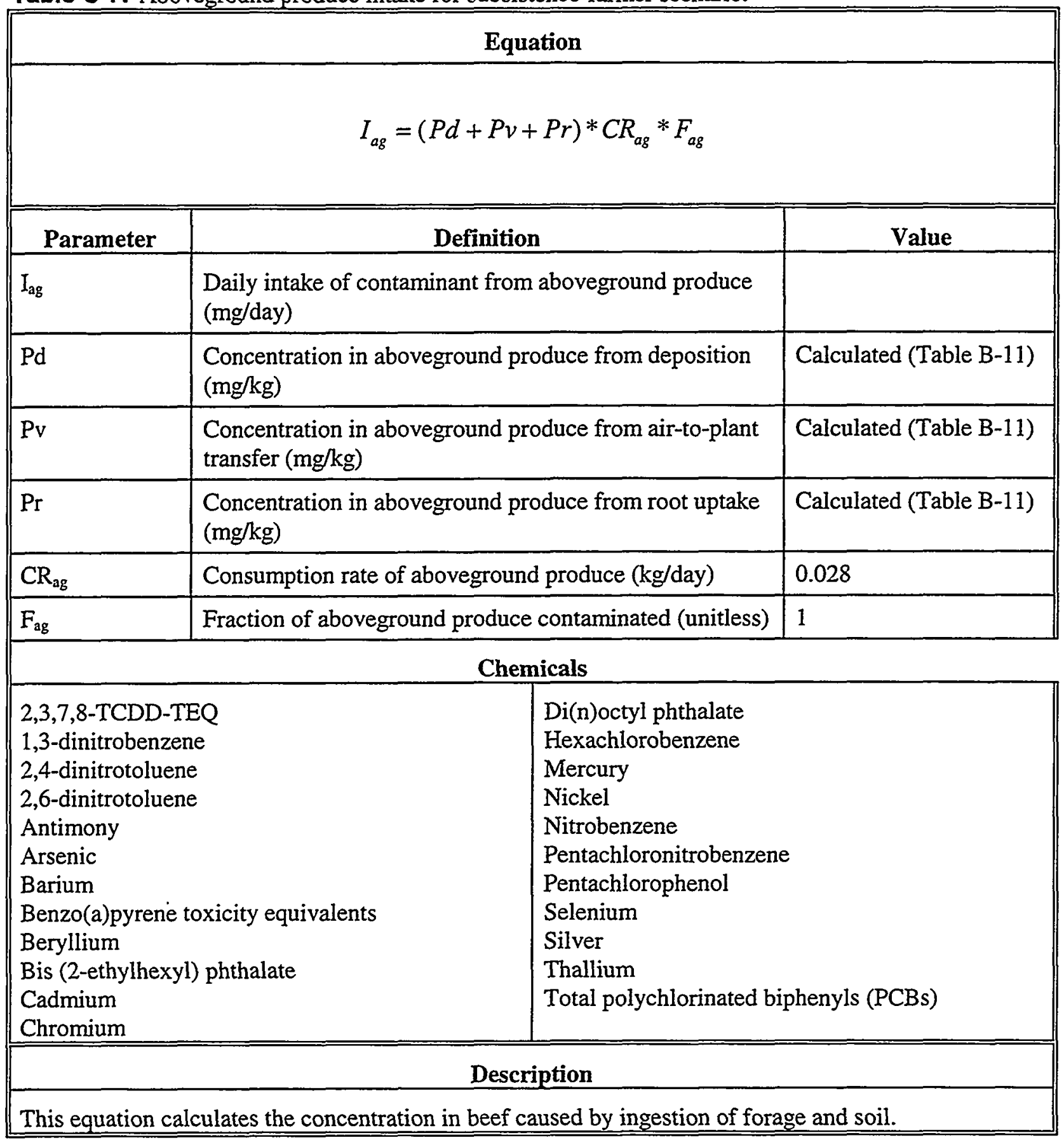

Source: EPA, 1994, Guidance for Performing Screening Level Risk Analyses at Combustion Facilities Burning Hazardous Wastes, Draft, U.S. Environmental Protection Agency, Office of Emergency and Remedial Response, December 14. 
Table C-8. Beef and milk intake for subsistence-farmer scenario.

\begin{tabular}{|c|c|c|c|}
\hline \multicolumn{4}{|c|}{ Equation } \\
\hline \multicolumn{4}{|c|}{$\begin{array}{l}I_{\text {beef }}=A_{\text {beef }} * C R_{\text {beef }} * F_{\text {beef }} \\
I_{\text {milk }}=A_{\text {milk }} * C R_{\text {milk }} * F_{\text {milk }}\end{array}$} \\
\hline Parameter & \multicolumn{2}{|c|}{ Definition } & Value \\
\hline$I_{\text {beef }}$ & \multicolumn{2}{|c|}{ Daily intake of contaminant from beef (mg/day) } & \\
\hline$A_{\text {beef }}$ & \multicolumn{2}{|c|}{ Concentration in beef $(\mathrm{mg} / \mathrm{kg})$} & Calculated (Table C-11) \\
\hline $\mathrm{CR}_{\text {beef }}$ & \multicolumn{2}{|c|}{ Consumption rate of beef $(\mathrm{kg} /$ day $)$} & 0.057 \\
\hline$F_{\text {beef }}$ & \multicolumn{2}{|c|}{ Fraction of beef contaminated (unitless) } & 1 \\
\hline$I_{\text {milk }}$ & \multicolumn{2}{|c|}{ Daily intake of contaminant from milk (mg/day) } & Calculated (Table C-12) \\
\hline$A_{\text {milk }}$ & \multicolumn{2}{|c|}{ Concentration in milk $(\mathrm{mg} / \mathrm{kg})$} & Calculated (Table C-11) \\
\hline $\mathrm{CR}_{\text {milk }}$ & \multicolumn{2}{|c|}{ Consumption rate of milk (kg/day) } & 0.18 \\
\hline$F_{\text {milk }}$ & \multicolumn{2}{|c|}{ Fraction of milk contaminated (unitless) } & 1 \\
\hline \multicolumn{4}{|c|}{ Chemicals } \\
\hline \multicolumn{2}{|c|}{$\begin{array}{l}\text { 2,3,7,8-TCDD-TEQ } \\
\text { 1,3-dinitrobenzene } \\
\text { 2,4-dinitrotoluene } \\
\text { 2,6-dinitrotoluene } \\
\text { Antimony } \\
\text { Arsenic } \\
\text { Barium } \\
\text { Benzo(a)pyrene toxicity equivalents } \\
\text { Beryllium } \\
\text { Bis (2-ethylhexyl) phthalate } \\
\text { Cadmium } \\
\text { Chromium }\end{array}$} & \multicolumn{2}{|c|}{$\begin{array}{l}\text { Di(n)octyl phthalate } \\
\text { Hexachlorobenzene } \\
\text { Mercury } \\
\text { Nickel } \\
\text { Nitrobenzene } \\
\text { Pentachloronitrobenzene } \\
\text { Pentachlorophenol } \\
\text { Selenium } \\
\text { Silver } \\
\text { Thallium } \\
\text { Total polychlorinated biphenyls (PCBs) }\end{array}$} \\
\hline
\end{tabular}

Source: EPA, 1994, Guidance for Performing Screening Level Risk Analyses at Combustion Facilities Burning Hazardous Wastes, Draft, U.S. Environmental Protection Agency, Office of Emergency and Remedial Response, December 14. 
Table C-9. Total daily intake for subsistence-farmer scenario.

\begin{tabular}{|c|c|c|c|}
\hline \multicolumn{4}{|c|}{ Equation } \\
\hline \multicolumn{4}{|c|}{$I=I_{\text {soil }}+I_{a g}+I_{b e e f}+I_{m i l k}+I_{d w}$} \\
\hline Parameter & \multicolumn{2}{|c|}{ Definition } & Value \\
\hline I & \multicolumn{2}{|c|}{ Total daily intake of contaminant (mg/day) } & \\
\hline$I_{\text {soil }}$ & \multicolumn{2}{|c|}{ Daily intake of contaminant from soil (mg/day) } & Calculated (Table C-12) \\
\hline$\overline{I_{a g}}$ & \multicolumn{2}{|c|}{$\begin{array}{l}\text { Daily intake of contaminant from aboveground produce } \\
\text { (mg/day) }\end{array}$} & Calculated (Table C-12) \\
\hline$I_{\text {beef }}$ & \multicolumn{2}{|c|}{ Daily intake of contaminant from beef ( $\mathrm{mg} /$ day) } & Calculated (Table C-12) \\
\hline$I_{\text {milk }}$ & \multicolumn{2}{|c|}{ Daily intake of contaminant from milk (mg/day) } & Calculated (Table C-12) \\
\hline$I_{d w}$ & \multicolumn{2}{|c|}{$\begin{array}{l}\text { Daily intake of contaminant from drinking water } \\
\text { (mg/day) }\end{array}$} & Calculated (Table C-12) \\
\hline \multicolumn{4}{|c|}{ Chemicals } \\
\hline \multicolumn{2}{|c|}{$\begin{array}{l}\text { 2,3,7,8-TCDD-TEQ } \\
\text { 1,3-dinitrobenzene } \\
\text { 2,4-dinitrotoluene } \\
\text { 2,6-dinitrotoluene } \\
\text { Antimony } \\
\text { Arsenic } \\
\text { Barium } \\
\text { Benzo(a)pyrene toxicity equivalents } \\
\text { Beryllium } \\
\text { Bis (2-ethylhexyl) phthalate } \\
\text { Cadmium } \\
\text { Chromium }\end{array}$} & \multicolumn{2}{|c|}{$\begin{array}{l}\text { Di(n)octyl phthalate } \\
\text { Hexachlorobenzene } \\
\text { Mercury } \\
\text { Nickel } \\
\text { Nitrobenzene } \\
\text { Pentachloronitrobenzene } \\
\text { Pentachlorophenol } \\
\text { Selenium } \\
\text { Silver } \\
\text { Thallium } \\
\text { Total polychlorinated biphenyls (PCBs) }\end{array}$} \\
\hline
\end{tabular}

Source: EPA, 1994, Guidance for Performing Screening Level Risk Analyses at Combustion Facilities Burning Hazardous Wastes, Draft, U.S. Environmental Protection Agency, Office of Emergency and Remedial Response, December 14. 
Table C-10. Average intake for subsistence farmer via inhalation.

\begin{tabular}{|c|c|c|}
\hline \multicolumn{3}{|c|}{ Equation } \\
\hline \multicolumn{3}{|c|}{$A D I($ inh $) i, j=\frac{C(\text { air })_{i, j} * I R_{j} * E T * E F * E D_{j} * 0.001}{B W * A T}$} \\
\hline Parameter & Definition & Value \\
\hline $\mathrm{ADI}(\mathrm{inh})_{\mathrm{ij}}$ & $\begin{array}{l}\text { Average daily intake via inhalation ( } \mathrm{mg} / \mathrm{kg} \text {-day) for } \\
\text { chemical } \mathrm{i} \text { in exposure scenario } \mathrm{j}\end{array}$ & \\
\hline $\mathrm{C}(\mathrm{air})_{\mathrm{ij}}$ & $\begin{array}{l}\text { Ambient air concentration }\left(\mu \mathrm{g} / \mathrm{m}^{3}\right) \text { for chemical } \mathrm{i} \text { in } \\
\text { exposure scenario } \mathrm{j}\end{array}$ & Tables 9 and 10 \\
\hline $\mathrm{Ir}_{\mathbf{j}}$ & Inhalation rate $\left(\mathrm{m}^{3} /\right.$ hour $)$ & 0.83 \\
\hline ET & Exposure time (hour/day) & 24 \\
\hline EF & Exposure frequency (day/year) & 350 \\
\hline$E D_{j}$ & Exposure duration (year) for exposure scenario $j$ & 40 \\
\hline $\mathrm{BW}_{\mathrm{j}}$ & Body weight $(\mathrm{kg})$ for exposure scenario $\mathrm{j}$ & 70 \\
\hline AT & Averaging time (days) & 25,550 \\
\hline 0.001 & Unit conversion factor $(\mathrm{mg} / \mu \mathrm{g})$ & \\
\hline \multicolumn{3}{|c|}{ Description } \\
\hline
\end{tabular}

Source: EPA, 1994, Guidance for Performing Screening Level Risk Analyses at Combustion Facilities Burning Hazardous Wastes, Draft, U.S. Environmental Protection Agency, Office of Emergency and Remedial Response, December 14. 
Table C-11. Beef and milk calculations (mg/kg) for subsistence farmer.

\begin{tabular}{|c|c|c|c|c|c|}
\hline Chemical & $\mathrm{Pd}$ & Pv & $\operatorname{Pr}$ & $A_{\text {beef }}$ & $A_{\text {milk }}$ \\
\hline Antimony & $1.53 \mathrm{E}-09$ & $0.00 \mathrm{E}+00$ & $2.73 E-12$ & $1.35 \mathrm{E}-11$ & $2.02 \mathrm{E}-12$ \\
\hline Arsenic & $6.12 E-14$ & $0.00 \mathrm{E}+00$ & $2.68 \mathrm{E}-16$ & $1.09 E-15$ & $4.89 \mathrm{E}-15$ \\
\hline Barium & $4.26 \mathrm{E}-14$ & $0.00 \mathrm{E}+00$ & $1.18 \mathrm{E}-14$ & $7.76 \mathrm{E}-17$ & $2.62 \mathrm{E}-16$ \\
\hline Benzo(a)pyrene & $6.13 \mathrm{E}-08$ & 4.52E-05 & $2.44 \mathrm{E}-07$ & $1.40 \mathrm{E}-05$ & $6.71 \mathrm{E}-06$ \\
\hline Beryllium & $9.12 \mathrm{E}-10$ & $0.00 \mathrm{E}+00$ & $2.24 \mathrm{E}-12$ & $8.16 \mathrm{E}-12$ & $1.09 \mathrm{E}-14$ \\
\hline Cadmium & $1.52 \mathrm{E}-12$ & $0.00 \mathrm{E}+00$ & $1.53 \mathrm{E}-13$ & $1.82 \mathrm{E}-12$ & $1.71 \mathrm{E}-13$ \\
\hline Chromium VI & $0.00 \mathrm{E}+00$ & $0.00 \mathrm{E}+00$ & $3.78 \mathrm{E}-14$ & $2.81 \mathrm{E}-14$ & $1.15 \mathrm{E}-14$ \\
\hline 1,3-dinitrobenzene(PIC) & $0.00 \mathrm{E}+00$ & $1.69 \mathrm{E}-07$ & $5.83 \mathrm{E}-03$ & $4.10 \mathrm{E}-08$ & $1.94 \mathrm{E}-08$ \\
\hline 2,4-dinitrotoluene & $0.00 \mathrm{E}+00$ & $1.23 \mathrm{E}-07$ & 2.82E-07 & $9.06 \mathrm{E}-12$ & $4.26 \mathrm{E}-12$ \\
\hline 2,4-dinitrotoluene(PIC) & $0.00 \mathrm{E}+00$ & $4.04 \mathrm{E}-03$ & $9.23 \mathrm{E}-03$ & $2.96 \mathrm{E}-07$ & $1.39 \mathrm{E}-07$ \\
\hline 2,6-dinitrotoluene(PIC) & $0.00 \mathrm{E}+00$ & $3.50 \mathrm{E}-03$ & $1.30 \mathrm{E}-02$ & $2.80 \mathrm{E}-07$ & $1.34 \mathrm{E}-07$ \\
\hline Di(n)octyl phthalate & $2.04 \mathrm{E}-10$ & $6.61 \mathrm{E}-06$ & 1.19E-09 & $0.00 E+00$ & $0.00 E+00$ \\
\hline $2,3,78-\mathrm{TCDD}$ & $4.88 \mathrm{E}-12$ & $7.00 \mathrm{E}-10$ & $3.61 E-12$ & $2.71 \mathrm{E}-10$ & $6.85 E-11$ \\
\hline Lead & $8.51 \mathrm{E}-10$ & $0.00 E+00$ & $1.46 \mathrm{E}-10$ & $3.85 \mathrm{E}-12$ & $4.10 \mathrm{E}-12$ \\
\hline Mercury & $4.40 E-05$ & $0.00 \mathrm{E}+00$ & $4.62 \mathrm{E}-08$ & $9.97 \mathrm{E}-05$ & $2.66 \mathrm{E}-07$ \\
\hline Nickel & $1.03 E-12$ & $0.00 \mathrm{E}+00$ & $4.76 \mathrm{E}-15$ & $5.57 \mathrm{E}-14$ & $1.38 \mathrm{E}-14$ \\
\hline Nitrobenzene(PIC) & $0.00 E+00$ & $1.27 \mathrm{E}-05$ & $1.14 \mathrm{E}-04$ & $1.93 E-09$ & $9.11 \mathrm{E}-10$ \\
\hline Pentachloronitrobenzene(PIC) & $0.00 \mathrm{E}+00$ & $1.64 \mathrm{E}-06$ & 1.39E-07 & $1.81 \mathrm{E}-08$ & $8.44 \mathrm{E}-09$ \\
\hline Pentachlorophenol & $0.00 \mathrm{E}+00$ & $4.44 \mathrm{E}-07$ & $2.42 \mathrm{E}-08$ & $1.32 \mathrm{E}-08$ & $6.14 \mathrm{E}-09$ \\
\hline Selenium & $3.88 \mathrm{E}-08$ & $0.00 E+00$ & $1.15 \mathrm{E}-11$ & $5.12 E-09$ & $2.05 \mathrm{E}-09$ \\
\hline Silver & $3.47 \mathrm{E}-14$ & $0.00 E+00$ & $2.59 \mathrm{E}-17$ & $9.16 \mathrm{E}-16$ & $9.16 \mathrm{E}-15$ \\
\hline Thallium & $1.52 \mathrm{E}-08$ & $0.00 \mathrm{E}+00$ & 8.29E-10 & 5.72E-09 & $4.26 \mathrm{E}-10$ \\
\hline
\end{tabular}


Table C-12. Intake calculations ( $\mathrm{mg} / \mathrm{kg}$ ) for subsistence farmer.

\begin{tabular}{|c|c|c|c|c|c|c|}
\hline Chemical & $I_{\text {soil }}$ & $\mathrm{I}_{\mathrm{ag}}$ & $\mathrm{I}_{\mathrm{dw}}$ & $I_{\text {beef }}$ & $I_{\text {milk }}$ & $I_{\text {total }}$ \\
\hline Antimony & $1.36 \mathrm{E}-15$ & $5.92 \mathrm{E}-13$ & $0.00 \mathrm{E}+00$ & $7.69 \mathrm{E}-13$ & $3.64 \mathrm{E}-13$ & $1.73 \mathrm{E}-12$ \\
\hline Arsenic & $7.44 \mathrm{E}-19$ & $2.81 E-17$ & $0.00 \mathrm{E}+00$ & $6.21 \mathrm{E}-17$ & $8.79 E-16$ & $9.70 \mathrm{E}-16$ \\
\hline Barium & $7.85 \mathrm{E}-18$ & $3.44 \mathrm{E}-16$ & $0.00 \mathrm{E}+00$ & $4.42 \mathrm{E}-18$ & $4.72 \mathrm{E}-17$ & $4.03 \mathrm{E}-16$ \\
\hline Benzo(a)pyrene & 2.22E-09 & $1.95 \mathrm{E}-08$ & $0.00 \mathrm{E}+00$ & $7.98 \mathrm{E}-07$ & $1.21 \mathrm{E}-06$ & 2.03E-06 \\
\hline Beryllium & $2.24 \mathrm{E}-14$ & $3.71 E-13$ & $0.00 E+00$ & $4.65 \mathrm{E}-13$ & $1.97 \mathrm{E}-15$ & $8.60 \mathrm{E}-13$ \\
\hline Cadmium & 8.52E-17 & $4.81 \mathrm{E}-15$ & $0.00 \mathrm{E}+00$ & $1.04 \mathrm{E}-13$ & $3.07 \mathrm{E}-14$ & $1.39 \mathrm{E}-13$ \\
\hline Chromium VI & $3.44 \mathrm{E}-18$ & $1.24 \mathrm{E}-15$ & $0.00 E+00$ & $1.60 \mathrm{E}-15$ & $2.07 \mathrm{E}-15$ & $4.92 \mathrm{E}-15$ \\
\hline 1,3-dinitrobenzene(PIC) & $1.10 \mathrm{E}-07$ & $4.08 \mathrm{E}-05$ & $0.00 E+00$ & 2.34E-09 & $3.48 \mathrm{E}-09$ & 4.09E-05 \\
\hline 2,4-dinitrotoluene & $1.05 \mathrm{E}-11$ & 7.94E-09 & $0.00 \mathrm{E}+00$ & $5.16 \mathrm{E}-13$ & $7.67 \mathrm{E}-13$ & 7.95E-09 \\
\hline 2,4-dinitrotoluene(PIC) & $3.42 \mathrm{E}-07$ & $2.60 \mathrm{E}-04$ & $0.00 E+00$ & $1.69 \mathrm{E}-08$ & $2.51 \mathrm{E}-08$ & $2.60 \mathrm{E}-04$ \\
\hline 2,6-dinitrotoluene(PIC) & 4.08E-07 & $3.66 \mathrm{E}-04$ & $0.00 \mathrm{E}+00$ & $1.60 \mathrm{E}-08$ & $2.42 \mathrm{E}-08$ & 3.67E-04 \\
\hline Di(n)octyl phthalate & $6.62 \mathrm{E}-11$ & $1.88 \mathrm{E}-09$ & $0.00 \mathrm{E}+00$ & $0.00 \mathrm{E}+00$ & $0.00 E+00$ & $1.95 \mathrm{E}-09$ \\
\hline $2,3,78-\mathrm{TCDD}$ & $1.10 \mathrm{E}-13$ & $2.99 \mathrm{E}-13$ & $0.00 \mathrm{E}+00$ & $1.55 \mathrm{E}-11$ & $1.23 \mathrm{E}-11$ & $2.82 E-11$ \\
\hline Lead & $8.11 E-13$ & $4.38 \mathrm{E}-12$ & $0.00 \mathrm{E}+00$ & $2.19 \mathrm{E}-13$ & $7.39 \mathrm{E}-13$ & $6.15 E-12$ \\
\hline Mercury & 2.31E-09 & $1.61 \mathrm{E}-08$ & $0.00 \mathrm{E}+00$ & $5.68 \mathrm{E}-06$ & $4.78 \mathrm{E}-08$ & $5.75 \mathrm{E}-06$ \\
\hline Nickel & $2.97 \mathrm{E}-17$ & $4.82 \mathrm{E}-16$ & $0.00 E+00$ & $3.18 \mathrm{E}-15$ & $2.49 E-15$ & $6.18 \mathrm{E}-15$ \\
\hline Nitrobenzene(PIC) & $3.36 \mathrm{E}-09$ & $3.20 \mathrm{E}-06$ & $0.00 E+00$ & $1.10 \mathrm{E}-10$ & $1.64 \mathrm{E}-10$ & $3.20 \mathrm{E}-06$ \\
\hline Pentachloronitrobenzene(PIC) & $1.71 E-10$ & $4.34 \mathrm{E}-09$ & $0.00 \mathrm{E}+00$ & $1.03 E-09$ & $1.52 \mathrm{E}-09$ & $7.06 \mathrm{E}-09$ \\
\hline Pentachlorophenol & $5.39 \mathrm{E}-11$ & $8.03 \mathrm{E}-10$ & $0.00 E+00$ & $7.50 \mathrm{E}-10$ & $1.10 \mathrm{E}-09$ & 2.71E-09 \\
\hline Selenium & $7.17 \mathrm{E}-14$ & $1.34 \mathrm{E}-11$ & $0.00 \mathrm{E}+00$ & $2.92 \mathrm{E}-10$ & $3.69 \mathrm{E}-10$ & $6.74 \mathrm{E}-10$ \\
\hline Silver & $6.47 \mathrm{E}-21$ & $1.24 \mathrm{E}-17$ & $0.00 \mathrm{E}+00$ & $5.22 \mathrm{E}-17$ & $1.65 \mathrm{E}-15$ & $1.71 \mathrm{E}-15$ \\
\hline Thallium & $3.95 \mathrm{E}-13$ & $2.83 \mathrm{E}-11$ & $0.00 \mathrm{E}+00$ & $3.26 \mathrm{E}-10$ & $7.68 \mathrm{E}-11$ & $4.32 \mathrm{E}-10$ \\
\hline
\end{tabular}


Appendix D

Exposure Calculations for Adult Resident 
Table D-1. Soil intake for adult-resident scenario.

\begin{tabular}{|c|c|c|c|}
\hline \multicolumn{4}{|c|}{ Equation } \\
\hline \multicolumn{4}{|c|}{$I_{\text {soil }}=S C * C R_{\text {soil }} * F_{\text {soil }}$} \\
\hline Parameter & \multicolumn{2}{|c|}{ Definition } & Value \\
\hline$I_{\text {soil }}$ & \multicolumn{2}{|c|}{ Daily intake of contaminant from soil (mg/day) } & \\
\hline $\mathrm{Sc}$ & \multicolumn{2}{|c|}{ Soil concentration $(\mathrm{mg} / \mathrm{kg})$} & Calculated (Table B-12) \\
\hline $\mathrm{CR}_{\text {soil }}$ & \multicolumn{2}{|c|}{ Consumption rate of soil (kg/day) } & 0.0001 \\
\hline $\mathrm{F}_{\text {soil }}$ & \multicolumn{2}{|c|}{ Fraction of consumed soil contaminated (unitless) } & 1 \\
\hline \multicolumn{4}{|c|}{ Chemicals } \\
\hline \multicolumn{2}{|c|}{$\begin{array}{l}\text { 2,3,7,8-TCDD-TEQ } \\
\text { 1,3-dinitrobenzene } \\
\text { 2,4-dinitrotoluene } \\
\text { 2,6-dinitrotoluene } \\
\text { Antimony } \\
\text { Arsenic } \\
\text { Barium } \\
\text { Benzo(a)pyrene toxicity equivalents } \\
\text { Beryllium } \\
\text { Bis (2-ethylhexyl) phthalate } \\
\text { Cadmium } \\
\text { Chromium }\end{array}$} & \multicolumn{2}{|c|}{$\begin{array}{l}\text { Di(n)octyl phthalate } \\
\text { Hexachlorobenzene } \\
\text { Mercury } \\
\text { Nickel } \\
\text { Nitrobenzene } \\
\text { Pentachloronitrobenzene } \\
\text { Pentachlorophenol } \\
\text { Selenium } \\
\text { Silver } \\
\text { Thallium } \\
\text { Total polychlorinated biphenyls (PCBs) }\end{array}$} \\
\hline
\end{tabular}


Table D-2. Aboveground vegetable intake for adult-resident scenario.

\begin{tabular}{|c|c|c|c|}
\hline \multicolumn{4}{|c|}{ Equation } \\
\hline \multicolumn{4}{|c|}{$I_{a g}=(P d+P v+P r) * C R_{a g} * F_{a g}$} \\
\hline Parameter & \multicolumn{2}{|c|}{ Definition } & Value \\
\hline$I_{a g}$ & \multicolumn{2}{|c|}{$\begin{array}{l}\text { Daily intake of contaminant from aboveground } \\
\text { vegetables (mg/day) }\end{array}$} & \\
\hline $\mathrm{Pd}$ & \multicolumn{2}{|c|}{$\begin{array}{l}\text { Concentration in aboveground vegetables from } \\
\text { deposition }(\mathrm{mg} / \mathrm{kg})\end{array}$} & Calculated (Table B-12) \\
\hline $\mathrm{Pv}$ & \multicolumn{2}{|c|}{$\begin{array}{l}\text { Concentration in aboveground vegetables from air-to- } \\
\text { plant transfer }(\mathrm{mg} / \mathrm{kg})\end{array}$} & Calculated (Table B-12) \\
\hline $\operatorname{Pr}$ & \multicolumn{2}{|c|}{$\begin{array}{l}\text { Concentration in aboveground produce from root uptake } \\
(\mathrm{mg} / \mathrm{kg})\end{array}$} & Calculated (Table B-12) \\
\hline $\mathrm{CR}_{\mathrm{ag}}$ & \multicolumn{2}{|c|}{ Consumption rate of aboveground vegetables ( $\mathrm{kg} /$ day) } & 0.028 \\
\hline Fag & \multicolumn{2}{|c|}{$\begin{array}{l}\text { Fraction of aboveground vegetables contaminated } \\
\text { (unitless) }\end{array}$} & 0.25 \\
\hline \multicolumn{4}{|c|}{ Chemicals } \\
\hline \multicolumn{2}{|c|}{$\begin{array}{l}\text { 2,3,7,8-TCDD-TEQ } \\
\text { 1,3-dinitrobenzene } \\
\text { 2,4-dinitrotoluene } \\
\text { 2,6-dinitrotoluene } \\
\text { Antimony } \\
\text { Arsenic } \\
\text { Barium } \\
\text { Benzo(a)pyrene toxicity equivalents } \\
\text { Beryllium } \\
\text { Bis (2-ethylhexyl) phthalate } \\
\text { Cadmium } \\
\text { Chromium }\end{array}$} & \multicolumn{2}{|c|}{$\begin{array}{l}\text { Di(n)octyl phthalate } \\
\text { Hexachlorobenzene } \\
\text { Mercury } \\
\text { Nickel } \\
\text { Nitrobenzene } \\
\text { Pentachloronitrobenzene } \\
\text { Pentachlorophenol } \\
\text { Selenium } \\
\text { Silver } \\
\text { Thallium } \\
\text { Total polychlorinated biphenyls (PCBs) }\end{array}$} \\
\hline
\end{tabular}

Source: EPA, 1994, Guidance for Performing Screening Level Risk Analyses at Combustion Facilities Burning Hazardous Wastes, Draft, U.S. Environmental Protection Agency, Office of Emergency and Remedial Response, December 14. 
Table D-3. Total daily intake for adult-resident scenario.

\begin{tabular}{|c|c|c|c|}
\hline \multicolumn{4}{|c|}{ Equation } \\
\hline \multicolumn{4}{|c|}{$I=I_{s o i l}+I_{a g}+I_{d w}$} \\
\hline Parameter & \multicolumn{2}{|c|}{ Definition } & Value \\
\hline I & \multicolumn{2}{|c|}{ Total daily intake of contaminant (mg/day) } & \\
\hline$I_{\text {soil }}$ & \multicolumn{2}{|c|}{ Daily intake of contaminant from soil (mg/day) } & Calculated (Table D-5) \\
\hline$I_{\mathrm{ag}}$ & \multicolumn{2}{|c|}{$\begin{array}{l}\text { Daily intake of contaminant from aboveground } \\
\text { vegetables }(\mathrm{mg} / \mathrm{kg})\end{array}$} & Calculated (Table D-5) \\
\hline $\mathrm{I}_{\mathrm{dw}}$ & \multicolumn{2}{|c|}{$\begin{array}{l}\text { Daily intake of contaminant from drinking water } \\
\text { (mg/day) }\end{array}$} & Calculated (Table D-5) \\
\hline \multicolumn{4}{|c|}{ Chemicals } \\
\hline \multicolumn{2}{|c|}{$\begin{array}{l}\text { 2,3,7,8-TCDD-TEQ } \\
\text { 1,3-dinitrobenzene } \\
\text { 2,4-dinitrotoluene } \\
\text { 2,6-dinitrotoluene } \\
\text { Antimony } \\
\text { Arsenic } \\
\text { Barium } \\
\text { Benzo(a)pyrene toxicity equivalents } \\
\text { Beryllium } \\
\text { Bis (2-ethylhexyl) phthalate } \\
\text { Cadmium } \\
\text { Chromium }\end{array}$} & \multicolumn{2}{|c|}{$\begin{array}{l}\text { Di(n)octyl phthalate } \\
\text { Hexachlorobenzene } \\
\text { Mercury } \\
\text { Nickel } \\
\text { Nitrobenzene } \\
\text { Pentachloronitrobenzene } \\
\text { Pentachlorophenol } \\
\text { Selenium } \\
\text { Silver } \\
\text { Thallium } \\
\text { Total polychlorinated biphenyls (PCBs) }\end{array}$} \\
\hline
\end{tabular}

Source: EPA, 1994, Guidance for Performing Screening Level Risk Analyses at Combustion Facilities Burning Hazardous Wastes, Draft, U.S. Environmental Protection Agency, Office of Emergency and Remedial Response, December 14. 
Table D-4. Average for adult resident intake via inhalation.

\begin{tabular}{|c|c|c|}
\hline \multicolumn{3}{|c|}{ Equation } \\
\hline \multicolumn{3}{|c|}{$A D I($ inh $) i, j=\frac{C(\text { air })_{i, j} * I R_{j} * E T * E F * E D_{j} * 0.001}{B W_{j}^{*} A T}$} \\
\hline Parameter & Definition & Value \\
\hline $\mathrm{ADI}(\mathrm{inh})_{\mathrm{i}, \mathrm{j}}$ & $\begin{array}{l}\text { Average daily intake via inhalation ( } \mathrm{mg} / \mathrm{kg} \text {-day) for } \\
\text { chemical } \mathrm{i} \text { in exposure scenario } \mathrm{j}\end{array}$ & \\
\hline$C(\text { air })_{i, j}$ & $\begin{array}{l}\text { Ambient air concentration }\left(\mu \mathrm{g} / \mathrm{m}^{3}\right) \text { for chemical } i \text { in } \\
\text { exposure scenario } j\end{array}$ & Tables 9 and 10 \\
\hline$I_{j}$ & Inhalation rate $\left(\mathrm{m}^{3} / \mathrm{hour}\right)$ & 0.83 \\
\hline ET & Exposure time (hour/day) & 24 \\
\hline $\mathrm{EF}$ & Exposure frequency (day/year) & 350 \\
\hline$E D_{j}$ & Exposure duration (year) for exposure scenario $j$ & 30 \\
\hline $\mathrm{BW}_{\mathrm{j}}$ & Body weight $(\mathrm{kg})$ for exposure scenario $\mathrm{j}$ & 70 \\
\hline AT & Averaging time (day) & 25,550 \\
\hline 0.001 & Unit conversion factor $(\mathrm{mg} / \mu \mathrm{g})$ & \\
\hline \multicolumn{3}{|c|}{ Description } \\
\hline
\end{tabular}

Source: EPA, 1994, Guidance for Performing Screening Level Risk Analyses at Combustion Facilities Burning Hazardous Wastes, Draft, U.S. Environmental Protection Agency, Office of Emergency and Remedial Response, December 14. 
Table D-5. Intake calculations (mg/day) for adult resident.

\begin{tabular}{|c|c|c|c|c|}
\hline Chemical & $I_{\text {soil }}$ & $I_{a g}$ & $I_{d w}$ & $I_{\text {total }}$ \\
\hline Antimony & $1.82 \mathrm{E}-15$ & $1.54 \mathrm{E}-13$ & $0.00 \mathrm{E}+00$ & $1.56 \mathrm{E}-13$ \\
\hline Arsenic & $9.93 \mathrm{E}-19$ & $7.66 \mathrm{E}-18$ & $0.00 E+00$ & $8.66 \mathrm{E}-18$ \\
\hline Barium & $1.02 \mathrm{E}-17$ & $1.10 \mathrm{E}-16$ & $0.00 \mathrm{E}+00$ & $1.20 \mathrm{E}-16$ \\
\hline Benzo(a)pyrene & $2.30 \mathrm{E}-09$ & $4.95 \mathrm{E}-09$ & $0.00 \mathrm{E}+00$ & $7.25 \mathrm{E}-09$ \\
\hline Beryllium & $2.99 \mathrm{E}-14$ & $9.79 \mathrm{E}-14$ & $0.00 \mathrm{E}+00$ & $1.28 \mathrm{E}-13$ \\
\hline Cadmium & $1.14 \mathrm{E}-16$ & $1.56 \mathrm{E}-15$ & $0.00 \mathrm{E}+00$ & $1.67 \mathrm{E}-15$ \\
\hline Chromium VI & $0.00 E+00$ & $3.98 \mathrm{E}-16$ & $0.00 \mathrm{E}+00$ & $3.98 \mathrm{E}-16$ \\
\hline 1,3-dinitrobenzene(PIC) & $0.00 E+00$ & $5.44 \mathrm{E}-05$ & $0.00 \mathrm{E}+00$ & $5.44 \mathrm{E}-05$ \\
\hline 2,4-dinitrotoluene & $1.39 \mathrm{E}-11$ & $2.64 \mathrm{E}-09$ & $0.00 \mathrm{E}+00$ & $2.66 \mathrm{E}-09$ \\
\hline 2,4-dinitrotoluene(PIC) & $4.56 \mathrm{E}-07$ & $8.64 \mathrm{E}-05$ & $0.00 \mathrm{E}+00$ & $8.69 E-05$ \\
\hline 2,6-dinitrotoluene(PIC) & $5.43 E-07$ & $1.22 \mathrm{E}-04$ & $0.00 \mathrm{E}+00$ & $1.23 \mathrm{E}-04$ \\
\hline Di(n)octyl phthalate & $6.12 E-11$ & $4.70 \mathrm{E}-10$ & $0.00 E+00$ & 5.32E-10 \\
\hline 2,3,78-TCDD & $1.11 \mathrm{E}-13$ & $7.50 \mathrm{E}-14$ & $0.00 E+00$ & $1.86 \mathrm{E}-13$ \\
\hline Lead & $7.47 \mathrm{E}-13$ & $1.01 \mathrm{E}-12$ & $0.00 \mathrm{E}+00$ & $1.76 \mathrm{E}-12$ \\
\hline Mercury & $3.08 \mathrm{E}-09$ & 4.14E-09 & $0.00 \mathrm{E}+00$ & $7.22 \mathrm{E}-09$ \\
\hline Nickel & $3.96 \mathrm{E}-17$ & $1.32 \mathrm{E}-16$ & $0.00 \mathrm{E}+00$ & $1.71 \mathrm{E}-16$ \\
\hline Nitrobenzene(PIC) & 4.48E-09 & $1.07 \mathrm{E}-06$ & $0.00 \mathrm{E}+00$ & 1.07E-06 \\
\hline Pentachloronitrobenzene(PIC) & $2.28 \mathrm{E}-10$ & $1.41 \mathrm{E}-09$ & $0.00 \mathrm{E}+00$ & $1.64 \mathrm{E}-09$ \\
\hline Pentachlorophenol & $7.19 \mathrm{E}-11$ & $2.57 \mathrm{E}-10$ & $0.00 \mathrm{E}+00$ & $3.29 \mathrm{E}-10$ \\
\hline Selenium & 9.57E-14 & $3.38 \mathrm{E}-12$ & $0.00 \mathrm{E}+00$ & $3.47 \mathrm{E}-12$ \\
\hline Silver & $8.63 E-21$ & $3.17 E-18$ & $0.00 \mathrm{E}+00$ & 3.17E-18 \\
\hline Thallium & $5.26 E-13$ & $9.02 \mathrm{E}-12$ & $0.00 \mathrm{E}+00$ & $9.54 \mathrm{E}-12$ \\
\hline
\end{tabular}




\section{Appendix E}

\section{Exposure Calculations for Child Resident}


Table E-1. Soil intake for child-resident scenario.

\begin{tabular}{|c|c|c|c|}
\hline \multicolumn{4}{|c|}{ Equation } \\
\hline \multicolumn{4}{|c|}{$I_{\text {soil }}=S c * C R_{\text {soil }} * F_{\text {soil }}$} \\
\hline Parameter & \multicolumn{2}{|c|}{ Definition } & Value \\
\hline$I_{\text {soil }}$ & \multicolumn{2}{|c|}{ Daily intake of contaminant from soil (mg/kg) } & \\
\hline $\mathrm{Sc}$ & \multicolumn{2}{|c|}{ Soil concentration (mg/kg) } & Calculated (Table B-13) \\
\hline $\mathrm{Cr}_{\text {soil }}$ & \multicolumn{2}{|c|}{ Consumption rate of soil (kg/day) } & 0.0002 \\
\hline$F_{\text {soil }}$ & \multicolumn{2}{|c|}{ Fraction of consumed soil contaminated (unitless) } & 1 \\
\hline \multicolumn{4}{|c|}{ Chemicals } \\
\hline \multicolumn{2}{|c|}{$\begin{array}{l}\text { 2,3,7,8-TCDD-TEQ } \\
\text { 1,3-dinitrobenzene } \\
\text { 2,4-dinitrotoluene } \\
\text { 2,6-dinitrotoluene } \\
\text { Antimony } \\
\text { Arsenic } \\
\text { Barium } \\
\text { Benzo(a)pyrene toxicity equivalents } \\
\text { Beryllium } \\
\text { Bis (2-ethylhexyl) phthalate } \\
\text { Cadmium } \\
\text { Chromium }\end{array}$} & \multicolumn{2}{|c|}{$\begin{array}{l}\text { Di(n)octyl phthalate } \\
\text { Hexachlorobenzene } \\
\text { Mercury } \\
\text { Nickel } \\
\text { Nitrobenzene } \\
\text { Pentachloronitrobenzene } \\
\text { Pentachlorophenol } \\
\text { Selenium } \\
\text { Silver } \\
\text { Thallium } \\
\text { Total polychlorinated biphenyls }(\mathrm{PCBs})\end{array}$} \\
\hline
\end{tabular}


Table E-2. Aboveground vegetable intake for child-resident scenario.

\begin{tabular}{|c|c|c|c|}
\hline \multicolumn{4}{|c|}{ Equation } \\
\hline \multicolumn{4}{|c|}{$I_{a g}=(P d+P v+P r) * C R_{a g} * F_{a g}$} \\
\hline Parameter & \multicolumn{2}{|c|}{ Definition } & Value \\
\hline$I_{a g}$ & \multicolumn{2}{|c|}{$\begin{array}{l}\text { Daily intake of contaminant from aboveground } \\
\text { vegetables (mg/day) }\end{array}$} & \\
\hline $\mathrm{Pd}$ & \multicolumn{2}{|c|}{$\begin{array}{l}\text { Concentration in aboveground vegetables from } \\
\text { deposition }(\mathrm{mg} / \mathrm{kg} \text { ) }\end{array}$} & Calculated (Table B-13) \\
\hline $\mathrm{Pv}$ & \multicolumn{2}{|c|}{$\begin{array}{l}\text { Concentration in aboveground vegetables from air-to- } \\
\text { plant transfer }(\mathrm{mg} / \mathrm{kg})\end{array}$} & Calculated (Table B-13) \\
\hline $\operatorname{Pr}$ & \multicolumn{2}{|c|}{$\begin{array}{l}\text { Concentration in aboveground vegetables from root } \\
\text { uptake }(\mathrm{mg} / \mathrm{kg})\end{array}$} & Calculated (Table B-13) \\
\hline $\mathrm{CR}_{\mathrm{ag}}$ & \multicolumn{2}{|c|}{ Consumption rate of aboveground vegetables ( $\mathrm{kg} /$ day) } & 0.005 \\
\hline$F_{a g}$ & \multicolumn{2}{|c|}{$\begin{array}{l}\text { Fraction of aboveground vegetables contaminated } \\
\text { (unitless) }\end{array}$} & 0.25 \\
\hline \multicolumn{4}{|c|}{ Chemicals } \\
\hline \multicolumn{2}{|c|}{$\begin{array}{l}\text { 2,3,7,8-TCDD-TEQ } \\
\text { 1,3-dinitrobenzene } \\
\text { 2,4-dinitrotoluene } \\
\text { 2,6-dinitrotoluene } \\
\text { Antimony } \\
\text { Arsenic } \\
\text { Barium } \\
\text { Benzo(a)pyrene toxicity equivalents } \\
\text { Beryllium } \\
\text { Bis (2-ethylhexyl) phthalate } \\
\text { Cadmium } \\
\text { Chromium }\end{array}$} & \multicolumn{2}{|c|}{$\begin{array}{l}\text { Di(n)octyl phthalate } \\
\text { Hexachlorobenzene } \\
\text { Mercury } \\
\text { Nickel } \\
\text { Nitrobenzene } \\
\text { Pentachloronitrobenzene } \\
\text { Pentachlorophenol } \\
\text { Selenium } \\
\text { Silver } \\
\text { Thallium } \\
\text { Total polychlorinated biphenyls (PCBs) }\end{array}$} \\
\hline
\end{tabular}

Source: EPA, 1994, Guidance for Performing Screening Level Risk Analyses at Combustion Facilities Burning Hazardous Wastes, Draft, U.S. Environmental Protection Agency, Office of Emergency and Remedial Response, December 14. 
Table E-3. Total daily intake for child-resident scenario.

\begin{tabular}{|c|c|c|c|}
\hline \multicolumn{4}{|c|}{ Equation } \\
\hline \multicolumn{4}{|c|}{$I=I_{\text {soil }}+I_{a g}+I_{d w}$} \\
\hline Parameter & \multicolumn{2}{|c|}{ Definition } & Value \\
\hline 1 & \multicolumn{2}{|c|}{ Total daily intake of contaminant (mg/day) } & \\
\hline$I_{\text {soil }}$ & \multicolumn{2}{|c|}{ Daily intake of contaminant from soil (mg/day) } & Calculated (Table E-5) \\
\hline$I_{\mathrm{ag}}$ & \multicolumn{2}{|c|}{$\begin{array}{l}\text { Daily intake of contaminant from aboveground } \\
\text { vegetables (mg/day) }\end{array}$} & Calculated (Table E-5) \\
\hline $\mathrm{I}_{\mathrm{dw}}$ & \multicolumn{2}{|c|}{$\begin{array}{l}\text { Daily intake of contaminant from drinking water } \\
\text { (mg/day) }\end{array}$} & Calculated (Table E-5) \\
\hline \multicolumn{4}{|c|}{ Chemicals } \\
\hline \multicolumn{2}{|c|}{$\begin{array}{l}\text { 2,3,7,8-TCDD-TEQ } \\
\text { 1,3-dinitrobenzene } \\
\text { 2,4-dinitrotoluene } \\
\text { 2,6-dinitrotoluene } \\
\text { Antimony } \\
\text { Arsenic } \\
\text { Barium } \\
\text { Benzo(a)pyrene toxicity equivalents } \\
\text { Beryllium } \\
\text { Bis (2-ethylhexyl) phthalate } \\
\text { Cadmium } \\
\text { Chromium }\end{array}$} & \multicolumn{2}{|c|}{$\begin{array}{l}\text { Di(n)octyl phthalate } \\
\text { Hexachlorobenzene } \\
\text { Mercury } \\
\text { Nickel } \\
\text { Nitrobenzene } \\
\text { Pentachloronitrobenzene } \\
\text { Pentachlorophenol } \\
\text { Selenium } \\
\text { Silver } \\
\text { Thallium } \\
\text { Total polychlorinated biphenyls (PCBs) }\end{array}$} \\
\hline
\end{tabular}

Source: EPA, 1994, Guidance for Performing Screening Level Risk Analyses at Combustion Facilities Burning Hazardous Wastes, Draft, U.S. Environmental Protection Agency, Office of Emergency and Remedial Response, December 14. 
Table E-4. Average intake for child via inhalation.

\begin{tabular}{|c|c|c|}
\hline \multicolumn{3}{|c|}{ Equation } \\
\hline \multicolumn{3}{|c|}{$A D I($ inh $) i, j=\frac{C(\text { air })_{i, j} * I R_{j} * E T * E F * E D_{j} * 0.001}{B W_{j} * A T}$} \\
\hline Parameter & Definition & Value \\
\hline $\mathrm{ADI}(\mathrm{inh})_{\mathrm{i}, \mathrm{j}}$ & $\begin{array}{l}\text { Average daily intake via inhalation ( } \mathrm{mg} / \mathrm{kg} \text {-day) for } \\
\text { chemical } i \text { in exposure scenario } \mathrm{j}\end{array}$ & \\
\hline$C(\text { air })_{i, j}$ & $\begin{array}{l}\text { Ambient air concentration }\left(\mu \mathrm{g} / \mathrm{m}^{3}\right) \text { for chemical } i \text { in } \\
\text { exposure scenario } j\end{array}$ & Tables 9 and 10 \\
\hline $\mathrm{Ir}_{\mathbf{j}}$ & Inhalation rate $\left(\mathrm{m}^{3} / \mathrm{hour}\right)$ & 0.3 \\
\hline ET & Exposure time (hour/day) & 24 \\
\hline $\mathrm{EF}$ & Exposure frequency (day/year) & 350 \\
\hline$E d_{j}$ & Exposure duration (year) for exposure scenario $\mathrm{j}$ & 6 \\
\hline$B W_{j}$ & Body weight $(\mathrm{kg})$ for exposure scenario $\mathrm{j}$ & 15 \\
\hline $\mathrm{AT}$ & Averaging time (day) & 25,550 \\
\hline 0.001 & Unit conversion factor $(\mathrm{mg} / \mu \mathrm{g})$ & \\
\hline \multicolumn{3}{|c|}{ Description } \\
\hline
\end{tabular}

Source: EPA, 1994, Guidance for Performing Screening Level Risk Analyses at Combustion Facilities Burning Hazardous Wastes, Draft, U.S. Environmental Protection Agency, Office of Emergency and Remedial Response, December 14. 
Table E-5. Intake calculations (mg/day) for child resident.

\begin{tabular}{|c|c|c|c|c|}
\hline Chemical & $I_{\text {soil }}$ & $I_{2 g}$ & $\mathrm{I}_{\mathrm{dw}}$ & $I_{\text {total }}$ \\
\hline Antimony & $1.21 \mathrm{E}-14$ & $3.82 \mathrm{E}-14$ & $0.00 \mathrm{E}+00$ & 5.03E-14 \\
\hline Arsenic & $6.48 \mathrm{E}-18$ & $2.38 \mathrm{E}-18$ & $0.00 \mathrm{E}+00$ & $8.86 \mathrm{E}-18$ \\
\hline Barium & $4.53 \mathrm{E}-17$ & $4.31 \mathrm{E}-17$ & $0.00 E+00$ & $8.84 \mathrm{E}-17$ \\
\hline Benzo(a)pyrene & $6.59 \mathrm{E}-09$ & $1.02 \mathrm{E}-09$ & $0.00 \mathrm{E}+00$ & $7.61 \mathrm{E}-09$ \\
\hline Beryllium & $1.89 \mathrm{E}-13$ & $2.56 \mathrm{E}-14$ & $0.00 \mathrm{E}+00$ & $2.15 \mathrm{E}-13$ \\
\hline Cadmium & $6.70 \mathrm{E}-16$ & $7.77 \mathrm{E}-16$ & $0.00 E+00$ & $1.45 \mathrm{E}-15$ \\
\hline Chromium VI & $3.01 \mathrm{E}-17$ & $2.15 \mathrm{E}-16$ & $0.00 \mathrm{E}+00$ & $2.46 \mathrm{E}-16$ \\
\hline 1,3-dinitrobenzene(PIC) & $9.78 \mathrm{E}-07$ & $3.24 \mathrm{E}-05$ & $0.00 \mathrm{E}+00$ & $3.34 \mathrm{E}-05$ \\
\hline 2,4-dinitrotoluene & $9.29 \mathrm{E}-11$ & $1.57 \mathrm{E}-09$ & $0.00 E+00$ & $1.66 \mathrm{E}-09$ \\
\hline 2,4-dinitrotoluene(PIC) & $3.04 \mathrm{E}-06$ & $5.13 \mathrm{E}-05$ & $0.00 E+00$ & 5.44E-05 \\
\hline 2,6-dinitrotoluene(PIC) & $3.62 \mathrm{E}-06$ & 7.25E-05 & $0.00 \mathrm{E}+00$ & $7.61 \mathrm{E}-05$ \\
\hline Di(n)octyl phthalate & $1.50 \mathrm{E}-10$ & $8.43 E-11$ & $0.00 \mathrm{E}+00$ & $2.34 \mathrm{E}-10$ \\
\hline 2,3,78-TCDD & $3.06 \mathrm{E}-13$ & $1.51 \mathrm{E}-14$ & $0.00 \mathrm{E}+00$ & $3.21 \mathrm{E}-13$ \\
\hline Lead & $1.82 \mathrm{E}-12$ & $2.18 \mathrm{E}-13$ & $0.00 \mathrm{E}+00$ & $2.04 \mathrm{E}-12$ \\
\hline Mercury & $1.83 \mathrm{E}-08$ & $8.91 \mathrm{E}-10$ & $0.00 \mathrm{E}+00$ & $1.92 \mathrm{E}-08$ \\
\hline Nickel & $2.49 \mathrm{E}-16$ & $4.04 \mathrm{E}-17$ & $0.00 E+00$ & $2.89 \mathrm{E}-16$ \\
\hline Nitrobenzene(PIC) & $2.98 \mathrm{E}-08$ & $6.34 \mathrm{E}-07$ & $0.00 \mathrm{E}+00$ & $6.64 \mathrm{E}-07$ \\
\hline Pentachloronitrobenzene(PIC) & $1.52 \mathrm{E}-09$ & $7.91 \mathrm{E}-10$ & $0.00 \mathrm{E}+00$ & 2.31E-09 \\
\hline Pentachlorophenol & $4.73 E-10$ & $1.39 E-10$ & $0.00 \mathrm{E}+00$ & $6.11 \mathrm{E}-10$ \\
\hline Selenium & $6.36 \mathrm{E}-13$ & $6.47 \mathrm{E}-13$ & $0.00 \mathrm{E}+00$ & $1.28 \mathrm{E}-12$ \\
\hline Silver & $5.75 \mathrm{E}-20$ & $6.66 \mathrm{E}-19$ & $0.00 \mathrm{E}+00$ & $7.23 \mathrm{E}-19$ \\
\hline Thallium & $3.32 \mathrm{E}-12$ & $4.59 \mathrm{E}-12$ & $0.00 \mathrm{E}+00$ & $7.91 \mathrm{E}-12$ \\
\hline
\end{tabular}




\section{Appendix F}

\section{Risk Characterization Calculations}


Table F-1. Excess cancer risk (per chemical) for subsistence farmer from indirect exposure.

\begin{tabular}{|c|c|c|c|}
\hline \multicolumn{4}{|c|}{ Equation } \\
\hline \multicolumn{4}{|c|}{ Cancer Risk $_{i}=\frac{I * E D * E F * C S F}{B W * A T * 365}$} \\
\hline Parameter & \multicolumn{2}{|c|}{ Definition } & Value \\
\hline Cancer Risk $_{\mathrm{i}}$ & \multicolumn{2}{|c|}{ Individual lifetime cancer risk from chemical i (unitless) } & (Table F-31) \\
\hline I & \multicolumn{2}{|c|}{ Total daily intake of chemical (mg/day) } & Calculated (Appendix C) \\
\hline $\mathrm{ED}$ & \multicolumn{2}{|c|}{ Exposure duration (year) } & 40 \\
\hline $\mathrm{EF}$ & \multicolumn{2}{|c|}{ Exposure frequency (day/year) } & 350 \\
\hline $\mathrm{CSF}$ & \multicolumn{2}{|c|}{ Oral cancer slope factor (per mg/kg-day) } & $\begin{array}{l}\text { Chemical-specific } \\
\text { (Appendix B) }\end{array}$ \\
\hline $\mathrm{BW}$ & \multicolumn{2}{|l|}{ Body weight $(\mathrm{kg})$} & 70 \\
\hline AT & \multicolumn{2}{|c|}{ Averaging time (year) } & 70 \\
\hline 365 & \multicolumn{2}{|c|}{ Unit conversion factor (day/year) } & \\
\hline \multicolumn{4}{|c|}{ Chemicals } \\
\hline \multicolumn{2}{|c|}{$\begin{array}{l}\text { Arsenic } \\
\text { Beryllium } \\
\text { Benzo(a)pyrene toxicity equivalents } \\
\text { Bis (2-ethylhexyl) phthalate } \\
\text { Hexachlorobenzene }\end{array}$} & \multicolumn{2}{|c|}{$\begin{array}{l}\text { Total polychlorinated biphenyls (PCBs) } \\
\text { Pentachloronitrobenzene } \\
\text { Pentachlorophenol } \\
\text { 2,3,7,8-TCDD toxicity equivalents }\end{array}$} \\
\hline
\end{tabular}

Source: EPA, 1994, Guidance for Performing Screening Level Risk Analyses at Combustion Facilities Burning Hazardous Wastes, Draft, U.S. Environmental Protection Agency, Office of Emergency and Remedial Response, December 14. 
Table F-2. Total excess cancer risk for subsistence farmer from indirect exposure.

\begin{tabular}{|c|c|c|c|}
\hline \multicolumn{4}{|c|}{ Equation } \\
\hline \multicolumn{4}{|c|}{ Total Cancer Risk $=\sum_{i}$ Cancer Risk $_{i}$} \\
\hline Parameter & \multicolumn{2}{|c|}{ Definition } & Value \\
\hline $\begin{array}{l}\text { Total Cancer } \\
\text { Risk }\end{array}$ & \multicolumn{2}{|c|}{$\begin{array}{l}\text { Total individual lifetime cancer risk for all chemicals } \\
\text { (unitless) }\end{array}$} & (Table F-31) \\
\hline Cancer Risk $_{\mathbf{i}}$ & \multicolumn{2}{|c|}{$\begin{array}{l}\text { Individual lifetime cancer risk for chemical carcinogen i } \\
\text { (unitless) }\end{array}$} & Calculated (Table F-31) \\
\hline \multicolumn{4}{|c|}{ Chemicals } \\
\hline \multicolumn{2}{|c|}{$\begin{array}{l}\text { Arsenic } \\
\text { Beryllium } \\
\text { Benzo(a)pyrene toxicity equivalents } \\
\text { Bis (2-ethylhexyl) phthalate } \\
\text { Hexachlorobenzene }\end{array}$} & \multicolumn{2}{|c|}{$\begin{array}{l}\text { Total polychlorinated biphenyls (PCBs) } \\
\text { Pentachloronitrobenzene } \\
\text { Pentachlorophenol } \\
\text { 2,3,7,8-TCDD toxicity equivalents }\end{array}$} \\
\hline
\end{tabular}

Table F-3. Excess cancer risk (per chemical) for subsistence farmer from direct exposure.

\begin{tabular}{|c|c|c|}
\hline \multicolumn{3}{|c|}{ Equation } \\
\hline \multicolumn{3}{|c|}{ Cancer Risk(inh $)_{i, j}=A D I(i n h)_{i, j} * C S F(i n h)_{i}$} \\
\hline Parameter & Definition & Value \\
\hline $\begin{array}{l}\text { Cancer } \\
\text { Risk(inh) })_{i, j}\end{array}$ & $\begin{array}{l}\text { Excess lifetime cancer risk via inhalation (unitless) for } \\
\text { chemical i in the subsistence-farmer exposure scenario }\end{array}$ & Table F-34 \\
\hline $\mathrm{ADI}(\mathrm{inh})_{\mathrm{i}, \mathrm{j}}$ & $\begin{array}{l}\text { Average daily intake via inhalation (mg/kg-day) for } \\
\text { chemical i in the subsitence-farmer exposure scenario }\end{array}$ & Appendix C \\
\hline $\operatorname{CSF}(\mathrm{inh})_{\mathrm{i}}$ & $\begin{array}{l}\text { Inhalation carcinogenic slope factor (per } \mathrm{mg} / \mathrm{kg} \text {-day) for } \\
\text { chemical } i\end{array}$ & Appendix B \\
\hline \multicolumn{3}{|c|}{ Description } \\
\hline
\end{tabular}

Source: EPA, 1994, Guidance for Performing Screening Level Risk Analyses at Combustion Facilities Burning Hazardous Wastes, Draft, U.S. Environmental Protection Agency, Office of Emergency and Remedial Response, December 14. 
Table F-4. Total excess cancer risk for subsistence farmer from direct exposure.

\begin{tabular}{|c|c|c|}
\hline \multicolumn{3}{|c|}{ Equation } \\
\hline \multicolumn{3}{|c|}{ Total Cancer Risk(inh $)_{j}=\sum_{i} \operatorname{Cancer} \operatorname{Risk}(\text { inh })_{i, j}$} \\
\hline Parameter & Definition & Value \\
\hline $\begin{array}{l}\text { Total Cancer } \\
\text { Risk(inh) }{ }_{j}\end{array}$ & $\begin{array}{l}\text { Total excess lifetime cancer risk via inhalation (unitless) } \\
\text { for subsistence-farmer exposure scenario }\end{array}$ & Table F-34 \\
\hline $\begin{array}{l}\text { Cancer } \\
\text { Risk(inh) }\end{array}$ & $\begin{array}{l}\text { Excess lifetime cancer risk via inhalation (unitless) for } \\
\text { chemical i in subsistence-farmer exposure scenario }\end{array}$ & Table F-34 \\
\hline \multicolumn{3}{|c|}{ Description } \\
\hline
\end{tabular}

Table F-5. Total excess cancer risk for subsistence farmer.

\begin{tabular}{|c|c|c|}
\hline \multicolumn{3}{|c|}{ Equation } \\
\hline \multicolumn{3}{|c|}{ Total Excess Cancer Risk R $_{j}=$ Total Cancer Risk $(\text { inh })_{j}+$ Total Cancer Risk(oral $)_{j}$} \\
\hline Parameter & Definition & Value \\
\hline $\begin{array}{l}\text { Total Excess } \\
\text { Cancer Risk }_{\mathbf{j}}\end{array}$ & $\begin{array}{l}\text { Excess lifetime cancer risk via all routes (unitless) in the } \\
\text { subsistence-farmer exposure scenario }\end{array}$ & Table F-31 \\
\hline $\begin{array}{l}\text { Total Cancer } \\
\text { Risk(inh) }{ }_{j}\end{array}$ & $\begin{array}{l}\text { Total excess lifetime risk via inhalation (unitless) in the } \\
\text { subsistence-farmer exposure scenario }\end{array}$ & Table F-34 \\
\hline $\begin{array}{l}\text { Total Cancer } \\
\text { Risk(oral) }\end{array}$ & $\begin{array}{l}\text { Total excess lifetime cancer risk via indirect (i.e., oral) } \\
\text { exposures (unitless) in subsistence-farmer exposure } \\
\text { scenario }\end{array}$ & Table F-31 \\
\hline \multicolumn{3}{|c|}{ Description } \\
\hline \multicolumn{3}{|c|}{$\begin{array}{l}\text { To determine the overall carcinogenic risk from all exposure pathways, both the direct (inhalation) and } \\
\text { indirect (oral) exposure pathways, the total cancer risk for the direct pathway is added to the total } \\
\text { cancer risk for the indirect pathway. }\end{array}$} \\
\hline
\end{tabular}

Source: EPA, 1994, Guidance for Performing Screening Level Risk Analyses at Combustion Facilities Burning Hazardous Wastes, Draft, U.S. Environmental Protection Agency, Office of Emergency and Remedial Response, December 14. 
Table F-6. Excess cancer risk (per chemical) for adult resident from indirect exposure.

\begin{tabular}{|c|c|c|c|}
\hline \multicolumn{4}{|c|}{ Equation } \\
\hline \multicolumn{4}{|c|}{ 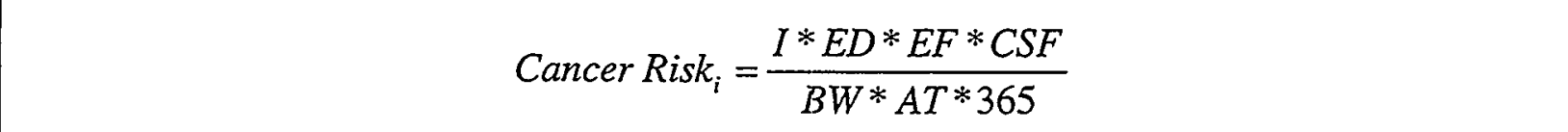 } \\
\hline Parameter & \multicolumn{2}{|c|}{ Definition } & Value \\
\hline Cancer Risk & \multicolumn{2}{|c|}{ Individual lifetime cancer risk from chemical i (unitless) } & Table F-31 \\
\hline I & \multicolumn{2}{|c|}{ Total daily intake of chemical (mg/day) } & Calculated (Appendix D) \\
\hline $\mathrm{ED}$ & \multicolumn{2}{|c|}{ Exposure duration (year) } & 30 \\
\hline $\mathrm{EF}$ & \multicolumn{2}{|c|}{ Exposure frequency (day/year) } & 350 \\
\hline CSF & \multicolumn{2}{|c|}{ Oral cancer slope factor (per mg/kg-day) } & $\begin{array}{l}\text { Chemical-specific } \\
\text { (Appendix B) }\end{array}$ \\
\hline BW & \multicolumn{2}{|l|}{ Body weight $(\mathrm{kg})$} & 70 \\
\hline AT & \multicolumn{2}{|c|}{ Averaging time (year) } & 70 \\
\hline 365 & \multicolumn{2}{|c|}{ Unit conversion factor (day/year) } & \\
\hline \multicolumn{4}{|c|}{ Chemicals } \\
\hline \multicolumn{2}{|c|}{$\begin{array}{l}\text { Arsenic } \\
\text { Beryllium } \\
\text { Benzo(a)pyrene toxicity equivalents } \\
\text { Bis (2-ethylhexyl) phthalate } \\
\text { Hexachlorobenzene }\end{array}$} & \multicolumn{2}{|c|}{$\begin{array}{l}\text { Total polychlorinated biphenyls (PCBs) } \\
\text { Pentachloronitrobenzene } \\
\text { Pentachlorophenol } \\
\text { 2,3,7,8-TCDD toxicity equivalents }\end{array}$} \\
\hline
\end{tabular}

Source: EPA, 1994, Guidance for Performing Screening Level Risk Analyses at Combustion Facilities Burning Hazardous Wastes, Draft, U.S. Environmental Protection Agency, Office of Emergency and Remedial Response, December 14. 
Table F-7. Total excess cancer risk for adult resident from indirect exposure.

\begin{tabular}{|c|c|c|c|}
\hline \multicolumn{4}{|c|}{ Equation } \\
\hline \multicolumn{4}{|c|}{ Total Cancer Risk $=\sum_{i}$ Cancer Risk $_{i}$} \\
\hline Parameter & & & Value \\
\hline $\begin{array}{l}\text { Total Cancer } \\
\text { Risk }\end{array}$ & $\begin{array}{l}\text { Total individual lif } \\
\text { (unitless) }\end{array}$ & sk for all chemicals & Table F-31 \\
\hline Cancer Risk & $\begin{array}{l}\text { Individual lifetime } \\
\text { (unitless) }\end{array}$ & chemical carcinogen $i$ & Calculated (Table F-31) \\
\hline \multicolumn{4}{|c|}{ Chemicals } \\
\hline \multicolumn{2}{|c|}{$\begin{array}{l}\text { Arsenic } \\
\text { Beryllium } \\
\text { Benzo(a)pyrene toxicity equivalents } \\
\text { Bis (2-ethylhexyl) phthalate } \\
\text { Hexachlorobenzene }\end{array}$} & \multicolumn{2}{|c|}{$\begin{array}{l}\text { Total polychlorinated biphenyls (PC } \\
\text { Pentachloronitrobenzene } \\
\text { Pentachlorophenol } \\
\text { 2,3,7,8-TCDD toxicity equivalents }\end{array}$} \\
\hline
\end{tabular}

Table F-8. Excess cancer risk (per chemical) for adult resident from direct exposure.

\begin{tabular}{|c|c|c|}
\hline \multicolumn{3}{|c|}{ Equation } \\
\hline \multicolumn{3}{|c|}{ Cancer Risk(inh $)_{i, j}=A D I(i n h)_{i, j} * C S F(i n h)_{i}$} \\
\hline Parameter & Definition & Value \\
\hline $\begin{array}{l}\text { Cancer } \\
\text { Risk(inh) })_{i, j}\end{array}$ & $\begin{array}{l}\text { Excess lifetime cancer risk via inhalation (unitless) for } \\
\text { chemical i in the adult-resident exposure scenario }\end{array}$ & Table F-34 \\
\hline $\mathrm{ADI}(\mathrm{inh})_{\mathrm{ij}}$ & $\begin{array}{l}\text { Average daily intake via inhalation ( } \mathrm{mg} / \mathrm{kg} \text {-day) for } \\
\text { chemical } \mathrm{i} \text { in the adult-resident exposure scenario }\end{array}$ & Appendix D \\
\hline $\operatorname{CSF}(\mathrm{inh})_{\mathrm{i}}$ & $\begin{array}{l}\text { Inhalation carcinogenic slope factor (per } \mathrm{mg} / \mathrm{kg} \text {-day) for } \\
\text { chemical } i\end{array}$ & Appendix B \\
\hline \multicolumn{3}{|c|}{ Description } \\
\hline
\end{tabular}

Source: EPA, 1994, Guidance for Performing Screening Level Risk Analyses at Combustion Facilities Burning Hazardous Wastes, Draft, U.S. Environmental Protection Agency, Office of Emergency and Remedial Response, December 14. 
Table F-9. Total excess cancer risk for adult resident from direct exposure.

\begin{tabular}{|c|c|c|}
\hline \multicolumn{3}{|c|}{ Equation } \\
\hline \multicolumn{3}{|c|}{ Total Cancer Risk(inh $)_{j}=\sum_{i}$ Cancer Risk(inh $)_{i, j}$} \\
\hline Parameter & Definition & Value \\
\hline $\begin{array}{l}\text { Total Cancer } \\
\text { Risk(inh) })_{j}\end{array}$ & $\begin{array}{l}\text { Total excess lifetime cancer risk via inhalation (unitless) } \\
\text { for adult-resident exposure scenario }\end{array}$ & Table F-34 \\
\hline $\begin{array}{l}\text { Cancer } \\
\text { Risk(inh) })_{i, j}\end{array}$ & $\begin{array}{l}\text { Excess lifetime cancer risk via inhalation (unitless) for } \\
\text { chemical i in adult-resident exposure scenario }\end{array}$ & Table F-34 \\
\hline \multicolumn{3}{|c|}{ Description } \\
\hline $\begin{array}{l}\text { The direct canc } \\
\text { carcinogens vic }\end{array}$ & $\begin{array}{l}\text { k is estimated by summing the lifetime cancer risk for a } \\
\text { inhalation route of exposure. }\end{array}$ & cals that are \\
\hline
\end{tabular}

Table F-10. Total excess cancer risk for adult resident.

\begin{tabular}{|c|c|c|}
\hline \multicolumn{3}{|c|}{ Equation } \\
\hline \multicolumn{3}{|c|}{ Total Excess Cancer Risk R $_{j}=$ Total Cancer Risk(inh) $)_{j}+$ Total Cancer Risk(oral) $)_{j}$} \\
\hline Parameter & Definition & Value \\
\hline $\begin{array}{l}\text { Total Excess } \\
\text { Cancer Risk }\end{array}$ & $\begin{array}{l}\text { Total excess lifetime cancer risk via all routes (unitless) } \\
\text { in the adult-resident exposure scenario }\end{array}$ & Table F-31 \\
\hline $\begin{array}{l}\text { Total Cancer } \\
\text { Risk(inh) }\end{array}$ & $\begin{array}{l}\text { Total excess lifetime cancer risk via inhalation (unitless) } \\
\text { in the adult-resident exposure scenario }\end{array}$ & Table F-34 \\
\hline $\begin{array}{l}\text { Total Cancer } \\
\text { Risk(oral) }\end{array}$ & $\begin{array}{l}\text { Total excess lifetime cancer risk via indirect (i.e., oral) } \\
\text { exposures (unitless) in adult-resident exposure scenario }\end{array}$ & Table F-31 \\
\hline \multicolumn{3}{|c|}{ Description } \\
\hline \multicolumn{3}{|c|}{$\begin{array}{l}\text { To determine the overall carcinogenic risk from all exposure pathways, both the direct (inhalation) and } \\
\text { indirect (oral) exposure pathways, the total cancer risk for the direct pathway is added to the total } \\
\text { cancer risk for the indirect pathway. }\end{array}$} \\
\hline
\end{tabular}

Source: EPA, 1994, Guidance for Performing Screening Level Risk Analyses at Combustion Facilities Burning Hazardous Wastes, Draft, U.S. Environmental Protection Agency, Office of Emergency and Remedial Response, December 14. 
Table F-11. Excess cancer risk (per chemical) for child resident from indirect exposure.

\begin{tabular}{|c|c|c|c|}
\hline \multicolumn{4}{|c|}{ Equation } \\
\hline \multicolumn{4}{|c|}{ Cancer Risk $_{i}=\frac{I * E D * E F * C S F}{B W * A T * 365}$} \\
\hline Parameter & \multicolumn{2}{|c|}{ Definition } & Value \\
\hline Cancer Risk $\mathrm{i}_{\mathrm{i}}$ & \multicolumn{2}{|c|}{ Individual lifetime cancer risk from chemical i (unitless) } & Table F-31 \\
\hline I & \multicolumn{2}{|c|}{ Total daily intake of chemical (mg/day) } & Calculated (Appendix E) \\
\hline ED & \multicolumn{2}{|c|}{ Exposure duration (year) } & 6 \\
\hline $\mathrm{EF}$ & \multicolumn{2}{|c|}{ Exposure frequency (day/year) } & 350 \\
\hline CSF & \multicolumn{2}{|c|}{ Oral cancer slope factor (per mg/kg-day) } & $\begin{array}{l}\text { Chemical-specific } \\
\text { (Appendix B) }\end{array}$ \\
\hline $\mathrm{BW}$ & \multicolumn{2}{|l|}{ Body weight (kg) } & 15 \\
\hline $\mathrm{AT}$ & \multicolumn{2}{|c|}{ Averaging time (year) } & 70 \\
\hline 365 & \multicolumn{2}{|c|}{ Unit conversion factor (day/year) } & \\
\hline \multicolumn{4}{|c|}{ Chemicals } \\
\hline \multicolumn{2}{|c|}{$\begin{array}{l}\text { Arsenic } \\
\text { Beryllium } \\
\text { Benzo(a)pyrene toxicity equivalents } \\
\text { Bis (2-ethylhexyl) phthalate } \\
\text { Hexachlorobenzene }\end{array}$} & \multicolumn{2}{|c|}{$\begin{array}{l}\text { Total polychlorinated biphenyls (PCBs) } \\
\text { Pentachloronitrobenzene } \\
\text { Pentachlorophenol } \\
\text { 2,3,7,8-TCDD toxicity equivalents }\end{array}$} \\
\hline
\end{tabular}

Source: EPA, 1994, Guidance for Performing Screening Level Risk Analyses at Combustion Facilities Burning Hazardous Wastes, Draft, U.S. Environmental Protection Agency, Office of Emergency and Remedial Response, December 14. 
Table F-12. Total excess cancer risk for child resident from indirect exposure.

\begin{tabular}{|c|c|c|c|}
\hline \multicolumn{4}{|c|}{ Equation } \\
\hline \multicolumn{4}{|c|}{ Total Cancer Risk $=\sum_{i}$ Cancer Risk $_{i}$} \\
\hline Parameter & \multicolumn{2}{|c|}{ Definition } & Value \\
\hline $\begin{array}{l}\text { Total Cancer } \\
\text { Risk }\end{array}$ & \multicolumn{2}{|c|}{$\begin{array}{l}\text { Total individual lifetime cancer risk for all chemicals } \\
\text { (unitless) }\end{array}$} & Table F-31 \\
\hline Cancer Risk R $_{\mathrm{i}}$ & \multicolumn{2}{|c|}{$\begin{array}{l}\text { Individual lifetime cancer risk for chemical carcinogen i } \\
\text { (unitless) }\end{array}$} & Calculated (Table F-31) \\
\hline \multicolumn{4}{|c|}{ Chemicals } \\
\hline $\begin{array}{r}\text { Benzo( } \\
\text { Bis } \\
\end{array}$ & $\begin{array}{l}\text { Arsenic } \\
\text { Beryllium } \\
\text { yrene toxicity equivalents } \\
\text {-ethylhexyl) phthalate } \\
\text { exachlorobenzene }\end{array}$ & \multicolumn{2}{|c|}{$\begin{array}{l}\text { Total polychlorinated biphenyls (PCBs) } \\
\text { Pentachloronitrobenzene } \\
\text { Pentachlorophenol } \\
\text { 2,3,7,8-TCDD toxicity equivalents }\end{array}$} \\
\hline
\end{tabular}

Table F-13. Excess cancer risk (per chemical) for child resident from direct exposure.

\begin{tabular}{|c|c|c|}
\hline \multicolumn{3}{|c|}{ Equation } \\
\hline \multicolumn{3}{|c|}{ Cancer Risk(inh $)_{i, j}=A D I(i n h)_{i, j} * C S F(i n h)_{i}$} \\
\hline Parameter & Definition & Value \\
\hline $\begin{array}{l}\text { Cancer } \\
\text { Risk(inh) })_{i, j}\end{array}$ & $\begin{array}{l}\text { Excess lifetime cancer risk via inhalation (unitless) for } \\
\text { chemical i in the child-resident scenario }\end{array}$ & Table F-34 \\
\hline $\operatorname{ADI}(\mathrm{inh})_{\mathrm{i}, \mathrm{j}}$ & $\begin{array}{l}\text { Average daily intake via inhalation ( } \mathrm{mg} / \mathrm{kg} \text {-day) for } \\
\text { chemical i in the child-resident exposure scenario }\end{array}$ & Appendix E \\
\hline $\mathrm{CSF}(\mathrm{inh})_{\mathrm{i}}$ & $\begin{array}{l}\text { Inhalation carcinogenic slope factor (per } \mathrm{mg} / \mathrm{kg} \text {-day) for } \\
\text { chemical } i\end{array}$ & Appendix B \\
\hline \multicolumn{3}{|c|}{ Description } \\
\hline
\end{tabular}

Source: EPA, 1994, Guidance for Performing Screening Level Risk Analyses at Combustion Facilities Burning Hazardous Wastes, Draft, U.S. Environmental Protection Agency, Office of Emergency and Remedial Response, December 14. 
Table F-14. Total excess cancer risk for child resident from direct exposure.

\begin{tabular}{|c|c|c|}
\hline \multicolumn{3}{|c|}{ Equation } \\
\hline \multicolumn{3}{|c|}{ Total Cancer Risk(inh $)_{j}=\sum_{i} \operatorname{Cancer} \operatorname{Risk}(\text { inh })_{i, j}$} \\
\hline Parameter & Definition & Value \\
\hline $\begin{array}{l}\text { Total Cancer } \\
\text { Risk(inh) } \\
\end{array}$ & $\begin{array}{l}\text { Total excess lifetime cancer risk via inhalation (unitless) } \\
\text { for child-resident exposure scenario }\end{array}$ & Table F-34 \\
\hline $\begin{array}{l}\text { Cancer } \\
\text { Risk(inh) })_{i, j}\end{array}$ & $\begin{array}{l}\text { Excess lifetime cancer risk via inhalation (unitless) for } \\
\text { chemical i in child-resident exposure scenario }\end{array}$ & Table F-34 \\
\hline \multicolumn{3}{|c|}{ Description } \\
\hline $\begin{array}{l}\text { The total exce } \\
\text { all carcinoger }\end{array}$ & $\begin{array}{l}\text { cer risk from direct exposure is estimated by summing } \\
\text { he inhalation route of exposure. }\end{array}$ & cancer $r i$ \\
\hline
\end{tabular}

Table F-15. Total excess cancer risk for child resident.

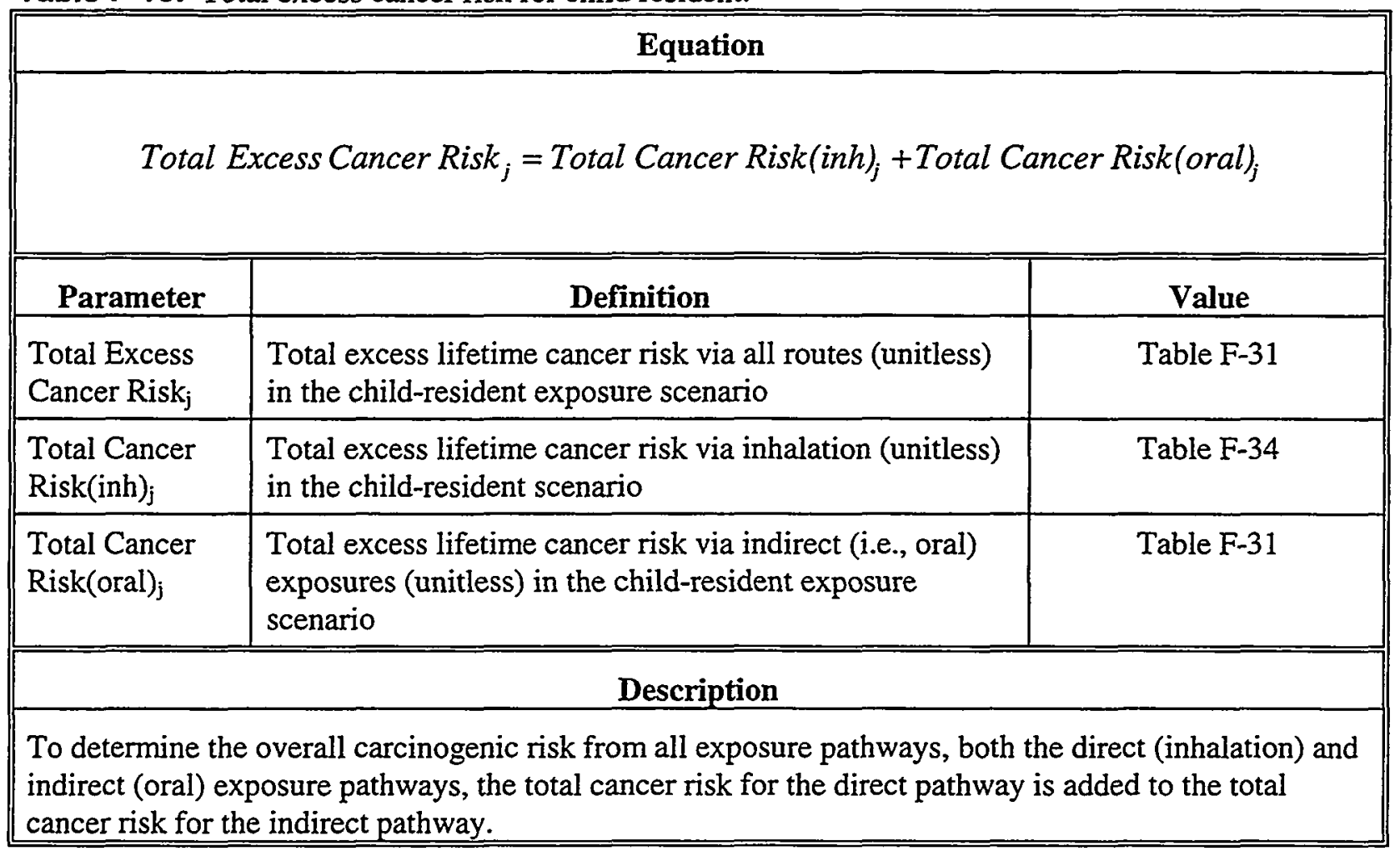

Source: EPA, 1994, Guidance for Performing Screening Level Risk Analyses at Combustion Facilities Burning Hazardous Wastes, Draft, U.S. Environmental Protection Agency, Office of Emergency and Remedial Response, December 14. 
Table F-16. Hazard quotient for individual chemicals for subsistence farmer from noncarcinogens (indirect exposure).

\begin{tabular}{|c|c|c|c|}
\hline \multicolumn{4}{|c|}{ Equation } \\
\hline \multicolumn{4}{|c|}{$H Q=\frac{I}{B W * R f D}$} \\
\hline Parameter & \multicolumn{2}{|c|}{ Definition } & Value \\
\hline $\mathrm{HQ}$ & \multicolumn{2}{|c|}{ Hazard quotient (unitless) } & Table F-32 \\
\hline I & \multicolumn{2}{|c|}{ Total daily intake of chemical (mg/day) } & Calculated (Appendix C) \\
\hline $\mathrm{BW}$ & \multicolumn{2}{|c|}{ Body weight $(\mathrm{kg})$} & 70 \\
\hline RfD & \multicolumn{2}{|c|}{ Reference dose (mg/kg-day) } & $\begin{array}{c}\text { Chemical-specific } \\
\text { (Appendix B) }\end{array}$ \\
\hline \multicolumn{4}{|c|}{ Chemicals } \\
\hline \multicolumn{2}{|c|}{$\begin{array}{l}\text { Arsenic } \\
\text { Beryllium } \\
\text { Bis (2-ethylhexyl) phthalate } \\
\text { 1,3-dinitrobenzene } \\
\text { 2,4-dinitrobenzene } \\
\text { 2,6-dinitrobenzene } \\
\text { Di(n)octyl phthalate } \\
\text { Hexachlorobenzene } \\
\text { Mercury } \\
\text { Nitrobenzene } \\
\end{array}$} & \multicolumn{2}{|c|}{$\begin{array}{l}\text { Pentachloror } \\
\text { Pentachlorol } \\
\text { Antimony } \\
\text { Barium } \\
\text { Cadmium } \\
\text { Chromium } \\
\text { Nickel } \\
\text { Thallium } \\
\text { Silver } \\
\text { Selenium } \\
\end{array}$} \\
\hline
\end{tabular}

Source: EPA, 1994, Guidance for Performing Screening Level Risk Analyses at Combustion Facilities Burning Hazardous Wastes, Draft, U.S. Environmental Protection Agency, Office of Emergency and Remedial Response, December 14. 
Table F-17. Hazard index for liver effects for subsistence farmer from noncarcinogens.

\begin{tabular}{|c|c|c|c|}
\hline \multicolumn{4}{|c|}{ Equation } \\
\hline \multicolumn{4}{|c|}{$H I_{\text {liver }}=\sum_{i} H Q_{i}$} \\
\hline Parameter & \multicolumn{2}{|c|}{ Definition } & Value \\
\hline $\mathrm{HI}_{\text {bver }}$ & \multicolumn{2}{|c|}{ Hazard index for liver effects (unitless) } & Table F-33 \\
\hline $\mathrm{HQ}_{\mathrm{i}}$ & \multicolumn{2}{|c|}{$\begin{array}{l}\text { Hazard quotient for chemical i with liver effects } \\
\text { (unitless) }\end{array}$} & Calculated (Table F-33) \\
\hline \multicolumn{4}{|c|}{ Chemicals } \\
\hline \multicolumn{2}{|c|}{$\begin{array}{l}\text { Bis (2-ethlyhexyl) phthalate } \\
\text { Di(n)octylphthalate }\end{array}$} & \multicolumn{2}{|c|}{$\begin{array}{l}\text { Hexachlorobenzene } \\
\text { Pentachloronitrobenzene } \\
\text { Pentachlorophenol }\end{array}$} \\
\hline
\end{tabular}

Table F-18. Hazard index for neurotoxic effects for subsistence farmer from noncarcinogens.

\begin{tabular}{|c|c|c|}
\hline \multicolumn{3}{|c|}{ Equation } \\
\hline \multicolumn{3}{|c|}{$H I_{\text {neurotoxic }}=\sum_{i} H Q_{i}$} \\
\hline Parameter & Definition & Value \\
\hline $\mathrm{Hi}_{\text {neurotoxic }}$ & Hazard index for neurotoxic effects (unitless) & Table F-33 \\
\hline $\mathrm{Hq}_{\mathrm{i}}$ & $\begin{array}{l}\text { Hazard quotient for chemical i with neurotoxic effects } \\
\text { (unitless) }\end{array}$ & Calculated (Table F-33) \\
\hline \multicolumn{3}{|c|}{ Chemicals } \\
\hline \multicolumn{3}{|c|}{$\begin{array}{l}\text { 2,4-dinitrotoluene } \\
\text { 2,6-dinitrotoluene } \\
\text { Mercury }\end{array}$} \\
\hline
\end{tabular}

Source: EPA, 1994, Guidance for Performing Screening Level Risk Analyses at Combustion Facilities Burning Hazardous Wastes, Draft, U.S. Environmental Protection Agency, Office of Emergency and Remedial Response, December 14. 
Table F-19. Hazard quotient for individual chemicals for subsistence farmer from noncarcinogens (direct exposure).

\begin{tabular}{|c|c|c|}
\hline \multicolumn{3}{|c|}{ Equation } \\
\hline \multicolumn{3}{|c|}{$H Q(\text { inh })_{i, j}=\frac{C(\text { air })_{i, j} * 0.001}{R F C_{i}}$} \\
\hline Parameter & Definition & Value \\
\hline $\mathrm{HQ}(\mathrm{inh})_{\mathbf{i j}}$ & $\begin{array}{l}\text { Hazard quotient via inhalation (unitless) for chemical } i \text { in } \\
\text { the subsistence-farmer exposure scenario }\end{array}$ & Table F-35 \\
\hline $\mathrm{C}(\text { air })_{\mathrm{ij}}$ & $\begin{array}{l}\text { Concentration in air }\left(\mu \mathrm{g} / \mathrm{m}^{3} \text {, from ISC3) for chemical i in }\right. \\
\text { the subsistence-farmer exposure scenario }\end{array}$ & Appendix A \\
\hline $\mathrm{RFC}_{\mathrm{i}}$ & Reference concentration $\left(\mathrm{mg} / \mathrm{m}^{3}\right)$ for chemical $\mathrm{i}$ & Appendix B \\
\hline 0.001 & Units conversion factor $(\mathrm{mg} / \mu \mathrm{g})$ & \\
\hline \multicolumn{3}{|c|}{ Description } \\
\hline
\end{tabular}

Table F-20. Hazard index for subsistence farmer from noncarcinogens

\begin{tabular}{|c|c|c|}
\hline \multicolumn{3}{|c|}{ Equation } \\
\hline \multicolumn{3}{|c|}{$H I(i n h)_{j, k}=\sum_{i} H Q(i n h) i, j, k$} \\
\hline Parameter & Definition & Value \\
\hline $\mathrm{HI}(\mathrm{inh})_{\mathrm{j}, \mathrm{k}}$ & $\begin{array}{l}\text { Hazard index via inhalation (unitless) for target organ } \mathrm{k} \\
\text { in the subsistence-farmer exposure scenario }\end{array}$ & Table F-35 \\
\hline $\mathrm{HQ}(\mathrm{inh})_{\mathrm{i}, \mathrm{j}, \mathrm{k}}$ & $\begin{array}{l}\text { Hazard quotient via inhalation (unitless) for target organ } \\
\mathrm{k} \text { for chemical in the subsistence-farmer exposure } \\
\text { scenario }\end{array}$ & Table F-35 \\
\hline \multicolumn{3}{|c|}{ Description } \\
\hline \multicolumn{3}{|c|}{$\begin{array}{l}\text { For the screening analysis, hazard quotients for inhalation exposures to chemicals that affect the same } \\
\text { target organ are added together to obtain a hazard index for the target organ. The hazard quotients } \\
\text { affecting the same organ are summed to obtain the hazard index for each exposure scenario. }\end{array}$} \\
\hline
\end{tabular}

Source: EPA, 1994, Guidance for Performing Screening Level Risk Analyses at Combustion Facilities Burning Hazardous Wastes, Draft, U.S. Environmental Protection Agency, Office of Emergency and Remedial Response, December 14. 
Table F-21. Hazard quotient for individual chemicals for adult resident from noncarcinogens (indirect exposure).

\begin{tabular}{|c|c|c|c|}
\hline \multicolumn{4}{|c|}{ Equation } \\
\hline \multicolumn{4}{|c|}{$H Q=\frac{I}{B W^{*} R f D}$} \\
\hline Parameter & \multicolumn{2}{|c|}{ Definition } & Value \\
\hline $\mathrm{HQ}$ & \multicolumn{2}{|c|}{ Hazard quotient (unitless) } & Table F-32 \\
\hline I & \multicolumn{2}{|c|}{ Total daily intake of chemical (mg/day) } & Calculated (Appendix D) \\
\hline BW & \multicolumn{2}{|c|}{ Body weight (kg) } & 70 \\
\hline RfD & \multicolumn{2}{|c|}{ Reference dose (mg/kg-day) } & $\begin{array}{l}\text { Chemical-specific } \\
\text { (Appendix B) }\end{array}$ \\
\hline \multicolumn{4}{|c|}{ Chemicals } \\
\hline \multicolumn{2}{|c|}{$\begin{array}{l}\text { Arsenic } \\
\text { Beryllium } \\
\text { Bis (2-ethylhexyl) phthalate } \\
\text { 1,3-dinitrobenzene } \\
\text { 2,4-dinitrobenzene } \\
\text { 2,6-dinitrobenzene } \\
\text { Di(n)octyl phthalate } \\
\text { Hexachlorobenzene } \\
\text { Mercury } \\
\text { Nitrobenzene } \\
\end{array}$} & \multicolumn{2}{|c|}{$\begin{array}{l}\text { Pentachloro } \\
\text { Pentachloro } \\
\text { Antimony } \\
\text { Barium } \\
\text { Cadmium } \\
\text { Chromium } \\
\text { Nickel } \\
\text { Thallium } \\
\text { Silver } \\
\text { Selenium }\end{array}$} \\
\hline
\end{tabular}

Source: EPA, 1994, Guidance for Performing Screening Level Risk Analyses at Combustion Facilities Burning Hazardous Wastes, Draft, U.S. Environmental Protection Agency, Office of Emergency and Remedial Response, December 14. 
Table F-22. Hazard index for liver effects for adult resident from noncarcinogens.

\begin{tabular}{|c|c|c|c|}
\hline \multicolumn{4}{|c|}{ Equation } \\
\hline \multicolumn{4}{|c|}{$H I_{\text {liver }}=\sum_{i} H Q_{i}$} \\
\hline Parameter & \multicolumn{2}{|c|}{ Definition } & Value \\
\hline $\mathrm{HI}_{\text {liver }}$ & \multicolumn{2}{|c|}{ Hazard index for liver effects (unitless) } & Table F-33 \\
\hline $\mathrm{HQ}_{\mathrm{i}}$ & \multicolumn{2}{|c|}{$\begin{array}{l}\text { Hazard quotient for chemical i with liver effects } \\
\text { (unitless) }\end{array}$} & Calculated (Table F-33) \\
\hline \multicolumn{4}{|c|}{ Chemicals } \\
\hline \multicolumn{2}{|c|}{$\begin{array}{l}\text { Bis (2-ethlyhexyl) phthalate } \\
\text { Di(n)octylphthalate }\end{array}$} & \multicolumn{2}{|c|}{$\begin{array}{l}\text { Hexachlorobenzene } \\
\text { Pentachloronitrobenzene } \\
\text { Pentachlorophenol }\end{array}$} \\
\hline
\end{tabular}

Table F-23. Hazard index for neurotoxic effects for adult-resident from noncarcinogens.

\begin{tabular}{|c|c|c|}
\hline \multicolumn{3}{|c|}{ Equation } \\
\hline \multicolumn{3}{|c|}{$H I_{\text {neurotoxic }}=\sum_{i} H Q_{i}$} \\
\hline Parameter & Definition & Value \\
\hline $\mathrm{HI}_{\text {neurotoxic }}$ & Hazard index for neurotoxic effects (unitless) & (Table F-33) \\
\hline $\mathrm{HQ}_{\mathrm{i}}$ & $\begin{array}{l}\text { Hazard quotient for chemical i with neurotoxic effects } \\
\text { (unitless) }\end{array}$ & Calculated (Table F-33) \\
\hline \multicolumn{3}{|c|}{ Chemicals } \\
\hline $\begin{array}{l}\text { 2,4-dinitrotolu } \\
\text { 2,6-dinitrotolu } \\
\text { Mercury }\end{array}$ & & \\
\hline
\end{tabular}

Source: EPA, 1994, Guidance for Performing Screening Level Risk Analyses at Combustion Facilities Burning Hazardous Wastes, Draft, U.S. Environmental Protection Agency, Office of Emergency and Remedial Response, December 14. 
Table F-24. Hazard quotient for adult resident from noncarcinogens (direct exposure).

\begin{tabular}{|c|c|c|}
\hline \multicolumn{3}{|c|}{ Equation } \\
\hline \multicolumn{3}{|c|}{$H Q(\text { inh })_{i, j}=\frac{C(\text { air })_{i, j} * 0.001}{R F C_{i}}$} \\
\hline Parameter & Definition & Value \\
\hline $\mathrm{HQ}(\mathrm{inh})_{\mathrm{i}, \mathrm{j}}$ & $\begin{array}{l}\text { Hazard quotient via inhalation (unitless) for chemical i in } \\
\text { the adult resident exposure scenario }\end{array}$ & (Table F-35) \\
\hline $\mathrm{C}(\text { air })_{\mathrm{i}, \mathrm{j}}$ & $\begin{array}{l}\text { Concentration in air }\left(\mu \mathrm{g} / \mathrm{m}^{3} \text {, from ISC3) for chemical i in }\right. \\
\text { the adult resident exposure scenario }\end{array}$ & (Appendix A) \\
\hline $\mathrm{RFC}_{\mathrm{i}}$ & Reference concentration $\left(\mathrm{mg} / \mathrm{m}^{3}\right)$ for chemical $\mathrm{i}$ & (Appendix B) \\
\hline 0.001 & Units conversion factor $(\mathrm{mg} / \mu \mathrm{g})$ & \\
\hline \multicolumn{3}{|c|}{ Description } \\
\hline
\end{tabular}

Table F-25. Hazard index for adult resident from noncarcinogens.

\begin{tabular}{||c|l|c||}
\hline \multicolumn{2}{|c||}{ Equation } \\
\hline \multicolumn{1}{|c||}{$H I(i n h)_{j, k}=\sum_{i} H Q(i n h)_{i, j, k}$} \\
\hline \hline Parameter & \multicolumn{1}{|c||}{ Definition } & Value \\
\hline$H I(\text { inh })_{j, k}$ & $\begin{array}{l}\text { Hazard index via inhalation (unitless) for target organ } \mathrm{k} \\
\text { in the adult-resident exposure scenario }\end{array}$ & Table F-35 \\
\hline $\mathrm{HQ}(\mathrm{inh})_{\mathrm{i}, \mathrm{j}, \mathrm{k}}$ & $\begin{array}{l}\text { Hazard quotient via inhalation (unitless) for target organ } \\
\mathrm{k} \text { for chemical in the adult-resident exposure scenario }\end{array}$ & Table F-35 \\
\hline \hline & \multicolumn{1}{|c||}{ Description } \\
\hline $\begin{array}{l}\text { For the screening analysis, the hazard quotients for inhalation exposures to chemicals that affect the } \\
\text { same target organ are added together to obtain a hazard index for the target organ. The hazard quotients } \\
\text { affecting the same organ are summed to obtain the hazard index for each exposure scenario. }\end{array}$
\end{tabular}

Source: EPA, 1994, Guidance for Performing Screening Level Risk Analyses at Combustion Facilities Burning Hazardous Wastes, Draft, U.S. Environmental Protection Agency, Office of Emergency and Remedial Response, December 14. 
Table F-26. Hazard quotient for child resident from noncarcinogens (indirect exposure)

\begin{tabular}{|c|c|c|c|}
\hline \multicolumn{4}{|c|}{ Equation } \\
\hline \multicolumn{4}{|c|}{$H Q=\frac{I}{B W^{*} * R f D}$} \\
\hline Parameter & \multicolumn{2}{|c|}{ Definition } & Value \\
\hline HQ & \multicolumn{2}{|c|}{ Hazard quotient (unitless) } & (Table F-32) \\
\hline I & \multicolumn{2}{|c|}{ Total daily intake of chemical (mg/day) } & Calculated \\
\hline $\mathrm{BW}$ & \multicolumn{2}{|c|}{ Body weight (kg) } & 15 \\
\hline $\operatorname{RfD}$ & \multicolumn{2}{|c|}{ Reference dose (mg/kg-day) } & $\begin{array}{c}\text { Chemical-specific } \\
\text { (Appendix B) }\end{array}$ \\
\hline \multicolumn{4}{|c|}{ Chemicals } \\
\hline \multicolumn{2}{|c|}{$\begin{array}{l}\text { Arsenic } \\
\text { Beryllium } \\
\text { Bis (2-ethylhexyl) phthalate } \\
\text { 1,3-dinitrobenzene } \\
\text { 2,4-dinitrobenzene } \\
\text { 2,6-dinitrobenzene } \\
\text { Di(n)octyl phthalate } \\
\text { Hexachlorobenzene } \\
\text { Mercury } \\
\text { Nitrobenzene } \\
\end{array}$} & \multicolumn{2}{|c|}{$\begin{array}{l}\text { Pentachloror } \\
\text { Pentachlorol } \\
\text { Antimony } \\
\text { Barium } \\
\text { Cadmium } \\
\text { Chromium } \\
\text { Nickel } \\
\text { Thallium } \\
\text { Silver } \\
\text { Selenium } \\
\end{array}$} \\
\hline
\end{tabular}

Source: EPA, 1994, Guidance for Performing Screening Level Risk Analyses at Combustion Facilities Burning Hazardous Wastes, Draft, U.S. Environmental Protection Agency, Office of Emergency and Remedial Response, December 14. 
Table F-27. Hazard index for liver effects for child resident from noncarcinogens.

\begin{tabular}{|c|c|c|c|}
\hline \multicolumn{4}{|c|}{ Equation } \\
\hline \multicolumn{4}{|c|}{$H I_{\text {liver }}=\sum_{i} H Q_{i}$} \\
\hline Parameter & \multicolumn{2}{|c|}{ Definition } & Value \\
\hline $\mathrm{HI}_{\text {liver }}$ & \multicolumn{2}{|c|}{ Hazard index for liver effects (unitless) } & (Table F-33) \\
\hline $\mathrm{HQ}_{\mathrm{i}}$ & \multicolumn{2}{|c|}{$\begin{array}{l}\text { Hazard quotient for chemical i with liver effects } \\
\text { (unitless) }\end{array}$} & Calculated (Table F-33) \\
\hline \multicolumn{4}{|c|}{ Chemicals } \\
\hline \multicolumn{2}{|c|}{$\begin{array}{l}\text { Bis (2-ethlyhexyl) phthalate } \\
\text { Di(n)octylphthalate }\end{array}$} & \multicolumn{2}{|c|}{$\begin{array}{l}\text { Hexachlorobenzene } \\
\text { Pentachloronitrobenzene } \\
\text { Pentachlorophenol }\end{array}$} \\
\hline
\end{tabular}

Table F-28. Hazard index for neurotoxic effects for child resident from noncarcinogens.

\begin{tabular}{|c|c|c|}
\hline \multicolumn{3}{|c|}{ Equation } \\
\hline \multicolumn{3}{|c|}{$H I_{\text {neurotoxic }}=\sum_{i} H Q_{i}$} \\
\hline Parameter & Definition & Value \\
\hline $\mathrm{HI}_{\text {neurotoxic }}$ & Hazard index for neurotoxic effects (unitless) & Table F-33 \\
\hline $\mathrm{HQ}_{\mathrm{i}}$ & $\begin{array}{l}\text { Hazard quotient for chemical i with neurotoxic effects } \\
\text { (unitless) }\end{array}$ & Table F-33 \\
\hline \multicolumn{3}{|c|}{ Chemicals } \\
\hline \multicolumn{3}{|c|}{$\begin{array}{l}\text { 2,4-dinitrotoluene } \\
\text { 2,6-dinitrotoluene } \\
\text { Mercury }\end{array}$} \\
\hline
\end{tabular}

Source: EPA, 1994, Guidance for Performing Screening Level Risk Analyses at Combustion Facilities Burning Hazardous Wastes, Draft, U.S. Environmental Protection Agency, Office of Emergency and Remedial Response, December 14. 
Table F-29. Hazard quotient for child resident from noncarcinogens (direct exposure).

\begin{tabular}{|c|c|c|}
\hline \multicolumn{3}{|c|}{ Equation } \\
\hline \multicolumn{3}{|c|}{$H Q(\text { inh })_{i, j}=\frac{C(\text { air })_{i, j} * 0.001}{R F C_{i}}$} \\
\hline Parameter & Definition & Value \\
\hline $\mathrm{HQ}(\mathrm{inh})_{\mathrm{ij}}$ & $\begin{array}{l}\text { Hazard quotient via inhalation (unitless) for chemical i in } \\
\text { the child resident exposure scenario }\end{array}$ & Table F-35 \\
\hline$C(\text { air })_{i j}$ & $\begin{array}{l}\text { Concentration in air }\left(\mu \mathrm{g} / \mathrm{m}^{3} \text {, from ISC3) for chemical } \mathrm{i} \text { in }\right. \\
\text { the child resident exposure scenario }\end{array}$ & Appendix A \\
\hline $\mathrm{RFC}_{\mathbf{i}}$ & Reference concentration $\left(\mathrm{mg} / \mathrm{m}^{3}\right)$ for chemical i & Appendix B \\
\hline 0.001 & Units conversion factor $(\mathrm{mg} / \mu \mathrm{g})$ & \\
\hline \multicolumn{3}{|c|}{ Description } \\
\hline
\end{tabular}

Table F-30. Hazard index for child resident from noncarcinogens.

\begin{tabular}{|c|c|c|}
\hline \multicolumn{3}{|c|}{ Equation } \\
\hline \multicolumn{3}{|c|}{$H I(i n h)_{j, k}=\sum_{i} H Q(i n h) i, j, k$} \\
\hline Parameter & Definition & Value \\
\hline $\mathrm{HI}(\mathrm{inh})_{\mathrm{j} . \mathrm{k}}$ & $\begin{array}{l}\text { Hazard index via inhalation (unitless) for target organ } \mathrm{k} \\
\text { in the child resident exposure scenario }\end{array}$ & (Table F-36) \\
\hline$H Q(\text { inh })_{i, j, k}$ & $\begin{array}{l}\text { Hazard quotient via inhalation (unitless) for target organ } \\
\mathrm{k} \text { for chemical in the child resident exposure scenario }\end{array}$ & (Table F-36) \\
\hline \multicolumn{3}{|c|}{ Description } \\
\hline \multicolumn{3}{|c|}{$\begin{array}{l}\text { For the screening analysis, the hazard quotients for inhalation exposures to chemicals that affect the } \\
\text { same target organ are added together to obtain a hazard index for target organ. This is done for each } \\
\text { exposure scenario. }\end{array}$} \\
\hline
\end{tabular}

Source: EPA, 1994, Guidance for Performing Screening Level Risk Analyses at Combustion Facilities Burning Hazardous Wastes, Draft, U.S. Environmental Protection Agency, Office of Emergency and Remedial Response, December 14. 
Table F-31. Indirect exposure excess cancer risk.

\begin{tabular}{lccc}
\hline \multicolumn{1}{c}{ Chemical } & $\begin{array}{c}\text { Subsistence-Farmer } \\
\text { Cancer Risk }\end{array}$ & $\begin{array}{c}\text { Adult-Resident } \\
\text { Cancer Risk }\end{array}$ & $\begin{array}{c}\text { Child-Resident } \\
\text { Cancer Risk }\end{array}$ \\
\hline Arsenic & $1 \mathrm{E}-17$ & $8 \mathrm{E}-20$ & $7 \mathrm{E}-20$ \\
Benzo(a)pyrene & $1 \mathrm{E}-08$ & $3 \mathrm{E}-11$ & $7 \mathrm{E}-11$ \\
Beryllium & $3 \mathrm{E}-14$ & $3 \mathrm{E}-15$ & $5 \mathrm{E}-15$ \\
Coplaner PCBs & $9 \mathrm{E}-12$ & $3 \mathrm{E}-13$ & $1 \mathrm{E}-12$ \\
$2,3,7,8-\mathrm{TCDD}$ & $2 \mathrm{E}-08$ & $8 \mathrm{E}-11$ & $4 \mathrm{E}-10$ \\
Pentachloronitrobenzene(PIC) & $1 \mathrm{E}-11$ & $3 \mathrm{E}-12$ & $3 \mathrm{E}-12$ \\
Pentachlorophenol & $3 \mathrm{E}-12$ & $2 \mathrm{E}-13$ & $4 \mathrm{E}-13$ \\
Total indirect cancer risk & $\mathbf{3 E - 0 8}$ & $\mathbf{1 E}-10$ & $\mathbf{5 E}-10$ \\
Total inhalation risk (see Table F-34) & $\mathbf{2 E - 0 7}$ & $\mathbf{2 E - 0 7}$ & $\mathbf{2 E - 0 7}$ \\
Total excess cancer risk & $\mathbf{2 E - 0 7}$ & $\mathbf{2 E - 0 7}$ & $\mathbf{2 E}-07$ \\
\hline
\end{tabular}

Table F-32. Indirect exposure hazard quotients.

\begin{tabular}{lccc}
\hline \multicolumn{1}{c}{ Chemical } & $\begin{array}{c}\text { Subsistence- } \\
\text { Farmer Hazard } \\
\text { Quotient }\end{array}$ & $\begin{array}{c}\text { Adult-Resident } \\
\text { Hazard Quotient }\end{array}$ & $\begin{array}{c}\text { Child-Resident } \\
\text { Hazard Quotient }\end{array}$ \\
\hline Antimony & $6 \mathrm{E}-11$ & $6 \mathrm{E}-12$ & $9 \mathrm{E}-12$ \\
Arsenic & $4 \mathrm{E}-14$ & $4 \mathrm{E}-16$ & $2 \mathrm{E}-15$ \\
Barium & $8 \mathrm{E}-17$ & $2 \mathrm{E}-17$ & $8 \mathrm{E}-17$ \\
Beryllium & $2 \mathrm{E}-12$ & $3 \mathrm{E}-13$ & $3 \mathrm{E}-12$ \\
Cadmium & $2 \mathrm{E}-12$ & $2 \mathrm{E}-14$ & $1 \mathrm{E}-13$ \\
Chromium VI & $1 \mathrm{E}-14$ & $1 \mathrm{E}-15$ & $3 \mathrm{E}-15$ \\
1,3-dinitrobenzene(PIC) & $2 \mathrm{E}-03$ & $7 \mathrm{E}-04$ & $3 \mathrm{E}-03$ \\
2,4-dinitrotoluene(PIC) & $1 \mathrm{E}-04$ & $4 \mathrm{E}-05$ & $2 \mathrm{E}-04$ \\
2,6-dinitrotoluene(PIC) & $2 \mathrm{E}-04$ & $7 \mathrm{E}-05$ & $3 \mathrm{E}-04$ \\
Di(n)octyl phthalate & $1 \mathrm{E}-09$ & $4 \mathrm{E}-10$ & $8 \mathrm{E}-10$ \\
Mercury & $3 \mathrm{E}-04$ & $3 \mathrm{E}-07$ & $4 \mathrm{E}-06$ \\
Nickel & $2 \mathrm{E}-15$ & $5 \mathrm{E}-16$ & $5 \mathrm{E}-15$ \\
Nitrobenzene(PIC) & $9 \mathrm{E}-05$ & $3 \mathrm{E}-05$ & $9 \mathrm{E}-05$ \\
Pentachloronitrobenzene(PIC) & $3 \mathrm{E}-08$ & $8 \mathrm{E}-09$ & $5 \mathrm{E}-08$ \\
Pentachlorophenol & $1 \mathrm{E}-09$ & $2 \mathrm{E}-10$ & $1 \mathrm{E}-09$ \\
Selenium & $2 \mathrm{E}-09$ & $1 \mathrm{E}-11$ & $2 \mathrm{E}-11$ \\
Silver & $5 \mathrm{E}-15$ & $9 \mathrm{E}-18$ & $1 \mathrm{E}-17$ \\
Thallium & $8 \mathrm{E}-08$ & $1 \mathrm{E}-09$ & $7 \mathrm{E}-09$ \\
Total Hazard Index & 0.002 & 0.0007 & 0.003 \\
\hline a. The total hazard index is irrespective of specific toxic effects (i.e., liver or neurotoxin). Also, the total hazard index only \\
includes the nitroaromatic PIC with the highest hazard quotient (1,3-dinitrobenzene).
\end{tabular}


Table F-33. Indirect exposure hazard quotient and hazard index for chemicals with liver or neurotoxin effects.

\begin{tabular}{|c|c|c|c|c|c|c|}
\hline \multirow[b]{2}{*}{ Chemical } & \multicolumn{2}{|c|}{ Subsistence-Farmer HQ } & \multicolumn{2}{|c|}{ Adult-Resident HQ } & \multicolumn{2}{|c|}{ Child-Resident HQ } \\
\hline & Liver & Neurotoxin & Liver & Neurotoxin & Liver & Neurotoxin \\
\hline 2,4-Dinitrotoluene & & $6 \mathrm{E}-08$ & & $2 \mathrm{E}-08$ & & $6 \mathrm{E}-08$ \\
\hline 2,6-Dinitrotoluene(PIC) & & $5 E-03$ & & $2 \mathrm{E}-03$ & & $5 \mathrm{E}-03$ \\
\hline Di(n)octyl phthalate & $1 \mathrm{E}-09$ & & $4 \mathrm{E}-10$ & & $8 \mathrm{E}-10$ & \\
\hline Mercury & & $3 E-04$ & & $3 E-07$ & & $4 \mathrm{E}-06$ \\
\hline $\begin{array}{l}\text { Pentachloronitro- } \\
\text { benzene(PIC) }\end{array}$ & $3 \mathrm{E}-08$ & & $8 E-09$ & & $5 \mathrm{E}-08$ & \\
\hline Pentachlorophenol & $1 \mathrm{E}-09$ & & $2 E-10$ & & $1 E-09$ & \\
\hline Total Hazard Index & 3E-08 & 5E-03 & 9E-09 & 2E-03 & 5E-08 & $5 E-03$ \\
\hline
\end{tabular}

Table F-34. Cancer risk estimates for inhalation route of exposure at the INEEL boundary.

\begin{tabular}{lccc}
\hline & $\begin{array}{r}\text { Air Conc. } \\
\left(\mathrm{ug} / \mathrm{m}^{3}\right)\end{array}$ & URF & $\begin{array}{c}\text { Inhala } \\
\text { Cancer risk }\end{array}$ \\
\hline Aniline & $8.45 \mathrm{E}-06$ & $1.63 \mathrm{E}-06$ & $1 \mathrm{E}-11$ \\
Arsenic & $7.33 \mathrm{E}-14$ & $4.30 \mathrm{E}-03$ & $3 \mathrm{E}-16$ \\
Benzene & $5.21 \mathrm{E}-08$ & $7.80 \mathrm{E}-06$ & $4 \mathrm{E}-13$ \\
Benzo(a)pyrene & $1.04 \mathrm{E}-07$ & $8.86 \mathrm{E}-04$ & $9 \mathrm{E}-11$ \\
Beryllium & $9.94 \mathrm{E}-10$ & $2.40 \mathrm{E}-03$ & $2 \mathrm{E}-12$ \\
Bromoform & $5.21 \mathrm{E}-08$ & $1.10 \mathrm{E}-06$ & $6 \mathrm{E}-14$ \\
Cadmium & $1.55 \mathrm{E}-12$ & $1.80 \mathrm{E}-03$ & $3 \mathrm{E}-15$ \\
Carbon tetrachloride & $5.21 \mathrm{E}-08$ & $1.50 \mathrm{E}-05$ & $8 \mathrm{E}-13$ \\
Chloroform & $5.21 \mathrm{E}-08$ & $2.30 \mathrm{E}-05$ & $1 \mathrm{E}-12$ \\
Chromium & $5.53 \mathrm{E}-13$ & $1.20 \mathrm{E}-02$ & $7 \mathrm{E}-15$ \\
1,2-Dichloroethane & $5.21 \mathrm{E}-08$ & $2.60 \mathrm{E}-05$ & $1 \mathrm{E}-12$ \\
$1,4-$ Dioxane & $3.91 \mathrm{E}-05$ & $3.14 \mathrm{E}-06$ & $1 \mathrm{E}-10$ \\
Formaldehyde & $4.53 \mathrm{E}-08$ & $1.30 \mathrm{E}-05$ & $6 \mathrm{E}-13$ \\
2,3,7,8-TCDD & $6.83 \mathrm{E}-12$ & $3.43 \mathrm{E}+01$ & $2 \mathrm{E}-10$ \\
Hydrazine & $1.77 \mathrm{E}-06$ & $4.90 \mathrm{E}-03$ & $9 \mathrm{E}-09$ \\
(Iso)thiourea & $2.20 \mathrm{E}-07$ & $5.56 \mathrm{E}-04$ & $1 \mathrm{E}-10$ \\
Methylene chloride & $5.21 \mathrm{E}-08$ & $4.70 \mathrm{E}-07$ & $2 \mathrm{E}-14$ \\
Nickel & $5.30 \mathrm{E}-13$ & $2.40 \mathrm{E}-04$ & $1 \mathrm{E}-16$ \\
Pentachloronitrobenzene(PIC) & $2.49 \mathrm{E}-03$ & $7.43 \mathrm{E}-05$ & $2 \mathrm{E}-07$ \\
Pentachlorophenol & $1.04 \mathrm{E}-07$ & $3.43 \mathrm{E}-05$ & $4 \mathrm{E}-12$ \\
Tetrachloroethylene & $5.21 \mathrm{E}-08$ & $3.14 \mathrm{E}-05$ & $2 \mathrm{E}-12$ \\
$1,1,2-$ Trichloroethane & $5.21 \mathrm{E}-08$ & $1.60 \mathrm{E}-05$ & $8 \mathrm{E}-13$ \\
& & & $2 \mathrm{E}-07$ \\
\hline & & &
\end{tabular}


Table F-35. Noncarcinogenic hazard quotient estimates for inhalation exposure at INEEL boundary.

\begin{tabular}{|c|c|c|c|}
\hline & $\begin{array}{l}\text { Air Conc. } \\
\left(\mathrm{ug} / \mathrm{m}^{3}\right)\end{array}$ & $\begin{array}{c}\mathrm{RfC} \\
\left(\mathrm{mg} / \mathrm{m}^{3}\right) \\
\end{array}$ & $\mathrm{HQ}$ \\
\hline Acetonitrile & $5.00 \mathrm{E}-07$ & $5.00 \mathrm{E}-02$ & $1 \mathrm{E}-08$ \\
\hline Aniline & $8.45 \mathrm{E}-06$ & $1.00 \mathrm{E}-03$ & $8 \mathrm{E}-06$ \\
\hline Antimony & $1.86 \mathrm{E}-09$ & $2.50 \mathrm{E}-02$ & $7 \mathrm{E}-11$ \\
\hline Barium & $4.35 \mathrm{E}-14$ & $5.00 \mathrm{E}-04$ & $9 E-14$ \\
\hline Benzene & $5.21 E-08$ & $9.00 \mathrm{E}-03$ & $6 \mathrm{E}-09$ \\
\hline Beryllium & $9.94 \mathrm{E}-10$ & $2.00 \mathrm{E}-05$ & $5 E-08$ \\
\hline Bromoform & $5.21 \mathrm{E}-08$ & $7.00 \mathrm{E}-02$ & $7 \mathrm{E}-10$ \\
\hline Butylbenzylphthalate & $1.04 \mathrm{E}-09$ & $7.00 \mathrm{E}-01$ & $1 \mathrm{E}-12$ \\
\hline Cadmium & $1.55 \mathrm{E}-12$ & $2.00 \mathrm{E}-04$ & $8 \mathrm{E}-12$ \\
\hline Carbon disulfide & $4.14 \mathrm{E}-06$ & $7.30 \mathrm{E}-01$ & $6 \mathrm{E}-09$ \\
\hline Carbon monoxide & $1.90 \mathrm{E}+00$ & $1.00 \mathrm{E}+01$ & $2 \mathrm{E}-04$ \\
\hline Carbon tetrachloride & $5.21 \mathrm{E}-08$ & $2.00 \mathrm{E}-03$ & $3 E-08$ \\
\hline Chlorobenzene & $5.21 \mathrm{E}-08$ & $2.00 \mathrm{E}-02$ & $3 \mathrm{E}-09$ \\
\hline Chloroform & $5.21 \mathrm{E}-08$ & $3.01 E-03$ & $2 \mathrm{E}-08$ \\
\hline Chromium & $5.53 E-13$ & $1.02 \mathrm{E}-04$ & $5 E-12$ \\
\hline Dibutylphthalate & $1.04 \mathrm{E}-09$ & $3.50 \mathrm{E}-01$ & $3 E-12$ \\
\hline 1,2-Dichloroethane & $5.21 \mathrm{E}-08$ & $1.02 \mathrm{E}-02$ & $5 E-09$ \\
\hline Diethylphthalate & $1.34 \mathrm{E}-08$ & $2.80 \mathrm{E}+00$ & $5 E-12$ \\
\hline 1,3-Dinitrobenzene(PIC) & $2.98 \mathrm{E}-02$ & $3.50 \mathrm{E}-04$ & $9 E-02$ \\
\hline 2,4-Dinitrophenol & $8.45 \mathrm{E}-07$ & $7.00 \mathrm{E}-03$ & $1 E-07$ \\
\hline 2,4-Dinitrotoluene & $9.88 \mathrm{E}-07$ & $7.00 \mathrm{E}-03$ & $1 \mathrm{E}-07$ \\
\hline 2,4-Dinitrotoluene(PIC) & $3.23 \mathrm{E}-02$ & $7.00 \mathrm{E}-03$ & $5 \mathrm{E}-03$ \\
\hline 2,6-Dinitrotoluene(PIC) & $3.23 \mathrm{E}-02$ & $3.50 \mathrm{E}-03$ & $9 E-03$ \\
\hline Di(n)octyl phthalate & $1.04 \mathrm{E}-09$ & $7.00 \mathrm{E}-02$ & $1 \mathrm{E}-11$ \\
\hline Ethylene glycol & $6.52 \mathrm{E}-06$ & $7.00 \mathrm{E}+00$ & $9 \mathrm{E}-10$ \\
\hline Formic acid & $2.52 \mathrm{E}-06$ & $7.00 \mathrm{E}+00$ & $4 \mathrm{E}-10$ \\
\hline Hydrogen chloride & $5.61 \mathrm{E}-03$ & $1.99 \mathrm{E}-02$ & $3 E-04$ \\
\hline Hydrogen fluoride & $3.19 E-03$ & $2.60 \mathrm{E}-02$ & $1 \mathrm{E}-04$ \\
\hline Lead & $8.70 E-10$ & $1.50 \mathrm{E}-03$ & $6 \mathrm{E}-10$ \\
\hline Mercury & $9.94 \mathrm{E}-05$ & $3.00 \mathrm{E}-04$ & $3 E-04$ \\
\hline Methyl ethyl ketone & $1.77 \mathrm{E}-06$ & $1.00 E+00$ & $2 \mathrm{E}-09$ \\
\hline Methylene chloride & $5.21 \mathrm{E}-08$ & $3.00 E+00$ & $2 \mathrm{E}-11$ \\
\hline
\end{tabular}


Table F-35. (continued).

\begin{tabular}{|c|c|c|c|}
\hline & $\begin{array}{l}\text { Air Conc. } \\
\left(\mathrm{ug} / \mathrm{m}^{3}\right)\end{array}$ & $\begin{array}{c}\mathrm{RfC} \\
\left(\mathrm{mg} / \mathrm{m}^{3}\right)\end{array}$ & $\mathrm{HQ}$ \\
\hline Naphthalene & $1.04 \mathrm{E}-07$ & $3.01 \mathrm{E}-03$ & $3 E-08$ \\
\hline Nitric acid & 8.64E-01 & $2.50 \mathrm{E}-01$ & $3 E-03$ \\
\hline Nitrobenzene(PIC) & $2.17 \mathrm{E}-02$ & $2.00 \mathrm{E}-03$ & $1 E-02$ \\
\hline Nitrogen dioxide & $3.03 E+00$ & $3.50 E+00$ & $9 E-04$ \\
\hline Pentachloronitrobenzene(PIC) & $2.49 \mathrm{E}-03$ & $1.05 \mathrm{E}-02$ & $2 \mathrm{E}-04$ \\
\hline Pentachlorophenol & $1.04 \mathrm{E}-07$ & $1.05 \mathrm{E}-01$ & 1E-09 \\
\hline Phenol & $1.77 \mathrm{E}-06$ & $2.10 \mathrm{E}+00$ & $8 \mathrm{E}-10$ \\
\hline Pyridine & $1.51 \mathrm{E}-04$ & $3.50 \mathrm{E}-03$ & $4 \mathrm{E}-05$ \\
\hline Selenium & $4.72 E-08$ & $1.00 \mathrm{E}-02$ & $5 E-09$ \\
\hline Silver & $3.54 \mathrm{E}-14$ & $5.00 \mathrm{E}-03$ & $7 \mathrm{E}-15$ \\
\hline Sulfur dioxide & $1.42 \mathrm{E}-02$ & $8.00 \mathrm{E}-02$ & $2 E-04$ \\
\hline Tetrachloroethylene & $5.21 \mathrm{E}-08$ & $2.70 \mathrm{E}-01$ & $2 \mathrm{E}-10$ \\
\hline Thallium & $1.55 \mathrm{E}-08$ & $2.80 \mathrm{E}-04$ & $6 E-08$ \\
\hline Toluene & $5.21 \mathrm{E}-08$ & $4.00 \mathrm{E}-01$ & $1 \mathrm{E}-10$ \\
\hline 1,2,4-Trichlorobenzene & $1.04 \mathrm{E}-07$ & $2.00 \mathrm{E}-01$ & $5 E-10$ \\
\hline 1,1,1-Trichloroethane & $5.21 \mathrm{E}-08$ & $1.02 \mathrm{E}-01$ & $5 E-10$ \\
\hline 1,1,2-Trichloroethane & $5.21 \mathrm{E}-08$ & $1.40 \mathrm{E}-02$ & 4E-09 \\
\hline Trichloroethylene & $5.21 \mathrm{E}-08$ & $2.10 \mathrm{E}-02$ & $2 E-09$ \\
\hline Uranium & $4.91 \mathrm{E}-13$ & $1.00 \mathrm{E}-02$ & $5 E-14$ \\
\hline \multicolumn{2}{|l|}{ Total Hazard Index ${ }^{2}$} & & $\underline{0.09}$ \\
\hline
\end{tabular}


Table F-36. Direct exposure (inhalation) hazard quotient and hazard index for chemicals with liver or neurotoxin effects.

\begin{tabular}{|c|c|c|c|c|c|c|}
\hline \multirow[b]{2}{*}{ Chemical } & \multicolumn{2}{|c|}{$\begin{array}{c}\text { Subsistence-Farmer } \\
\mathrm{HQ}\end{array}$} & \multicolumn{2}{|c|}{$\begin{array}{c}\text { Adult-Resident } \\
\text { HQ } \\
\end{array}$} & \multicolumn{2}{|c|}{$\begin{array}{c}\text { Child-Resident } \\
\text { HQ } \\
\end{array}$} \\
\hline & Liver & Neurotoxin & Liver & Neurotoxin & Liver & Neurotoxin \\
\hline 2,4-Dinitrotoluene & & $1 \mathrm{E}-07$ & & $1 \mathrm{E}-07$ & & $1 \mathrm{E}-07$ \\
\hline 2,4-Dinitrotoluene (PIC) & & $4 \mathrm{E}-03$ & & 4E-03 & & $4 \mathrm{E}-03$ \\
\hline 2,6-Dinitrotoluene (PIC) & & $9 \mathrm{E}-03$ & & $9 \mathrm{E}-03$ & & 9E-03 \\
\hline Di(n)octylphthalate & $1 \mathrm{E}-11$ & & $1 \mathrm{E}-11$ & & $1 \mathrm{E}-11$ & \\
\hline Mercury & & $3 E-04$ & & $3 E-04$ & & $3 E-04$ \\
\hline $\begin{array}{l}\text { Pentachloronitrobenzene } \\
\text { (PIC) }\end{array}$ & 2E-04 & & 2E-04 & & $2 \mathrm{E}-04$ & \\
\hline Pentachlorophenol & $1 \mathrm{E}-09$ & & $1 \mathrm{E}-09$ & & 1E-09 & \\
\hline Total hazard index & 2E-04 & 1E-02 & 2E-04 & 1E-02 & 2E-04 & 1E-02 \\
\hline
\end{tabular}


Table F-37. Acute inhalation exposure to transient travelers on U.S. Highway 20.

\begin{tabular}{|c|c|c|c|c|}
\hline Chemical & $\begin{array}{c}\text { U.S. } 20 \\
\text { Chemical Air } \\
\text { Concentration } \\
\left(\mathrm{ug} / \mathrm{m}^{3}\right) \\
\end{array}$ & $\begin{array}{c}\text { State of ID } \\
\text { AAC/AACC } \\
\text { or EPA } 9 \text { PRG } \\
\left(\mathrm{ug} / \mathrm{m}^{3}\right)\end{array}$ & & $\begin{array}{c}\text { Ratio of air } \\
\text { concentration to } \\
\text { AAC/AACC } \\
\text { or PRG }\end{array}$ \\
\hline Acetonitrile & 3.72E-06 & $3.35 E+03$ & & $1.11 \mathrm{E}-09$ \\
\hline Aniline & $8.69 \mathrm{E}-06$ & $1.40 \mathrm{E}-01$ & & $6.21 \mathrm{E}-05$ \\
\hline Antimony & $1.38 \mathrm{E}-08$ & $2.50 \mathrm{E}+01$ & & $5.54 \mathrm{E}-10$ \\
\hline Arsenic & $7.54 \mathrm{E}-14$ & 2.30E-04 & & $3.28 \mathrm{E}-10$ \\
\hline Barium & $3.23 \mathrm{E}-13$ & $2.50 \mathrm{E}+01$ & & $1.29 \mathrm{E}-14$ \\
\hline Benzene & $5.36 \mathrm{E}-08$ & $1.20 \mathrm{E}-01$ & & $4.47 \mathrm{E}-07$ \\
\hline Benzo(a)pyrene & $1.07 \mathrm{E}-07$ & $3.00 \mathrm{E}-04$ & & $3.58 \mathrm{E}-04$ \\
\hline Beryllium & $1.02 \mathrm{E}-09$ & $4.20 \mathrm{E}-03$ & & $2.43 \mathrm{E}-07$ \\
\hline Bromoform & 3.87E-07 & $2.50 \mathrm{E}+02$ & & $1.55 \mathrm{E}-09$ \\
\hline Butylbenzylphthalate & 7.75E-09 & $7.30 \mathrm{E}+02$ & PRG & $1.06 \mathrm{E}-11$ \\
\hline Cadmium & $1.60 \mathrm{E}-12$ & $5.60 \mathrm{E}-04$ & & $2.85 \mathrm{E}-09$ \\
\hline Carbon disulfide & $3.07 \mathrm{E}-05$ & $1.50 \mathrm{E}+03$ & & $2.05 \mathrm{E}-08$ \\
\hline Carbon monoxide & $1.41 E+01$ & $1.00 \mathrm{E}+04$ & NAAQS & $1.41 \mathrm{E}-03$ \\
\hline Carbon tetrachloride & $5.36 \mathrm{E}-08$ & $6.70 \mathrm{E}-02$ & & $8.00 \mathrm{E}-07$ \\
\hline Chlorobenzene & $3.87 \mathrm{E}-07$ & $1.75 \mathrm{E}+04$ & & $2.21 \mathrm{E}-11$ \\
\hline Chloroform & $5.36 \mathrm{E}-08$ & 4.30E-02 & & $1.25 \mathrm{E}-06$ \\
\hline Chromium & $5.69 \mathrm{E}-13$ & $8.30 \mathrm{E}-05$ & & $6.85 \mathrm{E}-09$ \\
\hline Dibutylphthalate & $7.75 \mathrm{E}-09$ & $2.50 \mathrm{E}+02$ & & $3.10 \mathrm{E}-11$ \\
\hline 1,2-Dichloroethane & $5.36 \mathrm{E}-08$ & $2.00 \mathrm{E}+03$ & & $2.68 \mathrm{E}-11$ \\
\hline Diethylphthalate & $9.92 \mathrm{E}-08$ & $2.50 \mathrm{E}+02$ & & $3.97 \mathrm{E}-10$ \\
\hline 1,3-Dinitrobenzene(PIC) & $2.22 \mathrm{E}-01$ & $5.00 E+01$ & & $4.43 \mathrm{E}-03$ \\
\hline 2,4-Dinitrophenol & $6.28 \mathrm{E}-06$ & $7.30 \mathrm{E}+00$ & PRG & $8.60 \mathrm{E}-07$ \\
\hline 2,4-Dinitrotoluene & $7.34 \mathrm{E}-06$ & $7.30 \mathrm{E}+00$ & PRG & $1.01 \mathrm{E}-06$ \\
\hline 2,4-Dinitrotoluene(PIC) & $2.40 \mathrm{E}-01$ & $7.30 \mathrm{E}+00$ & PRG & $3.29 \mathrm{E}-02$ \\
\hline 2,6-Dinitrotoluene(PIC) & 3.32E-02 & $3.70 \mathrm{E}+00$ & PRG & $8.98 \mathrm{E}-03$ \\
\hline Di(n)octyl phthalate & $7.75 \mathrm{E}-09$ & $7.30 \mathrm{E}+01$ & PRG & $1.06 \mathrm{E}-10$ \\
\hline 1,4-Dioxane & 4.02E-05 & $7.10 \mathrm{E}-01$ & & $5.66 \mathrm{E}-05$ \\
\hline Ethylene glycol & 4.85E-05 & $6.35 \mathrm{E}+03$ & & 7.63E-09 \\
\hline Formaldehyde & $4.66 \mathrm{E}-08$ & $7.70 \mathrm{E}-02$ & & $6.05 \mathrm{E}-07$ \\
\hline Formic acid & $1.87 \mathrm{E}-05$ & $4.70 \mathrm{E}+02$ & & $3.99 \mathrm{E}-08$ \\
\hline
\end{tabular}


Table F-37. (continued).

\begin{tabular}{|c|c|c|c|c|}
\hline Chemical & $\begin{array}{c}\text { U.S. } 20 \\
\text { Chemical Air } \\
\text { Concentration } \\
\left(\mathrm{ug} / \mathrm{m}^{3}\right)\end{array}$ & $\begin{array}{c}\text { State of } \mathrm{D} \\
\text { AAC/AACC } \\
\text { or EPA 9 PRG } \\
\left(\mathrm{ug} / \mathrm{m}^{3}\right)\end{array}$ & & $\begin{array}{l}\text { Ratio of air } \\
\text { concentration to } \\
\text { AAC/AACC } \\
\text { or PRG }\end{array}$ \\
\hline $2,3,7,8-\mathrm{TCDD}$ & $7.03 \mathrm{E}-12$ & 2.20E-08 & & $3.20 \mathrm{E}-04$ \\
\hline Hydrazine & $1.82 \mathrm{E}-06$ & $3.40 \mathrm{E}-04$ & & $5.36 \mathrm{E}-03$ \\
\hline Hydrogen chloride & 4.17E-02 & $3.75 \mathrm{E}+02$ & & $1.11 \mathrm{E}-04$ \\
\hline Hydrogen fluoride & $2.37 \mathrm{E}-02$ & $2.60 \mathrm{E}+01$ & & $9.12 \mathrm{E}-04$ \\
\hline (Iso)thiourea & $1.63 \mathrm{E}-06$ & $1.80 \mathrm{E}-03$ & & $9.08 \mathrm{E}-04$ \\
\hline Lead & $6.46 \mathrm{E}-09$ & $1.50 \mathrm{E}+00$ & NAAQS & 4.31E-09 \\
\hline Mercury & $7.38 \mathrm{E}-04$ & $2.50 \mathrm{E}+00$ & & $2.95 \mathrm{E}-04$ \\
\hline Methyl ethyl ketone & $1.32 \mathrm{E}-05$ & $2.95 E+04$ & & $4.46 \mathrm{E}-10$ \\
\hline Methylene chloride & $5.36 \mathrm{E}-08$ & $2.40 \mathrm{E}-01$ & & 2.23E-07 \\
\hline Naphthalene & $7.75 \mathrm{E}-07$ & $2.50 E+04$ & & $3.10 E-11$ \\
\hline Nickel & $5.45 \mathrm{E}-13$ & $4.20 \mathrm{E}-03$ & & $1.30 \mathrm{E}-10$ \\
\hline Nitric acid & $6.42 E+00$ & $2.50 E+02$ & & $2.57 \mathrm{E}-02$ \\
\hline Nitrobenzene(PIC) & $1.62 \mathrm{E}-01$ & $2.50 \mathrm{E}+02$ & & $6.46 \mathrm{E}-04$ \\
\hline Nitrogen dioxide & $2.25 E+01$ & $1.00 \mathrm{E}+02$ & & $2.25 \mathrm{E}-01$ \\
\hline Pentachloronitrobenzene(PIC) & $1.85 \mathrm{E}-02$ & $2.50 \mathrm{E}+01$ & & $7.38 \mathrm{E}-04$ \\
\hline Pentachlorophenol & 7.75E-07 & $2.50 E+01$ & & $3.10 \mathrm{E}-08$ \\
\hline Phenol & $1.32 \mathrm{E}-05$ & $9.50 \mathrm{E}+02$ & & $1.38 \mathrm{E}-08$ \\
\hline Pyridine & $1.12 E-03$ & $7.50 \mathrm{E}+02$ & & $1.50 \mathrm{E}-06$ \\
\hline Selenium & $3.51 \mathrm{E}-07$ & $1.00 E+01$ & & $3.51 \mathrm{E}-08$ \\
\hline Silver & $2.63 E-13$ & $5.00 E+00$ & & $5.26 \mathrm{E}-14$ \\
\hline Sulfur dioxide & $1.06 \mathrm{E}-01$ & $8.00 \mathrm{E}+01$ & & $1.32 \mathrm{E}-03$ \\
\hline Tetrachloroethylene & $5.36 \mathrm{E}-08$ & $2.10 \mathrm{E}+00$ & & $2.55 \mathrm{E}-08$ \\
\hline Thallium & $1.15 \mathrm{E}-07$ & $5.00 \mathrm{E}+00$ & & $2.31 E-08$ \\
\hline Toluene & $3.87 \mathrm{E}-07$ & $1.88 \mathrm{E}+04$ & & $2.07 \mathrm{E}-11$ \\
\hline 1,2,4-Trichlorobenzene & $7.75 \mathrm{E}-07$ & $1.85 E+03$ & & $4.19 \mathrm{E}-10$ \\
\hline 1,1,1-Trichloroethane & 3.87E-07 & $9.55 \mathrm{E}+04$ & & $4.05 E-12$ \\
\hline 1,1,2-Trichloroethane & $5.36 \mathrm{E}-08$ & $6.20 \mathrm{E}-02$ & & $8.65 \mathrm{E}-07$ \\
\hline Trichloroethylene & $3.87 \mathrm{E}-07$ & $1.35 E+04$ & & $2.88 \mathrm{E}-11$ \\
\hline Uranium & $3.65 \mathrm{E}-12$ & $1.00 \mathrm{E}+01$ & & $3.65 \mathrm{E}-13$ \\
\hline
\end{tabular}


Appendix G

\section{WAG 5 Fauna and Functional Groups}


Table G-1. Faunal functional groups and species potentially present in the NWCF assessment area..

\begin{tabular}{|c|c|c|c|c|c|}
\hline Class & $\begin{array}{c}\text { Functional } \\
\text { Group }\end{array}$ & Taxonomic Name & Common Name & $\begin{array}{c}\text { Distribution } \\
\text { Status }^{2}\end{array}$ & $\begin{array}{l}\text { Abundancel } \\
\text { Sseason/stat }\end{array}$ \\
\hline \multirow[t]{4}{*}{ Aves } & AV121 & Carduelis pinus & Pine siskin & $f, d$ & S5, M3 \\
\hline & & Carduelis tristis & American goldfinch & $\mathrm{d}, \mathrm{ss}$ & M5 \\
\hline & & $\begin{array}{l}\text { Coccothraustes } \\
\text { vespertinus }\end{array}$ & Evening grosbeak & d & S5, M3 \\
\hline & & Bombycilla cedrorum & Cedar waxwing & $f, d$ & S5,M3,W5 \\
\hline \multirow[t]{14}{*}{ Aves } & AV122 & Passer domesticus & House sparrow & $f, d$ & $\mathrm{~B} 2, \mathrm{Ml}, \mathrm{W} 3$ \\
\hline & & Selasphorus rufus & Rufous hummingbird & d & S3, M3 \\
\hline & & Zenaida macroura & Mourning dove & sw & $\mathrm{B} 1, \mathrm{M} 3, \mathrm{~W} 5$ \\
\hline & & Chondestes grammacus & Lark sparrow & sw & S3, M5 \\
\hline & & Plectrophenax nivalis & Snow bunting & g, ss & w5 \\
\hline & & Leucosticte arctoa & Rosy finch & ss & M5, W5 \\
\hline & & Carpodacus mexicanus & House finch & $f, d$ & S3, M3 \\
\hline & & Perdix perdix & Gray partridge & $g, s s, f$ & R3 \\
\hline & & Alectoris chukar & Chukar & $\mathrm{g}, \mathrm{ss}$ & R3 \\
\hline & & Dendragapus obscurus & Blue grouse & f & S6 \\
\hline & & $\begin{array}{l}\text { Centrocercus } \\
\text { urophasianus }\end{array}$ & Sage grouse & $s s, g, f$ & R2 \\
\hline & & Eremophila alpestris & Horned lark & g, ss & $\mathrm{R} 2$ \\
\hline & & Junco hyemalis & Dark-eyed junco & sw & M3 \\
\hline & & Columba livia & Rock dove & sw & $\mathrm{R} 2$ \\
\hline Aves & AV132 & Porzana carolina & Sora & $\mathrm{w}, \mathrm{f}$ & B5, M5 \\
\hline \multirow[t]{11}{*}{ Aves } & AV210 & Contopus borealis & Olive-sided flycatcher & d & S5, M5 \\
\hline & & Empidonax difficilis & Western flycatcher & d & S5 \\
\hline & & Myiarchus cinerascens & Ash-throated flycatcher & d & S5 \\
\hline & & Tyrannus verticalis & Westem kingbird & $f, d, j$ & B3, M3 \\
\hline & & Tyrannus tyrannus & Eastern kingbird & $f, d, j$ & $\mathrm{~B} 3, \mathrm{M} 3$ \\
\hline & & Tachycineta bicolor & Tree swallow & $\mathrm{d}, \mathbf{j}$ & B3, M3 \\
\hline & & Tachycineta thalassina & Violet-green swallow & $\mathrm{d}, \mathbf{j}$ & B4, M4 \\
\hline & & Myadestes townsendi & Townsend's Solitaire & d & S5, M5 \\
\hline & & Chordeiles minor & Common nighthawk & sw & B2, M3 \\
\hline & & Aeronautes saxatalis & White-throated swift & d & S5 \\
\hline & & Sayomis saya & Say's phoebe & $s s, d, f, j$ & B3, M3 \\
\hline \multirow[t]{4}{*}{ Aves } & AV210A & Stelgidopteryx serripennis & Northem rough-winged swallow & $\mathrm{d}, \mathrm{j}$ & B3, M3 \\
\hline & & Riparia riparia & Bank swallow & $d, j$ & $\mathrm{~B} 5, \mathrm{M} 3$ \\
\hline & & Hirundo pyrrhonota & Cliff swallow & $d, j$ & B2, M2 \\
\hline & & Hirundo rustica & Barn swallow & $d, j$ & B2, M3 \\
\hline \multirow[t]{4}{*}{ Aves } & AV221 & Regulus calendula & Ruby-crowned kinglet & d & M3, W6 \\
\hline & & Sialia mexicana & Westem bluebird & ss & S5, M5 \\
\hline & & Bombycilla garrulus & Bohemian waxwing & $f, d$ & S3, M2, W3 \\
\hline & & Vireo gilvus & Warbling vireo & d & S5, M5 \\
\hline
\end{tabular}


Table G-1. (continued).

\begin{tabular}{|c|c|c|c|c|c|}
\hline Class & $\begin{array}{c}\text { Functional } \\
\text { Group }\end{array}$ & Taxonomic Name & Common Name & $\begin{array}{c}\text { Distribution/ } \\
\text { Status }^{\mathrm{a}}\end{array}$ & $\begin{array}{l}\text { Abundance/ } \\
\text { Sseason/stat } \\
\end{array}$ \\
\hline & & Dendroica petechia & Yellow warbler & d & B5, M3 \\
\hline & & Dendroica coronata & Yellow-rumped warbler & d & S3, M3 \\
\hline & & Dendroica townsendi & Townsend's warbler & $d$ & M5 \\
\hline & & Geothlypis trichas & Common yellowthroat & d & S5 \\
\hline & & Wilsonia pusilla & Wilson's warbler & d & S5, M5 \\
\hline & & Icteria virens & Yellow-breasted chat & d & S5 \\
\hline & & Piranga ludoviciana & Western tanager & d & S3, M3 \\
\hline & & $\begin{array}{l}\text { Pheucticus } \\
\text { melanocephalus }\end{array}$ & Black-headed grosbeak & sw & S5, M5 \\
\hline & & Icterus galbula & Northern oriole & d & S3, M3 \\
\hline & & Picoides pubescens & Downy woodpecker & d & B5, M5 \\
\hline & & Colaptes auratus & Northern flicker & d & B3, M3 \\
\hline \multirow[t]{24}{*}{ Aves } & AV222 & Larus pipixcan & Franklin's gull & $\mathrm{w}, \mathrm{ss}$ & S3, M3 \\
\hline & & Larus californicus & California gull & $w, s s$ & S5, M3 \\
\hline & & Sturnus vulgaris & European starling & sw & R3 \\
\hline & & Troglodytes aedon & House wren & d & R3 \\
\hline & & Sialia currucoides & Mountain bluebird & ss & S3, M3 \\
\hline & & Turdus migratorius & American robin & sw & B2, M2 \\
\hline & & Oreoscoptes montanus & Sage thrasher & ss & $\mathrm{B} 2, \mathrm{M} 2$ \\
\hline & & Passerina amoena & Lazuli bunting & d & S5, M5 \\
\hline & & Spizella passerina & Chipping sparrow & $f, d, s s$ & M5 \\
\hline & & Spizella breweri & Brewer's sparrow & ss & B2, M2 \\
\hline & & Amphispiza bilineata & Black-throated sparrow & ss & S5, M5 \\
\hline & & Amphispiza belli & Sage sparrow & ss & B2, M2 \\
\hline & & Passerculus sandwichensis & Savannah sparrow & d, $g$ & S5, M3 \\
\hline & & Zonotrichia leucophrys & White-crowned sparrow & ss & M4 \\
\hline & & Stumella neglecta & Western meadowlark & $g, s s$ & $\mathrm{~B} 2, \mathrm{M} 2, \mathrm{~W} 3$ \\
\hline & & Euphagus cyanocephalus & Brewer's blackbird & sw & B2, M2, W5 \\
\hline & & Molothrus ater & Brown-headed cowbird & ss & B3, M3 \\
\hline & & Charadrius vociferus & Killdeer & sw & B2, M2 \\
\hline & & Anthus spinoletta & Water pipit & ss & M5 \\
\hline & & Pipilo chlorurus & Green-tailed towhee & ss & S3, M3 \\
\hline & & Pipilo erythrophthalmus & Rufous-sided towhee & sw & S3, M3 \\
\hline & & Pooecetes gramineus & Vesper sparrow & g, ss & B3, M3 \\
\hline & & Calamospiza melanocorys & Lark bunting & ss & S5, M5 \\
\hline & & Melospiza melodia & Song sparrow & $d$ & S5, M3 \\
\hline \multirow[t]{2}{*}{ Aves } & AV222A & Salpinctes obsoletus & Rock wren & ss & B3, M3 \\
\hline & & Catherpes mexicanus & Canyon wren & ss & S5, M5 \\
\hline \multirow[t]{2}{*}{ Aves } & AV232 & Agelaius phoeniceus & Red-winged blackbird & $w$, ss & B3, M3 \\
\hline & & Xanthocephalus & Yellow-headed blackbird & $w, d$ & B4, M3 \\
\hline
\end{tabular}


Table G-1. (continued).

\begin{tabular}{|c|c|c|c|c|c|}
\hline Class & $\begin{array}{c}\text { Functional } \\
\text { Group }\end{array}$ & Taxonomic Name & Common Name & $\begin{array}{c}\text { Distribution/ } \\
\text { Status }\end{array}$ & $\begin{array}{l}\text { Abundance/ } \\
\text { Sseason/stat }\end{array}$ \\
\hline & & xanthocephalus & & & \\
\hline \multirow[t]{6}{*}{ Aves } & AV310 & Accipiter striatus & Sharp-shinned hawk & sw & S5, M5, W5 \\
\hline & & Accipiter cooperii & Cooper's hawk & sw & S3, M5, W5 \\
\hline & & Accipiter gentilis & Northern goshawk & sw & S5, M5, W5 \\
\hline & & Falco columbarius & Merlin & sw & R5 \\
\hline & & Falco peregrinus & Peregrine falcon & sw & S5, M5, W5 \\
\hline & & Falco mexicanus & Prairie falcon & sw & R3 \\
\hline \multirow[t]{16}{*}{ Aves } & AV322 & Nyctea scandiaca & Snowy owl & sw & W5 \\
\hline & & Haliaeetus leucocephalus & Bald eagle & sw & M5, W3 \\
\hline & & Falco sparverius & American kestrel & sw & B2, M2, W3 \\
\hline & & Circus cyaneus & Northern harrier & sw & R2 \\
\hline & & Buteo swainsoni & Swainson's hawk & sw & B3, M3, w5 \\
\hline & & Buteo jamaicensis & Red-tailed hawk & sw & B3, M3, W5 \\
\hline & & Buteo regalis & Ferruginous hawk & sw & B3, M3, W5 \\
\hline & & Lanius excubitor & Northern shrike & sw & M3, w5 \\
\hline & & Lanius ludovicianus & Loggerhead shrike & ss & B3 \\
\hline & & Bubo virginianus & Great horned owl & sw & R3 \\
\hline & & Asio otus & Long-eared owl & d & B4, M4 \\
\hline & & Asio flammeus & Short-eared owl & ss, g & B3, M3 \\
\hline & & Aegolius acadicus & Northern saw-whet owl & sw & S6, M6, W6 \\
\hline & & Aquila chrysaetos & Golden eagle & sw & B3, M4, W2 \\
\hline & & Cathartes aura & Turkey vulture & sw & S3, M3, w6 \\
\hline & & Buteo lagopus & Rough-legged hawk & sw & S6, M2, W2 \\
\hline Aves & AV322A & Athene cunicularia & Burrowing owl & ss, g & B3, M3, W6 \\
\hline \multirow[t]{6}{*}{ Aves } & AV422 & Aphelocoma coerulescens & Scrub jay & $U$ & $\mathrm{U}$ \\
\hline & & Pica pica & Black-billed magpie & sw & R2 \\
\hline & & Corvus brachyrhynchos & American crow & sw & R3 \\
\hline & & Phasianus colchicus & Ring-necked pheasant & g, ss & R3 \\
\hline & & Corvus corax & Common raven & sw & R3 \\
\hline & & Larus argentatus & Herring gull & $w, s s, g$ & S3, M3 \\
\hline Aves & AV432 & Larus delawarensis & Ring-billed gull & $w, s s, g$ & S3, M3 \\
\hline Mammalia & $\mathrm{M} 121$ & Erethizon dorsatum & Porcupine & $r, f$ & 14 \\
\hline \multirow[t]{6}{*}{ Mammalia } & M122 & Lepus townsendii & White-tailed jackrabbit & sw, ss & $\mathrm{R} 4$ \\
\hline & & Lepus californicus & Black-tailed jackrabbit & sw, ss & R1,R4 (cyclic) \\
\hline & & $\begin{array}{l}\text { Reithrodontomys } \\
\text { megalotis }\end{array}$ & Western harvest mouse & sw, ss, $g$ & $\mathrm{R} 2$ \\
\hline & & Cervus elaphus & Elk & sw & $\mathrm{R} 4$ \\
\hline & & Odocoileus hemionus & Mule deer & sw, ss, g & $\mathrm{R} 3$ \\
\hline & & Antilocapra americana & Pronghorn & $s w, s s, f$ & $\mathrm{R} 1$ \\
\hline Mammalia & $\mathrm{M} 122 \mathrm{~A}$ & Sylvilagus nuttallii & Nuttall's cottontail & sw, ss, f & $\mathrm{R} 2$ \\
\hline
\end{tabular}


Table G-1. (continued).

\begin{tabular}{|c|c|c|c|c|c|}
\hline Class & $\begin{array}{c}\text { Functional } \\
\text { Group }\end{array}$ & Taxonomic Name & Common Name & $\begin{array}{c}\text { Distribution/ } \\
\text { Status }^{\mathrm{a}}\end{array}$ & $\begin{array}{c}\text { Abundance/ } \\
\text { Sseason/stat } \\
\end{array}$ \\
\hline & & Brachylagus idahoensis & Pygmy rabbit & ss, ro & R2 \\
\hline & & Marmota flaviventris & Yellow-bellied marmot & sw, ro & R3 \\
\hline & & Spermophilus townsendii & Townsend's ground squirrel & $s w, s s, f$ & $\mathrm{R} 2$ \\
\hline & & Perognathus parvus & Great basin pocket mouse & sw, ss & $\mathrm{R} 3$ \\
\hline & & Dipodomys ordii & Ord's kangaroo rat & sw, ss, g & $\mathrm{R} 2$ \\
\hline & & Neotoma cinerea & Bushy-tailed woodrat & sw, ro & R2 \\
\hline & & Microtus montanus & Montane vole & $s w, g, f$ & R1,R4 (cyclic) \\
\hline & & Lagurus curatus & Sagebrush vole & ss & R3 \\
\hline Mammalia & M123 & Thomomys talpoides & Northern pocket gopher & ss & R4 \\
\hline \multirow[t]{2}{*}{ Mammalia } & M210 & Lasiurus cinereus & Hoary bat & $d, j$ & $\mathrm{U} 3$ \\
\hline & & Lasionycteris noctivagans & Silver-haired bat & sw & M4 \\
\hline \multirow[t]{5}{*}{ Mammalia } & M210A & Myotis leibii & Small-footed myotis & sw, ro & $\mathrm{R} 2$ \\
\hline & & Eptesicus fuscus & Big-brown bat & $s w, f, c$ & R3 \\
\hline & $\cdot$ & Plecotus townsendii & Townsend's western big-eared bat & sw, c & R2 \\
\hline & & Myotis lucifugus & Little Brown myotis & sw, f & 12 \\
\hline & & Myotis californicus & Califomia myotis & sw & $\mathrm{U} 2$ \\
\hline \multirow[t]{2}{*}{ Mammalia } & M222 & Sorex merriami & Merriam's shrew & sw, ss & R4 \\
\hline & & Onychomys leucogaster & Northern grasshopper mouse & sw, ss & R4 \\
\hline \multirow[t]{3}{*}{ Mammalia } & M322 & Mustela frenata & Long-tailed weasel & sw, ss & R2 \\
\hline & & Taxidea taxus & Badger & sw & R3 \\
\hline & & Felis rufus & Bobcat & $s w, s s, j$ & R4 \\
\hline \multirow[t]{5}{*}{ Mammalia } & M422 & Tamias minimus & Least chipmunk & sw, ss & $\mathrm{R} 1$ \\
\hline & & Peromyscus maniculatus & Deer mouse & sw & $\mathrm{R} 1$ \\
\hline & & Rattus norvegicus & Norway rat & NW/NE INEEL; ag & R5 (?) \\
\hline & & Mus musculus & House mouse & f & R5 (?) \\
\hline & & Spilogale gracilis & Western spotted skunk & sw, ro & R5 \\
\hline Mammalia & $\mathrm{M} 422 \mathrm{~A}$ & Canis latrans & Coyote & sw & $\mathrm{R} 2$ \\
\hline \multirow[t]{3}{*}{ Reptilia } & R222 & Phrynosoma douglasii & Short-horned lizard & sw, ss & $\mathrm{R} 1$ \\
\hline & & Sceloporus graciosus & Sagebrush lizard & sw, ss & R1 \\
\hline & & Eumeces skiltonianus & Westem skink & South INEEL & R5 \\
\hline \multirow[t]{5}{*}{ Reptilia } & R322 & Masticophis taeniatus & Desert striped whipsnake & NE INEEL, ss & R3 \\
\hline & & Pituophis melanoleucus & Gopher snake & sw, ss & $\mathrm{R} 2$ \\
\hline & & Thamnophis elegans & Western garter snake & sw & $\mathrm{R} 3$ \\
\hline & & Coluber constrictor & Western racer & sw & 15 \\
\hline & & Crotalus viridis & Westem rattlesnake & sw, ss & R2 \\
\hline $\begin{array}{l}\text { w } \\
\text { ss } \\
d \\
\mathrm{j} \\
\mathrm{g}\end{array}$ & $\begin{array}{l}\text { On or near water } \\
\text { Shrub-steppe } \\
\text { Deciduous or ripar } \\
\text { Juniper woodland } \\
\text { Grassland }\end{array}$ & & & & \\
\hline
\end{tabular}


Table G-1. (continued).

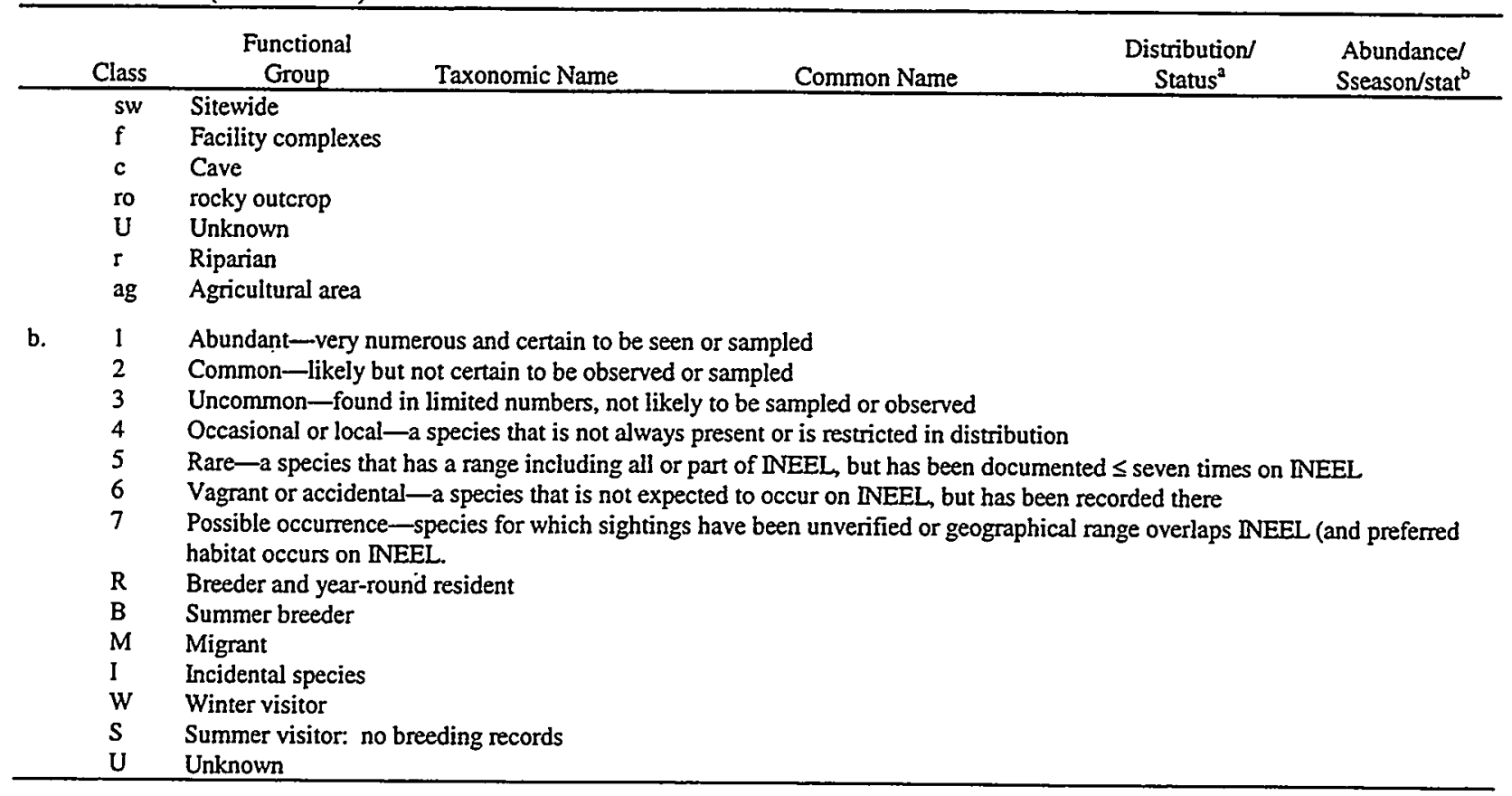


Table G-2. Functional groups and species not included in the literature search or individually evaluated for the WAG 5 ERA.

\begin{tabular}{|c|c|c|c|c|c|}
\hline $\begin{array}{l}\text { Functional } \\
\text { Group }\end{array}$ & Common Name & Habitat $^{2}$ & $\begin{array}{l}\text { Abundancel } \\
\text { Seasons }\end{array}$ & $\begin{array}{l}\text { Regulatory } \\
\text { Status }^{\mathrm{c}}\end{array}$ & Criteria for Exclusion \\
\hline \multirow[t]{3}{*}{ A232 } & Great basin spadefoot toad & w & $\mathrm{R} 2$ & & Geographic-aquatic, sinks, and spreading areas \\
\hline & Boreal chorus frog & W & R4 & & Geographic-aquatic \\
\hline & Western toad & $w, d$ & U7 & & Incidental species \\
\hline \multirow[t]{3}{*}{ AV122 } & Black-chinned hummingbird & ag,d & U7 & & Possible but not recorded on INEEL \\
\hline & Calliope hummingbird & ag,d & $\mathrm{U} 7$ & & Possible but not recorded on $\mathbb{N} E E L$ \\
\hline & Sharp-tailed grouse & $\mathrm{g}, \mathrm{ss}$ & 16 & & Incidental species \\
\hline \multirow[t]{2}{*}{ AV 122} & Broad-tailed hummingbird & ag,d & U7 & & Possible but not recorded on INEEL \\
\hline & Blue grouse & $\mathrm{F}$ & S6 & & Vagrant species \\
\hline \multirow[t]{4}{*}{ AV142 } & Snow goose & w & M5 & & Geographic-on or near water \\
\hline & Green-winged teal & W & S5, M5 & & Geographic-on or near water \\
\hline & Redhead & W & S5, M5, w5 & & Geographic-on or near water \\
\hline & Ring-necked duck & W & S5, M5 & & Geographic-on or near water \\
\hline \multirow[t]{12}{*}{ AV143 } & Tundra swan & $\mathrm{W}$ & M5 & & Geographic-on or near water \\
\hline & Canada goose & W & $\mathrm{S} 3, \mathrm{M} 3$ & & Geographic-on or near water \\
\hline & Mallard & $\mathrm{W}$ & $\mathrm{B} 2, \mathrm{M} 2, \mathrm{~W} 3$ & & Geographic —on or near water \\
\hline & Northern pintail & w & $\mathrm{S3}, \mathrm{M} 3$ & & Geographic-on or near water \\
\hline & Blue-winged teal & $w$ & $\mathrm{~B} 2, \mathrm{M} 3$ & & Geographic —on or near water \\
\hline & Cinnamon teal & $\mathrm{W}$ & S3, M3 & & Geographic-on or near water \\
\hline & Northern shoveler & W & B3, M3 & & Geographic-on or near water \\
\hline & Gadwall & $\mathrm{W}$ & $\mathrm{S} 3, \mathrm{M} 3$ & & Geographic —on or near water \\
\hline & American wigeon & W & S3, M3 & & Geographic -on or near water \\
\hline & Canvasback & w & B5, M5 & & Geographic-on or near water \\
\hline & Ross' goose & W & I6 & & Incidental species \\
\hline & White-fronted goose & w & 16 & & Incidental species \\
\hline \multirow[t]{5}{*}{ AV210 } & Gray flycatcher & $g, s s, j$ & U7 & & Incidental species \\
\hline & Westem wood-pewee & $\mathrm{D}$ & 16 & & Incidental species \\
\hline & Willow flycatcher & $\mathrm{D}$ & U7 & & Incidental species \\
\hline & Dusky flycatcher & $\mathrm{D}$ & U7 & & Incidental species \\
\hline & Common poor-will & $\mathrm{J}$ & 16 & & Incidental species \\
\hline \multirow[t]{9}{*}{ AV221 } & Black-and-white warbler & $\mathrm{U}$ & I6 & & Incidental species \\
\hline & Swainson's thrush & $\mathrm{U}$ & I6 & & Incidental species \\
\hline & Blue-gray gnatcatcher & $\mathrm{U}$ & 16 & & Incidental species \\
\hline & Red-naped sapsucker & $\mathrm{U}$ & I6 & & Incidental species \\
\hline & Lewis' woodpecker & $\mathrm{U}$ & 16 & & Incidental species \\
\hline & MacGillivray's warbler & $\mathrm{U}$ & I6 & & Incidental species \\
\hline & Orange-crowned warbler & $\mathrm{U}$ & 16 & & Incidental species \\
\hline & American redstart & $\mathrm{F}$ & M6 & & Vagrant species \\
\hline & Mountain chickadee & $\mathrm{d}, \mathrm{j}$ & U7 & & Incidental species \\
\hline
\end{tabular}


Table G-2. (continued).

\begin{tabular}{|c|c|c|c|c|c|}
\hline $\begin{array}{l}\text { Functional } \\
\text { Group }\end{array}$ & Common Name & Habitat $^{2}$ & $\begin{array}{l}\text { Abundance/ } \\
\text { Seasons }{ }^{\mathrm{b}}\end{array}$ & $\begin{array}{l}\text { Regulatory } \\
\text { Status }^{\mathrm{c}}\end{array}$ & Criteria for Exclusion \\
\hline & Lapland longspur & g,ss & U7 & & Incidental species \\
\hline & Hairy woodpecker & ag,d & U7 & & Incidental species \\
\hline & Black-capped chickadee & $\mathrm{d}, \mathrm{j}$ & U7 & & Incidental species \\
\hline \multirow[t]{9}{*}{ AV222 } & Varied thrush & Ss & W6 & & Vagrant species (winter) \\
\hline & Flammulated owl & & 16 & & Incidental species \\
\hline & Harris' sparrow & & 16 & & Incidental species \\
\hline & Hermit thrush & & 16 & & Incidental species \\
\hline & Lincoln's sparrow & & 16 & & Incidental species \\
\hline & Northern mockingbird & J & S6 & & Geographical-juniper woodland habitat \\
\hline & Lapland longspur & g,ss & 17 & & Incidental species \\
\hline & Westem sandpiper & W & 16 & & Incidental species \\
\hline & Semipalmated plover & $\mathrm{w}$ & I6 & & Incidental species \\
\hline \multirow[t]{7}{*}{ AV232 } & Virginia rail & W & U7 & & Incidental species \\
\hline & Marsh wren & W & U7 & & Incidental species \\
\hline & Baird's sandpiper & w & I6 & & Incidental species \\
\hline & Mountain plover & $\mathrm{U}$ & I6 & & Incidental species \\
\hline & Orchard oriole & $U$ & I6 & & Incidental species \\
\hline & Spotted sandpiper & w & S3, M3 & & Geographic -on or near water \\
\hline & Least sandpiper & w & S5, M5 & & Geographic —on or near water \\
\hline \multirow[t]{9}{*}{ AV233 } & Cattle egret & w & 16 & & Incidental species \\
\hline & Black-necked stilt & $\mathrm{W}$ & 16 & & Incidental species \\
\hline & Snowy egret & $w$ & 16 & & Incidental species \\
\hline & Solitary sandpiper & $w$ & S5, M3 & & Geographic —on or near water \\
\hline & Marbled godwit & $w$ & S3, M5 & & Geographic —on or near water \\
\hline & Long-billed dowitcher & $w$ & M5 & & Geographic-on or near water \\
\hline & Common snipe & $w$ & S5, M5 & & Geographic-on or near water \\
\hline & White-faced ibis & $\underline{\mathbf{w}}$ & $\underline{\text { S5, M5 }}$ & & Geographic - on or near water \\
\hline & Long-billed curlew & $\underline{\underline{w}}$ & $\underline{\mathrm{S} 3, \mathrm{M} 3}$ & & Geographic -on or near water \\
\hline \multirow[t]{3}{*}{ AV241 } & Wood duck & w & S6, M5 & & Geographic-on or near water \\
\hline & Red-necked phalarope & $w$ & M5 & & Geographic-on or near water \\
\hline & Wilson's phalarope & $w$ & S3, M3 & & Geographic —on or near water \\
\hline \multirow[t]{8}{*}{ AV242 } & Surf scoter & w & 16 & & Incidental species \\
\hline & Barrow's goldeneye & $w$ & S6, M5 & & Vagrant species \\
\hline & Lesser scaup & w & S5, M3, W3 & & Geographic-on or near water \\
\hline & Common goldeneye & w & S5, M3, W3 & & Geographic $\longrightarrow$ on or near water \\
\hline & Barrow's goldeneye & $\mathbf{w}$ & S6, M5 & & Geographic-on or near water \\
\hline & Ruddy duck & w & $\mathrm{B} 5, \mathrm{M} 3$ & & Geographic $\longrightarrow$ on or near water \\
\hline & Lesser yellowlegs & $w$ & S5, M5 & & Geographic —on or near water \\
\hline & Bonaparte's gull & $w$ & M5 & & Geographic —on or near water \\
\hline
\end{tabular}


Table G-2. (continued).

\begin{tabular}{|c|c|c|c|c|c|}
\hline $\begin{array}{c}\text { Functional } \\
\text { Group }\end{array}$ & Common Name & Habitat ${ }^{2}$ & $\begin{array}{c}\text { Abundancel } \\
\text { Seasons }{ }^{\mathrm{b}} \\
\end{array}$ & $\begin{array}{c}\text { Regulatory } \\
\text { Status }^{c}\end{array}$ & Criteria for Exclusion \\
\hline & Bufflehead & w & S5, M3 & & Geographic - on or near water \\
\hline & Pied-billed grebe & w & S5, M5 & & Geographic-on or near water \\
\hline & Horned grebe & $\mathbf{w}$ & M5 & & Geographic-on or near water \\
\hline & Eared grebe & $\mathbf{w}$ & B5, M3, W3 & & Geographic-on or near water \\
\hline AV310 & Gyrfalcon & sw & M6 & SSC,S & Incidental species \\
\hline \multirow[t]{3}{*}{ AV322 } & Northern pygmy owl & $d$ & U7 & SSC & Incidental species \\
\hline & Boreal owI & & 16 & & Incidental species \\
\hline & Western screech owl & $d$ & $\mathrm{u} 7$ & & Incidental species \\
\hline AV332 & Northern saw-whet owl & sw & S6, M6, W6 & & Vagrant species \\
\hline AV333 & Green-backed heron & $w$ & S6, M6 & & Vagrant species \\
\hline \multirow[t]{2}{*}{ AV342 } & Red-breasted merganser & w & 16 & & Incidental species \\
\hline & Black-legged kittiwake & w & W6 & & Vagrant species (winter) \\
\hline \multirow[t]{4}{*}{ AV422 } & Hooded merganser & $\mathrm{w}$ & 16 & & Incidental species \\
\hline & Double-crested cormorant & $\mathbf{w}$ & 16 & & Incidental species \\
\hline & Blue jay & $\mathrm{U}$ & 16 & & Incidental species \\
\hline & Clark's nutcracker & $\mathrm{j}$ & S4, M4, W5 & & Geographical-juniper woodland habitat \\
\hline AV432 & American avocet & $\mathbf{w}$ & S2, M3 & & Geographic-on or near water \\
\hline \multirow[t]{2}{*}{ AV433 } & Sandhill crane & $\mathrm{U}$ & I6 & & Incidental species \\
\hline & Great egret & $w$ & S5, M5 & & Geographic -on or near water \\
\hline AV442 & American coot & $w$ & R3 & & Geographic—on or near water \\
\hline \multirow[t]{2}{*}{ M122 } & Moose & sw & T6 & & Transient species - Rare \\
\hline & Mountain sheep & N NEEL & T6 & & Transient species - Rare \\
\hline \multirow[t]{2}{*}{ M132 } & Muskrat & w & S5,W5 (cyclic) & & Geographical—aquatic habitat (Big Lost River) \\
\hline & Beaver & $w$ & $\mathrm{R} 4, \mathrm{~S}, \mathrm{~W}$ & & Geographical-aquatic habitat (Big Lost River) \\
\hline \multirow[t]{4}{*}{ M210 } & Yuma myotis & sw & U7 & & Incidental species \\
\hline & Silver-haired bat & sw & U7 & & Incidental species \\
\hline & Westem pipistrelle & sw & U7 & $\mathrm{C} 2, \mathrm{SSC}, \mathrm{S}$ & Incidental species \\
\hline & Fringed myotis & sw & U7 & SSC & Incidental species \\
\hline \multirow[t]{2}{*}{ M210A } & Long-legged myotis & sw & U7 & & Incidental species \\
\hline & Pallid bat & sw & U7 & & Incidental species \\
\hline \multirow[t]{4}{*}{ M322 } & Mountain lion & sw & T6 & & Transient species-Rare \\
\hline & Striped skunk & ag,d & U7 & & Incidental species \\
\hline & Short-tailed weasel (ermine) & ag,d & U7 & & Incidental species \\
\hline & Red fox & ag,d & U7 & & Incidental species \\
\hline M422 & Racoon & ag,d & U7 & & Incidental species \\
\hline O242 & Shorthead sculpin & $w$ & $\mathrm{R} 2$ & & Geographical一aquatic species (Big Lost River) \\
\hline \multirow[t]{3}{*}{0243} & Mountain whitefish & w & $\mathrm{R} 2$ & & Geographical-aquatic species (Big Lost River) \\
\hline & Speckled dace & w & R3 & & Geographical-aquatic species (Big Lost River) \\
\hline & Cutthroat trout & $w$ & U7 & & Geographical_aquatic species (Big Lost River) \\
\hline
\end{tabular}


Table G-2. (continued).

\begin{tabular}{|c|c|c|c|c|c|}
\hline $\begin{array}{c}\text { Functional } \\
\text { Group }\end{array}$ & Common Name & Habitat ${ }^{2}$ & $\begin{array}{c}\text { Abundancel } \\
\text { Seasons }{ }^{\mathrm{b}}\end{array}$ & $\begin{array}{l}\text { Regulatory } \\
\text { Status }^{c}\end{array}$ & Criteria for Exclusion \\
\hline \multirow[t]{3}{*}{0342} & Rainbow trout & $\mathbf{w}$ & $\mathrm{R} 2$ & & Geographical-aquatic species (Big Lost River) \\
\hline & Brook trout & w & R3 & & Geographical—aquatic species (Big Lost River) \\
\hline & Utah chub & w & U7 & & Geographical-aquatic species (Big Lost River) \\
\hline 0442 & Kokanee salmon & $\mathbf{w}$ & M3 & & Geographical-aquatic species (Big Lost River) \\
\hline R222 & Leopard lizard & NE INEEL & R4 & & $\begin{array}{l}\text { Geographical-observations restricted to NE } \\
\text { INEEL }\end{array}$ \\
\hline R232 & Tiger salamander & w & U7 & & Incidental species \\
\hline \multirow[t]{4}{*}{ R322 } & Rubber boa & $\mathbf{U}$ & 16 & & Incidental species \\
\hline & Ringneck snake & sw & U7 & NL,SSC & Incidental species \\
\hline & Common garter Snake & sw & U7 & & Incidental species \\
\hline & Night snake & sw & U7 & $s$ & Incidental species \\
\hline
\end{tabular}

a. ag Agriculture

w On or near water

ss Shrub-steppe

d Deciduous or riparian

j Juniper woodland

g Grassland

sw Sitewide

f Facility complexes

U Unknown

r Riparian

b. 1 Abundant-very numerous and certain to be seen or sampled.

2 Common-likely but not certain to be observed or sampled.

3 Uncommon-found in limited numbers, not likely to be sampled or observed.

4 Occasional or local -a species that is not always present or is restricted in distribution.

5 Rare-a species that has a range including all or part of NEEL, but has been documented $\leq$ seven times on $\mathbb{N E E L}$.

6 Vagrant or accidental-a species that is not expected to occur on INEEL, but has been recorded there.

7 Possible occurrence-species for which sightings have been verified or geographical range overlaps INEEL (and preferred habitat

$\mathrm{R}$ occurs on INEEL)

I Breeder and year-round resident.

$M \quad$ Incidental.

W Migrant.

$S \quad$ Winter visitor.

T Summer visitor - no breeding records.

U Transient.

Unknown

c. Species management codes for federal (FED) listing, Bureau of Land Management (BLM), U.S. Forest Service Region 4 (USFS), and Audubon Blue List (AUDBL): $C 2=$ category 2 species; $3 c=$ no longer considered for listing; $E=$ endangered species; $N L=$ not listed; $S S C=$ species of special concern: $T=$ threatened species: $S=$ sensitive 
COPC:

Test Organisms:

Exposure Medium:

Test Endpoint:

Reference:

\section{Antimony (Antimony Potassium Tartrate) CAS 7440-36-0}

Mouse (Omnivore, Order-Rodentia)

Drinking water

LOAEL mice (significance unknown)

Schroeder, H.A., M. Mitchner, and J.J. Balassa, 1968, Zirconium, Niobium, Antimony and Fluorine in Mice: Effects of Growth Survival and Tissue Levels, Journal of Nutrition, 95:95-101.

Kanisawa, M. and H.A. Schroeder, 1969, "Life term studies on the effect of trace elements on spontaneous tumor in mice and rats." Cancer Research, 29(4):892-895.

QCE: $\quad 1.25 \mathrm{mg} / \mathrm{kg}$-day $\quad(5 \mathrm{mg} / \mathrm{L}$ water $)(7.5 \mathrm{~mL}$ water $/$ day $)(1 \mathrm{~L} / 1000 \mathrm{~mL}) / 0.03 \mathrm{~kg} \mathrm{BW}$

\begin{tabular}{|c|c|c|c|c|c|c|}
\hline \multicolumn{5}{|c|}{$\begin{array}{l}\text { Adjustment Factors } \\
\text { (AF) }\end{array}$} & \multicolumn{2}{|c|}{ Justification for adjustment factor } \\
\hline \multicolumn{2}{|l|}{$\mathrm{R}$} & 1 & 2 & 3 & \multicolumn{2}{|c|}{$\begin{array}{l}\mathrm{R}=1 \text { is } \mathrm{AF} \text { for same order and trophic level } \\
\mathrm{R}=2 \text { is } \mathrm{AF} \text { for different order and same trophic level } \\
\mathrm{R}=3 \text { is } A F \text { for different order and trophic level }\end{array}$} \\
\hline I & & 1 & 1 & 1 & \multicolumn{2}{|c|}{ Chronic toxicity studies with adequate numbers of animals. } \\
\hline $\mathrm{Q}_{1}$ & & 0.5 & 0.5 & 0.5 & \multicolumn{2}{|c|}{$\begin{array}{l}\text { Endpoint could occur (lifespan, longevity), but of uncertain } \\
\text { ecological significance }\end{array}$} \\
\hline$Q_{2}$ & & 1 & 1 & 1 & \multicolumn{2}{|l|}{ Chronic study } \\
\hline$Q_{3}$ & & 2 & 2 & 2 & \multicolumn{2}{|l|}{ LOAEL endpoint } \\
\hline $\mathrm{U}$ & & 2 & 2 & 2 & \multicolumn{2}{|c|}{ Large chronic study, but no reproductive endpoints examined. } \\
\hline M & & 0.5 & 0.5 & 0.5 & \multicolumn{2}{|c|}{ Soluble salts in the drinking water were used } \\
\hline Total A & & 1 & 2 & 3 & \multicolumn{2}{|c|}{$\mathrm{R} * \mathrm{I} * \mathrm{Q}_{1} * \mathrm{Q}_{2} * \mathrm{Q}_{3} * \mathrm{U} * \mathrm{M}=$ Total $\mathrm{AF}$} \\
\hline QCE $(m$ & /kg-day) & 1.25 & 1.25 & 1.25 & \multicolumn{2}{|l|}{$\mathrm{QCE}=$ quantified critical endpoint } \\
\hline TRV & & 1.25 & 0.625 & 0.417 & \multicolumn{2}{|c|}{ Toxicity Reference Value $=\mathrm{QCE} /$ Total $\mathrm{AF}$} \\
\hline $\begin{array}{c}\mathrm{R} \\
\text { Value }\end{array}$ & \multicolumn{2}{|c|}{$\begin{array}{c}\mathrm{TRV} \\
(\mathrm{mg} / \mathrm{kg} \text {-day) }\end{array}$} & & & Justification & $\begin{array}{l}\text { Appropriate Functional } \\
\text { Group }\end{array}$ \\
\hline 1 & 1.25 & & \multicolumn{3}{|c|}{$\begin{array}{l}\text { Test organism is in the same order and trophic level as } \\
\text { the functional group members }\end{array}$} & none \\
\hline 2 & 0.625 & & \multicolumn{3}{|c|}{$\begin{array}{l}\text { Test organism is in a different order and same trophic } \\
\text { level from the functional group members }\end{array}$} & $\mathrm{M} 422, \mathrm{M} 422 \mathrm{~A}$ \\
\hline 3 & 0.417 & & \multicolumn{3}{|c|}{$\begin{array}{l}\text { Test organism is in a different order and trophic level } \\
\text { from the functional group members }\end{array}$} & $\begin{array}{l}\text { M122, M122A, M121, } \\
\text { M123, M132 M210, M210A, } \\
\text { M222, M322 }\end{array}$ \\
\hline
\end{tabular}


COPC:

Test Organisms:

Exposure Medium:

Test Endpoint:

Reference:
Arsenic CAS 7778-43-0

Mallard (Herbivore, Order-Anseriformes)

Oral in diet (Arensic as sodium arsenite)

NOAEL

U.S. Fish and Wildlife Service. 1964. Pesticide-wildlife studies, 1963: a review of Fish and Wildlife Service investigations during the calendar year. FWS Circular 199.

$5.14 \mathrm{mg} / \mathrm{kg}$-day $\quad((51.35 \mathrm{mg} \mathrm{As} / \mathrm{kg}$ food $) *(0.1 \mathrm{~kg}$ food/day $)) /(1 \mathrm{~kg} \mathrm{BW})$

QCE:

Justification for adjustment factor

\begin{tabular}{|c|c|c|c|c|c|c|}
\hline \multicolumn{5}{|c|}{$\begin{array}{l}\text { Adjustment Factors } \\
\text { (AF) }\end{array}$} & \multicolumn{2}{|c|}{ Justification for adjustment factor } \\
\hline $\mathrm{R}$ & & 1 & 2 & 3 & \multicolumn{2}{|c|}{$\begin{array}{l}\text { Same trophic level but different order than members of } \\
\text { functional groups }\end{array}$} \\
\hline $\mathrm{I}$ & & 2 & 2 & 2 & \multicolumn{2}{|c|}{ Reasonable number of animals tested } \\
\hline $\mathrm{Q}_{1}$ & & 1 & 1 & 1 & \multicolumn{2}{|c|}{ Mortality, is ecologically relevant } \\
\hline $\mathrm{Q}_{2}$ & & 1 & 1 & 1 & \multicolumn{2}{|c|}{ Chronic duration (over 128 days) } \\
\hline $\mathrm{Q}_{3}$ & & 1 & 1 & 1 & \multicolumn{2}{|l|}{ NOAEL } \\
\hline $\mathrm{U}$ & & 2 & 2 & 2 & \multicolumn{2}{|c|}{$\begin{array}{l}\text { Multiple doses }(100,250,500 \text {, and } 1000 \text { ppm sodium } \\
\text { arsenite) examined with both a NOAEL and a LOAEL } \\
\text { established. However, no reproductive endpoints examined. }\end{array}$} \\
\hline Total A & & 4 & 8 & 12 & \multicolumn{2}{|c|}{$\mathrm{R} * \mathrm{I} * \mathrm{Q}_{1} * \mathrm{Q}_{2} * \mathrm{Q}_{3} * \mathrm{U}=$ Total AF } \\
\hline $\mathrm{QCE}(\mathrm{m}$ & /kg-day) & 5.14 & 5.14 & 5.14 & \multicolumn{2}{|c|}{$\mathrm{QCE}=$ quantified critical endpoint } \\
\hline TRV & & 1.29 & 0.64 & 0.43 & \multicolumn{2}{|c|}{ Toxicity Reference Value $=$ QCE $/$ Total AF } \\
\hline $\begin{array}{c}\mathrm{R} \\
\text { Value }\end{array}$ & \multicolumn{2}{|c|}{$\begin{array}{c}\mathrm{TRV} \\
\text { (mg/kg-day) }\end{array}$} & \multicolumn{3}{|c|}{ Justification } & $\begin{array}{l}\text { Appropriate Functional } \\
\text { Group }\end{array}$ \\
\hline 1 & 1.29 & \multicolumn{4}{|c|}{$\begin{array}{l}\text { Test organism is in the same order and trophic level as } \\
\text { the functional group members }\end{array}$} & AV142, AV143 \\
\hline 2 & 0.64 & \multicolumn{4}{|c|}{$\begin{array}{l}\text { Test organism is in a different order and same trophic } \\
\text { level from the functional group members }\end{array}$} & AV121, AV122, AV132 \\
\hline 3 & 0.43 & \multicolumn{4}{|c|}{$\begin{array}{l}\text { Test organism is in a different order and trophic level } \\
\text { from the functional group members }\end{array}$} & $\begin{array}{l}\text { AV210, AV210A, } \\
\text { AV221, AV222, } \\
\text { AV222A, AV232, } \\
\text { AV233, AV241, AV242, } \\
\text { AV310, AV322, AV333, } \\
\text { AV342, AV422, AV432, } \\
\text { AV433, AV442 }\end{array}$ \\
\hline
\end{tabular}


COPC:

Test Organisms:

Exposure Medium:

Test Endpoint:

Reference:
Arsenic CAS $7778-43-0$

Rat (Omnivore, Order-Rodentia)

Diet as sodium arsenate or sodium arsenite

NOAEL

Byron, W.R., et al., 1967, "Pathologic changes in rats and dogs from two-year feeding of sodium arsenite or sodium arsenate," Toxicology and Applied

Pharmacology, 10:132-147.

$3.1 \mathrm{mg} / \mathrm{kg}$-day $\quad(62.5 \mathrm{mg} / \mathrm{kg}$ food $) *(0.0189 \mathrm{~kg} /$ day $) /(0.382 \mathrm{~kg} \mathrm{BW})$

QCE:

Justification for adjustment factor

Adjustment Factors (AF)

\begin{tabular}{|c|c|c|c|c|}
\hline $\mathrm{R}$ & 1 & 2 & 3 & $\begin{array}{l}\text { Different trophic level and order than members of functional } \\
\text { groups. }\end{array}$ \\
\hline I & 2 & 2 & 2 & $\begin{array}{l}300 \text { weanling rats. Data does not show a good dose- } \\
\text { response curve low-dose range. }\end{array}$ \\
\hline$Q_{1}$ & 1 & 1 & 1 & $\begin{array}{l}\text { Levels of } 62.5 \mathrm{ppm} \text { arsenic as arsenite and } 125 \mathrm{ppm} \text { arsenic } \\
\text { as arsenate did not cause common bile duct enlargement and } \\
\text { did not affect survival. Weight was slightly reduced in } \\
\text { females at the } 62.5 \mathrm{ppm} \text { arsenic as arsenite. }\end{array}$ \\
\hline$Q_{2}$ & 1 & 1 & 1 & Chronic study. \\
\hline $\mathrm{Q}_{3}$ & 1 & 1 & 1 & $\begin{array}{l}\text { NOAEL using lowest NOAEL from either arsenite or } \\
\text { arsenate }\end{array}$ \\
\hline $\mathrm{U}$ & 2 & 2 & 2 & $\begin{array}{l}\text { Good overall design, but no reproductive studies in the two } \\
\text { years. }\end{array}$ \\
\hline Total AF & 4 & 8 & 12 & $\mathrm{R} * \mathrm{I} * \mathrm{Q}_{1} * \mathrm{Q}_{2} * \mathrm{Q}_{3} * \mathrm{U}=$ Total AF \\
\hline $\mathrm{QCE}$ (mg/kg-day) & 3.1 & 3.1 & 3.1 & $\mathrm{QCE}=$ quantified critical endpoint \\
\hline TRV & 0.78 & 0.39 & 0.26 & Toxicity Reference Value = QCE Total AF \\
\hline
\end{tabular}

\begin{tabular}{ccll}
\hline $\begin{array}{c}\mathrm{R} \\
\text { Value }\end{array}$ & $\begin{array}{c}\text { TRV } \\
(\mathrm{mg} / \mathrm{kg} \text {-day })\end{array}$ & \multicolumn{1}{c}{ Justification } & $\begin{array}{c}\text { Appropriate Functional } \\
\text { Group }\end{array}$ \\
\hline 1 & 0.78 & $\begin{array}{l}\text { Test organism is in the same order and trophic level as } \\
\text { the functional group members }\end{array}$ & none \\
2 & 0.39 & $\begin{array}{l}\text { Test organism is in a different order and same trophic } \\
\text { level from the functional group members }\end{array}$ & M422, M422A \\
& & $\begin{array}{l}\text { Test organism is in a different order and trophic level } \\
\text { from the functional group members }\end{array}$ & $\begin{array}{l}\text { M122, M122A, M121, } \\
\text { M123, M132 M210, } \\
\text { M210A, M222, M322 }\end{array}$ \\
\hline
\end{tabular}


Test Organisms: Exposure Medium: Test Endpoint:

Reference:
Rat (Omnivore, Order-Rodentia)

Drinking water

NOAEL

Perry, H.M. et al. 1989, "Hypertension and associated cardiovascular abnormalities induced by chronic barium feeding," Journal of Toxicology and Environmental Health, 28(3):373-388.

Kopp, S.J. et al. 1985, "Cardiovascular dysfunction and hypersensitivity to sodium pentobarbital induced by chronic barium chloride ingestion, Toxicology and Applied Pharmacology, 77(23):303-314.

QCE: $5.1 \mathrm{mg} / \mathrm{kg}$-day

Adjustment Factors

$(\mathrm{AF})$

Justification for adjustment factor

\begin{tabular}{|c|c|c|c|c|c|c|}
\hline \multicolumn{2}{|l|}{$\mathrm{R}$} & 1 & 2 & 3 & \multicolumn{2}{|c|}{$\begin{array}{l}R=1 \text { is } A F \text { for same order and trophic level } \\
R=2 \text { is } A F \text { for different order and same trophic level } \\
R=3 \text { is } A F \text { for different order and trophic level }\end{array}$} \\
\hline I & & 1 & 1 & 1 & \multicolumn{2}{|c|}{ Chronic toxicity studies with adequate numbers of animals } \\
\hline$Q_{1}$ & & 1 & 1 & 1 & \multicolumn{2}{|c|}{$\begin{array}{l}\text { Although endpoint examined (increased blood pressure at higher } \\
\text { doses) could occur in ecological receptors, the absence of any } \\
\text { effects on growth and longevity at any dose argues against its } \\
\text { ecological relevance. But at the NOAEL dose, no hypersensitivity } \\
\text { was observed. }\end{array}$} \\
\hline $\mathrm{Q}_{2}$ & & 1 & 1 & 1 & \multicolumn{2}{|l|}{ Chronic study (16 months) } \\
\hline$Q_{3}$ & & 1 & 1 & 1 & \multicolumn{2}{|l|}{ NOAEL } \\
\hline $\mathrm{U}$ & & 1 & 1 & 1 & \multicolumn{2}{|c|}{ Concordant results in several detailed studies } \\
\hline M & & 0.5 & 0.5 & 0.5 & \multicolumn{2}{|c|}{ Soluble salt in the drinking water was used } \\
\hline Total A & & 0.5 & 1.0 & 1.5 & \multicolumn{2}{|c|}{$\mathrm{R} * \mathrm{I} * \mathrm{Q}_{1} * \mathrm{Q}_{2} * \mathrm{Q}_{3} * \mathrm{U} * \mathrm{M}=$ Total $\mathrm{AF}$} \\
\hline $\mathrm{QCE}(\mathrm{m}$ & g/kg-day) & 5.1 & 5.1 & 5.1 & \multicolumn{2}{|l|}{$Q C E=$ quantified critical endpoint } \\
\hline TRV & & 10.2 & 5.1 & 3.4 & \multicolumn{2}{|c|}{ Toxicity Reference Value $=\mathrm{QCE} /$ Total $\mathrm{AF}$} \\
\hline $\begin{array}{c}\mathrm{R} \\
\text { Value }\end{array}$ & \multicolumn{2}{|c|}{$\begin{array}{c}\mathrm{TRV} \\
\text { (mg/kg-day) }\end{array}$} & & & Justification & $\begin{array}{l}\text { Appropriate Functional } \\
\text { Group }\end{array}$ \\
\hline 1 & 10.2 & \multicolumn{4}{|c|}{$\begin{array}{l}\text { Test organism is in the same order and trophic level as } \\
\text { the functional group members }\end{array}$} & none \\
\hline 2 & 5.1 & \multicolumn{4}{|c|}{$\begin{array}{l}\text { Test organism is in a different order and same trophic } \\
\text { level from the functional group members }\end{array}$} & $\mathrm{M} 422, \mathrm{M} 422 \mathrm{~A}$ \\
\hline 3 & 3.4 & \multicolumn{4}{|c|}{$\begin{array}{l}\text { Test organism is in a different order and trophic level } \\
\text { from the functional group members }\end{array}$} & $\begin{array}{l}\text { M121, M122, M122A, } \\
\text { M132, M210, M210A, } \\
\text { M222, M322 }\end{array}$ \\
\hline
\end{tabular}

*BW given by an earlier Perry article, ingestion rate specified in the article

**note-10ppm had some adverse effects such as an increase in blood pressure and tissue concentration. 
COPC:

Test Organisms:

Exposure Medium:

Test Endpoint:

Reference:

Beryllium (Beryllium sulfate) CAS 7440-41-7

QCE:

Rat (Omnivore, Order-Rodentia)

Drinking water

NOAEL

Schroeder, H.A., and M. Mitchner, 1975, Life-Term Studies in Rats: Effects of Aluminum, Barium, Beryllium and Tungsten, J. Nutr. 105: 421-427.

(5mg/L water)*(0.046L/day) $/ 0.35 \mathrm{~kg} \mathrm{BW}$

\begin{tabular}{|c|c|c|c|c|c|c|}
\hline \multicolumn{5}{|c|}{$\begin{array}{l}\text { Adjustment Factors } \\
\qquad(\mathrm{AF})\end{array}$} & \multicolumn{2}{|c|}{ Justification for adjustment factor } \\
\hline \multicolumn{2}{|l|}{$\mathrm{R}$} & 1 & 2 & 3 & \multicolumn{2}{|c|}{$\begin{array}{l}R=1 \text { is } A F \text { for same order and trophic level } \\
R=2 \text { is } A F \text { for different order and same trophic level } \\
R=3 \text { is } A F \text { for different order and trophic level }\end{array}$} \\
\hline I & & 1 & 1 & 1 & \multicolumn{2}{|c|}{ Chronic toxicity studies with adequate numbers of animals } \\
\hline $\mathrm{Q}_{1}$ & & 1 & 1 & 1 & \multicolumn{2}{|c|}{ Ecologically relevant endpoint (life-span, growth). } \\
\hline $\mathrm{Q}_{2}$ & & 1 & 1 & 1 & \multicolumn{2}{|l|}{ Chronic study } \\
\hline $\mathrm{Q}_{3}$ & & 1 & 1 & 1 & \multicolumn{2}{|l|}{ NOAEL endpoint } \\
\hline$U$ & & 2 & 2 & 2 & \multicolumn{2}{|c|}{ Large chronic study, but no reproductive endpoints examined } \\
\hline M & & 0.5 & 0.5 & 0.5 & \multicolumn{2}{|c|}{ Soluble salt in the drinking water used } \\
\hline Total A & & 1 & 2 & 3 & \multicolumn{2}{|c|}{$R * I * Q_{1} * Q_{2} * Q_{3} * U * M=$ Total AF } \\
\hline QCE $(n$ & /kg-day) & 0.66 & 0.66 & 0.66 & \multicolumn{2}{|l|}{$\mathrm{QCE}=$ quantified critical endpoint } \\
\hline TRV & & 0.66 & 0.33 & 0.22 & \multicolumn{2}{|c|}{ Toxicity Reference Value $=\mathrm{QCE} /$ Total AF } \\
\hline $\begin{array}{c}\mathrm{R} \\
\text { Value }\end{array}$ & \multicolumn{2}{|c|}{$\begin{array}{c}\text { TRV } \\
(\mathrm{mg} / \mathrm{kg} \text {-day) }\end{array}$} & & & Justification & $\begin{array}{l}\text { Appropriate Functional } \\
\quad \text { Group }\end{array}$ \\
\hline 1 & 0.66 & & \multicolumn{3}{|c|}{$\begin{array}{l}\text { Test organism is in the same order and trophic level as } \\
\text { the functional group members }\end{array}$} & None \\
\hline 2 & 0.33 & & \multicolumn{3}{|c|}{$\begin{array}{l}\text { Test organism is in a different order and same trophic } \\
\text { level from the functional group nembers }\end{array}$} & $\mathrm{M} 422, \mathrm{M} 422 \mathrm{~A}$ \\
\hline 3 & 0.22 & & \multicolumn{3}{|c|}{$\begin{array}{l}\text { Test organism is in a different order and trophic level } \\
\text { from the functional group members }\end{array}$} & $\begin{array}{l}\text { M121, M122, M122A, } \\
\text { M132, M210, M210A, } \\
\text { M222, M322 }\end{array}$ \\
\hline
\end{tabular}

*Ingestion rate specified by EPA (EPA, 1985a). 
COPC:

Test Organisms:

Exposure Medium:

Test Endpoint:

Reference:

QCE:
Cadmium CAS 7440-43-9

Black Duck (Herbivore, Order-Anseriformes)

Diet

LOAEL

Heinz, G.H. and Haseltine, S.D., 1983, "Altered Avoidance Behavior of Young Black Ducks Fed Cadmium". Environ. Toxicol. Chem. 2:419-421. As cited in Eisler, 1985.

$0.14 \mathrm{mg} / \mathrm{kg}$-day $\quad(4 \mathrm{mg} / \mathrm{kg}) *(0.06 \mathrm{~kg} /$ day $) / 1.7 \mathrm{~kg} \mathrm{BW}$

\begin{tabular}{|c|c|c|c|c|c|c|}
\hline \multicolumn{5}{|c|}{$\begin{array}{c}\text { Adjustment Factors } \\
\text { (AF) }\end{array}$} & \multicolumn{2}{|c|}{ Justification for adjustment factor } \\
\hline $\mathrm{R}$ & & 1 & 2 & 3 & \multicolumn{2}{|c|}{$\begin{array}{l}R=1 \text { is } A F \text { for same order and trophic level } \\
R=2 \text { is } A F \text { for different order and same trophic level } \\
R=3 \text { is } A F \text { for different order and trophic level }\end{array}$} \\
\hline I & & 1 & 1 & 1 & \multicolumn{2}{|c|}{$\begin{array}{l}\text { Adequate numbers tested, males, females and juveniles given the } \\
\text { doses. }\end{array}$} \\
\hline $\mathrm{Q}_{1}$ & & 1 & 1 & 1 & \multicolumn{2}{|c|}{ Ecologically relevant endpoint (behavior). } \\
\hline $\mathrm{Q}_{2}$ & & 1 & 1 & 1 & \multicolumn{2}{|l|}{ Chronic (90-day) exposure } \\
\hline $\mathrm{Q}_{3}$ & & 2 & 2 & 2 & \multicolumn{2}{|l|}{ LOAEL endpoint } \\
\hline$U$ & & 2 & 2 & 2 & \multicolumn{2}{|c|}{$\begin{array}{l}\text { Reproductive endpoints and sensitive life stage examined, but only } \\
\text { data given was on the flight response of the juveniles. }\end{array}$} \\
\hline $\mathbf{M}$ & & 0.5 & 0.5 & 0.5 & \multicolumn{2}{|l|}{ Cadmium chloride in the feed } \\
\hline Total Al & & 2 & 4 & 6 & \multicolumn{2}{|c|}{$\mathrm{R} * \mathrm{I} * \mathrm{Q}_{1} * \mathrm{Q}_{2} * \mathrm{Q}_{3} * \mathrm{U} * \mathrm{M}=$ Total $A F$} \\
\hline $\mathrm{QCE}(\mathrm{m}$ & /kg-day) & 0.14 & 0.14 & 0.14 & \multicolumn{2}{|l|}{$\mathrm{QCE}=$ quantified critical endpoint } \\
\hline TRV & & 0.07 & 0.04 & 0.2 & \multicolumn{2}{|c|}{ Toxicity Reference Value $=\mathrm{QCE} /$ Total $\mathrm{AF}$} \\
\hline $\begin{array}{c}\mathrm{R} \\
\text { Value }\end{array}$ & \multicolumn{2}{|c|}{$\begin{array}{c}\text { TRV } \\
\text { (mg/kg-day) }\end{array}$} & & & Justification & Appropriate Functional Group \\
\hline 1 & 0.07 & \multicolumn{4}{|c|}{$\begin{array}{l}\text { Test organism is in the same order and trophic level as the } \\
\text { functional group members }\end{array}$} & AV142, AV143 \\
\hline 2 & 0.04 & \multicolumn{4}{|c|}{$\begin{array}{l}\text { Test organism is in a different order and same trophic level } \\
\text { from the functional group members }\end{array}$} & AV121, AV122, AV132 \\
\hline 3 & 0.02 & \multicolumn{4}{|c|}{$\begin{array}{l}\text { Test organism is in a different order and trophic level from } \\
\text { the functional group members }\end{array}$} & $\begin{array}{l}\text { AV210, AV210A, AV221, } \\
\text { AV222, AV222A, AV232, } \\
\text { AV233, AV242, AV310, } \\
\text { AV322, AV333, AV342, } \\
\text { AV422, AV432, AV433, } \\
\text { AV442 }\end{array}$ \\
\hline
\end{tabular}


COPC:

Test Organisms:

Exposure Medium:

Test Endpoint:

Reference:
Cadmium CAS 7440-43-9

Rat (Omnivore, Order-Rodentia)

Diet

LOAEL

Wills, J.H., Groblewski, G.E., Coulston, F., 1981, Chronic and Multigeneration Toxicities of Small Concentrations of Cadmium in the Diet of Rats, Ecotoxicol. Environ. Safety. 5:452-464.

ATSDR, Agency for Toxic Substance Disease Registry, 1989, Toxicological Profile for Cadmium, March, 1989.

QCE: $\quad 5.5 \mathrm{E}-3 \mathrm{mg} / \mathrm{kg}$-day Specified

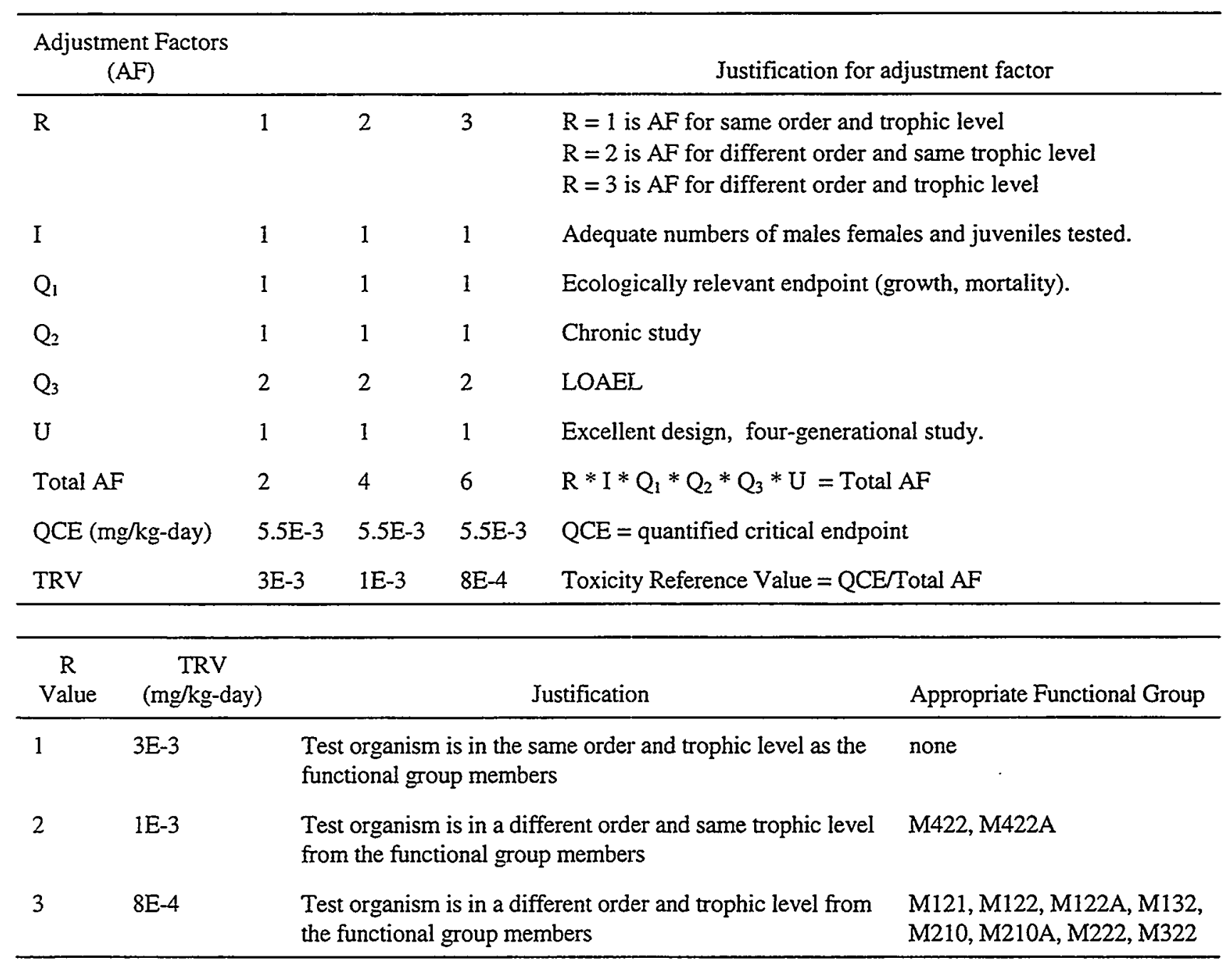


COPC:

Test Organisms:

Exposure Medium:

Test Endpoint:

Reference:

QCE:
Chromium (III) CAS 7440-47-3

Chicken (Omnivore, Order-Galliformes)

Diet

NOAEL

Romoser, G.L., W.A. Dudley, L.J. Machlin, and L. Loveless, 1961, Toxicity of Vanadium and Chromium for the Growing Chick, Poultry Science, 40:1171-1173. $49 \mathrm{mg} / \mathrm{kg}$-day

\begin{tabular}{|c|c|c|c|c|c|c|}
\hline \multicolumn{5}{|c|}{$\begin{array}{l}\text { Adjustment Factors } \\
\text { (AF) }\end{array}$} & \multicolumn{2}{|c|}{ Justification for adjustment factor } \\
\hline $\mathbf{R}$ & & 1 & 2 & 3 & \multicolumn{2}{|c|}{$\begin{array}{l}R=1 \text { is } A F \text { for same order and trophic level } \\
R=2 \text { is } A F \text { for different order and same trophic level } \\
R=3 \text { is } A F \text { for different order and trophic level }\end{array}$} \\
\hline I & & 2 & 2 & 2 & \multicolumn{2}{|l|}{ Primary source unavailable } \\
\hline $\mathrm{Q}_{1}$ & & 1 & 1 & 1 & \multicolumn{2}{|c|}{ Ecologically relevant endpoint (growth, mortality). } \\
\hline $\mathrm{Q}_{2}$ & & 2 & 2 & 2 & \multicolumn{2}{|l|}{ Subchronic exposure duration } \\
\hline$Q_{3}$ & & 1 & 1 & 1 & \multicolumn{2}{|l|}{ NOAEL endpoint } \\
\hline $\mathrm{U}$ & & 3 & 3 & 3 & \multicolumn{2}{|l|}{ Old study, limited endpoints } \\
\hline Total AF & & 12 & 24 & 36 & \multicolumn{2}{|c|}{$\mathrm{R} * \mathrm{I} * \mathrm{Q}_{1} * \mathrm{Q}_{2} * \mathrm{Q}_{3} * \mathrm{U}=$ Total AF } \\
\hline $\mathrm{QCE}(\mathrm{m}$ & (kg-day) & 49 & 49 & 49 & \multicolumn{2}{|c|}{$Q C E=$ quantified critical endpoint } \\
\hline TRV & & 4.1 & 2.0 & 1.4 & \multicolumn{2}{|c|}{ Toxicity Reference Value $=\mathrm{QCE} /$ Total $\mathrm{AF}$} \\
\hline $\begin{array}{c}\mathrm{R} \\
\text { Value }\end{array}$ & \multicolumn{2}{|c|}{$\begin{array}{c}\text { TRV } \\
\text { (mg/kg-day) }\end{array}$} & \multicolumn{3}{|c|}{ Justification } & Appropriate Functional Group \\
\hline 1 & 4.1 & & \multicolumn{3}{|c|}{$\begin{array}{l}\text { Test organism is in the same order and trophic level } \\
\text { as the functional group members }\end{array}$} & none \\
\hline 2 & 2.0 & & \multicolumn{3}{|c|}{$\begin{array}{l}\text { Test organism is in a different order and same trophic } \\
\text { level from the functional group members }\end{array}$} & AV422, AV432, AV433,AV442 \\
\hline 3 & 1.4 & & \multicolumn{3}{|c|}{$\begin{array}{l}\text { Test organism is in a different order and trophic level } \\
\text { from the functional group members }\end{array}$} & $\begin{array}{l}\text { AV121, AV122, AV132, AV142, } \\
\text { AV143, AV210, AV210A, } \\
\text { AV221, AV222, AV222A, } \\
\text { AV232, AV233, AV241, AV242, } \\
\text { AV310, AV322, AV333, AV342 }\end{array}$ \\
\hline
\end{tabular}


COPC:

Test Organisms:

Exposure Medium:

Test Endpoint:

Reference:
Rat (Omnivore, Order-Rodentia)

Diet

NOAEL

Ivankovic and Preussmann, 1975, Absence of Toxic and Carcinogenic Effects After Administration of High Doses of Chromic Oxide Pigment in Subacute and LongTerm Feeding Experiments in Rats, Food Cosmet, Toxicol.. 13(3): 347-351.
$1800 \mathrm{~g} / \mathrm{kg}$ total dose consumed at highest dose rate, administered 5 days/week for 120 weeks ( $\sim 840$ days total), corrected for \% $\mathrm{Cr}$.

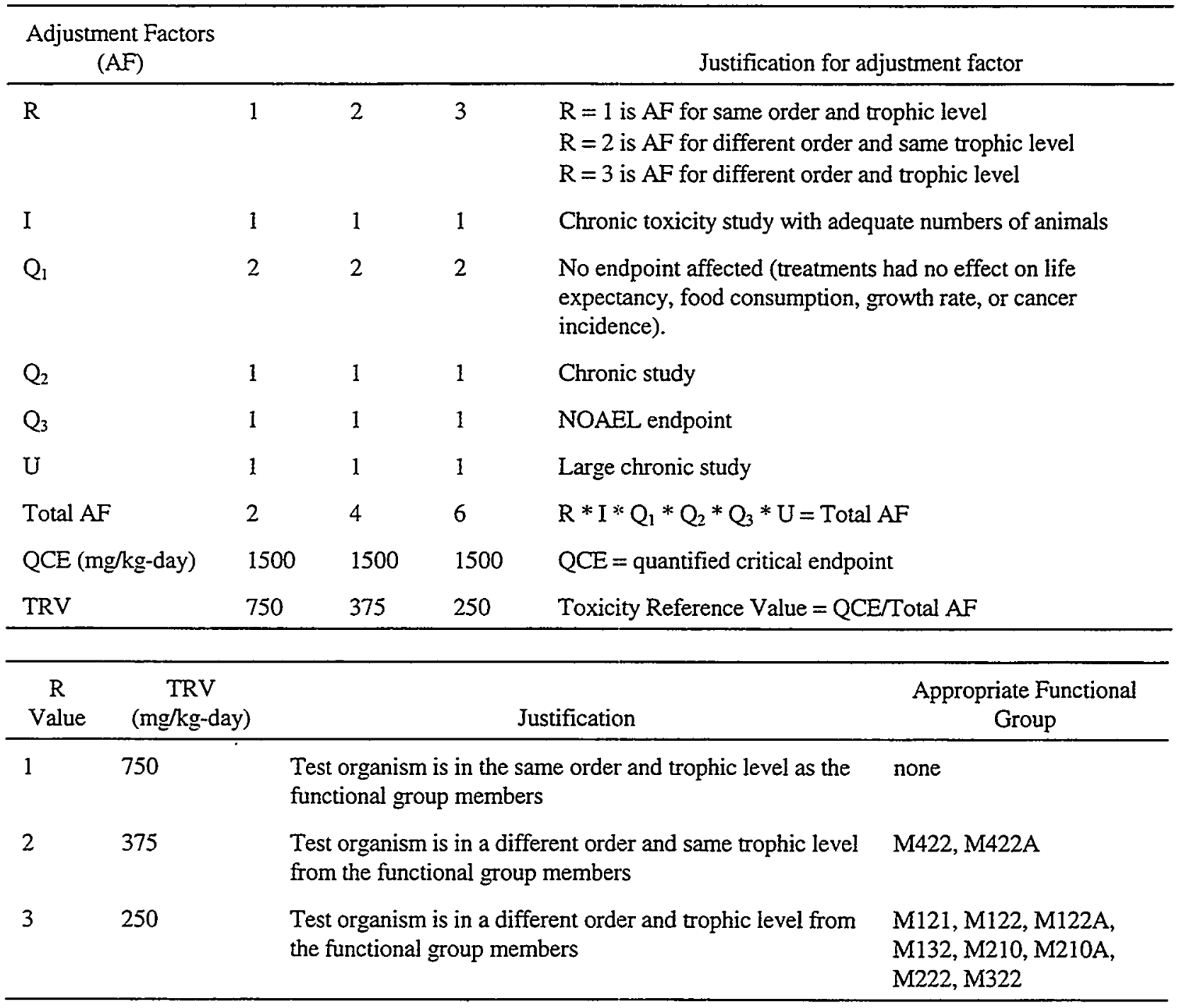


COPC:

Test Organisms: Exposure Medium: Test Endpoint:

Reference:

\section{Chromium (VI) CAS 7440-47-3}

Dog (Omnivore, Order-Carnivora)

Drinking water

NOAEL

Steven et al. (1976) cited in Eisler (1986)

Anwar, R.A., et al., 1961, "Chronic Toxicity Studies. Part III. Chronic Toxicity of Cadmium and Chromium in Dogs", Archives of Environmental Health, 3:456-460.

Steven, J.D. et al., 1976, Effects of Chromium in the Canadian Environment, RCC No. 15017, National Resources Council, Ottawa, Canada.

QCE:
$(11.2 \mathrm{mg} / \mathrm{L})(3.1 \mathrm{~mL} / 100 \mathrm{~g}$ day)(8730g)(1L/1000mL)/8.73 kg BW

\begin{tabular}{|c|c|c|c|c|c|c|}
\hline \multicolumn{5}{|c|}{$\begin{array}{c}\text { Adjustment Factors } \\
(\mathrm{AF})\end{array}$} & \multicolumn{2}{|c|}{ Justification for adjustment factor } \\
\hline $\mathrm{R}$ & & 1 & 2 & 3 & \multicolumn{2}{|c|}{$\begin{array}{l}R=1 \text { is } A F \text { for same order and trophic level } \\
R=2 \text { is } A F \text { for different order and same trophic level } \\
R=3 \text { is } A F \text { for different order and trophic level }\end{array}$} \\
\hline I & & 2 & 2 & 2 & \multicolumn{2}{|c|}{ Smaller number of female dogs only. No males tested. } \\
\hline $\mathrm{Q}_{1}$ & & 1 & 1 & 1 & \multicolumn{2}{|l|}{ No endpoint observed } \\
\hline $\mathrm{Q}_{2}$ & & 1 & 1 & 1 & \multicolumn{2}{|l|}{ Chronic duration (4 years) } \\
\hline$Q_{3}$ & & 1 & 1 & 1 & \multicolumn{2}{|l|}{ NOAEL } \\
\hline $\mathrm{U}$ & & 2 & 2 & 2 & \multicolumn{2}{|c|}{ No reproductive endpoint studied, but good duration of testing. } \\
\hline M & & 0.5 & 0.5 & 0.5 & \multicolumn{2}{|l|}{ Soluble salt placed in the drinking water. } \\
\hline Total A & & 2 & 4 & 6 & \multicolumn{2}{|c|}{$R * I * Q_{1} * Q_{2} * Q_{3} * U * M=$ Total AF } \\
\hline QCE $(n$ & (kg-day) & 0.30 & 0.30 & 0.30 & \multicolumn{2}{|l|}{$\mathrm{QCE}=$ quantified critical endpoint } \\
\hline TRV & & 0.15 & 0.08 & 0.05 & \multicolumn{2}{|c|}{ Toxicity Reference Value $=\mathrm{QCE} /$ Total $\mathrm{AF}$} \\
\hline $\begin{array}{c}\mathrm{R} \\
\text { Value }\end{array}$ & \multicolumn{2}{|c|}{$\begin{array}{c}\text { TRV } \\
\text { (mg/kg-day) }\end{array}$} & & & Justification & Appropriate Functional Group \\
\hline 1 & 0.15 & & \multicolumn{3}{|c|}{$\begin{array}{l}\text { Test organism is in the same order and trophic level as the } \\
\text { functional group members }\end{array}$} & $\mathrm{M} 422 \mathrm{~A}$ \\
\hline 2 & 0.08 & & \multicolumn{3}{|c|}{$\begin{array}{l}\text { Test organism is in a different order and same trophic level } \\
\text { from the functional group members }\end{array}$} & M422 \\
\hline 3 & 0.05 & & \multicolumn{3}{|c|}{$\begin{array}{l}\text { Test organism is in a different order and trophic level from } \\
\text { the functional group members }\end{array}$} & $\begin{array}{l}\text { M121, M122, M122A, M123, } \\
\text { M210, M210A, M222, M322 }\end{array}$ \\
\hline
\end{tabular}


COPC:

Test Organisms:

Exposure Medium:

Test Endpoint:

Reference:

QCE:
Lead CAS 7439-92-1

Chicken (Omnivore, Order-Galliformes)

Diet

NOAEL

Eisler, R., 1988, Lead Hazards to Fish, Wildlife, and Invertebrates: A Synoptic Review, Fish and Wildife Service. Bio. Rep. No. 14. April, 1985.

$26 \mathrm{mg} / \mathrm{kg}$-day
$500 \mathrm{mg} / \mathrm{kg}$ in diet converted to dose by multiplying by $0.105 \mathrm{~kg} /$ day ingestion rate and dividing by $2 \mathrm{~kg} \mathrm{BW}$

\section{Adjustment Factors \\ $(\mathrm{AF})$}

Justification for adjustment factor

\begin{tabular}{|c|c|c|c|c|}
\hline $\mathrm{R}$ & 1 & 2 & 3 & $\begin{array}{l}R=1 \text { is } A F \text { for same order and trophic level } \\
R=2 \text { is } A F \text { for different order and same trophic level } \\
R=3 \text { is } A F \text { for different order and trophic level }\end{array}$ \\
\hline I & 3 & 3 & 3 & Secondary source \\
\hline$Q_{1}$ & 1 & 1 & 1 & Endpoint ecologically relevant (growth) \\
\hline $\mathrm{Q}_{2}$ & 2 & 2 & 2 & Subchronic study \\
\hline $\mathrm{Q}_{3}$ & 1 & 1 & 1 & NOAEL endpoint \\
\hline U & 3 & 3 & 3 & $\begin{array}{l}\text { Limited information. Dietary NOAEL appears consistent for a } \\
\text { variety of species. }\end{array}$ \\
\hline Total AF & 18 & 36 & 54 & $\mathrm{R} * \mathrm{I} * \mathrm{Q}_{1} * \mathrm{Q}_{2} * \mathrm{Q}_{3} * \mathrm{U}=$ Total AF \\
\hline $\mathrm{QCE}$ (mg/kg-day) & 26 & 26 & 26 & $\mathrm{QCE}=$ quantified critical endpoint \\
\hline TRV & 1.4 & 0.72 & 0.48 & Toxicity Reference Value $=\mathrm{QCE} /$ Total AF \\
\hline
\end{tabular}

\begin{tabular}{|c|c|c|c|}
\hline $\begin{array}{c}\mathrm{R} \\
\text { Value }\end{array}$ & $\begin{array}{c}\text { TRV } \\
\text { (mg/kg-day) }\end{array}$ & Justification & Appropriate Functional Group \\
\hline 1 & 1.4 & $\begin{array}{l}\text { Test organism is in the same order and trophic level } \\
\text { as the functional group members }\end{array}$ & none \\
\hline 2 & 0.72 & $\begin{array}{l}\text { Test organism is in a different order and same trophic } \\
\text { level from the functional group members }\end{array}$ & AV422, AV432, AV433,AV442 \\
\hline 3 & 0.48 & $\begin{array}{l}\text { Test organism is in a different order and trophic level } \\
\text { from the functional group members }\end{array}$ & $\begin{array}{l}\text { AV121, AV122, AV132, AV142, } \\
\text { AV143, AV210, AV210A, AV221, } \\
\text { AV222, AV222A, AV232, AV233, } \\
\text { AV241, AV242, AV310, AV322, } \\
\text { AV333, AV342 }\end{array}$ \\
\hline
\end{tabular}


COPC:

Test Organisms:

Exposure Medium:

Test Endpoint:

Reference:
Lead CAS 7439-92-1

Rat (Omnivore, Order-Rodentia)

Oral in diet as lead acetate

NOAEL

Azar, A., H.J. Trochimowicz, M.E. Maxfield, 1973, "Review of Lead Studies in Animals Carried Out at Haskell Laboratory: Two-Year Feeding Study and

Response to Hemorrhage Study", In Environmental Health Aspects of Lead:

Proceedings, International Symposium, D. Barth et al. (ed.) Commission of European Communities, pp 199-210.

QCE:

$(100 \mathrm{mg} / \mathrm{kg}$ food $) *(.028 \mathrm{~kg} / \mathrm{day}) / 0.35 \mathrm{~kg} \mathrm{BW}$

\begin{tabular}{|c|c|c|c|c|c|c|}
\hline \multicolumn{5}{|c|}{$\begin{array}{l}\text { Adjustment Factors } \\
\text { (AF) }\end{array}$} & \multicolumn{2}{|c|}{ Justification for adjustment factor } \\
\hline \multicolumn{2}{|l|}{$\mathbf{R}$} & 1 & 2 & 3 & \multicolumn{2}{|c|}{$\begin{array}{l}\mathrm{R}=1 \text { is } \mathrm{AF} \text { for same order and trophic level } \\
\mathrm{R}=2 \text { is } \mathrm{AF} \text { for different order and same trophic level } \\
\mathrm{R}=3 \text { is } \mathrm{AF} \text { for different order and trophic level }\end{array}$} \\
\hline \multicolumn{2}{|l|}{ I } & 1 & 1 & 1 & \multicolumn{2}{|c|}{$\begin{array}{l}50 \text { male and } 50 \text { female rats per dose level. Reproductive three } \\
\text { generation (during critical life stage) study. }\end{array}$} \\
\hline \multicolumn{2}{|l|}{$\mathrm{Q}_{1}$} & 1 & 1 & 1 & \multicolumn{2}{|c|}{$\begin{array}{l}\text { Mortality, \# of tumors, weight gain, \# or pregnancies, \# of pups born } \\
\text { alive, fertility index, gestation index, viability index or lactation } \\
\text { index. Ecologically relevant endpoint. }\end{array}$} \\
\hline \multicolumn{2}{|l|}{$\mathrm{Q}_{2}$} & 1 & 1 & 1 & \multicolumn{2}{|l|}{ Chronic } \\
\hline \multicolumn{2}{|l|}{$\mathrm{Q}_{3}$} & 1 & 1 & 1 & \multicolumn{2}{|l|}{ NOAEL } \\
\hline \multicolumn{2}{|c|}{$U$} & 1 & 1 & 1 & \multicolumn{2}{|c|}{$\begin{array}{l}\mathrm{Pb} \text { as lead acetate was fed for a three-generation six-litter study at } \\
\text { multiple dosages }(0,10,50,100,1000,2000 \mathrm{ppm}) \text {. At } 1000 \text { and } \\
2000 \mathrm{ppm} \text { dietary } \mathrm{Pb} \text {, the average weight of weanling rats was } \\
\text { slightly decreased. At } 10 \mathrm{ppm} \text { stippled cells were increased. A } \\
\text { decrease in ALAD activity was seen at } 50 \mathrm{ppm} \text { (however these are } \\
\text { not considered adverse effects). } 100 \mathrm{ppm} \mathrm{Pb} \text { is considered the } \\
\text { NOAEL. }\end{array}$} \\
\hline \multicolumn{2}{|c|}{ Total AF } & 1 & 2 & 3 & \multicolumn{2}{|l|}{$\mathrm{R} * \mathrm{I} * \mathrm{Q}_{1} * \mathrm{Q}_{2} * \mathrm{Q}_{3} * \mathrm{U}=$ Total AF } \\
\hline \multicolumn{2}{|c|}{$\mathrm{QCE}$ (mg/kg-day) } & 8.0 & 8.0 & 8.0 & \multicolumn{2}{|l|}{$\mathrm{QCE}=$ quantified critical endpoint } \\
\hline \multicolumn{2}{|l|}{ TRV } & 8.0 & 4.0 & 2.7 & \multicolumn{2}{|c|}{ Toxicity Reference Value $=\mathrm{QCE} /$ Total $\mathrm{AF}$} \\
\hline $\begin{array}{c}\mathrm{R} \\
\text { Value }\end{array}$ & \multicolumn{2}{|c|}{$\begin{array}{c}\text { TRV } \\
\text { (mg/kg-day) }\end{array}$} & & & Justification & $\begin{array}{l}\text { Appropriate Functional } \\
\text { Group }\end{array}$ \\
\hline 1 & \multicolumn{2}{|l|}{8.0} & \multicolumn{3}{|c|}{$\begin{array}{l}\text { Test organism is in the same order and trophic level as the } \\
\text { functional group members }\end{array}$} & None \\
\hline 2 & \multicolumn{2}{|l|}{4.0} & \multicolumn{3}{|c|}{$\begin{array}{l}\text { Test organism is in a different order and same trophic level } \\
\text { from the functional group members }\end{array}$} & $\mathrm{M} 422, \mathrm{M} 422 \mathrm{~A}$ \\
\hline 3 & \multicolumn{2}{|l|}{2.7} & \multicolumn{3}{|c|}{$\begin{array}{l}\text { Test organism is in a different order and trophic level from } \\
\text { the functional group members }\end{array}$} & $\begin{array}{l}\text { M121, M122, M122A, } \\
\text { M132, M210, M210A, } \\
\text { M222, M322 }\end{array}$ \\
\hline
\end{tabular}

*Wiseman, J., "Feeding of Non-ruminant Livestock.” Butterworths; Boston, MA. 1987. 
COPC:

Test Organisms:

Exposure Medium:

Test Endpoint:

Reference:
Chickens (Omnivore, Order-Galliformes)

Oral in drinking water

NOAEL

Thaxton, P., L.A. Cogburn, and C.R. Parkhurst, 1973. Dietary mercury as related to the blood chemistry in young chickens. Poultry Science 52:1212-1214 (cited in National Academy of Sciences, 1980. Mineral Tolerance of Domestic Animals. Washington, DC).

$12.1 \mathrm{mg} / \mathrm{kg}$-day
$(125 \mathrm{mg} / \mathrm{L}) *(0.097 \mathrm{~kg} \operatorname{diet} / \mathrm{kg}$ bw/day $) *$

\begin{tabular}{|c|c|c|c|c|}
\hline $\begin{array}{l}\text { Adjustment Factors } \\
\text { (AF) }\end{array}$ & & & & Justification for adjustment factor \\
\hline $\bar{R}$ & 1 & 2 & 3 & $\begin{array}{l}R=1 \text { is } A F \text { for same order and trophic level } \\
R=2 \text { is } A F \text { for different order and same trophic level } \\
R=3 \text { is } A F \text { for different order and trophic level }\end{array}$ \\
\hline I & 2 & 2 & 2 & $\begin{array}{l}\text { Results were inconsistent, however a similar study by Parkhurst and } \\
\text { Thaxton, } 1973^{\mathrm{a}} \text { reported toxic effects in young boilers at } 250 \mathrm{ppm} \\
\text { (similar study) including growth reduction, decreased feed and water } \\
\text { efficiencies, alterations in the sizes of certain organs, } \\
\text { immunosuppression, \& mortality at } 250 \mathrm{ppm} \text { as LOAEL. }\end{array}$ \\
\hline$Q_{\mathbf{I}}$ & 1 & 1 & 1 & $\begin{array}{l}\text { Study determined minor effects of dietary } \mathrm{Hg} \text { on plasma levels of } \\
\text { glucose, total protein, total lipids and other blood chemistry. } \\
\text { Endpoint is possible in receptor in the field. }\end{array}$ \\
\hline $\mathrm{Q}_{2}$ & 1 & 1 & 1 & Chronic exposure (6 weeks) \\
\hline $\mathrm{Q}_{3}$ & 1 & 1 & 1 & NOAEL ( 125 ppm see discussion above) \\
\hline U & 2 & 2 & 2 & $\begin{array}{l}\text { Adequate numbers of test animais, } 120 \text { young chickens at each } 5 \text { dose } \\
\text { levels. Reasonable design. Multiple doses assessed }(0,5,25,125 \text {, } \\
250 \text { ppm) and NOAEL established but no LOAEL and results were } \\
\text { inconsistent.. }\end{array}$ \\
\hline M & 0.5 & 0.5 & 0.5 & Administered as $\mathrm{HgCl}_{2}$ in drinking water. \\
\hline Total AF & 2 & 4 & 6 & $\mathrm{R} * \mathrm{I} * \mathrm{Q}_{1} * \mathrm{Q}_{2} * \mathrm{Q}_{3} * \mathrm{U}=$ Total AF \\
\hline QCE (mg/kg-day) & 12.1 & 12.1 & 12.1 & $\mathrm{QCE}=$ quantified critical endpoint \\
\hline TRV & 6.05 & 3.03 & 2.02 & Toxicity Reference Value $=\mathrm{QCE} /$ Total $\mathrm{AF}$ \\
\hline
\end{tabular}

\begin{tabular}{|c|c|c|c|}
\hline $\begin{array}{c}\mathrm{R} \\
\text { Value }\end{array}$ & $\begin{array}{c}\mathrm{TRV} \\
(\mathrm{mg} / \mathrm{kg} \text {-day) }\end{array}$ & Justification & Appropriate Functional Group \\
\hline 1 & 6.05 & $\begin{array}{l}\text { Test organism is in the same order and trophic level as the } \\
\text { functional group members }\end{array}$ & none \\
\hline 2 & 3.03 & $\begin{array}{l}\text { Test organism is in a different order and same trophic level } \\
\text { from the functional group members }\end{array}$ & $\begin{array}{l}\text { AV422, AV432, AV433, } \\
\text { AV442 }\end{array}$ \\
\hline 3 & 2.02 & $\begin{array}{l}\text { Test organism is in a different order and trophic level from } \\
\text { the functional group members }\end{array}$ & $\begin{array}{l}\text { AV121, AV122, AV132, } \\
\text { AV142, AV143, AV210, } \\
\text { AV210A, AV221, AV222, } \\
\text { AV222A, AV232, AV233, } \\
\text { AV241, AV242, AV310, } \\
\text { AV322, AV333, AV342 }\end{array}$ \\
\hline
\end{tabular}

Parkhurst, C.R., and P. Thaxton, 1973. Toxicity of mercury to young chickens. 1. Effect on growth and mortality. Poultry Science 52:273-276.

* Wiseman, J., "Feeding of Non-ruminant Livestock." Butterworths; Boston, MA. 1987. 
COPC:

Test Organisms:

Exposure Medium:

Test Endpoint:

Reference:

QCE:
Mercury (Inorganic) CAS 7439-97-6

Mouse (Omnivore, Order-Rodentia)

Oral in drinking water

NOAEL

Schroeder and Mitchner, 1975. "Life-term effects of mercury, methylmercury and nine other trace metals on mice" J. Nutr. 105:452.

$0.68 \mathrm{mg} / \mathrm{kg}$-day

Calculated $5 \mathrm{ppm} \mathrm{Hg}$ as mercuric chloride*.

\begin{tabular}{|c|c|c|c|c|c|c|}
\hline \multicolumn{5}{|c|}{$\begin{array}{l}\text { Adjustment Factors } \\
\text { (AF) }\end{array}$} & \multicolumn{2}{|c|}{ Justification for adjustment factor } \\
\hline $\mathrm{R}$ & & 1 & 2 & 3 & \multicolumn{2}{|c|}{$\begin{array}{l}\mathrm{R}=1 \text { is } \mathrm{AF} \text { for same order and trophic level } \\
\mathrm{R}=2 \text { is } \mathrm{AF} \text { for different order and same trophic level } \\
\mathrm{R}=3 \text { is } \mathrm{AF} \text { for different order and trophic level }\end{array}$} \\
\hline I & & 2 & 2 & 2 & \multicolumn{2}{|c|}{$\begin{array}{l}\text { Groups of } 36 \text { to } 54 \text { mice of each sex were exposed. One control } \\
\text { group. At } 5 \mathrm{ppm} \text { longevity tended to decrease in males and increase } \\
\text { in females. }\end{array}$} \\
\hline$Q_{1}$ & & 1 & 1 & 1 & \multicolumn{2}{|c|}{$\begin{array}{l}\text { Body weight, tumors, edema, blanching of incisor teeth, life-spans } \\
\text { and longevities }\end{array}$} \\
\hline $\mathrm{Q}_{2}$ & & 1 & 1 & 1 & \multicolumn{2}{|l|}{ Lifetime exposure } \\
\hline$Q_{3}$ & & 1 & 1 & 1 & \multicolumn{2}{|l|}{ NOAEL } \\
\hline $\mathrm{U}$ & & 2 & 2 & 2 & \multicolumn{2}{|c|}{$\begin{array}{l}\text { No reproductive endpoint or sensitive life stage examined. Random- } \\
\text { bred white Swiss mice of Charles River CD strain. } 5 \mathrm{ppm} \mathrm{Hg} \text { as } \\
\text { mercuric chloride in the basal drinking water. Only one dose tested } \\
\text { and no LOAEL established. }\end{array}$} \\
\hline M & & 0.5 & 0.5 & 0.5 & \multicolumn{2}{|l|}{ Placed in drinking water. } \\
\hline Total A & & 2 & 4 & 6 & \multicolumn{2}{|l|}{$\mathrm{R} * \mathrm{I} * \mathrm{Q}_{1} * \mathrm{Q}_{2} * \mathrm{Q}_{3} * \mathrm{U}=$ Total $\mathrm{AF}$} \\
\hline $\mathrm{QCE}(\mathrm{n}$ & (kg-day) & 0.68 & 0.68 & 0.68 & \multicolumn{2}{|l|}{$\mathrm{QCE}=$ quantified critical endpoint } \\
\hline TRV & & 0.34 & 0.17 & 0.11 & \multicolumn{2}{|c|}{ Toxicity Reference Value $=\mathrm{QCE} / \mathrm{Total} \mathrm{AF}$} \\
\hline $\begin{array}{c}\mathrm{R} \\
\text { Value }\end{array}$ & \multicolumn{2}{|c|}{$\begin{array}{c}\text { TRV } \\
(\mathrm{mg} / \mathrm{kg} \text {-day) }\end{array}$} & & & Justification & Appropriate Functional Group \\
\hline 1 & 0.34 & \multicolumn{4}{|c|}{$\begin{array}{l}\text { Test organism is in the same order and trophic level as the } \\
\text { functional group members }\end{array}$} & none \\
\hline 2 & 0.17 & \multicolumn{4}{|c|}{$\begin{array}{l}\text { Test organism is in a different order and same trophic level } \\
\text { from the functional group members }\end{array}$} & $\mathrm{M} 422, \mathrm{M} 422 \mathrm{~A}$ \\
\hline 3 & 0.11 & \multicolumn{4}{|c|}{$\begin{array}{l}\text { Test organism is in a different order and trophic level from } \\
\text { the functional group members }\end{array}$} & $\begin{array}{l}\text { M121, M122, M122A, M132, } \\
\text { M210, M210A, M222, M322 }\end{array}$ \\
\hline
\end{tabular}

* $\left[(5 \mathrm{mg} \mathrm{Hg} 2 / \mathrm{L}\right.$ water $) *\left(\left(0.0051 \mathrm{~L}\right.\right.$ water $\left.\left./ \mathrm{day}^{* *}\right) / 0.0373 \mathrm{~kg} \mathrm{BW}\right]$

Ingestion rate of water calculated using allometric equation from the Wildlife Factors Handbook (EPA 1993)

$\mathrm{WI}=0.099 \mathrm{BW}^{0.9}$ 
COPC:

Test Organisms:

Exposure Medium:

Test Endpoint:

Reference:
Mallard Duck (Herbivore, Order-Anseriformes, Anas platyrhynchos)

Oral in diet

LOAEL

Heinz, G. H. 1979. Methyl mercury: reproductive and behavioral effects on three generations of mallard ducks. J. Wildl. Mgmt. 43:394-401.

$0.064 \mathrm{mg} / \mathrm{kg}$-day $(0.5 \mathrm{mg} / \mathrm{kg}$ food) $(128 \mathrm{~g}$ food $/$ day $)(1 \mathrm{~kg} / 1000 \mathrm{~g}) / 1 \mathrm{~kg} \mathrm{BW}$

QCE:

Justification for adjustment factor

\begin{tabular}{|c|c|c|c|c|c|c|}
\hline \multicolumn{5}{|c|}{$\begin{array}{l}\text { Adjustment Factors } \\
\text { (AF) }\end{array}$} & \multicolumn{2}{|c|}{ Justification for adjustment factor } \\
\hline $\mathrm{R}$ & & 1 & 2 & 3 & \multicolumn{2}{|c|}{$\begin{array}{l}R=1 \text { is } A F \text { for same order and trophic level } \\
R=2 \text { is } A F \text { for different order and same trophic level } \\
R=3 \text { is } A F \text { for different order and trophic level }\end{array}$} \\
\hline I & & 2 & 2 & 2 & \multicolumn{2}{|c|}{$\begin{array}{l}\text { Only one dose level, however, this was a three generation study } \\
\text { that showed significant effects from control. }\end{array}$} \\
\hline $\mathrm{Q}_{1}$ & & 1 & 1 & 1 & \multicolumn{2}{|c|}{$\begin{array}{l}\text { Endpoints include reproductive endpoints (i.e. \# of eggs and } \\
\text { hatchlings). Ecologically relevant endpoint }\end{array}$} \\
\hline $\mathrm{Q}_{2}$ & & 1 & 1 & 1 & \multicolumn{2}{|l|}{ Chronic } \\
\hline $\mathrm{Q}_{3}$ & & 2 & 2 & 2 & \multicolumn{2}{|l|}{ LOAEL - one dose only } \\
\hline $\mathrm{U}$ & & 2 & 2 & 2 & \multicolumn{2}{|c|}{$\begin{array}{l}3 \text { generations ( }>1 \text { yr. and during a critical life stage) and } \\
\text { reproductive endpoints examined. However, only } 1 \text { dose } \\
\text { considered. }\end{array}$} \\
\hline Total AF & & 8 & 16 & 24 & \multicolumn{2}{|c|}{$\mathrm{R} * \mathrm{I} * \mathrm{Q}_{1} * \mathrm{Q}_{2} * \mathrm{Q}_{3} * \mathrm{U}=$ Total AF } \\
\hline $\mathrm{QCE}(\mathrm{m}$ & kg-day) & 0.064 & 0.064 & 0.064 & \multicolumn{2}{|l|}{$\mathrm{QCE}=$ quantified critical endpoint } \\
\hline TRV & & 0.008 & 0.004 & 0.003 & \multicolumn{2}{|c|}{ Toxicity Reference Value $=\mathrm{QCE} /$ Total $\mathrm{AF}$} \\
\hline $\begin{array}{c}\mathrm{R} \\
\text { Value } \\
\end{array}$ & \multicolumn{2}{|c|}{$\begin{array}{c}\text { TRV } \\
\text { (mg/kg-day) }\end{array}$} & & & ustification & Appropriate Functional Group \\
\hline 1 & 0.008 & \multicolumn{4}{|c|}{$\begin{array}{l}\text { Test organism is in the same order and trophic level as the } \\
\text { functional group members }\end{array}$} & AV142, AV143 \\
\hline 2 & 0.004 & \multicolumn{4}{|c|}{$\begin{array}{l}\text { Test organism is in a different order and same trophic level } \\
\text { from the functional group members }\end{array}$} & AV121, AV122, AV132 \\
\hline 3 & 0.003 & \multicolumn{4}{|c|}{$\begin{array}{l}\text { Test organism is in a different order and trophic level from } \\
\text { the functional group members }\end{array}$} & $\begin{array}{l}\text { AV210, AV210A, AV221, } \\
\text { AV222, AV222A, AV232, } \\
\text { AV233, AV241, AV242, } \\
\text { AV310, AV322, AV333, } \\
\text { AV342, AV422, AV432, } \\
\text { AV433, AV442 }\end{array}$ \\
\hline
\end{tabular}




\section{COPC:}

Test Organisms:

Exposure Medium:

Test Endpoint:

Reference:

QCE:

\section{Mercury (Organic) CAS 7439-97-6}

Mouse (Omnivore, Order-Rodentia)

Oral in drinking water

NOAEL

Schroeder and Mitchner, 1975. "Life-term effects of mercury, methylmercury and nine other trace metals on mice" J. Nutr. 105:452.

$0.14 \mathrm{mg} / \mathrm{kg}$-day $\quad$ Calculated, $1 \mathrm{ppm} \mathrm{Hg}$ as methylmercury acetate*

\begin{tabular}{|c|c|c|c|c|}
\hline $\begin{array}{l}\text { Adjustment Facto } \\
\text { (AF) }\end{array}$ & & & & Justification for adjustment factor \\
\hline $\mathrm{R}$ & 1 & 2 & 3 & $\begin{array}{l}R=1 \text { is } A F \text { for same order and trophic level } \\
R=2 \text { is } A F \text { for different order and same trophic level } \\
R=3 \text { is } A F \text { for different order and trophic level }\end{array}$ \\
\hline I & 2 & 2 & 2 & $\begin{array}{l}\text { Groups of } 36 \text { to } 54 \text { mice of each sex were exposed. One control } \\
\text { group. } 5 \mathrm{ppm} \mathrm{Hg} \text { as methylmercury acetate for } 70 \text { days and } 1 \mathrm{ppm} \\
\text { subsequently in the drinking water. } 5 \mathrm{ppm} \text { was toxic but } 1 \mathrm{ppm} \\
\text { appears to have beneficial effects, with the mice that survived gaining } \\
\text { weight and living longer than litter mates given } 1 \mathrm{ppm} \text { from time of } \\
\text { weaning. }\end{array}$ \\
\hline $\mathrm{Q}_{1}$ & 1 & 1 & 1 & $\begin{array}{l}\text { Body weight, tumors, edema, blanching of incisor teeth, life-spans } \\
\text { and longevities. }\end{array}$ \\
\hline$Q_{2}$ & 1 & 1 & 1 & Lifetime exposure \\
\hline $\mathrm{Q}_{3}$ & 1 & 1 & 1 & NOAEL \\
\hline $\mathrm{U}$ & 2 & 2 & 2 & $\begin{array}{l}\text { Average study design with limited number of doses, and no } \\
\text { reproductive endpoint or sensitive life stage examined. Random-bred } \\
\text { white Swiss mice of Charles River CD strain. Both a NOAEL and } \\
\text { LOAEL established. }\end{array}$ \\
\hline M & 0.5 & 0.5 & 0.5 & Methylmercury acetate placed in drinking water. \\
\hline Total AF & 2 & 4 & 6 & $\mathrm{R} * \mathrm{I} * \mathrm{Q}_{1} * \mathrm{Q}_{2} * \mathrm{Q}_{3} * \mathrm{U}=$ Total AF \\
\hline $\mathrm{QCE}$ (mg/kg-day) & 0.14 & 0.14 & 0.14 & $\mathrm{QCE}=$ quantified critical endpoint \\
\hline TRV & 0.07 & 0.04 & 0.02 & Toxicity Reference Value $=\mathrm{QCE} /$ Total AF \\
\hline
\end{tabular}

\begin{tabular}{llll}
\hline $\begin{array}{l}\mathrm{R} \\
\text { Value }\end{array}$ & $\begin{array}{l}\text { TRV } \\
(\mathrm{mg} / \mathrm{kg} \text {-day })\end{array}$ & Justification & Appropriate Functional Group \\
\hline 1 & 0.07 & $\begin{array}{l}\text { Test organism is in the same order and trophic level as the } \\
\text { functional group members }\end{array}$ & none \\
2 & 0.04 & $\begin{array}{l}\text { Test organism is in a different order and same trophic level } \\
\text { from the functional group members }\end{array}$ & M422, M422A \\
3 & 0.02 & $\begin{array}{l}\text { Test organism is in a different order and trophic level from } \\
\text { the functional group members }\end{array}$ & $\begin{array}{l}\text { M121, M122, M122A, M132, } \\
\text { M210, M210A, M222, M322 }\end{array}$ \\
\hline
\end{tabular}

*[(1 mg Hg$/ \mathrm{L}) *(0.0051 \mathrm{~L}$ water $/$ day $* *) / 0.0373 \mathrm{~kg} \mathrm{BW}]=0.14 \mathrm{mg} / \mathrm{kg} \mathrm{BW}$-day

**Ingestion rate of water calculated using allometric equation from the Wildlife Factors Handbook (EPA 1993) $\mathrm{WI}=0.099 \mathrm{BW}^{0.9}$ 
COPC:

Test Organisms:

Exposure Medium:

Test Endpoint:

Reference:

QCE:
Nickel CAS 7440-02-0

Mallard Duck (Herbivore, Order-Anseriformes)

Oral in diet

NOAEL

Cain, B.W. and E.A. Pafford, 1981, "Effects of Dietary Nickel on Survival and

Growth of Mallard Duckling", Arch. Environm. Contam. Toxicol. 10, 737-745.

$77.4 \mathrm{mg} / \mathrm{kg}$-day $(774 \mathrm{mg} / \mathrm{kg}$ food)(78.2g food/day $)(1 \mathrm{~kg} / 1000 \mathrm{~g}) / 0.782 \mathrm{~kg} \mathrm{BW}$

\begin{tabular}{|c|c|c|c|c|c|c|}
\hline \multicolumn{5}{|c|}{$\begin{array}{l}\text { Adjustment Factors } \\
(\mathrm{AF})\end{array}$} & \multicolumn{2}{|c|}{ Justification for adjustment factor } \\
\hline $\mathrm{R}$ & & 1 & 2 & 3 & \multicolumn{2}{|c|}{$\begin{array}{l}R=1 \text { is } A F \text { for same order and trophic level } \\
R=2 \text { is } A F \text { for different order and same trophic level } \\
R=3 \text { is } A F \text { for different order and trophic level }\end{array}$} \\
\hline I & & 2 & 2 & 2 & \multicolumn{2}{|c|}{$\begin{array}{l}36 \text { ducklings divided into } 6 \text { cages with } 6 \text { birds per cage ( } 3 \text { male } 3 \\
\text { female). } 12 \text { birds were given a dose of either } 176,774 \text {, or } 1069 \\
\text { ppm. }\end{array}$} \\
\hline$Q_{1}$ & & 1 & 1 & 1 & \multicolumn{2}{|c|}{$\begin{array}{l}\text { Development endpoints measured (body weight, bill length, } \\
\text { humerus, heart, liver, gizzard, kidneys). }\end{array}$} \\
\hline $\mathrm{Q}_{2}$ & & 1 & 1 & 1 & \multicolumn{2}{|l|}{ Chronic study (60-90 days) } \\
\hline $\mathrm{Q}_{3}$ & & 1 & 1 & 1 & \multicolumn{2}{|l|}{ NOAEL } \\
\hline U & & 1 & 1 & 1 & \multicolumn{2}{|c|}{$\begin{array}{l}\text { The study considered exposure over } 90 \text { days, the } 774 \mathrm{ppm} \text { dose was } \\
\text { considered a NOAEL and the } 1069 \mathrm{ppm} \text { was the LOAEL. }\end{array}$} \\
\hline Total A & & 2 & 4 & 6 & \multicolumn{2}{|l|}{$\mathrm{R} * \mathrm{I} * \mathrm{Q}_{1} * \mathrm{Q}_{2} * \mathrm{Q}_{3} * \mathrm{U}=$ Total AF } \\
\hline QCE $(n$ & /kg-day) & 77.4 & 77.4 & 77.4 & \multicolumn{2}{|l|}{$\mathrm{QCE}=$ quantified critical endpoint } \\
\hline TRV & & 38.7 & 19.4 & 12.9 & \multicolumn{2}{|c|}{ Toxicity Reference Value $=\mathrm{QCE} /$ Total AF } \\
\hline $\begin{array}{c}\mathrm{R} \\
\text { Value }\end{array}$ & \multicolumn{2}{|c|}{$\begin{array}{c}\text { TRV } \\
\text { (mg/kg-day) }\end{array}$} & & & Justification & $\begin{array}{l}\text { Appropriate Functional } \\
\text { Group }\end{array}$ \\
\hline 1 & 38.7 & & \multicolumn{3}{|c|}{$\begin{array}{l}\text { Test organism is in the same order and trophic level as } \\
\text { the functional group members }\end{array}$} & AV142, AV143 \\
\hline 2 & 19.4 & & \multicolumn{3}{|c|}{$\begin{array}{l}\text { Test organism is in a different order and same trophic } \\
\text { level from the functional group members }\end{array}$} & AV121, AV122, AV132 \\
\hline 3 & 12.9 & & \multicolumn{3}{|c|}{$\begin{array}{l}\text { Test organism is in a different order and trophic level } \\
\text { from the functional group members }\end{array}$} & $\begin{array}{l}\text { AV210, AV210A, AV221, } \\
\text { AV222, AV222A, AV232, } \\
\text { AV233, AV241, AV242, } \\
\text { AV310, AV322, AV333, } \\
\text { AV342, AV422, AV432, } \\
\text { AV433, AV442 }\end{array}$ \\
\hline
\end{tabular}




\section{COPC:}

Test Organisms:

Exposure Medium:

Test Endpoint:

Reference:
Nickel CAS 7440-02-0

Beagle Dog (Omnivore, Order-Carnivora)

Diet

NOAEL

Ambrose, A.M. et al. 1976, Long-Term Toxicologic Assessment of Nickel in Rats and Dogs, J. Food Sci. Technol. 13:181-187.

$114 \mathrm{mg} / \mathrm{kg}$-day $\quad(2500 \mathrm{mg} / \mathrm{kg})(430 \mathrm{~g} / \mathrm{day})(1 \mathrm{~kg} / 1000 \mathrm{~g}) / 9.41 \mathrm{~kg} \mathrm{BW}$

QCE:

\begin{tabular}{|c|c|c|c|c|c|c|}
\hline \multicolumn{5}{|c|}{$\begin{array}{l}\text { Adjustment Factors } \\
(\mathrm{AF})\end{array}$} & \multicolumn{2}{|c|}{ Justification for adjustment factor } \\
\hline \multicolumn{2}{|l|}{$\mathrm{R}$} & 1 & 2 & 3 & \multicolumn{2}{|c|}{$\begin{array}{l}R=1 \text { is } A F \text { for same order and trophic level } \\
R=2 \text { is } A F \text { for different order and same trophic level } \\
R=3 \text { is } A F \text { for different order and trophic level }\end{array}$} \\
\hline \multicolumn{2}{|l|}{ I } & 1 & 1 & 1 & \multicolumn{2}{|c|}{ Chronic toxicity study with adequate numbers of animals } \\
\hline \multicolumn{2}{|l|}{$Q_{1}$} & 1 & 1 & 1 & \multicolumn{2}{|l|}{ Body weight gain } \\
\hline \multicolumn{2}{|l|}{$Q_{2}$} & 1 & 1 & 1 & \multicolumn{2}{|l|}{ Chronic study } \\
\hline \multicolumn{2}{|l|}{$Q_{3}$} & 1 & 1 & 1 & \multicolumn{2}{|l|}{ NOAEL endpoint } \\
\hline \multicolumn{2}{|l|}{$U$} & 2 & 2 & 2 & \multicolumn{2}{|c|}{$\begin{array}{l}\text { Doses given to both males and females at: } 0,100,1000 \text {, and } 2500 \\
\text { ppm. No effects for dogs on diets at } 100 \text { and } 1000 \mathrm{ppm} \text {. }\end{array}$} \\
\hline \multicolumn{2}{|c|}{ Total AF } & 2 & 4 & 6 & \multicolumn{2}{|l|}{$\mathrm{R} * \mathrm{I} * \mathrm{Q}_{1} * \mathrm{Q}_{2} * \mathrm{Q}_{3} * \mathrm{U}=$ Total AF } \\
\hline \multicolumn{2}{|c|}{$\mathrm{QCE}$ (mg/kg-day) } & 114 & 114 & 114 & \multicolumn{2}{|l|}{$Q C E=$ quantified critical endpoint } \\
\hline \multicolumn{2}{|l|}{ TRV } & 57.0 & 28.5 & 19.0 & \multicolumn{2}{|c|}{ Toxicity Reference Value $=\mathrm{QCE} / \mathrm{Total} \mathrm{AF}$} \\
\hline $\begin{array}{c}\mathrm{R} \\
\text { Value }\end{array}$ & \multicolumn{2}{|c|}{$\begin{array}{c}\mathrm{TRV} \\
(\mathrm{mg} / \mathrm{kg} \text {-day) }\end{array}$} & & & Justification & Appropriate Functional Group \\
\hline 1 & \multicolumn{2}{|l|}{57.0} & \multicolumn{3}{|c|}{$\begin{array}{l}\text { Test organism is in the same order and trophic level as the } \\
\text { functional group members }\end{array}$} & $\mathrm{M} 422 \mathrm{~A}$ \\
\hline 2 & \multicolumn{2}{|l|}{28.5} & \multicolumn{3}{|c|}{$\begin{array}{l}\text { Test organism is in a different order and same trophic level } \\
\text { from the functional group members }\end{array}$} & M422 \\
\hline 3 & \multicolumn{2}{|l|}{19.0} & \multicolumn{3}{|c|}{$\begin{array}{l}\text { Test organism is in a different order and trophic level from } \\
\text { the functional group members }\end{array}$} & $\begin{array}{l}\text { M121, M122, M122A, M123, } \\
\text { M210, M210A, M222, M322 }\end{array}$ \\
\hline
\end{tabular}


COPC:

Test Organisms: Exposure Medium: Test Endpoint: Reference:
Selenium (Sodium selenite) CAS 7782-49-2

Mallard (Herbivore, Order-Anseriformes)

Diet

NOAEL

Heinz, G.H. et al. 1987, "Reproduction in mallards fed selenium," Environmental Toxicology and Chemistry, 6:423-433.

Eisler, R. 1985, Selenium Hazards to Fish, Wildlife, and Invertebrates: A Synoptic Review, U.S. Fish and Wildlife Service, Biological Report, 85(1.5).

EPA. 1993, Ch. 9. Selenium Effects at Kesterson Reservoir, A Review of Ecological Assessment Case Studies from a Risk Assessment Perspective, EPA/630/R-92/005.

QCE: $\quad 0.5 \mathrm{mg} / \mathrm{kg}$-day $\quad(5 \mathrm{mg} / \mathrm{kg} * 0.1 \mathrm{~kg}$ feed $) / 1 \mathrm{~kg}$ bird

\begin{tabular}{|c|c|c|c|c|c|c|}
\hline \multicolumn{5}{|c|}{$\begin{array}{l}\text { Adjustment Factors } \\
(\mathrm{AF})\end{array}$} & \multicolumn{2}{|c|}{ Justification for adjustment factor } \\
\hline $\mathrm{R}$ & & 1 & 2 & 3 & \multicolumn{2}{|c|}{$\begin{array}{l}R=1 \text { is } A F \text { for same order and trophic level } \\
R=2 \text { is } A F \text { for different order and same trophic level } \\
R=3 \text { is } A F \text { for different order and trophic level }\end{array}$} \\
\hline I & & 2 & 2 & 2 & \multicolumn{2}{|c|}{$\begin{array}{l}10 \text { pairs for five doses tested, study results consistent with other } \\
\text { studies in chickens and quail, repro/devel. toxicity analysis only. }\end{array}$} \\
\hline$Q_{1}$ & & 1 & 1 & 1 & \multicolumn{2}{|c|}{ Ecologically relevant endpoint (reproduction) } \\
\hline $\mathrm{Q}_{2}$ & & 1 & 1 & 1 & \multicolumn{2}{|l|}{ Chronic study ( $2-4$ mos.) } \\
\hline $\mathrm{Q}_{3}$ & & 1 & 1 & 1 & \multicolumn{2}{|l|}{ NOAEL endpoint } \\
\hline $\mathrm{U}$ & & 1 & 1 & 1 & \multicolumn{2}{|c|}{ Reproductive study only with different forms of selenium } \\
\hline Total Al & & 2 & 4 & 6 & \multicolumn{2}{|c|}{$R * I * Q_{1} * Q_{2} * Q_{3} * U=$ Total AF } \\
\hline $\mathrm{QCE}(\mathrm{m}$ & kg-day) & 0.5 & 0.5 & 0.5 & \multicolumn{2}{|l|}{ QCE $=$ quantified critical endpoint } \\
\hline TRV & & 0.25 & 0.13 & 0.08 & \multicolumn{2}{|c|}{ Toxicity Reference Value $=\mathrm{QCE} /$ Total AF } \\
\hline $\begin{array}{c}R \\
\text { Value }\end{array}$ & \multicolumn{2}{|c|}{$\begin{array}{c}\text { TRV } \\
\text { (mg/kg-day) }\end{array}$} & & & Justification & Appropriate Functional Group \\
\hline 1 & 0.25 & & \multicolumn{3}{|c|}{$\begin{array}{l}\text { Test organism is in the same order and trophic level as the } \\
\text { functional group members }\end{array}$} & AV142, AV143 \\
\hline 2 & 0.13 & & \multicolumn{3}{|c|}{$\begin{array}{l}\text { Test organism is in a different order and same trophic level } \\
\text { from the functional group members }\end{array}$} & AV121, AV122, AV132 \\
\hline 3 & 0.08 & & \multicolumn{3}{|c|}{$\begin{array}{l}\text { Test organism is in a different order and trophic level from } \\
\text { the functional group members }\end{array}$} & $\begin{array}{l}\text { AV210, AV210A, AV221, } \\
\text { AV222, AV222A, AV232, } \\
\text { AV233, AV241, AV242, } \\
\text { AV310, AV322, AV333, } \\
\text { AV342, AV422, AV432, } \\
\text { AV433, AV442 }\end{array}$ \\
\hline
\end{tabular}


COPC:

Test Organisms:

Exposure Medium:

Test Endpoint:

Reference:
Selenium CAS 7782-49-2

Rat (Omnivore, Order-Rodentia)

Drinking water

NOAEL

Rosenfeld, I. and O.A. Beath. 1954. Effect of selenium on reproduction in rats.

Proc. Soc. Exp. Biol. Med. 87:295-297.

$0.20 \mathrm{mg} / \mathrm{kg}$-day $(1.5 \mathrm{mg} / \mathrm{L}$ water $)(46 \mathrm{~mL}$ water $/$ day $)(1 \mathrm{~L} / 1000 \mathrm{~mL}) / 0.35 \mathrm{~kg}$ BW

\begin{tabular}{|c|c|c|c|c|c|c|}
\hline \multicolumn{3}{|c|}{$\begin{array}{l}\text { Adjustment } \\
\text { Factors (AF) }\end{array}$} & & & \multicolumn{2}{|c|}{ Justification for adjustment factor } \\
\hline \multicolumn{2}{|l|}{$\mathrm{R}$} & 1 & 2 & 3 & \multicolumn{2}{|c|}{$\begin{array}{l}R=1 \text { is } A F \text { for same order and trophic level } \\
R=2 \text { is } A F \text { for different order and same trophic level } \\
R=3 \text { is } A F \text { for different order and trophic level }\end{array}$} \\
\hline $\mathrm{I}$ & & 1 & 1 & 1 & \multicolumn{2}{|c|}{ Chronic toxicity studies with adequate numbers of animals } \\
\hline$Q_{3}$ & & 1 & 1 & 1 & \multicolumn{2}{|c|}{$\begin{array}{l}\text { Ecologically relevant endpoint (reproduction, number of young } \\
\text { reared) }\end{array}$} \\
\hline $\mathrm{Q}_{2}$ & & 1 & 1 & 1 & \multicolumn{2}{|l|}{ Chronic study } \\
\hline $\mathrm{Q}_{3}$ & & 1 & 1 & 1 & \multicolumn{2}{|l|}{ NOAEL endpoint } \\
\hline $\mathrm{U}$ & & 1 & 1 & 1 & \multicolumn{2}{|c|}{$\begin{array}{l}\text { Older study, but analyzed } 5 \text { breeding cycles and } 2 \text { generations. } \\
\text { A more recent study by Nobunaga et al. (1979) reports a NOAEL } \\
\text { of } 390 \mathrm{ug} / \mathrm{kg} / \text { day selenite for mice reproductive success. }\end{array}$} \\
\hline $\mathrm{M}$ & & 0.5 & 0.5 & 0.5 & \multicolumn{2}{|l|}{ Placed in drinking water } \\
\hline Total AJ & & 0.5 & 1.0 & 1.5 & \multicolumn{2}{|c|}{$\mathrm{R} * \mathrm{I} * \mathrm{Q}_{1} * \mathrm{Q}_{2} * \mathrm{Q}_{3} * \mathrm{U} * \mathrm{M}=$ Total $\mathrm{AF}$} \\
\hline $\mathrm{QCE}(\mathrm{m}$ & (kg-day) & 0.20 & 0.20 & 0.20 & \multicolumn{2}{|l|}{ QCE = quantified critical endpoint } \\
\hline TRV & & 0.40 & 0.20 & 0.13 & \multicolumn{2}{|c|}{ Toxicity Reference Value $=\mathrm{QCE} /$ Total AF } \\
\hline $\begin{array}{c}\mathrm{R} \\
\text { Value } \\
\end{array}$ & \multicolumn{2}{|c|}{$\begin{array}{c}\text { TRV } \\
\text { (mg/kg-day) }\end{array}$} & & & Istification & $\begin{array}{c}\text { Appropriate Functional } \\
\text { Group }\end{array}$ \\
\hline 1 & \multicolumn{2}{|l|}{0.40} & \multicolumn{3}{|c|}{$\begin{array}{l}\text { Test organism is in the same order and trophic level as the } \\
\text { functional group members }\end{array}$} & none \\
\hline 2 & \multicolumn{2}{|l|}{0.20} & \multicolumn{3}{|c|}{$\begin{array}{l}\text { Test organism is in a different order and same trophic level } \\
\text { from the functional group members }\end{array}$} & $\mathrm{M} 422, \mathrm{M} 422 \mathrm{~A}$ \\
\hline 3 & \multicolumn{2}{|l|}{0.13} & \multicolumn{3}{|c|}{$\begin{array}{l}\text { Test organism is in a different order and trophic level from } \\
\text { the functional group members }\end{array}$} & $\begin{array}{l}\text { M121, M122, M122A, } \\
\text { M132, M210, M210A, } \\
\text { M222, M322 }\end{array}$ \\
\hline
\end{tabular}


COPC:

Test Organisms:

Exposure Medium:

Test Endpoint:

Reference:

QCE:

Turkey (Omnivore, Order-Galliformes)

Oral

LOAEL

Friberg, L., et al., 1979. Handbook on the Toxicology of Metals; Elsevier/North Holland Biomedical Press. Pp. 57-586.

$87.3 \mathrm{mg} / \mathrm{kg}$-day (900 ppm converted with $0.097 \mathrm{~kg} / \mathrm{kg}$ bw/d from Wiseman, 1987)*

\begin{tabular}{|c|c|c|c|c|c|c|}
\hline \multicolumn{5}{|c|}{$\begin{array}{l}\text { Adjustment Factors } \\
\text { (AF) }\end{array}$} & \multicolumn{2}{|l|}{ Justification for adjustment factor } \\
\hline \multicolumn{2}{|l|}{$\mathrm{R}$} & 1 & 2 & 3 & \multicolumn{2}{|c|}{$\begin{array}{l}R=1 \text { is } A F \text { for same order and trophic level } \\
R=2 \text { is } A F \text { for different order and same trophic level } \\
R=3 \text { is } A F \text { for different order and trophic level }\end{array}$} \\
\hline \multicolumn{2}{|l|}{ I } & 1 & 1 & 1 & \multicolumn{2}{|c|}{$\begin{array}{l}\text { Adequate number of organisms used with effects exerted on the } \\
\text { cardiovascular, hepatic, and hematopoietic systems }\end{array}$} \\
\hline \multicolumn{2}{|l|}{$\mathrm{Q}_{1}$} & 1 & 1 & 1 & \multicolumn{2}{|c|}{ Ecologically relevant endpoint (mortality) } \\
\hline \multicolumn{2}{|l|}{$\mathrm{Q}_{2}$} & 1 & 1 & 1 & \multicolumn{2}{|l|}{ Chronic duration (18 weeks) } \\
\hline \multicolumn{2}{|l|}{$\mathrm{Q}_{3}$} & 2 & 2 & 2 & \multicolumn{2}{|l|}{ LOAEL } \\
\hline \multicolumn{2}{|l|}{$\mathrm{U}$} & 1 & 1 & 1 & \multicolumn{2}{|l|}{ Good study design } \\
\hline \multicolumn{2}{|c|}{ Total AF } & 2 & 4 & 6 & \multicolumn{2}{|c|}{$\mathrm{R} * \mathrm{I} * \mathrm{Q}_{1} * \mathrm{Q}_{2} * \mathrm{Q}_{3} * \mathrm{U}=$ Total AF } \\
\hline \multicolumn{2}{|c|}{$\mathrm{QCE}$ (mg/kg-day) } & 87.3 & 87.3 & 87.3 & \multicolumn{2}{|l|}{$\mathrm{QCE}=$ quantified critical endpoint } \\
\hline \multicolumn{2}{|l|}{ TRV } & 43.7 & 21.8 & 14.6 & \multicolumn{2}{|c|}{ Toxicity Reference Value $=\mathrm{QCE} /$ Total AF } \\
\hline $\begin{array}{l}\mathrm{R} \\
\text { Value }\end{array}$ & $\begin{array}{l}\text { TRV } \\
(\mathrm{mg} / \mathrm{kg} \text {-day) }\end{array}$ & & Justificati & & & $\begin{array}{l}\text { Appropriate Functional } \\
\text { Group }\end{array}$ \\
\hline 1 & 43.7 & & $\begin{array}{l}\text { Test orga } \\
\text { the functi }\end{array}$ & $\begin{array}{l}\mathrm{m} \text { is in } \\
\text { al grou }\end{array}$ & $\begin{array}{l}\text { le same order and trophic level as } \\
\text { nembers }\end{array}$ & none \\
\hline 2 & 21.8 & & $\begin{array}{l}\text { Test orga } \\
\text { level from }\end{array}$ & $\begin{array}{l}m \text { is in } \\
\text { ae func }\end{array}$ & $\begin{array}{l}\text { different order and same trophic } \\
\text { nal group members }\end{array}$ & $\begin{array}{l}\text { AV422, AV432, } \\
\text { AV433,AV442 }\end{array}$ \\
\hline 3 & 14.6 & & $\begin{array}{l}\text { Test orga } \\
\text { from the }\end{array}$ & $\begin{array}{l}\mathrm{m} \text { is in } \\
\text { ctiona }\end{array}$ & $\begin{array}{l}\text { different order and trophic level } \\
\text { roup members }\end{array}$ & $\begin{array}{l}\text { AV121, AV122, AV132, } \\
\text { AV142, AV143, AV210, } \\
\text { AV210A, AV221, AV222, } \\
\text { AV222A, AV232, AV233, } \\
\text { AV241, AV242, AV310, } \\
\text { AV322, AV333, AV342 }\end{array}$ \\
\hline
\end{tabular}

*Wiseman, J., "Feeding of Non-ruminant Livestock." Butterworths; Boston, MA. 1987. 
Test Organisms:

Exposure Medium:

Test Endpoint:

Reference:

QCE:
Swine (Omnivore, Order-Artiodactyla)

Oral

NOAEL

Van Vleet, J.F., 1976. Induction of Lesions of Selenium-Vitamin E Deficiency in Pigs Fed Silver; American Journal of Veterinary Research, 37:1415-1420.

$68.0 \mathrm{mg} / \mathrm{kg}$-day (converted with $0.034 \mathrm{~kg} / \mathrm{kg}$ bw/d, Wiseman 1987 )*

\begin{tabular}{|c|c|c|c|c|c|c|}
\hline \multicolumn{5}{|c|}{$\begin{array}{l}\text { Adjustment Factors } \\
\text { (AF) }\end{array}$} & \multicolumn{2}{|l|}{ Justification for adjustment factor } \\
\hline \multicolumn{2}{|l|}{$\mathbf{R}$} & 1 & 2 & 3 & \multicolumn{2}{|c|}{$\begin{array}{l}R=1 \text { is } A F \text { for same order and trophic level } \\
R=2 \text { is } A F \text { for different order and same trophic level } \\
R=3 \text { is } A F \text { for different order and trophic level }\end{array}$} \\
\hline \multicolumn{2}{|l|}{$\mathbf{I}$} & 1 & 1 & 1 & \multicolumn{2}{|c|}{$\begin{array}{l}\text { Two experiments with multiple test groups fed differing diets and } \\
\text { supplemented with varying concentrations of silver acetate }\end{array}$} \\
\hline \multicolumn{2}{|l|}{$Q_{1}$} & 1 & 1 & 1 & \multicolumn{2}{|c|}{ Endpoints relevant (growth, mortality) } \\
\hline \multicolumn{2}{|l|}{$\mathrm{Q}_{2}$} & 2 & 2 & 2 & \multicolumn{2}{|l|}{ Subchronic study (4 weeks) } \\
\hline \multicolumn{2}{|l|}{$\mathrm{Q}_{3}$} & 1 & 1 & 1 & \multicolumn{2}{|l|}{ NOAEL } \\
\hline \multicolumn{2}{|l|}{$\mathrm{U}$} & 1 & 1 & 1 & \multicolumn{2}{|c|}{$\begin{array}{l}\text { Good study design with adequate supporting sources (Walker, } \\
1971 \text { )** }\end{array}$} \\
\hline \multicolumn{2}{|c|}{ Total AF } & 2 & 4 & 6 & \multicolumn{2}{|c|}{$\mathrm{R} * \mathrm{I} * \mathrm{Q}_{1} * \mathrm{Q}_{2} * \mathrm{Q}_{3} * \mathrm{U}=$ Total $\mathrm{AF}$} \\
\hline \multicolumn{2}{|c|}{ QCE (mg/kg-day) } & 68.0 & 68.0 & 68.0 & \multicolumn{2}{|l|}{$\mathrm{QCE}=$ quantified critical endpoint } \\
\hline \multicolumn{2}{|l|}{ TRV } & 34.0 & 17.0 & 11.3 & \multicolumn{2}{|c|}{ Toxicity Reference Value $=\mathrm{QCE} /$ Total AF } \\
\hline $\begin{array}{l}\mathrm{R} \\
\text { Value }\end{array}$ & $\begin{array}{l}\text { TRV } \\
\text { (mg/kg-day }\end{array}$ & & Justificat & & & $\begin{array}{l}\text { Appropriate Functional } \\
\text { Group }\end{array}$ \\
\hline 1 & 34.0 & & $\begin{array}{l}\text { Test orga } \\
\text { the functi }\end{array}$ & $\begin{array}{l}m \text { is in } \\
\text { al grou }\end{array}$ & $\begin{array}{l}\text { e same order and trophic level as } \\
\text { nembers }\end{array}$ & None \\
\hline 2 & 17.0 & & $\begin{array}{l}\text { Test orga } \\
\text { level fron }\end{array}$ & $\begin{array}{l}m \text { is in } \\
\text { he func }\end{array}$ & $\begin{array}{l}\text { different order and same trophic } \\
\text { nal group members }\end{array}$ & $\mathrm{M} 422, \mathrm{M} 422 \mathrm{~A}$ \\
\hline 3 & 11.3 & & $\begin{array}{l}\text { Test orga } \\
\text { from the }\end{array}$ & $\begin{array}{l}\mathrm{m} \text { is in } \\
\text { ctiona }\end{array}$ & $\begin{array}{l}\text { different order and trophic level } \\
\text { oup members }\end{array}$ & $\begin{array}{l}\text { M121, M122, M122A, M123, } \\
\text { M210, M210A, M222, M322 }\end{array}$ \\
\hline
\end{tabular}

* Wiseman, J., "Feeding of Non-ruminant Livestock." Butterworths; Boston, MA. 1987.

**Walker, F., 1971. Experimental Argyria: A Model for Basement Membrane Studies; British Journal of Experimental Pathology, 52:589-593.

COPC:

Test Organisms:

Exposure Medium:

Test Endpoint:

\section{Thallium CAS 7440-28-0}

Quail (Omnivore, Order-Galliformes)

Oral in diet (bread)

FEL 
Reference:

QCE:
Shaw, P.A., 1933, "Toxicity and deposition of thallium in certain game birds," Journal of Pharmacology and Experimental Therapeutics, 48(4):478-487. $12 \mathrm{mg} / \mathrm{kg}$-day

\begin{tabular}{|c|c|c|c|c|c|c|}
\hline \multicolumn{5}{|c|}{$\begin{array}{l}\text { Adjustment Factors } \\
\text { (AF) }\end{array}$} & \multicolumn{2}{|c|}{ Justification for adjustment factor } \\
\hline $\mathrm{R}$ & & 1 & 2 & 3 & \multicolumn{2}{|c|}{$\begin{array}{l}R=1 \text { is } A F \text { for same order and trophic level } \\
R=2 \text { is } A F \text { for different order and same trophic level } \\
R=3 \text { is } A F \text { for different order and trophic level }\end{array}$} \\
\hline I & & 3 & 3 & 3 & \multicolumn{2}{|c|}{$\begin{array}{l}\text { Very old study, doses and effects poorly characterized, only high } \\
\text { doses and lethal endpoints considered }\end{array}$} \\
\hline $\mathrm{Q}_{1}$ & & 1 & 1 & 1 & \multicolumn{2}{|l|}{ Ecologically relevant endpoint (lethality) } \\
\hline $\mathrm{Q}_{2}$ & & 3 & 3 & 3 & \multicolumn{2}{|l|}{ Acute duration } \\
\hline $\mathrm{Q}_{3}$ & & 3 & 3 & 3 & \multicolumn{2}{|l|}{ FEL for lethality } \\
\hline $\mathrm{U}$ & & 3 & 3 & 3 & \multicolumn{2}{|c|}{ Very old study, poorly designed and analyzed } \\
\hline Total AF & & 81 & 162 & 243 & \multicolumn{2}{|l|}{$\mathrm{R} * \mathrm{I} * \mathrm{Q}_{1} * \mathrm{Q}_{2} * \mathrm{Q}_{3} * \mathrm{U}=$ Total $A F$} \\
\hline $\mathrm{QCE}(\mathrm{m}$ & (kg-day) & 12 & 12 & 12 & \multicolumn{2}{|l|}{$\mathrm{QCE}=$ quantified critical endpoint } \\
\hline TRV & & 0.15 & 0.07 & 0.05 & \multicolumn{2}{|c|}{ Toxicity Reference Value $=\mathrm{QCE} /$ Total AF } \\
\hline $\begin{array}{c}\mathrm{R} \\
\text { Value }\end{array}$ & \multicolumn{2}{|c|}{$\begin{array}{c}\text { TRV } \\
\text { (mg/kg-day) }\end{array}$} & & & Justification & $\begin{array}{l}\text { Appropriate Functional } \\
\text { Group }\end{array}$ \\
\hline 1 & 0.15 & & \multicolumn{3}{|c|}{$\begin{array}{l}\text { Test organism is in the same order and trophic level as the } \\
\text { functional group members }\end{array}$} & none \\
\hline 2 & 0.07 & & \multicolumn{3}{|c|}{$\begin{array}{l}\text { Test organism is in a different order and same trophic level } \\
\text { from the functional group members }\end{array}$} & $\begin{array}{l}\text { AV422, AV432, } \\
\text { AV433,AV442 }\end{array}$ \\
\hline 3 & 0.05 & & \multicolumn{3}{|c|}{$\begin{array}{l}\text { Test organism is in a different order and trophic level from } \\
\text { the functional group members }\end{array}$} & $\begin{array}{l}\text { AV121, AV122, AV132, } \\
\text { AV142, AV143, AV210, } \\
\text { AV210A, AV221, AV222, } \\
\text { AV222A, AV232, AV233, } \\
\text { AV241, AV242, AV310, } \\
\text { AV322, AV333, AV342 }\end{array}$ \\
\hline
\end{tabular}


COPC:

Test Organisms:

Exposure Medium:

Test Endpoint:

Reference:

QCE:
Thallium CAS 7440-28-0

Rat (Omnivore, Order-Rodentia)

Oral in Diet

LOAEL Hair loss

Downs, W., Scott, J., Steadman, L., Maynard, E., 1960, "Acute and Sub-acute

Toxicity Studies of Thallium Compounds", Industrial Hygiene Joumal, pp. 399406.

$1.8 \mathrm{mg} / \mathrm{kg}$-day Specified (Average between 1-3 depending on the BW)

\begin{tabular}{|c|c|c|c|c|c|c|}
\hline \multicolumn{3}{|c|}{$\begin{array}{l}\text { Adjustment } \\
\text { Factors (AF) }\end{array}$} & & & \multicolumn{2}{|c|}{ Justification for adjustment factor } \\
\hline \multicolumn{2}{|l|}{$\mathrm{R}$} & 1 & 2 & 3 & \multicolumn{2}{|c|}{$\begin{array}{l}R=1 \text { is } A F \text { for same order and trophic level } \\
R=2 \text { is } A F \text { for different order and same trophic level } \\
R=3 \text { is } A F \text { for different order and trophic level }\end{array}$} \\
\hline \multicolumn{2}{|l|}{ I } & 2 & 2 & 2 & \multicolumn{2}{|c|}{ Smaller number of male and female rats tested, no juveniles tested. } \\
\hline \multicolumn{2}{|l|}{$\mathrm{Q}_{1}$} & 1 & 1 & 1 & \multicolumn{2}{|l|}{ Ecologically relevant endpoint } \\
\hline \multicolumn{2}{|l|}{$\mathrm{Q}_{2}$} & 2 & 2 & 2 & \multicolumn{2}{|l|}{ Subchronic duration } \\
\hline \multicolumn{2}{|l|}{$Q_{3}$} & 2 & 2 & 2 & \multicolumn{2}{|l|}{ LOAEL } \\
\hline \multicolumn{2}{|l|}{$\mathrm{U}$} & 2 & 2 & 2 & \multicolumn{2}{|c|}{$\begin{array}{l}\text { Good design, a variety of compounds tested, reproductive endpoints } \\
\text { not examined. Compound is thallium acetate. Similar } \\
\text { responsiveness for thallium oxide. }\end{array}$} \\
\hline \multicolumn{2}{|c|}{ Total AF } & 16 & 32 & 48 & \multicolumn{2}{|l|}{$\mathrm{R} * \mathrm{I} * \mathrm{Q}_{1} * \mathrm{Q}_{2} * \mathrm{Q}_{3} * \mathrm{U}=$ Total AF } \\
\hline \multicolumn{2}{|c|}{$\mathrm{QCE}$ (mg/kg-day) } & 1.8 & 1.8 & 1.8 & \multicolumn{2}{|l|}{$\mathrm{QCE}=$ quantified critical endpoint } \\
\hline \multicolumn{2}{|l|}{ TRV } & 0.11 & 0.06 & 0.04 & \multicolumn{2}{|c|}{ Toxicity Reference Value $=\mathrm{QCE} /$ Total AF } \\
\hline $\begin{array}{c}\mathrm{R} \\
\text { Value }\end{array}$ & \multicolumn{2}{|c|}{$\begin{array}{c}\mathrm{TRV} \\
\text { (mg/kg-day) }\end{array}$} & & & Justification & $\begin{array}{l}\text { Appropriate Functional } \\
\text { Group }\end{array}$ \\
\hline 1 & \multicolumn{2}{|l|}{0.11} & \multicolumn{3}{|c|}{$\begin{array}{l}\text { Test organism is in the same order and trophic level as the } \\
\text { functional group members }\end{array}$} & none \\
\hline 2 & \multicolumn{2}{|l|}{0.06} & \multicolumn{3}{|c|}{$\begin{array}{l}\text { Test organism is in a different order and same trophic level } \\
\text { from the functional group members }\end{array}$} & $\mathrm{M} 422, \mathrm{M} 422 \mathrm{~A}$ \\
\hline 3 & \multicolumn{2}{|l|}{0.04} & \multicolumn{3}{|c|}{$\begin{array}{l}\text { Test organism is in a different order and trophic level from } \\
\text { the functional group members }\end{array}$} & $\begin{array}{l}\text { M121, M122, M122A, } \\
\text { M132, M210, M210A, } \\
\text { M222, M322 }\end{array}$ \\
\hline
\end{tabular}


COPC:

Test Organisms:

Exposure Medium:

Test Endpoint:

Reference:

QCE:

\section{1,1,1 Trichloroethane CAS 71-55-6}

Mouse (Omnivore, Order-Rodentia)

Drinking water

NOAEL

Lane, R.W., B.L. Riddle, and J.F. Borzelleca. 1982. "Effects of 1,2-

dichloroethane and 1,1,1-trichoroethane in drinking water on reproduction and development in mice." Toxicol. Appl. Pharmacol. 63: 409-421.

$1000 \mathrm{mg} / \mathrm{kg}$-day body weight $0.035 \mathrm{~kg}$; water consumption: $6 \mathrm{ml} / \mathrm{d}$ (from study).

\begin{tabular}{|c|c|c|c|c|c|c|}
\hline \multicolumn{5}{|c|}{$\begin{array}{l}\text { Adjustment Factors } \\
\text { (AF) }\end{array}$} & \multicolumn{2}{|c|}{ Justification for adjustment factor } \\
\hline \multicolumn{2}{|l|}{$\mathrm{R}$} & 1 & 2 & 3 & \multicolumn{2}{|c|}{$\begin{array}{l}R=1 \text { is } A F \text { for same order and trophic level } \\
R=2 \text { is } A F \text { for different order and same trophic level } \\
R=3 \text { is } A F \text { for different order and trophic level }\end{array}$} \\
\hline I & & 1 & 1 & 1 & \multicolumn{2}{|c|}{$\begin{array}{l}\text { Study exposure through } 2 \text { generations and included critical life } \\
\text { stages. }\end{array}$} \\
\hline $\mathrm{Q}_{1}$ & & 1 & 1 & 1 & \multicolumn{2}{|c|}{$\begin{array}{l}\text { Ecologically relevant endpoint (pup survival, weight gain, fertility, } \\
\text { gestation, viability, lactation). }\end{array}$} \\
\hline $\mathrm{Q}_{2}$ & & 1 & 1 & 1 & \multicolumn{2}{|l|}{ Chronic } \\
\hline $\mathrm{Q}_{3}$ & & 1 & 1 & 1 & \multicolumn{2}{|l|}{ NOAEL } \\
\hline $\mathrm{U}$ & & 2 & 2 & 2 & \multicolumn{2}{|c|}{$\begin{array}{l}\text { Because no significant differences were observed at any dose level } \\
\text { the maximum dose considered was a NOAEL. }\end{array}$} \\
\hline M & & 0.5 & 0.5 & 0.5 & \multicolumn{2}{|l|}{ Placed in the drinking water. } \\
\hline Total A] & & 1 & 2 & 3 & \multicolumn{2}{|c|}{$R * I * Q_{1} * Q_{2} * Q_{3} * U * M=$ Total AF } \\
\hline QCE $(m$ & /kg-day) & 1000 & 1000 & 1000 & \multicolumn{2}{|l|}{$\mathrm{QCE}=$ quantified critical endpoint } \\
\hline TRV & & 1000 & 500 & 333 & \multicolumn{2}{|c|}{ Toxicity Reference Value = QCE/Total AF } \\
\hline $\begin{array}{c}\mathrm{R} \\
\text { Value }\end{array}$ & \multicolumn{2}{|c|}{$\begin{array}{c}\mathrm{TRV} \\
(\mathrm{mg} / \mathrm{kg}-\text { day })\end{array}$} & & & Justification & $\begin{array}{l}\text { Appropriate Functional } \\
\text { Group }\end{array}$ \\
\hline 1 & 1000 & & \multicolumn{3}{|c|}{$\begin{array}{l}\text { Test organism is in the same order and trophic level as } \\
\text { the functional group members }\end{array}$} & none \\
\hline 2 & 500 & & \multicolumn{3}{|c|}{$\begin{array}{l}\text { Test organism is in a different order and same trophic } \\
\text { level from the functional group members }\end{array}$} & $\mathrm{M} 422, \mathrm{M} 422 \mathrm{~A}$ \\
\hline 3 & 333 & & \multicolumn{3}{|c|}{$\begin{array}{l}\text { Test organism is in a different order and trophic level } \\
\text { from the functional group members }\end{array}$} & $\begin{array}{l}\text { M122, M122A, M121, } \\
\text { M123, M132 M210, } \\
\text { M210A, M222, M322 }\end{array}$ \\
\hline
\end{tabular}


COPC:

Test Organisms:

Exposure Medium:

Test Endpoint:

Reference:

\section{1,2,4-Trichlorobenzene CAS 120-82-1}

Rat (Omnivore, Order-Rodentia)

Oral

NOAEL

Carlson, G.P., and R.G., Tardiff, 1976, Effect of Chlorinated Benzenes on the Metabolism of Foreign Organic Compounds, Toxicology and Applied Pharmacology, 36:383-394.

Kitchin, K.T. and M.T. Ebron, 1980, "Maternal hepatic and embryonic effects of 1,2,4-trichlorobenzene in the rat, rabbit, and beagle dog," Environmental Res., 31:362-373.

QCE: $\quad 20 \mathrm{mg} / \mathrm{kg}$-day

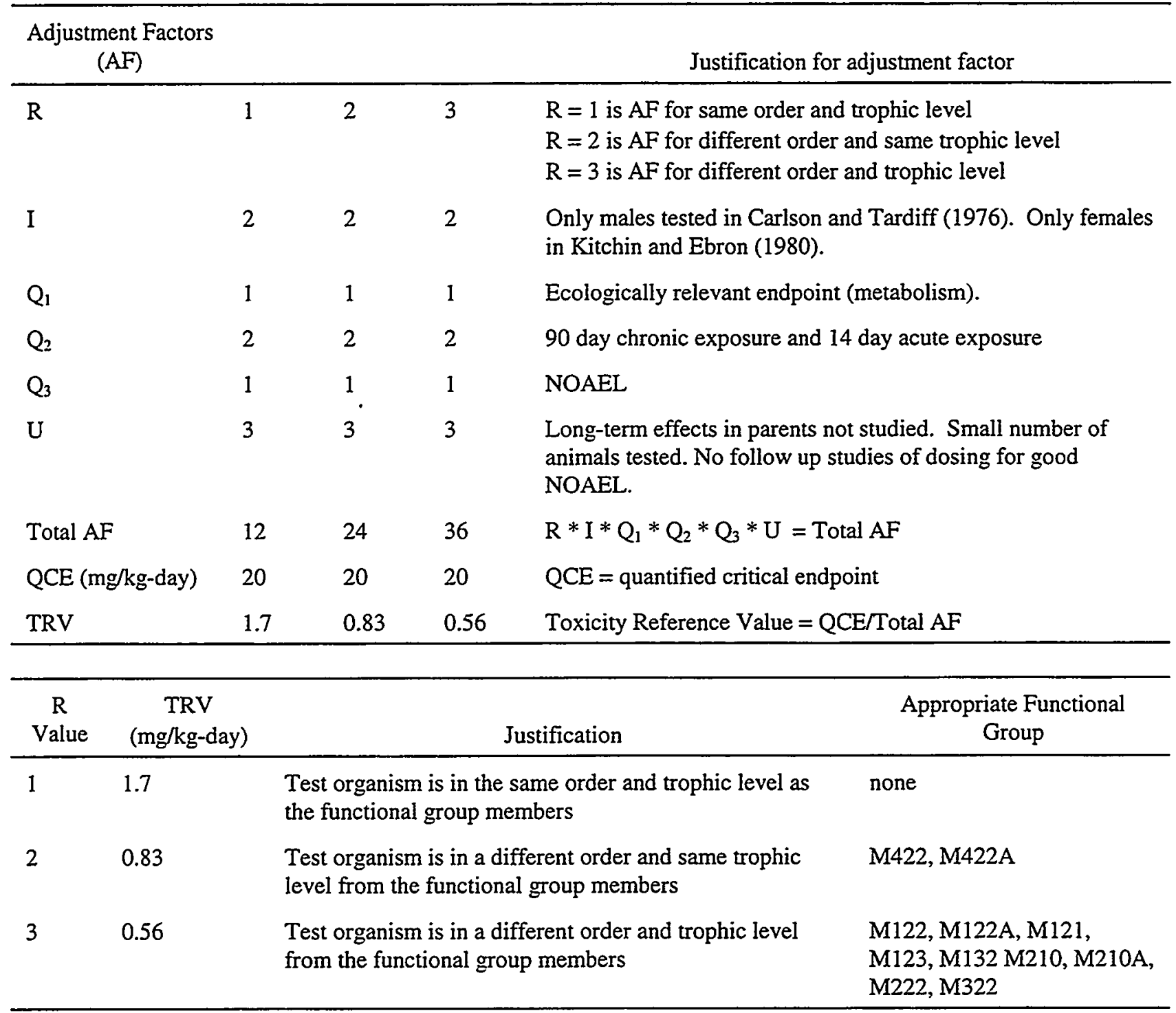


COPC:

Test Organisms:

Exposure Medium:

Test Endpoint:

Reference:
Mouse (Omnivore, Order-Rodentia)

Drinking water

NOAEL

Lane, R.W., B.L. Riddle, and J.F. Bozelleca. 1982. Effects of 1,2-

dichloroehtane and 1,1,1-trichloroethane in drinking water on reproduction and development in mice. Toxicol. Appl. Pharmacol. 63:409-421.

$50 \mathrm{mg} / \mathrm{kg}$-day

\section{QCE:}

Justification for adjustment factor

\begin{tabular}{|c|c|c|c|c|c|c|}
\hline \multicolumn{5}{|c|}{$\begin{array}{l}\text { Adjustment Factors } \\
\text { (AF) }\end{array}$} & \multicolumn{2}{|l|}{ Justification for adjustment factor } \\
\hline \multicolumn{2}{|l|}{$\mathrm{R}$} & 1 & 2 & 3 & \multicolumn{2}{|c|}{$\begin{array}{l}R=1 \text { is } A F \text { for same order and trophic level } \\
R=2 \text { is } A F \text { for different order and same trophic level } \\
R=3 \text { is } A F \text { for different order and trophic level }\end{array}$} \\
\hline \multicolumn{2}{|l|}{ I } & 1 & 1 & 1 & \multicolumn{2}{|c|}{$\begin{array}{l}\text { Study exposure through } 2 \text { generations and included critical life } \\
\text { stages. Three dose levels: } 5,15 \text {, and } 50 \mathrm{mg} / \mathrm{kg} / \text { day. }\end{array}$} \\
\hline \multicolumn{2}{|l|}{$\mathrm{Q}_{1}$} & 1 & 1 & 1 & \multicolumn{2}{|c|}{$\begin{array}{l}\text { Ecologically relevant endpoint (pup survival, weight gain, fertility, } \\
\text { gestation, viability, lactation, reproduction). }\end{array}$} \\
\hline \multicolumn{2}{|l|}{$\mathrm{Q}_{2}$} & 1 & 1 & 1 & \multicolumn{2}{|l|}{ Chronic study ( 2 generations) } \\
\hline \multicolumn{2}{|l|}{$\mathrm{Q}_{3}$} & 1 & 1 & 1 & \multicolumn{2}{|l|}{ NOAEL } \\
\hline \multicolumn{2}{|l|}{$\mathrm{U}$} & 2 & 2 & 2 & \multicolumn{2}{|c|}{$\begin{array}{l}\text { Because no significant differences were observed at any dose level } \\
\text { the maximum dose considered was a NOAEL. }\end{array}$} \\
\hline \multicolumn{2}{|l|}{ M } & 0.5 & 0.5 & 0.5 & \multicolumn{2}{|l|}{ Placed in the drinking water. } \\
\hline \multicolumn{2}{|c|}{ Total AF } & 1 & 2 & 3 & \multicolumn{2}{|c|}{$\mathrm{R} * \mathrm{I} * \mathrm{Q}_{1} * \mathrm{Q}_{2} * \mathrm{Q}_{3} * \mathrm{U} * \mathrm{M}=$ Total AF } \\
\hline \multicolumn{2}{|c|}{$\mathrm{QCE}(\mathrm{mg} / \mathrm{kg}$-day) } & 50 & 50 & 50 & \multicolumn{2}{|l|}{ QCE $=$ quantified critical endpoint } \\
\hline \multicolumn{2}{|l|}{ TRV } & 50 & 25 & 17 & \multicolumn{2}{|c|}{ Toxicity Reference Value $=\mathrm{QCE} /$ Total $\mathrm{AF}$} \\
\hline $\begin{array}{l}\mathrm{R} \\
\text { Value }\end{array}$ & $\begin{array}{l}\text { TRV } \\
\text { (mg/kg-day) }\end{array}$ & & Justifica & & & $\begin{array}{l}\text { Appropriate Functional } \\
\text { Group }\end{array}$ \\
\hline 1 & 50 & & $\begin{array}{l}\text { Test org } \\
\text { the func }\end{array}$ & $\mathrm{m}$ is $\mathrm{i}$ & $\begin{array}{l}\text { e same order and trophic level as } \\
\text { nembers }\end{array}$ & none \\
\hline 2 & 25 & & $\begin{array}{l}\text { Test org } \\
\text { level fro }\end{array}$ & $\begin{array}{l}\mathrm{m} \text { is } \mathrm{i} \\
\text { e fun }\end{array}$ & $\begin{array}{l}\text { different order and same trophic } \\
\text { nal group members }\end{array}$ & M422, M422A \\
\hline 3 & 17 & & $\begin{array}{l}\text { Test org } \\
\text { from the }\end{array}$ & $\begin{array}{l}\mathrm{m} \text { is } \mathrm{i} \\
\text { ction }\end{array}$ & $\begin{array}{l}\text { different order and trophic level } \\
\text { roup members }\end{array}$ & $\begin{array}{l}\text { M121, M122, M122A, M132, } \\
\text { M210, M210A, M222, M322 }\end{array}$ \\
\hline
\end{tabular}


COPC:

Test Organisms:

Exposure Medium:

Test Endpoint:

Reference:

\section{1,2-Dichloroethane CAS 107-06-2}

Chicken (Omnivore, Order-Galliformes)

Oral in diet

NOAEL

Alumot, E., M. Meidler, and P. Holstein. 1976. Tolerance and acceptable daily intake of ethylene dichloride in the chicken diet. FD. Cosmet. Toxicol. 14:111114.

QCE:
$17.2 \mathrm{mg} / \mathrm{kg}$-day $(250 \mathrm{mg} / \mathrm{kg}$ food $)(0.11 \mathrm{~kg}$ food/day $) / 1.6 \mathrm{~kg} \mathrm{BW}$

\begin{tabular}{|c|c|c|c|c|c|c|}
\hline \multicolumn{5}{|c|}{$\begin{array}{l}\text { Adjustment Factors } \\
(\mathrm{AF})\end{array}$} & \multicolumn{2}{|l|}{ Justification for adjustment factor } \\
\hline \multicolumn{2}{|l|}{$\mathrm{R}$} & 1 & 2 & 3 & \multicolumn{2}{|c|}{$\begin{array}{l}R=1 \text { is } A F \text { for same order and trophic level } \\
R=2 \text { is } A F \text { for different order and same trophic level } \\
R=3 \text { is } A F \text { for different order and trophic level }\end{array}$} \\
\hline \multicolumn{2}{|l|}{ I } & 2 & 2 & 2 & \multicolumn{2}{|c|}{ Chickens given 1,2-dichloroehtane at two doses: 250 and $500 \mathrm{ppm}$. } \\
\hline \multicolumn{2}{|l|}{$\mathrm{Q}_{1}$} & 1 & 1 & 1 & \multicolumn{2}{|c|}{ Ecologically relevant endpoint (reproduction) } \\
\hline \multicolumn{2}{|l|}{$\mathrm{Q}_{2}$} & 1 & 1 & 1 & \multicolumn{2}{|c|}{ Chronic study ( 2 years and during a critical lifestage) } \\
\hline \multicolumn{2}{|l|}{$Q_{3}$} & 1 & 1 & 1 & \multicolumn{2}{|l|}{ NOAEL } \\
\hline \multicolumn{2}{|l|}{$\mathrm{U}$} & 1 & 1 & 1 & \multicolumn{2}{|c|}{$\begin{array}{l}\text { Egg production was reduced at the } 500 \mathrm{ppm} \text { dose but was not } \\
\text { affected at the } 250 \mathrm{ppm} \text { dose, due to this result the } 250 \mathrm{ppm} \text { was } \\
\text { considered the NOAEL and the } 500 \mathrm{ppm} \text { dose the LOAEL. }\end{array}$} \\
\hline \multicolumn{2}{|c|}{ Total AF } & 2 & 4 & 6 & \multicolumn{2}{|c|}{$\mathrm{R} * \mathrm{I} * \mathrm{Q}_{1} * \mathrm{Q}_{2} * \mathrm{Q}_{3} * \mathrm{U}=$ Total AF } \\
\hline \multicolumn{2}{|c|}{$\mathrm{QCE}$ (mg/kg-day) } & 17.2 & 17.2 & 17.2 & \multicolumn{2}{|l|}{$\mathrm{QCE}=$ quantified critical endpoint } \\
\hline \multicolumn{2}{|l|}{ TRV } & 8.6 & 4.3 & 2.9 & \multicolumn{2}{|c|}{ Toxicity Reference Value $=\mathrm{QCE} /$ Total AF } \\
\hline $\begin{array}{l}\mathrm{R} \\
\text { Value }\end{array}$ & $\begin{array}{l}\text { TRV } \\
\text { (mg/kg-day) }\end{array}$ & & Justificati & & & $\begin{array}{l}\text { Appropriate Functional } \\
\text { Group }\end{array}$ \\
\hline 1 & 8.6 & & $\begin{array}{l}\text { Test orgar } \\
\text { the functi }\end{array}$ & $\begin{array}{l}n \text { is in } \\
1 \text { grou }\end{array}$ & $\begin{array}{l}\text { le same order and trophic level as } \\
\text { members }\end{array}$ & none \\
\hline 2 & 4.3 & & $\begin{array}{l}\text { Test orgar } \\
\text { level from }\end{array}$ & $\mathrm{m}$ is in & $\begin{array}{l}\text { different order and same trophic } \\
\text { nal group members }\end{array}$ & $\begin{array}{l}\text { AV422, AV432, } \\
\text { AV433,AV442 }\end{array}$ \\
\hline 3 & 2.9 & & $\begin{array}{l}\text { Test orgar } \\
\text { from the } f\end{array}$ & $\mathrm{~m}$ is in & $\begin{array}{l}\text { different order and trophic level } \\
\text { roup members }\end{array}$ & $\begin{array}{l}\text { AV121, AV122, AV132, } \\
\text { AV142, AV143, AV210, } \\
\text { AV210A, AV221, AV222, } \\
\text { AV222A, AV232, AV233, } \\
\text { AV241, AV242, AV310, } \\
\text { AV322, AV333, AV342 }\end{array}$ \\
\hline
\end{tabular}


COPC:

Test Organisms:

Exposure Medium:

Test Endpoint:

Reference:

\section{1,4-Dioxane CAS 123-91-1}

Rat (Omnivore, Order-Rodentia)

Oral intubation

NOAEL

Giavini, E., C. Vismara, and L. Broccia. 1985. Teratogenesis study of dioxane in rats. Toxicol. Lett. 26:85-88.

$0.5 \mathrm{mg} / \mathrm{kg}$-day

QCE:

Justification for adjustment factor

\begin{tabular}{|c|c|c|c|c|c|c|}
\hline \multicolumn{5}{|c|}{$\begin{array}{l}\text { Adjustment Factors } \\
\text { (AF) }\end{array}$} & \multicolumn{2}{|l|}{ Justification for adjustment factor } \\
\hline \multicolumn{2}{|l|}{$\mathrm{R}$} & 1 & 2 & 3 & \multicolumn{2}{|c|}{$\begin{array}{l}R=1 \text { is } A F \text { for same order and trophic level } \\
R=2 \text { is } A F \text { for different order and same trophic level } \\
R=3 \text { is } A F \text { for different order and trophic level }\end{array}$} \\
\hline \multicolumn{2}{|l|}{ I } & 1 & 1 & 1 & \multicolumn{2}{|c|}{$\begin{array}{l}\text { Rats were given 1,4-dioxane at three dose levels: } 0.25,0.5 \text {, and } 1.0 \\
\mathrm{mg} / \mathrm{kg} / \text { day. }\end{array}$} \\
\hline \multicolumn{2}{|l|}{$Q_{1}$} & 1 & 1 & 1 & \multicolumn{2}{|c|}{ Ecologically relevant endpoint (reproduction) } \\
\hline \multicolumn{2}{|l|}{$\mathrm{Q}_{2}$} & 1 & 1 & 1 & \multicolumn{2}{|c|}{ Chronic study (days 6-15 of gestation) } \\
\hline \multicolumn{2}{|l|}{$Q_{3}$} & 1 & 1 & 1 & \multicolumn{2}{|l|}{ NOAEL } \\
\hline \multicolumn{2}{|l|}{$\mathrm{U}$} & 1 & 1 & 1 & \multicolumn{2}{|c|}{$\begin{array}{l}\text { Maternal toxicity and reduced fetal weights were observed among } \\
\text { the rats receiving the } 1.0 \mathrm{mg} / \mathrm{kg} / \text { day dose while the other two doses } \\
\text { had no effects on the rats. The } 0.5 \mathrm{mg} / \mathrm{kg} / \text { day dose was thus } \\
\text { considered the NOAEL and the } 1.0 \mathrm{mg} / \mathrm{kg} / \text { day dose was considered } \\
\text { the LOAEL. }\end{array}$} \\
\hline \multicolumn{2}{|c|}{ Total AF } & 1 & 2 & 3 & \multicolumn{2}{|c|}{$R * I * Q_{1} * Q_{2} * Q_{3} * U=$ Total AF } \\
\hline \multicolumn{2}{|c|}{$\mathrm{QCE}$ (mg/kg-day) } & 0.5 & 0.5 & 0.5 & \multicolumn{2}{|l|}{$\mathrm{QCE}=$ quantified critical endpoint } \\
\hline \multicolumn{2}{|l|}{ TRV } & 0.50 & 0.25 & 0.17 & \multicolumn{2}{|c|}{ Toxicity Reference Value $=\mathrm{QCE} /$ Total AF } \\
\hline $\begin{array}{l}\mathrm{R} \\
\text { Value }\end{array}$ & $\begin{array}{l}\text { TRV } \\
\text { (mg/kg-day) }\end{array}$ & & Tustificati & & & $\begin{array}{l}\text { Appropriate Functional } \\
\text { Group }\end{array}$ \\
\hline 1 & 0.50 & & $\begin{array}{l}\text { Test orga } \\
\text { he functi }\end{array}$ & is in & $\begin{array}{l}\text { same order and trophic level as } \\
\text { embers }\end{array}$ & none \\
\hline 2 & 0.25 & & $\begin{array}{l}\text { Test orga } \\
\text { evel from }\end{array}$ & $\begin{array}{l}n \text { is in } \\
\text { e func }\end{array}$ & $\begin{array}{l}\text { different order and same trophic } \\
\text { nal group members }\end{array}$ & $\mathrm{M} 422, \mathrm{M} 422 \mathrm{~A}$ \\
\hline 3 & 0.17 & & $\begin{array}{l}\text { Test orga } \\
\text { Tom the }\end{array}$ & $\begin{array}{l}m \text { is in } \\
\text { ctional }\end{array}$ & $\begin{array}{l}\text { different order and trophic level } \\
\text { oup members }\end{array}$ & $\begin{array}{l}\text { M121, M122, M122A, M132, } \\
\text { M210, M210A, M222, M322 }\end{array}$ \\
\hline
\end{tabular}

COPC:

Test Organisms:
Acetonitrile CAS 75-05-8

Rat (Omnivore, Order-Rodentia) 
Exposure Medium:

Test Endpoint:

Reference:

QCE:
Oral (gavage)

NOAEL

International Research and Development Corp., IRDC, 1981, "Acetonitrile, Teratology study in rats," Unpublished study sponsored by Monsanto Company. $190 \mathrm{mg} / \mathrm{kg}$-day

\begin{tabular}{|c|c|c|c|c|c|c|}
\hline \multicolumn{5}{|c|}{$\begin{array}{l}\text { Adjustment Factors } \\
\text { (AF) }\end{array}$} & \multicolumn{2}{|c|}{ Justification for adjustment factor } \\
\hline \multicolumn{2}{|l|}{$\mathrm{R}$} & 1 & 2 & 3 & \multicolumn{2}{|c|}{$\begin{array}{l}R=1 \text { is } A F \text { for same order and trophic level } \\
R=2 \text { is } A F \text { for different order and same trophic level } \\
R=3 \text { is } A F \text { for different order and trophic level }\end{array}$} \\
\hline \multicolumn{2}{|l|}{ I } & 2 & 2 & 2 & \multicolumn{2}{|c|}{$\begin{array}{l}\text { Groups of } 25 \text { Charles River rats treated by gavage with } 0,124,190 \text {, } \\
\text { or } 275 \mathrm{mg} / \mathrm{kg} \text {-day of acetonitrile on gestation days } 6 \text { to } 19 .\end{array}$} \\
\hline \multicolumn{2}{|l|}{$Q_{1}$} & 1 & 1 & 1 & \multicolumn{2}{|l|}{ Ecologically relevant endpoint } \\
\hline \multicolumn{2}{|l|}{$\mathrm{Q}_{2}$} & 2 & 2 & 2 & \multicolumn{2}{|l|}{ Subchronic (14 day) study } \\
\hline \multicolumn{2}{|l|}{$Q_{3}$} & 1 & 1 & 1 & \multicolumn{2}{|l|}{ NOAEL } \\
\hline \multicolumn{2}{|l|}{$\mathrm{U}$} & 3 & 3 & 3 & \multicolumn{2}{|c|}{ Inadequate information, unpublished study. } \\
\hline \multicolumn{2}{|c|}{ Total AF } & 12 & 24 & 36 & \multicolumn{2}{|c|}{$\mathrm{R} * \mathrm{I} * \mathrm{Q}_{1} * \mathrm{Q}_{2} * \mathrm{Q}_{3} * \mathrm{U}=$ Total $\mathrm{AF}$} \\
\hline \multicolumn{2}{|c|}{ QCE (mg/kg-day) } & 190 & 190 & 190 & \multicolumn{2}{|l|}{$\mathrm{QCE}=$ quantified critical endpoint } \\
\hline \multicolumn{2}{|l|}{ TRV } & 16 & 7.9 & 5.3 & \multicolumn{2}{|c|}{ Toxicity Reference Value $=\mathrm{QCE} /$ Total AF } \\
\hline $\begin{array}{l}\mathrm{R} \\
\text { Value } \\
\end{array}$ & \multicolumn{2}{|c|}{$\begin{array}{l}\text { TRV } \\
(\mathrm{mg} / \mathrm{kg} \text {-day) }\end{array}$} & \multicolumn{2}{|c|}{ Justification } & & $\begin{array}{l}\text { Appropriate Functional } \\
\text { Group }\end{array}$ \\
\hline 1 & \multicolumn{2}{|l|}{16} & \multicolumn{3}{|c|}{$\begin{array}{l}\text { Test organism is in the same order and trophic level as } \\
\text { the functional group members }\end{array}$} & none \\
\hline 2 & \multicolumn{2}{|l|}{7.9} & \multicolumn{3}{|c|}{$\begin{array}{l}\text { Test organism is in a different order and same trophic } \\
\text { level from the functional group members }\end{array}$} & $\mathrm{M} 422, \mathrm{M} 422 \mathrm{~A}$ \\
\hline 3 & 5.3 & \multicolumn{4}{|c|}{$\begin{array}{l}\text { Test organism is in a different order and trophic level } \\
\text { from the functional group members }\end{array}$} & $\begin{array}{l}\text { M122, M122A, M121, } \\
\text { M123, M132 M210, M210A, } \\
\text { M222, M322 }\end{array}$ \\
\hline
\end{tabular}


COPC:

Test Organisms:

Exposure Medium:

Test Endpoint:

Reference:

QCE:

Mouse (Omnivore, Order-Rodentia)

Oral (gavage)

LOAEL

Nawrot, P.S. and R.E. Staples. 1979. "Embryofetal toxicity and teratogenicity of benzene and toluene in the mouse." Teratology. 19: 41A.

$263.6 \mathrm{mg} / \mathrm{kg}$-day

$(0.3 \mathrm{~mL}$ Benzene $/ \mathrm{kg} \mathrm{BW})(0.8787 \mathrm{~g}$ Benzene $/ \mathrm{mL}$ Benzene $)(1000 \mathrm{mg} / \mathrm{g})=263.6 \mathrm{mg} / \mathrm{kg}$-day

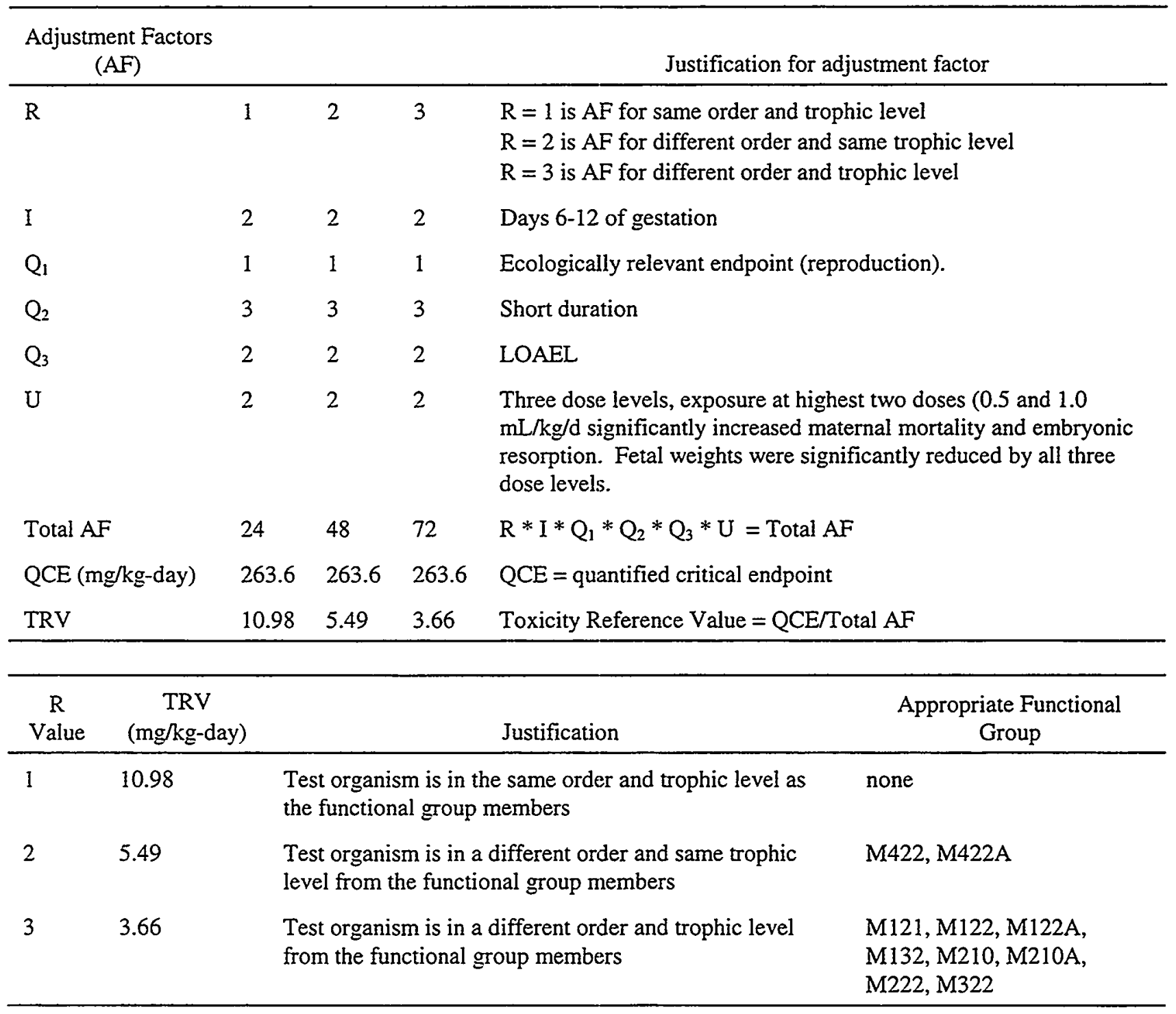


COPC:

Test Organisms:

Exposure Medium:

Test Endpoint:

Reference:

QCE:
Mouse (Omnivore, Order-Rodentia)

Oral (gavage)

FEL

Klein, M., 1963. "Susceptibility of Strain B6AF/j Hybrid Infant Mice to Tumorigenesis with 1,2-Benxanthracene, deoxycyclic acid, and 3methylcholanthrene", Cancer Research, 23:1701-1707.

\begin{tabular}{|c|c|c|c|c|c|c|}
\hline \multicolumn{5}{|c|}{$\begin{array}{l}\text { Adjustment Factors } \\
\text { (AF) }\end{array}$} & \multicolumn{2}{|c|}{ Justification for adjustment factor } \\
\hline \multicolumn{2}{|l|}{$\mathrm{R}$} & 1 & 2 & 3 & \multicolumn{2}{|c|}{$\begin{array}{l}R=1 \text { is } A F \text { for same order and trophic level } \\
R=2 \text { is } A F \text { for different order and same trophic level } \\
R=3 \text { is } A F \text { for different order and trophic level }\end{array}$} \\
\hline \multicolumn{2}{|l|}{ I } & 2 & 2 & 2 & \multicolumn{2}{|l|}{ Infant males tested. } \\
\hline \multicolumn{2}{|l|}{$Q_{1}$} & 1 & 1 & 1 & \multicolumn{2}{|l|}{ Cancer endpoint } \\
\hline \multicolumn{2}{|l|}{$\mathrm{Q}_{2}$} & 1 & 1 & 1 & \multicolumn{2}{|l|}{ Chronic (547-day) study } \\
\hline \multicolumn{2}{|l|}{$Q_{3}$} & 3 & 3 & 3 & \multicolumn{2}{|l|}{ FEL } \\
\hline \multicolumn{2}{|l|}{$\mathrm{U}$} & 3 & 3 & 3 & \multicolumn{2}{|c|}{$\begin{array}{l}\text { Statistical evaluation of data not reported. Number of animals tested } \\
\text { not reported. }\end{array}$} \\
\hline \multicolumn{2}{|c|}{ Total AF } & 18 & 36 & 54 & \multicolumn{2}{|l|}{$\mathrm{R} * \mathrm{I} * \mathrm{Q}_{1} * \mathrm{Q}_{2} * \mathrm{Q}_{3} * \mathrm{U}=$ Total $\mathrm{AF}$} \\
\hline \multicolumn{2}{|c|}{ QCE (mg/kg-day) } & 500 & 500 & 500 & \multicolumn{2}{|l|}{$\mathrm{QCE}=$ quantified critical endpoint } \\
\hline \multicolumn{2}{|l|}{ TRV } & 27.8 & 13.9 & 9.26 & \multicolumn{2}{|c|}{ Toxicity Reference Value $=\mathrm{QCE} /$ Total AF } \\
\hline $\begin{array}{c}\mathrm{R} \\
\text { Value }\end{array}$ & \multicolumn{2}{|c|}{$\begin{array}{l}\text { TRV } \\
\text { (mg/kg-day) }\end{array}$} & & & Justification & Appropriate Functional Group \\
\hline 1 & 27.8 & \multicolumn{4}{|c|}{$\begin{array}{l}\text { Test organism is in the same order and trophic level as the } \\
\text { functional group members }\end{array}$} & none \\
\hline 2 & 13.9 & \multicolumn{4}{|c|}{$\begin{array}{l}\text { Test organism is in a different order and same trophic level } \\
\text { from the functional group members }\end{array}$} & $\mathrm{M} 422, \mathrm{M} 422 \mathrm{~A}$ \\
\hline 3 & 9.26 & \multicolumn{4}{|c|}{$\begin{array}{l}\text { Test organism is in a different order and trophic level from } \\
\text { the functional group members }\end{array}$} & $\begin{array}{l}\text { M121, M122, M122A, M132, } \\
\text { M210, M210A, M222, M322 }\end{array}$ \\
\hline
\end{tabular}


COPC:

Test Organisms:

Exposure Medium:

Test Endpoint:

Reference:
Rat (Omnivore, Order-Rodentia)

Diet

NOAEL

National Toxicology Program (NTP), 1985, Twenty-six week subchronic study and modified mating trial in F344 rats. Butyl benyl phthalate. Final Report. Project No. 12307-02-03, Hazelton Laboratories America, unpublished study, cited in IRIS.

QCE: $\quad 159 \mathrm{mg} / \mathrm{kg}$-day

\begin{tabular}{|c|c|c|c|c|c|c|}
\hline \multicolumn{2}{|c|}{$\begin{array}{l}\text { Adjustment } \\
\text { Factors (AF) }\end{array}$} & & & & \multicolumn{2}{|c|}{ Justification for adjustment factor } \\
\hline $\mathrm{R}$ & & 1 & 2 & 3 & \multicolumn{2}{|c|}{$\begin{array}{l}R=1 \text { is } A F \text { for same order and trophic level } \\
R=2 \text { is } A F \text { for different order and same trophic level } \\
R=3 \text { is } A F \text { for different order and trophic level }\end{array}$} \\
\hline \multicolumn{2}{|l|}{ I } & 3 & 3 & 3 & \multicolumn{2}{|c|}{$\begin{array}{l}\text { Only } 15 \text { males per group were tested. No females or juveniles } \\
\text { tested. }\end{array}$} \\
\hline \multicolumn{2}{|l|}{$Q_{1}$} & 1 & 1 & 1 & \multicolumn{2}{|l|}{ Ecologically relevant endpoint } \\
\hline \multicolumn{2}{|l|}{$\mathrm{Q}_{2}$} & 2 & 2 & 2 & \multicolumn{2}{|l|}{ Subchronic study } \\
\hline \multicolumn{2}{|l|}{$\mathrm{Q}_{3}$} & 1 & 1 & 1 & \multicolumn{2}{|l|}{ NOAEL endpoint } \\
\hline \multicolumn{2}{|l|}{$\mathrm{U}$} & 2 & 2 & 2 & \multicolumn{2}{|c|}{$\begin{array}{l}\text { Good overall design but no supporting studies of chronic duration } \\
\text { available }\end{array}$} \\
\hline \multicolumn{2}{|c|}{ Total AF } & 12 & 24 & 36 & \multicolumn{2}{|c|}{$\mathrm{R} * \mathrm{I} * \mathrm{Q}_{1} * \mathrm{Q}_{2} * \mathrm{Q}_{3} * \mathrm{U}=$ Total $\mathrm{AF}$} \\
\hline \multicolumn{2}{|c|}{$\begin{array}{l}\mathrm{QCE}(\mathrm{mg} / \mathrm{kg}- \\
\text { day) }\end{array}$} & 159 & 159 & 159 & \multicolumn{2}{|l|}{$\mathrm{QCE}=$ quantified critical endpoint } \\
\hline \multicolumn{2}{|l|}{ TRV } & 13.3 & 6.63 & 4.42 & \multicolumn{2}{|c|}{ Toxicity Reference Value $=\mathrm{QCE} /$ Total AF } \\
\hline $\begin{array}{c}\mathrm{R} \\
\text { Value }\end{array}$ & \multicolumn{2}{|c|}{$\begin{array}{c}\text { TRV } \\
\text { (mg/kg-day) }\end{array}$} & & & Justification & $\begin{array}{l}\text { Appropriate Functional } \\
\text { Group }\end{array}$ \\
\hline 1 & 13.3 & & \multicolumn{3}{|c|}{$\begin{array}{l}\text { Test organism is in the same order and trophic level as } \\
\text { the functional group members }\end{array}$} & none \\
\hline 2 & 6.63 & & \multicolumn{3}{|c|}{$\begin{array}{l}\text { Test organism is in a different order and same trophic } \\
\text { level from the functional group members }\end{array}$} & $\mathrm{M} 422, \mathrm{M} 422 \mathrm{~A}$ \\
\hline 3 & 4.42 & & \multicolumn{3}{|c|}{$\begin{array}{l}\text { Test organism is in a different order and trophic level } \\
\text { from the functional group members }\end{array}$} & $\begin{array}{l}\text { M121, M122, M122A, } \\
\text { M132, M210, M210A, } \\
\text { M222, M322 }\end{array}$ \\
\hline
\end{tabular}


COPC:

Test Organisms:

Exposure Medium:

Test Endpoint:

Reference:
Carbon disulfide CAS 75-15-0

Rabbit and rat (Herbivore, Order-Lagomorpha; Omnivore, Order-Rodentia)

Inhalation

NOAEL

Hardin, B.D., et al., 1981. "Testing of Selected Workplace Chemicals for

Teratogenic Potential", Scandinavian Journal of Work and Environmental Health, 7(4):66-75.

QCE:
$11 \mathrm{mg} / \mathrm{kg}$-day $\left(62.3 \mathrm{mg} / \mathrm{m}^{3}\right) *\left(1.6 \mathrm{~m}^{3} /\right.$ day $)(6 \mathrm{~h} / 24 \mathrm{~h})(0.5$ adsorption $) /$

$(1.13 \mathrm{~kg} \mathrm{BW})$

\begin{tabular}{|c|c|c|c|c|c|c|}
\hline \multicolumn{5}{|c|}{$\begin{array}{l}\text { Adjustment Factors } \\
\text { (AF) }\end{array}$} & \multicolumn{2}{|c|}{ Justification for adjustment factor } \\
\hline \multicolumn{2}{|l|}{$\mathbf{R}$} & 1 & 2 & 3 & \multicolumn{2}{|c|}{$\begin{array}{l}\mathrm{R}=1 \text { is } \mathrm{AF} \text { for same order and trophic level } \\
\mathrm{R}=2 \text { is } \mathrm{AF} \text { for different order and same trophic level } \\
\mathrm{R}=3 \text { is } \mathrm{AF} \text { for different order and trophic level }\end{array}$} \\
\hline \multicolumn{2}{|l|}{ I } & 3 & 3 & 3 & \multicolumn{2}{|l|}{ Low number (29) of female rats tested. } \\
\hline \multicolumn{2}{|l|}{$Q_{1}$} & 1 & 1 & 1 & \multicolumn{2}{|c|}{ Ecologically relevant endpoint (reproduction). } \\
\hline \multicolumn{2}{|l|}{$\mathrm{Q}_{2}$} & 2 & 2 & 2 & \multicolumn{2}{|l|}{ Subchronic exposure } \\
\hline \multicolumn{2}{|l|}{$\mathrm{Q}_{3}$} & 1 & 1 & 1 & \multicolumn{2}{|l|}{ NOAEL } \\
\hline \multicolumn{2}{|l|}{$U$} & 2 & 2 & 2 & \multicolumn{2}{|c|}{$\begin{array}{l}\text { Multispecies study that evaluated reproductive toxicological } \\
\text { endpoints, such as reproduction. Supporting oral chronic toxicity } \\
\text { studies are lacking, actual data not presented. }\end{array}$} \\
\hline \multicolumn{2}{|c|}{ Total AF } & 12 & 24 & 36 & \multicolumn{2}{|l|}{$\mathrm{R} * \mathrm{I} * \mathrm{Q}_{1} * \mathrm{Q}_{2} * \mathrm{Q}_{3} * \mathrm{U}=$ Total AF } \\
\hline \multicolumn{2}{|c|}{ QCE (mg/kg-day) } & 11 & 11 & 11 & \multicolumn{2}{|l|}{$\mathrm{QCE}=$ quantified critical endpoint } \\
\hline \multicolumn{2}{|l|}{ TRV } & 0.92 & 0.46 & 0.31 & \multicolumn{2}{|c|}{ Toxicity Reference Value $=\mathrm{QCE} /$ Total AF } \\
\hline $\begin{array}{c}\mathrm{R} \\
\text { Value }\end{array}$ & \multicolumn{2}{|c|}{$\begin{array}{l}\mathrm{TRV}(\mathrm{mg} / \mathrm{kg}- \\
\text { day) }\end{array}$} & & & Justification & Appropriate Functional Group \\
\hline 1 & \multicolumn{2}{|l|}{0.92} & \multicolumn{3}{|c|}{$\begin{array}{l}\text { Test organism is in the same order and trophic level as the } \\
\text { functional group members }\end{array}$} & none \\
\hline 2 & 0.46 & \multicolumn{4}{|c|}{$\begin{array}{l}\text { Test organism is in a different order and same trophic level } \\
\text { from the functional group members }\end{array}$} & $\begin{array}{l}\text { M121, M122, M122A, M123, } \\
\text { M132 }\end{array}$ \\
\hline 3 & 0.31 & \multicolumn{4}{|c|}{$\begin{array}{l}\text { Test organism is in a different order and trophic level from } \\
\text { the functional group members }\end{array}$} & $\begin{array}{l}\text { M210, M210A, M222, M322, } \\
\text { M422, M422A }\end{array}$ \\
\hline
\end{tabular}

*Data of inhalation, BW and adsorption acquired from IRIS. 
COPC:

Test Organisms:

Exposure Medium:

Test Endpoint:

Reference:

QCE:
Carbon tetrachloride CAS 56-23-5

Rat (Omnivore, Order-Rodentia)

Oral in diet

NOAEL

Reproduction

Alumot, E., Nachtomi, E., Mandel. E., and Holstein, P., 1976, "Tolerance and Acceptable Daily Intake of Chlorinated Fumigants in the Rat Diet", Fd. Cosmet. Toxicol. , 14:105-110.

$10 \mathrm{mg} / \mathrm{kg}$-day
Average of $10-18 \mathrm{mg} / \mathrm{kg}$ bw-day specified in article

\begin{tabular}{|c|c|c|c|c|c|c|}
\hline \multicolumn{5}{|c|}{$\begin{array}{l}\text { Adjustment Factors } \\
\qquad(\mathrm{AF})\end{array}$} & \multicolumn{2}{|c|}{ Justification for adjustment factor } \\
\hline $\mathrm{R}$ & & 1 & 2 & 3 & \multicolumn{2}{|c|}{$\begin{array}{l}R=1 \text { is } A F \text { for same order and trophic level } \\
R=2 \text { is } A F \text { for different order and same trophic level } \\
R=3 \text { is } A F \text { for different order and trophic level }\end{array}$} \\
\hline I & & 1 & 1 & 1 & \multicolumn{2}{|c|}{ Adequate numbers of male and females tested (180) } \\
\hline$Q_{1}$ & & 1 & 1 & 1 & \multicolumn{2}{|c|}{ Ecologically relevant endpoint (reproduction, growth, fertility). } \\
\hline $\mathrm{Q}_{2}$ & & 1 & 1 & 1 & \multicolumn{2}{|l|}{ Chronic (2 year) study } \\
\hline $\mathrm{Q}_{3}$ & & 1 & 1 & 1 & \multicolumn{2}{|l|}{ NOAEL endpoint } \\
\hline $\mathrm{U}$ & & 1 & 1 & 1 & \multicolumn{2}{|c|}{ Reproductive endpoints and sensitive life stage examined. } \\
\hline Total A & & 1 & 2 & 3 & \multicolumn{2}{|c|}{$\mathrm{R} * \mathrm{I} * \mathrm{Q}_{1} * \mathrm{Q}_{2} * \mathrm{Q}_{3} * \mathrm{U}=$ Total AF } \\
\hline $\mathrm{QCE}(\mathrm{m}$ & /kg-day) & 10 & 10 & 10 & \multicolumn{2}{|l|}{$\mathrm{QCE}=$ quantified critical endpoint } \\
\hline TRV & & 10 & 5.0 & 3.3 & \multicolumn{2}{|c|}{ Toxicity Reference Value $=\mathrm{QCE} /$ Total AF } \\
\hline $\begin{array}{c}\mathrm{R} \\
\text { Value }\end{array}$ & \multicolumn{2}{|c|}{$\begin{array}{c}\mathrm{RV} \\
(\mathrm{mg} / \mathrm{kg} \text {-day) }\end{array}$} & \multicolumn{3}{|c|}{ Justification } & Appropriate Functional Group \\
\hline 1 & \multicolumn{2}{|l|}{10} & \multicolumn{3}{|c|}{$\begin{array}{l}\text { Test organism is in the same order and trophic level as the } \\
\text { functional group members }\end{array}$} & None \\
\hline 2 & \multicolumn{2}{|l|}{5.0} & \multicolumn{3}{|c|}{$\begin{array}{l}\text { Test organism is in a different order and same trophic level } \\
\text { from the functional group members }\end{array}$} & $\mathrm{M} 422, \mathrm{M} 422 \mathrm{~A}$ \\
\hline 3 & \multicolumn{2}{|l|}{3.3} & \multicolumn{3}{|c|}{$\begin{array}{l}\text { Test organism is in a different order and trophic level from } \\
\text { the functional group members }\end{array}$} & $\begin{array}{l}\text { M121, M122, M122A, M132, } \\
\text { M210, M210A, M222, M322 }\end{array}$ \\
\hline
\end{tabular}


COPC:

Test Organisms:

Exposure Medium:

Test Endpoint:

Reference:

\section{Chloroform CAS 67-66-3}

Rat (Omnivore, Order-Rodentia)

Gavage

NOAEL

Palmer, A.K. et al., 1979, "Safety Evaluation of Toothpaste Containing

Chloroform II. Long Term Studies in Rats", Journal of Environmental

Pathology and Toxicology 2:821-833.

QCE:

$150 \mathrm{mg} / \mathrm{kg}$-day

\begin{tabular}{|c|c|c|c|c|c|c|}
\hline \multicolumn{5}{|c|}{$\begin{array}{l}\text { Adjustment Factors } \\
\qquad(\mathrm{AF})\end{array}$} & \multicolumn{2}{|c|}{ Justification for adjustment factor } \\
\hline $\mathrm{R}$ & & 1 & 2 & 3 & \multicolumn{2}{|c|}{$\begin{array}{l}\mathrm{R}=1 \text { is } \mathrm{AF} \text { for same order and trophic level } \\
\mathrm{R}=2 \text { is } \mathrm{AF} \text { for different order and same trophic level } \\
\mathrm{R}=3 \text { is } \mathrm{AF} \text { for different order and trophic level }\end{array}$} \\
\hline I & & 2 & 2 & 2 & \multicolumn{2}{|c|}{$\begin{array}{l}\text { Groups of } 50 \text { cesarean-derived SPF Sprague-Dawley rats of each } \\
\text { sex administered received the one dose. }\end{array}$} \\
\hline$Q_{1}$ & & 1 & 1 & 1 & \multicolumn{2}{|c|}{ Ecologically relevant endpoints (liver, kidney, gonads) } \\
\hline $\mathrm{Q}_{2}$ & & 1 & 1 & 1 & \multicolumn{2}{|c|}{ Long-term chronic study (94 weeks) } \\
\hline$Q_{3}$ & & 1 & 1 & 1 & \multicolumn{2}{|l|}{ NOAEL } \\
\hline $\mathrm{U}$ & & 2 & 2 & 2 & \multicolumn{2}{|c|}{$\begin{array}{l}\text { Depression of food consumption in females only. Four dose levels } \\
\text { tested: } 15,30,150 \text {, and } 410 \mathrm{mg} / \mathrm{kg} \text {-day. }\end{array}$} \\
\hline Total A & & 4 & 8 & 12 & \multicolumn{2}{|c|}{$\mathrm{R} * \mathrm{I} * \mathrm{Q}_{1} * \mathrm{Q}_{2} * \mathrm{Q}_{3} * \mathrm{U}=$ Total AF } \\
\hline $\mathrm{QCE}(\mathrm{m}$ & (kg-day) & 150 & 150 & 150 & \multicolumn{2}{|l|}{ QCE $=$ quantified critical endpoint } \\
\hline TRV & & 37.5 & 18.8 & 12.5 & \multicolumn{2}{|c|}{ Toxicity Reference Value $=\mathrm{QCE} /$ Total $\mathrm{AF}$} \\
\hline $\begin{array}{c}\mathrm{R} \\
\text { Value }\end{array}$ & \multicolumn{2}{|c|}{$\begin{array}{c}\text { TRV } \\
(\mathrm{mg} / \mathrm{kg} \text {-day) }\end{array}$} & & & Justification & $\begin{array}{l}\text { Appropriate Functional } \\
\text { Group }\end{array}$ \\
\hline 1 & 37.5 & \multicolumn{4}{|c|}{$\begin{array}{l}\text { Test organism is in the same order and trophic level as } \\
\text { the functional group members }\end{array}$} & none \\
\hline 2 & 18.8 & \multicolumn{4}{|c|}{$\begin{array}{l}\text { Test organism is in a different order and same trophic } \\
\text { level from the functional group members }\end{array}$} & $\mathrm{M} 422, \mathrm{M} 422 \mathrm{~A}$ \\
\hline 3 & 12.5 & \multicolumn{4}{|c|}{$\begin{array}{l}\text { Test organism is in a different order and trophic level } \\
\text { from the functional group members }\end{array}$} & $\begin{array}{l}\text { M121, M122, M122A, } \\
\text { M132, M210, M210A, } \\
\text { M222, M322 }\end{array}$ \\
\hline
\end{tabular}


COPC:

Test Organisms:

Exposure Medium:

Test Endpoint:

Reference:

QCE:
Diethylphthalate CAS 84-66-2

Rat (Omnivore, Order-Rodentia)

Oral

NOAEL

Brown, D., et al., 1978, "Short-term oral toxicity study of diethylphthalate in the rat," Food Cosmet. Toxicol., 16:415-422.

$750 \mathrm{mg} / \mathrm{kg}$-day

\begin{tabular}{|c|c|c|c|c|}
\hline $\begin{array}{l}\text { Adjustment Factors } \\
(\mathrm{AF})\end{array}$ & & & & Justification for adjustment factor \\
\hline $\mathrm{R}$ & 1 & 2 & 3 & $\begin{array}{l}R=1 \text { is } A F \text { for same order and trophic level } \\
R=2 \text { is } A F \text { for different order and same trophic level } \\
R=3 \text { is } A F \text { for different order and trophic level }\end{array}$ \\
\hline I & 2 & 2 & 2 & $\begin{array}{l}\text { CD rats ( } 15 / \text { sex) evaluated. Additional groups of five rats/sex fed } \\
\text { similar diets. }\end{array}$ \\
\hline $\mathrm{Q}_{1}$ & 1 & 1 & 1 & Ecologically relevant endpoint \\
\hline $\mathrm{Q}_{2}$ & 1 & 1 & 1 & Chronic (16-weeks) study \\
\hline$Q_{3}$ & 1 & 1 & 1 & NOAEL \\
\hline $\mathrm{U}$ & 2 & 2 & 2 & $\begin{array}{l}\text { Sufficient numbers of rats of both sexes employed and multiple } \\
\text { endpoints studied. }\end{array}$ \\
\hline Total AF & 4 & 8 & 12 & $\mathrm{R} * \mathrm{I} * \mathrm{Q}_{1} * \mathrm{Q}_{2} * \mathrm{Q}_{3} * \mathrm{U}=$ Total AF \\
\hline $\mathrm{QCE}$ (mg/kg-day) & 750 & 750 & 750 & $\mathrm{QCE}=$ quantified critical endpoint \\
\hline TRV & 188 & 93.8 & 62.5 & Toxicity Reference Value $=\mathrm{QCE} /$ Total $\mathrm{AF}$ \\
\hline
\end{tabular}

Appropriate Functional Groups:

\begin{tabular}{|c|c|c|c|}
\hline $\begin{array}{c}\mathrm{R} \\
\text { Value }\end{array}$ & $\begin{array}{c}\text { TRV } \\
\text { (mg/kg-day) }\end{array}$ & Justification & $\begin{array}{l}\text { Appropriate Functional } \\
\text { Group }\end{array}$ \\
\hline 1 & 188 & $\begin{array}{l}\text { Test organism is in the same order and trophic level as the } \\
\text { functional group members }\end{array}$ & none \\
\hline 2 & 93.8 & $\begin{array}{l}\text { Test organism is in a different order and same trophic level } \\
\text { from the functional group members }\end{array}$ & $\mathrm{M} 422, \mathrm{M} 422 \mathrm{~A}$ \\
\hline 3 & 62.5 & $\begin{array}{l}\text { Test organism is in a different order and trophic level from } \\
\text { the functional group members }\end{array}$ & $\begin{array}{l}\text { M121, M122, M122A, } \\
\text { M132, M210, M210A, } \\
\text { M222, M322 }\end{array}$ \\
\hline
\end{tabular}


COPC:

Test Organisms:

Exposure Medium:

Test Endpoint:

Reference:

\section{Di-n-butylphthalate CAS 84-74-2}

Rat (Omnivore, Order-Rodentia)

Oral

NOAEL

Smith, C.C., 1953, "Toxicity of butyl stearate, dibutyl sebacate, dibutyl phthalate, and methoxyethyl oleate," Archives of Hygiene and Occupational Medicine, 7:310318.

QCE: $\quad 125 \mathrm{mg} / \mathrm{kg}$-day

\begin{tabular}{|c|c|c|c|c|c|c|}
\hline \multicolumn{5}{|c|}{$\begin{array}{l}\text { Adjustment } \\
\text { Factors (AF) }\end{array}$} & \multicolumn{2}{|c|}{ Justification for adjustment factor } \\
\hline \multicolumn{2}{|l|}{$\mathrm{R}$} & 1 & 2 & 3 & \multicolumn{2}{|c|}{$\begin{array}{l}R=1 \text { is } A F \text { for same order and trophic level } \\
R=2 \text { is } A F \text { for different order and same trophic level } \\
R=3 \text { is } A F \text { for different order and trophic level }\end{array}$} \\
\hline \multicolumn{2}{|l|}{ I } & 3 & 3 & 3 & \multicolumn{2}{|c|}{ Only one sex tested. No juveniles tested. } \\
\hline \multicolumn{2}{|l|}{$Q_{1}$} & 1 & 1 & 1 & \multicolumn{2}{|l|}{ Ecologically relevant endpoint } \\
\hline \multicolumn{2}{|l|}{$\mathrm{Q}_{2}$} & 1 & 1 & 1 & \multicolumn{2}{|l|}{ Long-term (1-year) study } \\
\hline \multicolumn{2}{|l|}{$Q_{3}$} & 1 & 1 & 1 & \multicolumn{2}{|l|}{ NOAEL endpoint } \\
\hline \multicolumn{2}{|l|}{$U$} & 3 & 3 & 3 & \multicolumn{2}{|c|}{$\begin{array}{l}\text { No histopathologic evaluation reported. Existence of other } \\
\text { subchronic studies to support the critical effect and the magnitude of } \\
\text { the LOAEL are not available. Not clear if effects observed at } \\
\text { higher treatment doses were dose-related. }\end{array}$} \\
\hline \multicolumn{2}{|c|}{ Total AF } & 9 & 18 & 27 & \multicolumn{2}{|l|}{$\mathrm{R} * \mathrm{I} * \mathrm{Q}_{1} * \mathrm{Q}_{2} * \mathrm{Q}_{3} * \mathrm{U}=$ Total AF } \\
\hline \multicolumn{2}{|c|}{ QCE (mg/kg-day) } & 125 & 125 & 125 & \multicolumn{2}{|l|}{$\mathrm{QCE}=$ quantified critical endpoint } \\
\hline \multicolumn{2}{|l|}{ TRV } & 13.9 & 6.94 & 4.63 & \multicolumn{2}{|c|}{ Toxicity Reference Value $=\mathrm{QCE} /$ Total AF } \\
\hline $\begin{array}{c}\mathrm{R} \\
\text { Value }\end{array}$ & \multicolumn{2}{|c|}{$\begin{array}{c}\text { TRV } \\
(\mathrm{mg} / \mathrm{kg} \text {-day) }\end{array}$} & & & Justification & $\begin{array}{l}\text { Appropriate Functional } \\
\text { Group }\end{array}$ \\
\hline 1 & \multicolumn{2}{|l|}{13.9} & \multicolumn{3}{|c|}{$\begin{array}{l}\text { Test organism is in the same order and trophic level as the } \\
\text { functional group members }\end{array}$} & none \\
\hline 2 & 6.94 & & \multicolumn{3}{|c|}{$\begin{array}{l}\text { Test organism is in a different order and same trophic level } \\
\text { from the functional group members }\end{array}$} & $\mathrm{M} 422, \mathrm{M} 422 \mathrm{~A}$ \\
\hline 3 & 4.63 & & \multicolumn{3}{|c|}{$\begin{array}{l}\text { Test organism is in a different order and trophic level from } \\
\text { the functional group members }\end{array}$} & $\begin{array}{l}\text { M121, M122, M122A, } \\
\text { M132, M210, M210A, } \\
\text { M222, M322 }\end{array}$ \\
\hline
\end{tabular}


COPC:

Test Organisms:

Exposure Medium:

Test Endpoint:

Reference:
Di-n-octylphthalate CAS 117-84-0

Rat (Omnivore, Order-Rodentia)

Diet

LOAEL

Piekacz, H., 1971, "Effect of dioctyl and dibutyl phthalates on the organisms of rats after oral administration in prolonged experiment. II. Subacute and chronic toxicity," Rocz. Panstw. Zakl. Higl., 22(3): 295-307. *

$174 \mathrm{mg} / \mathrm{kg}$-day $\quad(3500 \mathrm{mg} / \mathrm{kg}$ food $)(0.0189 \mathrm{~kg}$ food/day) $/ 0.38 \mathrm{~kg} \mathrm{BW}$

QCE:

Justification for adjustment factor

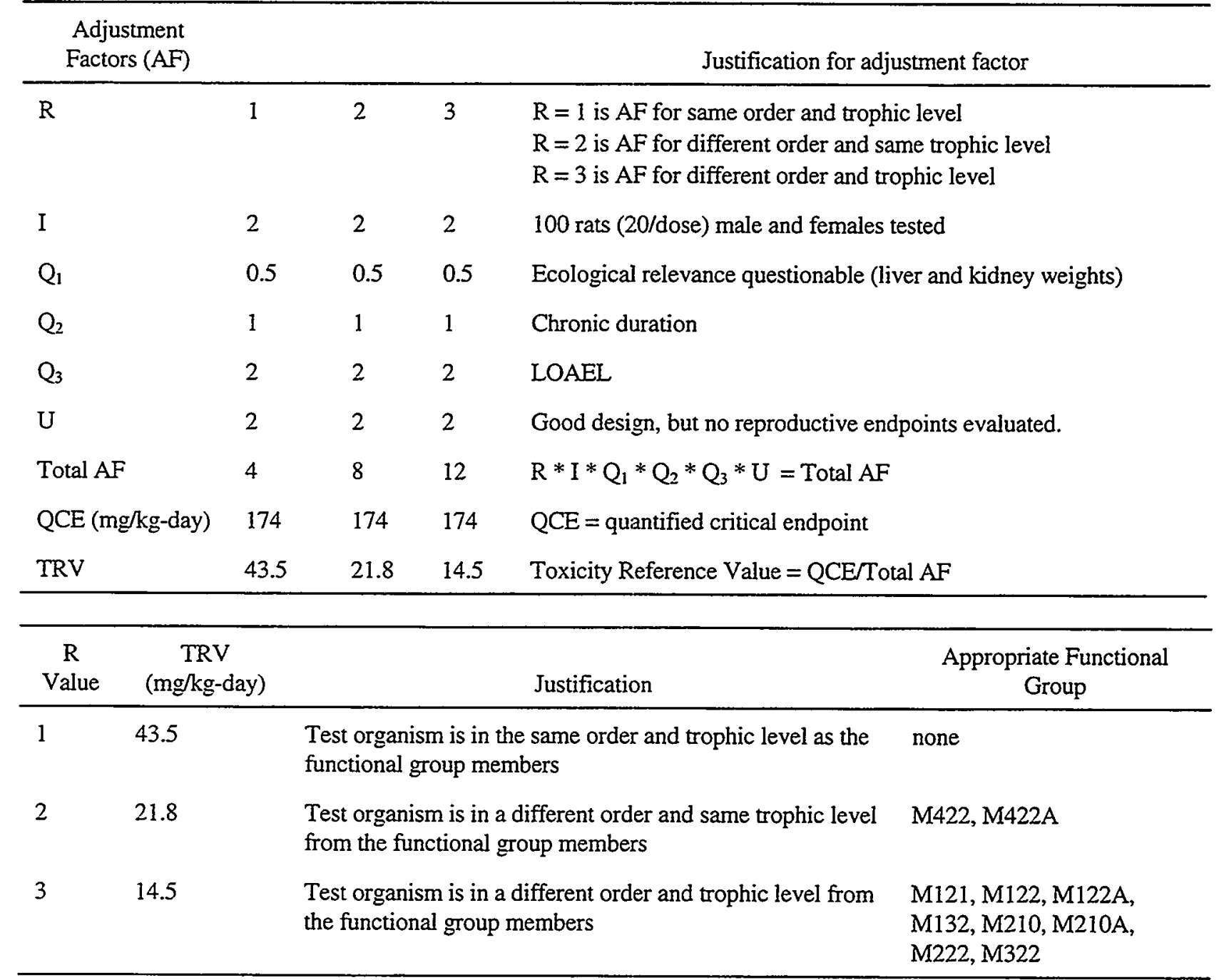

*Entire article is in Polish-there is a summary on the last page in English 
COPC:

Test Organisms:

Exposure Medium:

Test Endpoint:

Reference:

QCE:
Formaldehyde CAS 50-00-0

Rat (Omnivore, Order-Rodentia)

Oral (drinking water)

NOAEL

Til, H.P., et al., 1989, "Two-Year Drinking Water Study of Formaldehyde in Rats", Food Chemical Toxicol, 27: 77-87.

$15 \mathrm{mg} / \mathrm{kg}$-day

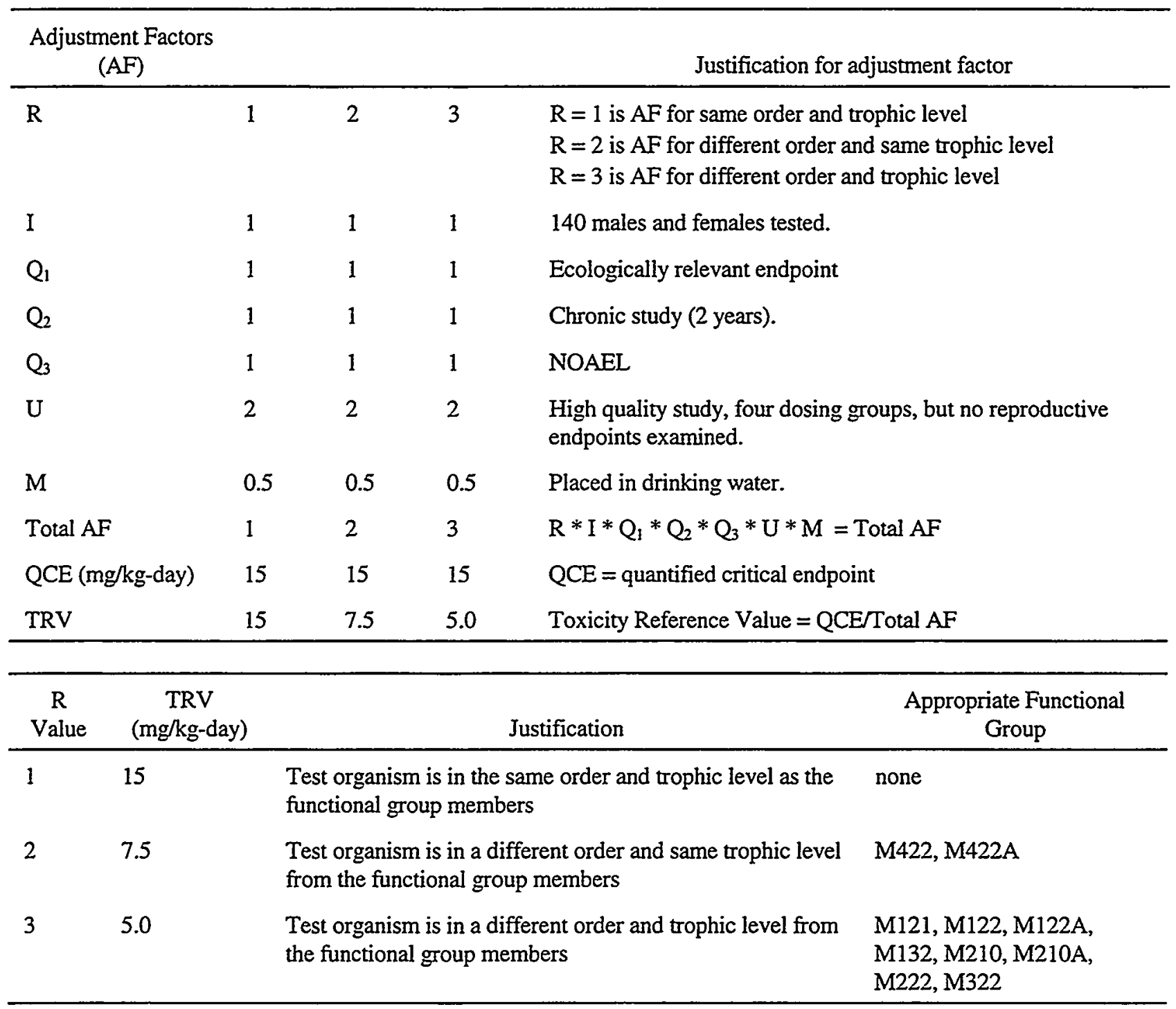


COPC:

Test Organisms:

Exposure Medium:

Test Endpoint:

Reference:
Rat (Omnivore, Order-Rodentia)

Oral via drinking water

NOAEL

Cox, G.E., D.E. Barley, and K. Morganreidge, 1975, Toxicity Studies in Rats

With 2-Butanol Including Growth, Reproduction, and Teratologic Observations, Food and Drug Research Laboratories, Inc., Report No. 91MR R 1673, Waverly, New York.

$1771 \mathrm{mg} / \mathrm{kg}$-day

QCE:

Justification for adjustment factor

\begin{tabular}{|c|c|c|c|c|}
\hline $\begin{array}{l}\text { Adjustment Factors } \\
\text { (AF) }\end{array}$ & & & & Justification for adjustment factor \\
\hline $\mathrm{R}$ & 1 & 2 & 3 & $\begin{array}{l}R=1 \text { is } A F \text { for same order and trophic level } \\
R=2 \text { is } A F \text { for different order and same trophic level } \\
R=3 \text { is } A F \text { for different order and trophic level }\end{array}$ \\
\hline I & 1 & 1 & 1 & Multigenerational, multi-sex study \\
\hline $\mathrm{Q}_{1}$ & 1 & 1 & 1 & Ecologically relevant endpoint \\
\hline $\mathrm{Q}_{2}$ & 2 & 2 & 2 & Subchronic study, 9 weeks per generation \\
\hline $\mathrm{Q}_{3}$ & 1 & 1 & 1 & NOAEL \\
\hline $\mathrm{U}$ & 2 & 2 & 2 & $\begin{array}{l}\text { Numerous development endpoints measured. Long-term } \\
\text { effects in parents not studied. Adequate number of animals } \\
\text { tested. Supporting chronic toxicity studies with other species } \\
\text { are lacking. }\end{array}$ \\
\hline M & 0.5 & 0.5 & 0.5 & Placed in the drinking water. \\
\hline Total AF & 2 & 4 & 6 & $\mathrm{R} * \mathrm{I} * \mathrm{Q}_{1} * \mathrm{Q}_{2} * \mathrm{Q}_{3} * \mathrm{U} * \mathrm{M}=$ Total $A F$ \\
\hline $\mathrm{QCE}$ (mg/kg-day) & 1771 & 1771 & 1771 & $\mathrm{QCE}=$ quantified critical endpoint \\
\hline TRV & 885.5 & 442.8 & 295.2 & Toxicity Reference Value $=\mathrm{QCE} / \mathrm{Total} \mathrm{AF}$ \\
\hline
\end{tabular}

\begin{tabular}{|c|c|c|c|}
\hline $\begin{array}{c}\mathrm{R} \\
\text { Value }\end{array}$ & $\begin{array}{c}\text { TRV } \\
\text { (mg/kg-day) }\end{array}$ & Justification & $\begin{array}{c}\text { Appropriate Functional } \\
\text { Group }\end{array}$ \\
\hline 1 & 885.5 & $\begin{array}{l}\text { Test organism is in the same order and trophic level as } \\
\text { the functional group members }\end{array}$ & none \\
\hline 2 & 442.8 & $\begin{array}{l}\text { Test organism is in a different order and same trophic } \\
\text { level from the functional group members }\end{array}$ & $\mathrm{M} 422, \mathrm{M} 422 \mathrm{~A}$ \\
\hline 3 & 295.2 & $\begin{array}{l}\text { Test organism is in a different order and trophic level } \\
\text { from the functional group members }\end{array}$ & $\begin{array}{l}\text { M122, M122A, M121, } \\
\text { M123, M132, M210, } \\
\text { M210A, M222, M322 }\end{array}$ \\
\hline
\end{tabular}


COPC:

Test Organisms:

Exposure Medium:

Test Endpoint:

Reference:

QCE:
Methylene chloride (dichloromethane) CAS 75-09-2

Rat (Omnivore, Order-Rodentia)

Drinking water

NOAEL

National Cancer Association, 1982, 24-Month Chronic Toxicity and Oncogenicity Study of Methylene Chloride in Rats, prepared by Hazleton Laboratories, Inc.

Vienna, VA, unpublished data cited in IRIS.

$5.85 \mathrm{mg} / \mathrm{kg}$-day

\begin{tabular}{|c|c|c|c|c|c|c|}
\hline \multicolumn{5}{|c|}{$\begin{array}{l}\text { Adjustment Factors } \\
\text { (AF) }\end{array}$} & \multicolumn{2}{|c|}{ Justification for adjustment factor } \\
\hline \multicolumn{2}{|l|}{$\mathrm{R}$} & 1 & 2 & 3 & \multicolumn{2}{|c|}{$\begin{array}{l}R=1 \text { is } A F \text { for same order and trophic level } \\
R=2 \text { is } A F \text { for different order and same trophic level } \\
R=3 \text { is } A F \text { for different order and trophic level }\end{array}$} \\
\hline \multicolumn{2}{|l|}{ I } & 2 & 2 & 2 & \multicolumn{2}{|l|}{ Both sexes tested. No juveniles tested. } \\
\hline \multicolumn{2}{|l|}{$\mathrm{Q}_{1}$} & 1 & 1 & 1 & \multicolumn{2}{|c|}{ Ecologically relevant endpoint (liver histology) } \\
\hline \multicolumn{2}{|l|}{$\mathrm{Q}_{2}$} & 1 & 1 & 1 & \multicolumn{2}{|l|}{ Long-term (2-year) study } \\
\hline \multicolumn{2}{|l|}{$Q_{3}$} & 1 & 1 & 1 & \multicolumn{2}{|l|}{ NOAEL } \\
\hline \multicolumn{2}{|l|}{$\mathrm{U}$} & 1 & 1 & 1 & \multicolumn{2}{|c|}{$\begin{array}{l}\text { Well-conducted study, four doses tested: } 5.85,50,125 \text {, and } 250 \\
\mathrm{mg} / \mathrm{kg} \text {-day. }\end{array}$} \\
\hline \multicolumn{2}{|l|}{ M } & 0.5 & 0.5 & 0.5 & \multicolumn{2}{|l|}{ Placed in drinking water } \\
\hline \multicolumn{2}{|c|}{ Total AF } & 1 & 2 & 3 & \multicolumn{2}{|c|}{$\mathrm{R} * \mathrm{I} * \mathrm{Q}_{1} * \mathrm{Q}_{2} * \mathrm{Q}_{3} * \mathrm{U} * \mathrm{M}=$ Total AF } \\
\hline \multicolumn{2}{|c|}{$\mathrm{QCE}$ (mg/kg-day) } & 5.85 & 5.85 & 5.85 & \multicolumn{2}{|l|}{ QCE $=$ quantified critical endpoint } \\
\hline \multicolumn{2}{|l|}{ TRV } & 5.85 & 2.93 & 1.95 & \multicolumn{2}{|c|}{ Toxicity Reference Value $=\mathrm{QCE} /$ Total $\mathrm{AF}$} \\
\hline $\begin{array}{c}\mathrm{R} \\
\text { Value }\end{array}$ & \multicolumn{2}{|c|}{$\begin{array}{c}\text { TRV } \\
\text { (mg/kg-day) }\end{array}$} & & & Justification & Appropriate Functional Group \\
\hline 1 & 5.85 & & \multicolumn{3}{|c|}{$\begin{array}{l}\text { Test organism is in the same order and trophic level as the } \\
\text { functional group members }\end{array}$} & none \\
\hline 2 & 2.93 & & \multicolumn{3}{|c|}{$\begin{array}{l}\text { Test organism is in a different order and same trophic level } \\
\text { from the functional group members }\end{array}$} & $\mathrm{M} 422, \mathrm{M} 422 \mathrm{~A}$ \\
\hline 3 & 1.95 & & \multicolumn{3}{|c|}{$\begin{array}{l}\text { Test organism is in a different order and trophic level from } \\
\text { the functional group members }\end{array}$} & $\begin{array}{l}\text { M121, M122, M122A, M132, } \\
\text { M210, M210A, M222, M322 }\end{array}$ \\
\hline
\end{tabular}


COPC:

Test Organisms:

Exposure Medium:

Test Endpoint:

Reference:
Naphthalene CAS 91-20-3

Mouse (Omnivore, Order-Rodentia)

Oral

NOAEL

Shopp et al., 1984, "Naphthalene toxicity in CD-1 mice: General toxicology and immunotoxicology," Fundamental and Applied Toxicology, 4:406-419.

$5.3 \mathrm{mg} / \mathrm{kg}$-day

QCE:

Justification for adjustment factor

\begin{tabular}{|c|c|c|c|c|c|c|}
\hline \multicolumn{3}{|c|}{$\begin{array}{l}\text { Adjustment } \\
\text { Factors (AF) }\end{array}$} & & & \multicolumn{2}{|c|}{ Justification for adjustment factor } \\
\hline \multicolumn{2}{|l|}{$\mathrm{R}$} & 1 & 2 & 3 & \multicolumn{2}{|c|}{$\begin{array}{l}R=1 \text { is } A F \text { for same order and trophic level } \\
R=2 \text { is } A F \text { for different order and same trophic level } \\
R=3 \text { is } A F \text { for different order and trophic level }\end{array}$} \\
\hline \multicolumn{2}{|l|}{ I } & 2 & 2 & 2 & \multicolumn{2}{|c|}{$\begin{array}{l}\text { Adequate numbers of male and females tested ( } 40-112 \text { of each sex), } \\
\text { no juveniles tested. }\end{array}$} \\
\hline \multicolumn{2}{|l|}{$Q_{1}$} & 1 & 1 & 1 & \multicolumn{2}{|l|}{ Ecologically relevant endpoint } \\
\hline \multicolumn{2}{|l|}{$\mathrm{Q}_{2}$} & 1 & 1 & 1 & \multicolumn{2}{|l|}{ Chronic (90-day) study } \\
\hline \multicolumn{2}{|l|}{$\mathrm{Q}_{3}$} & 1 & 1 & 1 & \multicolumn{2}{|l|}{ NOAEL endpoint } \\
\hline \multicolumn{2}{|l|}{$\mathrm{U}$} & 2 & 2 & 2 & \multicolumn{2}{|c|}{$\begin{array}{l}\text { Reasonable design, but no reproductive endpoints or sensitive life } \\
\text { stages examined. }\end{array}$} \\
\hline \multicolumn{2}{|c|}{ Total AF } & 4 & 8 & 12 & \multicolumn{2}{|l|}{$R * I * Q_{1} * Q_{2} * Q_{3} * U=$ Total AF } \\
\hline \multicolumn{2}{|c|}{ QCE (mg/kg-day) } & 5.3 & 5.3 & 5.3 & \multicolumn{2}{|l|}{$\mathrm{QCE}=$ quantified critical endpoint } \\
\hline \multicolumn{2}{|l|}{ TRV } & 1.3 & 0.66 & 0.44 & \multicolumn{2}{|c|}{ Toxicity Reference Value $=\mathrm{QCE} /$ Total AF } \\
\hline $\begin{array}{c}\mathrm{R} \\
\text { Value }\end{array}$ & \multicolumn{2}{|c|}{$\begin{array}{c}\text { TRV } \\
\text { (mg/kg-day) }\end{array}$} & & & Justification & $\begin{array}{l}\text { Appropriate Functional } \\
\text { Group }\end{array}$ \\
\hline 1 & \multicolumn{2}{|l|}{1.3} & \multicolumn{3}{|c|}{$\begin{array}{l}\text { Test organism is in the same order and trophic level as the } \\
\text { functional group members }\end{array}$} & none \\
\hline 2 & \multicolumn{2}{|l|}{0.66} & \multicolumn{3}{|c|}{$\begin{array}{l}\text { Test organism is in a different order and same trophic level } \\
\text { from the functional group members }\end{array}$} & $\mathrm{M} 422, \mathrm{M} 422 \mathrm{~A}$ \\
\hline 3 & \multicolumn{2}{|l|}{0.44} & \multicolumn{3}{|c|}{$\begin{array}{l}\text { Test organism is in a different order and trophic level from } \\
\text { the functional group members }\end{array}$} & $\begin{array}{l}\text { M121, M122, M122A, } \\
\text { M132, M210, M210A, } \\
\text { M222, M322 }\end{array}$ \\
\hline
\end{tabular}


COPC:

Test Organisms:

Exposure Medium:

Test Endpoint:

Reference:

\section{Pentachlorophenol (PCP) CAS 87-86-5}

Rat (Omnivore, Order-Rodentia)

Oral in diet

NOAEL

Schwetz, B.A. et al. 1978. Results of two-year toxicity and reproduction studies on pentachlorophenol in rats. pp. 301-309 in R. Rao, ed., Pentachlorophenol:

Chemistry, Pharmacology, and Environmental Toxicology. Plenum Press, New York. $401 \mathrm{pp}$.

$0.24 \mathrm{mg} / \mathrm{kg}$-day

\section{QCE:}

Justification for adjustment factor

\begin{tabular}{|c|c|c|c|c|c|c|}
\hline \multicolumn{5}{|c|}{$\begin{array}{l}\text { Adjustment Factors } \\
\text { (AF) }\end{array}$} & \multicolumn{2}{|l|}{ Justification for adjustment factor } \\
\hline \multicolumn{2}{|l|}{$\mathrm{R}$} & 1 & 2 & 3 & \multicolumn{2}{|c|}{$\begin{array}{l}\mathrm{R}=1 \text { is } \mathrm{AF} \text { for same order and trophic level } \\
\mathrm{R}=2 \text { is } \mathrm{AF} \text { for different order and same trophic level } \\
\mathrm{R}=3 \text { is } \mathrm{AF} \text { for different order and trophic level }\end{array}$} \\
\hline \multicolumn{2}{|l|}{ I } & 2 & 2 & 2 & \multicolumn{2}{|c|}{ Rats tested at two dose levels: 3 and $30 \mathrm{ppm}$} \\
\hline \multicolumn{2}{|l|}{$Q_{1}$} & 1 & 1 & 1 & \multicolumn{2}{|c|}{ Ecologically relevant endpoint (reproduction) } \\
\hline \multicolumn{2}{|l|}{$Q_{2}$} & 1 & 1 & 1 & \multicolumn{2}{|c|}{$\begin{array}{l}\text { Chronic study ( } 62 \text { days prior to mating, } 15 \text { days during mating, and } \\
\text { through gestation and lactation). }\end{array}$} \\
\hline \multicolumn{2}{|l|}{$Q_{3}$} & 1 & 1 & 1 & \multicolumn{2}{|l|}{ NOAEL } \\
\hline \multicolumn{2}{|l|}{$\mathrm{U}$} & 1 & 1 & 1 & \multicolumn{2}{|c|}{$\begin{array}{l}\text { No adverse effects were observed at the } 3 \text { ppm level while survival } \\
\text { and growth were significantly reduced, greater than } 20 \% \text {, in rats fed } \\
\text { the } 30 \mathrm{ppm} \text { dose. The } 3 \text { ppm dose was considered the NOAEL and } \\
\text { the } 30 \mathrm{ppm} \text { dose was considered the LOAEL. }\end{array}$} \\
\hline \multicolumn{2}{|c|}{ Total AF } & 2 & 4 & 6 & \multicolumn{2}{|c|}{$\mathrm{R} * \mathrm{I} * \mathrm{Q}_{1} * \mathrm{Q}_{2} * \mathrm{Q}_{3} * \mathrm{U}=$ Total AF } \\
\hline \multicolumn{2}{|c|}{ QCE (mg/kg-day) } & 0.24 & 0.24 & 0.24 & \multicolumn{2}{|l|}{$\mathrm{QCE}=$ quantified critical endpoint } \\
\hline \multicolumn{2}{|l|}{ TRV } & 0.12 & 0.06 & 0.04 & \multicolumn{2}{|c|}{ Toxicity Reference Value $=\mathrm{QCE} /$ Total $\mathrm{AF}$} \\
\hline $\begin{array}{l}\mathrm{R} \\
\text { Value }\end{array}$ & $\begin{array}{l}\mathrm{TRV} \\
\text { (mg/kg-day) }\end{array}$ & & Justificati & & & $\begin{array}{l}\text { Appropriate Functional } \\
\text { Group }\end{array}$ \\
\hline 1 & 0.12 & & $\begin{array}{l}\text { Test orgar } \\
\text { the functic }\end{array}$ & $\begin{array}{l}\mathrm{m} \text { is in } \\
\text { al grou }\end{array}$ & $\begin{array}{l}\text { e same order and trophic level as } \\
\text { members }\end{array}$ & none \\
\hline 2 & 0.06 & & $\begin{array}{l}\text { Test orgar } \\
\text { level from }\end{array}$ & $\begin{array}{l}m \text { is in } \\
\text { he func }\end{array}$ & $\begin{array}{l}\text { different order and same trophic } \\
\text { nal group members }\end{array}$ & $\mathrm{M} 422, \mathrm{M} 422 \mathrm{~A}$ \\
\hline 3 & 0.04 & & $\begin{array}{l}\text { Test orgar } \\
\text { from the f }\end{array}$ & m is in & $\begin{array}{l}\text { different order and trophic level } \\
\text { roup members }\end{array}$ & $\begin{array}{l}\text { M121, M122, M122A, M132, } \\
\text { M210, M210A, M222, M322 }\end{array}$ \\
\hline
\end{tabular}


COPC:

Test Organisms:

Exposure Medium:

Test Endpoint:

Reference:

QCE:
Phenol CAS 108-95-2

Rat (Omnivore, Order-Rodentia)

Oral in water

NOAEL

NTP, 1983, Teratologic Evaluation of Phenol in CD Rats and Mice. Report prepared by Research Triangle Institute, Research Triangle Park, NC. NTIS PB83247726, Gov. Rep. Announce Index 83(25):6247.

$60 \mathrm{mg} / \mathrm{kg}$-day

\begin{tabular}{|c|c|c|c|c|}
\hline $\begin{array}{l}\text { Adjustment Factors } \\
\text { (AF) }\end{array}$ & & & & Justification for adjustment factor \\
\hline $\mathrm{R}$ & 1 & 2 & 3 & $\begin{array}{l}R=1 \text { is } A F \text { for same order and trophic level } \\
R=2 \text { is } A F \text { for different order and same trophic level } \\
R=3 \text { is } A F \text { for different order and trophic level }\end{array}$ \\
\hline I & 1 & 1 & 1 & $\begin{array}{l}\text { Low variability because similar studies exhibited no effects at a dose } \\
\text { rate on order of magnitude higher that the NOAEL }\end{array}$ \\
\hline$Q_{1}$ & 1 & 1 & 1 & Ecologically relevant endpoint (reduced fetal body weight). \\
\hline $\mathrm{Q}_{2}$ & 3 & 3 & 3 & Acute ( 9 days) \\
\hline $\mathrm{Q}_{3}$ & 1 & 1 & 1 & NOAEL \\
\hline $\mathrm{U}$ & 1 & 1 & 1 & $\begin{array}{l}\text { High quality studies with four dose levels and during a critical life } \\
\text { stage (gestation). }\end{array}$ \\
\hline M & 0.5 & 0.5 & 0.5 & Placed in drinking water \\
\hline Total AF & 1.5 & 3 & 4.5 & $\mathrm{R} * \mathrm{I} * \mathrm{Q}_{1} * \mathrm{Q}_{2} * \mathrm{Q}_{3} * \mathrm{U} * \mathrm{M}=$ Total AF \\
\hline $\mathrm{QCE}$ (mg/kg-day) & 60 & 60 & 60 & $\mathrm{QCE}=$ quantified critical endpoint \\
\hline TRV & 40 & 20 & 13 & Toxicity Reference Value $=\mathrm{QCE} /$ Total $\mathrm{AF}$ \\
\hline
\end{tabular}

Appropriate Functional Groups:

\begin{tabular}{llll}
$\begin{array}{c}\mathrm{R} \\
\text { Value }\end{array}$ & $\begin{array}{c}\mathrm{TRV} \\
\text { (mg/kg-day) }\end{array}$ & \multicolumn{1}{c}{ Justification } & Appropriate Functional Group \\
\hline 1 & 40 & $\begin{array}{l}\text { Test organism is in the same order and trophic level as the } \\
\text { functional group members }\end{array}$ & none \\
2 & 20 & $\begin{array}{l}\text { Test organism is in a different order and same trophic level } \\
\text { from the functional group members }\end{array}$ & M422, M422A \\
3 & 13 & $\begin{array}{l}\text { Test organism is in a different order and trophic level from } \\
\text { the functional group members }\end{array}$ & $\begin{array}{l}\text { M121, M122, M122A, M132, } \\
\text { M210, M210A, M222, M322 }\end{array}$ \\
\hline
\end{tabular}


COPC:

Test Organisms:

Exposure Medium:

Test Endpoint:

Reference:
Tetrachloroethylene CAS 127-18-4

Mouse (Swiss-cox) (Omnivore, Order-Rodentia)

Gavage (in corn oil)

NOAEL (hepatoxicity)

Buben, J.A., and E.J. O'Flaherty, 1985, Delineation of the Role of Metabolism in the Hepatotoxicity of Trichloroethylene and Perchloroethylene: A Dose-Effect Study, Toxicol. and Appl. Pharmacol. 78:105-122.

\section{QCE:}

Adjusted from 5 to 7 times per week.

\begin{tabular}{|c|c|c|c|c|c|c|}
\hline \multicolumn{5}{|c|}{$\begin{array}{l}\text { Adjustment Factors } \\
(\mathrm{AF})\end{array}$} & \multicolumn{2}{|c|}{ Justification for adjustment factor } \\
\hline $\mathrm{R}$ & & 1 & 2 & 3 & \multicolumn{2}{|c|}{$\begin{array}{l}R=1 \text { is } A F \text { for same order and trophic level } \\
R=2 \text { is } A F \text { for different order and same trophic level } \\
R=3 \text { is } A F \text { for different order and trophic level }\end{array}$} \\
\hline I & & 2 & 2 & 2 & \multicolumn{2}{|c|}{ Exposure not during critical time frame, males only } \\
\hline$Q_{1}$ & & 1 & 1 & 1 & \multicolumn{2}{|c|}{ Ecologically relevant endpoint (hepatotoxicity) } \\
\hline $\mathrm{Q}_{2}$ & & 1 & 1 & 1 & \multicolumn{2}{|l|}{ Chronic (6 weeks) } \\
\hline $\mathrm{Q}_{3}$ & & 1 & 1 & 1 & \multicolumn{2}{|l|}{ NOAEL } \\
\hline $\mathrm{U}$ & & 2 & 2 & 2 & \multicolumn{2}{|c|}{$\begin{array}{l}\text { Mice were exposed for } 5 \text { days/week. } 7 \text { day/week exposure was } \\
\text { estimated. Hepatoxicity was observed at doses of } 100 \mathrm{mg} / \mathrm{kg} \text { - } \\
\text { day (probably increased triglycerides is adverse effect). }\end{array}$} \\
\hline Total AF & & 4 & 8 & 12 & \multicolumn{2}{|c|}{$\mathrm{R} * \mathrm{I} * \mathrm{Q}_{1} * \mathrm{Q}_{2} * \mathrm{Q}_{3} * \mathrm{U}=$ Total $\mathrm{AF}$} \\
\hline $\mathrm{QCE}(\mathrm{m}$ & (kg-day) & 14 & 14 & 14 & \multicolumn{2}{|l|}{$\mathrm{QCE}=$ quantified critical endpoint } \\
\hline TRV & & 3.5 & 1.8 & 1.2 & \multicolumn{2}{|c|}{ Toxicity Reference Value $=\mathrm{QCE} / \mathrm{Total} \mathrm{AF}$} \\
\hline $\begin{array}{c}\mathrm{R} \\
\text { Value }\end{array}$ & \multicolumn{2}{|c|}{$\begin{array}{c}\text { TRV } \\
\text { (mg/kg-day) }\end{array}$} & \multicolumn{4}{|c|}{ Justification } \\
\hline 1 & \multicolumn{2}{|l|}{3.5} & \multicolumn{3}{|c|}{$\begin{array}{l}\text { Test organism is in the same order and trophic level as the } \\
\text { functional group members }\end{array}$} & none \\
\hline 2 & \multicolumn{2}{|l|}{1.8} & \multicolumn{3}{|c|}{$\begin{array}{l}\text { Test organism is in a different order and same trophic level } \\
\text { from the functional group members }\end{array}$} & $\mathrm{M} 422, \mathrm{M} 422 \mathrm{~A}$ \\
\hline 3 & \multicolumn{2}{|l|}{1.2} & \multicolumn{3}{|c|}{$\begin{array}{l}\text { Test organism is in a different order and trophic level from } \\
\text { the functional group members }\end{array}$} & $\begin{array}{l}\text { M121, M122, M122A, } \\
\text { M132, M210, M210A, } \\
\text { M222, M322 }\end{array}$ \\
\hline
\end{tabular}


COPC:

Test Organisms:

Exposure Medium:

Test Endpoint:

Reference:

QCE:
Toluene CAS 108-88-3

Rat (Omnivore, Order-Rodentia)

Oral (corn oil)

NOAEL

National Toxicology Program (NTP), 1989, Toxicology and Carcinogenesis Studies of Toluene in F/344 Rats and B6C3F1 Mice, Technical Report Series No. 371, Research Triangle Park, NC.

$223 \mathrm{mg} / \mathrm{kg}$-day

(312 $\mathrm{mg} / \mathrm{kg}$-day)(5days fed/7 days in week)

\begin{tabular}{|c|c|c|c|c|c|c|}
\hline \multicolumn{5}{|c|}{$\begin{array}{c}\text { Adjustment Factors } \\
(\mathrm{AF})\end{array}$} & \multicolumn{2}{|c|}{ Justification for adjustment factor } \\
\hline $\mathrm{R}$ & & 1 & 2 & 3 & \multicolumn{2}{|c|}{$\begin{array}{l}R=1 \text { is } A F \text { for same order and trophic level } \\
R=2 \text { is } A F \text { for different order and same trophic level } \\
R=3 \text { is } A F \text { for different order and trophic level }\end{array}$} \\
\hline $\mathrm{I}$ & & 2 & 2 & 2 & \multicolumn{2}{|c|}{ Males and females tested. No juveniles tested. } \\
\hline $\mathrm{Q}_{1}$ & & 1 & 1 & 1 & \multicolumn{2}{|l|}{ Ecologically relevant endpoint } \\
\hline $\mathrm{Q}_{2}$ & & 1 & 1 & 1 & \multicolumn{2}{|l|}{ Chronic (13-week) exposure } \\
\hline$Q_{3}$ & & 1 & 1 & 1 & \multicolumn{2}{|l|}{ NOAEL } \\
\hline$U$ & & 2 & 2 & 2 & \multicolumn{2}{|c|}{$\begin{array}{l}\text { Good number of animals per treatment group tested ( } 20 \text { per dose). } \\
\text { Supporting chronic toxicity studies for reproductive and } \\
\text { development effects are lacking. }\end{array}$} \\
\hline Total A & & 4 & 8 & 12 & \multicolumn{2}{|l|}{$\mathrm{R} * \mathrm{I} * \mathrm{Q}_{1} * \mathrm{Q}_{2} * \mathrm{Q}_{3} * \mathrm{U}=$ Total AF } \\
\hline QCE ( $\mathrm{n}$ & /kg-day) & 223 & 223 & 223 & \multicolumn{2}{|l|}{$\mathrm{QCE}=$ quantified critical endpoint } \\
\hline TRV & & 55.8 & 27.9 & 18.6 & \multicolumn{2}{|c|}{ Toxicity Reference Value $=\mathrm{QCE} /$ Total AF } \\
\hline $\begin{array}{c}\mathrm{R} \\
\text { Value }\end{array}$ & \multicolumn{2}{|c|}{$\begin{array}{c}\mathrm{TRV} \\
\text { (mg/kg-day) }\end{array}$} & & & Justification & $\begin{array}{l}\text { Appropriate Functional } \\
\text { Group }\end{array}$ \\
\hline 1 & 55.8 & & \multicolumn{3}{|c|}{$\begin{array}{l}\text { Test organism is in the same order and trophic level as the } \\
\text { functional group members }\end{array}$} & none \\
\hline 2 & 27.9 & & \multicolumn{3}{|c|}{$\begin{array}{l}\text { Test organism is in a different order and same trophic level } \\
\text { from the functional group members }\end{array}$} & $\mathrm{M} 422, \mathrm{M} 422 \mathrm{~A}$ \\
\hline 3 & 18.6 & & \multicolumn{3}{|c|}{$\begin{array}{l}\text { Test organism is in a different order and trophic level from } \\
\text { the functional group members }\end{array}$} & $\begin{array}{l}\text { M121, M122, M122A, } \\
\text { M132, M210, M210A, } \\
\text { M222, M322 }\end{array}$ \\
\hline
\end{tabular}


COPC:

Test Organisms:

Exposure Medium:

Test Endpoint:

Reference:
Trichloroethylene CAS 79-01-6

Rat (Omnivore, Order-Rodentia)

Oral

NOAEL

Manson, J. M. et al., 1984, "Effect of Oral Exposure to Trichloroethylene on Female Reproduction Function" Toxicology 32:229-242.

$100 \mathrm{mg} / \mathrm{kg}$-day

QCE:

Justification for adjustment factor

\begin{tabular}{|c|c|c|c|c|c|c|}
\hline \multicolumn{5}{|c|}{$\begin{array}{l}\text { Adjustment Factors } \\
\qquad(\mathrm{AF})\end{array}$} & \multicolumn{2}{|c|}{ Justification for adjustment factor } \\
\hline $\mathrm{R}$ & & 1 & 2 & 3 & \multicolumn{2}{|c|}{$\begin{array}{l}R=1 \text { is } A F \text { for same order and trophic level } \\
R=2 \text { is } A F \text { for different order and same trophic level } \\
R=3 \text { is } A F \text { for different order and trophic level }\end{array}$} \\
\hline I & & 2 & 2 & 2 & \multicolumn{2}{|c|}{$\begin{array}{l}\text { Secondary source so information on number and sexes of animals } \\
\text { tested unknown. }\end{array}$} \\
\hline$Q_{1}$ & & 1 & 1 & 1 & \multicolumn{2}{|c|}{ Ecologically relevant endpoint (reproduction) } \\
\hline $\mathrm{Q}_{2}$ & & 2 & 2 & 2 & \multicolumn{2}{|l|}{ Subchronic exposure } \\
\hline $\mathrm{Q}_{3}$ & & 1 & 1 & 1 & \multicolumn{2}{|c|}{ NOAEL - no effects on female fertility or neonatal survival } \\
\hline$U$ & . & 1 & 1 & 1 & \multicolumn{2}{|c|}{$\begin{array}{l}\text { Limited information and reproductive endpoints and sensitive life } \\
\text { stages examined. }\end{array}$} \\
\hline Total AF & & 4 & 8 & 12 & \multicolumn{2}{|l|}{$\mathrm{R} * \mathrm{I} * \mathrm{Q}_{1} * \mathrm{Q}_{2} * \mathrm{Q}_{3} * \mathrm{U}=$ Total $\mathrm{AF}$} \\
\hline $\mathrm{QCE}(\mathrm{m}$ & kg-day) & 100 & 100 & 100 & \multicolumn{2}{|l|}{$\mathrm{QCE}=$ quantified critical endpoint } \\
\hline TRV & & 25 & 13 & 8.3 & \multicolumn{2}{|c|}{ Toxicity Reference Value $=\mathrm{QCE} /$ Total AF } \\
\hline $\begin{array}{c}\mathrm{R} \\
\text { Value }\end{array}$ & \multicolumn{2}{|c|}{$\begin{array}{c}\text { TRV } \\
\text { (mg/kg-day) }\end{array}$} & & & Justification & Appropriate Functional Group \\
\hline 1 & 25 & & \multicolumn{3}{|c|}{$\begin{array}{l}\text { Test organism is in the same order and trophic level as the } \\
\text { functional group members }\end{array}$} & none \\
\hline 2 & 13 & & \multicolumn{3}{|c|}{$\begin{array}{l}\text { Test organism is in a different order and same trophic level } \\
\text { from the functional group members }\end{array}$} & $\mathrm{M} 422, \mathrm{M} 422 \mathrm{~A}$ \\
\hline 3 & 8.3 & & \multicolumn{3}{|c|}{$\begin{array}{l}\text { Test organism is in a different order and trophic level from } \\
\text { the functional group members }\end{array}$} & $\begin{array}{l}\text { M121, M122, M122A, M132, } \\
\text { M210, M210A, M222, M322 }\end{array}$ \\
\hline
\end{tabular}


COPC:

Test Organisms: Exposure Medium:

Test Endpoint:

Reference:

Ring-necked pheasants (Omnivore, Order-Galliformes)

Intraperitoneal injection (weekly)

NOAEL

Nosek, J.A., S.R. Craven, J.R. Sullivan, S.S. Hurley, and R.E. Peterson, 1992, "Toxicity and reproductive effects of 2,3,7,8-tetrachlorodibenzo-p-dioxin in ring-necked pheasant hens," J. Toxicol. Environ. Health., 35:187-198.

QCE: $1.4 \mathrm{E}-5 \mathrm{mg} / \mathrm{kg}$-day

\begin{tabular}{|c|c|c|c|c|c|c|}
\hline \multicolumn{5}{|c|}{$\begin{array}{l}\text { Adjustment Factors } \\
\qquad(\mathrm{AF})\end{array}$} & \multicolumn{2}{|c|}{ Justification for adjustment factor } \\
\hline \multicolumn{2}{|l|}{$\mathrm{R}$} & 1 & 2 & 3 & \multicolumn{2}{|c|}{$\begin{array}{l}R=1 \text { is } A F \text { for same order and trophic level } \\
R=2 \text { is } A F \text { for different order and same trophic level } \\
R=3 \text { is } A F \text { for different order and trophic level }\end{array}$} \\
\hline \multicolumn{2}{|l|}{ I } & 1 & 1 & 1 & \multicolumn{2}{|c|}{$\begin{array}{l}7 \text { females per dose tested. Three dose levels tested: } \\
0.01,0.1,1 \mu \mathrm{p} / \mathrm{kg} \mathrm{BW} / \text { week. }\end{array}$} \\
\hline \multicolumn{2}{|l|}{$Q_{1}$} & 0.1 & 0.1 & 0.1 & \multicolumn{2}{|c|}{$\begin{array}{l}\text { Intraperitoneal injection unlikely in field (mortality, } \\
\text { egg production, hatchability). }\end{array}$} \\
\hline \multicolumn{2}{|l|}{$\mathrm{Q}_{2}$} & 1 & 1 & 1 & \multicolumn{2}{|c|}{10 weeks and during a critical life stage (reproduction) } \\
\hline \multicolumn{2}{|l|}{$\mathrm{Q}_{3}$} & 1 & 1 & 1 & \multicolumn{2}{|l|}{ NOAEL } \\
\hline \multicolumn{2}{|l|}{$\mathrm{U}$} & 2 & 2 & 2 & \multicolumn{2}{|c|}{$\begin{array}{l}\text { Egg production and hatchability was significantly } \\
\text { reduced among birds receiving } 1 \mu \mathrm{p} / \mathrm{kg} / \text { week dose. No } \\
\text { significant effects were observed among the other two } \\
\text { dose levels so the } 0.1 \mu \mathrm{p} / \mathrm{kg} / \text { week was considered the } \\
\text { NOAEL. }\end{array}$} \\
\hline \multicolumn{2}{|c|}{ Total AF } & 0.2 & 0.4 & 0.6 & \multicolumn{2}{|c|}{$\mathrm{R} * \mathrm{I} * \mathrm{Q}_{1} * \mathrm{Q}_{2} * \mathrm{Q}_{3} * \mathrm{U}=$ Total AF } \\
\hline \multicolumn{2}{|c|}{ QCE (mg/kg-day) } & $1.4 \mathrm{E}-5$ & $1.4 \mathrm{E}-5$ & $1.4 \mathrm{E}-5$ & \multicolumn{2}{|c|}{$\mathrm{QCE}=$ quantified critical endpoint } \\
\hline \multicolumn{2}{|l|}{ TRV } & $7.0 \mathrm{E}-5$ & $3.5 \mathrm{E}-5$ & $2.3 \mathrm{E}-5$ & \multicolumn{2}{|c|}{ Toxicity Reference Value $=\mathrm{QCE} /$ Total AF } \\
\hline $\begin{array}{c}\mathrm{R} \\
\text { Value }\end{array}$ & \multicolumn{2}{|c|}{$\begin{array}{c}\mathrm{TRV} \\
(\mathrm{mg} / \mathrm{kg} \text {-day) }\end{array}$} & & \multicolumn{2}{|c|}{ Justification } & $\begin{array}{l}\text { Appropriate Functional } \\
\text { Group }\end{array}$ \\
\hline 1 & $7.0 \mathrm{E}-5$ & \multicolumn{5}{|c|}{$\begin{array}{l}\text { Test organism is in the same order and trophic level as } \\
\text { the functional group members }\end{array}$} \\
\hline 2 & $3.5 \mathrm{E}-5$ & \multicolumn{4}{|c|}{$\begin{array}{l}\text { Test organism is in a different order and same trophic } \\
\text { level from the functional group members }\end{array}$} & $\begin{array}{l}\text { AV422, AV432, } \\
\text { AV433,AV442 }\end{array}$ \\
\hline 3 & $2.3 E-5$ & \multicolumn{4}{|c|}{$\begin{array}{l}\text { Test organism is in a different order and trophic level } \\
\text { from the functional group members }\end{array}$} & $\begin{array}{l}\text { AV121, AV122, AV132, } \\
\text { AV142, AV143, AV210, } \\
\text { AV210A, AV221, AV222, } \\
\text { AV222A, AV232, AV233, } \\
\text { AV241, AV242, AV310, } \\
\text { AV322, AV333, AV342 }\end{array}$ \\
\hline
\end{tabular}


COPC:

Test Organisms:

Exposure Medium:

Test Endpoint:

Reference:

QCE:

\section{2,3,7,8-Tetrachloro Dibenzodioxin (TCDD) CAS 51207-31-9}

Rat (Omnivore, Order-Rodentia)

Oral in diet

NOAEL

Murray, F.J. et al. 1979, "Three-generation reproduction study of rats given 2,3,7,8-tetrachlorodibenzo-p-dioxin (TCDD) in the diet," Toxicol. Appl. Pharmacol., 50:241-252.

$1 \mathrm{E}-6 \mathrm{mg} / \mathrm{kg}$-day

\begin{tabular}{|c|c|c|c|c|c|c|}
\hline \multicolumn{5}{|c|}{$\begin{array}{l}\text { Adjustment Factors } \\
(\mathrm{AF})\end{array}$} & \multicolumn{2}{|c|}{ Justification for adjustment factor } \\
\hline \multicolumn{2}{|l|}{$\mathrm{R}$} & 1 & 2 & 3 & \multicolumn{2}{|c|}{$\begin{array}{l}R=1 \text { is } A F \text { for same order and trophic level } \\
R=2 \text { is } A F \text { for different order and same trophic level } \\
R=3 \text { is } A F \text { for different order and trophic level }\end{array}$} \\
\hline \multicolumn{2}{|l|}{ I } & 1 & 1 & 1 & \multicolumn{2}{|c|}{$\begin{array}{l}\text { Adequate number of male and female rats, and juveniles } \\
\text { were also tested (three generations) at three dose levels: } \\
0.001,0.01 \text {, and } 0.1 \mu \mathrm{p} / \mathrm{kg} \mathrm{BW} / \mathrm{d} \text {. }\end{array}$} \\
\hline \multicolumn{2}{|l|}{$Q_{1}$} & 1 & 1 & 1 & \multicolumn{2}{|c|}{$\begin{array}{l}\text { Ecologically relevant endpoint (fertility, neonatal } \\
\text { survival). }\end{array}$} \\
\hline \multicolumn{2}{|l|}{$\mathrm{Q}_{2}$} & 1 & 1 & 1 & \multicolumn{2}{|c|}{$\begin{array}{l}\text { Long-term ( } 3 \text { generations, > } 1 \text { year) including critical } \\
\text { life stages (reproduction). }\end{array}$} \\
\hline \multicolumn{2}{|l|}{$\mathrm{Q}_{3}$} & 1 & 1 & 1 & \multicolumn{2}{|l|}{ NOAEL } \\
\hline \multicolumn{2}{|l|}{ U } & 1 & 1 & 1 & \multicolumn{2}{|c|}{$\begin{array}{l}\text { Fertility and neonatal survival was significantly reduced } \\
\text { among rats receiving } 0.1 \mu \mathrm{p} / \mathrm{kg} / \mathrm{d} \text { and } 0.01 \mu \mathrm{p} / \mathrm{kg} / \mathrm{d} \text {. The } \\
0.001 \mu \mathrm{p} / \mathrm{kg} / \mathrm{d} \text { dose showed no significant differences } \\
\text { and was considered the NOAEL and the } 0.01 \mu \mathrm{p} / \mathrm{kg} / \mathrm{d} \\
\text { was the LOAEL. }\end{array}$} \\
\hline \multicolumn{2}{|c|}{ Total AF } & 1 & 2 & 3 & \multicolumn{2}{|c|}{$\mathrm{R} * \mathrm{I} * \mathrm{Q}_{1} * \mathrm{Q}_{2} * \mathrm{Q}_{3} * \mathrm{U}=$ Total AF } \\
\hline \multicolumn{2}{|c|}{$\mathrm{QCE}$ (mg/kg-day) } & $1 E-6$ & $1 \mathrm{E}-6$ & $1 \mathrm{E}-6$ & \multicolumn{2}{|c|}{$\mathrm{QCE}=$ quantified critical endpoint } \\
\hline \multicolumn{2}{|l|}{ TRV } & $1 \mathrm{E}-6$ & $5 \mathrm{E}-7$ & $3 \mathrm{E}-7$ & \multicolumn{2}{|c|}{ Toxicity Reference Value $=\mathrm{QCE} /$ Total AF } \\
\hline $\begin{array}{c}\mathrm{R} \\
\text { Value } \\
\end{array}$ & \multicolumn{2}{|l|}{$\begin{array}{c}\mathrm{TRV} \\
\text { (mg/kg-day) }\end{array}$} & & \multicolumn{2}{|c|}{ Justification } & $\begin{array}{l}\text { Appropriate Functional } \\
\text { Group }\end{array}$ \\
\hline 1 & $1 \mathrm{E}-6$ & \multicolumn{4}{|c|}{$\begin{array}{l}\text { Test organism is in the same order and trophic level as } \\
\text { the functional group members }\end{array}$} & none \\
\hline 2 & $5 \mathrm{E}-7$ & \multicolumn{4}{|c|}{$\begin{array}{l}\text { Test organism is in a different order and same trophic } \\
\text { level from the functional group members }\end{array}$} & $\mathrm{M} 422, \mathrm{M} 422 \mathrm{~A}$ \\
\hline 3 & $3 \mathrm{E}-7$ & \multicolumn{4}{|c|}{$\begin{array}{l}\text { Test organism is in a different order and trophic level } \\
\text { from the functional group members }\end{array}$} & $\begin{array}{l}\text { M122, M122A, M121, } \\
\text { M123, M132 M210, M210A, } \\
\text { M222, M322 }\end{array}$ \\
\hline
\end{tabular}


COPC:

Test Organisms:

Exposure Medium:

Test Endpoint:

Reference:

Rat (Omnivore, Order-Rodentia)

Drinking water

NOAEL

Cody, T.E., et al., 1981. 1,3-Dinitrobenzene: Toxic Effects In Vivo and In Vitro, Journal of Toxicology and Environmental Health, 7:829-847.

QCE:

\begin{tabular}{|c|c|c|c|c|c|c|}
\hline \multicolumn{5}{|c|}{$\begin{array}{l}\text { Adjustment Factors } \\
\text { (AF) }\end{array}$} & \multicolumn{2}{|l|}{ Justification for adjustment factor } \\
\hline \multicolumn{2}{|l|}{$\mathrm{R}$} & 1 & 2 & 3 & \multicolumn{2}{|c|}{$\begin{array}{l}R=1 \text { is } A F \text { for same order and trophic level } \\
R=2 \text { is } A F \text { for different order and same trophic level } \\
R=3 \text { is } A F \text { for different order and trophic level }\end{array}$} \\
\hline \multicolumn{2}{|l|}{ I } & 1 & 1 & 1 & \multicolumn{2}{|c|}{4 groups of 20 male and 20 female weanling rats } \\
\hline \multicolumn{2}{|l|}{$Q_{1}$} & 1 & 1 & 1 & \multicolumn{2}{|c|}{ Ecologically relevant endpoint (reproduction) } \\
\hline \multicolumn{2}{|l|}{$\mathrm{Q}_{2}$} & 1 & 1 & 1 & \multicolumn{2}{|l|}{ Chronic study (16 weeks) } \\
\hline \multicolumn{2}{|l|}{$\mathrm{Q}_{3}$} & 1 & 1 & 1 & \multicolumn{2}{|l|}{ NOAEL } \\
\hline \multicolumn{2}{|l|}{$U$} & 2 & 2 & 2 & \multicolumn{2}{|c|}{$\begin{array}{l}\text { Slight to moderate decrease in spermatogenesis; middle exposure } \\
\text { level was associated with increased spleen weights; this reaction } \\
\text { may be related to handling stress rather than compound } \\
\text { administration, it was difficult to classify the exposure level as a } \\
\text { NOAEL or a LOAEL }\end{array}$} \\
\hline \multicolumn{2}{|l|}{ M } & 0.5 & 0.5 & 0.5 & \multicolumn{2}{|l|}{ Placed in the drinking water } \\
\hline \multicolumn{2}{|c|}{ Total AF } & 1 & 2 & 3 & \multicolumn{2}{|c|}{$\mathrm{R} * \mathrm{I} * \mathrm{Q}_{1} * \mathrm{Q}_{2} * \mathrm{Q}_{3} * \mathrm{U} * \mathrm{M}=$ Total $A F$} \\
\hline \multicolumn{2}{|c|}{$\mathrm{QCE}(\mathrm{mg} / \mathrm{kg}$-day) } & 0.4 & 0.4 & 0.4 & \multicolumn{2}{|l|}{$\mathrm{QCE}=$ quantified critical endpoint } \\
\hline \multicolumn{2}{|l|}{ TRV } & 0.4 & 0.2 & 0.1 & \multicolumn{2}{|c|}{ Toxicity Reference Value $=\mathrm{QCE} /$ Total AF } \\
\hline $\begin{array}{l}\mathrm{R} \\
\text { Value }\end{array}$ & $\begin{array}{l}\text { TRV } \\
\text { (mg/kg-day) }\end{array}$ & & Justifica & & & $\begin{array}{l}\text { Appropriate Functional } \\
\text { Group }\end{array}$ \\
\hline 1 & 0.4 & & $\begin{array}{l}\text { Test org } \\
\text { the func }\end{array}$ & $\mathrm{m}$ is $\mathrm{i}$ & $\begin{array}{l}\text { e same order and trophic level as } \\
\text { nembers }\end{array}$ & none \\
\hline 2 & 0.2 & & $\begin{array}{l}\text { Test org } \\
\text { level fro }\end{array}$ & m is & $\begin{array}{l}\text { different order and same trophic } \\
\text { nal group members }\end{array}$ & $\mathrm{M} 422, \mathrm{M} 422 \mathrm{~A}$ \\
\hline 3 & 0.1 & & $\begin{array}{l}\text { Test org } \\
\text { from the }\end{array}$ & $\begin{array}{l}\mathrm{m} \text { is } \mathrm{i} \\
\text { action }\end{array}$ & $\begin{array}{l}\text { different order and trophic level } \\
\text { roup members }\end{array}$ & $\begin{array}{l}\text { M121, M122, M122A, M132, } \\
\text { M210, M210A, M222, M322 }\end{array}$ \\
\hline
\end{tabular}

COPC:

Test Organisms:
Nitrobenzene CAS 98-95-3

Rat (Omnivore, Order-Rodentia) 


$\begin{array}{ll}\text { Exposure Medium: } & \text { Oral (gavage) } \\ \text { Test Endpoint: } & \text { FEL } \\ \text { Reference: } & \text { Levin, A.A. 1988, "The Reversibility of Nitrobenzene Induced Testicular Toxicity: } \\ & \text { Continuous Monitoring of Sperm Output from Vasocystotomized Rats", } \\ & \text { Toxicology 53:219-230. } \\ \text { QCE: } & 300 \mathrm{mg} / \mathrm{kg} \text {-day }\end{array}$

\begin{tabular}{|c|c|c|c|c|}
\hline $\begin{array}{l}\text { Adjustment Factors } \\
\text { (AF) }\end{array}$ & & & & Justification for adjustment factor \\
\hline $\mathbf{R}$ & 1 & 2 & 3 & $\begin{array}{l}R=1 \text { is } A F \text { for same order and trophic level } \\
R=2 \text { is } A F \text { for different order and same trophic level } \\
R=3 \text { is } A F \text { for different order and trophic level }\end{array}$ \\
\hline $\mathrm{I}$ & 2 & 2 & 2 & $\begin{array}{l}\text { Only males tested, but numbers were adequate. Observed effects in } \\
\text { the study were noted at lower levels via inhalation }\end{array}$ \\
\hline$Q_{1}$ & 1 & 1 & 1 & Ecologically relevant endpoint (Decreased sperm production). \\
\hline $\mathrm{Q}_{2}$ & 3 & 3 & 3 & Acute study duration \\
\hline$Q_{3}$ & 3 & 3 & 3 & FEL \\
\hline $\mathrm{U}$ & 3 & 3 & 3 & $\begin{array}{l}\text { Reasonable design, looked at reproductive (sperm generation) } \\
\text { endpoint and morphological endpoints. No NOAEL and LOAEL } \\
\text { established, only one dose tested. }\end{array}$ \\
\hline Total AF & 54 & 108 & 162 & $\mathrm{R} * \mathrm{I} * \mathrm{Q}_{1} * \mathrm{Q}_{2} * \mathrm{Q}_{3} * \mathrm{U}=$ Total AF \\
\hline $\mathrm{QCE}(\mathrm{mg} / \mathrm{kg}$-day) & 300 & 300 & 300 & $\mathrm{QCE}=$ quantified critical endpoint \\
\hline TRV & 5.56 & 2.78 & 1.85 & Toxicity Reference Value $=\mathrm{QCE} /$ Total $\mathrm{AF}$ \\
\hline
\end{tabular}

Appropriate Functional Groups:

\begin{tabular}{llll}
\hline $\begin{array}{l}\mathrm{R} \\
\text { Value }\end{array}$ & $\begin{array}{l}\text { TRV } \\
(\mathrm{mg} / \mathrm{kg} \text {-day })\end{array}$ & Justification & Appropriate Functional Group \\
\hline 1 & 5.56 & $\begin{array}{l}\text { Test organism is in the same order and trophic level as the } \\
\text { functional group members }\end{array}$ & none \\
2 & 2.78 & $\begin{array}{l}\text { Test organism is in a different order and same trophic level } \\
\text { from the functional group members }\end{array}$ & M422, M422A \\
3 & 1.85 & $\begin{array}{l}\text { Test organism is in a different order and trophic level from } \\
\text { the functional group members }\end{array}$ & $\begin{array}{l}\text { M121, M122, M122A, M132, } \\
\text { M210, M210A, M222, M322 }\end{array}$ \\
\hline
\end{tabular}

COPC:

Test Organisms: Exposure Medium:

\section{2,4-Dinitrotoluene CAS 121-14-2}

Mouse (Omnivore, Order-Rodentia)

Diet 
Test Endpoint:

Reference:

QCE:
LOAEL

Hong, C.B., et al., 1985. Subchronic and Chronic Toxicity Studies of 2,4Dinitrotoluene. Part III. CD-1 Mice, Journal of the American College of Toxicology, 4(4):257-269.

$14 \mathrm{mg} / \mathrm{kg}$-day

\begin{tabular}{|c|c|c|c|c|c|c|}
\hline \multicolumn{5}{|c|}{$\begin{array}{l}\text { Adjustment Factors } \\
(\mathrm{AF})\end{array}$} & \multicolumn{2}{|l|}{ Justification for adjustment factor } \\
\hline \multicolumn{2}{|l|}{$\mathrm{R}$} & 1 & 2 & 3 & \multicolumn{2}{|c|}{$\begin{array}{l}R=1 \text { is } A F \text { for same order and trophic level } \\
R=2 \text { is } A F \text { for different order and same trophic level } \\
R=3 \text { is } A F \text { for different order and trophic level }\end{array}$} \\
\hline $\mathrm{I}$ & & 1 & 1 & 1 & \multicolumn{2}{|c|}{ Groups of 38 male and female weanling mice (CD-1 strain) } \\
\hline$Q_{1}$ & & 1 & 1 & 1 & \multicolumn{2}{|c|}{ Ecologically relevant endpoint (reproduction) } \\
\hline $\mathrm{Q}_{2}$ & & 1 & 1 & 1 & \multicolumn{2}{|l|}{ Chronic study ( 2 years) } \\
\hline $\mathrm{Q}_{3}$ & & 2 & 2 & 2 & \multicolumn{2}{|l|}{ LOAEL } \\
\hline $\mathrm{U}$ & & 2 & 2 & 2 & \multicolumn{2}{|c|}{$\begin{array}{l}\text { Males exposed to this dose equivalent had a decreased body weight } \\
\text { gain. No NOAEL was established. }\end{array}$} \\
\hline Total A & & 4 & 8 & 12 & \multicolumn{2}{|c|}{$\mathrm{R} * \mathrm{I} * \mathrm{Q}_{1} * \mathrm{Q}_{2} * \mathrm{Q}_{3} * \mathrm{U}=$ Total AF } \\
\hline QCE ( & g/kg-day) & 14 & 14 & 14 & \multicolumn{2}{|l|}{$\mathrm{QCE}=$ quantified critical endpoint } \\
\hline TRV & & 3.5 & 1.8 & 1.2 & \multicolumn{2}{|c|}{ Toxicity Reference Value $=\mathrm{QCE} /$ Total AF } \\
\hline $\begin{array}{l}\mathrm{R} \\
\text { Value }\end{array}$ & \multicolumn{2}{|l|}{$\begin{array}{l}\mathrm{TRV} \\
(\mathrm{mg} / \mathrm{kg} \text {-day) }\end{array}$} & \multicolumn{3}{|c|}{ Justification } & $\begin{array}{l}\text { Appropriate Functional } \\
\text { Group }\end{array}$ \\
\hline 1 & \multicolumn{2}{|l|}{3.5} & \multicolumn{3}{|c|}{$\begin{array}{l}\text { Test organism is in the same order and trophic level as } \\
\text { the functional group members }\end{array}$} & none \\
\hline 2 & \multicolumn{2}{|l|}{1.8} & \multicolumn{3}{|c|}{$\begin{array}{l}\text { Test organism is in a different order and same trophic } \\
\text { level from the functional group members }\end{array}$} & $\mathrm{M} 422, \mathrm{M} 422 \mathrm{~A}$ \\
\hline 3 & \multicolumn{2}{|l|}{1.2} & \multicolumn{3}{|c|}{$\begin{array}{l}\text { Test organism is in a different order and trophic level } \\
\text { from the functional group members }\end{array}$} & $\begin{array}{l}\text { M121, M122, M122A, M132, } \\
\text { M210, M210A, M222, M322 }\end{array}$ \\
\hline
\end{tabular}

COPC:

Test Organisms:

Exposure Medium:

Test Endpoint:
2,6-Dinitrotoluene CAS 606-20-2

Dog (Omnivore, Order-Carnivora)

Diet

LOAEL 
Lee, C.C. et al. 1976. Mammalian Toxicity of Munitions Compounds, Phase II, Effects of Multiple Doses, Part III: 2,6-Dinitrotoluene, Progress Report No. 4, Midwest Research Report Institute Project No. 3900-B, Contract No. DAMD17-74-C-4073.

QCE: $20 \mathrm{mg} / \mathrm{kg}$-day

\begin{tabular}{|c|c|c|c|c|c|c|}
\hline \multicolumn{5}{|c|}{$\begin{array}{l}\text { Adjustment Factors } \\
\text { (AF) }\end{array}$} & \multicolumn{2}{|l|}{ Justification for adjustment factor } \\
\hline \multicolumn{2}{|l|}{$\mathrm{R}$} & 1 & 2 & 3 & \multicolumn{2}{|c|}{$\begin{array}{l}R=1 \text { is } A F \text { for same order and trophic level } \\
R=2 \text { is } A F \text { for different order and same trophic level } \\
R=3 \text { is } A F \text { for different order and trophic level }\end{array}$} \\
\hline I & & 1 & 1 & 1 & \multicolumn{2}{|c|}{$\begin{array}{l}4 \text { groups of } 4 \text { females and } 4 \text { male beagle dogs were given } 4,20 \text {, or } \\
100 \mathrm{mg} / \mathrm{kg} / \text { day of } 2,6-\mathrm{DNT} \text { in capsules. }\end{array}$} \\
\hline$Q_{1}$ & & 1 & 1 & 1 & \multicolumn{2}{|c|}{ Ecologically relevant endpoints (weight gain, reproductive effects) } \\
\hline $\mathrm{Q}_{2}$ & & 1 & 1 & 1 & \multicolumn{2}{|l|}{ Chronic study (13 weeks) } \\
\hline $\mathrm{Q}_{3}$ & & 2 & 2 & 2 & \multicolumn{2}{|l|}{ LOAEL } \\
\hline $\mathrm{U}$ & & 2 & 2 & 2 & \multicolumn{2}{|c|}{$\begin{array}{l}\text { The } 4 \mathrm{mg} / \mathrm{kg} / \text { day dose showed little if any toxic effects while the } 20 \\
\text { and } 100 \mathrm{mg} / \mathrm{kg} / \text { day doses showed more severe effects. The latter } \\
\text { two doses produced decreased feed intake and atrophy of the testes. } \\
\text { All dogs in the } 100 \mathrm{mg} / \mathrm{kg} / \text { day dose group died so the } 20 \mathrm{mg} / \mathrm{kg} / \text { day } \\
\text { was considered the LOAEL. }\end{array}$} \\
\hline Total A & & 4 & 8 & 12 & \multicolumn{2}{|c|}{$R * I * Q_{1} * Q_{2} * Q_{3} * U=$ Total AF } \\
\hline $\mathrm{QCE}(\mathrm{n}$ & /kg-day) & 20 & 20 & 20 & \multicolumn{2}{|l|}{$\mathrm{QCE}=$ quantified critical endpoint } \\
\hline TRV & & 5.0 & 2.5 & 1.7 & \multicolumn{2}{|c|}{ Toxicity Reference Value $=\mathrm{QCE} /$ Total $\mathrm{AF}$} \\
\hline $\begin{array}{l}\mathrm{R} \\
\text { Value }\end{array}$ & \multicolumn{2}{|l|}{$\begin{array}{l}\text { TRV } \\
(\mathrm{mg} / \mathrm{kg} \text {-day) }\end{array}$} & \multicolumn{2}{|c|}{ Justification } & & $\begin{array}{l}\text { Appropriate Functional } \\
\text { Group }\end{array}$ \\
\hline 1 & \multicolumn{2}{|l|}{5.0} & \multicolumn{3}{|c|}{$\begin{array}{l}\text { Test organism is in the same order and trophic level as } \\
\text { the functional group members }\end{array}$} & M422A \\
\hline 2 & \multicolumn{2}{|l|}{2.5} & \multicolumn{3}{|c|}{$\begin{array}{l}\text { Test organism is in a different order and same trophic } \\
\text { level from the functional group members }\end{array}$} & M422 \\
\hline 3 & \multicolumn{2}{|l|}{1.7} & \multicolumn{3}{|c|}{$\begin{array}{l}\text { Test organism is in a different order and trophic level } \\
\text { from the functional group members }\end{array}$} & $\begin{array}{l}\text { M121, M122, M122A, M123, } \\
\text { M210, M210A, M222, M322 }\end{array}$ \\
\hline
\end{tabular}

COPC:

Test Organisms: Exposure Medium: Test Endpoint: Reference:

\section{Pentachloronitrobenzene (PCNB) CAS 82-68-8}

Chicken (Omnivore, Order-Galliformes)

Oral in diet

NOAEL

Dunn, J.S. et al. 1979. Effect of pentachloronitrobenzene upon egg production, hatchability, and residue accumulation in the tissues of White Leghorn hens. Toxicol. Appl. Pharmacol. 48: 425-433. 


\begin{tabular}{|c|c|c|c|c|c|c|}
\hline \multicolumn{5}{|c|}{$\begin{array}{l}\text { Adjustment Factors } \\
\text { (AF) }\end{array}$} & \multicolumn{2}{|l|}{ Justification for adjustment factor } \\
\hline $\mathrm{R}$ & \multicolumn{2}{|r|}{1} & 2 & 3 & \multicolumn{2}{|c|}{$\begin{array}{l}R=1 \text { is } A F \text { for same order and trophic level } \\
R=2 \text { is } A F \text { for different order and same trophic level } \\
R=3 \text { is } A F \text { for different order and trophic level }\end{array}$} \\
\hline I & & 1 & 1 & 1 & \multicolumn{2}{|c|}{ Hens tested at four dose levels: $10,50,100$, and $1000 \mathrm{ppm}$. } \\
\hline $\mathrm{Q}_{1}$ & & 1 & 1 & 1 & \multicolumn{2}{|c|}{ Ecologically relevant endpoint (reproduction) } \\
\hline $\mathrm{Q}_{2}$ & & 1 & 1 & 1 & \multicolumn{2}{|c|}{ Chronic study, 35 weeks (>10 during a critical lifestage) } \\
\hline $\mathrm{Q}_{3}$ & & 1 & 1 & 1 & \multicolumn{2}{|l|}{ NOAEL } \\
\hline $\mathrm{U}$ & & 2 & 2 & 2 & \multicolumn{2}{|c|}{$\begin{array}{l}\text { Egg production and egg hatchability was reduced among birds } \\
\text { receiving the } 1000 \mathrm{ppm} \text { dose. No effects were observed at the } \\
\text { other dose levels so the } 100 \mathrm{ppm} \text { dose was considered the NOAEL. }\end{array}$} \\
\hline Total $A$ & & 2 & 4 & 6 & \multicolumn{2}{|c|}{$\mathrm{R} * \mathrm{I} * \mathrm{Q}_{1} * \mathrm{Q}_{2} * \mathrm{Q}_{3} * \mathrm{U}=$ Total $\mathrm{AF}$} \\
\hline QCE ( & (kg-day) & 7.07 & 7.07 & 7.07 & \multicolumn{2}{|l|}{$\mathrm{QCE}=$ quantified critical endpoint } \\
\hline TRV & & 3.54 & 1.77 & 1.18 & \multicolumn{2}{|c|}{ Toxicity Reference Value $=\mathrm{QCE} / \mathrm{Total} \mathrm{AF}$} \\
\hline $\begin{array}{l}\mathrm{R} \\
\text { Value }\end{array}$ & \multicolumn{2}{|l|}{$\begin{array}{l}\text { TRV } \\
\text { (mg/kg-day) }\end{array}$} & \multicolumn{2}{|c|}{ Justification } & & $\begin{array}{l}\text { Appropriate Functional } \\
\text { Group }\end{array}$ \\
\hline 1 & 3.54 & & \multicolumn{3}{|c|}{$\begin{array}{l}\text { Test organism is in the same order and trophic level as } \\
\text { the functional group members }\end{array}$} & none \\
\hline 2 & 1.77 & & \multicolumn{3}{|c|}{$\begin{array}{l}\text { Test organism is in a different order and same trophic } \\
\text { level from the functional group members }\end{array}$} & $\begin{array}{l}\text { AV422, AV432, } \\
\text { AV433,AV442 }\end{array}$ \\
\hline 3 & 1.18 & & \multicolumn{3}{|c|}{$\begin{array}{l}\text { Test organism is in a different order and trophic level } \\
\text { from the functional group members }\end{array}$} & $\begin{array}{l}\text { AV121, AV122, AV132, } \\
\text { AV142, AV143, AV210, } \\
\text { AV210A, AV221, AV222, } \\
\text { AV222A, AV232, AV233, } \\
\text { AV241, AV242, AV310, } \\
\text { AV322, AV333, AV342 }\end{array}$ \\
\hline
\end{tabular}




\section{Appendix $\mathrm{H}$}

Revised Responses to Technical Review Comments for the Screening Level Risk Assessment (SLRA) for the New Waste Calcining Facility

\section{December 1998}

Revised April 1999 


\section{REVISED RESPONSES TO \\ TECHNICAL REVIEW COMMENTS FOR THE SCREENING LEVEL RISK ASSESSMENT (SLRA) FOR THE NEW WASTE CALCINING FACILITY IDAHO NATIONAL ENGINEERING AND ENVIRONMENTAL LABORATORY (INEEL) \\ December 1998 \\ Revised April 1999}

\section{INTRODUCTION}

This document provides revised responses to Technical Review Comments for the Screening Level Risk Assessment (SLRA) for the New Waste Calcining Facility (Draft Revision 2, September 1997), EPA ID No. ID4890008952, received on March 18, 1998 from the DEQ Hazardous Waste Permitting Bureau (HWPB) . A response to these NOD comments and a revised SLRA (Revision 3 ) was submitted to DEQ in May 1998. In November 1998, a letter was received from DEQ stating that the NOD responses were not acceptable, the SLRA was not reviewed by EPA or DEQ, and a final SLRA be submitted to DEQ no later than December 31, 1998. This document provides revised NOD responses which describe the additional revisions made for this SLRA submittal (Revision 4a). Included are a general discussion of the SLRA process as specified in EPA guidance, description of some revisions made after submittal of the Revision 2 that were not identified in the review comments, and DOE's revised responses to the general and specific review comments included in the March NOD. The current revision of the SLRA contains significant additional analyses and discussion relating to the NOD comments.

For this SLRA and all previous versions, Contaminants of Potential Concern (COPCs) were determined and emission rates were calculated using best available process knowledge rather than trial burn measurements, which have proven impossible in the past due to the high acid environment of the NWCF offgas. This process knowledge consisted of conservative feed rate concentrations, conservative estimates of offgas partitioning and HEPA filtration, and conservative estimates Products of Incomplete Combustion (PIC) formation using worst-case combinations of known PIC precursors in the feed. New emissions testing is planned for the NWCF in an Offgas Demonstration Project (ODP) during the period January through April, 1999, after which it is planned to shutdown the NWCF. The results of the ODP, which are estimated to be available by the end of June 1999, will be used to determine whether the COPC emission rates evaluated in this SLRA conservatively bound the impacts from NWCF operations. If the ODP results show that actual emissions are higher than those evaluated in the SLRA, or if significant additional COPCs are detected, then DOE may decide to further revise this SLRA. This decision will also be based on the results of the High Level Waste Environmental Impact Statement (HLWEIS) which will determine whether or not the NWCF will be restarted. If a decision is made to restart the NWCF, then the SLRA may be further revised using the COPC emission rates determined in the ODP and new risk assessment guidance published in EPA's draft Human Health Protocol for Hazardous Waste Combustion Facilities (EPA530-D-98-001A, July 1998) (HHRAP). The decision on the future of the NWCF is scheduled to be made by June 1, 2000.

This revision of the SLRA was completed in accordance with concise guidelines specified in 1) Guidance for Performing Screening Level Risk Analyses at Combustion Facilities Burning Hazardous Waste, EPA Draft Attachment C, December 14, 1998 and 2) Exposure Assessment Guidance for RCRA Hazardous Waste Combustion Facilities, EPA530-R-94-021, April 1994. Since submittal of Revision 3 of the SLRA in May 1998, The new HHRAP was published by EPA in July 1998. Significant efforts were made in

a. Letter from Randal W. Steger, Manager, DEQ Hazardous Waste Permitting Bureau, to Donald N. Rasch, DOE Idaho Operations Office, March 16, 1998. 
Revision 4 of the SLRA to incorporate some of these new risk assessment methods. However, because this guidance was not released by EPA until after submittal of Revision 3 and because the State response to the May 1998 Revision 3 was not received from DEQ until November 22, 1998, not all of the new HHRAP requirements could be incorporated in time to meet the DEQ's December 31, 1998 "final" SLRA submittal date.

A major concern expressed by DEQ in their November letter response was that the qualitative ecological risk discussion included as part of Revision 3 (Section 8) was not adequate. The letter stated, "an ecological component to the risk assessment is required" and that the SLRA must evaluate the "potential magnitude of the ecological effects" from NWCF emissions. DOE believes that the qualitative ecological risk discussion in Revision 3 was done in accordance with the most current EPA SLRA guidance (1994) available at the time (which specifies a qualitative ecological risk assessment) and that it was also a "component" of the May 1998 Revision 3 of the SLRA. Although EPA has not currently published new quantitative ecological risk assessment guidelines, a Risk Assessment Work Plan (RAWP) that describes quantitative ecological risk assessment methods done for another EPA Region X combustion unit ${ }^{b}$ was received by DOE in early December 1998. This RAWP is reportedly based on new ecological risk assessment methods for combustion units which may be published by the EPA's Office of Solid Waste (OSW) in the Spring of 1999. However, although this RAWP list critical input parameters and methods required to do an adequate quantitative assessment, there was not adequate time to perform this assessment for the NWCF SLRA by December 31, 1998. DOE will re-examine the need to do a full quantitative ecological risk assessment after the HLWEIS is published and a decision is made on whether to restart and permit the NWCF. This decision will be made by June 1, 2000, in accordance with the Notice of Noncompliance Consent Order.

Revision 5 Addendum (April 1999) - A quantitative Screening Level Ecological Risk Assessment (SLERA) was completed for revision 5 of the SLRA (Section 8 ).

\section{GENERAL RESPONSE TO THE NOD}

The 1994 EPA risk assessment guidance that was followed for this SLRA was developed with conservative assumptions to adequately bound investigation of refined exposure scenarios or additional detailed assessment. As the guidance states (p. C-1-1), "The screening procedure is intended to give a conservative estimate of the potential risk in order to determine whether a more detailed site-specific assessment is warranted...If the final estimated risk is below levels of concern, then there is good reason to conclude that further analysis of the risk from stack emissions is unnecessary." Since the results of the NWCF SLRA indicate that potential health impacts are significantly less than health criteria, additional refined investigations beyond the scope of the guidance should not be necessary. However, for this revision, effort was made to address additional exposure concerns that would not necessarily affect the final risk results.

Based on both the 1994 EPA risk assessment guidance and the new HHRAP, the objectives of the NWCF SLRA were to demonstrate that maximum potential risk from NWCF emissions is less than the $10^{-5}$ cancer risk criteria and 0.25 non-cancer hazard index. Efforts to develop best-estimate predictions at significantly less impact levels than these criteria were not considered to be justified. Since the maximum risk estimate determined in the SLRA is a factor of 10 less than the risk criteria, additional refinements that would likely reduce the risk estimate were not done. An example of this would be the very difficult investigation of all

b. Allied Technology Group, Inc. (ATG) Risk Assessment Work Plan for the ATG Richland Mixed Waste Facility, October 9, 1998. 
Products of Incomplete Combustion (PICs) when it can be demonstrated through conservative assumptions of feed materials and conservation of mass that worst-case production of a subset of highly toxic indicator PICs (dioxins/furans and nitroaromatics) would bound the impacts from all PICs actually emitted.

\section{REVISIONS NOT IDENTIFIED IN TECHNICAL REVIEW COMMENTS}

An error was identified in a parameter value input for soil volatilization loss (rainfall rate was mistakenly used for the universal gas constant). Correction of this error resulted in a significant decrease in indirect impacts for volatile constituents. As a result, indirect risk decreased from $1 \mathrm{E}-06$ to $1 \mathrm{E}-07$ and the indirect hazard index decreased from 0.07 to 0.02 .

Mercury (Hg) emission estimates were increased based on $\mathrm{Hg}$ analyses of charcoal beds in the main stack radioiodine sampler during NWCF campaign $\mathrm{H}-4$ from June 25,1997 through December 23, 1997. These measurements indicated $2.9 \%$ to $3.24 \%$ of the $\mathrm{Hg}$ in the feed was being released out the main stack, which is higher than the $1 \%$ assumed in the SLRA. As a result, $\mathrm{Hg}$ releases were increased in the SLRA from 28 $\mathrm{kg} / \mathrm{y}$ to $100 \mathrm{~kg} / \mathrm{y}$ (corresponds to a $3.57 \% \mathrm{Hg}$ release rate). This increased the SLRA hazard quotient for $\mathrm{Hg}$ from 0.0003 to 0.001 (indirect). The SLRA health criteria for hazard index is 0.25 . Revision 5 Addendum - Mercury emission estimates (and the resulting hazard) were recalculated based on analysis of three charcoal filter samples (see section 2).

The 1996 main stack emissions of iodine- $129\left({ }^{129} \mathrm{~T}\right)$ was corrected from $0.0554 \mathrm{Ci}$ to $0.106 \mathrm{Ci}$ to account for an undetected increase in dilution air entering the main stack gaseous monitoring system ${ }^{c}$. This increased the maximum calculated risk from $8 \mathrm{E}-07$ to $1 \mathrm{E}-6$ (Section 6.4).

The Idaho Chemical Processing Plant (ICPP) changed its name to the Idaho Nuclear Technology and Engineering Center (INTEC) after transmittal of Revision 3 of the SLRA. This revision has replaced ICPP with INTEC.

\section{GENERAL COMMENTS}

1. Certain significant gaseous emissions are not considered in the SLRA beyond the acute inhalation effects. These emissions which include some highly noxious materials such as oxides of nitrogen $\left(\mathrm{NO}_{\mathrm{x}}\right)$ nitric acid $\left(\mathrm{HNO}_{3}\right)$ sulfur dioxide $\left(\mathrm{SO}_{2}\right)$, and hydrogen fluoride (HF) must be evaluated in the SLRA (see Specific Comment \#13, below).

Response: The SLRA was revised as requested. The gases listed in the comment $\left(\mathrm{NO}_{2}, \mathrm{HNO}_{3}, \mathrm{SO}_{2}\right.$, and HF) were not evaluated in the original calculations because EPA inhalation toxicity criteria (URFs and RfCs) were not available. In the revised SLRA, toxicity criteria are calculated from either EPA Region III Risk Based Concentrations (RBCs) or State of Idaho AACCs/AACs. The resulting risk or HQ for each gas is now included in the inhalation risk (Table 8) and the inhalation HQ calculations (Table 9). Revision 5 Addendum - new toxicity values were used (see section 5).

c. LMITCO letter from S.K. Zohner to J.P. Law, ${ }^{129}$ I CORRECTION TO THE 1996 RADIOACTIVE NESHAP REPORT FOR THE INEEL - SKZ-05-98, July 28, 1998. 
2. The assumption that the composition of the emissions from the calciner is inert with respect to the other off-gas streams is not appropriate. The air pollution control devices and stack are ancillary equipment to the calciner and the potential for reactions that result in toxic emissions as a result of the mixing of many off-gas streams must be evaluated and incorporated in the SLRA.

Response: The SLRA was revised to include a discussion of the potential for additional reactions in the off-gas streams and resulting PIC emissions. The NWCF operates continually and contributes the vast majority of radionuclide, gases, chlorine, metals, and organic emissions to the main stack. Other significant off-gas waste streams which are intermittently vented to the main stack include the High Level Liquid Waste Evaporator (HLWE) and the Liquid Effluent Treatment and Disposal facility (LET\&D). The HLWE does not operate at the same time as the NWCF. The LET\&D has smaller emission rates of the same general types of contaminants as the NWCF, and, as a result, would not contribute appreciably to formulation of additional contaminants as a result of mixing in the off-gas stream. In addition, the general possibility of additional reactions in the offgas and main stack are extremely remote because of the ambient temperature, high flow rate (123,000 acfm), and low contaminant concentrations in the offgas. Therefore, detailed evaluation of these other off-gas streams would not result in appreciable change to the COPC list and the respective COPC emission rates. Revision 5 Addendum - quantitative estimates of emission rates from other NWCF/main stack sources have been made and assessed in the risk assessment (see section 2).

3. Potentially significant on-site receptors have not been evaluated. The adult resident scenario does not factor in the highly likely combination of residence and worker exposures (see Specific Comments 9 and 10 below). On-site hunter and herder scenarios shall be added to the SLRA (see Specific Comments 1 and 10 below).

Response: The SLRA was revised as follows:

Onsite Worker Impacts. Maximum inhalation impacts for an INEEL worker at any adjacent on-site INEEL facility (excluding INTEC) were evaluated by examining the maximum air concentration isopleths shown in Figure 7 and the inhalation toxicity criteria given in Tables 8 and 9 . The maximum air concentration at any adjacent facility is $0.025 \mathrm{ug} / \mathrm{m}^{3}$ per g/s at the northwest corner of the Central Facilities Area (CFA) (UTM location 342630 East and 4821520 North) which is $40 \%$ of the maximum off-site concentration $\left(0.062 \mathrm{ug} / \mathrm{m}^{3} \mathrm{per} \mathrm{g} / \mathrm{s}\right)$ (the off-site concentration is higher because of elevated terrain) Using the off-site risk results from Table 8, the maximum cancer risk to an individual that continuously resided at the worstcase CFA location would be 3.2E-07 (40\% of the maximum offsite cancer risk). Since workers are only present for 2000 hours per year (out of the total 8760 hours per year), the maximum cancer risk scaled for worker residence time ( $x 2000 \mathrm{hrs} / 8760 \mathrm{hrs}$ ) is $7.3 \mathrm{E}-08$. The maximum total hazard index was calculated to be 0.036 , or $40 \%$ of the maximum offsite hazard index $(0.09)$ in Table 9 . Indirect (ingestion) impacts to workers were not assessed because there is no food grown or produced at the INEEL. Revision $\mathbf{5}$ Addendum - the worker and herdsman cancer risks and hazard quotients were revised based on revised emission rate data (see Section 6).

On-site Herdsman Scenario. A hypothetical herdsman was assumed to reside for $1 / 3$ of a year at the point of maximum deposition on the INEEL south of US20 (where grazing is allowed). The herdsman is assumed to be exposed to contaminants through inhalation and consumption of meat from livestock (sheep or cattle) that have been raised at that location and incidental soil ingestion. The herdsman consumption rates for these media and the years of exposure are assumed to be the same as those evaluated for 
subsistence farmer scenario. The herdsman consumes no contaminated milk or produce because dairy cows or produce production are not allowed on the INEEL.

The maximum inhalation impacts at this location were evaluated in a similar manner to the on-site worker (above) by scaling the maximum off-site inhalation impacts given in Tables 8 and 9 based on the ratio of air concentrations between the herdsman location and the maximum off-site impact location. Using Figure 7, the maximum air concentration at any location south of U.S. highway 20 is $0.065 \mathrm{ug} / \mathrm{m}^{3} \mathrm{per} \mathrm{g} / \mathrm{s}$ which is almost the same as the maximum off-site location $\left(0.062 \mathrm{ug} / \mathrm{m}^{3} \mathrm{per} \mathrm{g} / \mathrm{s}\right)$ (the off-site value is relatively high because of elevated terrain). Accounting for the assumed $1 / 3$ year residence time at the grazing location, the maximum risk due to inhalation would be $8 \mathrm{E}-07 / 3$, or $2.7 \mathrm{E}-07$. The maximum total Hazard Index would be approximately the same as that at the maximum offsite location in Table 9, 0.09 .

Revision 5 Addendum - the worker and herdsman cancer risks and hazard quotients were revised based on revised emission rate data (see Section 6).

An upper-bound estimate of the indirect (ingestion) impacts for the herdsman were assessed by assuming that the indirect fate/transport equations and parameter values used for the subsistence farmer bound the herdsman's potential intake. Since total intake (and therefore risk) is directly proportional to deposition rate (deposition rate is in the numerator of the soil equation) and the exposure time, the calculated subsistence farmer total indirect cancer risk from Table 12 (1E-07) can be scaled to upper-bound herdsman risk by multiplying by the ratio of deposition rates at the two locations $\left(D_{\text {herd }} / D_{\text {farm }}\right)$ and the ratio of the annual residence times for the two scenarios $\left(T_{\text {herd }} / T_{\text {farm }}=4\right.$ months $/ 12$ months $\left.=1 / 3\right)$. Using Figure 8 , the maximum deposition rate at any herdsman location south of U.S. highway 20 is $1.3 \mathrm{E}-03 \mathrm{~g} / \mathrm{m}^{2}$-year per g/s. Dividing this value by the maximum off-site deposition rate (at which the subsistence farmer was evaluated) of $6.9 \mathrm{E}-04 \mathrm{~g} / \mathrm{m}^{2}$-year per $\mathrm{g} / \mathrm{s}$ gives a $D_{\text {herd }} / D_{\text {fam }}$ value of 1.9 . Multiplying the subsistence farmer risk from Table $12(1 \mathrm{E}-07)$ by these factors $(0.33 \times 1.9=0.63)$ gives an estimated total indirect cancer risk estimate for the herdsman of $6.3 \mathrm{E}-08$. The indirect exposure hazard index for the herdsman was calculated to be 0.011 , by multiplying the indirect hazard index for the farmer (6E-03, Table 13) by the ratio of the deposition rates at the two locations (1.9). By scaling the subsistence farmer total impacts, both the cancer risk estimate and the hazard index estimate for the herdsman are overestimates of any potential herdsman risk because the herdsman does not consume contaminated milk or produce (as assumed for the farmer). Revision 5 Addendum - the worker and herdsman cancer risks and hazard quotients were revised based on revised emission rate data (see Section 6).

On-site hunter scenarios south of the NWCF facility are not considered a significant exposure scenario (relative to other assessed scenarios) because:

1) Controlled hunting access is allowed only within one-half mile of the INEEL boundary on infrequent occasions and usually only occurs on the north end of the site adjacent to the farms west of Mud Lake (approximately $50 \mathrm{~km}$ northeast of NWCF) and on the northwest site boundary on the southern terminus of the Lemhi Range. A revised figure (Figure 1) was added to the SLRA to show these areas.

2) The Environmental Science and Research Foundation (Warren and Mitchell, in press) recently completed a major big game dose study on the INEEL that examined measured radionuclide concentrations in deer and pronghorn antelope on the INEEL over the period 1972 through 1996. In the vast majority of animals examined, tissue concentrations were similar to background levels and were attributed to global fallout from nuclear weapons testing. Although this study did not examine organic or metal contaminant concentrations, it indicates that this exposure pathway is not likely to be significant at the INEEL. 
3) Calculated impacts for a hypothetical hunter are bounded by the subsistence farmer scenario because of the relative ingestion rates of contaminated meat assumed in the exposure equations (the hunter eats limited amounts of potentially contaminated game while the farmer continuously consumes contaminated beef, milk, and vegetables). Since the calculated subsistence farmer risk (1E-07) and hazard index (0.006) were significantly less than the SLRA criteria (1E-05 risk and 0.25 hazard index), the calculated hypothetical hunter impacts would also be less than these criteria.

4. Based on the modeling described in the SLRA, it is unclear whether the areas of highest deposition were outside the boundaries of the INEEL or whether only the highest areas outside the boundaries of the INEEL were considered. The text shall identify the areas of highest deposition and adjust the SLRA as appropriate. Figures $4,5,6$, and 7 should be revised to present this information more clearly. Scales should be added and, where appropriate, landmarks other than the gross UTM coordinates included.

Response: The SLRA was revised. It is stated in Chapter 3 that only off-INEEL locations and U.S. public highways that traverse the INEEL were evaluated in the refined grid modeling. All maximum off-site deposition results occurred on the north end of Big Southern Butte which is shown in Figure 5. Figure 5 has been modified to more clearly identify INEEL landmarks. Figures 7 and 8 were included as an aid to the reader to demonstrate that 1) the maximum vapor concentration and particulate deposition rate values occurred on the same (Big Southern Butte) refined grid and 2) the grid boundaries adequately encompassed the maximum values (the maximum value was centered in the grid). A larger scale landmark map is included with each of these figures.

5. The dispersion modeling analysis that was conducted using the 50-kilometer coarse grid evaluated only annual average concentrations for the particulate and vapor scenarios. The results of these modeling runs were used to select the location of the fine receptor grids. Because maximum short-term impacts can occur in different locations than maximum annual impacts, short-term concentrations should be evaluated in the coarse grid model runs. The results of these model runs should be used to develop additional fine receptor grids, if necessary.

Response: The SLRA was revised to better explain why a coarse grid is not needed to assess shortterm impacts. Maximum short-term impacts for the public will occur on U.S. highway 20 (a line) which is adequately assessed using a string of discrete receptors (shown in Figure 6).

6. Emissions of radionuclides from the calciner must be accounted for in terms of overall risk, even though radiation releases are not a direct subject of the RCRA Part B permit application. Because those releases contribute to the overall risk posed by the calciner, they must be accounted for to assess whether releases from the calciner pose no unacceptable risks to human health or the environment (see Section 2.2.5). Slope values for individual radionuclides are available in Health Effects Assessment Summary Tables (HEAST). A methodology for estimating excess cancer risks from radioactive materials is detailed in EPA document, "Radiation Exposure and Risk Assessment Manual (RERAM): Risk Assessment Using Radionuclide Slope Factors, Office of Radiation and 
Indoor Air, June 1996, EPA 402-R-96-016." A summary of this approach can also be found in EPA document "A Summary of Radiation Risk Assessment Using Radionuclide Slope Factors," August 1996. Application of this approach is also addressed in OSWER No. 9200.4-18.

Response: The SLRA was revised. Radionuclides were evaluated for lifetime excess cancer risk using the 1997 INEEL National Emission Standards for Hazardous Air Pollutants (NESHAP) dose rate from the INTEC main stack $(0.316 \mathrm{mrem} / \mathrm{yr})$, current EPA risk factors for morbidity taken from Estimating Radiogenic Cancer Risk (EPA 402-R-93-076), which is the basis for the RERAM document, and conservative assumptions of exposure duration. Radionuclide risk was not calculated using radionuclide slope factors because: (1) the current exposure equations given in the combustion guidance need to be revised by EPA to include the effects of decay and ingrowth and the fate and transport parameter values for common radionuclides, (2) there are several technical problems with using slope factors, which were developed for buried waste at CERCLA sites, to assess surface fallout from combustion facilities (e.g. the ground surface external exposure slope factor assumes an infinite thickness of the radionuclide in the soil while fallout remains mostly on the surface), and 3) risk from radionuclides should be calculated consistently with the EPA NESHAP requirements, which uses the fate and transport equations in the CAP88 code. Both are EPA assessments for the same facility releases, and both are subject to public review. It is generally recognized that the CAP- 88 fate and transport equations are conservative compared to those in the combustion guidance. For instance, CAP-88 defaults to a 100-yr-soil buildup time for surface deposition resulting in much higher indirect intake (from food products and ground surface gamma pathways).

\section{SPECIFIC COMMENTS}

1. Section 1.3, page 4. The text states that stock herdsmen and hunters are permitted within the INEEL boundary; however, short-term modeled impacts have not been evaluated inside the facility boundary. The dispersion modeling should include receptors to evaluate potential short-term impacts to herdsmen and hunters.

Response: The SLRA was revised to include a on-site herdsman scenario. The hunter scenario was examined and determined not to be a significant scenario. The basis for this determination was added to the SLRA (see response to General Comment \# 3)

2. Section 2. This section of the SLRA must be amended to discuss the potential for fugitive emissions from the facility (i.e., tank farm facility, etc.) and any potential air pollution control equipment bypass events. Any fugitive emissions or bypass events identified should be estimated and incorporated into the risk assessment. Also, as this is an operating facility, a discussion of actual upset operating events that have occurred (e.g., problems with the fluidized bed or temperature excursions) should be included and compared with the upset factors used in the risk assessment.

Response: The SLRA was revised to include the following discussion of the potential for fugitive emissions, air pollution control by-pass events, and upset operating events: 
Fugitive emissions are prevented by operating the INTEC processes, including the tank farm, under vacuum so that leakage is inward. The process equipment is located in cells whose exiting ventilation air is monitored to verify the absence of leakage from the process equipment. The cell ventilation air is discharged to the stack.

The most significant air pollution control by-pass event is filter deterioration that is a partial by-pass. Filter deterioration is considered in Appendix $\mathrm{C}$ of Appendix $\mathrm{A}$ and averaged into the average filter efficiency used for the calculations (see discussion on upset factors, below). The silica-gel adsorbers can be bypassed. The emission rate calculations took no credit for the adsorbers $(D F=1)$ to conservatively account for this. The scrub system cannot be bypassed. Its loss of scrub solution leads to a rapid shutdown.

Most operating upsets result in reduced feed rates or shutdown thus reducing emissions. Maximum emissions of the most significant species (e.g., $\mathrm{Hg}$ ) occur with smooth operation at the maximum feed rate. Temperature excursions have not been observed. The controller is programmed to shut off feed if a temperature excursion occurs. Inadequate fluidization leads to reduced feed rates and often to shutdown. Plugging of the solids discharge from the product removal cyclone leads to increased solids flow into the scrub system. The incremental solids from the cyclone are relatively large and readily removed by the scrubber. The increased solids to the scrubber usually leads to increased scrub solution purging which reduces the $\mathrm{Hg}$ emission. Excessive fines generation from improper feed composition results in increased fines to the scrub system and possibly to increased solids emissions. Improper feed formulations usually lead to reduced feed rates and they are normally corrected when the problem is recognized.

No upset factors (increases in the calculated emission rates modeled in the risk assessment) were used or needed for most of the organic and volatile metal constituents (those with an assumed DF of 1) because $100 \%$ of the feed constituents were assumed to be released (what goes out cannot be greater than what goes in). An upset factor of 1.45 was applied to the five organic constituents with an assumed DF of 100. No upset factors were used or needed for the PICs that were evaluated because PIC emissions assumed $100 \%$ of the necessary precursors were converted to a worst-case PIC release rate (please read section 2.2.4). An upset factor was indirectly incorporated for non-volatile metal emissions by using a "degraded" NWCF ( 3 bank) HEPA filter decontamination factor $(\mathrm{DF}=1 \mathrm{E}+5$, penetration $=1 \mathrm{E}-5)$. This $\mathrm{DF}$ was determined by examining 3 years of on-line filter performance measurements (see Appendix A). The NWCF HEPA filters always meet a maximum test criteria of $\mathrm{DF}>1 \mathrm{E}+7$ (penetration $<9 \mathrm{E}-8$ ) at installation and normally meet this criteria in annual tests thereafter. The use of the degraded DF $(1 E+5)$ in the risk assessment is equivalent to a "filtration upset factor" of $100(1 \mathrm{E}+7 / 1 \mathrm{E}+5)$, which conservatively bounds the EPA default upset factors. Revision 5 Addendum - the particulate DF has been revised (see Section 2).

3. Section 2.2.1, page 13. Most of the "decontamination factors" for metals discussed in this section are derived from the effects of the high-efficiency particulate air (HEPA) filters; however, HEPA filters are effective only for particles over a certain size, typically 0.1 micrometers. The filters have little effect on smaller particles including volatilized chemicals that are present in molecular-sized particles. Although the volatile metal compounds are handled acceptably, there is no mention here or in Appendix A of any determination of the actual size distribution of the particles containing the nonvolatile metals. If any part of that size distribution is less than the effective cutoff point of the HEPA filters, the actual emissions can be 9 to 11 orders of magnitude higher than the assumed worst-case emissions used in the SLRA and still be consistent with the measured emission rates. The revised SLRA must contain information on particle size distribution 
that will support the conclusions on the efficacy of the filters or must include suitably larger emission estimates of the nonvolatile metals.

Response: This comment is based on an incorrect premise that HEPA filters do not remove fine particles. HEPA filters do remove effectively particles smaller than 0.1 micron diameter, although by a different removal mechanisms than the larger particles (if this were not true, industrial clean rooms would not be possible). HEPA filters have a minimum removal efficiency at a particle diameter, which depends on particle size and shape, between 0.1 and 0.3 microns. HEPA filters are normally rated for a test aerosol approximating the most-penetrating particle size (e.g., 0.3 micron DOP particles). Both larger and smaller particle sizes are removed at a higher efficiency than the rated efficiency. See reference: A. Lieberman, \& R. D. Scott, "Atmospheric Particle Penetration through High Efficiency Filters", Proceedings of the 11th AEC Air Cleaning Conference, (1970), Conf 700816, p. 751-764. Also, please see the discussion on nonvolatile metal filter upset factors in the previous comment.

The size of the particles in the NWCF effluent containing the metals cannot be measured because concentrations are too small to measure. The particle size distribution expected to be discharging from a series of HEPA filters centers on the particle size for which the filters are least efficient. For air modeling purposes, particle sizes were calculated from published emissions data from medical waste incinerators and penetration through three HEPA filters (see comment \#8). This was the same method used to calculate the particle size distribution for the Waste Experimental Reduction Facility (WERF).

4. Section 2.2.1, page 14, Table 2. The metals presented in this table are based on guidance for human health effects. Additional metals such as aluminum, copper, and zinc can have a significant effect on environmental receptors. While the NWCF waste feed is known to contain aluminum complexes, the waste composition data does not contain information on these elements. These additional metals shall be added as appropriate to the list of. chemicals emitted from the calciner and included as appropriate in the SLRA.

Response: The SLRA was revised to include the following discussion:

Other low-toxicity metals (e.g. zinc and copper) are present in some the waste. The aluminum species in the NWCF feed all become inert solids $\left(\mathrm{Al}_{2} \mathrm{O}_{3}\right.$ or $\left.\mathrm{NaAlO}_{2}\right)$ which are emitted only in small quantities. Copper and zinc are present in the waste only in trace concentrations (from their use in chemical analyses) and are likewise emitted only as solids. The trace emissions of all these metals are then subject to removal by four banks of HEPA filters (overall decontamination factor of $6 \mathrm{E}+11$; see section 2.2.1). Revision 5 Addendum - Zine and manganese were evaluated for the ecological risk assessment (section 8) using preliminary offgas emissions sampling results. Also, the particulate DF has been revised (see section 2).

5. Section 2.23. A copy of reference, Schindler, R.E., 1995, should be provided so it may be reviewed in support of the proposed characterization of organic emissions from the burning of kerosene fuel. Schindler states that the primary organic emissions of burning kerosene fuel consist of $\mathrm{CO}, \mathrm{CO}_{2}$, and some unburned fuel consisting mostly of nontoxic light hydrocarbons (methane and ethane). This statement is not consistent with the emission data reported to the air program, which indicates stack emissions of 1.38 tons per year of hexone, (4-methyl-2-pentanone or methyl isobutyl ketone) and 2.37 tons per year of methanol. Further, chloromethane and dichloromethane (methylene chloride) are 
potential emissions from the burning of kerosene fuel with chlorine bearing materials (see Specific Comment 7 below).

Response: The emissions of MIBK and methanol reported in the air program are earlier worst-case estimates of maximum potential concentrations in one out of six waste tanks that will be calcined. They have not been identified as COPCs through sampling of the NWCF feed. The ODP may provide some additional information on these low toxicity compounds when it is performed in early 1999. However, the potential formation of chemicals like chloromethane and methylene chloride is conservatively accounted for by assuming all available chlorine in the feed forms the much more toxic PIC, pentachloronitrobenzene (see response to comment 7 , below). This assumption conservatively bounds the risk from any combination of PICs that require chlorine to form (including chloromethane and methylene chloride).

6. Sections 2.2.3 and 2.2.4. The SLRA must include a factor to account for the mass of the unknown organic compounds in the stack emissions.

Response: The "unknown organic emissions factor" referred to in the comment is used when the risk assessment is based on measured stack emissions, only a portion of which are identified compounds. Since the NWCF emissions are based on conservative assumptions of $100 \%$ release of organics in the feed and $100 \%$ conversion of the unbumed fuel to a toxic indicator PIC (see response to comment 7 , below) rather than stack emissions testing and since there are no significant unknown organics in the feed, no unknown organic emissions factor is required. The SLRA was therefore not revised.

7. Section 2.2.4, page 18, paragraph 4. This paragraph states that chlorinated organic compounds were eliminated from consideration because of process knowledge and the limited availability of chlorine; however, Section 2.2 .2 , page 15 , states that hydrogen chloride is one of the acids emitted from calciner operations. The presence of available chlorine is further indicated by the combined emission rate of 3.36 tons per year $\mathrm{CI}_{2} / \mathrm{HCl}$ reported in the emission inventory for the CCP main stack. If hydrogen chloride is emitted from the calciner, chlorine is available to serve as a precursor for chlorinated organic compounds. Chlorinated organic compounds must be added back to the assessment. The presence of fluorine in the stack emissions indicates that fluorinated (and chloro-fluoro) organic compounds must also be evaluated in the assessment. The SLRA shall include potential emissions of PAHs, PCBs, and phthalates because the data provided in the Appendices indicates the presence of precursors (i.e., benzene, chlorine, etc) for these compounds.

Response: The SLRA text was revised. The statement that "chlorinated organic compounds were eliminated from consideration" was in error and was removed from the SLRA text. Chlorinated organic compounds were conservatively assessed for dioxins and furans (section 2.2.4.1) and the nitroaromatics (section 2.2.4.2) which are the primary PICs of concern in the high $\mathrm{NO}_{\mathrm{x}}$ atmosphere of the NWCF offgas. Revision 5 Addendum - PAHs, coplaner PCBs, and phthalates were evaluated.

The following additional discussion concerning chlorinated organic emissions was added to section 2.2.4.2:

Since it not known which specific chlorinated organic PICs might be formed in the offgas, it was conservatively assumed that assumed all of the chlorine in the feed $(0.18 \mathrm{~g} / \mathrm{s})$ reacted to form the 
highly toxic pentachloronitrobenzene (PCNB). Assessment of the maximum potential formation of PCNB provides a reasonably conservative bound for impacts from any combination of potential PICs that are of concern in the NWCF offgas because of its relatively high toxicity. For example, PCNB has an EPA Region III Risk Based Concentration (RBC) in air of $0.024 \mathrm{ug} / \mathrm{m}^{3}$ compared to $3.8 \mathrm{ug} / \mathrm{m}^{3}$ for dichloromethane and $0.99 \mathrm{ug} / \mathrm{m}^{3}$ for methylene chloride. The lower RBC for PCNB indicates that this compound is from 41 to 158 times as toxic and therefore provides a conservative bound to the health impact assessment. Revision 5 Addendum - the chlorine emission rate and therefore the maximum potential formation of PCNB have been revised (see Section 2).

An additional section (2.2.4.3) was added to discuss the potential formation, release, and relative impacts from other organic PICs:

Fluorinated (and chloro-fluoro) compounds were not evaluated in the SLRA for the following reasons: 1 ) reasonably conservative estimates of fluorine in the offgas are extremely low (5E-02 $\mathrm{g} / \mathrm{s}), 2$ ) the only fluorinated (and chloro-fluoro) compounds listed on the EPA PIC list are freon species that have very low toxicity values compared to the PICs evaluated, and 3) evaluation is not justified based on the overall results of the SLRA.

PAHs, PCBs, and phthalates are not evaluated in the SLRA because 1) they are not present in significant quantities in the waste feed, 2) the potential for PIC formation of these compounds in the NWCF offgas is much less than the nitroaromatics (PCBs are difficult to synthesize), 3) the SLRA uses very conservative assumptions on nitroaromatic PIC formation (all available benzene/toluene and chlorine react to form all species of nitroaromatics) which provides a reasonable bound for these compounds, 4) no reliable method is available to calculate the offgas reaction rates for these compounds, and 5) stack gas sampling for PICs has not proven feasible due to the highly acidic offgas (see section 2.2.4). Revision 5 addendum - This paragraph was deleted, and quantitative estimates of PAHs, coplaner PCBs, and phthalates were evaluated.

8. Section 3.2, pages 24 and 25. This section provides model-input values for particulate diameter and mass fraction. Justification for these values should be provided.

Response: The SLRA was revised. No particle size data for NWCF emissions were available for air modeling input. Therefore, a method developed for the WERF SLRA was used. This method uses particle size distribution data from tests conducted on a medical waste incinerator with no APCE, as reported in California Air Resources Board (CARB) Test Report C-87-122, 1/31/90. The midpoint of the size distribution categories are then combined with HEPA filter removal efficiency data from Dennis et al. 1980, Industrial Filter 1992, \& Bergman et al. 1990. The method produces a size distribution that is smaller than the generic default values given in the combustion guidance. Smaller particulate sizes have been shown to be more conservative for INEEL assessments because the particulate are transported the longer distances required to reach the relatively distant INEEL receptor locations (less particulate falls out near the facility).

9. Section 4.0, page 32. The receptors considered here (and the supporting modeling discussed in Section 3.3) consider only off-INEEL residents and travelers on Highway 20. Because of the size of the buffer zones around the Idaho Chemical Processing Plant (ICPP) and other INEEL facilities, adult residents that are also highly likely to be INEEL workers at the ICPP and the Central Facilities Area (CFA) will receive greater chronic exposures, even from 45 to 50 hours per week exposures, than the off-site residents who 
are exposed for 168 hours per week In addition, acute exposures for adult resident/INEEL workers at the ICPP and the CFA will exceed those receptors on Highway 20. The revised SLRA must include an evaluation of these adult resident/INEEL worker scenarios.

Response: Workers at INTEC (ICPP) and CFA are exposed to lower chronic air concentrations than those evaluated at the maximum off-site impact location because of the elevated $(72 \mathrm{~m})$ plume height, their offcenterline plume location, and because of the elevated terrain and plume centerline location of the maximum off-site location (please see Figure 7). In response to the comment, maximum inhalation impacts for a worker at CFA was determined to be $9 \%$ of the maximum off-site cancer risk and $40 \%$ of the maximum off-site hazard index evaluated (see response to General Comment \#3). Therefore, a worker who works 2000 hours per year at the maximum INEEL facility impact location and resides the remaining portion of the year at the maximum off-site impact location will be less impacted than the assessed off-site scenarios which assumed continuous exposure at the maximum off-site impact location.

10. Section 4.1. The following exposure scenarios should be added to the SLRA to assume that all receptors that may be significantly exposed to emissions for the facility are evaluated:

- Subsistence farmer child

- Infant exposure to dioxins and furans via the ingestion of their mother's breast milk

- Adult resident/INEEL worker scenario

- Herdsman/hunter scenarios

Response: The SLRA was revised. An INEEL worker, on-site herdsman, and the breast milk pathway were assessed. The impacts from all of these scenarios were found to be negligible compared to the assessed scenarios. The hunter scenario was investigated and determined to be an insignificant (or nonexistent) exposure pathway on the south end of the INEEL. It was found that the HHRAP methods defined for the new subsistence farmer child scenario (e.g. ingestion rates) are inconsistent with the 1994 guidance methods used to evaluate the other scenarios in this SLRA and would result in calculated impacts that are not comparable with these other scenarios. Since there was not time to re-evaluate all of the scenarios using the new guidance, the subsistence farmer child was not assessed. Revision $\mathbf{5}$ addendum a subsistence farmer child scenario was evaluated.

11. Section 4.2.2, page 33. The beef and dairy exposure route assumes all contaminants of concern bioaccumulate in the muscle tissue. The SLRA should include a justification why this assumption is appropriate.

Response: The SLRA was revised. Text was changed to indicate for beef exposure contaminants bioaccumulate in the muscle tissue while for dairy exposure the contaminants bioaccumulate in the cow's milk.

12. Section 5.0, page 35. The 1997 edition (most recent edition) of HEAST should be used and referenced in this section. 
Response: The SLRA was revised. The SLRA will be updated to reflect the 1997 edition of HEAST and will be referenced in this section of the SLRA. Revision 5 Addendum - additional sources of toxicity data were used including those listed in the ATG RAWP and those from EPA Region 9 (on-line).

13. The text states that chemicals lacking EPA toxicity values were not assessed in this SLRA. This policy led to the omission from the SLRA risk estimation of the six chemicals that comprise the gaseous emissions listed in Table 3 and make up more than $95 \%$ of the total emissions. There are non-EPA inhalation toxicity values for these noxious gases, both permissible exposure levels from the Occupational Safety and Health Administration and threshold limit values from the American Conference of Governmental Industrial Hygienists. These human-derived toxicity values, adjusted by appropriate uncertainty factors, should be used to estimate risk from the gaseous emissions.

For the Toxicity Assessment, EPA Region 10 risk assessors (Marcia Bailey) can be of assistance in obtaining provisional toxicity values for many chemicals and/or exposure routes from the EPA's National Center for Environmental Assessment when such values are not available on Integrated Risk Information Service (IRIS) or in HEAST. ATSDR Minimal Risk Values may also be used as a fourth source of values. However, none of the four will contain the acute values needed to assess that risk. Other sources such as those used for occupational protection may be consulted. EPA Region 10 risk assessors can assist in identifying sources of appropriate acute toxicity values.

PCBs should be evaluated pursuant to the new toxicity criteria available on IRIS since October 1, 1996.

Response: The SLRA was revised. Risks and hazard quotients for chemicals without verified EPA toxicity values will be calculated using EPA Region III Risk Based Concentrations (RBCs) for air or State of Idaho acceptable ambient concentrations (AACs) for non-carcinogens, as published in the Section 585 of the Rules for the Control of Air Pollution in Idaho (IDAPA 16.01.01). The State of Idaho AACs are calculated as 1/100 of the OSHA Permissible Exposure Level (PEL) and were only used for five contaminants that did not have RBCs. Revision 5 Addendum - revised toxicity values from the ATG RAWP and EPA Region 9 (on-line) have been used.

Comparisons of short-term impacts to acute toxicity values are not necessary if it can be shown that maximum impacts are less than more conservative (lower) chronic toxicity criteria. PCBs are not evaluated in the SLRA (see response to Specific Comment \#7). Revision 5 addendum - coplaner PCBs were evaluated in the SLRA.

14. Section 6, page, 39. An evaluation of the noncancer effects of dioxin should also be performed in SLRA. A "margin of exposure" approach should be used for estimating potential noncancer health effects arising from incremental exposures to dioxins. Using this approach, one determines the ratio of the estimated daily dose of dioxins from a particular source to the average daily intake of dioxins in the general population. The general background level of exposure of adults to dioxins is estimated at 1 to 3 picograms 
(pg)kilograms (kg)/day. Current U.S. EPA guidance recommends that, if the ratio of exposure to this background level is "very small," the noncancer effects from the incremental exposure are to be judged as negligible.

Response: The SLRA was revised. An evaluation of noncancer effects of dioxin has been added to the SLRA and was found to be negligible.

15. Section 6.1, page 41. The discussion of mercury and its different Hazard Index due to neurotoxic effects should be expanded. A risk assessment is expected to be reviewed by the public and should, therefore, be as clear as possible. In Appendix A, p A-16, it is stated that the "largest and probably dominant hazardous emission" is mercury, due to its "volatility as $\mathrm{HgCl}_{2}$ and relatively high concentration in the tank farm."

Response: The SLRA was revised. Additional chemicals with neurotoxic effects have been added to the discussion.

16. Section 6.3, page 47. A reference should be provided for the EPA air and soil lead levels cited.

Response: The SLRA was revised. Reference to EPA Region III, 1996 has been added to the text.

17. Section 6.4, page 47, second paragraph. This paragraph states that the SLRA for the calciner demonstrates that the facility meets all EPA requirements for the operation of a combustion facility and that no further analysis of the risk is necessary. Based on this review, significant issues still remain to be resolved, particularly involving radionuclides, ecological risk, additional exposure scenarios, and reflecting actual performance testing missions data.

Response: The SLRA was revised. Assessment of potential radionuclide risk has been added to SLRA. Additional exposure scenarios were assessed (see response to General Comment \#3). A statement was added to the conclusions that the results of this risk assessment were based of conservative estimates of emissions calculated using the best-available process knowledge and that additional assessment may be performed based on the results of the planned Offgas Demonstration Project (ODP) scheduled for January through April, 1999. Revision 5 addendum - In addition to the above, a quantitative ecological risk assessment was performed.

18. Section 7. The source term and exposure assessment discussions focus solely upon uncertainties that would tend to bias the SLRA to the conservative side. All known or potential uncertainties must be discussed. (An obvious example for this draft SLRA is not knowing what products of incomplete combustion might be produced from chemical reactions between the feedstock and the kerosene and the possible recombination products from reactions in the mixing of the various stack gases, since emissions have yet to be sampled and analyzed.) 
Response: The SLRA was revised to better describe the uncertainty associated with types and quantities of specific PICs that may be formed in the offgas and why this uncertainty exists (inability to sample the highly acidic offgas and the difficulty in predicting PIC formation). However, the methods used in the SLRA to assess the maximum impacts from any possible PIC formation (see response to Specific Comment \#7) assume a worst-case combination of feed materials to form the maximum possible formation rate of indicator PICs (dioxins/furans and nitroaromatics) that are both likely to be formed in the NWCF offgas and are highly toxic. Similar assumptions could be used to calculate upper bound formation of other chlorinated organic PICs which are less likely to be formed in the offgas and which are likely to be less toxic. However, conservation of mass (in the benzene and chlorine feed rates) would require that the nitroaromatic emission rates be reduced, and it is unlikely that the total hazard (emission rate times toxicity summed across all PICs) would be increased. It is important to stress that the purpose of this SLRA is to provide a high level of confidence that no unacceptable health impacts will occur as a result of NWCF operations, not necessarily to predict exactly what is going on in the offgas.

An additional section on radionuclides was added to the exposure assessment uncertainty (section 7.3). In the radionuclide exposure assessment (section 6.4), the annual risk determined from the 1997 NESHAPS dose was multiplied by exposure duration of 40 years for the subsistence farmer and 30 years for the adult resident to obtain lifetime risk. This is conservative because the vast majority of the dose (and therefore risk) will occur during the 16-year time period that the NWCF will actually operate. After NWCF operations cease, the residual dose from activity remaining in the soil will be significantly less than the dose calculated in the NESHAPS assessment, which is largely a result of ingestion of food products that are contaminated on the surface by fallout during facility operations. These exposure duration assumptions will overpredict lifetime risk for the subsistence farmer and adult resident by a factor of approximately 2 .

19. Section 7.0, Tables 6 and 7. The toxicity values listed in these tables were current through 1996. The primary source, EPA's IRIS, is updated at least once per month and is now available, without a fee, on the Internet. During preparation of the revised SLRA, IRIS and other sources should be checked to ensure that current toxicity values are used.

Response: The SLRA was revised. The toxicity data has been updated with data from the 1997 HEAST and on-line IRIS database. Revision 5 Addendum - Toxicity values were updated again using additonal sources (ATG RAWP and EPA Region 9 on-line data.

20. Section 8. The treatment of ecological receptors is very abbreviated. There should be an identification and discussion of chemicals (e.g., HF, Al) emitted from the calciner that pose particular risks to the flora and fauna described in the text as having been identified as potential receptors at the site. The following statement made in the Conclusions' section of this 3-page chapter, makes it clear that the ecological considerations have been inadequately addressed:

"Ecological effects are not likely to be significant at the population, community, or ecosystem levels, although measurable effects may be conceivable in individual biota, in areas adjacent to the [facility]."

Insufficient information is provided in the SLRA to evaluate that statement or the potential magnitude of ecological effects that may arise (or which have already 
occurred) due to emissions from this operating facility. The ecological assessment portion of the SLRA shall consider:

actual contaminants of concern, food web interactions, sensitive receptors, and ecosystems found in the area of impact.

The SLRA shall be revised, as appropriate, to address these concerns.

Response: DOE believes that the qualitative ecological risk discussion in this SLRA was done in accordance with the most current EPA SLRA guidance (1994) available at the time (which specifies a qualitative ecological risk assessment) and that it was also a "component" of the May 1998 Revision 3 of the SLRA. Although EPA has not currently published new quantitative ecological risk assessment guidelines, a Risk Assessment Work Plan (RAWP) that describes quantitative ecological risk assessment methods done for another EPA Region X combustion unit ${ }^{d}$ was received by DOE in early December 1998. This RAWP is reportedly based on new ecological risk assessment methods for combustion units which may be published by the EPA's Office of Solid Waste (OSW) in the Spring of 1999. However, although this RAWP list critical input parameters and methods required to do an adequate quantitative assessment, there was not adequate time to perform this assessment for the NWCF SLRA by December 31, 1998. DOE will re-examine the need to do a full quantitative ecological risk assessment after the HLWEIS is published and a decision is made on whether to restart and permit the NWCF. This decision will be made by June 30,2000, in accordance with the Notice of Noncompliance Consent Order. Revision $\mathbf{5}$ Addendum - a quantitative ecological risk assessment has been added (section 8).

21. Appendix A, Section 61 page A-15. The citations on this page include numbers 20 and 18 , however, Section 8 has neither reference, although it does have two versions of reference number 17. This discrepancy should be corrected in the revised SLRA.

Response: The SLRA was revised. The reference discrepancy was corrected.

22. Appendix E, Table E-4. Correct the inhalation factor for children to $10 \mathrm{~m}^{3} /$ day for consistency with Risk Assessment Guidance for Superfund: Volume 1. Human Health Evaluation (Part A). OERR. Washington, D.C. OERR 9200 6-303-894 (RAGS-Part A).

Response: The inhalation rate presented is taken from Guidance for Performing Screening Level Risk Analyses at Combustion Facilities Burning Hazardous Waste (EPA, 1994). Since, the direct inhalation risks were calculated based on URFs and RfCs (inhalation intakes were not calculated), the inhalation rate is not used in the risk calculation. A note is added in this revision to make this clear.

d. Allied Technology Group, Inc. (ATG) Risk Assessment Work Plan for the ATG Richland Mixed Waste Facility, October 9, 1998. 